\title{
Opowiedzieć Uniwersytet
}

Łódź akademicka w biografiach wpisanych w losy Uniwersytetu Łódzkiego 
留 
Kaja Kaźmierska Katarzyna Waniek Agata Zysiak

\section{Opowiedzieć Uniwersytet}

Łódź akademicka w biografiach wpisanych w losy Uniwersytetu Lódzkiego

Wydanie 2 uzupełnione
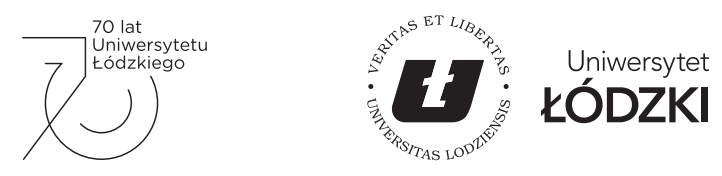


\title{
Kaja Kaźmierska, Katarzyna Waniek, Agata Zysiak - Uniwersytet Łódzki Wydział Ekonomiczno-Socjologiczny, Katedra Socjologii Kultury 90-214 Łódź, ul. Rewolucji 1905 r. nr 41/43
}

\author{
RECENZENT \\ Joanna Wawrzyniak \\ REDAKTOR INICJUJĄCY \\ Iwona Gos \\ OPRACOWANIE REDAKCYJNE \\ Anna Wojczyńska \\ SKŁAD KOMPUTEROWY \\ Stawomir Gurdata \\ KOREKTA TECHNICZNA \\ Leonora Wojciechowska \\ PROJEKT OKŁADKI \\ Stämpfli Polska Sp. z o.o.
}

Zdjęcie wykorzystane na okładce pochodzi ze zbiorów Archiwum UŁ

Wydanie drugie sfinansowane ze środków statutowych Katedry Socjologii Kultury UŁ

Wydrukowano z gotowych materiałów dostarczonych do Wydawnictwa UŁ

C Copyright by Authors, Łódź 2016

(C) Copyright for this edition by Uniwersytet Łódzki, Łódź 2016

Wydane przez Wydawnictwo Uniwersytetu Łódzkiego

Wydanie II (uzupełnione). W.07567.16.0.K

Ark. druk. 28,25

ISBN 978-83-8088-285-0

e-ISBN 978-83-8088-286-7

Wydawnictwo Uniwersytetu Łódzkiego

90-131 Łódź, Lindleya 8

www.wydawnictwo.uni.lodz.pl

e-mail: ksiegarnia @uni.lodz.pl

tel. (42) 6655863 
Dowiedzieliśmy się, że każda jednostka żyje, z pokolenia na pokolenie, w jakimś społeczeństwie, że jej życie układa się w jaką́s biografię, która przeżywa ona w ramach pewnej sekwencji historycznej. Przez sam fakt życia człowiek przyczynia sie, choćby w znikomym stopniu, do kształtowania tego społeczeństwa i biegu jego historii, i to pomimo że sam jest tworem spoleczeństwa oraz jego historycznych nacisków i pchnięć.

Charles Wright Mills, Wyobraźnia socjologiczna 

Wszystkim, których historie życia splotty się z losami Uniwersytetu Łódzkiego 



\section{Spis treści}

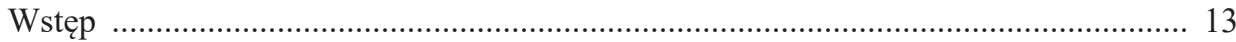

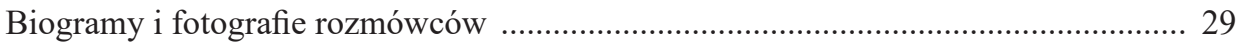

Rozdział I. Inicjacja w świat nauki ................................................................... 37

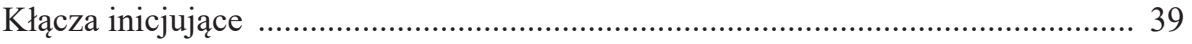

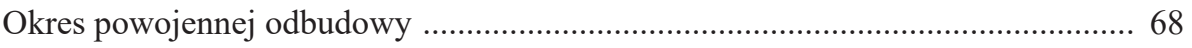

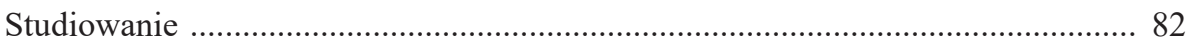

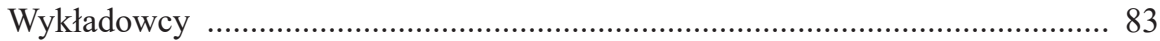

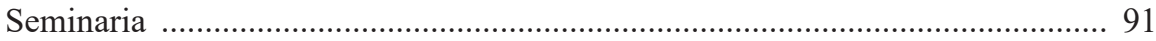

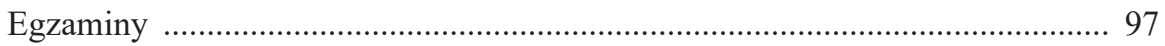

Rozdział II. Wędrówka z Mistrzem .................................................................. 107

Profesora Adama Szpunara wspomina Biruta Lewaszkiewicz-Petrykowska ....... 110

Profesora Aleksandra Kamińskiego wspomina Olga Czerniawska ...................... 113

Profesora Wacława Szuberta wspomina Michał Seweryński ............................... 123

Profesora Mieczysława Wallisa wspomina Wanda Nowakowska ....................... 128

Profesor Stefanię Skwarczyńską i profesora Bolesława Lewickiego wspomina

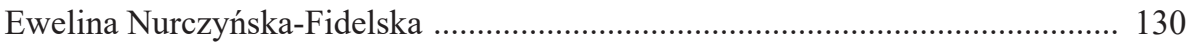

Profesor Stefanię Skwarczyńską wspomina Teresa Cieślikowska ........................ 135

Profesor Antoninę Kłoskowską wspomina Zbigniew Bokszański ........................ 136

Profesor Kazimierę Zawistowicz-Adamską wspomina Bronisława Kopczyńska-

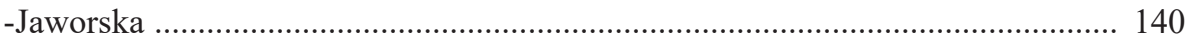

Profesorów Tadeusza Kotarbińskiego, Tadeusza Krońskiego i Bronisława Baczko wspomina Ryszard Panasiuk .............................................................. 141

Profesora Ludwika Straszewicza wspomina Stanisław Liszewski ....................... 144

Profesora Konrada Jażdżewskiego wspomina Jerzy Kmieciński ......................... 145

Profesora Jana Wojciechowskiego wspomina Jan Ziomek ................................... 147

Profesora Witolda Janowskiego wspomina Zbigniew Jakubowski ........................ 148

Profesor Annę Chrząszczewską wspomina Romuald Skowroński ........................ 148

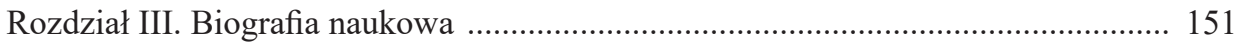

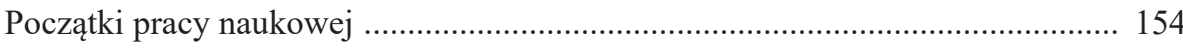

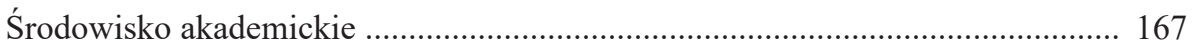




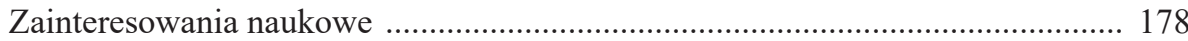

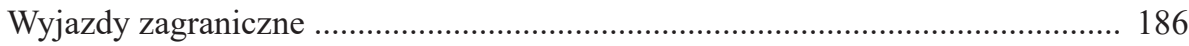

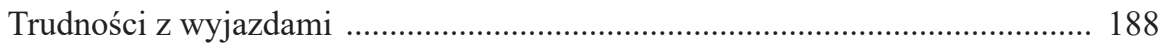

Różnorodność doświadczeń a dyscypliny nauki ............................................ 191

Co dzieje się za żelazną kurtyną? .................................................................. 209

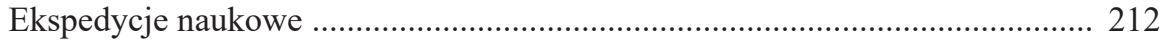

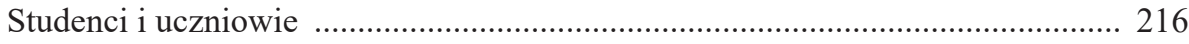

Rozdział IV. Konteksty historyczne ................................................................... 225

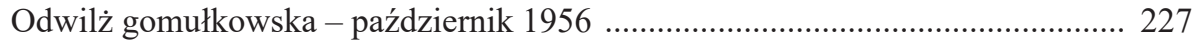

Losy niepokornej socjologii 1951-1965 ........................................................ 232

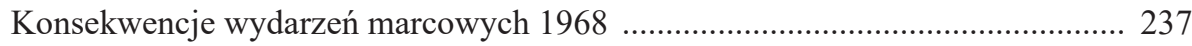

Epoka gierkowska - lata siedemdziesiąte ....................................................... 250

Lata osiemdziesiąte i „Solidarność” ................................................................. 252

Strajk studencki 1980-1981: „„Od solidarnościowego odruchu do ideologicznej determinacji» o silnym emocjonalnym podłożu" ................................................ 255

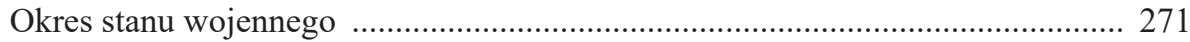

Obrady Okrągłego Stołu i transformacja ustrojowa: „ziścił się sen, ale zapowiadała się droga przez mękę"... ............................................................................. 275

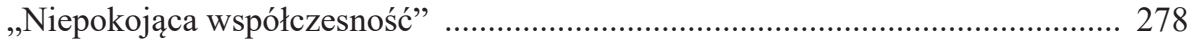

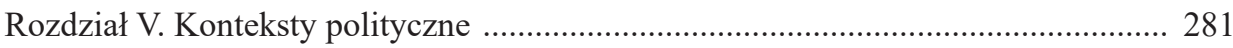

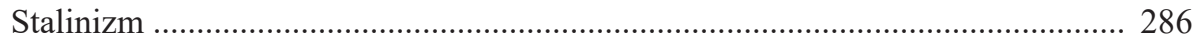

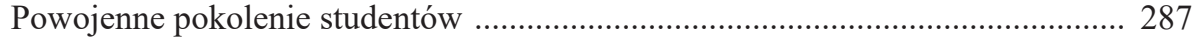

Atmosfera studiowania - relacje między wykładowcami a studentami ............ 287

Atmosfera studiowania - relacje między studentami ....................................... 293

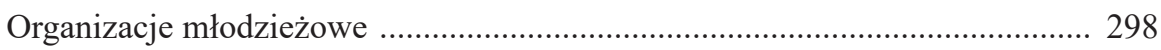

Świadectwa moralności, inwigilacja i kontrola ................................................ 303

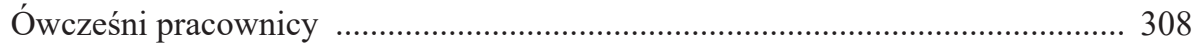

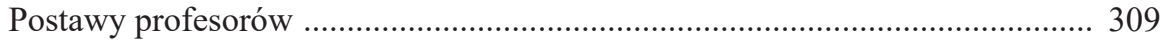

Obowiązkowe szkolenia i egzaminy z marksizmu .......................................... 312

Ideologizacja nauki a kariera akademicka …………….............................. 315

Ingerencje władz w proces edukacyjny ...................................................... 318

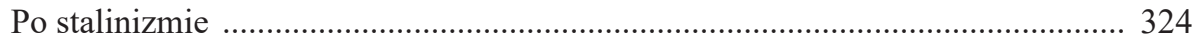

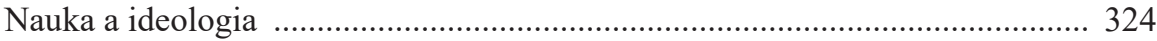

Na tle innych krajów bloku wschodniego ....................................................... 330

Przestrzenie wolności i konsekwencje niesubordynacji .................................. 337

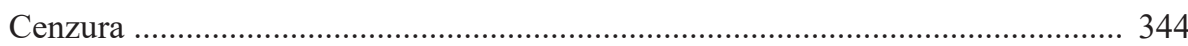


Rozdział VI. Miejsca i materialność akademii ...................................................... 351

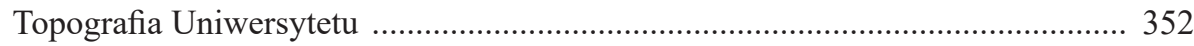

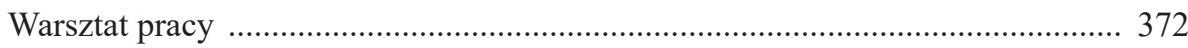

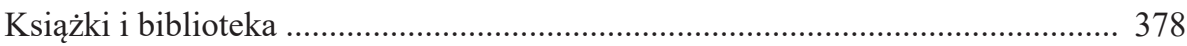

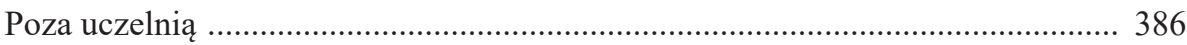

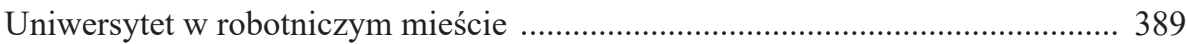

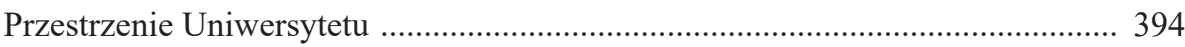

Zamiast zakończenia. Universitas - czym był, czym jest Uniwersytet? .................... 397

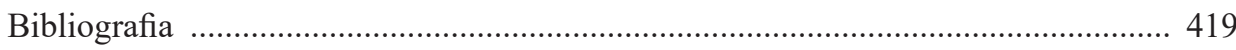

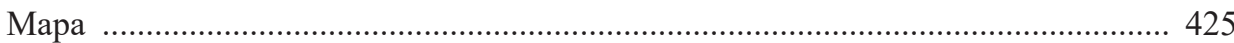

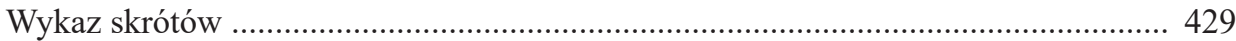

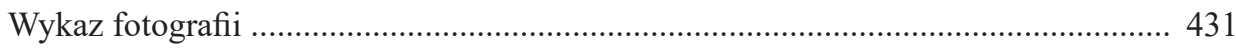

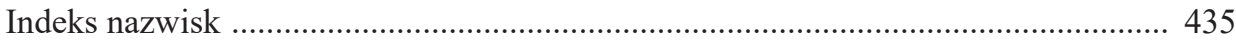

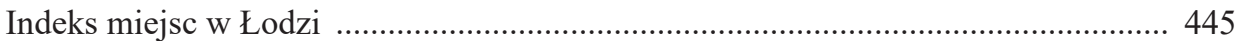

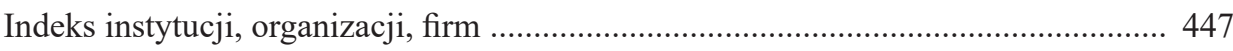

Indeks nazw geograficznych ........................................................................... 451 

http://dx.doi.org/10.18778/8088-285-0

\section{Wstęp}

Kto przedsiębierze próbę $i$ doznaje zawodu, ten $w$ każdym razie zdobywa pouczenie; kto nie przedsiębierze próby, ten traci bezcenne możliwości.

Tadeusz Kotarbiński, Traktat o dobrej robocie

Autorzy z reguły przygotowują wstęp do swoich publikacji na samym końcu procesu pisania książki. Stanowi on zazwyczaj pewną syntezę dokonanej pracy i chociaż ma pełnić funkcję w prowadzenia, z perspektywy autora często bywa formą bilansu początkowego zamysłu z efektem końcowym. Tak jest i w tym przypadku. Kiedy pod koniec 2010 roku rozpoczynaliśmy w Katedrze Socjologii Kultury, przy współpracy ze Stowarzyszeniem Topografie, projekt roboczo zatytułowany Łódź akademicka w biografiach, nasze założenia zostały sformułowane w sposób następujący:

Celem projektu jest przeprowadzenie wywiadów narracyjno-biograficznych z emerytowanymi pracownikami naukowymi Uniwersytetu Łódzkiego (przede wszystkim z profesorami), których tematem będą ich doświadczenia życiowe związane ze studiami a następnie pracą na UŁ. Chodzi nam o odtworzenie historii społecznej uczelni zapisanej w doświadczeniach życiowych jej świadków i zarazem twórców życia akademickiego. Pokolenie profesorów, dziś w większości osiemdziesięciolatków, to również pierwsze pokolenie studentów w 65 -letniej historii uczelni. ${ }^{1}$ Ich historie życia wpisane w historię UŁ pozwolą odtworzyć początki funkcjonowania Uniwersytetu, ożywić pamięć o pokoleniu pracowników naukowych zakładających uczelnię, opisać, jak funkcjonował Uniwersytet na tle przemian społeczno-politycznych w Polsce. Mamy też nadzieję, że poprzez opowieści biograficzne zachowane zostaną również obrazki z życia uczelni w formie „,historyjek rodzajowych”, anegdot, które być może historycznie nie są tak znaczące, ale pozwalają odtworzyć społeczny klimat życia akademickiego oraz pokazać historię osób je tworzących jako „zwykłych ludzi”. Ważnym zamierzeniem projektu jest odtworzenie opowieści o pierwszym pokoleniu profesorów w perspektywie relacji mistrz-uczeń, aby pokazać wagę pokoleniowej transmisji pasji naukowych i zaznaczyć tym samym, iż intelektualna historia UŁ wybiega niejako poza 65 lat istnienia uczelni, należy ją

\footnotetext{
${ }^{1}$ Pamiętajmy, że tekst ten powstał w 2010 roku - w czasie 65-lecia Uniwersytetu Łódzkiego.
} 
bowiem poszerzyć o historię pokolenia pierwszych, przedwojennych pracowników nauki, którzy zakładali poszczególne kierunki na UŁ. Poza tym zwrócenie uwagi na relację mistrz-uczeń wydaje się ważne z perspektywy współczesności, kiedy wzór taki jest dużo rzadszy. Tak zaprojektowane badania wpisują się w nurt badań określanych jako historia mówiona, wykorzystywanych w naukach społecznych, zwłaszcza w historii, socjologii czy antropologii kulturowej. Efektem projektu ma być publikacja zawierająca osobiste relacje dotyczące własnej biografii oraz uczelni. Planujemy podzielić publikację na dwie części - w pierwszej przedstawione zostaną opowieści biograficzne, $\mathrm{w}$ drugiej cytaty $\mathrm{z}$ wywiadów podporządkowane zostaną pojawiającym się w narracjach tematom związanym z życiem uczelni np. „,studia”, „uczeń-mistrz”, „kariera zawodowa”, „instytucje”, „życie codzienne uczelni”, „kontakty z zagranicą” itp. Warunkiem publikacji jakichkolwiek wypowiedzi będzie autoryzacja dokonana przez autorów.

Gdy z perspektywy pięciu lat czytamy zredagowaną wówczas informację służącą jako „wizytówka” prezentująca nasze zamierzenia, widzimy, iż wymaga ona komentarza dziś, kiedy zebrany został bogaty materiał i stanęłyśmy przed wyzwaniem jego opracowania w formie publikacji, której tematyka doskonale wpisuje się w jubileusz 70-lecia naszej uczelni.

Rozpocznijmy od najbardziej ogólnej kwestii. Na początku projekt ów miał w naszym zamyśle wymiar ,lokalny” - miał być ograniczony do określonego pola naszych badawczych (i nie tylko) zainteresowań. Chodziło o poznanie historii naszego uniwersytetu widzianej oczami naszych pracowników, zwłaszcza profesorów. Ta koncentracja na lokalności, po trosze związana z etykietą peryferyjności, jaką przypisuje się Łodzi, w tym i jej uczelni, początkowo usunęła z naszego pola widzenia szerszy, abstrahujący od szczególnego miejsca i swoistego czasu kontekst. Tymczasem, mimo pewnych dylematów, o których piszemy w dalszej części wstępu, z całym przekonaniem oddajemy do rąk Czytelnika książkę, która jak ufamy, stanowić będzie ciekawy głos w debacie nad kondycją współczesnego uniwersytetu - bezrefleksyjnie odchodzącego od idei wspólnoty ludzi poszukujących prawdy oraz zgłębiających tajniki wiedzy i niebezpiecznie dryfującego w kierunku współczesnej korporacji². Opracowanie to powstało na podstawie wspomnień pierwszego powojennego pokolenia studentów a następnie nauczycieli akademickich. Chociaż są one umieszczone w konkretnym miejscu i czasie, co nadaje im swoisty kontekst, chociaż są

${ }^{2}$ Szeroko pisze o tym Kamila Biały w swojej książce: Przemiany wspótczesnego uniwersytetu. Od idei von Humboldta do modelu uczelni przedsiębiorczej, Wydawnictwo Uniwersytetu Łódzkiego, Łódź 2011. Zob. także: Dominik Antonowicz, Od korporacji do instytucji, „Zagadnienia Naukoznawstwa" 2002, nr 4, s. 517-537. 
wyjątkowe przez niepowtarzalność każdej biografii, to stanowią zarazem część historii polskiej nauki. Przez pryzmat indywidualnych doświadczeń pokazane zostały ważne procesy społeczne, polityczne i uwarunkowania historyczne kształtujące na przestrzeni dekad ideę univeristas. W przedstawionych wspomnieniach Czytelnik znajdzie więc: ślady ważnych wydarzeń historycznych; opisy i komentarze umożliwiające rekonstrukcję dynamiki przemian świata akademii w jego wymiarze edukacyjnym, naukowym i badawczym; materiał umożliwiający konfrontację niedawnej przecież przeszłości z teraźniejszością życia uniwersyteckiego.

W jakimś sensie tryb pracy nad książką może także stanowić komentarz do dyskusji nad współczesną kondycją szkolnictwa wyższego w Polsce. W tym kontekście, jako autorki proponowanej Czytelnikowi publikacji mamy wrażenie, że opracowanie to jest dla nas dość nietypowym projektem i wymaga komentarza (być może dla nas samych), zwłaszcza w odniesieniu do konfrontacji naszych pierwotnych zamierzeń z ich finalnym rezultatem. O nietypowości przedsięwzięcia stanowi w pierwszej kolejności fakt, iż wynika ono z osobistych zainteresowań historią uniwersytetu wpisaną w kontekst doświadczeń biograficznych studiujących i pracujących w nim osób. Taka perspektywa wpisana jest w reprezentowany przez nas profil naukowo-badawczy - zajmujemy się metodą biograficzną - ale w czasie pracy nad Łodzia akademicka $w$ biografiach realizowałyśmy jednocześnie inne projekty, ograniczone przez fundatorów grantów ramami czasowymi, których nie wolno było przekroczyć. Pokazanie tych uwarunkowań wydaje się nam ważne, gdyż ciągle towarzyszyło nam napięcie związane $\mathrm{z}$ jednej strony $\mathrm{z}$ chęcią zaangażowania $\mathrm{w}$ proces zbierania materiału i jego analizy, a z drugiej strony z koniecznością wywiązywania się z innych aktywności badawczych. W rezultacie praca nad Łodzia akademicka podejmowana była niejako „po godzinach”, z różną dynamiką, regulowaną przez nasze możliwości czasowe oraz uzależnioną od pomocy innych osób, oferujących swoje wolontariacie wsparcie. Praca nad projektem wiązała się więc z, nietypowym dla dzisiejszego stylu uprawiania badań naukowych, komfortem działań „,półprywatnych”, bez presji czasu oraz z pozytywnym doświadczeniem mobilizacji i bezinteresownego zaangażowania wielu osób (zostaną one wymienione dalej) w proces gromadzenia materiałów, ich transkrypcji i dyskusji. Przez trzy lata regularnie spotykaliśmy się na seminariach, na których omawialiśmy zbierany materiał - wywiady biograficzno-narracyjne. Niejednokrotnie zapraszani byli na nie przedstawiciele dyscyplin, które reprezentowali autorzy narracji, by pomóc nam zrozumieć swoiste dla poszczególnych gałęzi nauki kulisty 
i uwarunkowania. Zarazem jednak ów komfort pracy bez presji oraz formuła wolontariatu były trudne do utrzymania w obliczu innych ograniczonych terminami zobowiązań. Jakie były tego konsekwencje? Najbardziej brzemienne to fakt, iż z niektórymi osobami nie zdążyłyśmy porozmawiać. Nie wszystkie zebrane adresy, numery telefonów, wstępne kontakty zostały w porę wykorzystane - wtedy, tłumaczyłyśmy sobie, z braku naszego czasu - dziś, kiedy nasi potencjalni rozmówcy odeszli, powiedziałybyśmy, że z braku należytej uwagi i zaangażowania oraz oceny co jest mniej, a co bardziej ważne. To w jakimś sensie niezwykłe, że wiadomość o śmierci osoby, z którą planowałyśmy porozmawiać, której nie znałyśmy osobiście, często nigdy nie widziałyśmy, która, być może, w ogóle nie zgodziłaby się na tę rozmowę (spotkałyśmy bowiem się z kilkoma odmowami), napawała nas poczuciem nieodwracalnej straty. Komfort bezczasowego rozciągnięcia projektu stał się więc w końcu pułapką.

Drugi aspekt wspomnianej nietypowości związany jest z zastosowaną metodą, która $\mathrm{w}$ tym przypadku sytuuje się między autobiograficznym wywiadem narracyjnym a historią mówioną. Z naszego punktu widzenia, badaczek przywiązujących wagę do procedur metodologicznych ${ }^{3}$, posługiwałyśmy się tu swego rodzaju hybrydą, co być może dobrze wpisuje się w perspektywę postmodernistyczną, ale w nas wywołało poczucie niepewności i dyskomfortu. Spróbujemy teraz przedstawić rodzące się w tym kontekście wątpliwości. W naszym zamyśle, podczas spotkań z przedstawicielami starszego pokolenia pracowników UŁ aranżacja sytuacji wywiadu oraz sposób jego prowadzenia zostały oparte przede wszystkim na technice autobiograficznego wywiadu narracyjnego. Rozmówcy byli zatem proszeni o improwizowaną, spontaniczną opowieść o własnym życiu obejmującą przede wszystkim, choć nie wyłącznie, ich karierę akademicką. To narratorzy (niemotywowani dodatkowymi pytaniami ze strony osoby słuchającej) sami decydowali o tym, jakie wydarzenia ze swojej historii życia odtworzą i w jaki sposób je zaprezentują. Zadaniem osoby prowadzącej wywiad było zatem uważne słuchanie i śledzenie opowieści tak, aby ewentualne luki czy niedopowiedzenia mogły zostać uzupełnione w drugiej części wywiadu. Oczywiście, były też kwestie, które nas interesowały i o które dopytywaliśmy, jeśli nie pojawiły się w głównej linii narracji lub zostały W niej omówione jedynie pobieżnie. W tej ostatniej części nasi rozmówcy byli traktowani przede wszystkim jako świadkowie określonych wydarzeń,

\footnotetext{
${ }^{3}$ Najczęściej poruszamy się w polu badań biograficznych, a zwłaszcza metody autobiograficznego wywiadu narracyjnego opracowanej przez Fritza Schützego.
} 
których relacja miała pomóc nam zrekonstruować sposób ich zapamiętania $\mathrm{i}$ interpretacji.

Prezentowany w tej książce materiał nie został jednak poddany pełnej procedurze analitycznej wypracowanej w metodzie autobiograficznego wywiadu narracyjnego, gdzie materiałem badawczym staje się tekst zanonimizowanej transkrypcji. Oznacza to zazwyczaj przede wszystkim zmianę imienia i nazwiska narratora, wszystkich pojawiających się w jego opowieści postaci, bardzo często także nazw geograficznych i tych związanych z przestrzenią publiczną (a czasem także prywatną) - z tym jednak zastrzeżeniem, aby owa zmiana nie wpłynęła na zrozumienie i interpretację rekonstruowanej relacji autobiograficznej. Postulat anonimizacji nie służy wyłącznie ochronie prywatności opowiadającego - choć jest to kwestia bardzo istotna - ma on również wymiar metodologiczny. Anonimizując narrację, niejako „odrywamy” ją od konkretnej osoby. Transkrypcja staje się tekstem kultury, przypadkiem analitycznym ukazującym typowe powiązanie określonych procesów biograficznych z badanymi zjawiskami społecznymi. Z oczywistych względów anonimizacja nie była możliwa $\mathrm{w}$ przypadku prezentowanych w tym tomie opowieści. Jakiekolwiek próby ukrycia prawdziwej tożsamości rozmówcy byłyby ogromnie trudne, a nam chodziło przecież o relacje konkretnych (należących do wąskiej grupy) ludzi. Rzecz jasna, każda z występujących w tej książce osób zgodziła się opowiedzieć o swoich losach pod własnym nazwiskiem wiedząc, czemu ma służyć ich relacja, jak zostanie wykorzystana oraz mając prawo do przeczytania własnych wspomnień (i ewentualnej ingerencji w nie).

Innym czynnikiem uniemożliwiającym zastosowanie procedury analitycznej wywiadu narracyjnego jest założenie, iż rzetelność metodologiczna materiału wyznaczona jest tu przez rodzaj tworzonej wobec słuchacza narracji. Powinna być ona zatem spontaniczną, wcześniej nieprzedstawioną i „nietrenowaną” opowieścią o przebiegu własnego życia. Tymczasem w momencie naszego spotkania rozmówcy mieli już zazwyczaj za sobą doświadczenie rekonstruowania własnej biografii (najczęściej $\mathrm{w}$ formie pisanej) przez siebie samych czy przez innych ${ }^{4}$. Co więcej, narracja była konstruowana na wzór swoistego wyobrażenia o tym, jak powinna wyglądać prezentacja historii życia (dokonań naukowych) intelektualisty/profesora. $\mathrm{Z}$ tego punktu widzenia często nagrywane przez nas opowieści nie były w pełni spontaniczne, a w konsekwencji bywały też niekompletne (narratorzy często zakładali bowiem, że określone informacje na ich temat

\footnotetext{
${ }^{4} \mathrm{~Np}$. w ramach cyklu wydawanego przez Łódzkie Towarzystwo Naukowe Moja droga do nauki.
} 
są powszechnie dostępne i znane). Z drugiej strony, potwierdziły się nasze oczekiwania wsparte doświadczeniem badawczym - mimo wszystko przeprowadzone rozmowy zachowały pewną swoistość, spontaniczność i unikalność odróżniającą je od pisemnej autoprezentacji. Nasi rozmówcy często zatrzymywali się na pewnym szczególe, przywoływali sceny, które przedstawiali w bardzo obrazowy sposób, wracając we wspomnieniach do społecznych, kulturowych czy politycznych kontekstów własnych doświadczeń biograficznych. Wspomnienia te budowane były wobec młodszych słuchaczy w trybie pamięci komunikacyjnej (szczegółowo omawiamy tę kwestię nieco dalej) - żywej interakcyjnej opowieści. Można założyć, że jakaś część z nich nie byłaby wzięta pod uwagę w trybie konstrukcji pisanej autobiografii naukowej. Rozmówcy korzystali z wytwarzającej się wobec słuchającego opowieści swobody w doborze podejmowanych kwestii i sposobie ich prezentacji, wpływając tym samym na długość i drobiazgowość określonych wątków.

Brak anonimizacji zobowiązywał nas do autoryzacji opowieści. Przedstawiałyśmy je w „surowej” (odzwierciedlającej język mówiony) formie transkrypcji wywiadu, czyli dosłownego zapisu spotkania. Taka transkrypcja umożliwia zarejestrowanie wszystkich interakcyjnych warunków tworzenia opowieści, co w przypadku przygotowania tej publikacji nie było tak bardzo istotne, lecz w odniesieniu do innych kontekstów badawczych, a zwłaszcza w perspektywie czasowej (np. reanalizy materiałów po latach) może być bardzo ważne. Przyjęłyśmy założenie, że skoro pracujemy na „surowym” materiale, uczciwszym będzie dokładnie taki sposób przekazania go naszym rozmówcom. Fragmenty zamieszczone w książce zostały natomiast poddane redakcji i korekcie. Jednak etap „negocjacji” z Autorami opowieści okazał się stosunkowo trudny z dwóch powodów. Po pierwsze, w niektórych przypadkach, gdy autoryzacja przebiegała dwustopniowo $^{5}$, niełatwo było rozmówcom opowieści zmierzyć się z transkrypcją narracji w formie spontanicznie wyartykułowanej opowieści. Konfrontacja z zapisem żywej mowy jest zawsze trudna, nawet gdy zaakceptuje się fakt, iż jednostkowe akty mowy tak właśnie wyglądają i znacząco różnią się od wypowiedzi pisemnej. Bywały więc przypadki, iż spotykałyśmy się z kategoryczną negacją zastosowanego podejścia, chociaż taka forma zapisu miała stanowić jedynie „surowy” materiał wyjściowy. Po drugie, a kwestia ta w jakimś sensie łączy się z wyżej omówioną, niejednokrotnie

\footnotetext{
${ }^{5}$ Niektórzy rozmówcy od razu wyrażali zgodę na wykorzystanie ich opowieści, do innych osób powracałyśmy z wybranymi do publikacji fragmentami, inni oczekiwali przedstawienia transkrypcji zaraz po jej wykonaniu.
} 
musiałyśmy negocjować formę autoprezentacji. Zdarzało się, iż w wyniku autoryzacji, z uzyskanej spontanicznej opowieści pozostawał opis sformalizowany regułami konstruowania akademickiej biografii, przypominający w stylistyce takie formy jak „Moja droga do nauki” czy „Sylwetki łódzkich uczonych". Nie taki był jednak cel tego przedsięwzięcia, które doskonale obrazuje tytuł książki - „Opowiedzieć Uniwersytet” - chodziło nam o uchwycenie tzw. żywej narracji, budowanej w najbardziej naturalnym dla człowieka jako homo socius typie kontaktu czyli komunikacji bezpośredniej. Tak bowiem tworzą się nasze wyobrażenia o świecie, buduje biograficzna i społeczna pamięć przeszłości. Są one bardzo zróżnicowane, gdyż zależą od indywidualnych interpretacji i różnych aspektów wyobrażeń zbiorowych. Zamiarem naszym było właśnie wzbogacenie owej różnorodności, o historię opowiedzianą, która nie zawsze musi pokrywać się $\mathrm{z}$ opracowaniem historycznym ale zawsze w swoisty sposób odnosi się do przeszłości. $Z$ tego też powodu zależało nam, aby cytowane wypowiedzi, mimo ich niezbędnej redakcji, zachowały ramę żywej opowieści tworzonej wobec i dla słuchacza w określonym miejscu i czasie. I tu musimy przyznać, że jako badaczki po raz pierwszy spotkałyśmy się i z tak nieufnymi rozmówcami, i z tak daleko idącą problematyzacją spisanych wywiadów, a niekiedy wręcz z niezrozumieniem perspektywy badawczej. Okoliczności te miały znaczący wpływ na sposób przedstawienia i omówienia zgromadzonego materiału empirycznego. Wobec pojawiających się w tym kontekście dylematów zmieniłyśmy pierwotną koncepcję książki, rezygnując z odrębnej prezentacji poszczególnych biografii i skoncentrowałyśmy się na pokazaniu różnych wątków, które ze zmienną intensywnością pojawiały się w większości opowieści.

Drugą, równoległą perspektywą badawczą, którą przyjęłyśmy jako punkt wyjścia, była historia mówiona, odnosząca się do relacji świadków, którzy opowiadając o własnych doświadczeniach biograficznych są zarazem uczestnikami historycznych zdarzeń i procesów społecznych. Ich relacja zyskuje status źródła historycznego - zasobem opowieści jest biograficzna pamięć zdarzeń, osób, kontekstów społecznych. Stąd pierwszoplanową wartością tych opowieści jest właśnie relacja świadka i odniesienie do rzeczywistości społecznej w możliwie jak najwierniejszy sposób. Nie dziwi więc fakt, iż autorstwo takiej relacji powinno być znane. Nie chodzi tu o anonimowość, lecz przeciwnie, o zachowanie własnego - rzec by można „imiennego” - śladu w historii. W dużej mierze zebrane przez nas opowieści wpisują się w tę formułę - chodziło nam o przywołanie obrazów z przeszłości, zachowanych w pamięci 
zdarzeń, dobrej (bądź niekiedy trudnej czy złej) pamięci o napotkanych na drodze kariery akademickiej wykładowcach, profesorach, mistrzach, o przywołanie atmosfery powojennego nowo tworzącego się uniwersytetu. Z satysfakcją możemy stwierdzić, iż w dużej mierze nasze oczekiwania zostały spełnione. Jednak i tu należy wysunąć jedno zastrzeżenie. Od początku publikacja ta nie miała być opracowaniem historycznym ${ }^{6}$. Pytając rozmówców o przeszłość, czyli stawiając w jakimś sensie pytanie o to „co" się wydarzyło w ich życiu w kontekście związku ich biografii z uniwersytetem, na pierwszym planie sytuowałyśmy to, ,jak" zapamiętali tamten czas. Ważne było to, w jaki sposób o nim opowiadają, co eksponują wpisując własne doświadczenia życiowe w dzieje uniwersytetu, nie zaś to, co dokładnie, kiedy i dlaczego się wydarzyło. Krótko mówiąc, nie unieważniając sfery wydarzeń i faktów oraz ich autentycznego powiązania $\mathrm{z}$ historią, na pierwszy plan wysuwamy tu kwestię interpretacji wydobywanych z pamięci i opowiedzianych zdarzeń i doświadczeń osobistych.

Jak już zaznaczyłyśmy, nasze spotkania z rozmówcami i będąca ich efektem opowieść dokonywały się w trybie pamięci komunikacyjnej. Pojęcie to zostało wprowadzone do nauk społecznych przez niemieckiego historyka Jana Assmanna. Pamięć komunikacyjna obejmuje wspomnienia dotyczące najbliższej przeszłości, które dzielimy z sobie współczesnymi:

Typową jej odmianą jest pamięć pokoleniowa. Grupa społeczna zyskuje ją w procesie historycznym; pamięć ta powstaje w czasie i przemija wraz

${ }^{6}$ Jest wiele prac opisujących historię powstania i rozwoju Uniwersytetu Łódzkiego. Najważniejsze z nich to: Bohdan Baranowski (red.), Uniwersytet Łódzki: historia, teraźniejszość, perspektywy, Wydawnictwo Uniwersytetu Łódzkiego, Łódź 1978; Bohdan Baranowski, Uniwersytet Łódzki 1945-1980, Wydawnictwo Uniwersytetu Łódzkiego, Łódź 1980; tegoż, Pierwsze lata Uniwersytetu Łódzkiego: 1945-1949, Wydawnictwo Uniwersytetu Łódzkiego, Łódź 1985; Bohdan Baranowski, Krzysztof Baranowski, Trudne lata Uniwersytetu Łódzkiego: 1949-1956, Wydawnictwo Uniwersytetu Łódzkiego, Łódź 1990; Jakubowski Zbigniew, Ludzie matematyki łódzkiej, Łódzkie Towarzystwo Naukowe, Łódź 2012; Jarosław Kita, Profesorowie Uniwersytetu Łódzkiego w latach 1945-1994: pro memoria, Wydawnictwo Uniwersytetu Łódzkiego, Łódź 1995; tegoż, Uniwersytet Łódzki w latach 1945-1995, Wydawnictwo Uniwersytetu Łódzkiego, Łódź 1996; Jarosław Kita i Stefan Pytlas, W stużbie nauki. Profesorowie Uniwersytetu Łódzkiego w latach 1945-2004: pro memoria, Wydawnictwo Uniwersytetu Łódzkiego, Łódź 2005; Wiesław Puś, Zarys historii Uniwersytetu Łódzkiego 1945-2015, Wydawnictwo Uniwersytetu Łódzkiego, Łódź 2015. Poszczególnych jednostek Uniwersytetu Łódzkiego dotyczą m.in. prace: Wanda Małgorzata Krajewska, 50 lat biologii i nauk o ziemi w Uniwersytecie Łódzkim: 1945-1995, Wydawnictwo Uniwersytetu Łódzkiego, Łódź 1995; Julian Kuciński, Czterdzieści lat Wydziału Ekonomiczno-Socjologicznego Uniwersytetu Łódzkiego 1965-2005, Wydawnictwo Uniwersytetu Łódzkiego, Łódź 2006. 
z nią, a dokładniej rzecz biorąc - wraz z członkami grupy, czyli nosicielami pamięci ${ }^{7}$.

Każda generacja jest depozytariuszem pamięci, jednak przedstawiciele danego pokolenia nie są tylko swego rodzaju ,nośnikami” pamięci, ale też jej kreatorami, aktywnymi interpretatorami zdarzeń i procesów społecznych, w które uwikłane zostały ich biografie. Pamięć komunikacyjna jest zatem kształtowana przez pokoleniową wspólnotę losu. Chociaż więc przekaz międzygeneracyjny jest jednym z warunków trwania danej zbiorowości w sensie społecznym i kulturowym, zakorzenienie doświadczeń w określonym miejscu i czasie czyni je zawsze do pewnego stopnia niepowtarzalnymi w kolejnych pokoleniach ${ }^{8}$. „Aktywność” pamięci generacyjnej charakteryzuje się też swoją dynamiką. Assmann zauważa w tym kontekście pewną prawidłowość: po czterdziestu latach od wydarzenia, kiedy jego świadkowie przeorientują, z racji wieku, swoje życie z przyszłości na przeszłość, wzrasta pragnienie utrwalenia i przekazania jej innym. W taki sposób tworzy się wspólnota pamięci komunikacyjnej, której zakres, choć wybiega poza czas pamięci jednego pokolenia, budowany jest w oparciu o bezpośrednie narracje świadków. Ów wspólny horyzont doświadczenia, zdaniem badaczy historii mówionej, sięga obecnie około osiemdziesięciu lat. Paul Ricoeur mówił o okresie stu lat. Pamięć, będąc przede wszystkim działaniem komunikacyjnym, staje się wymianą narracji o przeszłości. $\mathrm{Z}$ tego względu budowanie pamięci poprzez transmisję międzypokoleniową łączy perspektywę co najmniej kilku wcześniejszych pokoleń - „dlatego spotkanie pamięci z historią obejmuje nie mniej niż stulecie"'.

Pytając o początki uniwersytetu, o biografie akademickie, które rozpoczęły się blisko 70 lat temu, a których autorzy kształtowani byli przez przedwojenne pokolenie profesorów, odczułyśmy siłę pamięci komunikacyjnej. Uczestniczyłyśmy w procesie ,spotkania pamięci z historią”, które istotnie objęło ,nie mniej niż stulecie”. Same też niejako poddałyśmy się trybowi pamięci komunikacyjnej wypracowując w naszych dyskusjach nad materiałem wspólne interpretacje. Jednym z ważnych elementów tego procesu była wymiana własnych, biograficznie uformowanych perspektyw postrzegania uniwersytetu i jego historii. Tak się bowiem złożyło, że

\footnotetext{
${ }^{7}$ Jan Assmann, Pamięć kulturowa: pismo, zapamiętywanie i polityczna tożsamość w cywilizacjach starożytnych, Wydawnictwo Uniwersytetu Warszawskiego, Warszawa 2008, s. 66.

${ }^{8}$ Karl Mannheim, Essays on Sociology of Knowledge, Oxford University Press, New York 1952, s. $286-320$.

${ }^{9}$ Paul Ricoeur, Pamięć - zapomnienie - historia, [w:] Krzysztof Michalski (red.), Tożsamość w czasach zmiany, Społeczny Instytut Wydawniczy Znak, Kraków 1995, s. 22.
} 
autorki tego opracowania dzieli dokładnie różnica lat dziesięciu i dwudziestu i urodziły się w trzech kolejnych dekadach: lat sześćdziesiątych, siedemdziesiątych i osiemdziesiątych. Nasze własne doświadczenia związane $\mathrm{z}$ uniwersytetem sięgają więc odpowiednio początku lat osiemdziesiątych, dziewięćdziesiątych i dwutysięcznych.

Dzięki wspólnym działaniom przeprowadzonych i przepisanych zostało trzydzieści wywiadów biograficzno-narracyjnych, których długość wahała się od jednej do sześciu godzin. Wywiady w formie nagrań $\mathrm{i}$ inne materiały zostały zdeponowane w archiwum materiałów jakościowych Katedry Socjologii Kultury Uniwersytetu Łódzkiego. Z jednej strony można stwierdzić, że to ,jedynie" trzydzieści opowieści. Z drugiej strony trzeba podkreślić, że owe trzydzieści relacji, które przełożyło się na ponad tysiąc stron transkrypcji, stanowi niezwykle zróżnicowany materiał źródłowy i badawczy, ukazujący losy środowiska uniwersyteckiego Łodzi. Wśród naszych rozmówców znaleźli się bowiem przedstawiciele: socjologii, historii, pedagogiki, polonistyki, psychologii, filozofii, archeologii, kulturoznawstwa, etnologii, historii sztuki, prawa, biologii, geografii, ekonomii, matematyki, fizyki i chemii ${ }^{10}$. Większość narratorów to emerytowani profesorowie. Różnorodność i bogactwo wątków tworzących mozaikę obrazów, ale też układających się zarazem w pewien wspólny obraz uniwersytetu sprzed kilkudziesięciu lat, potraktować należy jako ważny głos świadków, swoistą reprezentację (choć nie reprezentatywność) środowiska profesorów, których opowieści umożliwiają rekonstrukcję procesu wcielania idei universitas $\mathrm{w}$ - zaprojektowanej jako robotnicza - uczelni i powolnego jej wygasania współcześnie.

Porzucając, ze względu na wymienione okoliczności, pierwotny zamysł prezentacji in extenso zebranych opowieści, stanęłyśmy przed wyzwaniem opracowania tego niezmiernie bogatego i interesującego materiału. Starałyśmy się wybrać wszystkie wątki poruszane przez naszych rozmówców i uporządkować je według wspólnie opracowanej logiki ich prezentacji. Wszystkie zatem przedstawione $\mathrm{w}$ tej książce pola tematyczne zostały ukształtowane przez narratorów. Jak już zostało wspomniane, nasi rozmówcy sami „układali” swoje wspomnienia, gdy zostali postawieni przed zadaniem opowieści o własnym życiu w kontekście kariery akademickiej. Mając ogólne wyobrażenie, jak taka opowieść może wyglądać, nigdy nie wiedziałyśmy, jak ostatecznie zostanie ona skonstruowana, na co dany rozmówca będzie kładł szczególny nacisk, co dla niego okaże się ważne, a co

${ }^{10}$ Krótkie biogramy oraz fotografie rozmówców zamieszczone zostały przed pierwszym rozdziałem. 
uzna za wątki poboczne. Spróbujmy zatem odpowiedzieć sobie na pytanie: Jakie są tego konsekwencje?

Po pierwsze, Czytelnik może czasem odnieść wrażenie, że nie zostały zachowane proporcje $\mathrm{w}$ opisie poszczególnych tematów. Wynika to właśnie $\mathrm{z}$ faktu, iż niektórym kwestiom narratorzy poświęcali więcej bądź mniej miejsca.

Po drugie, przy opracowaniu konkretnych kategorii, odnosząc się do najbardziej sugestywnych i obrazowych wypowiedzi, korzystałyśmy z określonej ,puli” rozmówców, którzy wybranym wątkom poświęcili szczególnie dużo uwagi, podczas gdy inni do tych samych kwestii odnosili się marginalnie lub wcale.

Po trzecie, co wiąże się z poprzednim rozwiązaniem, wybrane fragmenty opowieści mają różny ciężar gatunkowy. Znajdziemy wśród nich: poważne komentarze analityczne dotyczące wizji uniwersytetu; nostalgiczne wspomnienia wpisane w najbardziej dynamiczną fazę życia, jaką jest młodość; dowcipne anegdoty czy odtwarzane dziś z przymrużeniem oka zdarzenia, których pierwotna rama społeczna traktowana była bardzo poważnie (np. opowieści dotyczące cenzury, mogącej zaważyć na całej karierze akademickiej); wreszcie opowieści trudne, związane z cierpieniem własnym bądź innych.

Po czwarte, niektóre z prezentowanych fragmentów są szczególnie bogate w treści i odnoszą się do kilku aspektów życia akademickiego. Chociaż starałyśmy się tego unikać, w kilku miejscach mogą zdarzyć się drobne powtórzenia i powroty do tematyki poruszanej wcześniej bądź też tylko anonsowanie wątków rozwiniętych w kolejnym rozdziale. Niestety jest to konsekwencją „rozbicia” poszczególnych opowieści, wyodrębnienia różnych wątków i zarazem dążenia do zachowania kontekstu historii życia.

Po piąte, w prezentowanych fragmentach Czytelnik znajdzie sporo nawiązań do socjologii (i socjologów). Fakt ów doskonale ilustruje tezę o znaczeniu interakcyjnego kontekstu dla wytwarzania opowieści o życiu, kontekstu, który stanowi, w naszym odczuciu, o szczególnej wartości zebranych wspomnień wywołanych w trybie pamięci komunikacyjnej. Ponieważ większość z osób przeprowadzających wywiady reprezentowała socjologię, nawiązania do doświadczeń związanych z socjologami, również przez rozmówców reprezentujących nauki przyrodnicze i ścisłe, było naturalną konsekwencją tej sytuacji. Dodać przy tym trzeba, że z racji możliwości łatwego dotarcia do socjologów wywiadów z przedstawicielami tej dyscypliny mamy proporcjonalnie najwięcej, bo aż pięć. 
Należy zarazem podkreślić, że nasza rola nie ograniczyła się jedynie do redakcji zebranych fragmentów rozmów. Ich wybór oraz uporządkowanie są w dużej mierze zgodne $\mathrm{z}$ naszą interpretacją tego, co uznałyśmy za ważne w zebranych opowieściach. Nie poddając więc cytatów analizie ${ }^{11}$, tę pozostawiamy Czytelnikowi, za jej formę uznajemy samą konstrukcję książki - jej właśnie podporządkowany został wybór wypowiedzi. Innymi słowy, naszą uwagę przykuły przede wszystkim te wątki, które ujawniały napięcie między odtwarzanym w opowieściach a współczesnym obrazem uniwersytetu. Claude Lévi-Strauss w Myśli nieoswojonej odnosi się do wspomnienia o Indianinie, który przybywszy do Nowego Jorku, nie interesował się w ogóle, wywołującym zazwyczaj duże wrażenia, wielkomiejskim obrazem przestrzeni, lecz

całą ciekawość intelektualną poświęcał karłom, olbrzymom i kobietom z brodą, które pokazywano wówczas na Times Square, automatycznym dystrybutorom posiłków i mosiężnym kulkom ozdabiającym wejście do windy. (...) wszystko to kwestionowało jego kulturę i to właśnie ją - tylko ją - próbował znaleźć w pewnych aspektach naszej ${ }^{12}$.

Mamy wrażenie, że nasze podejście do zebranych materiałów podobne jest do postawy owego Indianina. Słuchając a potem czytając opowieści o uniwersytecie sprzed siedemdziesięciu czy sześćdziesięciu lat, porównywałyśmy je ze współczesnym obrazem naszej uczelni i próbowałyśmy w opowieściach o tamtym czasie odnaleźć cząstkę dzisiejszego uniwersytetu $^{13}$. Czy zawsze nam się to udawało? Z pewnością nie. Mamy tu na myśli przede wszystkim ideę universitas, a więc wyobrażenia uczelni jako wspólnoty profesorów i studentów, gdzie rozwój intelektualny i studiowanie, wsparte dyskusją akademicką, stanowią podstawowe ramy dla funkcjonowania akademii. Stąd tyle uwagi w zebranych opowieściach poświęciłyśmy sposobowi studiowania: seminariom, wykładom, egzaminom, figurze mistrza jako osobie kształtującej naukową (a często nie tylko) osobowość ucznia, pasji i zaangażowaniu we własny rozwój intelektualny oraz rozwój innych. Zostanie to pokazane w rozdziałach I i II. Mamy wrażenie,

\footnotetext{
${ }^{11}$ Tego typu analiza polegałaby m.in. na opisie struktur argumentacyjnych, sposobu prezentacji siebie i innych, interpretacji komentarzy opowiadanych sytuacji, odpowiedzi na pytania, jak skonstruowany jest opis zdarzeń i jakim interpretacjom narratora ma służyć itp.

${ }^{12}$ Claude Lévi-Strauss, Myśl nieoswojona, thum. Andrzej Zajączkowski, Wydawnictwo KR, Warszawa 2001, s. 33.

${ }^{13}$ Inspirację do zacytowania tego fragmentu stanowił artykuł Marcina Lubasia Lévi-Strauss, etnocentryzm i zróżnicowanie kulturowe, [w:] Ewa Nowicka, Małgorzata Głowacka-Grajper (red.), Antropolog i jego magia: wspótczesne inspiracje twórczościa Claude’a Lévi-Straussa, Zakład Wydawniczy Nomos, Kraków 2013.
} 
że niestety wiele się w tych kwestiach zmieniło i nie ukrywamy, że w odniesieniu do tej problematyki trudno jest nam zachować Weberowski postulat nauki wolnej od wartości. Nasza oceniająca i krytyczna perspektywa wyrażona jest przede wszystkim przez rozłożenie akcentów w prezentacji wątków w rozdziale I oraz dokładniej wyjaśniona w Zakończeniu. Zdajemy sobie też sprawę, iż perspektywa uwypuklająca pozytywne cechy ówczesnego uniwersytetu przesłania napięcia ideologiczne, wewnętrzne zależności i podporządkowania. Jest to uwarunkowane dwiema okolicznościami. Po pierwsze, nasi rozmówcy w zasadzie niewiele o tych aspektach mówili (kwestii uwarunkowań ideologiczno-politycznych poświęcamy przy tym osobny rozdział). Po drugie, nasze wyczulenie na różnicę między tamtym a współczesnym uniwersytetem ukształtowane jest przez dominujące dziś odczucie presji wyrażające się w oczekiwaniach instytucjonalnych, coraz bardziej rozbudowanych wymaganiach formalnych (charakterystycznych dla modelu uczelni przedsiębiorczej $)^{14}$ pozostawiających coraz mniej przestrzeni na ożywienie idei universitas. Uzupełnieniem obrazu zarysowanego w pierwszych dwóch rozdziałach jest rozdział III, w którym pokazujemy, co stanowiło kluczowe elementy biografii naukowej naszych rozmówców. $\mathrm{Z}$ kolei $\mathrm{w}$ odniesieniu do problematyki poruszanej w rozdziałach IV i V staramy się zachować dystans - zamiast ocen, krytyki i moralizowania, skupiamy się na przedstawieniu skomplikowanego charakteru ówczesnej rzeczywistości. Zestawiamy tu różne do niej nastawienia, pokazujemy odmienne, często przeciwstawne interpretacjie i komentarze naszych rozmówców dotyczące określonych wydarzeń. Rozdział ostatni - „Miejsca i materialność akademii" - choć, jak wskazuje tytuł, skoncentrowany jest na materialnym aspekcie rzeczywistości, stanowi, w naszym odczuciu, klamrę spinającą przeszłość z teraźniejszością, przez pokazanie powolnego wtapiania się uniwersytetu $\mathrm{w}$ tkankę naszego miasta. We wszystkich rozdziałach postanowiłyśmy przede wszystkim oddać głos naszym rozmówcom. Są oni bowiem nie tylko świadkami powstania uczelni, ale też jej współtwórcami przez związanie swoich losów z losami uniwersytetu.

Długo dyskutowałyśmy nad konstrukcją książki i zdajemy sobie sprawę, że przyjęta prezentacja materiału jest jednym z możliwych wariantów. W naszym zamyśle pierwsze trzy rozdziały skoncentrowane są wokół indywidualnych aspektów biografii naukowej, zaś trzy kolejne ukazują zbiorowe (tj. historyczne, społeczne i polityczne) uwarunkowania tych doświadczeń. Przy czym rozróżnienie na kolektywny i indywidualny aspekt

\footnotetext{
${ }^{14}$ Zob. Kamila Biały, Przemiany wspótczesnego uniwersytetu...
} 
biografii ma charakter czysto analityczny i służy uporządkowaniu opisu. Bierzemy też pod uwagę, iż przyjęta przez nas chronologia u Czytelnika, nie związanego bezpośrednio ze środowiskiem UŁ, może rodzić trudności w kontekstualizacji początkowych wątków. Książkę tę można rzecz jasna czytać wybierając poszczególne rozdziały, a nawet ich fragmenty, gdyż wszystkie części skonstruowane są przede wszystkim w oparciu o wybrane, często obszerne, cytaty z zebranych rozmów, a każdy z nich sam w sobie jest niezwykle interesujący. Zachęcamy zarazem do lektury całej pracy, która, mamy nadzieję, pozwala na stworzenie, choć z pewnością nie całościowego, to wielowymiarowego i barwnego obrazu naszej uczelni, naszkicowanego w opowieściach jej pracowników.

$* * *$

Podziękowania autora przybierają czasem formę rytualnej kontrybucji na rzecz sponsorów, osób wspomagających proces powstania książki, współpracowników. W przypadku naszej publikacji, której nietypowość została zaznaczona wcześniej, podziękowania mają charakter szczególny i nie wynikają z konieczności zadośćuczynienia konwencji.

Pragniemy zatem podziękować przede wszystkim naszym Rozmówcom - nestorom naszego Uniwersytetu reprezentującym przeróżne, dla nas niekiedy zupełnie odległe dyscypliny naukowe - za poświęcony nam czas, podjęty wysiłek opowiadania, a zwłaszcza możliwość spotkania, często w ich prywatnej przestrzeni domowej. Wysłuchanie opowieści umieszczonych w ramach różnych dyscyplin naukowych było dla nas nie tylko fascynujące, ale też bardzo pouczające, gdyż pozwalało nam zrozumieć uniwersalność i zarazem partykularność świata nauki. Dziękujemy naszym Rozmówcom za sprostanie trudnej próbie zmierzenia się z własną opowieścią na poziomie konfrontacji mowy żywej z jej literackim wyobrażeniem, którym każdy z nas posługuje się, zwłaszcza w odniesieniu do własnych autoprezentacji. Lista Rozmówców, wraz z krótkimi notkami biograficznymi, znajduje się poniżej.

Dziękujemy osobom, które korzystając z osobistych kontaktów, dotarły do niektórych Rozmówców i przeprowadziły z nimi wywiady: Ewie Ciszewskiej, Marcie Madejskiej, Adriannie Szczerbie, Marcie Piechockiej, Annie Rawickiej, Joannie Wygnańskiej, Sebastianowi Zaborowskiemu. Dziękujemy uczestnikom naszych seminariów badawczych - zwłaszcza Andrzejowi Czyżewskiemu - oraz innym naszym gościom, którzy komentowali wstępne analizy a także sugerowali nowe perspektywy. 
Dziękujemy wszystkim wolontariuszom, którzy wspierali nas w procesie transkrypcji wywiadów. Byli to studenci odbywający praktyki w Stowarzyszeniu Topografie oraz członkowie Stowarzyszenia: Izabela Smuga, Agnieszka Gajewska, Piotr Lipski. Za pomoc i szczególne wsparcie organizacyjne dziękujemy także Katarzynie Łuczak.

Dziękujemy naszym współpracownikom z Katedry Socjologii Kultury - profesorom: Zbigniewowi Bokszańskiemu i Kazimierzowi Kowalewiczowi, doktorom: Mieczysławowi Marciniakowi i Renacie Dopierale oraz doktorantom: Jackowi Burskiemu, Joannie Wygnańskiej, Patrycji Kruczkowskiej i Dorocie Rajchel, którzy na zebraniach katedry podzielili się swoimi komentarzami do pierwszej wersji książki.

Dziękujemy Dyrektorowi Archiwum UŁ dr Dariuszowi Klemantowiczowi oraz Andrzejowi Pielatowi za pomoc w wyszukiwaniu zdjęć zdeponowanych w Archiwum UŁ jak też Monice Borowczyk i Alinie Jabłońskiej za konsultacje merytoryczne dotyczące topografii miasta.

Dziękujemy J.M. Rektorowi Uniwersytetu Łódzkiego prof. Włodzimierzowi Nykielowi za życzliwe potraktowanie naszego projektu i finansowe wsparcie w pierwszej jego fazie. Otrzymane środki pozwoliły na sfinansowanie części transkrypcji.

Autorki tej publikacji dziękują też sobie nawzajem za mobilizację do działania, dobrą współpracę i pouczający proces wypracowywania wspólnej perspektywy prowadzącej do ostatecznego kształtu tej książki. Odwołując się do otwierającego wstęp motta, możemy wyrazić sobie wzajemną wdzięczność za przedsięwzięcie próby, zdobycie pouczenia i wspólny wysiłek, by nie utracić bezcennych możliwości. To, czy książkę można uznać za dobra robote, pozostawiamy ocenie Czytelnika. 



\section{Biogramy i fotografie rozmówców}

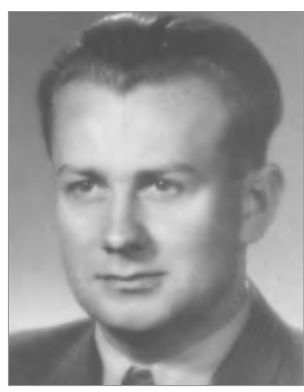

Fot. 1

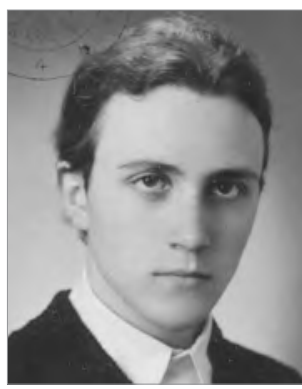

Fot. 2

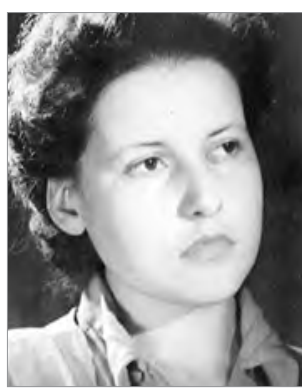

Fot. 3
Stefan Banasiak (ur. 1929) - historyk, absolwent nauk społecznych na Uniwersytecie Łódzkim, magisterium uzyskał w 1955 roku na Uniwersytecie Warszawskim. W 1953 roku rozpoczął pracę w UŁ w Katedrze Podstaw Marksizmu-Leninizmu, następnie Historii Polski Najnowszej, dyrektor Instytutu Historii w latach 1970-1978. Specjalizuje się w powojennych dziejach Polski.

Zbigniew Bokszański (ur. 1940) - socjolog, absolwent socjologii na Uniwersytecie Łódzkim, uczeń i współpracownik Antoniny Kłoskowskiej, wieloletni kierownik Katedry Socjologii Kultury UŁ, swoje prace naukowe poświęcił tematyce tożsamości zbiorowych i nowoczesności. W latach 1991-2001 profesor w Instytucie Stosowanych Nauk Społecznych Uniwersytetu Warszawskiego.

Teresa Cieślikowska (ur. 1926) - filolog, ukończyła polonistykę na Uniwersytecie Łódzkim. Kierownik Zakładu Teorii Literatury, potem Katedry Teorii Literatury, dyrektor Instytutu Teorii Literatury, Teatru i Filmu UŁ. Jej zainteresowania naukowe zorientowane są wokół tematyki intertekstualności i genealogii. 


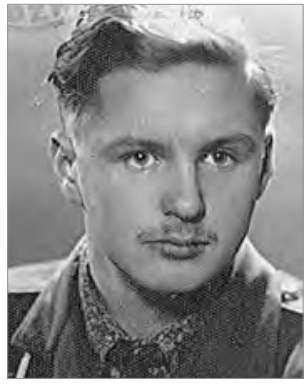

Fot. 4

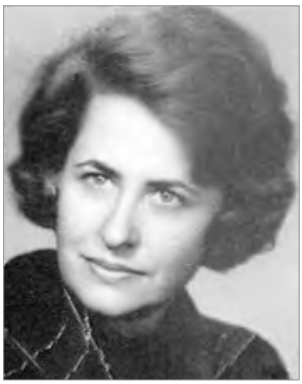

Fot. 5

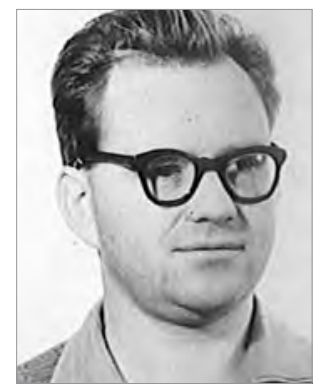

Fot. 6

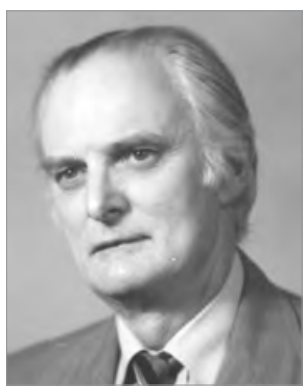

Jerzy Dietl (ur. 1927) - ekonomista, absolwent Akademii Handlowej w Poznaniu, związany z Uniwersytetem Łódzkim od lat siedemdziesiątych najpierw z Wydziałem EkonomicznoSocjologicznym, następnie $\mathrm{z}$ nowo utworzonym Wydziałem Zarządzania, gdzie współtworzył i kierował Katedrą Marketingu. Jego prace naukowe dotyczą przedsiębiorczości i marketingu, doradca „Solidarności”, senator I kadencji w wyborach w czerwcu 1989 roku.

Sławomir Cieślikowski (ur. 1926) - psycholog, absolwent Uniwerytetu Łódzkiego, orientalista (indianista, studiował u dr Stefana Franciszka Michalskiego w UŁ), aktywny psycholog i psychoterapeuta; naukowe publikacje z psychologii i teorii literatury staroindyjskiej, emerytowany starszy wykładowca w Instytucie Filologii Orientalnej Uniwersytetu Jagiellońskiego. Jego kariera naukowa przebiegała w sposób niestandardowy.

Olga Czerniawska (ur. 1930) - pedagog, absolwentka historii na Uniwersytecie Łódzkim, wicedyrektor Instytutu Pedagogiki, kierownik Zakładu Andragogiki i Gerontologii Społecznej a następnie Katedry Teorii Wychowania UŁ, prodziekan ds. studentów na Wydziale Filozoficzno-Historycznym (1980-1983), wieloletnia przewodnicząca łódzkiego Oddziału Polskiego Towarzystwa Gerontologicznego, specjalistka w zakresie historii oświaty dorosłych, poradnictwa i gerontologii.

Eugeniusz Czerniawski (ur. 1926, zm. 2015) - biolog, absolwent Uniwersytetu Łódzkiego, uczeń prof. Bernarda Zabłockiego, adiunkt w Katedrze Mikrobiologii Przemysłowej i Biotechnologii, vice dyrektor Instytutu Mikrobiologii i Immunologii, zaangażowany w rozbudowę infrastruktury Wydziału Biologii i Nauk o Ziemi, specjalizował się w mikrobiologii lekarskiej i przemysłowej, sterylizacji radiacyjnej, rozwinął badania stosowane w różnych gałęziach przemysłu.

Fot. 7 


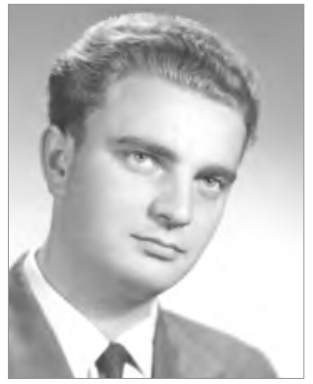

Fot. 8

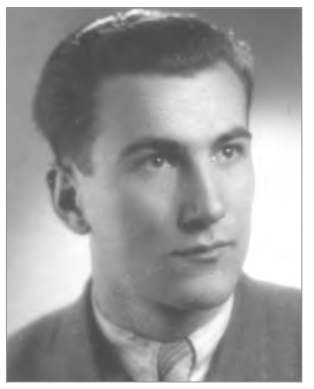

Fot. 9

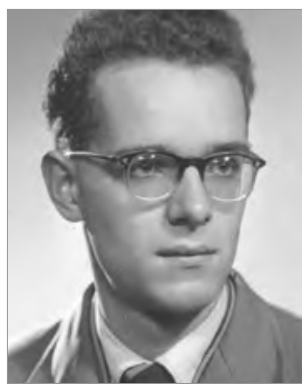

Fot. 10

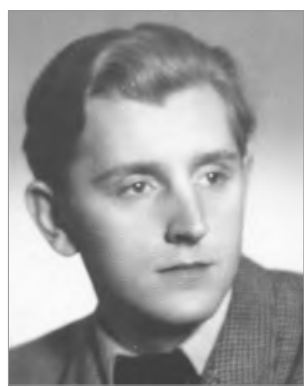

Jerzy S. Kmieciński (ur. 1927) - archeolog, absolwent Uniwersytetu Łódzkiego i uczeń Konrada Jażdżewskiego, wieloletni kierownik Katedry Archeologii UŁ oraz Ośrodka Badań i Studiów Wschodnich. Swoje prace naukowe poświęcił prahistorii oraz metodologii badań archeologicznych.

Ryszard Jajte (ur. 1933) - matematyk, profesor zwyczajny, absolwent Uniwersytetu Łódzkiego, twórca łódzkiej szkoły teorii prawdopodobieństwa, dyrektor instytutu Matematyki UŁ (19731981) oraz organizator i wieloletni kierownik Katedry Teorii Prawdopodobieństwa i Statystyki UŁ. Wykładał m. in. w USA, Kanadzie, RFN, Szwajcarii. Autor ponad 100 prac, w tym 2 monografii wydanych przez Springera.

Zbigniew Jakubowski (ur. 1934) - matematyk, absolwent Uniwersytetu Łódzkiego, uczeń Witolda Janowskiego. Początkowo pracował na Politechnice Łódzkiej, a następnie na Uniwersytecie Łódzkim. W 1970 r. zorganizował Zakład Matematyki Ogólnej, dziekan Wydziału Matematyki, Fizyki i Chemii. Pełnił wiele funkcji w Polskim Towarzystwie Matematycznym oraz ŁTN. W swoich badaniach zajmował się przede wszystkim geometryczną teorią funkcji analitycznych.

Krzysztof Jażdżewski (ur. 1938) - biolog, absolwent Uniwersytetu Łódzkiego związany z Katedrą Zoologii Bezkręgowców i Hydrobiologii, prorektor UŁ ds. nauki (1990-1996), pełnił funkcje kierownicze w Komitecie Zoologii PAN, specjalizuje się w biologii morza, w szczególności taksonomii i morfologii skorupiaków. Uczestnik naukowych wypraw polarnych.

Fot. 11 


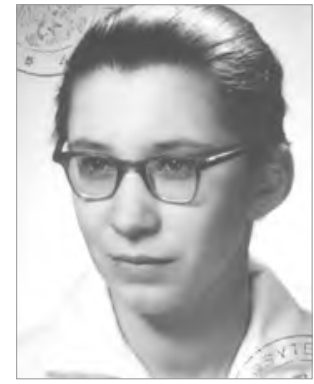

Fot. 12

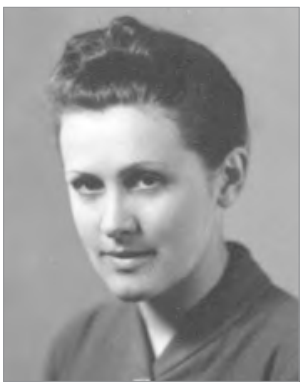

Fot. 13

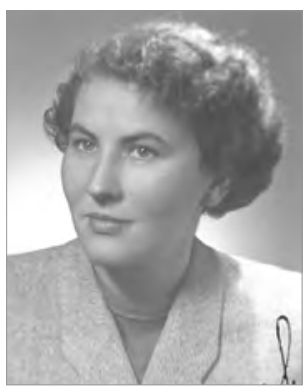

Fot. 14

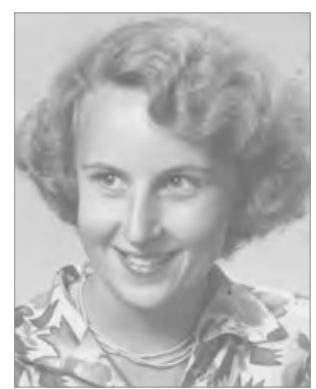

Fot. 15
Grażyna Kononowicz (ur. 1942) - absolwentka socjologii na Uniwersytecie Łódzkim, bibliotekarz dyplomowany, wieloletni pracownik i kierownik Biblioteki Socjologicznej im. Józefa Chałasińskiego, autorka opracowań bibliografii prof. Jana Szczepańskiego, Antoniny Kłoskowskiej oraz Jana Lutyńskiego (wspólnie z Krystyną Lutyńską).

Bronisława Kopczyńska-Jaworska (ur.1924) - etnografka, uczennica Kazimiery Zawistowicz-Adamskiej, z którą współtworzyła a następnie kierowała Katedrą Etnografii Uniwersytetu Łódzkiego. Początkowo zajmowała się badaniami kultury pasterskiej w Karpatach i na Bałkanach, następnie także kultury miasta.

Jolanta Kulpińska (ur. 1928) - absolwentka socjologii na Uniwersytecie Łódzkim, kierownik Zakładu Socjologii Przemysłu w latach 1971-1999, wieloletnia dyrektor Instytutu Socjologii UŁ (1976-1999) oraz redaktor naczelna Przeglądu Socjologicznego. W 1985 roku otrzymała tytuł doctora honoris causa Uniwersytetu w Tampere (Finlandia). Pole jej naukowych zainteresowań stanowi przede wszystkim socjologia pracy i przemysłu.

Biruta Lewaszkiewicz-Petrykowska (ur. 1927) - prawnik, absolwentka Uniwersytetu Jagiellońskiego, kierownik Katedry Prawa Cywilnego Uniwersytetu Łódzkiego, dwukrotnie dziekan Wydziału Prawa (1981-1984 oraz 1993-1996), sędzia Trybunału Konstytucyjnego, zajmuje się prawem cywilnym i prawem porównawczym. 


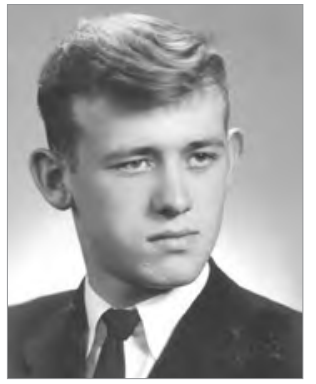

Fot. 16

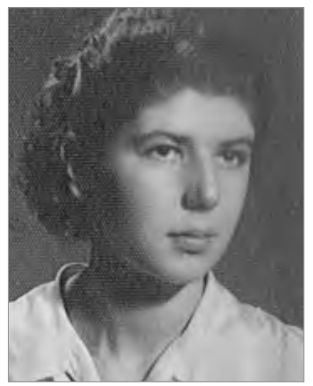

Fot. 17

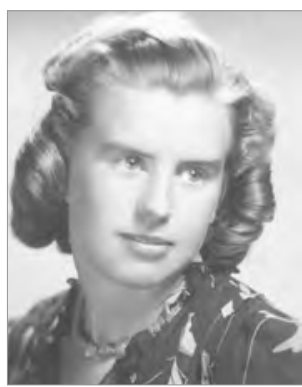

Fot. 18

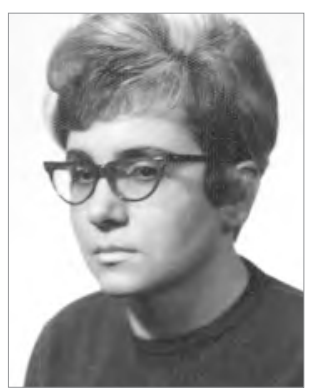

Fot. 19
Stanisław Liszewski (ur. 1940, zm. 2016) - geograf, absolwent Uniwersytetu Łódzkiego, twórca Zakładu Geografii Miast, dyrektor Instytutu Geografii Miast i Turyzmu UŁ, dziekan Wydziału Biologii i Nauk o Ziemi (1981-84), w latach 1984-1990 Prorektor a od 1996 do 2002 Rektor UŁ. Doctor honoris causa Politechniki Łódzkiej (2011) i Uniwersytetu w Preszowie na Słowacji (2013), wieloletni przewodniczący Łódzkiego Towarzystwa Naukowego. Specjalizował się w geografii miast i osadnictwie oraz geografii turyzmu.

Krystyna Lutyńska (ur. 1931) - socjolog, absolwentka Uniwersytetu Łódzkiego, pracowała w Katedrze Technik Społecznych Badań Terenowych UŁ kierowanej przez prof. Jana Szczepańskiego, a następnie długie lata w Instytucie Filozofii i Socjologii PAN gdzie przez dziesięć lat była kierownikiem Zakładu Metodologii Badań Społecznych. Wieloletnia przewodnicząca Oddziału Polskiego Towarzystwa Socjologicznego w Łodzi. Realizowała badania z zakresu struktury społecznej i socjologii zawodu, specjalizuje się w metodologii empirycznych badań społecznych.

Wanda Nowakowska (ur. 1929) - historyk sztuki, absolwentka Uniwersytetu Łódzkiego i wychowanka Mieczysława Wallisa, pracowała i przez wiele lat kierowała Zakładem, a następnie Katedrą Historii Sztuki oraz związanym z nim kierunkiem studiów reaktywowanym w 1992 roku po czterdziestu latach nieobecności na UŁ. W polu jej naukowych zainteresowań znajduje się polska krytyka artystyczna dziewiętnastego wieku - głównie Stanisława Witkiewicza, ojca; jak również problematyka nowożytnego malarstwa europejskiego.

Ewelina Nurczyńska-Fidelska (ur. 1938, zm. 2016) - profesor Uniwersytetu Łódzkiego, wykładowczyni Wyższej Szkoły Sztuki i Projektowania w Łodzi. Prezes Stowarzyszenia Kulturalno-Edukacyjnego „Venae Artis”. Autorka i redaktorka licznych publikacji filmoznawczych i monografii. Jedna z koordynatorek zrealizowanego we współpracy z Polskim Instytutem Sztuki Filmowej projektu Filmoteka Szkolna prowadzonego przez Centrum Edukacji Obywatelskiej. W 2010 roku laureatka Nagrody Polskiego Instytutu Sztuki Filmowej w kategorii „Krytyka filmowa". 


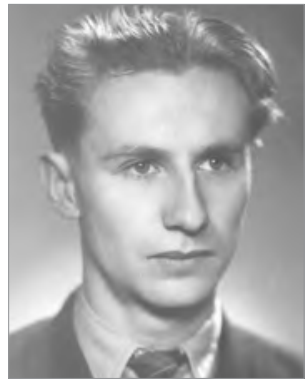

Fot. 20

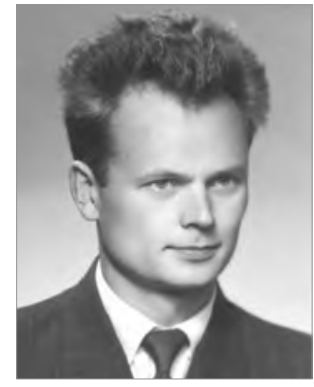

Fot. 21

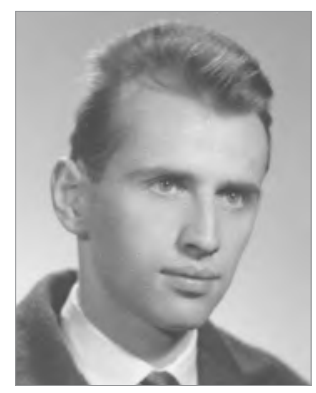

Fot. 22

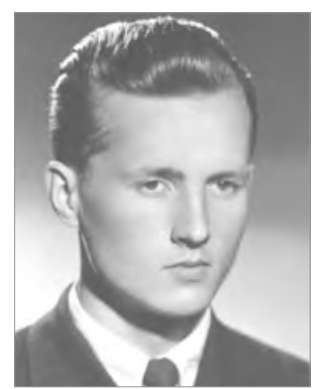

Fot. 23
Romuald Olaczek (ur. 1934) - przyrodnik, absolwent geografii Uniwersytetu Łódzkiego, uczeń Jakuba Mowszowicza, rozwijał zainteresowania naukami biologicznymi w Katedrze Geobotaniki i Ekologii Roślin UŁ, współtworzył kierunek studiów „Ochrona środowiska”. Prace naukowe poświęcał tematyce antropogenicznych przemian flory i fauny oraz ochronie przyrody.

Ryszard Panasiuk (ur. 1931) - historyk filozofii, absolwent Uniwersytetu Warszawskiego, uczeń Tadeusza Krońskiego i Bronisława Baczki, wieloletni kierownik Katedry Filozofii i Instytutu Filozofii UŁ. Swoje prace poświęcił filozofii niemieckiej XVIIXIX wieku w szczególności poglądom Kanta, Schellinga i Hegla i jego szkoły, w tym także Marksa. Wypromował 9 doktorów, opublikował 9 książek oraz ok. 180 artykułów.

Andrzej Piechocki (ur. 1938) - biolog, absolwent Uniwersytetu Łódzkiego, pracownik Katedry Zoologii Bezkręgowców i Hydrobiologii UŁ (w latach 1989-2008 jej kierownik), specjalista w zakresie taksonomii, biologii i ekologii mięczaków. Wieloletni członek Komitetu Zoologii PAN, redaktor naczelny serii wydawniczej „Fauna Słodkowodna Polski”. Kierownik ekspedycji naukowych UŁ na Saharę i do Afryki Zachodniej (1974/75) oraz do Konga (1988).

Michal Seweryński (ur. 1939) - prawnik, absolwent Uniwersytetu Łódzkiego, uczeń Wacława Szuberta, kierował Zakładem Zbiorowych Stosunków Pracy i Polityki Społecznej oraz Katedrą Prawa Europejskiego, prodziekan (1981-1984) i dziekan (1984-1987) Wydziału Prawa i Administracji, a następnie prorektor (19871990) i rektor (1990-1996) UŁ, pełnił funkcję ministra edukacji i nauki oraz ministra nauki i szkolnictwa wyższego (2005-2007), członek Papieskiej Rady ds. Świeckich w latach 1996-2006, senator RP VIII kadencji, specjalizuje się w międzynarodowym prawie pracy. 


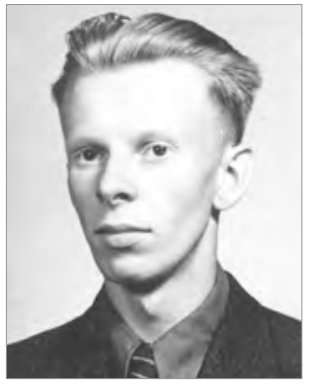

Fot. 24

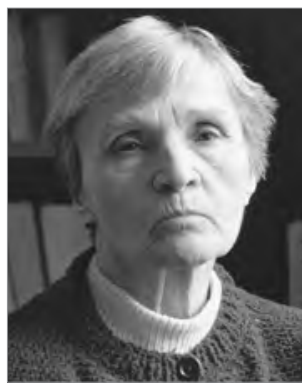

Fot. 25

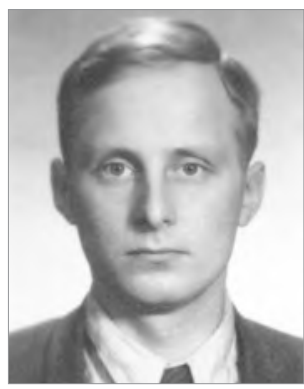

Fot. 26

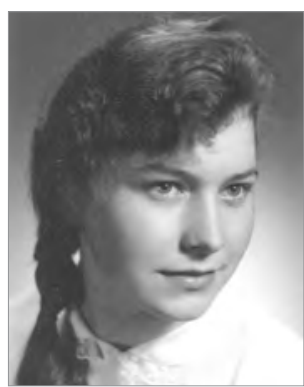

Janina Tobera (ur. 1944) - socjolog, absolwentka Uniwersytetu Łódzkiego, uczennica Aleksandra Kamińskiego i Antoniny Kłoskowskiej, pracowała w Katedrze Socjologii Kultury, działaczka Uniwersytetów Ludowych, łączy wykształcenie socjologiczne z zainteresowaniami pedagogicznymi, zajmowała się socjologią wychowania.

Romuald Skowroński (ur. 1926, zm. 2013) - chemik, absolwent Uniwersytetu Łódzkiego, pracował w Zakładzie a następnie Katedrze Chemii Organicznej. W latach 1958-1962 podczas pobytu w Paryżu prowadził badania naukowe zdobywając stopień Docteur ès sciences Uniwersytetu Paryskiego (Sorbony). Od 1970 zastępca dyrektora Instytutu Chemii. W latach 1972-1975 - prorektor UŁ ds. rozwoju, I zastępca Rektora. W latach 1975-1981 - rektor UŁ (dwie kadencje). W latach 1981-1990 - dyrektor Instytutu Chemii.

Krystyna Śreniowska (ur. 1914, zm. 2013) - historyk, absolwentka Uniwersytetu im. Jana Kazimierza we Lwowie, po wojnie podjęła pracę na Uniwersytecie Łódzkim w Instytucie Historii. Specjalizowała się w historii historiografii i studiach nad świadomością historyczną. Od lat 70 . była zaangażowana w działalność opozycyjną.

Edward Tranda (ur. 1924, zm. 2015) - biolog, absolwent Uniwersytetu Łódzkiego, przez wiele lat związany z Muzeum Przyrodniczym UŁ, jego badania dotyczyły zoogeografii, a w szczególności rodziny krętakowatych. Ceniony badacz ptaków i owadów.

Fot. 27 


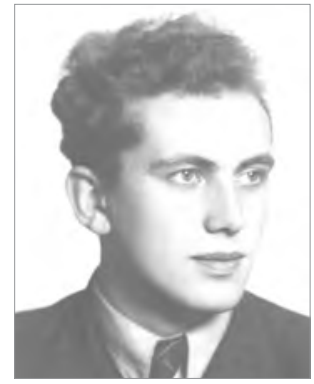

Fot. 28

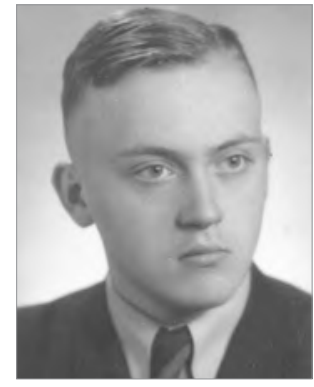

Fot. 29

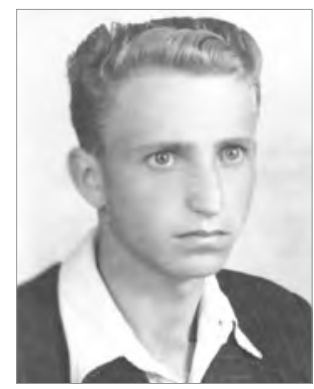

Fot. 30

Władysław Welfe (ur. 1927, zm. 2013) - makroekonomista, ekonometryk, absolwent Uniwersytetu Łódzkiego, twórca i wieloletni dyrektor Instytutu Ekonometrii i Statystyki UŁ, dziekan Wydziału Ekonomiczno-Socjologicznego (1967-1970), prorektor ds. nauki UŁ (1974-1978), członek Polskiej Akademii Nauk, członek Ukraińskiej Akademii Nauk, doctor honoris causa czterech uniwersytetów. Specjalista z zakresu makromodelowania i modeli wzrostu gospodarczego.

Leszek Wojtczak (ur. 1939) - fizyk, absolwent Uniwersytetu Łódzkiego, współorganizator i kierownik Katedry Fizyki Ciała Stałego UŁ, dziekan Wydziału Matematyki, Fizyki i Chemii (1984-1990), Rektor UŁ (1984-1990), specjalizuje się w zakresie teorii ciała stałego.

Jan Ziomek (ur. 1934, zm. 2014) - geograf, absolwent Uniwersytetu Łódzkiego, założyciel i kierownik Muzeum Geologicznego UŁ, nauczyciel akademicki Wydziału Biologii i Nauk o Ziemi oraz Wydziału Nauk Geograficznych, jego pasją była geologia. 


\section{Rozdzial I. Inicjacja w świat nauki}

Po powstaniu warszawskim do Krakowa się zwaliło pót Warszawy, tam
już oddychać nie można było. I wtedy mój mąż zostawit mnie w Krakowie
$i$ wyruszyt $w$ podróż (...). Gdzie nie pojechat, tam były gruzy. Wrocław
- gruzy, Gdańsk - okropny. Jednym słowem, nie bardzo sie było gdzie
zaczepić, bo wszystko było zniszczone $i$ ta Łódź nas zdumiewała, bo ona
stała na miejscu, nie było gruzów. To było coś bardzo dziwnego. Wrócił do
Krakowa i powiada, że próbujemy w Łodzi, że tutaj się tworzy uniwersytet Krakowa i powiada, że próbujemy w Łodzi, że tutaj się tworzy uniwersytet
- próbujemy $w$ Łodzi.

Z wywiadu z profesor Krystyną Śreniowską

W moim życiu Uniwersytet odegrat bardzo wielka rolę. W ogóle to, że ja się na tej socjologii znalazłam, to może tak troche przypadkowo, ale ci profesorowie, którzy mnie wtedy uczyli, mieli na mnie ogromny wpływ.

Z wywiadu z profesor Krystyną Lutyńską

Tak jak każda biografia jest wyjątkowa i niepowtarzalna, tak i każda z zebranych przez nas opowieści jest autorskim śladem odciśniętym na historii życia społecznego przez przedstawienie w niej obrazu osobistych doświadczeń. Jak już zostało to wyjaśnione we wstępie, rozmówcy sami decydowali o tym, od czego rozpoczną narrację i jakim etapom swojej biografii poświęcą mniej bądź więcej miejsca. Niektórzy zatem powracali do wspomnień z dzieciństwa, domu, postaci rodziców, wczesnych lat szkolnych. Inni rozpoczynali od podjęcia nauki w szkole średniej czy czasu studiów. Te swoiste dla każdej biografii doświadczenia wpisane zostały w społeczny cykl życia podporządkowany określonym jego etapom kształtowanym nie tylko przez indywidualne wybory, ale też przez okoliczności kulturowe, polityczne czy historyczne, tworząc świadectwo życia pokolenia urodzonego w okresie międzywojennym. Zapewne podobne obrazy spotkać można w wielu tak często dziś publikowanych (auto)biografiach i innych tekstach kultury o charakterze wspomnieniowym, odnoszących się do tamtego czasu. Przywołujemy zatem fragmenty narracji naszych rozmówców, by ,potwierdzić” ich przynależność generacyjną, a przez wspomnienia pokazać świat, którego pozostają częścią, a który, zwłaszcza w odniesieniu do 
interesującej nas tu problematyki, należy już do przeszłości. Jego obraz jest jednak wciąż żywy dzięki pamięci komunikacyjnej.

Niewątpliwie podjęty sposób budowania opowieści o dzieciństwie i okresie młodości podporządkowany został ogólnej ramie interpretacyjnej przeprowadzonych rozmów, jaką było spotkanie nestorów Uniwersytetu Łódzkiego, dziś w większości emerytowanych profesorów, z młodymi przedstawicielami (czasem studentami) naszej uczelni. Budując wspomnienia, narratorzy akcentowali więc momenty charakterystyczne dla późniejszej formacji akademickiej, a zwłaszcza te doświadczenia biograficzne, które odnosiły się do procesu kształcenia i edukacji. Jak zresztą zobaczymy, nie zawsze proces ów przebiegał gładko, bez porażek, z pełną świadomością i z od początku należytym zaangażowaniem. Ścieżki prowadzące naszych rozmówców do kariery akademickiej nawet u swego początku bywały kręte. Czasem rozbudzenie zainteresowania nauką, chęć zdobywania wiedzy czy wreszcie pasja związana z konkretną dyscypliną ewaluowały w czasie. Niektórzy wskazywali moment czy jedną scenę, która stanowiła o wyborze przyszłej drogi życiowej. Najczęściej przywoływanymi w tym kontekście elementami („siłami sprawczymi”) stały się dom rodzinny, ważne osoby (jak rodzic czy nauczyciel potrafiący zainteresować danym tematem), szkoła, środowisko rówieśnicze, ale także okoliczności historyczne związane z wojną czy, w okresie studiów, stalinowską reformą nauki. Jak to pokażemy dalej, niektórzy sięgali tu do wspomnień z dzieciństwa, w przypadku innych zainteresowania i pasja krystalizowały się dużo później. Jednak dla wszystkich bez wyjątku momentem kluczowym dla zetknięcia się ze światem akademii było wejście w rolę studenta. Pójście na uczelnię w czasach, kiedy studiowali nasi rozmówcy było udziałem cały czas dość wąskiej grupy młodzieży. To również jeden z powodów, dla którego decyzja o podjęciu studiów, wybór kierunku i początki studiowania były powszechnie poruszanym w narracjach tematem. Jednocześnie był to okres, kiedy biografia naukowa wciąż nie została domknięta i związek z uczelnią przyszłych jej pracowników był do pewnego momentu taki sam jak tysięcy innych studiujących młodych ludzi - uczęszczających na te same wykłady, podobnie spędzających czas wolny, przeżywających młodzieńcze zauroczenia i fascynacje, również te ideologiczne, o których opowiemy w dalszej części książki.

W tym rozdziale zamierzamy pokazać zatem, co przede wszystkim, w perspektywie samych rozmówców, stało się dla nich czynnikiem formacyjnym dla rozwoju przyszłych zainteresowań naukowych. Podążając za ich argumentacją, przedstawiamy opisaną w niektórych wspomnieniach 
charakterystykę przedwojennej szkoły, uczących w niej nauczycieli, wspierających wczesną edukację dzieci rodziców, krystalizujące się pasje, wreszcie naznaczające tę generację doświadczenie wojny, którego jedną z konsekwencji było zaburzenie fazy cyklu życia, związanej z intensywnym procesem edukacji.

Drugą część tego rozdziału poświęcimy doświadczeniu studiowania będącemu szczególnym okresem formacyjnym w biografii narratorów. Jego wyjątkowość jest argumentowana nie tylko ex post, jako wyraźnie zdefiniowany z dzisiejszej perspektywy zaczyn kariery akademickiej. Wynika ona również z osobliwości początków naszego uniwersytetu, który, zwłaszcza w pierwszej dekadzie swego istnienia, zgromadził wielu wybitnych polskich naukowców, oraz z niepowtarzalnego w kolejnych generacjach doświadczenia trybu studiowania, który zwłaszcza na skutek reformy uniwersytetu w 1948 roku z wolna zaczął zanikać i dziś w takim kształcie jest już nie do odtworzenia.

\section{Kłącza inicjujące}

Niezwykle ciekawym wątkiem w opowieściach naszych narratorów była próba znalezienia odpowiedzi na pytanie, co w istocie stanowiło ,zaczyn” ich późniejszej kariery uniwersyteckiej - nierzadko uwieńczonej profesurą. Patrząc wstecz na swoje życie, w sposób naturalny poszukiwali oni takich wydarzeń, rzeczy czy osób, które stanowiły dla nich inspirację, dały solidne podstawy dla intelektualnego i naukowego rozwoju, rozbudziły ich zainteresowania, a tym samym ukierunkowały ich sposób myślenia i ukształtowały postawy moralne. Mamy tu zatem do czynienia z próbą odtworzenia powiązanych i wzajemnie na siebie oddziałujących elementów takich jak: ludzie (nauczyciele, rodzice, dalsza rodzina, środowisko rówieśnicze czy sąsiedzkie), rzeczy, teorie i opowieści (historie i tradycje rodzinne, książki, obrazy) ${ }^{1}$, których kompozycję w indywidualnej biografii celnie uchwytuje metafora „kłączy inicjujących”. Trzeba raz jeszcze

\footnotetext{
${ }^{1}$ Znaleźć tu można wyraźne nawiązanie do koncepcji Floriana Znanieckiego, ujmującego wychowanie jako proces społeczny, w którym pierwszorzędną rolę odgrywają ,środowiska wychowawcze" (i ich określone układy) takie jak rodzina, grupy rówieśnicze, otoczenie sąsiedzkie, instytucje wychowania szkolnego oraz, na drugim planie: książki, kino, teatr (współcześnie należałoby dodać mass media). Zob. Florian Znaniecki, Socjologia wychowania, t. 1, Wydawnictwo Naukowe PWN, Warszawa 2001.

${ }^{2}$ Metaforą tą posługuje się Piotr Szenajch poszukujący ponadindywidualnych źródeł ,geniuszu” i „talentu”. W swoim podejściu odwołuje się on do koncepcji wprowadzonej do filozofii przez Gillesa Deleuze'a i Felixa Guattariego w Mille Plateaux (Éditions de minuit, Paris 1980) oraz jej rozwinięcia przez teorię aktora-sieci Brunona Latoura, przy czym znacznie od niej odchodzi. Sięga również do socjologii Pierre'a Bourdieu i filozofii podmiotowości Michaela Foucaulta.
} 
podkreślić, że owe elementy dodatkowo wplecione były w specyficzny kontekst społeczno-historyczny dzieciństwa i wchodzenia w dorosłość naszych rozmówców.

Jak zostało to zapowiedziane, zdobywanie wiedzy we wszystkich zgromadzonych przez nas opowieściach wysuwa się na plan pierwszy i stanowi przede wszystkim wartość autoteliczną. Wspólnym mianownikiem staje się przeto charakterystyczna orientacja biograficzna, którą najkrócej wyraża sformułowanie „pęd do wiedzy”. Manifestuje się ona w nieustannej ciekawości poznawczej (choć nie zawsze równoznacznej z byciem pilnym i dobrym uczniem), która nawet w niesprzyjających warunkach okupowanej Polski jest pielęgnowana i rozwijana.

Zanim przyjrzymy się określonym elementom, które w różnych konfiguracjach splatają się w indywidualnym doświadczeniu tworząc unikalną, jednostkową biografię naukową - zatrzymujemy się nieco dłużej przy jednym z nich. Otóż w niemalże każdej opowieści szczególny nacisk położony jest na system kształcenia (w zależności od wieku naszych narratorów obejmujący okres przedwojenny, wojenny i tuż powojenny lub ich kompilacje) na poziomie elementarnym (dzisiaj powiedzielibyśmy - podstawowym), gimnazjalnym i licealnym. Szkoła jest tu przedstawiana przede wszystkim jako „wspólnota” (Gemeinschaft) w rozumienia Ferdinanda Tönniesa ${ }^{3}$, wyrastająca ze wzajemnego szacunku i zaufania. Angażuje ona zatem „całe osoby”, opiera się na emocjonalnych więziach między nauczycielem/wychowawcą a jego uczniami/wychowankami oraz bliskich relacjach między członkami grupy rówieśniczej ${ }^{4}$. Dodatkowo eksponowany jest jej formatywny charakter, oparty na wspólnej hierarchii wartości ${ }^{5}$ i wzajemnej współpracy, daleko wykraczający poza pojmowanie szkoły jako miejsca, w którym odbywa się wyłącznie proces gromadzenia wiedzy. Być może to właśnie zdecydowało o tym, że w czasie okupacji hitlerowskiej nauczanie w różnych formach często jednak było kontynuowane (np. w postaci tajnych kompletów). Można zatem zaryzykować tezę, że to

Zob. P. Szenajch, materiał zaprezentowany na konferencji „Creative Applications of Biographical Research: Theory, Practice and Policy" na Uniwersytecie w Durham, wrzesień 2014, na podstawie niepublikowanej pracy doktorskiej pt. Ponadindywidualne uwarunkowania ,talentu” oraz kulturowe źródła i spoleczne koszty ich pomijania, przygotowywanej w Instytucie Filozofii i Socjologii PAN.

${ }^{3}$ Ferdinand Tönnies, Wspólnota i stowarzyszenie. Tłum. Małgorzata Łukasiewicz, Państwowe Wydawnictwo Naukowe PWN, Warszawa 1988.

${ }^{4}$ Interesujące jest to, że niemalże wszyscy nasi narratorzy wymieniają osoby, które razem z nimi uczęszczały do szkoły, co, w naszym mniemaniu, podkreśla znaczenie grupy rówieśniczej.

${ }^{5}$ Podkreślmy, że chodzi tu o umiejętność brania pod uwagę perspektywy innego oraz rozważania i szanowania jego punktu widzenia. 
swoiste podejście naszych rozmówców do systemu edukacji przekłada się na sposób, w jaki widzą oni i definiują później uniwersytet - piszemy o tym w rozdziale kończącym tę książkę. W opowieściach narratorów dotyczących ich kariery edukacyjnej poprzedzającej pójście na studia pojawiają się także różne postaci - zazwyczaj profesorowie gimnazjalni, licealni czy uniwersyteccy, którzy w wyniku wojennej tułaczki często nauczali czy wykładali wszędzie tam, gdzie rzucił ich los.

Rozpocznijmy od przedstawienia rozbudowanych fragmentów trzech narracji. Opowieści te ciekawie obrazują wskazane etapy biografii edukacyjnej pokolenia naszych rozmówców. Jako pierwszą pokazujemy relację Bronisławy Kopczyńskiej-Jaworskiej, która szczegółowo rekonstruuje swoją ścieżkę edukacyjną przed pójściem na studia etnograficzne na Uniwersytecie Łódzkim. Uchwytuje w niej ducha minionych czasów i wspaniale pokazuje ówczesne społeczno-kulturowe (a także polityczne) uwarunkowania procesu zdobywania wiedzy, podkreśla rolę swojej mamy, która początkowo była odpowiedzialna za jej wykształcenie, wskazuje postaci ważne dla łódzkiego szkolnictwa i rekonstruuje mapę edukacyjną przedwojennej Łodzi. Ten ostatni punkt jest dla nas szczególnie ciekawy i dlatego tym wspomnieniom oddajemy nieco więcej miejsca. Bronisława Kopczyńska-Jaworska opowiada także o tajnych kompletach, na które uczęszczała w Warszawie, i o konspiracyjnej edukacji, która w końcu wyzwoliła w niej pasję nauki. Mówi też o wyborze kierunku studiów, na który wpływ miał urok prof. Heleny Radlińskiej ${ }^{6}$.

Trudno w to uwierzyć ze względu na moje sędziwe lata, ale byłam wątłym dzieckiem i wobec tego po przyjeździe [do Lodzi z Poznania] nie chodziłam do szkoły, tylko przez rok uczyła mnie mama, która miała prawo nauczania, ponieważ po pierwszej wojnie skończyła nauczycielskie kursy. Potem chodziłam na prywatne komplety. Prowadziła je starsza pani, łodzianka, ewangeliczka, która najpierw kończyła kursy freblowskie ${ }^{7}$. To były kursy dla dzieci, potem nabyła ona prawo do nauczania początkowego. W latach dwudziestych, jeszcze w początku lat trzydziestych był taki system szkolny, że gimnazjum

\footnotetext{
${ }^{6}$ Helena Radlińska (1879-1954) - profesor pedagogiki, stworzyła pedagogikę społeczną w Polsce, w 1945 roku po przyjeździe do Łodzi uruchomiła na Uniwersytecie Łódzkim Zakład Pedagogiki Społecznej. Jej współpracownikami byli m.in. Aleksander Kamiński i Irena Lepalczyk.

${ }^{7}$ Kursy freblowskie (od nazwiska niemieckiego pedagoga Friedricha Wilhelma Fröbela żyjącego w latach 1782-1852), przygotowywały pedagogów i wychowawców do pracy z najmłodszymi dziećmi, które między innymi przez pielęgnację roślin i dbanie o ogród miały kształtować w sobie postawę szacunku wobec świata ludzi i przyrody. Stąd między innymi niemiecka nazwa przedszkola - Kindergarten (ogródek dziecięcy). Jednak w praktyce opisywanej przez prof. Jaworską wyglądały inaczej i dzieci nie miały zbyt dużo kontaktu z przyrodą.
} 
miało osiem klas, kończyło się maturą i do gimnazjum były tak zwane trzy klasy wstępne; nazywały się jeden, dwa, trzy, albo a, b, c. I w wielu rodzinach inteligenckich, a zwłaszcza ziemiańskich, uczono dzieci w domu albo prywatnie przez te trzy lata i one zdawały do gimnazjum, do pierwszej klasy gimnazjum, mając lat siedem, osiem, dziewięć, około dziesięciu lat. Gimnazjum kończyło się maturą i można było się uczyć dalej, studiować albo nie. I ta pani, do której ja chodziłam na tak zwane komplety, uczyła właśnie te wstępne klasy. Najpierw trzy, potem po reformie szkolnej, gdzie dopiero po czwartej klasie szkoły powszechnej szło się do gimnazjum, to uczyła przez cztery lata.

Gdy uczono się prywatnie, lekcje się odbywały po kolei w różnych domach. Jak ta pani się bardzo zestarzała, to już potem u niej w domu na Piotrkowskiej 181, koło tego domu, w którym przez dłuższy czas było Towarzystwo Naukowe. To były dzieci przeważnie łódzkiej plutokracji czy zamożniejszej inteligencji. Nawet miałam się uczyć z Karolkiem Geyerem', ale zachorował [śmiech] na szkarlatynę i wobec tego nie chodził razem z nami. Następnie, gdy skończyłam cztery klasy, to mnie mama, rodzice - mówię mama bo tą nauką to przede wszystkim się mama opiekowała - zapisali do szkoły Pryssewiczówny ${ }^{9}$, przez rok była Pryssewiczówny, potem kupił szkołę pan Tadeusz Czapczyński ${ }^{10}$, doktor, filolog polski. Po wojnie był pierwszym sekretarzem w ŁTN-ie [Łódzkim Towarzystwie Naukowym]. I szkoła nosiła imię Janiny Czapczyńskiej, bo właścicielką praktycznie była jego żona, on był dyrektorem szkoły. Była to, w moim mniemaniu, ale też innych wychowanek szkoły, bardzo dobra szkoła. Mieściła się najpierw na Sienkiewicza 46 w takiej kamienicy prywatnej nieciekawej, potem też w nieciekawej oficynie na Narutowicza 58, chyba koło anatomiku ${ }^{11}$, tam jest taka oficyna i tam ta szkoła potem się mieściła. W Łodzi było parę szkół, gimnazjów męskich i żeńskich, potem po tzw. reformie jędrzejewiczowskiej ${ }^{12} \mathrm{w}$ latach trzydziestych były gimnazja i licea.

${ }^{8}$ Chodzi tu o Karola juniora - syna Karola Geyera i Marii z Buchholtzów, wnuczki Karola Scheiblera jednego z najpotężniejszych łódzkich fabrykantów.

${ }^{9}$ Mowa tu o założonej przez Teofila Schmidtowa w drugiej połowie XIX wieku pierwszej w Łodzi szkole z wykładowym językiem polskim, która później stała się własnością Janiny Tymienieckiej. Ta, borykając się z problemami finansowymi, przekazała szkołę Janinie Pryssewiczównie. Obecnie jest to XII Liceum Ogólnokształcące im. Stanisława Wyspiańskiego w Łodzi.

${ }^{10}$ Tadeusz Czapczyński (1984-1958) - pedagog i wykładowca, ukończył studia z zakresu filologii polskiej i klasycznej na Uniwersytecie we Lwowie, wykładowca Wolnej Wszechnicy Polskiej, dyrektor opisywanej wyżej szkoły w latach 1934-1939 i 1945-1958. W latach 1950-1958 dyrektor Biura Łódzkiego Towarzystwa Naukowego.

${ }^{11}$ Anatomik - często używana potoczna nazwa Collegium Anatomicum mieszczącego się przy ulicy Narutowicza 60, gdzie wcześniej znajdował się Przytułek dla Starców i Kalek Łódzkiego Chrześcijańskiego Towarzystwa Dobroczynności.

${ }^{12}$ Reforma jędrzejewiczowska - reforma polskiego systemu edukacji na poziomie szkoły powszechnej i średniej, którą wprowadzono w 1932 roku z inicjatywy Ministra Wyznań Religijnych 
To były cztery klasy gimnazjum i dwie klasy licealne, na miejsce dawnego gimnazjum ośmioklasowego. Otóż w Łodzi było parę żeńskich szkół prywatnych i jedno tylko żeńskie gimnazjum państwowe i bezpłatne, do którego bardzo trudno było się dostać. To było gimnazjum na Pomorskiej ${ }^{13}$, jeszcze za carskich czasów była tam szkoła, chyba też gimnazjum żeńskie. W Łodzi był problem, jeżeli chodzi o dziewczęta i ich dalsze studia. Nie chodziło tylko o dziewczęta, ale również o chłopców, bo nie było żadnej szkoły wyższej. Była prywatna szkoła muzyczna, była średnio wyższa, chyba coś ze sztukami pięknymi związanego, taka trochę zawodowa, która jest na rogu Wierzbowej. Po wojnie w tym gmachu się mieścił zaczątek Wyższej Szkoły Sztuk Plastycznych. Otóż z męskich gimnazjów w całej Łodzi były cztery gimnazja państwowe i jeszcze bezpłatna szkoła miejska, znakomitej tradycji, za PRL III Liceum Ogólnokształcące na Sienkiewicza. To było miejskie gimnazjum. Też bezpłatne, i do tego cztery prywatne. Więc chłopcy mogli się o wiele łatwiej uczyć niż dziewczęta w tej jednej szkole tylko, w której nie trzeba było płacić.

\section{(...)}

Ja w szkole uczyłam się średnio, ale bez trudu i raczej mnie to nudziło. Szkoła była bardzo dobra, więc tak zwana inteligentna uczennica mogła znakomicie się przyczaić, w odpowiednim momencie zgłaszając się na ochotnika i robiąc dobre wrażenie. Ja byłam raczej zajęta życiem klasy. Był samorząd, byłam w harcerstwie, ale dość późno doń wstąpiłam. Siostra moja starsza była już w harcerstwie od wielu lat, przed wojną była drużynową szkolnej drużyny. Ukończyła kursy instruktorskie harcerskie, które odbywały się w miejscowości Bucze na Śląsku, mówiło się potocznie „na Buczu”. Po maturze była wysłana na kolonie organizowane przez harcerstwo w Belgii dla dzieci górników polskich. Wtedy to było ogromne przeżycie, pierwszy raz któraś z nas wyjeżdżała za granicę, bo ojciec to często wyjeżdżał. Siostra była aktywną harcerką, a ja wiecznie na coś chorowałam, wobec tego mama mi dłuższy czas nie pozwalała, abym jeździła na obozy. Ja dopiero w 1938 roku zaczęłam aktywnie działać w harcerstwie i przed wojną w 1939 roku, na ostatnich wakacjach, w lipcu przed wojną, byłam na obozie harcerskim w Konopnicy nad Wartą. Było to naturalnie bardzo frapujące. Kiedy się wojna rozpoczęła, w końcowych dniach sierpnia harcerze, harcerki były zmobilizowane w cudzysłowie. Była tak zwana harcerska służba pomocnicza i myśmy pełniły różne pomocnicze role w przededniu wojny.

i Oświecenia Publicznego Janusza Jędrzejewicza. Jej celem było przede wszystkim ujednolicenie systemu kształcenia i drożność szkół różnego poziomu w porozbiorowej (a zatem zróżnicowanej) Polsce.

${ }^{13}$ Obecnie IV Liceum Ogólnokształcące im. Emilii Sczanieckiej w Łodzi. 


\section{Dalej Bronisława Kopczyńska-Jaworska przechodzi do czasu wojny i opowiada:}

W końcu września wróciliśmy do Łodzi i po paru dniach, po aresztowaniach, zakładników aresztowano i tak dalej. Najgorzej było przed 11 listopada i to się tragicznie skończyło, bo Niemcy potem wymordowali tych zakładników ${ }^{14}$. I tak, siłą rozpędu ruszyła szkoła, to znaczy nauczyciele się zebrali, nie wszyscy, bo brakowało niektórych, bo nie wrócili z tych wrześniowych wędrówek, ale dyrektor był na miejscu w Łodzi i szkoła, kulejąc bo kulejąc, ale jako tako zaczęła działać. I te lekcje trwały przez listopad i chyba 4 grudnia wywieźli z Łodzi naszego dyrektora i wysiedlili go do tak zwanej Generalnej Guberni ${ }^{15}$. Nie wiem, czy pani wie, ale tutaj były takie masowe przesiedlenia ludności, zwłaszcza inteligenckiej z terenu Łodzi, Poznania, tych wszystkich miast, które zostały wcielone do Rzeszy, do Generalnej Guberni. Dyrektora wtedy wywieźli. Rano, gdy szłyśmy do szkoły, dowiedziałyśmy się, że dyrektora nie ma, że podobno zabrali go Niemcy, bo po jednym dniu się okazało, że oni są skomasowani na Lipowej i że tych ludzi wywożą do Guberni. Moją wychowawczynią była Anna Dylikowa ${ }^{16}$, później jeszcze profesor łódzkiego Uniwersytetu, i właśnie rodzinę Dylików wywieźli wtedy, więc nasza klasa się rozsypała. Jeszcześmy pochodziły do szkoły pytać, co dalej, i nie powiem pani, kiedy dokładnie, Niemcy wydali orzeczenie, że szkoły się zamyka, szkół dla polskich dzieci nie ma. Wobec tego poszliśmy do domu i pętaliśmy się tak tam.

Pojechaliśmy do Warszawy. Trochę się tam pałętałyśmy bez nauki. Po pewnym czasie okazało się, że jest w Warszawie pani Dylikowa i z panem Dylikiem urządza tajne nauczanie. Okazało się, że dalej nas będzie uczyć; znalazła się jakaś pani łacinniczka, nauczycielka z francuskiego - a od geografii była właśnie pani Dylikowa - i zaczęliśmy naukę na tych kompletach zorganizowanych przez łódzkie grono, a uczennicami były dziewczynki wysiedlone, czy z rodzicami, czy same, bo niektórzy rodzice wysyłali dzieci

\footnotetext{
${ }^{14}$ Mowa tu z pewnością o mającej miejsce w dniach 9-10 listopada 1939 roku akcji „Intelligenzaktion Litzmannstadt” (przeprowadzonej w ramach obejmującej cały kraj „Akcji Inteligencja”), której celem było wyeliminowanie polskiej inteligencji. W tych dniach wzięto do niewoli, a następnie rozstrzelano w lesie w okolicy Lućmierza ok. pięćset osób uznanych za elitę symboliczną (nauczycieli, urzędników, duchownych) miasta i okolic. Był to zaledwie początek mordów dokonywanych przez hitlerowców na łódzkiej inteligencji.

${ }^{15}$ Chodzi tutaj o wspomnianego wcześniej Tadeusza Czapczyńskiego. W listopadzie 1939 roku do Generalnej Guberni został wysiedlony zarówno on, jak i większość nauczycieli łódzkich.

${ }^{16}$ Anna Dylikowa (1912-2000) - geograf i geomorfolog. Komendantka żeńskiej komendy łódzkiej chorągwi harcerek ZHP w latach 1937-1939. Od 1965 roku profesor Uniwersytetu Łódzkiego. Żona Jana Dylika, profesora geografii na Uniwersytecie Łódzkim.
} 
z Łodzi w obawie przed Rassenamtem ${ }^{17}$, tak, że zebrał się taki zastęp cały $\mathrm{z}$ harcerstwa. Pani Dylikowa była harcmistrzynią Rzeczypospolitej i wobec tego nawiązała kontakt z warszawskimi harcerkami i myśmy były zorganizowaną drużyną łódzką na terenie Warszawy. Moja mama zaczęła się dowiadywać, jak to jest z tym nauczaniem, czy to się jakoś legalizuje. Okazało się, że szkoły warszawskie prowadzą kontrolę nad tym nauczaniem i wylądowałam na kompletach organizowanych przez szkołę im. Królewny Anny Wazówny - taki żeński odpowiednik znanej i bardzo zasłużonej warszawskiej szkoły męskiej imienia Mikołaja Reja. Obie te szkoły prowadził konsystorz ewangelicki, to znaczy władze ewangelickie. I tam właśnie na kompletach u Wazówny w 1943 roku zdałam maturę. W tym czasie zaczęłam się chętnie uczyć, bo to uczenie wojenne było o wiele przyjemniejsze, ciekawsze. Przyjemniejsze to może przesada, ale w każdym razie ciekawsze, ponieważ myśmy mieli tak normalnie jedno spotkanie z nauczycielem danego przedmiotu, wykład, zadana duża porcja do domu do przerobienia samodzielnego. Potem po tygodniu dyskutowało się o tym, czego się człowiek nauczył i czego jeszcze nie umiał, i to się wydawało o wiele ciekawsze, nie nudziłam się tak jak w szkole, gdzie straszne ilości godzin marnuje się nie wiadomo na co, a można się tego nauczyć w dwie godzinny dziennie.

\section{(...)}

Kiedy w 1943 roku zdałam maturę, naturalnie chciałam się uczyć dalej, ale, po pierwsze, nie bardzo wiedziałam, czego, co chciałabym dokładnie, a po drugie, był problem, żeby nawiązać kontakt personalny z jakimiś kompletami uniwersyteckimi. I było nieco zabawnie. Chciały mi pomóc dwie znajome rodziny. Jedna się ofiarowała, że mnie skontaktuje z profesorem Tatarkiewiczem ${ }^{18}$, a druga, że mnie skontaktuje z Heleną Radlińską, o której wtedy niewiele wiedziałam, ale wytłumaczono mi, że to osoba, która zajmuje się oświatą pozaszkolną i że to jest niezwykle ciekawa osoba, która prowadzi ciekawe studia. Umówili mnie: chyba w środę miałam pójść do Radlińskiej - miałam adres i bilecik polecający - a w piątek miałam pójść do Tatarkiewicza. Poszłam zatem najpierw do Radlińskiej i profesor Radlińska ${ }^{19}$ mnie uwiodła z miejsca. Była to niezwykle interesująca osobowość. Zaczynała mówić z taką powagą, a jednocześnie z tak dużym urokiem. Kiedy dowiedziała się, że ja jestem

${ }^{17}$ Chodzi tu o Rassenamt - urząd do spraw rasy, którego celem była ocena rasy obywateli terytoriów podbitych przez nazistowskie Niemcy. Wyszukiwano dzieci o aryjskiej urodzie, które odbierano rodzicom i przekazywano rodzinom niemieckim.

${ }^{18}$ Władysław Tatarkiewicz (1886-1980) - wybitny filozof i historyk filozofii, etyk, aksjolog i estetyk, członek stworzonej przez Kazimierza Twardowskiego lwowsko-warszawskiej szkoły filozoficznej. Autor monumentalnego dzieła Historia filozofii i Historia estetyki. Po wojnie wykładał na Uniwersytecie Jagiellońskim. W 1950 roku na mocy decyzji politycznej został odsunięty od pracy dydaktycznej.

${ }^{19}$ Zob. przypis $6 \mathrm{w}$ tym rozdziale. 
harcerką, to tylko pedagogika społeczna wchodziła w rachubę. Ona prowadziła komplety na Wolnej Wszechnicy Polskiej Warszawskiej i namówiła mnie na bibliotekarstwo... No i do Tatarkiewicza już nie poszłam. A potem już jako osoba dorosła i pracownik naukowy parę razy w życiu żałowałam, bo uważam, że jednak pracę $\mathrm{w}$ humanistyce powinno się zaczynać od filozofii i dopiero potem zmieniać [śmiech] świat, albo ulepszać, albo pogorszać i badać. A profesor Radlińska uważała, że pracownik oświatowy musi wiedzieć o różnicach środowisk kulturowych, i tak trafiłam na wykłady, gdzie spotkałam profesor Zawistowicz. Po wojnie, w Łodzi jej uczennicą i asystentką była niejaka pani magister Jadwiga Świątkowska i ona zaczęła mnie namawiać, żebym się przeniosła z bibliotekoznawstwa na etnografię. I tak się stało.

Odwołajmy się teraz do innej opowieści. W biografii Wandy Nowakowskiej ogromną rolę odegrał, by użyć kategorii Pierre'a Bourdieu ${ }^{20}$, kapitał kulturowy i społeczny a także niezwykły prezent, który otrzymała jako mała dziewczynka. Co ciekawe i wcale nierzadkie, nasza narratorka nie od razu trafiła na historię sztuki, która później stała się jej ścieżką naukową. Początkowo zdecydowała się na studia psychologiczne, które jednak bardzo ją rozczarowały. Zobaczmy zatem, jak opowiada o swoim ,środowisku wychowawczym" i edukacji poprzedzającej pójście na uniwersytet.

Jestem z urodzenia łodzianką, ale moje korzenie rodzinne sięgają znacznie dalej. Mój pradziadek [ojciec babki i dziadek matki] Leon Żukowski był nauczycielem greki i łaciny w gimnazjach warszawskich za caratu, ale za działalność niepodległościową [śmiech] został pozbawiony zawodu. Jednym z ich ośmiorga dzieci była moja babcia Felicja Żukowska, która kończyła gimnazjum Narcyzy Żmichowskiej w Warszawie, co bardzo zaciążyło na życiu zawodowym. I tam, w Warszawie poznała mojego dziadka o bardzo pospolitym nazwisku, Jana Kowalskiego [śmiech] i za niego wyszła za mąż. Przenieśli się do Częstochowy. Dziadek był tam jednym z dyrektorów takiej fabryki „Pelcerów”21. Tam też w 1899 roku urodziła się moja matka, która pamiętała, jak w 1905 roku robotnicy strajkowali. Przed pierwszą wojną światową w 1914 roku przenieśli się do Łodzi, gdzie mój dziadek zajął się działalnością społeczną, bo ponoć zawsze był społecznikiem. Babcia z kolei, będąc po tej szkole Żmichowskiej i dodatkowo posiadając wysokie umiejętności w zakresie robót ręcznych i kaligrafii, czego nie odziedziczyła jej kochana wnuczka [śmiech], otrzymała propozycję pracy w gimnazjum im. Elizy Orzeszkowej przy ulicy Kościuszki 21. Ale w związku z tym, że troszkę kulały dochody rodzinne [śmiech], to

${ }^{20}$ Zob. np. Pierre Bourdieu, Dystynkcja: społeczna krytyka władzy sadzenia, thum. Piotr Biłos, Wydawnictwo Naukowe Scholar, Warszawa 2005.

${ }^{21}$ Potoczna nazwa przędzalni i farbiarni wełny założonej w 1886 roku przez Belga Augusta Peltzera w Częstochowie. 
babcia zaczęła wydawać obiady dla stołowników z zewnątrz. Byli to przede wszystkim nauczyciele tego gimnazjum, bo dziadkowie mieszkali wówczas bardzo blisko na Wólczańskiej 41. A babcia gotowała pierwszorzędnie po tej szkole Narcyzy Żmichowskiej. Do tego gimnazjum poszła oczywiście moja mama i tam zdawała maturę. Opowiadała mi, że w jej klasie maturalnej wśród dwudziestu uczennic były tylko dwie katoliczki. Było to bowiem tak zwane gimnazjum społeczne sponsorowane przez bogate rodziny łódzkie - ewangelickie i żydowskie. Oni bardzo chcieli się asymilować w środowisku łódzkim i wchodzili w szerokie kręgi towarzyskie tradycyjnych łódzkich rodzin. A dom moich dziadków był „międzynarodowy” i ogromnie otwarty. I w takiej atmosferze potem ja się chowałam jako wnuczka. Z kolei mój dziadek od strony taty - Piotr Nowakowski - pochodził z Turku, gdzie był pisarzem gminnym, a babcia prowadziła dom i chowała czterech synów. Ojciec mój był ułanem, podporucznikiem, brał udział w wojnie polsko-bolszewickiej 1920 roku. Miał wtedy zaledwie osiemnaście lat i dostał wówczas Krzyż Walecznych za obronę Polski. Był także zaangażowany w harcerstwo, był harcmistrzem. Poznał moją mamę, kiedy z Turku, gdzie pracował we władzach gminnych, został przeniesiony do starostwa łódzkiego. W tym czasie moja mama była już po studiach w Krakowie na Uniwersytecie Jagiellońskim, bo w Łodzi nie było jeszcze uniwersytetu, i tam studiowała historię. Przyjechała do Łodzi i zaczęła wykładać w takim studium nauczycielskim, ale miała ogromną tremę, która uniemożliwiała jej zupełnie wykłady. Później na świat przyszłam ja i mieszkaliśmy w tym mieszkaniu dziadków. Mój ojciec awansował bardzo szybko. Był podobno bardzo zdolnym człowiekiem. Został wicestarostą w Kole, a potem, rok przed wojną, starostą w Łasku. 12 września 1939 roku w bitwie pod Seroczynem stracił całą prawą rękę i lewe oko. Kurował się w takim majątku zaprzyjaźnionym w Mrozach pod Warszawą i później od razu go koledzy warszawscy wciągnęli do konspiracji. Działał w AK, był członkiem Delegatury Rządu Londyńskiego, uczestnikiem Powstania Warszawskiego, przez cały sierpień był na Starym Mieście, gdzie cały czas lewą ręką pisał dziennik, który wkrótce zresztą zostanie opublikowany. W 1989 roku został pośmiertnie odznaczony przez Koło Żołnierzy Armii Krajowej w Londynie Krzyżem Armii Krajowej i Medalem Wojska za swoje dokonania w czasie wojny. A myśmy z mamą i babcią były w Łodzi. Tu mama pracowała od 1935 roku jako historyk w utworzonym wówczas Muzeum Historii i Sztuki im. Bartoszewiczów, gdzie pełniła funkcje sekretarki, bibliotekarki, załatwiała różne sprawy administracyjne i pomocniczo-naukowe. Wtedy ja jako mała dziewczynka byłam tam gościem i poznawałam sztukę i obrazy. Mama przynosiła do domu różne albumy i to był mój pierwszy kontakt ze sztuką. Wtedy też zaczęłam chodzić do szkoły Janiny Czapczyńskiej, którą jako bardzo dobrą wybrała mi babcia - w końcu nauczycielka [śmiech]. W 1940 roku musiałyśmy opuścić Łódź, po tym jak mamę wyrzucono z pracy w Muzeum, a mieszkanie zostało nam 
zabrane przez Niemców. Przebywałyśmy wówczas w Generalnej Guberni w Częstochowie i Krakowie, przygarnięte przez rodzinę babci. W 1941 roku po śmierci babci znalazłyśmy się w Warszawie. Tam chodziłam do słynnego gimnazjum Emilii Plater i tam się kształciłam normalnie, ale przede wszystkim mieszkałyśmy u wuja Jerzego Sienkiewicza, który był historykiem sztuki i był kustoszem Muzeum Narodowego. Był profesorem i w jego mieszkaniu pełno było oczywiście znakomitych książek, a przede wszystkim obrazów. Był zaprzyjaźniony z Olgą Boznańską i z Tadeuszem Makowskim²2. I to pogłębiało moje zainteresowania, które w dzieciństwie zaczęły się od mojej matki. Ona także inspirowała moje zainteresowania światem książek - bibliotekarka przecież! A sprzyjał temu następny po Warszawie i ostatni etap naszej wojennej tułaczki, a mianowicie dwuletni pobyt w Kielcach, gdzie uczęszczałam na tajne komplety i zbierałam pierwsze laury za wypracowania $\mathrm{z}$ języka polskiego u pani Marii Rychterówny. Pisałam wówczas swoje dziewczęce i okupacyjne wiersze, ale także zaczęłam pisać, prowadzone do dziś, pamiętniki. Potem wróciłyśmy do Łodzi, gdzie moja mama zaczęła ponownie pracować w muzeum w dawnym Pałacu Poznańskich na ulicy Więckowskiego 36. Po wojnie bardzo często jeździłam do mojego ojca, który został w Warszawie. Moi rodzice już dawno nie byli razem. Tam miałam kontakt z jego otoczeniem, z artystami. Wprowadzał mnie do słynnej kawiarenki „Lajkonik”, gdzie miał zresztą swój stolik, był takim kronikarzem tej kawiarenki, o czym mówi Eryk Lipiński ${ }^{23}$ w swoich wspomnieniach: jak Wiktor Nowakowski, prawnik, siedział tam, pisał tę historię [śmiech]... No i dzięki ojcu także ja miałam kontakt z Warszawą, w związku z czym chodziliśmy na wystawy do teatru i właśnie poznawałam tych różnych artystów w „Lajkoniku” przez ojca, co było dla mnie bardzo istotne. W Łodzi zaczęłam znów chodzić do szkoły Janiny Czapczyńskiej, ale od września 1945 roku przeniosłam się do Sczanieckiej ${ }^{24}$, bo tam była moja przyjaciółka dozgonna, nie żyjąca już Dzidka, a właściwie Jadwiga, Odolakówna - psycholog. Szkoły wprawdzie nigdy specjalnie nie lubiłam, ale fascynowały mnie lekcje języka polskiego prowadzone przez profesor Halinę Stolarzową, zwaną Minerwą i lekcje angielskiego prowadzone przez Stefanię Jażdżewską, która była osobą pełną ciepła. Uwielbiałam urzekającą swoją logiką łacinę, wykładaną przez naszego wychowawcę Zenona Koeppe, który codziennie rano w hallu naszej szkoły grzmiącym głosem wołał: „Panno

${ }^{22}$ Jerzy Sienkiewicz (1897-1980) - historyk sztuki, muzealnik, wybitny znawca malarstwa polskiego, kustosz Muzeum Narodowego w Warszawie. Olga Boznańska (1865-1940) - znana polska malarka epoki modernizmu tworząca głównie w Monachium i Paryżu. Tadeusz Makowski (18821932) - urodzony w Polsce malarz działający głównie w Paryżu.

${ }^{23}$ Eryk Lipiński (1908-1991) - satyryk, karykaturzysta, grafik. Twórca satyrycznego tygodnika „Szpilki”.

${ }^{24}$ Obecnie IV Liceum Ogólnokształcące im. Emilii Sczanieckiej mieszczące się w Łodzi przy ulicy Pomorskiej 16. 
Nowakowska! Znowu się pani spóźniła!” Był to fakt, bo nigdy nie znosiłam porannego wstawania. Lubiłam też moje koleżanki, w większości bardzo interesujące i wybitne jak Hanka Świda-Ziemba, która zresztą naszą klasę opisała w swojej książce Urwany lot $t^{25}$. I w tej szkole będąc, zaczęłam być postrzegana jako tak zwana gwiazda polonistyczna [śmiech], dobra byłam w tych przedmiotach humanistycznych, głównie w języku polskim, chociaż w łacinie i angielskim też. To był taki okres, kiedy oddawałam się też muzyce, bo mama wystarała się o poniemiecki półkoncertowy fortepian, bo mama też marzyła zawsze o tym, by się uczyć muzyki i myśmy obydwie z mamą chodziły na lekcje muzyki razem. Także grałyśmy na tym fortepianie i ja potrafiłam godzinami siedzieć i grać.

Opowieść o tym, jak jako szesnastoletnia uczennica Wanda Nowakowska przychodziła do swojej mamy, która pracowała w muzeum, zostaje później doprecyzowana. Na szczególną uwagę zasługuje w tym miejscu drobny z pozoru epizod, który stał się zaczynem dla rozbudzenia jej zainteresowania historią sztuki:

Wtedy też, gdy już uczęszczałam do Sczanieckiej, jesienią 1945 roku, wydarzyła się rzecz niezwykła, która zaciążyła na całym moim życiu. Przychodziłam wówczas po skończonych lekcjach do mamy, do pracy, żeby razem z nią wrócić do domu, bo było niebezpiecznie samemu chodzić po ulicach. A mama pracowała wówczas na placu Wolności w gmachu Muzeum Archeologicznego, gdzie zbiory i pracowników Muzeum Sztuki oczkujących na adaptację budynku przy ulicy Wólczańskiej 36 ,przytulił” dyrektor Konrad Jażdżewski ${ }^{26}$ - później mój profesor z historii sztuki prehistorycznej! Szkoła moja jest do dziś na Pomorskiej 16, było zatem blisko, ale musiałam czekać aż mama skończy pracę. A jak czekałam, to musiałam się gdzieś podziać. No to mama mówiła: „Wiesz co, córeńko, idź sobie do podziemi, tam są magazyny, obrazy, to sobie pooglądaj”. No i tak zrobiłam... Weszłam i nagle stanęłam jak wryta. Przede mną stał oparty o skrzynię obraz. Z obramowanego w złotą ramę pejzażu patrzyła na mnie kobieta w ciemnej sukni. Przyglądałam się jej, a łzy spływały mi po policzkach. Wtedy kątem oka zauważyłam, że otworzyły się

${ }^{25}$ Hanna Świda-Ziemba (1930-2012) - profesor socjologii, absolwentka Uniwersytetu Łódzkiego, od 1954 roku związana z Uniwersytetem Warszawskim. W swojej książce Urwany lot opisuje na przykładzie swoich kolegów powojenną młodzież, na której życiu odcisnęło się piętno wojny i chaos lat powojennych. Zob. Świda-Ziemba Hanna, Urwany lot. Pokolenie młodzieży powojennej w świetle listów i pamiętników z lat 1945-48, Wydawnictwo Literackie, Kraków 2003.

${ }^{26}$ Konrad Jażdżewski (1908-1985) - archeolog. Studia ukończył w Poznaniu pod kierunkiem prof. Józefa Kostrzewskiego; badacz prehistorii, od 1945 roku profesor Uniwersytetu Lódzkiego. W rozdziale poświęconym mistrzom jego sylwetkę opisuje Jerzy Kmieciński. 
drzwi i stanął w nich dyrektor Muzeum Marian Minich ${ }^{27}$. Zobaczył tę scenę, zamknął drzwi i bez słowa odszedł. To było jesienią późną... Przychodzi Boże Narodzenie, jestem w domu, mama w pracy, przychodzi woźny z muzeum z paczką wielką. Stawia ją na podłodze i powiada: „To dla panienki, od pana dyrektora”. „Dziękuję”. Ja rozpakowuję, a to ten obraz. „Boże! „Gioconda” Leonarda da Vinci!" No i tak to się zaczęło.

(...)

A kiedy przyszło do wyboru moich studiów, to wahałam się między chirurgią [śmiech] a polonistyką, a w rezultacie zwyciężyła psychologia. No i później te studia po pierwszym, drugim roku zdecydowanie mnie rozczarowały. Zdecydowanie. I chwała Bogu, że tak się stało. Byłam głęboko znudzona tą psychologią. Zaczęłam studiować równolegle historię sztuki u profesora Wallisa ${ }^{28}$, który mnie oczarował właśnie wtedy.

Przejdźmy teraz do reminiscencji Olgi Czerniawskiej, absolwentki historii, dziś emerytowanej profesor andragogiki, która wspomina swoją szkolną edukację rozpoczętą w przedwojennej Łodzi. W jej relacji znajdziemy nie tylko opis (wielokulturowego) środowiska, w którym jako mała dziewczynka podjęła naukę, ale także charakterystykę szczególnej formuły kształcenia (indywidualnego lub na tajnych kompletach) młodych osób w okresie okupacji i wreszcie powrót do „normalnej” szkoły po jej zakończeniu. Nawet w czasie wojny - jak to barwnie ilustruje Czerniawska - uczennice, co z pewnością typowe dla ich wieku, nie przestają płatać figli swojemu nauczycielowi, zakochują się w młodym przystojnym historyku, nie znoszą matematyczki czy czytają Alexandra Dumasa (to między innymi w tych lekturach Olga Czerniawska upatruje źródła swoich zainteresowań historią). Ciekawie też przedstawiony jest tu wątek powojennej edukacji związany z gimnazjum Janiny Czapczyńskiej, które - dzięki niezwykłej aktywności uczennic - tętniło pełnią życia:

Był moment, kiedy musiałam iść do szkoły i mama moja ze mną poszła. Na rogu Sterlinga jest taka duża szkoła, jedynka ${ }^{29}$, ale jak mnie tam zobaczyli, to powiedzieli mamie, żeby jakąś prywatną szkołę znalazła, że ja nie bardzo się do tej nadaję, bo ja byłam taka przestraszona. I rzeczywiście, mama znalazła

${ }^{27}$ Marian Minich (1898-1965) - urodzony we Lwowie historyk sztuki, w 1934 roku wygrał konkurs na dyrektora Muzeum Sztuki w Łodzi, którym kierował przez 30 lat (wyłączając okres okupacji).

${ }^{28}$ Mieczysław Wallis (1895-1975) - estetyk, teoretyk i historyk sztuki, kierował Katedrą Historii Sztuki, w latach 1955-1956 pełnił funkcję dziekana Wydziału Filozoficzno-Historycznego Uniwersytetu Łódzkiego.

${ }^{29}$ Aktualnie przy ulicy Sterlinga 24 znajduje się Szkoła Podstawowa i Publiczne Gimnazjum nr 1. 
Szkołę Pracy ${ }^{30}$, tam, gdzie teraz w tym pałacyku jest szkoła Montessori ${ }^{31}$. To była szkoła oparta właśnie o zasady pracy dla takich zmanierowanych dzieci. Wtedy część uczniów podjeżdżała tam samochodami, prywatni szoferzy je przywozili, to pani sobie wyobraża, jaka to była szkoła? Było w niej dużo dzieci żydowskich. Był taki chłopiec, który był bardzo chorowity, więc miał wszystko ze swoim nazwiskiem, łącznie z termometrem. Były też małe dzieci fabrykantów, pół-Niemców. Było w tamtym czasie społeczeństwo wielonarodowościowe, to i w szkole tak było. Między innymi moim kolegą był właściciel tego nowoczesnego domu na ulicy Kamińskiego. Nazywał się chyba Speer. Jego ojciec budował ten dom, był właścicielem. Potem kolegowałam się z takim chłopcem, który nazywał się Gatke. On był mały, a ja byłam dosyć wysoką dziewczynką, w każdym razie myśmy się bardzo przyjaźnili. Gdy były lekcje religii, a prowadziła je nie byle kto, bo siostra Ledóchowska ${ }^{32}$, urszulan$\mathrm{ka}, \mathrm{z}$ tej rodziny szlachetnej, piękna kobieta. Ona pozwalała zostawać temu, kto chciał, ale kto nie chciał, to wychodził z tej lekcji. Ona była bardzo mądrą kobietą, delikatną, i tak jakoś potrafiła w tej klasie nie budzić jakichś antagonizmów, tylko wszystko było dobrze. I w tej Szkole Pracy panowały pewne zasady. Na przykład, pisało się w zeszycie bez linii, nie wolno było żadnej linii mieć. Wszystko w jednym zeszycie było: polski, rachunki, wszystko. Szlaczki trzeba było robić, więc piękne szlaczki, rysunki. Taki jeden zeszyt ja do dzisiejszego dnia mam. I mam taki uraz, że linie, kratki to mnie doprowadzają do szału. Mam wszystko bez linii, to mi zostało z tej szkoły. Byli też tam dorośli, to znaczy starsze klasy to byli dorośli, więc myśmy się spotykali na korytarzu, na dole był dziedziniec, były organizacje, była krucjata, organizacje katolickie, bo wiadomo, że siostra prowadziła, ale wszystko było bezkonfliktowo. Szkoła miała osiedle, bo przed wojną była idea osiedli, że dzieci musiały wyjeżdżać w czasie roku szkolnego. Tak jak teraz jest zielona szkoła, to wtedy było osiedle. Na przykład gimnazjum Piłsudskiego ${ }^{33}$ i jeszcze inne szkoły miały budynki w Grotnikach, a myśmy nie mieli, ale wyjeżdżaliśmy na osiedle do

${ }^{30}$ Chodzi tu o eksperymentalną naówczas Miejską Szkołę Pracy, w której proces edukacyjny opierał się na aktywnym udziale uczniów w procesie dydaktycznym i we własnych poszukiwaniach badawczych. Zob. Joanna Sosnowska, Miejska Szkoła Pracy jako przyklad nowatorstwa pedagogicznego w szkolnictwie powszechnym międzywojennej Łodzi, [w:] Jolanta Bonar, Anna Buła (red.), Poznać - zrozumieć - doświadczyć: konstruowanie wiedzy nauczyciela wczesnej edukacji, Oficyna Wydawnicza Impuls, Kraków 2013, s. 187-208.

${ }^{31}$ Budynek ten mieści się przy ulicy Rewolucji 1905 r. 67.

${ }^{32}$ S. Józefa Ledóchowska (1907-1983) - urszulanka, najbliższa kuzynka S. Urszuli Ledóchowskiej (1865-1939) - świętej Kościoła katolickiego, założycielki Urszulanek Serca Jezusa Konającego. Była jej biografką i propagatorką. Część swojego życia spędziła w Łodzi, gdzie pracowała jako nauczycielka religii w szkołach powszechnych. Równocześnie studiowała pedagogikę na Wydziale Pedagogicznym Wolnej Wszechnicy Polskiej w Warszawie (Oddział w Łodzi) i w 1940 uzyskała dyplom magistra filozofii w zakresie pedagogiki. Po wojnie uzyskała tytuł magistra polonistyki.

${ }^{33}$ Gimnazjum im. Piłsudskiego od roku 1922 do dziś mieści się przy ulicy Kopcińskiego 54. 
Inowłodza. Ale to była taka dziwaczna szkoła, więc z jednym jechały opiekunki, bo on się bał sam spać, ze mną jechała moja mama. Wszyscy się dziwili: ja nie jadłam, miałam swoje dania, tylko je jadłam. Więc owsiankę na śniadanie, na obiad już nie pamiętam co, a na kolację jadłam takie kluseczki lane robione z jajka. I nic więcej nie jadłam. W każdym razie mama wyjechała, a z tamtymi kucharkami zawarła sojusz, te kluski miałam, tą owsiankę miałam i przeżyłam to osiedle. Szkołę podstawową zamknęli w 1939 roku. Byłam wtedy w trzeciej klasie, więc jeszcze się trochę lekcji odbywało, była nowa nauczycielka, bardzo sympatyczna, a potem już ją w ogóle zamknęli. Bibliotekę zlikwidowali, wzięło się różne książki z tej biblioteki do domu i rozpoczęło się naukę w prywatnych domach. Pamiętam, że rozpoczęły się tajne komplety, to znaczy nauczanie. Ale myśmy w Łodzi byli do 1940 roku, ponieważ rozpoczęły się wysiedlenia. Myśmy wyjechali, przez zieloną granicę przechodziliśmy, z Łodzi się wyjechało na wozie, to było wszystko przygotowane, do Głowna. Trochę rzeczy się wzięło, tata wziął te swoje wszystkie przybory potrzebne, żeby mógł pracować [tata był lekarzem weterynarii]. I wojnę spędziliśmy na Zabrzeźni pod Głownem. Ojciec mój został zakwalifikowany jako lekarz, wyodrębniono mu tam teren, w którym mógł leczyć, pracować. Musiał współpracować z innym, gorszym lekarzem, więc początkowo nie było dobrze, ale potem tamten korzystał z wiedzy mojego ojca. Ojciec mój robił operacje i jakoś razem funkcjonowali. Ojciec zarabiał, bo wtedy każdy ubój świni musiał być potwierdzany przez lekarza, mięso zbadane i chłopi za to dawali rąbanki, kawałek mięsa, także u nas tego mięsa było pełno. A ja chodziłam na tajne komplety do szkoły podstawowej. Prowadziła je taka bardzo zacna pani nauczycielka szkoły podstawowej. A potem, nie kończąc szkoły podstawowej, znalazłam się na tajnym komplecie w gimnazjum, który najpierw prowadził profesor Kruczkowski. To był pan, który się ubierał w taki czarny surdut, białe kołnierzyki, ale chyba kiepsko mu szło pranie... No i erudyta nie z tej ziemi, więc dla nas to był za mądry nauczyciel, ale wszystkiego nas uczył: i matematyki, i polskiego, i wszystkiego, wtedy była też łacina, greka, wszystkiego nas uczył. Mieliśmy podręczniki przedwojenne, ale robiliśmy to, co on sobie wymyślił. A myśmy go bardzo prześladowały, ponieważ to się odbywało u mnie w domu i on do nas przychodził. To się odbywało w pokoju, gdzie były porozkładane różne serwetki, i on jak siadał, to myśmy bez przerwy te serwetki poprawiały, że co on zrobił, jak to zrobił? On się rozbierał, zdejmował jakiś czarny płaszcz, więc: „O, to my weźmiemy już, panie profesorze, wieszamy”. I mieliśmy taki na przykład pomysł, że się łapało pchły z psa i wpuszczało w ten surdut, i potem się go ubierało. On się bronił: „Nie, dziękuję panienki, ja sam się ubiorę”. On się bał tych pcheł, które wynosił. Więc bardzośmy go maltretowały. Gotowałyśmy mu jedzenie, ale ono było niedogotowane... Ale to był wspaniały człowiek. Potem zaczęłyśmy chodzić na komplety. Tam zaprzyjaźniłam się z dwoma koleżankami. Jedna z nich skończyła chemię i była doktorem na Politechnice 
Warszawskiej, nie żyje już. Druga jest plastyczką i mieszka w Łodzi. Byli też jacyś młodzieńcy, było bardzo sympatycznie. Chodziliśmy do takiej prawdziwej nauczycielki i ta już nas systematycznie uczyła. To była pani Baczyńska, która była osobą bardzo wykształconą, świetnie znała łacinę i historię. Potem okazało się, że jest wielu bezrobotnych nauczycieli. Zatrudniła więc niezwykle przystojnego młodzieńca, który nas uczył historii. Wszystkie byłyśmy w nim zakochane. To był bratanek biskupa Tomczaka ${ }^{34}$ - Andrzej Tomczak ${ }^{35}$, który później był profesorem na uniwersytecie w Toruniu. Archiwista. Znana postać, wspaniały profesor, historię wspaniale wykładał. Po powstaniu warszawskim pojawiła się doskonała nauczycielka geografii, potem była matematyczka, której nie cierpieliśmy. Te komplety były bardzo dobrze prowadzone, a nas było trzy czy cztery. Z moją przyjaciółką Urszulką uczyłyśmy się bardzo intensywnie, naprawdę się uczyłyśmy. Jak przyjeżdżali parobkowie do mojego ojca, żeby go gdzieś tam zawieźć, to myśmy z nimi konferowały po łacinie czy po francusku i byłyśmy zdziwione, że oni nic nie rozumieją. Miałyśmy świetne przedwojenne podręczniki, takie jak Mówiq wieki. Czytałyśmy dużo, bo w Zabrzeźni było takie starsze małżeństwo, państwo Widulińscy, którzy mieli dużą bibliotekę. Przeczytałam wtedy wszystkie powieści Dumasa. Więc między innymi z tego Dumasa wynikła moja pasja do historii, ponieważ ja bardzo lubiłam historię, no i z tego profesora Andrzeja Tomczaka. Wojna się skończyła, wróciłyśmy do Łodzi. Właściwie przyszliśmy, bo to się pieszo szło. Szliśmy szosą, mróz niesłychany, z jednej strony trupy Niemców, Rosjan, takich Kałmuchów, to wszystko sztywne, bo zimne, a z drugiej strony ludzie szli z getta. W Łodzi poszliśmy do naszego mieszkania na Pomorskiej, w którym mieszkał Niemiec, właściciel czy dyrektor fabryki, więc ono nie było zniszczone, i tam zamieszkaliśmy. Ja postanowiłam iść do normalnej szkoły i znalazłam gimnazjum Janiny Czapczyńskiej na Narutowicza ${ }^{36}$. Poszłam tam i powiedziałam, że skończyłam dwie klasy gimnazjum i do trzeciej klasy gimnazjum tam się zapisałam. Wśród naszych profesorów na tych kompletach był nauczyciel, który się potem zjawił u Czapczyńkich, chyba profesor Sadowski, matematyk, człowiek zacności niesłychanej, był w PPS-ie. On był prawdziwym socjalistą i naprawdę wielkim humanistą. On właśnie potwierdził, że ja rzeczywiście te dwie klasy skończyłam. A klasa była mieszana, bo była młodzież w takim normalnym wieku, ale i osoby starsze. Część tej szkoły to były koszary radzieckie. Rosjanie tam siedzieli w oknach i mieli bardzo duży ubaw, bo myśmy na podwórzu miały zajęcia z gimnastyki. Wtedy to w ogóle po ulicach chodzili Rosjanie w piżamach, ci, którzy byli ranni. To była bardzo dobra szkoła. Jej

${ }^{34}$ Kazimierz Tomczak (1883-1967) - biskup sufragan łódzki w latach 1927-1967, profesor warszawskiego seminarium duchownego. Uznawany za najwybitniejszego teologa łódzkiego Kościoła.

${ }^{35}$ Chodzi tu o prof. Andrzeja Tomczaka (ur. 1922), historyka i archiwistę.

${ }^{36} \mathrm{O}$ tym samym gimnazjum opowiadają Bronisława Kopczyńska-Jaworska i Wanda Nowakowska. Patrz też przypis 9 i $10 \mathrm{w}$ tym rozdziale. 
dyrektorem był mąż pani Janiny Czapczyńskiej. Ona była taką przełożoną, ponieważ to była szkoła żeńska, to musiała być kobieta. Ona się w zasadzie nie pokazywała. Nauczyciele, jak się później okazało, wszyscy przeszli na uniwersytet jako profesorowie. I w tym gimnazjum zrodziło się moje zainteresowanie historią, ponieważ ja miałam, jedyna chyba, piątkę z historii, bo byłam osobą wybijającą się. Poszłam więc na studia na historię. Ale wracając do tej szkoły, to była to szkoła demokratyczna: myśmy miały samorząd, była spółdzielczość, robiłyśmy przedstawienia. Wystawiłyśmy przez siebie napisaną sztukę Kopciuszek, bardzo romantyczną, tam miłość była okrutnie rozwinięta w tym Kopciuszku. Dręczyłyśmy strasznie szkołę, bośmy robiły długie akademie poetyckie. Jak były imieniny Tadeusza Czapczyńskiego, to dawało mu się bukiet różowych goździków, które bardzo lubił, a później odbywała się niekończąca się akademia, gdzie wszyscy już tam zasypiali, a myśmy twardo czytały. Poza tym mieliśmy właśnie tego profesora Franciszka Sadowskiego, więc ponieważ on lubił słodkie rzeczy, to mu na imieniny każda dała serce z piernika i on tak siedział przy stole za górą tych pierników, ogromnie wzruszony. Historii uczył nas profesor Jackowski, dziwak nie z tej ziemi, fantazję miał ogromną, ale to był bardzo dobry historyk. I on mnie strasznie maltretował, ale piątkę z tej historii mi postawił!

Te trzy rozbudowane fragmenty narracji pozwoliły zarysować biograficzne i społeczne konteksty doświadczeń kształtujących pokoleniowe losy naszych rozmówców. W dalszej części tego podrozdziału pokażemy różne indywidualne warianty doświadczeń i przeżyć stopniowo prowadzących narratorów ku przyszłej karierze akademickiej (choć zapewne wtedy jeszcze nie w pełni zdawali sobie z tego sprawę).

Jolanta Kulpińska, socjolog, szczegółowo wspomina swoje lata szkolne i łódzkie gimnazjum, w którym znalazła się zaraz po wojnie. Opowiada także o swoich koleżankach, wskazując także na ich późniejsze kariery - niejako dodatkowo potwierdzające jakość ówczesnego wykształcenia. Wreszcie mówi też o wyśmienitych nauczycielach:

[W] czasie wojny w Warszawie oczywiście chodziłam do tajnej szkoły, także nie miałam pod tym względem żadnych przerw. To oddzielny rozdział, jak wyglądały oświata i szkolnictwo w czasie okupacji. Także po wojnie, kiedy wróciłyśmy do Łodzi, to był maj i ja od razu poszłam do gimnazjum, do czwartej klasy, którą zrobiłam w ciągu miesiąca, tak jak właściwie wszyscy. Dostałam się do klasy, która wtedy się organizowała, bo inne już były wcześniej, od stycznia. Przez ten miesiąc nie mając ani jednego podręcznika i chyba tylko jeden zeszyt [śmiech], jakoś jednak tę klasę zaliczyłam. I potem chodziłam już 
do liceum Konopnickiej na Wólczańskiej ${ }^{37}$. Chyba to było na Wólczańskiej, już nie pamiętam. To taki może interesujący moment: było bardzo mało licealnych klas humanistycznych i właśnie nasza klasa była trochę pozbierana, złożona z dziewczyn, które koniecznie chciały tylko klasy humanistyczne. Co zresztą w moim przypadku było dodatkowo uzasadnione tym, że ja jednak przez ten okres wojenny i powojenny z przedmiotami ścisłymi byłam dosyć na bakier. No, ale klasa humanistyczna nasza nie była zbyt liczna, natomiast odznaczała się tym, że połowa chyba klasy to są osoby jakoś znane w naszej humanistyce, bo w tej klasie była Inka Brodzka-Wald ${ }^{38}$, Alina Molska ${ }^{39}$, Basia Kruk-Michałowska, dziennikarka Zosia Dudzińska, nie pamiętam nazwiska Antosi, która pracowała w GUS-ie w Łodzi i tak dalej. Od razu klasa była rzeczywiście zainteresowana humanistyką, mieliśmy dobrych nauczycieli, większość zresztą naszych nauczycieli, jeszcze wtedy z liceum, znalazła się potem w uniwersytecie, albo pani od fizyki była później profesorem na politechnice. Więc byli to dobrzy nauczyciele, którzy traktowali nas tak trochę jako osoby bardziej dorosłe czy w każdym razie zainteresowane. To miało znaczenie, bo się śmiałyśmy, że jak klasa poszła na wagary, to do biblioteki miejskiej, a nie do parku [śmiech]. To nas bardziej interesowało i nasza dyrektorka, też potem pracownik PAN-u, zawsze nas tak strofowała, że myśmy sobie wybierały przedmioty, które nas interesowały, a innych nie.

Nieco dalej w swojej relacji Jolanta Kulpińska uzasadnia także wybór problematyki, którą przez lata zajmowała się w swojej pracy badawczej i naukowej, upatrując jego przyczyn we własnych wojennych doświadczeniach pracy przymusowej. Kiedy opowiada o powrocie ze studiów doktoranckich w Moskwie (o czym szczegółowo piszemy w podrozdziale poświęconym wyjazdom zagranicznym) i podjęciu współpracy z Janem Szczepańskim ${ }^{40}$, tak wyjaśnia swoje zainteresowania klasą robotniczą:

Może też jakąś rolę myślę odgrywały te moje doświadczenia pracy przymusowej w Niemczech. Bo po powstaniu znalazłam się w fabryce śrub czołgowych, która była tak bombardowana, że w rezultacie pracowałam w takiej hali, gdzie była tylko jedna ocalała maszyna. I ja tam byłam. Właściwie to nie było do

${ }^{37}$ Liceum Humanistyczne im. M. Konopnickiej znajdowało się najpewniej przy ulicy Wólczańskiej 55, w gmachu zajmowanym przed wojną przez Prywatne Gimnazjum Żeńskie Zofii Pętkowskiej i Weroniki Macińskiej.

${ }^{38}$ Alina Brodzka-Wald (1929-2011) - historyk literatury, wieloletni profesor w Instytucie Badań Literackich Polskiej Akademii Nauk.

${ }^{39}$ Alina Molska (1929-2011) - doktor socjologii, wykładała w Instytucie Socjologii Uniwersytetu Warszawskiego.

40 Jan Szczepański (1913-2004) - wybitny polski socjolog, urodzony w Ustroniu, przez wiele lat związany z Uniwersytetem Łódzkim (1945-1970), którego był profesorem, a później także rektorem. 
niczego już potrzebne, tylko coś trzeba było z nami zrobić, z tymi robotnikami. Dla mnie to nie było jakieś strasznie uciążliwe, ponieważ miałam bardzo silną świadomość, że wojna za chwilę się skończy, może nas jakoś nie zbombardują do końca. A jak się skończy, to ja pójdę do szkoły. Na pewno nie będę całe życie naciskała tego pedału i wykonywała tej niesłychanie rutynowej, niewykwalifikowanej, prościutkiej roboty. Ale zdałam sobie sprawę, że są ludzie, którzy to robią całe życie. I myślę, że to był jeden z elementów, który mnie tak związał z tą problematyką.

Romuald Skowroński, chemik, ze szczególnym szacunkiem wspomina nie tylko swoje liceum w Piotrkowie Trybunalskim i przypomina jego tradycje sięgające XVII wieku, ale mówi również o specyficznej atmosferze panującej na Uniwersytecie Łódzkim tuż po wojnie. Tak jak na wielu innych uczelniach, wiązała się ona z tym, że różnica wieku i doświadczeń między studentami (w konsekwencji wojny) bywała ogromna:

Oczywiście w czasie okupacji niemieckiej nie było żadnych szkół wyższych. Było tajne nauczanie. Takie tajne uniwersytety działały w Krakowie, w Warszawie, i tak samo szkoły średnie. Na tajnych kompletach nas było siedmiu, ośmiu, ze względów bezpieczeństwa. Zajęcia odbywały się w prywatnych mieszkaniach i myśmy mieli znakomitych profesorów. To była nie tylko profesura miejscowa, która była na bardzo wysokim poziomie, Piotrków miał znakomite gimnazjum i liceum imienia Chrobrego, które powstało pod koniec XVII wieku, otwarte przez jezuitów. Więc to był bardzo wysoki poziom w gimnazjum Chrobrego ${ }^{41}$. A na tych właśnie tajnych kompletach to mieliśmy profesorów ze Lwowa, z Wilna. To byli na ogół znakomici profesorowie Uniwersytetu i proszę mi wierzyć, że dostaliśmy naprawdę bardzo przyzwoite wykształcenie jeżeli chodzi o szkołę średnią. Ja zrobiłem maturę na tajnych kompletach. Zaraz po wyzwoleniu w styczniu 1945 roku Chrobry od razu otworzył swoje podwoje i liceum ukończyłem. I nie wiem czemu, po co, przecież ciągle byłem młody, właściwie w ciągu roku zrobiłem dwie klasy licealne. Muszę powiedzieć, że był ogromny pęd młodzieży do wiedzy. A młodzież była wtedy bardzo różna, mnóstwo było młodzieży właśnie z Kresów Polski, z Wilna i okolic, z okolic Lwowa i to było takie bardzo zróżnicowane towarzystwo, ale to było ciekawe, dlatego że to była taka wymiana sposobów bycia, pewnych przyzwyczajeń, a także i dość duża różnica wieku, jeżeli chodzi o studia. Tam byli koledzy, którzy rozpoczęli swoje studia, już przed wojną mieli dwa, trzy lata zaliczone, i był taki szczeniak jak ja, który zaczął te studia dość młodo, po wojnie.

${ }^{41}$ Założenie szkoły datuje się na rok 1675 . Obecnie jest to I Liceum Ogólnokształcące im. Bolesława Chrobrego, które mieści się przy al. Kopernika 1 w Piotrkowie Trybunalskim. 
Chociaż Jerzy Dietl, ekonomista, swoje wspomnienia dotyczące ścieżki edukacyjnej rozpoczyna od zastrzeżenia, że nie był ani cudownym dzieckiem, ani wzorowym uczniem, to ponownie „dobra przedwojenna szkoła” (tym razem w Poznaniu, później w Ostrowcu Świętokrzyskim) odgrywa kluczową rolę. W czasie okupacji pieczę nad rozwojem intelektualnym swego syna przejął ojciec, który miał niebagatelny wpływ nie tylko na jego edukację, ale i na postawę życiową. W tym ,nietypowym” procesie kształcenia uczestniczyli także profesorowie uniwersytetu, którzy w wyniku zawieruchy wojennej znaleźli się w miejscu zamieszkania młodego Jerzego Dietla i na prośbę ojca sprawdzali jego wiedzę. Wreszcie narrator rekonstruuje pewien swoisty dla tego pokolenia przebieg ścieżki edukacyjnej, która niejednokrotnie była z różnych względów przerywana i dlatego należało później nadrobić (często w przyspieszonym tempie) nagromadzone zaległości.

Muszę panią zmartwić tym, ja nie należałem do takich cudownych dzieci, co to od pierwszej klasy szkoły powszechnej wykazują się geniuszem. Raczej to nie miało miejsca, bo jak się pani domyśla, ze względu na mój wiek właściwie całe prawie gimnazjum odbyłem w czasie wojny na tajnych kompletach. Przed wojną, choć chodziłem do bardzo dobrej szkoły w Poznaniu, to znakomitym uczniem nie byłem, o czym świadczy chociażby to, że jak zdawałem egzamin do gimnazjum, a pani zapewne wie, że przed wojną zdawało się egzamin do gimnazjum po sześciu klasach szkoły powszechnej, to nauczyciele pytali mnie dwa razy, bo nie chcieli wierzyć, że jestem tak dobrze przygotowany, co wynikało z tego, że przed owym egzaminem nie wolno mi było z domu wychodzić przez trzy miesiące i ojciec mój, który był takim przymusowym emerytem już wtedy, pilnował mnie i stale uczył matematyki oraz łaciny, którą świetnie znał. No i jakoś to przebrnąłem. Później szkołę średnią kończyłem w Kongresówce, w Ostrowcu Świętokrzyskim, a przedtem jeszcze zdawałem eksternistycznie do drugiej klasy gimnazjalnej, bo byłem na wsi przez pierwszy rok wojny i ojciec był moim nauczycielem w pierwszej klasie gimnazjalnej. Przy czym może ciekawostką było to, że egzaminowali mnie profesorowie Uniwersytetu Poznańskiego, którzy byli wywiezieni i zajmowali się szkoleniem młodzieży, by jakoś przeżyć. Zresztą dobrzy znajomi ojca. Po wojnie moje studia były dosyć przyspieszone, ponieważ jeden rok w czasie wojny straciłem bezpowrotnie: siedziałem bezczynnie w więzieniach i obozach, po aresztowaniu na początku sierpnia w przedostatnim roku wojny. Ten czas spędziłem głównie w Niemczech. Potem wróciłem i w ciągu niecałych dwóch lat ukończyłem liceum i zdałem maturę, i równocześnie studiowałem. Tak więc zrobiłem trzy lata w ciągu półtora roku. Kończyłem studia w 1949 roku. 
Zbigniew Jakubowski, matematyk, opowiada o swoim przyjeździe do Łodzi, o tym, w jaki sposób zawierucha wojenna wpłynęła na myślenie jego rodziców (i z pewnością także wielu osób z tego pokolenia) o przyszłym zawodzie syna; mówi także o swoim profesorze z liceum Aleksandrze Nikołajczuku, który przekonywał go do wybrania matematyki jako kierunku studiów. Zanim przejdziemy do tego fragmentu, przyjrzyjmy się jeszcze krótko przedwojennym losom rodziny Jakubowskiego. Jego rodzice byli nauczycielami, którzy pracowali w oddalonych od siebie białoruskich wsiach i na tamtych terenach byli przedstawicielami niewielkiej polskiej inteligencji. Po ślubie podjęli pracę w szkole w Siemigostyczach - dużej wsi oddalonej o dwa kilometry od granicy polsko-rosyjskiej. Ojciec był jej kierownikiem, a mama pracowała jako nauczycielka. W 1937 roku przenieśli się do wsi Łosinka w powiecie Bielsk Podlaski i tam cała rodzina doczekała wojny. W sierpniu 1939 roku ojciec jako oficer rezerwy stawił się w Białymstoku na wezwanie mobilizacyjne. Nigdy już nie wrócił do domu, zginął w Katyniu. Mama zmuszona była przenieść się na zachód od Bielska Podlaskiego, gdzie mogła pracować w szkole do czerwca 1941 roku - aż do wkroczenia armii niemieckiej. O tym czasie Zbigniew Jakubowski wspomina:

Moja edukacja w czasie wojny kończyła się bądź w domu, bądź z panią, która nazywała się chyba Świerżowa, do której trzech czy czterech chłopaków chodziło na tajne korepetycje. To było w miasteczku Brańsk. W 1944 roku na te tereny wkroczyło wojsko radzieckie i stosunkowo szybko, nie wiem, czy już od września, ruszyły szkoły z językiem polskim, w których mama była też nauczycielką. Ja chodziłem do szkoły tam właśnie i w 1946 roku mama i mój późniejszy ojczym postanowili przyjechać do Łodzi. I jesteśmy teraz w październiku 1946 roku i jedziemy towarowym pociągiem przez Warszawę. Chyba na stacji Widzew była krańcówka ${ }^{42}$ i ze stacji Widzew ojczym wynajął rolwagi i przewiózł nas na Bałuty ${ }^{43}$, na ulicę Tokarzewskiego. I oczywiście tam po kilku dniach trafiłem do siódmej klasy w 28 Szkole Powszechnej, chyba to się nazywało wówczas, przepraszam, jeśli mylę nazwy. Siódmą klasę skończyłem na ulicy Franciszkańskiej, w tym budynku od kilku lat jest któryś z wydziałów naszej Wyższej Szkoły Sztuk Pięknych. Do ósmej klasy chodziłem na Staszica do 49 Szkoły, a do dziewiątej - jedenastej byłem w liceum wówczas ogólnokształcącym, tutaj na Spornej budynek ten stoi. Z tego sformułowania widać, że byłem rocznikiem, który wpadł na schody reformy szkolnictwa i byłem pierwszym rocznikiem, gdzie maturę robiło się po jedenastej

${ }^{42}$ Regionalna nazwa ostatniego przystanku, zajezdni lub pętli tramwajowej (także autobusowej) używana w Łodzi.

${ }^{43}$ Bałuty - dzielnica Łodzi. Dalej mowa o XI LO im. Michała Kajki mieszczącym się przy ulicy Spornej, zamkniętym w 1980 roku, jego wizytówką były przedmioty matematyczno-przyrodnicze. 
klasie. Ale myślę, że te rzeczy są znane. W XI Liceum miałem duże szczęście, że wśród nauczycieli spotkałem profesora Aleksandra Nikołajczuka, który uczył nas matematyki. Czasami młodzi pytają mnie, czy byłem bardzo dobrym uczniem czy innym. Ja bym ten temat wolał lekko pominąć. Natomiast $\mathrm{w}$ swoich opracowaniach i $\mathrm{w}$ rozmowach towarzyskich często wspominam profesora Nikołajczuka, dlatego że w okresie matury miał ze mną zasadnicze rozmowy i odradził mi pójście na politechnikę, a poradził, żebym poszedł na matematykę. Argumenty były różne. Myślę, że wówczas moi rówieśnicy mieli podobne dylematy. Ojczym na przykład, mama częściowo też, często wspominając doświadczenia ostatniej wojny, która tuż tuż się skończyła, cenili bardzo konkretny zawód. To znaczy inżynier, lekarz, natomiast tam jakaś matematyka, jakiś nauczyciel, to zaraz była mowa: „A jak coś wybuchnie, to szkoły będą zamknięte". To były ich świeże doświadczenia. W związku z tym ja trochę myślałem o politechnice, ale po tych dwóch, trzech rozmowach z profesorem Nikołajczukiem podjąłem decyzję, że idę na matematykę. Jeden $\mathrm{z}$ argumentów był taki, że jestem jednym z niewielu ówczesnych młodzieńców, który nie stracił na wojnie jeśli chodzi o szkołę, bo przecież straciłem ojca. Często mi go brakowało. Często zazdrościłem moim kolegom, że mają tatę. Ale ponieważ mama była nauczycielką i w tym środowisku nauczycielskim byliśmy, to mimo różnych zawirowań nie straciłem nic na szkole. Maturę robiłem w 1951 roku, mając siedemnaście lat. Musiałem wówczas pisać podanie do ministra, żeby wyraził zgodę. To nie było takie proste, bo musiała być opinia między innymi organizacji społeczno-politycznych i inne rzeczy. Przypominam to nie dla podkreślenia, że byłem kombatantem czy nie byłem, tylko by przypomnieć losy moich rówieśników. Minister wyraził zgodę na tę maturę i jeszcze jako nastolatek złożyłem podanie na Uniwersytet Łódzki, Wydział Matematyki, Fizyki i Chemii.

Początki kariery edukacyjnej Romualda Olaczka, biologa, układały się nieco inaczej. Jego rodzice i ogromna część najbliższych zginęła w czasie II wojny światowej. On sam został pod opieką babci. W 1952 roku podjął naukę w liceum pedagogicznym, które w owym czasie dawało zawód i było gwarantem pewnej pracy.

Zacznę od roku 1952. Skończyłem wtedy szkołę średnią w Łowiczu. Liceum pedagogiczne ${ }^{44}$, które wspominam jako najlepszą szkołę, do jakiej w życiu chodziłem. A chodziłem do dwóch szkół podstawowych, jednej w Warszawie, drugiej w Łowiczu, a potem do dwóch szkół średnich w Łowiczu. I to liceum pedagogiczne wywarło chyba największy wpływ nie tylko na mój rozwój umysłowy, ale na rozwój mojej osobowości. To była wyjątkowo dobra szkoła

${ }^{44}$ Liceum Pedagogiczne w Lowiczu funkcjonowało w latach 1937-1939 oraz 1945-1966. Mieściło się w budynku klasztoru bernardynów. 
i myślę, że większość liceów pedagogicznych taka była i ja często w gronie osób mojego pokolenia łatwo rozpoznaję tych, którzy kończyli licea pedagogiczne, inne zupełnie jeżeli chodzi o ducha panującego w szkole od liceów ogólnokształcących.

Jerzy Kmieciński, archeolog, wracając pamięcią do początków swojej edukacji diagnozuje ex post facto swoje zainteresowania archeologią, odwołując się przy tym do wyniesionego z domu habitusu, a przede wszystkim nawyku czytania książek. Wspomina również o zainteresowaniach swojego ojca starożytnością i opisuje, jak w czasie wyprawy na Okopy św. Trójcy pod Chocimiem znaleźli fragment terra sigillata [glina stemplowana: rodzaj naczyń wytwarzanych na terenie Włoch od I w. p.n.e., które można odnaleźć na obszarze Cesarstwa Rzymskiego].

Zanim jednak przejdziemy do opowieści profesora Kmiecińskiego, musimy wspomnieć o tym, że jego ojciec, o czym szczegółowo informuje nas sam narrator, był zawodowym oficerem i w okresie międzywojennym często wraz z całą rodziną zmuszony był przenosić się z miejsca na miejsce. Jedna z placówek, do której został oddelegowany, znajduje się w Czortkowie na Podolu, gdzie mały Jerzy Kmieciński został posłany do szkoły podstawowej. Rodzice dość niefortunnie zadecydowali, że może od razu pójść do drugiej klasy.

Cztery przedmioty i cztery „dwóje”. No i pani nauczycielka na wywiadówce powiedziała mojej mamie: „Wie pani, to jest dziecko takie nierozwojowe”. Ale ja zawziąłem się i w drugiej klasie, w drugim półroczu szkoły powszechnej, jakoś już sobie radę dałem. Szybko nauczyłem się płynnie czytać, bo już od trzeciej klasy czytałem Kraszewskiego, właściwie cały historyczny cykl: od Starej baśni po Saskie ostatki. Kraszewski swoimi powieściami objął całą historię Polski. Ojciec przynosił mi z pułkowej biblioteki książki, a ja czytałem wszystko od A do Z. Tak że zainteresowanie starożytnością, czy szerzej powiedziawszy, czasami odległymi ugruntowało się we mnie w zasadzie wtedy. Mój ojciec miał również zainteresowania starożytnością. Zawiózł mnie pewnego dnia z Czortkowa na Podolu, gdzie wtedy mieszkaliśmy, na tzw. Wały Trajana czy Okopy św. Trójcy niedaleko Chocimia. Krasiński umieścił tam akcję swojego poematu Nie-Boska komedia i tam ojciec znalazłszy fragment ceramiki powiedział do mnie: „Widzisz synku, naczynie, którego ułamek znaleźliśmy trzymał zapewne w ręku legionista rzymski przed dwu tysiącami lat”. Później, kiedy już studiowałem archeologię ustaliłem, że był to zapewne fragment terra sigillata. Myślę, że wydarzenie to stanowiło niewątpliwe bodziec w moich studiach i zainteresowaniach. 
Sięgnijmy teraz do biografii Krzysztofa Jażdżewskiego, biologa. Odnaleźć w niej możemy wiele kluczowych elementów środowiska socjalizacyjnego, których konfiguracja wpływa i kształtuje jego dalsze losy (omówimy je w nieco innej kolejności niż sam narrator). Nie do przecenienia jest tu rola ojca - wybitnego archeologa Konrada Jażdżewskiego ${ }^{45}$, który zaszczepił w swoim synu pasję nauki. Ogromne znaczenie miało również środowisko sąsiedzkie - tuż po wojnie bowiem rodzice naszego rozmówcy, $\mathrm{z}$ racji zawodu ojca, zamieszkali w kamienicy przeznaczonej na mieszkania dla kadry nowo tworzonego Uniwersytetu Łódzkiego. Tym samym młody Krzysztof Jażdżewski znalazł się w otoczeniu postaci wybitnych i nietuzinkowych, które nie tylko podpatrywał, ale także wiele się od nich uczył. Wreszcie, swój szczególny udział w rozbudzeniu jego pasji biologicznej miały wakacje spędzane na łonie przyrody oraz wuj-leśnik:

Gdy trafiliśmy do Łodzi, najpierw zamieszkaliśmy w hotelu bodajże na ulicy Próchnika czy Więckowskiego. A potem profesorowie dostawali mieszkania, takie, nazwijmy to, miejskie. Takim naszym ukochanym mieszkaniem przez wiele lat było mieszkanie na ulicy Kościuszki 52. To taka kamienica zbudowana tuż przed wojną, elegancka dosyć, czteropiętrowa, gdzie mieszkali profesorowie Uniwersytetu Łódzkiego. Niektórych sąsiadów jeszcze pamiętam: na czwartym piętrze mieszkał profesor Ireneusz Michalski ${ }^{46}$, przyjaciel ojca. To był antropolog, chodziłem na jego wykłady. Na trzecim piętrze, nad nami, mieszkał profesor Skupieński ${ }^{47}$. To był botanik, którego żona, rodowita Francuzka, była wielką przyjaciółką rodziny i od niej nauczyłem się pierwszych słów i różnych powiedzonek po francusku, bo babcie rozmawiały z panią Skupieńską po francusku i polecenia do dzieci były wydawane w tym języku. $\mathrm{Na}$ drugim piętrze nad nami, bo myśmy mieszkali na pierwszym, mieszkała rodzina profesora Dmochowskiego ${ }^{48}$, biochemika. Później też słuchałem jego wykładów. Na parterze mieszkał profesor Wiśniewski ${ }^{49}$, fizyk. Mieszkał tu też

${ }^{45}$ Zob. przypis $26 \mathrm{w}$ tym rozdziale.

${ }^{46}$ Ireneusz Michalski (1908-1965) - antropolog, profesor Uniwersytetu Łódzkiego. W 1945 roku zorganizował Zakład Antropologii na Wydziale Matematyczno-Przyrodniczym tegoż uniwersytetu. Twórca metody morfologiczno-porównawczej w systematyce człowieka (tzw. szkoła łódzka). Uczestnik wielu wypraw naukowych, w tym m.in. do Chin, Korei, Egiptu i Mongolii.

${ }^{47}$ Franciszek Ksawery Skupieński (1888-1962) - botanik, mikrobiolog, badacz grzybów i śluzowców. Przed wojną profesor Uniwersytetu Wileńskiego, potem Wyższej Szkoły Gospodarstwa Wiejskiego w Łodzi oraz od 1945 roku Uniwersytetu Łódzkiego.

${ }^{48}$ Antoni Dmochowski (1896-1983) - profesor biochemii, współtwórca Uniwersytetu Łódzkiego i tzw. łódzkiej szkoły biochemicznej, założyciel Katedry Biochemii na Uniwersytecie Łódzkim, która byłą pierwszą taką placówką w Polsce.

${ }^{49}$ Feliks Joachim Wiśniewski (1890-1963) - fizyk, profesor Wolnej Wszechnicy Polskiej, a po II wojnie światowej profesor Uniwersytetu Łódzkiego i Politechniki Łódzkiej. 
profesor Zabłocki ${ }^{50}$, który jest ważną osobą w tym gmachu, bo on jako prorektor Uniwersytetu przyczynił się do jego wybudowania ${ }^{51}$. To był mikrobiolog z kolei. Już w tej chwili nie wszystkich sąsiadów pamiętam z nazwiska, to się zresztą potem zmieniało, ale w każdym razie ten dom na Kościuszki 52 to takie wspaniałe dzieciństwo i młodość.

(...)

Mój ojciec był archeologiem i w swojej specjalności był dosłownie zakochany. Także takie różne dowcipy nawet były, jak to mówił do mojej mamy: „Kocham cię prawie tak jak archeologię". To było cudowne, wspaniałe małżeństwo. Dla mnie bardzo istotne były niektóre wyprawy z ojcem na wykopaliska. On mnie zabierał po prostu, to nie była wyprawa. Jako dziecko mogłem zobaczyć, jak naukowiec zajmuje się dziedziną, która go fascynuje, jak to robi, jak się tym przejmuje i jakie to jest ciekawe. Pokazanie samej pasji dla mnie bardzo dużo znaczyło. Ja się zupełnie czym innym zająłem, ale na pewno ojciec we mnie zaszczepił czy pokazał to, jak ważne jest, żeby robić w życiu to, co się lubi. I że to jest nawet ważniejsze niż pieniądze. Ja pamiętałem, jak zawsze mówił: „No wyobraź sobie też, że pracujesz na poczcie całe życie. I całe życie tylko przybijasz pieczątki na tych listach”. Troszeczkę za prosto może ocenił tę pracę. To może być dla kogoś ciekawe, ale w stosunku do tego, co robił archeolog czy biolog, to już nie jest takie ciekawe. Pokazał mi, że właśnie pasja i radość $\mathrm{z}$ tego, co się robi, to jest szalenie ważna sprawa w życiu. Na pewno pokazał mi na własnym przykładzie, jak bardzo go to poruszało. Był wybitnym uczonym, docenionym, bo został i członkiem Akademii już w późnym wieku, i doktorem honoris causa tej uczelni ${ }^{52}$, i był ceniony przez kolegów w Polsce i za granicą. Był znakomitym poliglotą, bo w dwunastu językach potrafił się porozumieć, a redagował taką serię wydawniczą „Glossarium Archaeologicum” w dwudziestu czterech językach. To było coś, powiedzmy, w rodzaju encyklopedii, gdzie różne garnki wykopane czy krzemienie były właśnie nazwane, jakieś konkretne rzeczy w dwudziestu czterech językach. W niektórych językach to znakomicie umiał się porozumieć, jak w niemieckim, francuskim, rosyjskim, czy angielskim. Umiał też mówić po duńsku, po czesku, a w niemieckim, to o ile wiem, w kilku dialektach umiał się porozumieć. I to bardzo się przydało, dlatego że w domu był taki kult języków. Mama germanistka i anglistka, ojciec, można powiedzieć, jeszcze lepiej [śmiech], więc nauka języka była bardzo dopilnowana. W szkole to miałem rosyjski i niemiecki. Od mamy angielski, od pani profesorowej Skupieńskiej dziecinne jakieś słówka francuskie,

${ }^{50}$ Bernard Zabłocki (1907-2002) - mikrobiolog i immunolog, absolwent Uniwersytetu im. Stefana Batorego, od 1945 roku profesor Uniwersytetu Łódzkiego, kierownik Katedry Mikrobiologii UŁ.

${ }^{51}$ Mowa tu o budynku mieszczącym się przy ulicy Banacha 14/16.

52 Prof. Konrad Jażdżewski dopiero w 1983 roku został członkiem Polskiej Akademii Nauk. W 1985 roku tuż przed jego śmiercią Uniwersytet Łódzki przyznał mu doktorat honoris causa. 
a potem nawet paru lekcji ona mi udzieliła. Nie uczyłem się, nie zdawałem żadnych egzaminów, ale po francusku się jakoś dogadam, a teksty biologiczne to czytam bez problemu. Ta wielojęzyczność miała potem ogromne znaczenie wspierające, bo każda dziedzina wiedzy potrzebuje tej znajomości języka. Teraz został tylko angielski, to już właściwie jest taka łacina międzynarodowa. Mieliśmy też dobrego nauczyciela rosyjskiego, a ponieważ mama i jej rodzeństwo urodzili się na Podolu, to kiedy po rewolucji bolszewickiej uciekła z rodziną do Polski, to przyjechała ze znajomością i ukraińskiego, i rosyjskiego - taką naturalną, bo tam wyrastała. Rosyjski oczywiście nie był może tak lubiany w Polsce z oczywistych względów, ale mama potrafiła pokazać też piękno tego języka, jak piękna jest szczególnie poezja i śpiewy - niezależnie od tych sympatii, antypatii. To samo niemieckiego dotyczyło. Niemiecki to był jeszcze bardziej wredny. Przecież dla nas Niemcy po wojnie to był najgorszy wróg. Natomiast to, że mama jako germanistka potrafiła mi pokazać piękno poezji Goethego i Schillera... Do dziś umiem zresztą Rękawiczkę Schillera po niemiecku.

\section{(...)}

Wracając do mojego dzieciństwa, bardzo wspaniałego... Nie zawsze było wesoło materialnie, bo po wojnie nikomu nie było za dobrze finansowo, nawet profesorowi uniwersytetu. A poza tym piątka dzieci, dwie babcie - to był ogromny dom do wyżywienia. Ale wakacje zawsze mieliśmy jakieś zapewnione, takie wiejsko-leśne. Spędzaliśmy je przede wszystkim u mojego ukochanego wujka Witka ${ }^{53}$, który był nadleśniczym w Lidzbarku Welskim. To takie cudowne miejsce, raj utracony... Coś pięknego, do dziś nie mogę mówić bez wzruszenia - to było tak wspaniałe miejsce. W dużej mierze tam właśnie rozbudził się we mnie ten zachwyt przyrodą i wodą. Zaczęło mnie to na pewno opanowywać, bo tam były grzyby, ryby... Łódki były nad jeziorem, więc można było tą łódką się przepłynąć kawałek. Malutka przystań, takie molo malutkie. Tam się uczyłem pływać. Pewnie tak zaczęło się może w 1947 roku, tak od dwunastego, trzynastego roku życia co wakacje tam się było. To miało, moim zdaniem, dla mnie jako przyrodnika wielkie znaczenie, bo rozwijało moje zamiłowania. Od razu wiedziałem, że pójdę na studia biologiczne. Ojciec tak trochę lekko z żalem przyjął to, że nie idę w jego kierunku, ale bardzo dobrze mnie rozumiał, bo sam lubił przyrodę i ja myślę, że nawet pierwsze takie zachęty do zwierzaków to od niego uzyskałem, jak mi pokazywał, czym się różni ślad zająca od śladu lisa na śniegu.

${ }^{53}$ Witold Kowalczewski pojawia się po raz pierwszy w relacji Krzysztofa Jażdżewskiego, kiedy z całą rodziną w czasie wojny chronią się u niego w leśniczówce w Kampinosie. Zob. też wspomnienia Krzysztofa Jażdżewskiego na: http://www.pth.home.pl/pobierz/Wiadomosci_2_2013.pdf (10.07.2015). 
Ciekawym materiałem porównawczym może być tu wywiad z biologiem Andrzejem Piechockim, który doskonale ilustruje wpływ wczesnych, powiązanych ze sobą, doświadczeń w życiu na rozwój i pielęgnację pasji ${ }^{54}$ :

Zacznę od wczesnych lat, od dzieciństwa czy może bardziej od czasów młodości, kiedy zaczęły się moje zainteresowania tym, co potem było przedmiotem działań w ciągu życia. Wcześnie przejawiałem zainteresowania przyrodnicze, skupione na roślinach i zwierzętach, ì może bardziej na zwierzętach, a wywodziło się to $\mathrm{z}$ wielu lektur, ale $\dot{\mathrm{i}} \mathrm{w}$ dużej mierze również $\mathrm{z}$ kontaktów z moim ojcem, który, mimo że był humanistą, żywo interesował się przyrodą, zwłaszcza ornitologią. W czasie wspólnych spacerów, ojciec lubił nas z siostrą zabierać na spacery, uczulał mnie na głosy ptaków, pokazywał je i nazywał. To była pierwsza przyczyna. Potem były specjalistyczne lektury o rybach, ptakach, owadach, mięczakach i innych zwierzętach. I jeszcze jedna ważna rzecz: w Bydgoszczy, gdzie chodziłem do szkoły, miałem świetną nauczycielkę biologii, która dostrzegła moje zainteresowania i robiła wszystko, żebym je pogłębiał. Kiedy byłem w dziesiątej klasie, to nawet dwa lub trzy razy, przygotowując się wcześniej oczywiście, przy jej obecności, prowadziłem lekcje z określonego zagadnienia. To była dla mnie bardzo ważna próba. Działałem też w kółku biologicznym, a wśród moich najbliższych przyjaciół był kolega, który również interesował się biologią. On potem studiował leśnictwo. Razem z nim uprawiałem turystykę związaną z naszymi zainteresowaniami: wędrowaliśmy po okolicach Bydgoszczy, zwiedzaliśmy rezerwaty przyrody, fotografowaliśmy pomnikowe drzewa, obserwowaliśmy ptaki. Ważne dla pogłębienia i rozwoju tych zainteresowań było też wędkarstwo i wyprawy turystyczne w odległe rejony. To był okres dziewiątej, dziesiątej, jedenastej klasy, lata pięćdziesiąte. Prawdziwa turystyka kwalifikowana: dalekie szlaki, wyludnione wsie, przepastne lasy. Na Pomorzu Zachodnim, nad ogromnym Jeziorem Drawskim, nie spotykaliśmy się ani jednego turysty. I myśmy w dwójkę lub trójkę takie eskapady odbywali, co nas bardzo hartowało i uczyło obserwowania przyrody. Ukończyłem szkołę średnią z bardzo dobrym wynikiem z biologii i wyruszyłem na studia do Łodzi.

Jeszcze innym, równie ciekawym impulsem do wyboru określonego kierunku studiów mogą stać się - jak to poniżej zilustruje Stanisław Liszewski, geograf - niezwykłe i fascynujące opowieści starszych kolegów:

W ostatniej klasie liceum miałem przyjaciela, który zresztą mieszkał w Rzgowie i był synem kierownika tamtejszej szkoły. Bardzo się zaprzyjaźniliśmy, bo on trochę kulał z przedmiotów matematyczno-fizycznych i ja czasami z nim

${ }^{54}$ Ta relacja należy do kolekcji wywiadów zgromadzonych przez studentów prof. Kai Kaźmierskiej $\mathrm{w}$ ramach prowadzonych przez nią zajęć z metody biograficznej. Odwołujemy się do tego wywiadu raz jeszcze w rozdziale III. 
odrabiałem lekcje, jeździłem do niego. I ten mój kolega miał starszego brata, który studiował we Wrocławiu geografię. Ja chciałem pójść na politechnikę i złożyłem tam papiery. Ale wspominam, brat kolegi wrócił właśnie z jakiejś wyprawy i fantastycznie opowiadał o swoich wrażeniach. Powiedziałem wtedy: trudno, idę na geografię. Obaj idziemy na geografię. I w pewnym momencie przeniosłem moje papiery na UŁ, na geografię. Nie wiem, czy nieszczęście, czy szczęście z tym związane - mój kolega nie zdał matury. I w końcu ja tylko poszedłem na geografię, już nie wiem, co się z nim dalej stało, bo jakoś ślad po nim zaginął. $\mathrm{W}$ taki sposób trafiłem na uniwersytet na geografię, mimo że miałem pomysł iść na politechnikę.

Z kolei Leszek Wojtczak, fizyk, specjalista w dziedzinie ciała stałego, odpowiadając na pytanie „Od kiedy był pan zdecydowany, że będzie to fizyka?", mówi:

To trudne pytanie. Ma pani przed sobą niezdecydowanego w młodości człowieka, który długo nie bardzo wiedział, co ma studiować. Interesowały mnie z jednej strony przedmioty ścisłe - brałem udział w olimpiadach: matematycznej, fizycznej i chemicznej. Jednocześnie pociągały mnie literatura, kultura, a przede wszystkim język francuski. Wielkim przeżyciem był dla mnie także udział w Kole Dramatycznym przy moim liceum. W 1955 roku zajęliśmy I miejsce w Polsce w konkursie teatrów amatorskich, wystawiając w Teatrze Starym w Krakowie II część Dziadów Adama Mickiewicza. Było to jedno z najpiękniejszych moich przeżyć związanych z grodem Kraka. (...) Trudno powiedzieć jednoznacznie, co zdecydowało o tym, że to będzie fizyka. Filologia kusiła, ale jednocześnie trochę przerażała wielką swobodą otwartości interpretacyjnej. Natomiast pośród nauk ścisłych fizyka była, i oczywiście jest, najbliższa filozofii. Głęboko rozumiana fizyka to de facto filozofia, i to chyba najbardziej mnie w młodości pociągało jako przygoda intelektualna.

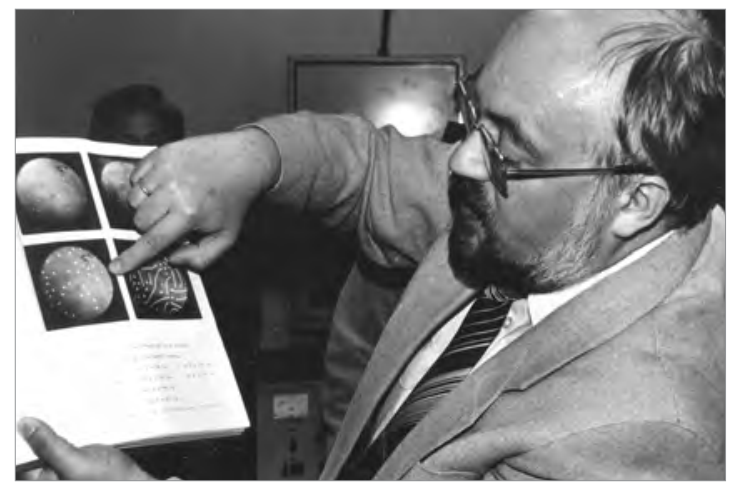

Fot. 31. Leszek Wojtczak i jego - nadal trwajaca - ,przygoda intelektualna” 
Przyjrzymy się teraz, jak Michał Seweryński, prawnik, rekonstruuje swoją ścieżkę edukacyjną, która prowadziła przez wczesne doświadczenia dydaktyczne w czasie udzielania korepetycji i była wspierana przez licealnych nauczycieli. Zobaczmy także, w jaki sposób dokonał wyboru studiów, mając przy tym na względzie określone uwarunkowania polityczne i późniejsze możliwości pracy:

Kiedyś szybko stawiało się pytania o to, kim będą nasze dzieci albo kim my byśmy chcieli być, co robić dalej? Może nie od razu w szkole podstawowej, bo wtedy dookoła tylko czekali, kiedy pójdę do roboty, żeby przynieść do domu trochę pieniędzy, żeby było z czego żyć. Ale szybko zacząłem udzielać korepetycji - uczyłem czytać moich kolegów. Nie wiem, czy dostawałem za to jakieś pieniądze, ale zawsze częstowano mnie obiadem. Pamiętam takiego mojego pierwszego kolegę, który mieszkał niedaleko i miał straszne trudności z czytaniem. Jego rodzice mnie poprosili, żebym mu pomagał. $Z$ czasem stało się to moim poważnym zajęciem, trochę dochodowym. Niewątpliwie szkoła była tym pierwszym miejscem, w którym pojawiły się te przyszłe, często nawet nieuświadomione uwarunkowania. Bo gdyby mi w tej szkole kiepsko szło, to bym nigdy w życiu nie poszedł na studia, prawda? Na szczęście w liceum spotkałem się z takimi nauczycielami, którzy rozmawiali z nami o studiach czy próbowali rozbudzić w nas i podtrzymać jakieś zainteresowanie. Oczywiście w liceum rozmawialiśmy dużo na temat tego, na jakie studia pójdziemy i co będziemy robić. Ja myślałem o dziennikarstwie, bo bardzo mnie to interesowało. Ale wiedziałem, że dziennikarstwo jest upolitycznione, więc wymyśliłem sobie, że będę dziennikarzem sportowym, bo może tam nie będzie takiego dużego uzależnienia politycznego. A oczywiście było. Był taki kierunek w Warszawie. Na szczęście dla mnie to dziennikarstwo zostało rozwiązane po wydarzeniach ' 56 roku. Zatem ten wybór mi odpadł. A potem wahałem się między historią i prawem. Ale myślałem sobie: jak pójdę na prawo, to co będę robił? Przecież to wszystko jest elementem polityki i elementem systemu. I tak się wahałem. I co będę robił po tej historii? Historia mnie interesowała, tak jak każdego chłopca interesują bitwy i wojny, prawda? Dużo czytałem na ten temat. Tylko nie mogłem sobie wyobrazić, co ja bym po tym wszystkim robił. Musiałbym nauczycielem zostać pewnie. Więc stanęło na prawie, w Uniwersytecie Łódzkim.

Na koniec odwołamy się do historii życia Jana Ziomka, który swoją opowieść rozpoczyna tak:

Jestem doktorem nauk przyrodniczych w zakresie geologii, ze specjalnością mineralogii, petrografii i geochemii. Po ukończeniu szkoły podstawowej wstąpiłem 
do Państwowego Liceum Pedagogicznego w Końskich ${ }^{55}$. Liceum Pedagogiczne ukończyłam w latach wczesnych pięćdziesiątych. Następnie rozpocząłem studia w Wyższej Szkole Pedagogicznej w Łodzi przy ulicy Kościuszki 21, na Wydziale Matematyczno-Przyrodniczym, na kierunku geografia, ze specjalnością geologia.

Następnie wspomina postać prof. Feliksa Różyckiego, który rozmiłował go w geologii i zaraził swoją pasją:

Pierwsze moje zamiłowanie do nauk przyrodniczych, szczególnie do geologii, związane było z uczestnictwem z profesorem Feliksem Różyckim ${ }^{56} \mathrm{w}$ wierceniach głębinowych studni na obszarze wielkiej Łodzi i od tej pory mój związek z geologią był bardzo systematyczny.

Jan Ziomek założył i przez lata kierował Muzeum Geologicznym Uniwersytetu Łódzkiego. Swoje plany związane z jego budową przedstawia tak:

Zafascynowanie muzeami wzięło się stąd, że jako uczeń szkoły podstawowej przy ulicy Kopcińskiego $54^{57}$ chodziłem codziennie na ulicę Lipową i szedłem ulicą Więckowskiego, i tam było Muzeum Sztuki ${ }^{58}$, i ja tam tą swoją torbę, tornister kładłem, kładłem ciapcie, jak to w muzeum, tam były piękne obrazy. Dzisiaj to bym tam nie poszedł, nawet bym tego nie rozumiał. I ja tam całymi godzinami siedziałem przy tych obrazach i je oglądałem. Wszystkie muzea zwiedzałem i nasiąkałem tak spokojnie. Lubiłem takie przestrzenie wolne, czyste, ładne, a w tym muzeum na Więckowskiego były parkiety lśniące i jak się szło tymi ciapciami, to było coś tak pięknego w tym wszystkim [szeptem, konfidencjonalnie]. I to skłoniło mnie do poszukiwania czegoś oryginalnego, ciekawego, ważnego. W zasadzie ten ogród skalny [mieści się on na dziedzińcu wewnętrznym Wydziału Nauk Geograficznych UŁ i pełni funkcje edukacyjne oraz naukowe] czy muzeum to stworzyłem ja. Tego nikt nie projektował.

Jak widzieliśmy, określone doświadczenia w historii życia, warunki społeczno-kulturowe, wydarzenia polityczne, znaczące postaci, niecodzienne okoliczności, doświadczenia, a nawet nabierające symbolicznego znaczenia przedmioty otwierały przed naszymi rozmówcami określone horyzonty poznawcze, uwrażliwiały, inspirowały czy zachęcały autorów zebranych przez nas opowieści do podjęcia określonej ścieżki naukowej, która

${ }^{55}$ Liceum to powstało w 1947 roku i działa do dzisiaj. Mieści się przy ulicy Sportowej 2 w Końskich.

${ }^{56}$ Feliks Różycki (1887-1981) - wybitny geograf i geolog. Od 1945 związany z Łodzią. Współtwórca i profesor Wydziału Matematyczno-Przyrodniczego Uniwersytety Łódzkiego.

${ }^{57}$ Obecnie znajduje się tam Publiczne Gimnazjum nr 28.

${ }^{58}$ Od 1948 roku przy ulicy Więckowskiego 36 znajduje się Muzeum Sztuki (przeniesione z Placu Wolności 1) posiadające najbogatsze w Polsce zbiory sztuki światowej XX i XXI w. 
w dużej mierze ukształtowała całe ich życie. Pierwszym jej etapem stawały się studia uniwersyteckie. Zanim przedstawimy wspomnienia $\mathrm{z}$ tego okresu warto naszkicować społeczno-polityczny obraz powojennej Łodzi.

\section{Okres powojennej odbudowy}

Kiedy podczas mroźnych miesięcy 1945 roku pierwsi profesorowie przyjeżdżali do Łodzi, wielu zaskakiwała dobra kondycja miasta. Pogłoski, jakie sobie wówczas przekazywano, okazywały się prawdą - Łódź była jednym z najmniej zniszczonych miast, a dodatkowo było już dość pewne, że powstanie w niej uniwersytet. Stosunkowo dobre warunki życia, bliskość zburzonej Warszawy spowodowały, że wielu mieszkańców stolicy w Łodzi przeczekiwało niepewny powojenny czas jak najbliżej prawdziwego domu. Położenie w centrum Polski w nowych granicach kraju sprzyjało ruchowi tranzytowemu, który zmieniał robotnicze miasto w punkt docelowy dla strudzonych podróżnych. O swojej powojennej tułaczce i pierwszych wrażeniach po przyjeździe do Łodzi opowiada pochodzący z Wilna Eugeniusz Czerniawski:

Wysiadłem w Białymstoku, bo to bliżej Wilna, a tam wszystko rozwalone, dworzec rozwalony, koniec, nie ma. To wróciłem, wsiadłem do tego wagonu. Ruszyliśmy. Pociąg jechał przez Warszawę: tramwaje powywracane, barykady. Dojechaliśmy do Kutna. W Kutnie dworzec taki piękny się zrobił, wyglądał niesamowicie, światło elektryczne jest, widać klomby, kwiaty są. Miasto normalne. Dworzec normalny. Nas przeładowali na węglarki bez dachu i jechaliśmy jak na wycieczce. Przyjeżdżam do Łodzi: zielone liście, bo to był pierwszy dzień Wielkanocy i pierwszy kwietnia, Prima Aprilis. Tak dojechałem do Łodzi. Jeszcze wojna była. Tam spotkałem znajomego pana, koło nas był taki sąsiad i on wcześniej przyjechał i powiedział, że na Zgierskiej są wolne mieszkania, a tramwaje nie kursowały, bo święto, szyby zamalowane. Pieszo szedłem przez miasto. Wrażenie było, bo miasto całe - ale to miasto to jednak nie Wilno.

W pierwszych miesiącach 1945 roku mówiono, że Łódź może stać się stolicą - liczba mieszkańców miasta przekraczała wówczas populację wyludnionej i zniszczonej Warszawy, czyniąc z Łodzi największe miasto w Polsce. Przemysł, mimo zawieruchy wojennej, nadal tu funkcjonował i taka zmiana wydawała się całkiem możliwa. Robotnicza Łódź, bezskutecznie starająca się o utworzenie uniwersytetu jeszcze przed wojną, doskonale nadawała się na miejsce otwarcia nowego rozdziału historii Polski. Bronisława Kopczyńska-Jaworska wspomina, że konieczność 
powołania jakiejkolwiek szkoły wyższej była powszechnie dyskutowana w Łodzi już dużo wcześniej:

To ma ścisły związek z tradycją powstawania Uniwersytetu w Lodzi, dlatego że właśnie Łódź walczyła przez wiele lat o jakąkolwiek wyższą szkołę, techniczną, ogólną humanistyczną. Była drugim co do wielkości miastem w Polsce, które nie miało wyższej uczelni. Pamiętam ze swoich młodych lat, że to stale się komentowało, to było bardzo istotne. Komentarze były takie, że po prostu władze państwowe nie chcą mieć takiego skupiska młodzieży w mieście, które w połowie jest o lewicowych poglądach, że to może być kosztowny eksperyment. Dlatego Łódź nie miała szkoły wyższej.

Zbigniew Bokszański tak widział pozycję Łodzi w owym czasie:

Łódź była ośrodkiem niesłychanie cennym, dlatego że Warszawa dopiero wstawała, podnosiła się z tych ruin dosłownie i w przenośni. I w Lodzi w ogóle było wszystko, co najlepsze, jeżeli idzie o takie zaplecze materialne.

Miasto, w czasie wojny opuszczone przez poprzednich mieszkańców najpierw pochodzenia żydowskiego (w Łodzi znajdowało się drugie największe getto na terenach II Rzeczypospolitej), a potem także niemieckiego, zapełniało się tysiącami uchodźców, przesiedleńców i chłopów poszukujących pracy w przemyśle (część fabryk funkcjonowała nieprzerwanie od początku wojny!). Wśród tłumów ściągających do miasta byli profesorowie, literaci, artyści, z Lublina przenosiły się całe redakcje („Kuźnica”, „Wieś”) - Łódź stawała się nie tylko przemysłową, ale i kulturalną stolicą, a wkrótce miała zostać i centrum naukowym. Tak wspomina decyzję o przyjeździe do Łodzi (która wówczas wydawała się kuszącą alternatywą wśród innych miast) Krystyna Śreniowska związana przed wojną z uniwersytetem we Lwowie:

Po powstaniu warszawskim do Krakowa się zwaliło pół Warszawy, tam już oddychać nie można było. I wtedy mój mąż zostawił mnie w Krakowie i wyruszył w podróż, gdzie by się osiedlić. Gdzie nie pojechał, tam były gruzy. Wrocław - gruzy, Gdańsk - okropny. Jednym słowem, nie bardzo się było gdzie zaczepić, bo wszystko było zniszczone i ta Łódź nas zdumiewała, bo ona stała na miejscu, nie było gruzów. To było coś bardzo dziwnego. Wrócił do Krakowa i powiada, że próbujemy w Łodzi, że tutaj się tworzy uniwersytet - próbujemy w Łodzi. Przyjechało tu wiele osób z Warszawy, które znałam. 
To tu odradzało się życie polityczne i kulturalne zrujnowanego przez wojnę państwa ${ }^{59}$. Zaczęło się tworzyć między innymi łódzkie środowisko historyczne, o czym opowiada Krystyna Śreniowska:

Pani profesor Gąsiorowska-Grabowska ${ }^{60}$, która miała takie oblicze lewicowe, zajęła się organizowaniem tego środowiska historycznego. Jej uczniem był Witold Kula ${ }^{61}$, który tu do Łodzi zjechał ze swoją małżonką. Też tutaj na początku pracował. Tak, Witek Kula i jego żona, nazywała się z domu Assorodobraj ${ }^{62}$. Była wychowanką Uniwersytetu Warszawskiego, to była bardzo poważna uczona ta Nina Assorodobraj. Najbardziej aktywnym organizacyjnie człowiekiem był Józef Chałasiński ${ }^{63}$.

Rosły w siłę intelektualne kręgi związane z „Kuźnicą” i wieloma innymi tytułami (także naukowymi - jak „Myśl Współczesna”). Pracę rozpoczynały teatry, zakładano przedszkola, szkoły, uczelnie odradzało się życie społeczne i kulturalne społeczności żydowskiej ${ }^{64}$ - w tle strajkowali robotnicy i trwały polityczne potyczki o władze. Łódź w zamyśle komunistycznej władzy miała pełnić funkcję emblematu ,,przezwyciężenia kapitalistycznej rzeczywistości” i była prezentowana jako symbol „dziejowej sprawiedliwości dla miasta-barykady"65. Te hasła często stały jednak w sprzeczności z faktycznymi działaniami aparatu państwowo-politycznego. Już w roku akademickim 1945/1946 Uniwersytet Łódzki był drugim - po Krakowie - największym uniwersytetem. Bronisława Kopczyńska-Jaworska wspomina:

${ }^{59}$ Irena Bołtuć-Staszewska i in., Tranzytem przez Łódź, Wydawnictwo Łódzkie, Łódź 1964; Bolesław Krasiewicz, Odbudowa szkolnictwa wyższego w Polsce Ludowej w latach 1944-1948, Zakład Narodowy im. Ossolińskich, Wrocław 1976, s. 135.

${ }^{60}$ Natalia Gąsiorowska-Grabowska (1881-1964) - historyk, badacz dziejów ruchu robotniczego, profesor Uniwersytetu Łódzkiego i Uniwersytetu Warszawskiego, profesor i rektor Wyższej Szkoły Pedagogicznej w Łodzi.

${ }^{61}$ Witold Kula (1916-1988) - specjalista w zakresie historii społeczno-gospodarczej. W latach 1950-1986 profesor Uniwersytetu Warszawskiego.

${ }^{62}$ Nina Assorodobraj (1908-1999) - socjolog, historyk myśli społecznej. W latach 1935-1977 profesor Uniwersytetu Warszawskiego; w latach 1945-1948 pracowała na Uniwersytecie Łódzkim. Razem ze Stanisławem Ossowskim i Józefem Chałasińskim brała udział w tworzeniu łódzkiej socjologii.

${ }^{63}$ Józef Chałasiński (1904-1979) - profesor socjologii, jeden z założycieli Uniwersytetu Łódzkiego i rektor tej uczelni w latach 1949-1952, członek PAN.

${ }^{64}$ Shimon Redlich, Na rozdrożu. Żydzi w powojennej Łodzi 1945-1950, Wydawnictwo IPN, Łódź, 2012.

${ }^{65}$ Tadeusz Chróścielewski, $W$ miejsce zleconego wstępu, [w:] Irena Bołtuć-Staszewska i in., Tranzytem przez Łódź..., s. 14. 
Wróciłam do Łodzi i tutaj, przynajmniej w tym naszym środowisku, była tylko jedna idea - a mianowicie Warszawa zburzona, Warszawy i uniwersytetu nie odbudują tak prędko. Tutaj do Łodzi zjeżdżało mnóstwo młodych ludzi, młodzieży, od razu rozeszła się wieść, że tu będzie organizowany Uniwersytet. Przez cały marzec chodziliśmy na Żeromskiego do budynku, do Szkoły Włókienniczej na Żeromskiego, gdzie było biuro organizacyjne tej mającej powstać uczelni. Dowiadywać się, czy już zapisują, czy otwierają, kiedy rozpoczną się zajęcia i tak dalej. Nie umiem właściwie... Oficjalna data otwarcia Uniwersytetu to 25 maja, natomiast na pewno w kwietniu chodziłam już na zajęcia, wydaje mi się, że w końcu marca też. Znalazłam gdzieś taki zapis mojego nieżyjącego męża, który napisał, że zapisał się na Wolną Wszechnicę - może na początku to się nazywało Wolna Wszechnica, nie wiem. Indeksu nawet zaczęłam gdzieś tam szukać, ale indeks jest dość późno wydany, bo dopiero w 1945 roku, także mieliśmy jakieś zaświadczenia od razu, ale wojna jeszcze trwała!

Pierwsze lata powojenne były okresem formacyjnym Uniwersytetu Łódzkiego. Stąd wspomnienie tych trudnych czasów - często już nawet nie bezpośrednie, ale zasłyszane od starszego pokolenia - pełni ważną funkcję kamienia węgielnego dla instytucji uniwersytetu. Z tych pierwszych lat we wspomnieniach naszych rozmówców powracają najczęściej dwa dominujące obrazy: ogromnego entuzjazmu odbudowy miasta oraz trudnych warunków powstawania i rozwoju nowego uniwersytetu. Razem tworzą opowieść o pionierskim wysiłku budowania największej, jak wtedy sądzono, uczelni - w zamierzeniu demokratycznej, o silnym postępowym, nawet lewicowym, charakterze.

Osoby przyjeżdżające po wojnie do Łodzi były zazwyczaj pozbawione dobytku. W całym kraju brakowało wszystkiego, a w mieście, w którym gromadziły się tysiące ludzi, nie było łatwo się odnaleźć. Ponownie Krystyna Śreniowska opowiada o tamtym czasie:

Nasza sytuacja materialna była kiepska, bo myśmy byli strasznie obdarci. Nie mieliśmy się w co ubrać. Przecież powstanie warszawskie nas też dobiło do końca. Także pod względem materialnym nam się powodziło bardzo słabiutko. Nie dlatego, że były niskie pobory, tylko dlatego, że myśmy mieli ogromne potrzeby ubraniowe i żywieniowe. Że Łódź była niezburzona, to było dla nas wszystkich wielkie szczęście. Ale początkowo ona pękała w szwach. Bo tych warszawiaków się tu zwaliła cała kupa i każdy chciał się jakoś zahaczyć i żyć.

Bronisława Kopczyńska-Jaworska wspomina swój powrót do zostawionego w 1940 roku łódzkiego mieszkania i rekonstruuje wrażenia, jakie były z tym związane: 
Myśmy tutaj, do tego mieszkania wróciły; siostra moja z przyjaciółką na piechotę z Warszawy przyszły. Jeszcze szły, nawet mostu pontonowego na Wiśle nie było, tylko po lodzie przeszły i przyszły tu do tego mieszkania. Niemiec, który tu mieszkał w czasie wojny, jak potem dowiedzieliśmy się od kogoś, kto tutaj jakoś przebytował w czasie wojny, to był tak zwany Baltendeutsche z Rygi i on już w lipcu 1944 roku wywiózł rodzinę do Niemiec, łącznie z zawartością domu. Także myśmy zastały gołe ściany, czarne papiery na oknach, nawet szklanek dwóch nie było. W wazonikach żeśmy piły zbożową kawę. I były tak: z dziurą materac, takie poduszki do łóżek, jakieś połamane łóżka, jakieś dziecinne łóżko, parę mebli, puste zupełnie mieszkanie, nic nie było. Ani jednego talerzyka, ani jednego garnuszka, nic nie było w tym domu. Myśmy tak koczowały ze starszą siostrą i przyjaciółką, i wszyscy koledzy, przyjaciele z czasów wojny i z Warszawy - to był taki domek zajezdny, bo przyjeżdżali tutaj, nocowali. Zanim znaleźli jakieś miejsce na mieście, u nas tutaj mieszkali i myśmy wszyscy wędrowali po tym pustym mieście.

Podobnie, w prowadzonym przez siebie dzienniku, przyjazd do Łodzi wspomina socjolog Jan Szczepański, późniejszy Rektor UŁ, który na długie lata związał się z naszą uczelnią:

16 XI 1945: Dzisiaj wstawiono mi szyby do kuchni i jednego pokoju na Narutowicza $41 \mathrm{~m} \mathrm{34}$, gdzie przydzielono mi mieszkanie uniwersyteckie. To jest owoc mojego udziału w administracji Uniwersytetu. Cały ostatni tydzień poświęciłem naszemu mieszkaniu. Mam trochę mebli i szyby, wprawdzie tylko pojedyncze, ale zawsze szyby. Zostały mi jeszcze 3 okna do oszklenia.

17 XI 1945: Mam już najniezbędniejsze rzeczy w mieszkaniu. Dzisiaj zdobyłem lampy, kupiłem miednicę, wiadro, przyniosłem trochę koksu i węgla. W ciągu przyszłego tygodnia doprowadzę je do stanu mieszkalnego, tzn. założę światło, wysprzątam i wyszoruję, przygotuję szafy i sprowadzę swoich [żonę i syna]. ${ }^{66}$

Stosunki nowo powstającej uczelni z nowymi władzami nie były łatwe, pomimo że Uniwersytet Łódzki miał być pierwszym ,prawdziwie demokratycznym" robotniczym uniwersytetem, a zgromadzone wokół ciało akademickie uchodziło na tle polskiej akademii za liberalne i lewicowe, a więc bardziej otwarte na reformy szkolnictwa wyższego i jego demokratyzację. Pierwszych rektorów Uniwersytetu Łódzkiego wspomina Jerzy Kmieciński:

${ }^{66}$ Jan Szczepański, Dzienniki z lat 1945-1968, Ustroń 2013, s. 20. 
Pierwszym rektorem Uniwersytetu Łódzkiego był Vieweger ${ }^{67}$, który był jak gdyby tę schedę przedwojenną wniósł ze sobą. $Z$ tego względu, że on był również rektorem filii Wolnej Wszechnicy Polskiej. To warszawska uczelnia Wolna Wszechnica Polska - taka postępowa dosyć szkoła, socjalizująca szkoła wyższa. I ona miała filie. Była jedyną wyższa szkołą, czy filią jedynej wyższej szkoły, która była przed wojną w Łodzi. I Vieweger właśnie był pierwszym rektorem, po nim był Kotarbiński ${ }^{68}$. A potem, potem był Chałasiński ${ }^{69}$.

Wielu z profesorów przybyłych do Łodzi pozostawało na marginesie przedwojennej akademii, która pod koniec lat trzydziestych zmagała się z rosnącym antysemityzmem i nastrojami nacjonalistycznymi. Nie chcieli oni powrotu tych przedwojennych wzorów, lecz dążyli do reformy i przebudowy uniwersytetu. Tym niemniej, kształt przyszłej uczelni był przedmiotem niekończących się sporów i polemik. Bronisława Kopczyńska-Jaworska relacjonuje:

Pierwszym rektorem Uniwersytetu Łódzkiego był profesor Teodor Vieweger ${ }^{70}$, który jakby kontynuował przedwojenną tradycję łódzkiej filii warszawskiej Wolnej Wszechnicy Polskiej, uczelni cieszącej się opinią postępowej uczelni akademickiej. Po nim rektorem został Tadeusz Kotarbiński ${ }^{71}$ następnie chyba Józef Chałasiński ${ }^{72}$, wybitny socjolog, który jednak dopuścił się likwidacji wielu kierunków humanistycznych i społecznych. Mówiło się też, że zostawił uczelnię „kadłubową”. Po październiku 1956 roku rektorem został Jan Szcze-

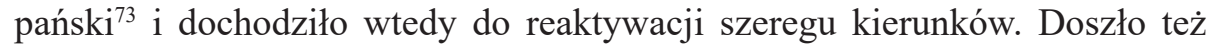
wtedy na jednej z Rad Wydziału Filozoficzno - Historycznego do zabawnego quid pro quo. Otóż z inicjatywą reaktywacji kierunku pedagogiki wystąpił pedagog, profesor Gluth ${ }^{74}$, argumentując zasadność tej inicjatywy tym, że kilku dyrektorów departamentów Ministerstwa Szkolnictwa Wyższego jest absol-

${ }^{67}$ Teodor Vieweger (1888-1945) - biolog specjalizujący się w badaniu pierwotniaków i orzęsek. Po ukończeniu gimnazjum w Warszawie udał się na studia medyczne na Uniwersytecie w Liège i zoologiczne w Brukseli, gdzie kilka lat później obronił doktorat w zakresie nauk przyrodniczych. Przed wojną był profesorem Wolnej Wszechnicy Polskiej w Warszawie. Dzięki jego inicjatywie Wolna Wszechnica Polska stała się uczelnią akademicką, a jej oddział został uruchomiony w Łodzi (1928). Brał udział w organizowaniu Uniwersytetu Łódzkiego po wojnie. Zginął tragicznie w wypadku samochodowym.

${ }^{68}$ Tadeusz Kotarbiński (1886-1981) - profesor filozofii, logik, współzałożyciel Uniwersytetu Łódzkiego i pierwszy rektor uczelni.

${ }^{69}$ Zob. przypis $63 \mathrm{w}$ tym rozdziale.

${ }^{70}$ Zob. przypis $67 \mathrm{w}$ tym rozdziale.

${ }^{71}$ Zob. przypis $68 \mathrm{w}$ tym rozdziale.

${ }^{72}$ Zob. przypis $63 \mathrm{w}$ tym rozdziale.

${ }^{73}$ Zob. przypis $40 \mathrm{w}$ tym rozdziale.

${ }^{74}$ Marian Gluth - pedagog społeczny, po roku 1945 profesor UŁ, kierownik Katedry Pedagogiki i Organizacji Szkolnictwa. 
wentami pedagogiki UŁ. Ministerstwo ze swoimi dyrektorami nie cieszyło się jednak najlepszą opinią w środowisku akademickim. Toteż gwałtowna reakcja wybitnego mediewisty Mariana Serejskiego ${ }^{75}$, który wykrzyknął „Ależ, panie kolego to chyba kontrargument!", spotkała się z burzliwym aplauzem.

Uniwersytet Łódzki szybko zaczął być nazywany „czerwonym uniwersytetem”, a wystąpienia Chałasińskiego, działalność „Kuźnicy”, „Wsi” czy - w mniejszym stopniu - „Myśli Współczesnej”, tylko umacniały ten pogląd. Marksizm szczerze i gorliwie upowszechniano jako nową doktrynę i metodologię nauki, organizowano dyskusje metodologiczne na socjologii (Józef Chałasiński) i historii (Natalia Gąsiorowska-Grabowska) ${ }^{76}$, a także szkolenia dla pracowników pomocniczych z metodologii badań (marksistowskich). ${ }^{77}$ Uruchomiono tzw. rok wstępny, ułatwiający dostęp do studiów młodzieży z niższych warstw społecznych. Zwłaszcza młodzi socjologowie i poloniści z zapałem budowali gmach nowej nauki. Poddając surowej ocenie tamten czas, warto pamiętać, że dla wielu osób z pokolenia ówczesnych studentów koniec lat czterdziestych pełen był nadziei i autentycznego, idealistycznego zapału. Biorąc pod uwagę realia II Rzeczypospolitej i brutalny okres okupacji, duża część wrażliwych społecznie badaczy wybierała marksizm świadomie, jak tysiące im podobnych intelektualistów z Europy Zachodniej, którzy jednak nigdy nie stanęli przed konfrontacją ideałów z polityczną rzeczywistością. Późniejsza profesor socjologii Krystyna Lutyńska, która studia rozpoczęła w 1949 roku, komentuje ten czas następująco:

Jednak wpływ marksizmu-leninizmu był bardzo duży. Należałam do tego pokolenia, które nie zdążyło wziąć udziału w ruchu oporu. Po wojnie bardzo chciałam zmieniać ten świat - takie hasła jak: „bezpłatna nauka”, „bezpłatna służba zdrowia”, ,równość”, ,jednakowe traktowanie”. Na wsi widziałam, jak traktowani byli parobcy - to wszystko jakoś tak przemawiało do mnie ${ }^{78}$.

$\mathrm{Z}$ drugiej strony jednak wartości autonomii uczelni i wolności badania, które mająca nadejść reforma szkolnictwa wyższego podważała, stanowiły dla łódzkich profesorów aksjomat i nie podlegały negocjacji, nawet w imię egalitaryzacji dostępu do wiedzy. Stalinizacja nauki przebiegała więc nie tyle na poziomie kolejnych rozporządzeń i ustaw, ale przede wszystkim na

${ }^{75}$ Marian Serejski (1987-1975) - profesor historii, mediewista. W latach 1948-1950 był dziekanem Wydziału Humanistycznego Uniwersytetu Łódzkiego.

${ }^{76}$ Zob. odpowiednio przypisy 63 i $60 \mathrm{w}$ tym rozdziale.

${ }^{77}$ Por. rozdz. V.

${ }^{78}$ Obszerniejszy fragment, w którym zawiera się ten cytat, omawiamy także w przypisie 3 w rozdziale IV. 
poziomie lokalnych negocjacji praktyk między aktorami społecznymi (profesorami, studentami, przedstawicielami władz, ale także instytucjami). $\mathrm{Na}$ przykład już w 1946 roku Zygmunt Szymanowski ${ }^{79}$ (działacz komunistyczny), prorektor Uniwersytetu Łódzkiego dzięki dobrym stosunkom w PPR pomagał „negocjować” status uczelni i nowych władz. Tak to przedstawia Bronisława Kopczyńska-Jaworska:

Kotarbiński ${ }^{80}$ rektorował, a Szymanowski był niesłychanie przydatny, dlatego że jak w 1946 roku studenci postanowili urządzić pochód $3 \mathrm{Maja}^{81}$, to były aresztowania studentów i pamiętam, żeśmy zgłaszali, kogo aresztowali i Szymanowski z Kotarbińskim jeździł do UB i tam usiłował tych studentów wyreklamować.

Także epilog tego wydarzenia stał się elementem pamięci komunikacyjnej $^{82}$ i wspominany jest nawet przez osoby, które studia rozpoczęły już wiele lat później i jedynie o nim słyszały, jak to ma miejsce w przypadku Janiny Tobery:

Profesor Kotarbiński jako rektor musiał udzielić nagany studentom zamieszanym w takie rozruchy na 3 Maja, bo były takie w 1946 roku: był pochód pierwszomajowy i trzeciomajowy, i ten trzeciomajowy był nielegalny chyba i były rozruchy tam. On to tak ustawił, bo polecono mu, żeby udzielił nagany, a nie chciał wyrzucać tych studentów ze studiów, bo to była najgorsza kara. Stąd nagany. I on wziął tych studentów i każdemu podawał rękę i mówił: „udzielam nagany”, „udzielam nagany”.

Starcie z władzami miało jednak dopiero nadejść. Uniwersytet w owym czasie był jeszcze, jak pokazuje profesor pedagogiki Olga Czerniawska, otwarty i stosunkowo niezależny:

Jeszcze rektor miał władzę, jeszcze partia nie kontrolowała wszystkiego, nie panoszyli się pierwsi sekretarze. Także studenci byli różni: byli księża, był ksiądz Król ${ }^{83}$, siostry urszulanki w habitach się przechadzały.

${ }^{79}$ Zygmunt Szymanowski (1873-1956) - lekarz bakteriolog, w latach 1945-1950 profesor na Uniwersytecie Łódzkim, później do końca życia pracował na Akademii Medycznej w Łodzi.

${ }^{80}$ Zob. przypis $68 \mathrm{w}$ tym rozdziale.

${ }^{81} 3$ maja 1946 roku w wielu miastach uniwersyteckich, przede wszystkim w Krakowie (zobacz przypis 12 w rozdziale III), ale także w Łodzi, odbyły się manifestacje studenckie, których celem było uczczenie usuniętego przez ówczesne władze święta 3 Maja.

${ }^{82} \mathrm{O}$ pojęciu ,pamięci komunikacyjnej” piszemy we wstępie.

${ }^{83}$ Ks. Józef Król (1916-2000) - urodzony w Stanach Zjednoczonych, salezjanin. Od 1948 roku przebywał w Łodzi, gdzie przy kościele św. Teresy prowadził pracę oratoryjną. Podjął tutaj studia z pedagogiki społecznej na Uniwersytecie Łódzkim, które ukończył w 1952 roku. Znany ze swojego antykomunistycznego zaangażowania. 


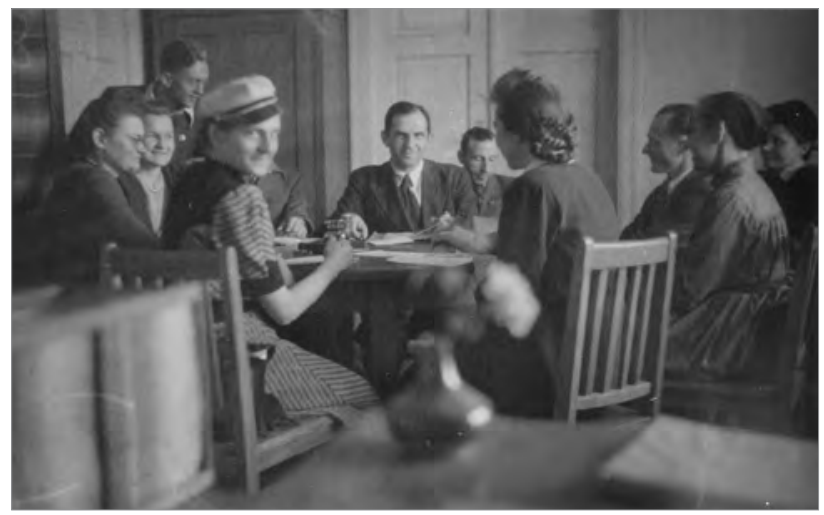

Fot. 32. Lata czterdzieste, seminarium dr Aleksandra Kamińskiego, Uniwersytecka 3

Najróżniejsze, nawet kontrowersyjne tematy mogły stanowić przedmiot akademickich polemik, o czym opowiada Bronisława Kopczyńska-Jaworska:

Pamiętam takie zebranie: pani Ossowska ${ }^{84}$ miała referat na temat genealogii inteligencji polskiej u Chałasińskiego ${ }^{85}$. Był Kotarbiński ${ }^{86}$, Kotarbińska ${ }^{87}$, Ossowski ${ }^{88}$, Szczepański ${ }^{89}$, całe grono pedagogiczne, a myśmy z zainteresowaniem słuchali, jak pani Ossowska w sposób niesłychanie kulturalny w pewnym momencie powiedziała: „Przydałoby się czasem więcej ołowiu, a mniej skrzydeł", bo miała zastrzeżenia do pewnych daleko idących wniosków w Społecznej genealogii inteligencji polskiej, która jednak odegrała ogromną rolę. To był wykład na inaugurację chyba trzeciego czy drugiego roku ruszającego Uniwersytetu i szalenie zbulwersował to towarzystwo. $Z$ opowiadań profesor Zawistowicz ${ }^{90}$ wiem, że podobno profesor Ułaszyn ${ }^{91}$, staruszek już, bardzo się zdenerwował i nie bardzo wszystko słyszał wyraźnie, więc chodził i mówił: „Co, jakie getto? O jakim getcie ona mówi? Co to za getto?” „Inteligenckie”.

${ }^{84}$ Maria Ossowska (1896-1974) - etyk, teoretyk i socjolog moralności, profesor Uniwersytetu Łódzkiego w latach 1945-1948, a następnie Uniwersytetu Warszawskiego oraz Instytutu Filozofii i Socjologii PAN.

${ }^{85}$ Zob. przypis $63 \mathrm{w}$ tym rozdziale.

${ }^{86}$ Zob. przypis $68 \mathrm{w}$ tym rozdziale.

${ }^{87}$ Janina Kamińska-Kotarbińska (1901-1997) - filozof i logik, profesor Uniwersytetu Łódzkiego w latach 1945-1951, później profesor Uniwersytetu Warszawskiego.

${ }^{88}$ Stanisław Ossowski (1897-1963) - socjolog, profesor Uniwersytetu Łódzkiego w latach 1945-1947 oraz Uniwersytetu Warszawskiego.

${ }^{89}$ Zob. przypis $40 \mathrm{w}$ tym rozdziale.

${ }^{90}$ Kazimiera Zawistowicz-Adamska (1897-1984) - profesor etnologii, w 1945 roku założyła na Uniwersytecie Łódzkim Zakład Etnografii.

${ }^{91}$ Henryk Ułaszyn (1874-1956) - językoznawca, slawista, profesor Uniwersytetu we Lwowie i Uniwersytetu Łódzkiego. 
Osobiście poczuł się dotknięty tym wykładem, który był szalenie sugestywny i właściwie zapadł chyba w świadomość zbiorową Polaków ${ }^{92}$.

To samo zresztą, jak kontynuuje Kopczyńska-Jaworska, dotyczyło otwartych dla wszystkich zajęć:

Na seminarium u Chałasińskiego siedziało chyba z pięćdziesiąt osób. Pamiętam tę narożną salę - seminaria odbywały się na czwartym piętrze. Chałasiński, Tola Kłoskowska ${ }^{93}$, która była już asystentką, siedziała tuż u jego boku i referowało się jakąś lekturę. On był entuzjastą Freuchena ${ }^{94}$ i rozmaitych książek o Eskimosach. Wobec tego w ciągu roku się o tych Eskimosach opowiadało, a potem były dyskusje. Pamiętam, że pośrodku sali siedział taki aktyw materializmu dialektycznego i historycznego. Tam też bywał, bo on był krótko w Łodzi na początku, wielki filozof i opozycjonista Kołakowski ${ }^{95}$. Ale ja zapamiętałam, że był taki Kuba Litwin ${ }^{96}$ i był taki Miller ${ }^{97}$ z socjologii, potem oni wyjechali do Szwajcarii, oni tak siedzieli w środku sali, a pod oknem siedziały takie, nie wiem czemu myśmy je tak nazwały, myszki z Caritasu, katoliczki z takiej organizacji młodzieżowej przy Caritasie, przy kościele jezuitów, prowadził je ksiądz Tomasz Rostworowski ${ }^{98}$. To była taka awangarda katolicka,

${ }^{92}$ Jeszcze w czasie wojny Józef Chałasiński pisał książkę Chłopi i panowie, gorzkie rozliczenie z czasami II RP, którego fragment stał się kanwą słynnego przemówienia ze stycznia 1946 roku, o którym tu mowa (później będącego podstawą Społecznej genealogii inteligencji polskiej), gdzie padały tak ostre sformułowania jak: ,u nas każde pokolenie inteligencji rozpoczyna pracę od początku i zawsze w ten sam sposób. Zawsze ta sama frazeologia ratowania zachodnioeuropejskiej kultury polskiej, zawsze ta sama Polska - przedmurze chrześcijaństwa. Zawsze to samo nieróbstwo myślowe uświęcone jakimś wyświechtanym, górnolotnym frazesem”. Jednak tezy pracy były znacznie ostrzejsze, znaczna część Chłopów i panów została opublikowana jako Przeszłość i przyszłość inteligencji polskiej, gdzie można przeczytać iż „(i)nteligenckie getto to była ogromną siłą reakcyjną, społeczną, pasożytującą na polskim życiu kulturalnym”, a ,inteligencja polska w swej strukturze wiąże się z cywilizacyjnym niedorozwojem Polski pod względem techniczno-gospodarczym" (Józef Chałasiński, Społeczna genealogia inteligencji polskiej, Czytelnik, Kraków 1947, s. 29; tegoż, Przeszłość i przyszłość inteligencji polskiej, Instytut Literacki, Rzym 1947).

${ }^{93}$ Antonina Kłoskowska (1919-2001) - socjolog, absolwentka Uniwersytetu Łódzkiego, profesor na Uniwersytecie Łódzkim i Uniwersytecie Warszawskim, w latach 1989-1994 przewodnicząca Polskiego Towarzystwa Socjologicznego, członek PAN.

${ }^{94}$ Peter Freuchen (1886-1957) - duński podróżnik, pisarz i antropolog, którego zainteresowania badawcze ogniskowały się na Grenlandii i życiu Inuitów.

95 Leszek Kołakowski (1927-2009) - wybitny współczesny filozof, zajmujący się przede wszystkim historią idei i historią filozofii. Studiował w Łodzi.

${ }^{96}$ Jakub Litwin (1920-1984) - historyk ruchu robotniczego i filozof. W latach 1950-1953 pracował w Instytucie Kształcenia Kadr Naukowych; był zastępcą kierownika Katedry Materializmu Dialektycznego i Historycznego. W 1951 roku obronił na Uniwersytecie Warszawskim pracę doktorską napisaną pod kierunkiem Tadeusza Kotarbińskiego. Wieloletni pracownik Uniwersytetu Łódzkiego.

${ }^{97}$ Andrzej Miller - student socjologii na Uniwersytecie Łódzkim w latach pięćdziesiątych.

${ }^{98}$ Ojciec Tomasz Rostworowski (1904-1974) - jezuita. W 1945 roku oddelegowany do Łodzi, gdzie został duszpasterzem akademickim. Pełnił tę funkcję do roku 1950. Aresztowany przez UB 
oni kolonie urządzali latem, jakieś wędrówki wzdłuż wybrzeża Bałtyku, ale ja akurat do tej grupy nie należałam. Ja się wtedy trzymałam z Wackiem Piotrowskim, który był najpierw narzeczonym, potem mężem mojej siostry, z Jankiem Lutyńskim $^{99}$, który później przyjechał, po roku, z Klemensem Szaniawskim ${ }^{100}$ i tym późniejszym dyrektorem OBOP-u, Szostkiewiczem ${ }^{101}$. Myśmy tak siedzieli przy drzwiach razem. Ja tam tak bardziej do towarzystwa niż do intelektu, ale tam tacy mądralińscy byli.

Warto pamiętać, że pierwsze powojenne roczniki studiujących niewiele przypominały późniejszą młodzież, która zdawszy maturę, próbowała swoich sił na uniwersytecie. Jeszcze na początku lat pięćdziesiątych średnia wieku absolwentów wynosiła ponad trzydzieści lat - nadrabianie zaległości wojennych i dostępność edukacji wyższej sprawiły, że studenckie czapki nosili często dorośli już ludzie mający własne rodziny. Krystyna Śreniowska wyjaśnia:

Młodzież, która się bardzo licznie garnęła do uczelni, to byli ludzie, którzy mieli za sobą walki partyzanckie, którzy przeżyli wojnę w sposób bardzo dramatyczny. Więc ta młodzież była bardzo dojrzała. Nawet powiedziałabym, jak wspominam, przejrzała życiowo. To znaczy oni wiekiem byli młodzi, ale doświadczeniami życiowymi to byli bardzo starzy. Ale bardzo się garnęli do nauki. Mogę powiedzieć, że to pierwszorzędna młodzież - ich możliwości intelektualne były oczywiście różne, ale jeżeli idzie o zapał, o chęć, to była pierwszorzędna kadra.

Do około 1948 roku uczelnie w dużej mierze zachowały swoją autonomię i poza incydentami w rodzaju wspomnianego powyżej kierowane były przez środowisko akademickie. W przypadku Uniwersytetu Łódzkiego był to Senat, w którego pracach uczestniczyli także przedstawiciele studentów. Uniwersytet Łódzki współpracował też z duszpasterstwem. Choć sam rektor Kotarbiński był zdeklarowanym ateistą, zapraszał duszpasterza akademickiego na posiedzenia Senatu. Zależało mu na budowie uczelni

zimą 1950 roku, a następnie skazany na 12 lat więzienia za rzekomą działalność antypaństwową. Został zwolniony w 1956 roku. Więcej na temat Caritasu piszemy w rozdziale V.

99 Jan Lutyński (1921-1988) - socjolog i metodolog, profesor Uniwersytetu Łódzkiego, Dyrektor Instytutu Socjologii UŁ, kierownik Zakładu Metod i Technik Badań Społecznych. Ekspert i doradca struktur związkowych „Solidarności”. W 1981 r. podczas strajku studenckiego na UŁ pełnił funkcję doradcy komitetu strajkowego. Wacław Piotrowski (1924-1998) - socjolog, absolwent łódzkiej socjologii i późniejszy profesor socjologii na Uniwersytecie Łódzkim.

${ }^{100}$ Klemens Szaniawski (1925-1990) - filozof, po wojnie związany z UŁ do 1949, gdzie pracował jako asystent w Katedrze Nauki o Moralności, profesor nadzwyczajny na Uniwersytecie Warszawskim.

${ }^{101}$ Stefan Szostkiewicz (1926-1988) - socjolog i metodolog. Inicjator powołania OBOP. Od momentu jego powstania w 1966 kierował pracami Ośrodka. 
zarządzanej w sposób demokratyczny. Jego wizją uniwersytetu była uczelnia tradycyjna w strukturze, zreformowana na poziomie dostępności, liberalnych treści, demokratycznego zarządzania. Oto jak widział on uczelnię, na czele której stanął:

Uniwersytet Łódzki chce być dostępny głównie dla dzieci rodzin ze sfer pracujących, chce być szczerze postępowy (a to, że jest nowy, ułatwia mu uniezależnienie się od średniowiecznego balastu pokutującego w tradycji starych wszechnic), chce być zdecydowanie laicki, chce mieć wolną rękę wobec wszelkich sztywnych systemów ideologicznych, światopoglądowych, historiozoficznych i innych. Chce służyć prawdzie wedle najlepszego rozumienia każdego poszczególnego badacza i nauczyciela. Niechaj prawda wyłania się z rzetelnej i wolnej dyskusji rzeczowej ${ }^{102}$.

Tymczasem Uniwersytet przeżywał wewnętrzne i zewnętrzne konflikty: starcia między przedwojennymi tradycjonalistami a marksizującym środowiskiem młodych uczonych, kłótnie na szczeblu władz lokalnych i rosnącą presję ze strony władz centralnych. Kolejnym rektorem Uniwersytetu Łódzkiego został Józef Chałasiński ${ }^{103}$, oponent Kotarbińskiego ${ }^{104}$, oceniający jego propozycję reform jako zbyt łagodną. Wspomniane wystąpienie Chałasińskiego o ,inteligenckim getcie” oddaje jego pogląd na ówczesną akademię. Dążył on do radykalniejszej przebudowy, proponując koncepcję „uspołecznionego" uniwersytetu, otwartego dla wszystkich, szczególnie zaś dla osób pochodzących z klas pracujących, o czym opowiada Janina Tobera:

Przede wszystkim Chałasiński miał koncepcję robotniczego uniwersytetu. Tylko że nic z tego nie wyszło. Ale podobno były tu jakoś przyspieszone matury, żeby młodzież robotnicza i chłopska miała szansę zdobyć wyższe wykształcenie, bo taka była koncepcja Chałasińskiego. Ale potem przyszedł 1949 rok i ofensywa ideologiczna, likwidacja socjologii. I pamiętam, jak profesor Lutyński ${ }^{105}$ o profesorze Kamińskim ${ }^{106}$ właśnie tak powiedział, że to był człowiek nieugięty. Jeżeli tylko ktoś chciał trochę samokrytyki przeprowadzić, tak jak Chałasiński samokrytykę przeprowadził, to wiadomo, że tę samokrytykę złożył i koniec. Ale jak ktoś nie chciał złożyć samokrytyki, to

102 „Dziennik Ludowy” nr 38, 7 lutego 1946; cyt. za: Piotr Hübner, Kotarbiński versus Chatasiński, „Forum Akademickie” 2011, nr 4, http://forumakademickie.pl/fa/2011/04/kotarbinski-versus-chalasinski/ (10.07.2015).

${ }^{103}$ Zob. przypis $63 \mathrm{w}$ tym rozdziale.

${ }^{104}$ Zob. przypis $68 \mathrm{w}$ tym rozdziale.

${ }^{105}$ Zob. przypis $99 \mathrm{w}$ tym rozdziale.

${ }^{106}$ Aleksander Kamiński (1903-1978) - pedagog, harcmistrz i wychowawca młodzieży, zatrudniony na Uniwersytecie Łódzkim do 1950 roku, odsunięty od nauczania z przyczyn ideologicznych, od 1958 roku ponownie zatrudniony. 
uznawano, że się stawiał. Przecież Ossowscy nie złożyli samokrytyki, prawda? A Kotarbiński to właściwie nie wiadomo jak. Szczepański ${ }^{107}$ przecież był doktorem przed wojną, to też niby jakoś powinien podpadać, ale nie miał jednak za sobą tylu dzieł. Radlińska ${ }^{108}$ jednak się nie nadawała już do tego, żeby po 1950 roku jakoś ją zaakceptowano. I potem jest w pierwszym zeszycie „Kultury i Społeczeństwa” taki tekst Drogi i bezdroża socjalizmu $w$ nauce polskiej Chałasińskiego. On pokazuje, jak to było, jak nauka była uzależniona od sytuacji ideologicznej, tylko o sobie oczywiście ani słóweczka, tylko te mechanizmy analizuje. Potem to było też w tej Mitologii społecz$n e j$, artykule, który się później ukazał za granicą. To już było dla władz nie do zniesienia, że ta jego krytyka wyszła poza Polskę ${ }^{109} \mathrm{z}$ jego nazwiskiem, a nazwisko było ważne.

Dynamiczny rozwój Uniwersytetu Łódzkiego został wstrzymany około 1948 roku. Wynikało to przede wszystkim z dwóch czynników: 1) wraz z rozbudową Warszawy część kadry, zwłaszcza profesorowie wcześniej związani z UW, zdecydowała się na powrót do stolicy i tym samym Łódź traciła swoją świeżo pozyskaną inteligencję; 2) rozpoczynająca się reforma nauki i szkolnictwa wyższego dzieliła uniwersytety na główny ośrodek w Warszawie, grupę dużych uniwersytetów (Kraków, Poznań, Wrocław) oraz grupę uczelni prowincjonalnych, do której został zakwalifikowany Uniwersytet Łódzki. Oznaczało to likwidację kilkunastu kierunków studiów (tę kwestię podejmujemy także dalej), obcięcie środków i marginalizację drugiego wówczas największego uniwersytetu w kraju. Dla wielu zmiana ta przesądzała o wyjeździe z Łodzi. Sytuację tę analizuje historyk Stefan Banasiak:

Uniwersytet powstał w mieście nieuniwersyteckim. Jak się Warszawa zaczęła odbudowywać, to przejmowała kadrę i część ludzi wyniosła się. Do Warszawy wyniosła się dyrektor Instytutu Historii Gąsiorowska ${ }^{110}$. Z socjologów Chałasiński ${ }^{111}$, Szczepański ${ }^{112}$.

${ }^{107}$ Zob. przypis $40 \mathrm{w}$ tym rozdziale.

${ }^{108}$ Zob. przypis $6 \mathrm{w}$ tym rozdziale.

${ }^{109}$ Mowa tu o wystąpieniu Chałasińskiego pt. „Sociology and Social Mythology in Post-war Poland" na IV Światowym Kongresie Socjologii w Mediolanie i Stresie we wrześniu 1959 roku. W wystąpieniu autor analizował wpływ mitu socjalistycznego na polskich socjologów. Większość z nich, w tym sam autor, popierała socjalizm, jednak Chałasiński podkreślił, jak kluczowe pozostawały kwestie jego charakterystyki oraz metod wprowadzania, krytykując jednocześnie ,polską drogę do socjalizmu". Artykuł został potraktowany jak paszkwil, a Chałasiński utracił obejmowane stanowiska. Od 1961 oku został odsunięty od zajęć także na Uniwersytecie Łódzkim, gdzie wciąż pozostawał zatrudniony mimo wcześniejszego wyjazdu do Warszawy.

${ }^{110}$ Zob. przypis $60 \mathrm{w}$ tym rozdziale.

${ }^{111}$ Zob. przypis $63 \mathrm{w}$ tym rozdziale.

112 Zob. przypis $40 \mathrm{w}$ tym rozdziale. 
Wątek ten pojawia się również w opowieści Bronisławy Kopczyńskiej-Jaworskiej, która pokazuje, w jaki sposób odpływ kadry akademickiej do Warszawy wiązał się z powstaniem Polskiej Akademii Nauk:

Rozpoczął się ten exodus warszawski. Ossowscy ${ }^{113}$ dość wcześnie w Warszawie zaczęli organizować zakład, po kongresie ${ }^{114}$ był zakaz nauczania. Ani Ossowscy nie mogli, ani Wallis ${ }^{115}$, ani Ajdukiewicz ${ }^{116}$, ani Kotarbiński ${ }^{117}$ nie prowadzili zajęć. Ale przenieśli się do Warszawy. Ostatecznym akcentem tych przenosin było utworzenie Polskiej Akademii Nauk w miejscu zlikwidowanej Polskiej Akademii Umiejętności. Wtedy Chałasiński został sekretarzem i przeniósł się do Warszawy.

Reforma obejmowała także parametryzację nauki, był to „okres ilości" 118 - uniwersytety musiały wykonywać narzucone przez Ministerstwo normy ${ }^{119}$, przyjmować określone kwoty studentów, spełniając proporcje ich pochodzenia społecznego. Studia zostały podzielone na dwa stopnie: praktyczne trzyletnie oraz rozszerzające dwuletnie, po których otrzymywało się stopień magistra. Studenci mieli uczyć się spraw praktycznych, przydatnych w przyszłym życiu zawodowym i już na studiach nawiązywać kontakt $\mathrm{z}$ potencjalnym pracodawcą, np. poprzez praktyki w zakładzie pracy czy instytucji publicznej. Wprowadzono zajęcia obowiązkowe, obce wcześniejszemu modelowi uniwersytetu - student miał spędzać na uczelni tyle godzin, ile robotnik w fabryce. Wielogodzinny, obowiązkowy program miał wyrównać szanse klasowe.

Zaczęto forsować tezę o odrębności nauki „burżuazyjnej” i ,socjalistycznej”. Naukę „burżuazyjną” należało oczywiście zlikwidować, a za jej przyczółki uznano przede wszystkim socjologię ${ }^{120}$, a także psychologię czy teorię organizacji i zarządzania. Właśnie pod szyldem walki z nauką burżuazyjną (przede wszystkim humanistyką, a zwłaszcza socjologią) zrealizowano I Kongres Nauki Polskiej, który zarysował podstawowe ramy

${ }^{113}$ Zob. odpowiednio przypis 82 i $86 \mathrm{w}$ tym rozdziale.

${ }^{114}$ Chodzi tu o I Kongres Nauki Polskiej, który odbył się 4 lipca 1951 roku, por. następna strona.

${ }^{115}$ Zob. przypis $28 \mathrm{w}$ tym rozdziale.

116 Kazimierz Ajdukiewicz (1890-1963) - filozof i logik, był przedstawicielem szkoły lwowsko-warszawskiej.

${ }^{117}$ Zob. przypis $68 \mathrm{w}$ tym rozdziale.

118 Janusz Tymowski, Organizacja szkolnictwa wyższego w Polsce, Państwowe Wydawnictwo Naukowe PWN, Warszawa 1980, s. 488.

${ }^{119}$ Ryszard Herczyński, Spętana nauka: opozycja intelektualna w Polsce 1945-1970, Wydawnictwo Naukowe Semper, Warszawa 2008, s. 118.

120 Tamże, s. 116. 
polityki naukowej państwa ludowego ${ }^{121}$. Stanowił on finałowy akt, zwieńczenie wysiłków reformy. Zdecydowano wówczas o wyłączeniu wydziałów rolniczych, ekonomicznych i medycznych z uniwersytetów, narzucono nową strukturę uczelni, próbując ograniczyć humanistów do jednego wydziału, w zależności od placówki: filozoficznego lub filozoficzno-historycznego (od 1951 roku). Ograniczono instytucjonalne kontakty międzynarodowe, przejęto kontrolę nad rynkiem wydawniczym, upaństwawiając drukarnie naukowe. Cała nauka, wpleciona $\mathrm{w}$ plan sześcioletni, podlegała parametryzacji i sprawozdawczości. Powstawały sylabusy do zajęć wzorowane na radzieckich ${ }^{122}$.

\section{Studiowanie}

Komentując opisane okoliczności polityczno-historyczne z perspektywy doświadczeń biograficznych rozmówców - powojennych studentów, trzeba stwierdzić, że sytuacja Uniwersytetu Łódzkiego jako młodej powojennej uczelni była dość szczególna. $Z$ reguły nowo powstające ośrodki akademickie przyciągają kilku wybitnych naukowców, którzy kierując się misją szerzenia wiedzy oraz upatrując możliwości samodzielnego działania, budowania własnego zespołu naukowego decydują się na pracę w uniwersytecie o tworzącej się dopiero historii - stając jednak w obliczu ogromnej niewiadomej. Tymczasem w pierwszej powojennej dekadzie studenci Uniwersytetu Łódzkiego mieli możliwość słuchania wykładów czy uczestniczenia w seminariach uczonych, którzy stanowili elitę intelektualną przedwojennego polskiego (a często i międzynarodowego) świata nauki. Dla części z tych profesorów pobyt w Łodzi stał się jedynie epizodem w ich karierze naukowej, miejscem tranzytu, jeśli nawiązać do tytułu książki Tranzytem przez Łódź123 opisującej losy powojennego nowo powstałego Uniwersytetu. Jednak dla wielu wybitnych naukowców Uniwersytet Łódzki okazał się stałym i ważnym punktem odniesienia w ich karierze naukowej. Okoliczności te miały niewątpliwy wpływ na biografię naukową naszych narratorów, którzy przywołując wspomnienie tamtego czasu, powracają niejako do roli studenta. Patrzą na swoich wykładowców z perspektywy młodych ludzi, przesiąkniętych pasją poznania, choć początkowo nie zawsze potrafiących sprostać intelektualnym wyzwaniom stawianym im przez profesorów. W tym duchu, w ramie nostalgicznych

${ }^{121}$ Piotr Hübner, I Kongres Nauki Polskiej jako forma realizacji założeń polityki naukowej państwa ludowego, Zakład Narodowy im. Ossolińskich, Wrocław 1983, s. 139-162.

${ }^{122}$ Connelly John, Polish Universities and State Socialism 1944-1968, [w:] Connelly J., Grüttner M. (red.), Universities under Dictatorship, Pennsylvania State University Press, University Park 2005, s. 126-128.

${ }^{123}$ Irena Bołtuć-Staszewska i in., Tranzytem przez Łódź, Wydawnictwo Łódzkie, Łódź 1964. 
obrazów i typowych dla studenckich wspomnień anegdot, nasi rozmówcy podkreślali przede wszystkim formatywny charakter tego czasu. Egzemplifikacją takiego podejścia może być przytoczona dalej w pełnym brzmieniu opowieść Krystyny Lutyńskiej, która wspomnienie okresu studiów rozpoczyna zdaniem: „W moim życiu Uniwersytet odegrał bardzo wielką rolę”.

W podrozdziale tym przedstawimy zatem wspomnienia byłych studentów naszej uczelni. Znajdziemy tu „typowe” dla każdego studenta opisy wykładowców - ich przyzwyczajenia, niekiedy uprzykrzające życie wymagania, obawy przed egzaminami, barwne charakterystyki fizjonomii czy temperamentów. Niektóre z przytoczonych dalej opowieści uznać można za epizody biograficzne, ukazane w formie nostalgicznych, humorystycznych czy pouczających anegdot. Interesujący jest jednak fakt, że właśnie takie epizody przekazane nam jako obrazy rozmów, konfrontacji egzaminacyjnych czy seminaryjnych, czasem przelotnych wręcz spotkań, utkwiły w pamięci rozmówców i zostały w ich opowieściach przywołane jako szczególnie znaczące w ich doświadczeniu życia akademickiego. Dominującą cechą tego doświadczenia jest już wówczas wyraźnie ukształtowana świadomość przywileju obcowania z wielkimi uczonymi reprezentującymi różne dziedziny nauki. Nasi rozmówcy zgodnie podkreślają, iż na drodze edukacji akademickiej dane im było spotkać wybitne umysły, postaci, które często stały się później promotorami ich prac magisterskich, doktorskich, współpracownikami, mistrzami, o czym piszemy w kolejnym rozdziale. Poza tym odwołanie się do czasu własnych studiów niejednokrotnie sprzyjało porównaniu tamtego uniwersytetu ze współczesnym. Czytelnik bez trudu zauważy różnicę między przeszłością a teraźniejszością...

\section{Wyktadowcy}

Wykłady i seminaria to najczęściej wspominane sposoby prowadzenia zajęć (dziś zapewne mówiono by o wykładach i ćwiczeniach). W tych pierwszych liczyła się przede wszystkim erudycja nauczyciela, w drugich w grę wchodził kontakt osobisty i konfrontacja własnych umiejętności z oczekiwaniami prowadzących. Zaczynamy od dwóch fragmentów ukazujących całe spektrum obrazów wykładowców, a przez to wyjątkowe znaczenie studiów akademickich dla opowiadających. Ocena ta podejmowana jest nie tyle przez pryzmat własnej kariery uniwersyteckiej, ile z ówczesnej pozycji studenta - nie zawsze mogącego sprostać stawianym mu wymaganiom ale zawsze przekonanego, iż jest/był częścią traktowanego na serio świata akademii. 
Krystyna Lutyńska w ten sposób wspomina swoje studia z zakresu nauk społecznych:

W moim życiu Uniwersytet odegrał bardzo wielką rolę. W ogóle to, że ja się na tej socjologii znalazłam, może tak trochę przypadkowo, ale ci profesorowie, którzy mnie wtedy uczyli, mieli na mnie ogromny wpływ. Nie tylko Chałasiński ${ }^{124}$, Szczepański ${ }^{125}$, ale i Kłoskowska ${ }^{126}$ na przykład. (...) Mieliśmy szczęście słuchać wykładów bardzo dobrych profesorów. O socjologach powiem za chwilę. Ale jeżeli chodzi o historyków, to słuchałam wykładów na przykład Natalii Gąsiorowskiej ${ }^{127}$, znakomity historyk gospodarczy. Był w Łodzi taki profesor historii, jakie on miał imię? Henryk, Henryk Katz ${ }^{128}$. On kształcił się w Anglii. To był komunista, marksista. Ale ponieważ kształcił się w Anglii, miał bardzo otwartą głowę. Wykładał historię ruchów robotniczych i robił to naprawdę w doskonały sposób. Kto tam jeszcze z historyków? Marian Serejski, znakomity profesor; pedagogów społecznych pani profesor Helena Radlińska ${ }^{129}$. Wszyscy oni już nie żyją. Później jej asystentka miała z nami zajęcia, pani Aleksandra Majewska ${ }^{130}$. Ona była znakomita, ponieważ nas prowadzała do fabryk, do przedszkoli, do dzieci niepełnosprawnych i tak dalej, do sierocińców. I to było znakomite. Robiło na nas ogromne wrażenie. Statystyki nas uczył Tadeusz Miller ${ }^{131}$. To był znakomity człowiek. On był tylko doktorem. Przeszedł przez Oświęcim, chodził z tym numerem. Ale tak jak on uczył statystyki, to śmiem powiedzieć, że nikt inny nie zrobiłby tego lepiej. Ale on nas uczył w znakomity sposób. Mieliśmy też do czynienia z profesor Kazimierą Zawistowicz, etnografem ${ }^{132}$. Zresztą i profesor Radlińska, i profesor Zawistowicz to już były mocno starsze panie. Profesor Radlińska mieszkała na Uniwersyteckiej 3 na parterze. Już właściwie leżała w łóżku, prowadziła jeszcze seminaria, ale to już była taka końcówka. Potem była profesor Jaworska, asystentka

${ }^{124}$ Zob. przypis $63 \mathrm{w}$ tym rozdziale.

${ }^{125}$ Zob. przypis $40 \mathrm{w}$ tym rozdziale.

${ }^{126}$ Zob. przypis $95 \mathrm{w}$ tym rozdziale.

${ }^{127}$ Zob. przypis $60 \mathrm{w}$ tym rozdziale.

${ }^{128}$ Henryk Katz (1914-1998) - historyk. Urodził się we Lwowie, gdzie studiował ekonomię. Studia kontynuował w Paryżu i Londynie. W czasie wojny służył w armii brytyjskiej. Zajmował się historią międzynarodowego ruchu robotniczego. W 1949 roku został zatrudniony na Uniwersytecie Łódzkim, w roku 1956 został mianowany docentem, a w roku 1968 musiał odejść z uniwersytetu.

${ }^{129}$ Zob. odpowiednio przypis 75 i $6 \mathrm{w}$ tym rozdziale.

${ }^{130}$ Aleksandra Majewska (1907-1990) - doktor pedagogiki, przedwojenna działaczka społeczna, asystentka prof. Heleny Radlińskiej, organizatorka Izb Wytrzeźwień w Łodzi, związana z Zakładem Pedagogiki Społecznej Uniwersytetu Łódzkiego.

131 Tadeusz Miller (1921-1980) - wybitny statystyk i demograf związany z Łodzią.

${ }^{132}$ Kazimiera Zawistowicz-Adamska (1897-1984) - profesor etnologii, w 1945 roku założyła na Uniwersytecie Łódzkim Zakład Etnografii. 
Zawistowicz. Filozofię, logikę wykładała pani Kotarbińska ${ }^{133}$, ale poznałam też profesora Kotarbińskiego ${ }^{134}$, uczyli mnie też znakomici asystenci, późniejsza profesor Ija Lazari Pawłowska ${ }^{135}$, Marian Przełęcki ${ }^{136}$, Tadeusz Pawłowski ${ }^{137}$. Także naprawdę kadra był znakomita, doborowa. Jan Szczepański miał wykład i seminarium z technik i badań społecznych. Wtedy napisał zresztą skrypt, na którym wychowało się bardzo, bardzo wiele pokoleń. No i i te zajęcia były niezapominane.

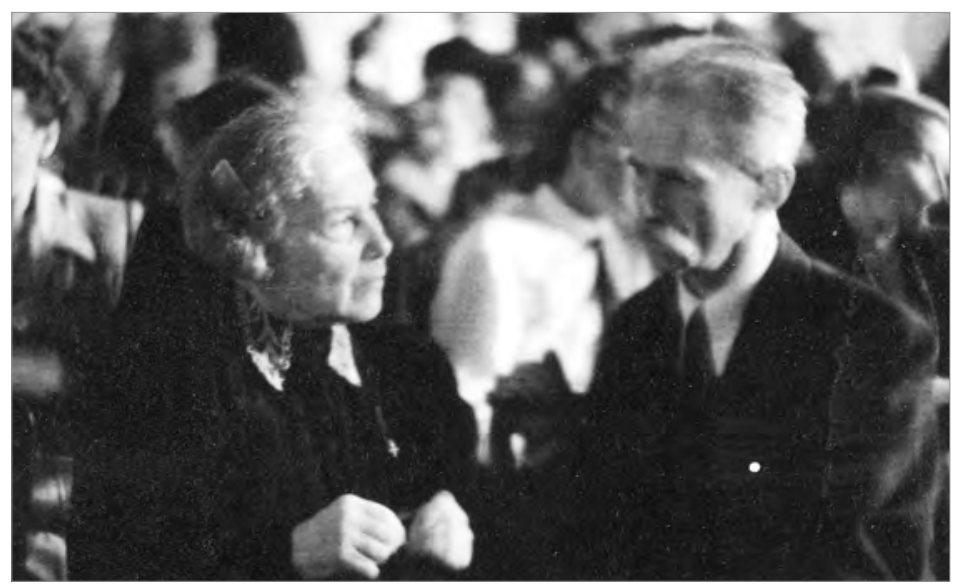

Fot. 33. Helena Radlińska i Tadeusz Kotarbiński

Z kolei Edward Tranda, ówczesny student biologii, przywołuje w pamięci wybitnych uczonych i wykładowców, ukazując różnorodność ich zainteresowań i charakterów:

Proszę pani, zakłady zoologii, które na tym wydziale powstały, były dwa. Mnie to szczególnie interesowało, bo ja się z tymi zakładami związałem. Był Zakład Zoologii Ogólnej, którym kierował profesor Leszek Pawłowski ${ }^{138}$, Leszek Kazimierz Pawłowski, tak by właściwie trzeba powiedzieć. To była postać bardzo ciekawa. Był to pan, który mieszkał całe życie w Pabianicach. Ale jednocześnie

${ }^{133}$ Janina Kamińska-Kotarbińska (1901-1997) - filozof i logik, profesor Uniwersytetu Łódzkiego w latach 1945-1951, później profesor Uniwersytetu Warszawskiego.

${ }^{134}$ Zob. przypis $68 \mathrm{w}$ tym rozdziale.

${ }^{135}$ Ija Lazari-Pawłowska (1921-1994) - etyk i filozof, twórczyni Katedry Etyki na Uniwersytecie Łódzkim.

${ }^{136}$ Marian Przełęcki (1923-2013) - logik i filozof, absolwent Uniwersytetu Łódzkiego, profesor Uniwersytetu Warszawskiego.

${ }^{137}$ Tadeusz Pawłowski (1924-1996) - logik i filozof. Absolwent i profesor Uniwersytetu Łódzkiego.

${ }^{138}$ Leszek Kazimierz Pawłowski (1902-1980) - zoolog, hydrobiolog, profesor Uniwersytetu Łódzkiego; twórca łódzkiej szkoły hydrobiologicznej, autor prac z zakresu systematyki, biologii i ekologii pijawek i wrotków. 
był wysokiej klasy uczonym - hydrobiologiem, specjalistą od dwóch grup bezkręgowców. Mianowicie był co najmniej europejskim, jak nie światowym specjalistą od pijawek. A druga grupa badań, które później już rozpoczął, to były wrotki. Wrotki to grupa planktonowych organizmów, ich nazwa łacińska to rotatoria, stanowią istotny składnik planktonu wraz ze skorupiakami i glonami oczywiście, to są tego typu organizmy, maleńkie, mikroskopijnej wielkości. Nagim okiem, tak żartobliwie powiem, właściwie niewidoczne. Je trzeba oglądać pod lupą lub mikroskopem. I praca nad nimi jest wyjątkowo żmudna i trudna. A profesor Pawłowski nie uciekał przed tego typu zadaniami, podejmował je i z dużym, dobrym efektem nad nimi pracował. On właściwie w Polsce rozpoczął badania nad wrotkami, bo nie pamiętam, żeby ktoś, dopiero później po nim, od niego uczyli się rozmaici ludzie, bo rozpoznawanie wrotków jest bardzo trudne. No więc, proszę pani, to był profesor Pawłowski, który przed wojną był związany z Wolną Wszechnicą Polską. A poza tym on był związany z uczelniami, z Uniwersytetem Warszawskim, w którym robił doktorat i habilitował się przed wojną jeszcze. Więc jak powstał Uniwersytet, to oczywiście on jako profesor Wolnej Wszechnicy włączył się natychmiast do prac nad organizacją tego organizmu, jakim był powstający Uniwersytet Łódzki.

\section{(...)}

Drugim profesorem zoologii był profesor Wolski. Tadeusz Wolski ${ }^{139}$, który pochodził z Warszawy. Też był związany już przed wojną z Wolną Wszechnicą Polską i z Łodzią. Po powstaniu warszawskim znalazł się w obozie w Niemczech, ale wrócił stamtąd. I prawdopodobnie nie miał do czego wracać w Warszawie i osiadł w Łodzi. Został tu natychmiast zaangażowany przez Uniwersytet, na profesora Uniwersytetu. On zajmował się rybami, ichtiologią. Profesor Wolski to był inny typ uczonego niż Pawłowski. I to były trochę inne charaktery. Profesor Pawłowski był bardziej zamknięty w sobie, był bardzo pracowity, mieszkał w Pabianicach, w tym mieszkaniu miał swoje laboratorium, przy którym pracował. A profesor Wolski, tak jak ja go pamiętam, to on po powrocie z obozu zaniewidział, był ślepy. I on już ze względu na swoją ślepotę to raczej teoretycznie zajmował się zoologią. Jego wykłady były bardziej takie specjalistyczne. On jako dobry zoolog w ogóle, ze szkoły warszawskiej, nie musiał wiele nowości zasięgać, żeby nam przekazywać bardzo interesujące dane. On był stale przyprowadzany do zakładu, jeżeli przychodził, przez asystentkę, panią doktor Marię Wojciechowską. Ona była taka bardzo mu oddana i pracowała razem z nim. Wolski zresztą miał tutaj również żonę, Jadwigę Wolską, która nazywana była przez nas, studentów, „Biedronką”. I ona miała z nami

139 Tadeusz Wolski (1890-1959) - biolog, ichtiolog; profesor Wolnej Wszechnicy Polskiej w Warszawie i oddziale łódzkim, po wojnie profesor Uniwersytetu Łódzkiego. 
rozmaite zajęcia dydaktyczne, prowadziła ćwiczenia w Zakładzie Zoologii. I co jest tutaj charakterystyczne dla tej sytuacji, w jakiej znalazł się profesor Wolski i w jakiej znalazła się uczelnia, to to że profesorowi Wolskiemu ze względu na jego kalectwo, w mieszkaniu przy Narutowicza 120, w takiej dwupiętrowej kamieniczce, na pierwszym piętrze urządzono salkę wykładową. Także profesor miał wykłady tam, nie musiał chodzić nigdzie. On miał wykłady z zoologii systematycznej i chyba z anatomii porównawczej. On się tam przygotowywał właśnie z panią Wojciechowską głównie, z żoną też. I on nie czytał, tylko mówił. To były bardzo ciekawe wykłady. Ja z nim miałem kontakt i on znał mnie z głosu. I nie pamiętam, chyba gdy byłem na trzecim czy nawet już na czwartym roku, już trudno to odtworzyć tak dokładnie, w każdym razie profesor przeszedł operację oczu, która przywróciła mu wzrok. I proszę pani, spotkaliśmy się na korytarzu, na Narutowicza, tam gdzie był jego zakład. Ja się ukłoniłem, przywitałem i przedstawiłem się, że jestem Tranda, „A to pan jest Tranda, to pan tak wygląda”, i tak się mi przygląda. Pierwszy raz zobaczył tego studenciaka, nie tylko usłyszał go, ale i zobaczył.

Krzysztof Jażdżewski również opowiada o wykładach profesora Pawłowskiego:

Profesor Pawłowski oczywiście był wykładowcą moim na studiach i on wykładał zoologię ogólną i hydrobiologię. To były pasjonujące wykłady, on miał taki styl szczególny z mnóstwem dygresji. To się niektórym nie podobało, bo przechodził z głównego wątku na poboczny i w ten poboczny wchodził daleko, daleko, ale wtedy najciekawsze rzeczy mówił. Mnie to się podobało w tych dygresjach. To były bardzo ciekawe wykłady. Z tych uniwersyteckich to chyba najbardziej profesora Pawłowskiego i poza tym bardzo lubiłem antropologa, naszego sąsiada z Kościuszki, to był profesor Ireneusz Michalski, który miał bardzo barwne wykłady, które też lubiłem. W każdym razie, w czasie studiów od razu wiedziałem, że nie zajmę się roślinami, czyli botaniką, tylko właśnie zoologią, i już tak w tym kierunku szedłem.

Kontynuując wątek nauk przyrodniczych, wróćmy do wspomnień Edwarda Trandy:

Wykłady z botaniki, na przykład profesora Skupieńskiego ${ }^{140}$, który był rektorem WSGW, odbywały się w kinie „Hel” na ulicy Zielonej. To się tam w tym lokalu odbywało, sala była i profesor Skupieński miał wykłady. Te wykłady były fantastyczne. Przecież nie było tak rozwiniętych technik wizualnych, jak to były później i dzisiaj są, więc trzeba było rysować. Albo rysowało się plansze, które rysowali plastycy. Plastyków zatrudniały zakłady i oni rysowali te

${ }^{140}$ Zob. przypisy 46 i $47 \mathrm{w}$ tym rozdziale. 
rzeczy. A profesor Skupieński wykłada, mówi na przykład o podziale komórki i jednocześnie to rysuje, i po kolei poszczególne fazy pod jego ręką ożywają na tablicy. To było fenomenalne, jak on potrafił to zrobić.

Anna Rawicka: Pewnie musiał też mieć zdolności manualne.

Edward Tranda: Oczywiście, że miał wybitne zdolności rysownicze. I proszę pani, trochę wybiegnę $\mathrm{w}$ przyszłość $\mathrm{w}$ tym momencie, bo to się tak jedno z drugim wiąże. Mianowicie jak zacząłem pracę w 1949 roku na Wydziale w Zakładzie Zoologii Ogólnej, to do moich obowiązków należało pójście przed wykładem profesora Pawłowskiego na ostatnie piętro do sali wykładowej z książkami, gdzie były zaznaczone ilustracje, które będą potrzebne profesorowi. Ja szybciutko machałem, te rysunki na tablicy. Także mnie koledzy młodsi znali z tego, że Tranda przychodził i mazał na tablicy. A później siadałem w ławce i słuchałem wykładu. Więc takie to były pod tym względem czasy.

Także Zbigniew Jakubowski jako student matematyki miał okazję uczestniczyć w zajęciach wybitnych wykładowców i uczonych z tej dziedziny:

Miałem przyjemność trafić na studiach na profesorów Zygmunta Charzyńskiego $^{141}$, Witolda Janowskiego ${ }^{142}$, Zygmunta Zahorskiego ${ }^{143}$, Włodzimierza Krysickiego ${ }^{144}$. Myślę, że kluczową rolę w moim dalszym życiu naukowym, które jeszcze się wtedy nie zaczęło, to odegrali profesorowie Janowski i Charzyński. Pamiętam, że wykład monograficzny profesora Charzyńskiego, i o tym piszę w którymś z opracowań ${ }^{145}$, który dotyczył teorii Löwne$\mathrm{ra}^{146}$, był bardzo dobrym wykładem. To znaczy w ogóle profesor Charzyński i nie tylko on to byli dobrzy fachowcy i pod względem dydaktycznym, i pod względem fachowym, jako matematycy.

${ }^{141}$ Zygmunt Charzyński (1914-2001) - matematyk, profesor Uniwersytetu Łódzkiego, wieloletni kierownik Zakładu Funkcji Analitycznych i Równań Różniczkowych Instytutu Matematyki Uniwersytetu Łódzkiego.

${ }^{142}$ Witold Janowski (1912-1972) - matematyk, związany w okresie powojennym z Politechniką Łódzką, wieloletni profesor Uniwersytetu Łódzkiego, na obu uczelniach pełnił wiele funkcji naukowo-organizacyjnych, specjalista w zakresie ekstremalnych zagadnień teorii funkcji analitycznych.

${ }^{143}$ Zygmunt Zahorski (1914-1998) - matematyk, uczeń Stefana Banacha, jednego z twórców lwowskiej szkoły matematycznej, profesor Uniwersytetu Łódzkiego.

${ }^{144}$ Włodzimierz Krysicki (1905-2001) - matematyk, profesor Politechniki Łódzkiej.

145 Jest to nawiązanie do publikacji: Zygmunt Charzyński (1914-2001) Kilka wspomnień, [w:] Matematyka czasów Weierstrassa, Materiały XV Ogólnopolskiej Szkoły Historii Matematyki, Kołobrzeg, 28.05.- 02.06.2001, Szczeciński Oddział PTM, Instytut Matematyki Uniwersytetu Szczecińskiego 2002, s. 185-192.

${ }^{146}$ Charles (Karl) Löwner (1893-1968) - matematyk, profesor Uniwersytetu Stanforda, specjalizujący się w geometrii różniczkowej i teorii funkcji analitycznych. 
Bronisława Kopczyńska-Jaworska studiując etnografię, uczęszczała z kolei na wykłady wybitnych socjologów Józefa Chałasińskiego ${ }^{147}$ i Stanisława Ossowskiego ${ }^{148}$ :

Chałasiński z kolei miał dar obrazowania. Świetnie wykładał, zupełnie nie było podręczników. On miał wykład z socjologii powszechnej, czyli miał regularny wykład z historii myśli społecznej na kierunku socjologicznym. Przychodził, siadał, te niebieskie wodniste oczka podnosił w górę i tak wpatrywał się w róg sali, cały czas nieruchomo siedział i jak maszynka opowiadał: osoba, dzieła, wstęp, omówienie, zakończenie. Także jak podręcznik się to notowało. Mam jeszcze parę notatek z tych czasów. A potem do egzaminu dostaliśmy nieliczne bibliograficzne jakieś opracowania, tłumaczenia, które były po polsku, co trzeba było przeczytać, strona od do. Podręcznik był z tego zrobiony. Wspaniale to wykładał. Natomiast Ossowski... kiedyś jak robiłam porządki w szufladzie, znalazłam swoją notatkę z wykładu Ossowskiego, już sama byłam wtedy nauczycielem i zaczęłam to przeglądać, i myślę sobie: „Boże, jakie to ciekawe, ale ja zupełnie nie pamiętam takich wykładów!”. Jak to się mówi, on perły przed wieprze rzucał. On był strasznie nerwowy, więc pierwsze piętnaście minut wykładu to była tortura. Profesor stawał przed tablicą, koło swojego stolika i zaczynał, jąkał się, zacinał, bełkotał, zaczynał coś mówić, przerywał i wreszcie po jakichś dziesięciu minutach zaskakiwał i zaczynał przepiękny wykład, który składał się jedna dygresja od drugiej. Także człowiek pilny, student z drugiego roku czy pierwszego, już po dwóch czy trzech minutach nie wiedział, do czego to się wszystko odnosi, bo to już była czwarta dygresja.

Grażyna Kononowicz była studentką socjologii w latach sześćdziesiątych. Oprócz przedstawicieli tej nauki wspomina też innych wykładowców, między innym historyka Stefana Kuczyńskiego ${ }^{149}$, który zasłynął ze szczególnego typu wykładów:

Pan profesor Kuczyński był bardzo barwną jednostką. Na wydziale był zwyczaj, że studenci pierwszego roku wszystkich kierunków na pierwszych zajęciach zbierali się w auli i pan profesor Kuczyński miał wykład na temat savoir-vivre'u. Jak się zachowywać, kto komu się pierwszy kłania, kto pierwszy wchodzi, kto wychodzi, jak się ubierać, czego nie wypada. Także to było bardzo pożyteczne, bo wielu ludzi dzisiaj też by mogło [śmiech] odbyć takie zajęcia. W każdym razie powiedział, że nie będzie nam się pierwszy kłaniał, ponieważ jest tylu studentów i studentek, że on nie odróżnia. To były bardzo praktyczne rzeczy: że do restauracji pierwsi wchodzą panowie, wyszukują

${ }^{147}$ Zob. przypis $63 \mathrm{w}$ tym rozdziale.

${ }^{148}$ Zob. przypis $88 \mathrm{w}$ tym rozdziale.

${ }^{149}$ Stefan Maria Kuczyński (1904-1985) - historyk, mediewista, w latach 1954-1969 profesor Uniwersytetu Łódzkiego. 


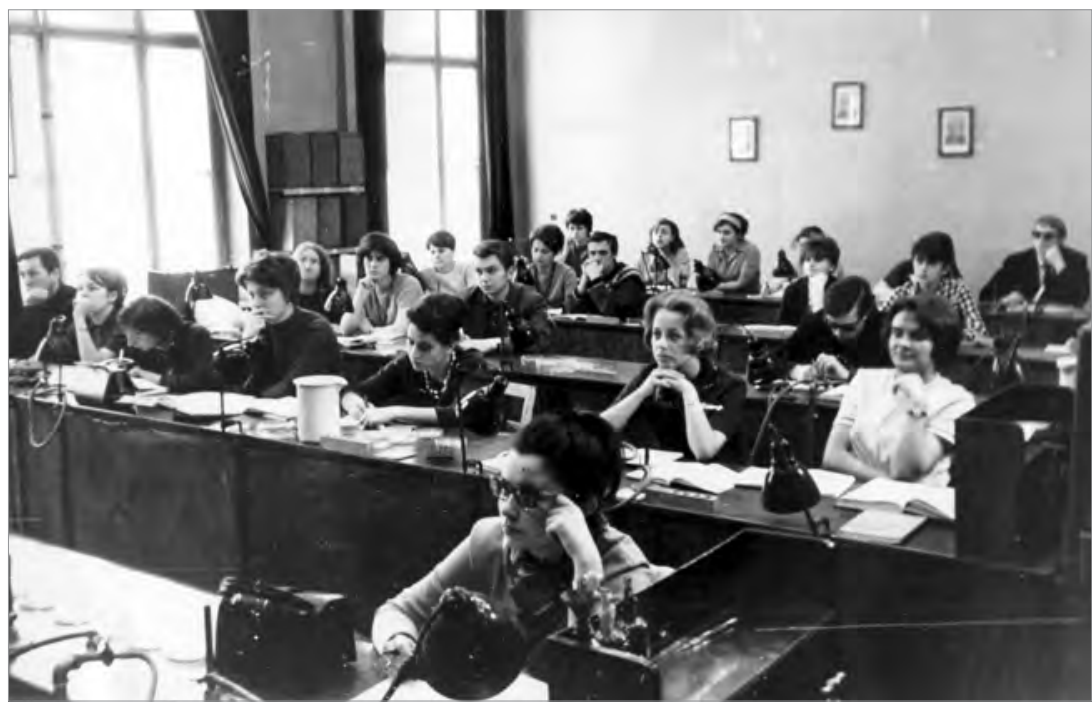

Fot. 34. Lata pięćdziesiąte, sala wykładowa przy Pomorskiej 18

miejsca i dopiero panie prowadzą do stolika, z tramwaju panowie wysiadają pierwsi i podają paniom rękę, przez drzwi się panią pierwszą puszcza - ale nie $\mathrm{w}$ restauracji okazuje się - pani pierwsza podaje panu rękę. Wtedy byli studenci, nie było telewizji, więc to wielu rzeczy się nie uczyło z telewizji, zresztą [śmiech] czego się można nauczyć teraz z telewizji. W każdym razie, to były takie dla wszystkich studentów wydziału zajęcia. I to było dopóki pan profesor Kuczyński w Łodzi pracował. Poza tym bardzo były ciekawe dyskusje pana profesora Kuczyńskiego z panem profesorem Serejskim ${ }^{150}$ na takich zajęciach - jeden do drugiego bardzo uprzejmie, jednocześnie dając do zrozumienia, że tamten to jest idiota, a ja wiem lepiej. No ale [śmiech] bardzo to było uprzejme i na bardzo wysokim poziomie kulturalnym [śmiech]. Tak że to też były ciekawostki. Ale z profesorem Kuczyńskim też mieliśmy zajęcia z historii. Myśmy bardzo lubili jego wykłady, bo on miał z nami historię wieków średnich i opowiadał nam niesamowite historie na temat kultury, obyczajów, religii, Indie, Persja, te tereny. A poza tym bardzo dokładnie nam opowiadał o epoce jagiellońskiej, jako że on specjalizował się w tym i na podstawie na przykład jakichś rachunków z dworu królewskiego czy innych snuł opowieści, co i jak tam było, jak się ubierało i tak dalej. Poza tym myśmy już na późniejszych latach chodzili na wykłady monograficzne i zajęcia dodatkowe. Więc ja na przykład chodziłam na zajęcia do pani profesor Stefanii Skwarczyńskiej ${ }^{151}$,

${ }^{150}$ Zob. przypis $75 \mathrm{w}$ tym rozdziale.

${ }^{151}$ Stefania Skwarczyńska (1902-1988) - teatrolog, teoretyk i historyk literatury, przed wojną związana z Uniwersytetem im. Jana Kazimierza we Lwowie, po 1945 roku profesor Uniwersytetu Łódzkiego i doktor honoris causa tej uczelni. 
to była filologia. Chodziłam na wykłady pana profesora Lewickiego ${ }^{152} \mathrm{z}$ filmoznawstwa wtedy, poza tym miałam zajęcia z panem profosem Mieczysławem Wallisem ${ }^{153}$, ojcem tego socjologa, on wtedy też jeszcze był w Łodzi. Tak że ja miałam, już pomijając socjologów, miałam bardzo ciekawe towarzystwo, które mnie nauczało, a z socjologów, to wiadomo, że był Szczepański, Chałasiński, Kłoskowska ${ }^{154}$, jeszcze wtedy pani na początku doktor, później docent, Lutyński ${ }^{155}$. Poza tym jeszcze były zajęcia z panią Salomeą Kowalewską ${ }^{156}$, ona zmarła chyba już. Ona pracowała razem z mężem w Warszawie, w PAN-owskim oddziale metod ${ }^{157}$. Tam był też, wiadomo, Gostkowski ${ }^{158}$, pani Hirszowicz-Bielińska ${ }^{159}$, Włodzimierz Wesołowski ${ }^{160} \ldots$

\section{Seminaria}

W czasach, gdy studiowali nasi rozmówcy, seminaria stanowiły bardzo ważny wymiar kształcenia akademickiego. Umożliwiały osobisty kontakt z prowadzącym, konfrontację własnej wiedzy z oczekiwaniami profesora, ale także możliwość sprawdzenia się w dyskusji z rówieśnikami. Jak zobaczymy, miały także charakter więziotwórczy, mobilizujący do koleżeńskiej pomocy, współpracy, ale też uczyły zasad akademickiej dyskusji i konstruktywnej krytyki. Były one zatem bardzo pouczającym, rozwijającym, choć niekiedy niełatwym doświadczeniem. Seminaria prowadzone przez niektórych profesorów cieszyły się szczególnym uznaniem. Wątek ten będzie przewijał się również w kolejnych częściach książki. W pamięci

${ }^{152}$ Bolesław W. Lewicki (1908-1981) - teoretyk filmu, krytyk i pedagog. Urodził się we Lwowie, gdzie ukończył filozofię na Uniwersytecie Jana Kazimierza. Od początku jego pasją był film i wiedza o filmie. Jest uznawany za twórcę polskiego filmoznawstwa. W 1960 roku utworzył Zakład Wiedzy o Filmie na Uniwersytecie Łódzkim; w późniejszych latach profesor Państwowej Wyższej Szkoły Filmowej w Łodzi.

${ }^{153}$ Zob. przypis $28 \mathrm{w}$ tym rozdziale.

${ }^{154}$ Zob. przypisy: 40, 63 i $93 \mathrm{w}$ tym rozdziale.

${ }^{155}$ Zob. przypis $99 \mathrm{w}$ tym rozdziale.

${ }^{156}$ Salomea Kowalewska (1924-2004) - socjolog, polonistka, profesor w Instytucie Filozofii i Socjologii PAN.

${ }^{157}$ Chodzi tu o Sekcję Technik i Narzędzi Badawczych IFiS PAN w Łodzi.

${ }^{158}$ Zygmunt Gostkowski (1926-2014) - socjolog, specjalista z zakresu metodologii badań społecznych, wieloletni kierownik Katedry Metod i Technik Badań Społecznych UŁ oraz pracownik Instytutu Filozofii i Socjologii PAN w Warszawie.

${ }^{159}$ Maria Hirszowicz (z domu Bielińska) (1925-2007) - docent socjologii na Uniwersytecie Warszawskim, zwolniona z pracy w konsekwencji wydarzeń marcowych w 1968 roku; pracę naukową kontynuowała na emigracji w Wielkiej Brytanii.

${ }^{160}$ Włodzimierz Wesołowski (ur. 1929) - socjolog, wieloletni pracownik w Instytucie Filozofii i Socjologii PAN w Warszawie. Studia socjologiczne ukończył na Uniwersytecie Łódzkim uczęszczając między innymi na seminaria Józefa Chałasińskiego i Jana Szczepańskiego. Tu też zdobył tytuł doktora i doktora habilitowanego. 
studentów studiujących kierunki społeczne wyjątkowo zapisały się seminaria prowadzone przez Józefa Chałasińskiego ${ }^{161}$, często pojawiały się w tym kontekście kwestie kompetencji językowych - umiejętności czytania i zrozumienia tekstów pisanych w językach obcych. Krystyna Lutyńska opowiada o swoich zmaganiach z lekturami w języku angielskim:

Pamiętam, że na seminarium Chałasińskiego miałam napisać referat o społeczności Zuni. Znałam angielski ze szkoły - czyli nie za bardzo. A tu miałam do przeczytania, nie pamiętam czy to była książka, czy artykuł po angielsku dość szybko. No i strasznie się denerwowałam. Ale jednocześnie z nami studiowali dużo starsi koledzy z doświadczeniem wojny i im pozwolono studiować tę socjologię do końca ${ }^{162}$. I to było dość ciekawe, bo ja na przykład jak wstępowałam na studia, to byłam bardzo młodziutka, skończyłam ledwo siedemnaście lat, zaczęłam osiemnaście. A koledzy starsi to mieli po czterdzieści pięć. Młodzież na moim roku była ubrana bardzo skromnie, w jakieś tam amerykańskie ciuchy, które były przerabiane i które się nosiło. A tam byli ludzie, którzy nosili właśnie jakieś kurtki z wojska Andersa czy tak jak mąż jakieś takie starocie (bo mąż siedział przecież w gułagu radzieckim). Więc bardzo to było ciekawe. I jeden właśnie taki były Andersowiec pomógł mi przetłumaczyć ten artykuł. On dobrze znał angielski. Napisałam ten referat. Sprawdzała go chyba Antonina Kłoskowska. I strasznie się skompromitowałam, ponieważ zrobiłam tam błąd ortograficzny w słowie mężczyzna [śmiech]. Napisałam [śmiech] przez 'en'. I pamiętam jeszcze, jak [śmiech] Tola podkreśliła na czerwono to słowo. Wygłaszało się te referaty przed Chałasińskim, który oceniał bardzo surowo. Zawsze kazał nam szukać tego centralnego problemu [naśladuje sposób mówienia Chałasińskiego]. [Z kolei] na studiach magisterskich chodziliśmy na seminarium do profesora Chałasińskiego, które nazywało się „Historia czasopiśmiennictwa XIX wieku". I to była wspaniała lekcja przez te dwa lata studiów magisterskich, bo Chałasiński zapraszał na to seminarium również profesorów $z$ różnych dyscyplin naukowych na przykład, profesora Szuberta ${ }^{163}$ - prawnika, profesora Serejskiego ${ }^{164}$ - historyka, profesor Skwarczyńską ${ }^{165}$ z polonistyki, Truchima $^{166} \mathrm{z}$ pedagogiki, Jaworską ${ }^{167} \mathrm{z}$ etnografii $\mathrm{i}$ innych. Więc to było na niesłychanie wysokim poziomie i bardzo ciekawe. $Z$ tym, że jak ja tam miałam referat, to wyszłam potem z płaczem, bo Chałasiński tak mnie zjechał.

${ }^{161}$ Zob. przypis $63 \mathrm{w}$ tym rozdziale.

${ }^{162} \mathrm{~W}$ okresie stalinizmu zlikwidowano rekrutację na kierunek.

${ }^{163}$ Wacław Szubert (1912-1994) - prawnik, specjalista prawa pracy, profesor Uniwersytetu Łódzkiego, dziekan Wydziału Prawa w latach 1953-1955 oraz 1965-1969.

${ }^{164}$ Zob. przypis $75 \mathrm{w}$ tym rozdziale.

${ }^{165}$ Zob. przypis $151 \mathrm{w}$ tym rozdziale.

${ }^{166}$ Stefan Truchim (1896-1967) - historyk kultury i oświaty, od 1945 roku profesor Uniwersytetu Łódzkiego.

${ }^{167}$ Bronisława Kopczyńska-Jaworska - patrz biogramy rozmówców. 
Kaja Kaźmierska: [śmiech]

Krystyna Lutyńska: On był bardzo, bardzo ostry. Ale potem napisałam bardzo dobrą pracę na temat czasopism rodzinnych w Polsce w końcu XIX wie$\mathrm{ku}$, a inni koledzy też mieli dobre prace i wszyscy zdobyliśmy magisteria z historii z zaznaczeniem „historia myśli społecznej”. Zresztą jak zdawaliśmy egzaminy u historyków, czy uczestniczyliśmy w seminariach historycznych, to też nam szli na rękę i dawali nam takie tematy, które wiązały się $\mathrm{z}$ socjologią.

Bronisława Kopczyńska-Jaworska również uczęszczała na seminarium prof. Chałasińskiego. W swojej relacji wspomina o referacie wygłoszonym na podstawie lektury w języku francuskim:

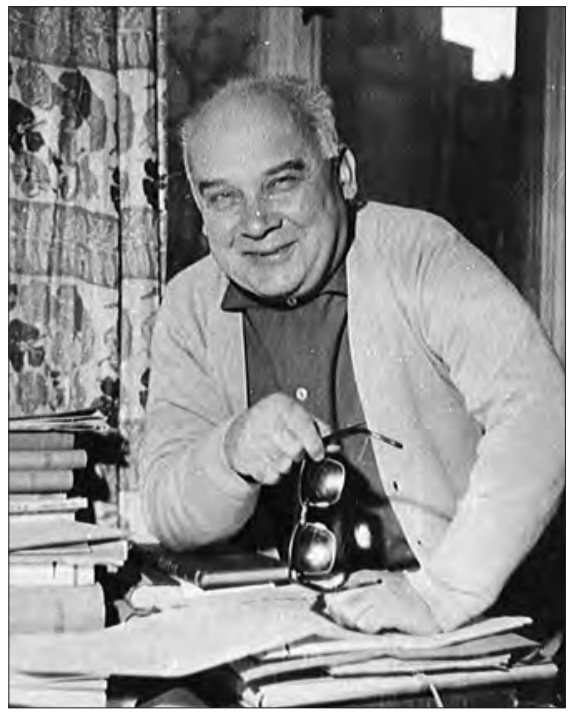

Fot. 35. Józef Chałasiński

Zaraz po wojnie była jakaś ekspozytura antykwaryczna francuska i tam nabyliśmy komplet etnograficznych monografii, m.in. Birket-Smitha ${ }^{168}$ właśnie, co to u Chałasińskiego referowałam, właśnie tego Birket-Smitha o Eskimosach. Takie monografie etnograficzne, to okropnie trudno było czytać, bo gdyby pani opisywała pracę dajmy na to chłopa polskiego, to też się nie wiedziało, jak się nazywały narzędzia czy inne, a tam mało tego, tam było to igloo, całe urządzenie, sanki. To po francusku było, ja powiedziałam, że uczyłam się francuskiego, miałam właśnie przygotować referat i okropnie się nad tym pociłam, bo po prostu nie mogłam znaleźć polskich słów, żeby to opisać: że płozy sań są otoczone owczą skórą [śmiech] czy rzeczy tego rodzaju.

Jolanta Kulpińska wracając myślą do okresu swoich studiów także mówi o wymogu czytania lektur w różnych językach. W jej wspomnieniu na pierwszy plan wysuwa się konieczność co najmniej biernej znajomości języka rosyjskiego:

Zawsze było też seminarium, więc trzeba było na nim pracować, ale listą lektur nikt się nie przejmował, czy znamy języki, czy nie, a lektur po polsku w końcu nie było tak wiele, więc wymyśliliśmy w ten sposób samopomoc koleżeńską - ci, co znali języki, robili nam ściągi. To dotyczyło zwłaszcza lektur po

\footnotetext{
${ }^{168}$ Kaj Birket-Smith (1893-1977) - duński filolog i antropolog, badacz Inuitów.
} 
rosyjsku. Bo Chałasiński uznał, że najlepiej poznać nie doktrynalnie, ale taki metodologicznie uzasadniony marksizm poprzez studiowanie prac historyków radzieckich, dobrych historyków radzieckich, którzy nie tylko przyznawali się, ale właśnie stosowali teorię, metodę Marksa. I to takie prace o średniowieczu i o wojnach chłopskich w Niemczech, o reformacji i kontrreformacji czytaliśmy, pamiętam. To były grube bardzo książki i dość trudne. Było dwóch kolegów, którzy znali rosyjski z powodu perypetii wojennych i właśnie bardzo dobre robili streszczenia dla nas. Tak bardzo żeśmy się nie mogli przyznawać do tego, że są takie bryki, ale też Chałasiński się tym nie interesował, skąd my wiemy - trzeba było wiedzieć. Te książki żeśmy cały rok na seminarium studiowali, omawiali poszczególne części, partie i tak dalej. To taka ciekawostka dwustronna, bo mówi i o ówczesnym sposobie studiowania, ale też o tym, jak odbywało się to w ten czas ograniczenia, wręcz zlikwidowania nauczania socjologicznego, ale jednocześnie profesorowie w różny sposób nie tylko sami przeżywali oczywiście, ale również w różny sposób na to reagowali. Chałasiński właśnie tak, że uczył nas właściwie w ten sposób również naukowej krytyki tych książek.

Podsumowaniem przytoczonych fragmentów może być komentarz studiującego nieco później Zbigniewa Bokszańskiego, który również porusza kwestię kompetencji językowych oraz konkretnych oczekiwań stawianych przed uczestnikami seminariów:

Była konieczność nauczenia się w dość szybkim czasie języka angielskiego, którego oczywiście do dzisiaj nie opanowałem tak jakbym sobie tego życzył, ale po półtora roku mogłem czytać już jakieś krótsze fragmenty sam z powodzeniem, zważywszy, że język socjologiczny, jak pani wie, jednak da się dość szybko opanować, nie jest to matematyka, ale podstawowy zasób słów, tych pięć tysięcy słów można sobie rzeczywiście jakoś przyswoić. I właściwie myśmy mieli znaczną część literatury w językach obcych. Literatury polskiej nie było przede wszystkim. Były albo tradycyjne z końca lat dwudziestych i z lat trzydziestych też, nieliczne stosunkowo, jeżeli idzie o podręczniki. Wobec tego myśmy na seminaria mieli po prostu referaty z obcych lektur. Tego po prostu się nie dało ominąć i właściwie na palcach jednej ręki można było policzyć takie seminaria, które profesor Kłoskowska ${ }^{169}$ prowadziła na pierwszym roku w oparciu o polskie teksty, więc już na pierwszym roku mieliśmy taką dawkę właśnie tych obcych lektur. Na drugim roku jeszcze więcej tego było, bo po prostu tak należało to robić w tym czasie i to też było takie stymulujące, to nasze dukanie po angielsku, po francusku czy po niemiecku. $\mathrm{Z}$ zainteresowaniem słuchaliśmy tego, co koledzy przygotowali. Był jeden egzemplarz, który dostawał referent i myśmy tego słuchali. Prowadzący zajęcia dokonywał

${ }^{169}$ Zob. przypis $93 \mathrm{w}$ tym rozdziale. 
korekt, wskazywał na jakieś punkty, na których warto się zatrzymać. Nie było żadnych plebiscytów na najbardziej uprzejmego i miłego wykładowcę, nie było schlebiania studentom, nie było jakiegoś miejsca na komplementy, po prostu była rzeczowa, a niekiedy taka bardzo krytyczna postawa ze strony pracowników. Przypominam sobie, jak profesor Chałasiński - ja byłem gościem na tym seminarium, bo to było rok wyżej, z jakiegoś tam powodu się znalazłem, referat miał kolega - profesor Chałasiński słuchał, słuchał tego i mówi: „Proszę pana, według ornitologii są trzy rodzaje ptaszków: tych, które latają wysoko, tych, które latają średnio i tych, które latają bardzo nisko. Pan należy do tych, które latają bardzo nisko". U nas z kolei po jakimś sprawdzianie ze wstępu do socjologii profesor Szczepański ${ }^{170}$ powiedział: „Proszę państwa, ja liczyłem na to, że jesteście na studiach i że przeczytacie coś więcej niż notatki z moich wykładów, ale wy, wy nie jesteście ciemniaki, wy jesteście czarniaki, to jest naprawdę nędza, co wy tu przedstawiacie".

Mimo stawianych przed studentami wyzwań (paradoksalnie dziś, choć dostęp do edukacji językowej jest dużo większy, trudno byłoby wyegzekwować od studentów czytanie tekstów w tak wielu językach obcych) rola seminariów była nie do przecenienia, o czym świadczyć mogą też i inne wspomnienia. Zbigniew Jakubowski wskazuje na inicjacyjny charakter seminariów kształtujących dalsze zainteresowania naukowe:

Studia były czteroletnie. Przede mną się skończyły studia trzy lata plus dwa i w którymś momencie to zarzucono jako niezdające egzaminu. Rozumiem, że po wojnie ta trzylatka powinna być, bo nie było kadry i w szkołach, i wszędzie, trzeba było w krótkim okresie ją wykształcić. Po trzylatce były dwa lata, na przykład profesor Mikołajczyk ${ }^{171}$, mój kolega, także obecnie emeryt, w Łodzi kończył studia trzyletnie i potem magisterium robił w Warszawie. Natomiast nasz rocznik był pierwszym, gdzie były czteroletnie studia i kończyły się egzaminem magisterskim. Nie pamiętam, czy te studia czteroletnie trwały przez dwa, trzy roczniki, nie więcej - potem rozpoczęły się studia pięcioletnie. Na czwartym roku mieliśmy wykład monograficzny, który prowadził profesor Zygmunt Charzyński ${ }^{172}$, i dwa seminaria. Jedno seminarium prowadził profesor Zygmunt Zahorski ${ }^{173}$, który przyszedł do nas do Łodzi z Krakowa po habilitacji i przez kilka lat kierował Katedrą Matematyki w Uniwersytecie. Natomiast drugie seminarium prowadzili wspólnie Zygmunt Charzyński i Witold Janowski ${ }^{174}$. Zarówno wykład monograficzny, jak i seminarium były

${ }^{170}$ Zob. przypis $40 \mathrm{w}$ tym rozdziale.

${ }^{171}$ Leon Mikołajczyk (ur. 1929, zm. 2016) - matematyk, specjalista w zakresie geometrycznej teorii funkcji zespolonych oraz teorii optymalizacji. Wieloletni pracownik Uniwersytetu Łódzkiego.

${ }^{172}$ Zob. przypis $141 \mathrm{w}$ tym rozdziale.

${ }^{173}$ Zob. przypis $143 \mathrm{w}$ tym rozdziale.

${ }^{174}$ Zob. przypis $142 \mathrm{w}$ tym rozdziale. 
z analizy zespolonej. Myślę, że w czasie wykładu i seminarium zostałem zarażony bakcylem analizy zespolonej, która wówczas najczęściej była nazywana funkcjami analitycznymi.

Biruta Lewaszkiewicz-Petrykowska opowiada o seminariach magisterskich prowadzonych przez prof. Adama Szpunara ${ }^{175}$ i kontynuowaniu ich formuły po dziś dzień:

Jak profesor Szpunar prowadził seminarium magisterskie, u nas był taki zwyczaj - który zresztą utrzymał się do tej pory - ja prowadzę seminarium magisterskie w tej chwili, ale na to seminarium przychodzi cała katedra, profesorowie i wszyscy asystenci, adiunkci i tak dalej, no i oczywiście studenci - tak samo było zawsze gdy prowadził seminarium magisterskie profesor Szpunar. Myśmy się często z profesorem nie zgadzali co do wielu kwestii w prawie. Dochodziło też między mną a Szpunarem czasem do tak ostrych dyskusji, że studenci mieli cyrk za darmo. Wyobraża pani sobie.

Kaja Kaźmierska: Mhm

Biruta Lewaszkiewicz-Petrykowska: Zawsze dyskusja była bardzo swobodna. Ja zresztą też zawsze studentom mówię, żeby się nie bali wyrażać swoich poglądów. A poza tym to jest jednak tak, przecież pani się zgodzi, bo zjawisko to występuje nie tylko w naukach prawnych, ale i w wielu naukach społecznych. Są takie problemy i takie dylematy, o które ludzie się spierają od stu lat i dłużej, i będą się spierać przez następne sto.

$\mathrm{Na}$ koniec przedstawmy scenę z ćwiczeń terenowych, typowych dla nauk przyrodniczych, ukazującą niezwykłe zaangażowanie i pasję wykładowców. Romuald Olaczek wspomina profesora Jakuba Mowszowicza ${ }^{176}$ :

Profesor Jakub Mowszowicz przywiązywał dużą wagę do zajęć w terenie i w każdą sobotę, a często w sobotę i niedzielę, organizował studentom ćwiczenia terenowe, ale tylko w okolicach Łodzi. $Z$ reguły było to tak: „Te ćwiczenia”, zapowiadał profesor „odbędziemy w lesie w Modlicy”. Modlica to jest nazwa wsi po drodze do Tuszyna i przystanku tramwajowego, bo wtedy z Łodzi jeździły tramwaje przez Rzgów do Tuszyna. Więc spotykaliśmy się studenci i asystenci profesora - o godzinie 8 na przystanku na placu Niepodległości, wsiadaliśmy w tramwaj i jechaliśmy do Modlicy. Ta podroż tramwajem trwała w jedną stronę ponad godzinę. Przez Rudę Pabianicką, przez Rzgów

${ }^{175}$ Adam Szpunar (1913-2002) - profesor prawa, specjalista w zakresie prawa cywilnego, w latach 1956-1962 rektor Uniwersytetu Łódzkiego.

${ }^{176}$ Jakub Mowszowicz (1901-1983) - urodzony w Wilnie biolog i botanik, profesor Uniwersytetu Łódzkiego. Doktorat uzyskał na tamtejszym Uniwersytecie Stefana Batorego. Badał florę regionu łódzkiego. Był jednym z założycieli łódzkiego Ogrodu Botanicznego. Przez wiele lat sprawował funkcję dziekana Wydziału Biologii i Nauki o Ziemi na Uniwersytecie Łódzkim. 
dojeżdżaliśmy do Modlicy. Kto był pierwszy raz na tych ćwiczeniach, to sobie wyobrażał, że profesor zaprowadzi nas do lasu, pokaże las, tam jest piękny bagienny las olszowy, gdzie indziej jodłowy, grąd z jodłą i bory sosnowe w różnych odmianach. A profesor był takim entuzjastą roślin, że ledwie wyszliśmy z tramwaju i stanęliśmy nad przydrożnym rowem na skraju lasu, nie wiadomo kiedy upływały trzy godziny ćwiczeń. Bo profesor pokazywał: a to taka roślina, a to inna. Stał w tym rowie [śmiech]. Studenci wianuszkiem dookoła z notatnikami w ręku, a profesor potrafił $\mathrm{z}$ tego rowu kilkadziesiąt gatunków roślin wydobyć, pokazać i opowiedzieć. No i zabawny epizod, bo zauważył, że jednak las jest i rosną drzewa [śmiech] i zwisają gałęzie, i że można na przykład pokazać różnicę pomiędzy liśćmi grabu i wiązu. Podobne, ale jednak różne. Tylko nie mógł biedny sięgnąć, żeby ułamać gałązkę. Więc nie myśląc wiele, odpina pasek od spodni, wyciąga pasek i ten pasek zarzuca, żeby gałąź przyciągnąć. Gałąź udało się przyciągnąc $\mathrm{w}$ dół, ale jednocześnie i spodnie profesora także nieco w dół poleciały [śmiech], ku skrywanej subtelnie uciesze studentów.

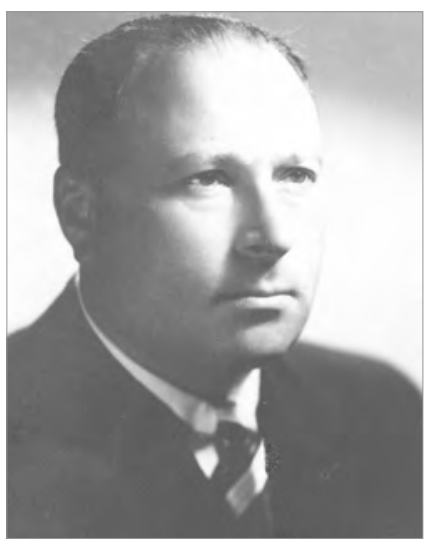

Fot. 36. Jakub Mowszowicz

\section{Egzaminy}

Nieodłącznym elementem procesu studiowania są egzaminy, a sytuacje egzaminacyjne bywają też często źródłem anegdotycznych opowieści. Znajdą się i takie w prezentowanych niżej fragmentach, ale na szczególną uwagę zasługuje w nich tryb przygotowania oraz znaczenie egzaminu w procesie studiowania. Doskonale wyjaśnia to ówczesny student psychologii, Sławomir Cieślikowski, opowiadając o egzaminie z tego właśnie przedmiotu:

[Pokazując indeks]. Egzaminów jak widać bardzo niewiele. Ale one były o wiele obszerniejsze niż dzisiaj i miały inne nastawienie. To znaczy cel egzaminów był inny niż dzisiaj. Dzisiaj tym celem jest przekazanie egzaminującemu, że się coś na dany temat wie. Wtedy wcale nie o to chodziło. Egzaminator sprawdzał, czy i w jakim zakresie i na jakim poziomie będę mógł prowadzić zajęcia na uniwersytecie z tego przedmiotu, który zdaję. Zupełnie co innego. Wobec tego, jeżeli ktoś ocenił mnie jako dobrego, to znaczyło tyle, że dany przedmiot mogę na uniwersytecie wykładać z wynikiem dobrym. Ja sobie to bardzo cenię. I teraz tak: przygotowuję się do pierwszego egzaminu u profesora 
Alberta Dryjskiego ${ }^{177}$, w kilka osób, bo tam kilkoro nas zdawało, i widzę, że literatura do egzaminu będzie tylko około siedemdziesięciu pozycji. To nie jest dużo, jak mam dwa lata czasu na przygotowanie się. No więc zabrałem się do czytania i opanowałem, ale nie wszystkie. Bo jedna nieduża, cienka książka była po norwesku.

Kaja Kaźmierska: [śmiech]

Sławomir Cieślikowski: Ja jej nie przeczytałem. „Czytał pan to? - Nie, panie profesorze, bo nie znam norweskiego. - To niech się pan zapisze na lektorat. Ale nie ma lektoratu norweskiego. - No tak, wy studenci nie jesteście zamożni. - To złóżcie się w kilku, idźcie z książeczką do tłumacza przysięgłego, zapłaćcie mu za thumaczenie, potem poprawcie według terminologii psychologicznej, bo on wam to zrobi źle i będziecie mieli lekturę". Był jeden, ale się nie podjął. Ja go nie szukałem, szukał go ktoś inny. Jeden. (...) Profesor Dryjski, to było rok później chyba, bo między podejściem do egzaminu i dowiedzeniem się, co trzeba umieć, a egzaminem upłynął długi czas. I bestia pamiętał! „A czytał Pan - i tu wymienił nazwisko, którego ja już nawet nie pamiętam - tego Norwega?". Mówię: „Nie”. „Będzie pan miał obniżony stopień. Umiał pan na piątkę, nie czytał pan, nie zna pan lektury. Dobrze, nie bardzo dobrze". Ostro, niesłusznie. W pierwszej chwili żachnąłem się, ale zrozumiałem, że on miał rację. Ja tej książki nie znam, bo lektury, których on wymagał, oprócz wiadomości szczegółowych dawały pogląd na jakieś duże zagadnienie, także warto się go było wyuczyć na pamięć i stosować w życiu. Więc ja nie wątpię, że w stosunku do tego Norwega było podobnie. Nie umiesz - masz obniżony stopień.

Jak widać z powyższego opisu, systematyczne i długie przygotowanie do egzaminu było traktowane jako reguła i służyło nie tyle zaliczeniu przedmiotu, ile zdobyciu trwałej i rzetelnej wiedzy, która miała być podstawą dalszych pogłębionych studiów. Z drugiej strony, jak zwykle w takich przypadkach, bywały też wyjątki od tej reguły. Wanda Nowakowska opowiada o egzaminie z logiki u profesor Janiny Kotarbińskiej ${ }^{178}$.

Jak studiowałam filozofię, bo właśnie od tego zaczęłam, chodziłam na wszystkie wykłady profesora Kotarbińskiego ${ }^{179} \mathrm{z}$ logiki, fascynujące. W ogóle z historii filozofii, ale to nie była filozofia, tylko logika. Ogromna aula. No i siedzieliśmy tam na tych piętrowych ławach. Nie egzaminował profesor Kotarbiński, on był bardzo zajęty. Egzaminowała jego żona - Janina Kotarbińska, która też była profesorem, i to bardzo dobrym. I pani profesor przyjeżdżała po prostu na te egzaminy tutaj, notabene byli w bardzo wielkiej przyjaźni Kotarbińscy

${ }^{177}$ Albert Dryjski (1889-1956) - psycholog eksperymentalny, uczeń Iwana Pawłowa, profesor Uniwersytetu Łódzkiego.

${ }^{178}$ Zob. przypis $133 \mathrm{w}$ tym rozdziale.

${ }^{179}$ Zob. przypis $68 \mathrm{w}$ tym rozdziale. 
i Wallisowie ${ }^{180}$. Bywali u siebie prywatnie - na herbaty, kolacje, to była wielka przyjaźń. Oni i Ossowscy. Profesorstwo Ossowscy, Stanisław od estetyki, a Maria od etyki ${ }^{181}$. I ja chodziłam na wykłady do nich obojga. Estetyka się właśnie ściśle wiązała z moimi zainteresowaniami. Ale wrócę do logiki, bo tamto wszystko pozostałe jakoś szło, ale ja się strasznie bałam, bo Kotarbińska była taka sroga i cięła jednego studenta po drugim. A ja byłam okropna zawsze z matematyki, zawsze miałam dwójki. Wiadomo, chorowałam też. To było w czerwcu, miałam mieć egzamin na początku czerwca i poszłam do pani później profesor Iji Pawłowskiej ${ }^{182}$, która była asystentką pani profesor, a Tadeusz Pawłowski ${ }^{183}$ był asystentem profesora Kotarbińskiego. Później miał zakład logiki, a później zakład estetyki, bo się przekwalifikował na estetykę. No i pani Ija zapytała: „Kiedy pani chce zdawać egzamin?”, bo ja prosiłam o materiały, no więc ja mówię: „Za trzy tygodnie pani profesor Kotarbińska będzie, to ja bym chciała”. Ona popatrzyła na mnie z politowaniem: „Za trzy tygodnie... A pani już zaczęła?”. Ja mówię: „Właśnie zaczynam się uczyć”. „No niech pani próbuje" - taka była odpowiedź. No dobrze. Pamiętam, że się uczyłam w truskawkach [śmiech]. Do dzisiaj mam pod tapczanem, tylne nogi tapczanu muszą być podniesione, to tam są te ogromne knigi i między innymi właśnie ten ogromny podręcznik, Logika matematyczna. Trzy tygodnie... No i przyszłam. Było nas troje. Jakiś mężczyzna, dziewczyna i ja. Nie pamiętam już, które z nich było po ilu, ale jedno z nich było już po dwóch niezdanych, a jedno było po jednym niezdanym. A ja pierwszy raz. To oni powiedzieli: „A! Jak się pani uczyła długo?”. Ja mówię: „Trzy tygodnie”. Tak było. „Eee!” Ale dobrze. No i poszliśmy, oczywiście osobno. Zresztą ja do dzisiaj mam ten zwyczaj. Broń Boże razem. Wiem, że jedno $\mathrm{z}$ nich zdało na trójkę. Jedno nie zdało znów, a ja zdałam na cztery. Wyszłam, poszłam do pani Iji i mówię: „Ja mam czwórkę!”. Ona mówi: „Naprawdę? - No tak. Nie wiem jak, ale mam czwórkę". Ale potem zaczęłam wierzyć W siebie. W matematykę.

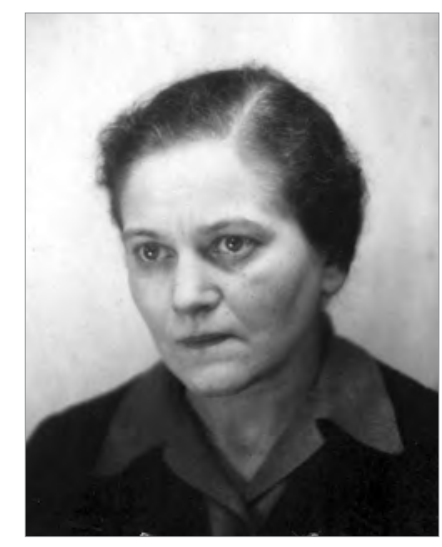

Fot. 37. Janina Kotarbińska

Sytuacje egzaminacyjne pokazują też odmienne od dzisiejszego definiowanie różnic statusowych wyrażanych np. przez oddzielenie sfery

\footnotetext{
${ }^{180}$ Zob. przypis $28 \mathrm{w}$ tym rozdziale.

${ }^{181}$ Zob. przypisy 84 i $88 \mathrm{w}$ tym rozdziale.

182 Zob. przypis $135 \mathrm{w}$ tym rozdziale.

${ }^{183}$ Zob. przypis $137 \mathrm{w}$ tym rozdziale.
} 
prywatnej i publicznej. Bronisława Kopczyńska-Jaworska opowiada o egzaminach „domowych”:

Egzamin to się zdawało $\mathrm{w}$ tych czasach często $\mathrm{w}$ domu, profesorowie nie mieli gabinetów do przyjmowania studentów. Pamiętam, że zdawałam u Chałasińskiego egzamin, miałam ogromną tremę, ponieważ on się nie lubił z moją profesor [Kazimierą Zawistowicz ${ }^{184}$ ] i ja się zawsze tak niepewnie czułam w jego obecności, ponieważ oni sobie wzajemnie dokuczali i zawsze byli odmiennego zdania. A ja byłam takim asystentem tych kłótni czy dyskusji, mówiąc delikatnie. No i egzamin był w domu. Chałasiński miał fenomenalną pamięć, on jak np. o czymś mówił czy w mniejszym gronie o czymś wykładał, to podchodził do książki na półce, przewracał kartki i znajdował cytat. Coś nieprawdopodobnego. No i ja u niego zdaję ten egzamin, a miałam taki pierścioneczek młodzieżowy, który nerwowo obracałam na palcu w trakcie tego egzaminu i w którymś momencie on mi upadł na podłogę [śmiech] i potoczył się gdzieś. Potem myśmy na czworakach z profesorem raczkowali po gabinecie i szukali pierścionka. Jak już go znalazłam, to miałam nogi jak z galarety, myślałam sobie - „Jezus Maria, co ja narobiłam”, ale on miał jakieś poczucie humoru i się nie obraził. Pamiętam, że spytał mnie o teorię kultury profesora Poniatowskiego ${ }^{185}$, nie, czy o ewolucjonizm i ja przez moment się zaczęłam zastanawiać, a on mnie - „Przecież pani na pewno czytała Poniatowskiego” - bo tam jest taka praca, w artykule na temat ewolucjonizmu. Ponieważ to była taka lektura codzienna na etnografii, wobec tego ja już przestałam się denerwować i wyklepałam wszystko, co wiedziałam na ten temat. No i szczęśliwa wybyłam z tego egzaminu. Jeden egzamin w domu zdawałam również u Konrada Jażdżewskiego ${ }^{186}$. To był uroczy człowiek, który mówił, że poza archeologią nie widzi świata, zresztą mówił: „Najwięcej w życiu kocham archeologię, nawet więcej od mojej ,żony”, którą bardzo kochał, z którą miał czworo czy pięcioro dzieci. Zdawałam egzamin i on mnie pytał o to i owo, a ja mu odpowiadałam, odpowiadałam i on zaczyna pytać o coś, czego nie było na wykładach ani w lekturach. „Bo pani tak świetnie odpowiada, to pomyślałem sobie, że może pani też coś o tym powie". Ale okazało się, że pani już o tym nic nie wie. Potem o coś innego mnie pytał, ja mówię, to on mi przerywa i sam zaczyna odpowiadać. No i z drugiego pokoju wydobywa się głos pani profesorowej - „Konradku, dopuść panią do głosu" [śmiech], także barwne były te spotkania.

Narratorka kontynuuje swoje wspomnienia, przeglądając indeks. Jej komentarz pokazuje, że również ówczesne curricula były z perspektywy

${ }^{184}$ Zob. przypis $132 \mathrm{w}$ tym rozdziale.

185 Stanisław Poniatowski (1884-1945) - etnograf, etnolog, przed wojną profesor Wolnej Wszechnicy Polskiej i Uniwersytetu Warszawskiego.

${ }^{186}$ Zob. przypis $26 \mathrm{w}$ tym rozdziale. 
studenta zhierarchizowane według porządku własnych zainteresowań i swojego uznania, co jest warte większej, a co mniejszej uwagi.

Także oglądałam właśnie ten indeks, to studia wyglądały zabawnie. Bo ja mam parę egzaminów, parę przedmiotów tylko wysłuchanych. Nie takie programy, które sama swego czasu układałam, bo byłoby dobrze, żeby studenci wiedzieli, więc się wymyślało następny jakiś koszmarny przedmiot, w którym się mieli nauczyć czegoś ciekawego. Dawniej inaczej te studia wyglądały. Student był zostawiony bardziej sam sobie, musiał dużo czytać i nie było tyle wykładów, dziesięć godzin zdaje się było według przepisów - maksymalnie dziesięć godzin. Mam więc egzamin chyba z czterech przedmiotów: z etnografii, socjologii, archeologii, językoznawstwa. Wstęp do socjologii, jakiś dziwny, ze zdumieniem wczoraj przeglądałam ten indeks, wiedza o Polsce współczesnej, podpisany jakimś gryzmołem, nawet nie pamiętam, nie byłam w stanie przeczytać, kto to. Nawet gdyby mnie ktoś chciał zamordować, nie pamiętam, że taki wykład był. Dobrze to o nim nie świadczy - o skali zainteresowania i starannym wymieceniu z pamięci, kiedy się skończył. Powiedzmy, że jeszcze na tym pierwszym roku jakieś bibliotekoznawstwo czy coś takiego miałam. Jeszcze historię oświaty zdawałam u profesor Radlińskiej ${ }^{187}$ na kompletach, ale w ogóle zupełnie inaczej się studiowało. Pamiętam, że na egzamin z filozofii to się miesiąc uczyłam pilnie. To nie była zresztą historia filozofii, to Janina Kamińska, późniejsza Kotarbińska ${ }^{188}$ prowadziła. [Zakres] tak jak Kotarbińskiego elementy poznania, semantyki i po trochu logiki formalnej. Takie egzaminy...

Grażyna Kononowicz wspomina egzaminy u profesorów Antoniny Kłoskowskiej i Jana Szczepańskiego ${ }^{189}$, którym przypisane były przeciwstawne etykiety groźnego i miłego egzaminatora. Niezależnie od tego oboje wykładowcy cieszyli się wielkim szacunkiem i poważaniem:

Był jakiś dystans zwłaszcza ze strony profesor Kłoskowskiej, bo ona tak traktowała wszystkich: była bardzo uprzejma, ale bardzo surowa, myśmy wszyscy jej się bali i było wiadomo, że jak się zda u niej egzamin z historii myśli społecznej na drugim roku, to właściwie można sobie dopisać przed nazwiskiem magister. Także ona była bardzo wymagająca. Nie byłam na jednym jej wykładzie, dlatego że byłam chora, i kupiłam od koleżanek te notatki z zajęć, a wtedy pierwsze pytanie, które ona zadała mi na egzaminie, było właśnie z tego wykładu, na którym nie byłam. Tak. A poza tym ona miała zwyczaj stawiania w zasadzie jednego pytania, ale to było tak sformułowane, że trzeba było znać cały materiał, od starożytności do dnia dzisiejszego. Bardzo pilnowała

\footnotetext{
${ }^{187}$ Zob. przypis $6 \mathrm{w}$ tym rozdziale.

${ }^{188}$ Zob. przypis $133 \mathrm{w}$ tym rozdziale.

${ }^{189}$ Zob. odpowiednio przypis: 93 i $40 \mathrm{w}$ tym rozdziale.
} 
też lektur: mnie spytała o jakąś książkę, której nie czytałam, już nie pamiętam, co to było, na szczęście to była lektura nieobowiązkowa, więc jak zapytała mnie, powiedziałam, że nie czytałam. Była bardzo niezadowolona, ale powiedziałam, że przecież to była lektura nieobowiązkowa, w związku z tym dała mi [śmiech] święty spokój. Także jej ludzie się po prostu bali, chociaż nikomu krzywdy nie zrobiła. W naszych czasach była bardzo surowa, później złagodniała z biegiem czasu. Ale była słynna historia, że jakiś student, ale to chyba nie był socjolog, zdawał u niej egzamin, zemdlał $\mathrm{z}$ wrażenia na egzaminie i ona wybiegła $\mathrm{z}$ tego swojego [śmiech] gabinetu, żeby pomocy szukać, żeby ten biedny chłopak wrócił do siebie.

\section{(...)}

W ogóle inaczej się prowadziło wtedy zajęcia i inaczej wyglądały egzaminy. Na przykład jak u profesora Szczepańskiego zdawaliśmy egzamin, to jeden z naszych kolegów, on bardzo nie lubił chodzić na egzaminy i w czasie sesji nagle opanowała go wielka miłość do kina i kiedy były zaliczenia, to on cały czas sobie chodził do kina, a myśmy mieli jego indeks i tylko podsuwaliśmy do podpisywania pracownikom. $Z$ tym że on przez cały rok bardzo pilnie studiował, to jest bardzo mądry człowiek, więc to nie to, że on po prostu nie umiał, tylko stres jakiś przeżywał. I nie przyszedł na egzamin do profesora Szczepańskiego, więc myśmy wszyscy już zdali, raptem te dziesięć osób, a Wojtusia nie ma.

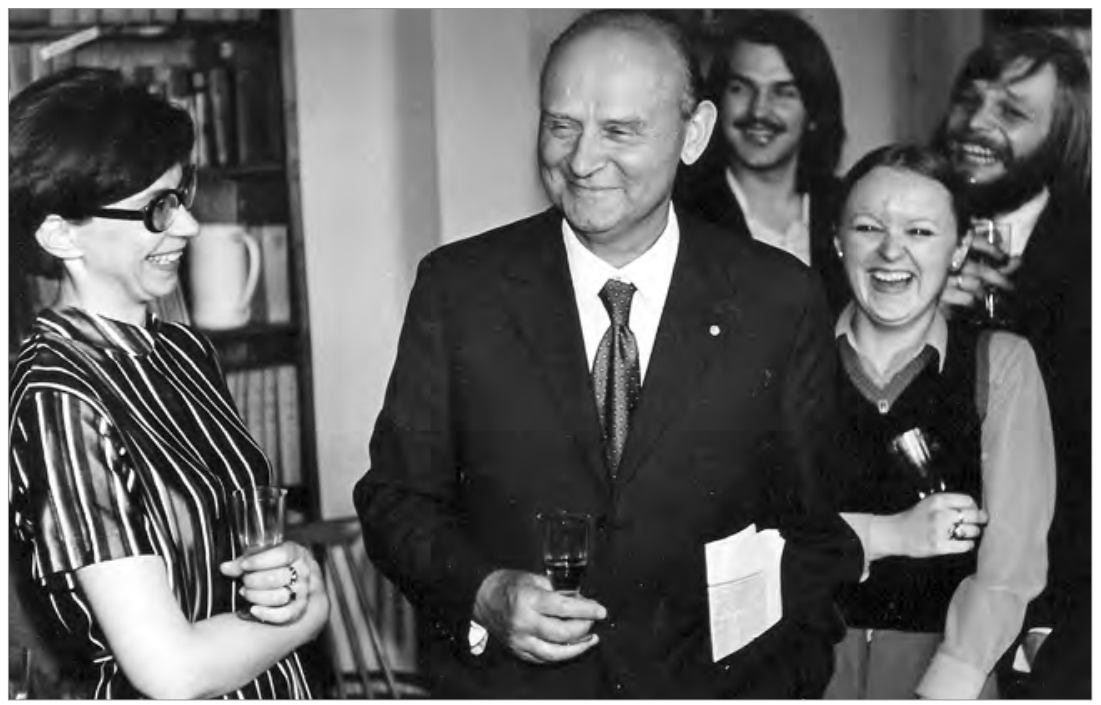

Fot. 38. Lata sześćdziesiąte. Jan Szczepański z grupa studentów

Na pierwszym planie z lewej strony Grażyna Kononowicz 
Więc pan profesor Szczepański się bardzo zainteresował, co się stało, dał panu obecnie profesorowi Słomczyńskiemu ${ }^{190}$ pieniądze na taksówkę, Maciek pojechał, Wojtka za kark, przywiózł na egzamin, Wojtuś wyszedł z piątką. Więc to nie to, że on nie umiał, tylko po prostu on nie lubił zdawać egzaminów i już. Nie wiem, czy gdzieś na innym kierunku inny profesor by się zdecydował, żeby przywieźć studenta na egzamin, ale wiedział, że on umie, tak że to było ciekawostkowo.

Na zakończenie tego podrozdziału przytaczamy opisy reprezentatywne dla często formułowanych w opowieściach narratorów opinii na temat niegdysiejszej atmosfery studiowania. Stanisław Liszewski opowiada o studiach geograficznych:

Moje studia wyglądały jednak inaczej niż obecnie. Po pierwsze dlatego, że było nas mało - to był trzydziestoosobowy rok, po drugie, że budynek, który wtedy zajmowała geografia, to był zabytkowy pałacyk przy ulicy Curie-Skłodowskiej 11, tam teraz jest Łódzkie Towarzystwo Naukowe, co zapewniało kontakt z profesorami na bieżąco. Poza tym były liczne wyjazdy terenowe.

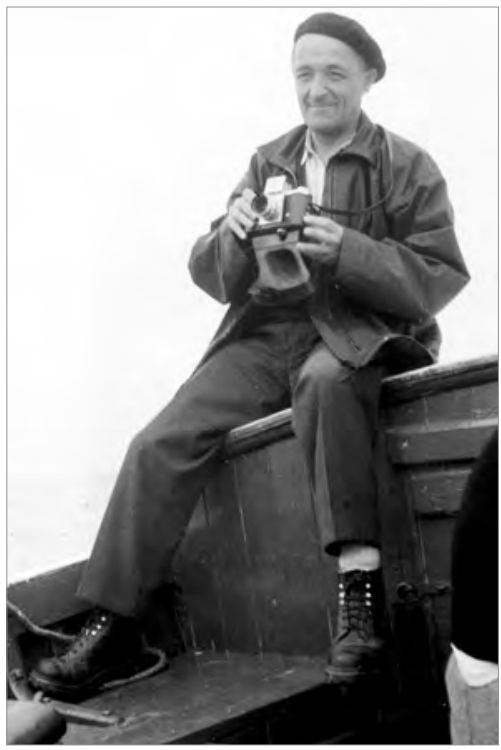

Fot. 39. Jan Dylik To były kameralne studia, każdy miał szansę rozmowy, spotkań, potem się ludzie wykruszali, w końcu tylko dwadzieścia parę osób skończyło te studia. Byliśmy zgrani, byliśmy taką dobrą paczką, a także i profesorowie byli z nami. I myślę, że to jest nie do porównania z dzisiejszą sytuacją. Pani pytała o atmosferę - ta dzisiejsza atmosfera studiów jest zupełnie nieporównywalna, ponieważ profesorowie traktowali nas poważnie, ale jednocześnie bardzo po koleżeńsku, czyli byliśmy młodszymi kolegami, uczestniczyliśmy w ich badaniach, jeździliśmy z nimi w teren. Szefem łódzkiej geografii był wówczas profesor Jan Dylik $^{191}$, znana i bardzo światowo uznana postać w geografii. Jego żona, pani profesor Anna Dylikowa ${ }^{192}$ była też znaczącą postacią. Ja potem po trzecim roku studiów lub po drugim, nie pomnę, wybrałem jako specjalizację

${ }^{190}$ Kazimierz Maciej Słomczyński (ur. 1943) - polski socjolog zajmujący się przede wszystkim badaniem struktury i ruchliwości społecznej oraz nierównościami społecznymi. Absolwent Uniwersytetu Łódzkiego. Od wielu lat pracownik IFiS PAN.

${ }^{191}$ Jan Dylik (1905-1973) - geograf, geomorfolog, od 1947 roku profesor Uniwersytetu Łódzkiego, w latach 1956-1972 przewodniczący Międzynarodowej Unii Geograficznej.

${ }^{192}$ Zob. przypis $16 \mathrm{w}$ tym rozdziale. 
geografię ekonomiczną, właściwie społeczno-ekonomiczną. I tak studiowałem w Katedrze Geografii Ekonomicznej pod kierunkiem profesora Ludwika Straszewicza ${ }^{193}$.

Zbigniew Bokszański i Grażyna Kononowicz wspominają studia socjologiczne.

Zbigniew Bokszański mówi między innymi tak:

Atmosfera była znakomita, także ja z ogromną przyjemnością te studia wspominam. Po pierwsze, ze względu na stosunek pracowników do nas, do studentów, ale także i stosunek studentów do pracowników był jednak trochę inny niż to się dzisiaj dzieje, zważywszy, że to byli ludzie uznani, pewna sława była z ich nazwiskami związana, renoma. Profesor Chałasiński ${ }^{194}$ przecież znany był bardzo szeroko w świecie. Napoleon polskiej socjologii, jak go nazywano $\mathrm{z}$ racji niskiego wzrostu, ale pełnego temperamentu i takiego energicznego człowieka.

Grażyna Kononowicz opowiada:

Poza tym wtedy jeszcze do profesorów studenci odnosili się z dużym szacunkiem. Może oni nie stwarzali takiego dystansu, ale mnie by było głupio podejść do profesora Szczepańskiego ${ }^{195}$ i o coś go pytać, z tym, że on był bardzo kontaktowy, taki sympatyczny. U Chałasińskiego ${ }^{196}$ z kolei wszystko było z daleka: to byli profesorowie, a my studenci. Ale Szczepański to był fenomen, bo on pamiętał wszystkich, z którymi miał do czynienia: i swoich studentów, i pracowników, a co było dla mnie zupełnie niepojęte przy jego tak licznych kontaktach na całym świecie, że on każdego kojarzył i jak rozpoczynał z kimś rozmowę, to akurat na tematy, które były związane $\mathrm{z}$ tą osobą. Ja byłam jedną z wielu studentów i później pracowników, tak że nie było tak, że to był mój osobisty znajomy.

W rozdziale tym przedstawiłyśmy dwie znaczące z perspektywy kolejnych stadiów biografii fazy doświadczeń edukacyjnych - kłącza inicjujące późniejsze zainteresowania naukowe oraz konkretyzujący je okres studiów. Jak pokazały przytoczone wypowiedzi, etap kształcenia akademickiego przeżywany był przede wszystkim przez pryzmat przywileju spotkania ze znamienitymi przedstawicielami różnych dziedzin nauki. $Z$ czasem, niekiedy jeszcze w okresie studiów, a w innych przypadkach już po podjęciu

${ }^{193}$ Ludwik Straszewicz (1916-1987) - ekonomista, geograf, od 1956 roku związany z Uniwersytetem Łódzkim, założyciel Oddziału Łódzkiego Polskiego Towarzystwa Urbanistycznego.

${ }^{194}$ Zob. przypis $63 \mathrm{w}$ tym rozdziale.

${ }^{195}$ Zob. przypis $40 \mathrm{w}$ tym rozdziale.

${ }^{196}$ Zob. przypis $63 \mathrm{w}$ tym rozdziale. 
pracy na uczelni, zaczynał rozwijać się szczególny typ więzi między młodym adeptem danej dyscypliny naukowej a dojrzałym jej przedstawicielem. W biografiach wielu rozmówców pojawiał się ktoś, kto (nie zawsze intencjonalnie) utwierdzał ich w trafności wyboru, kto stanowił dla nich punkt odniesienia i którego po latach mogą nazwać swoim mistrzem. O znaczeniu osoby mistrza, często nie tylko w życiu naukowym, może świadczyć fakt, iż nasi rozmówcy oddali im wiele miejsca w swoich wspomnieniach. $\mathrm{Z}$ tego powodu poświęcimy jej odrębny rozdział. 



\section{Rozdzial II. Wędrówka z Mistrzem}

Wychowanie jest sztuka podobna do sztuk pięknych raczej niż technika;
opiera się na osobistym takcie i talencie raczej niz na stosowaniu oderwanej
wiedzy.

Florian Znaniecki, Socjologia wychowania

Agata Zysiak: Mam wrażenie, że ta relacja mistrz-uczeń trochę już ginie. Michat Seweryński: Nie, niech pani w to nie wierzy. Jeśli jest mistrz, to będa zachwyceni uczniowie. Tylko nie każdy ma ten talent, nie każdy ma ten dar.

Z wywiadu z profesorem Michałem Seweryńskim

Jak to zostało zasygnalizowane pod koniec poprzedniego rozdziału, w biografiach wielu rozmówców pojawiała się osoba, która - mniej lub bardziej świadomie - ugruntowywała ich przekonanie o słuszności dokonanego wyboru, która stanowiła dla nich swoisty wzór czy autorytet i która najczęściej po latach opisywana jest z należytą estymą jako mistrz. W ich wspomnieniach odnaleźć można zatem wiele odniesień do uczonych-mistrzów należących do przedwojennego środowiska akademickiego. Pojawiają się oni najpierw jako wykładowcy, potem jako promotorzy, a następnie przełożeni i współpracownicy opowiadających. W większości przypadków odwołania do tych postaci występowały w wypowiedziach naszych rozmówców spontanicznie i wskazywały na szczególny typ więzi, który nazwałyśmy relacją mistrz-uczeń. Nasze zainteresowanie, kształtowane obrazem współczesnego uniwersytetu, inspirowane było pozytywnym zdumieniem wynikającym $\mathrm{z}$ faktu, iż $\mathrm{w}$ zgromadzonych opowieściach relacja mistrz-uczeń niejednokrotnie ukazywana była jako zasadniczy czynnik formacyjny. Słuchając tych wspomnień, miałyśmy wrażenie, że we współczesnym świecie akademickim mamy do czynienia, jeśli nie tyle z zanikiem takiej relacji, co z wyraźną jej dewaluacją. Być może wynika to $\mathrm{z}$ faktu, iż

[z]mienił się obraz uczonego. To już nie dziwak, pokazywany jeszcze w XIX wieku na karykaturach jako osoba zaniedbana, oderwana od rzeczywistości, zatopiona w swoich rozważaniach. Ta karykatura zresztą nigdy 
nie oddawała uczonym sprawiedliwości. W rzeczywistości byli to ludzie - mówię tu tylko o czołówce uczonych - traktujący naukę jako powołanie, wszechstronnie wykształceni, znający głównie języki europejskie, nierzadko też łacinę i klasyczną grekę, pilnie czytający całą dostępną im literaturę przedmiotu. Ludzie, którym doradzał sir Fred Hoyle, by poszli na ryby, tam bowiem w spokoju mogą myśleć o własnej pracy, a może nawet znaleźć dla niej inspirację ${ }^{1}$.

Uczeni, których przywołują w pamięci nasi rozmówcy opisując zarówno osobiste z nimi kontakty budujące relację mistrz-uczeń, jak i spotkania z wykładowcami, należeli właśnie do czołówki europejskiej i światowej nauki i w pełni odpowiadali przedstawionej przez Ryszarda Herczyńskiego charakterystyce, o czym świadczą zamieszczone w tym rozdziale opowieści.

Florian Znaniecki w książce Socjologia wychowania zwracał uwagę, iż zmiany w procesie wychowania i edukacji, dokonujące się wraz z instytucjonalizacją procesu dydaktycznego, wpłynęły również na zmianę roli społecznej nauczyciela. Współcześnie jego zadaniem jest przekazywanie wyspecjalizowanego wycinka wiedzy na temat określonego obszaru rzeczywistości, a nie wprowadzenie w życie społeczne jako takie ${ }^{2}$. Nie chodzi o to, aby w przyszłości uczeń był taki jak nauczyciel. „Uczeń nie jest już dla nauczyciela przyszłym towarzyszem, współpracownikiem, rywalem, naśladowcą lub następcą. Lecz tylko danym mu przedmiotem społecznym, w którym wyrobić należy pewne programowo ustalone cechy"3. Kiedyś natomiast nauczyciel wprowadzał ucznia

we własną sferę doświadczenia i działania; we własnej działalności dawał mu przykłady do naśladownictwa i wskazywał, jak je ma naśladować; sam był (przynamniej w zasadzie) wzorem dla niego; posługując się jego pomocą w miarę już nabytych przezeń uzdolnien, rozwijał zdolność do współdziałania; powierzając mu zaś z czasem czynności do spełnienia samodzielnie, wdrażał go do niezależnej pracy4 .

Chociaż Socjologia wychowania została wydana po raz pierwszy w roku 1930, stąd nieco archaiczny styl autora, poruszane przez Znanieckiego

${ }^{1}$ Ryszard Herczyński, Spętana nauka: opozycja intelektualna w Polsce 1945-1970, Wydawnictwo Naukowe Semper, Warszawa 2008, s. 12.

${ }^{2} \mathrm{~W}$ tym duchu pisał żyjący w epoce oświecenia filozof i teolog John Henry Newman. W swoich wykładach o idei uniwersytetu twierdził między innymi, że „Sztuka uniwersytetu jest wdrażanie do życia w społeczeństwie, a jego celem jest przystosowanie do świata". John Henry Newman, Idea Uniwersytetu, Państwowe Wydawnictwo Naukowe PWN, Warszawa 1990, s. 79.

${ }^{3}$ Florian Znaniecki, Socjologia wychowania, t. 1, PWN, Warszawa 2001, s. 99.

${ }^{4}$ Tamże, s. 98-99. 
problemy związane z modernizacją społeczeństw i postępującą specjalizacją różnych dziedzin życia, w tym systemu edukacji, wydają się nader aktualne i można je rozszerzyć również na sferę kształcenia akademickiego. W roku 1969 Jan Szczepański pisał, że

[w] odróżnieniu od nauczyciela szkoły średniej [nauczyciel akademicki] nie przekazuje wiedzy gotowej, podręcznikowej, lecz wprowadza swoich studentów w proces powstawania nauki, uczy ich metody rozwiązywania nowych zagadnień. Nie jest więc nauczycielem lecz mistrzem skupiającym koło siebie uczniów, którzy będą kontynuować jego dzieło 5 .

Jednocześnie w tej samej książce Szczepański twierdził, że tak zarysowana figura mistrza należy do przeszłości, a studia wyższe upodabniają się do liceum w odniesieniu do relacji między studentem a wykładowcą, prezentują tylko nieco trudniejsze treści. Cóż moglibyśmy powiedzieć dziś? Niewątpliwie krytyczne uwagi Znanieckiego z 1930 roku czy Szczepańskiego z 1969 roku należy wpisać w swoisty dla każdej generacji typ argumentacji, w którym porównanie przeszłości z teraźniejszością (zwłaszcza w odniesieniu do obyczajów i stylu życia) na ogół stawia tę pierwszą w lepszym świetle. Z drugiej strony, trzeba podkreślić, iż krytycyzm cytowanych autorów nie wynika jedynie $\mathrm{z}$ nostalgicznego oglądu przeszłości, ale również z refleksji nad współczesnymi im zjawiskami i procesami społecznych - w tym przypadku są nimi postępujące procesy umasowienia systemu kształcenia. Ze współczesnej perspektywy można powiedzieć, że dynamika tych procesów wzrasta. Umasowienie kształcenia również na poziomie wyższym i zmiana oczekiwań wobec jego efektów (w postaci przedsiębiorczego, kreatywnego i konkurencyjnego indywidualisty-praktyka) sprawiły między innymi, że niesłychanie trudno jest obecnie zbudować, opisaną przez Znanieckiego i Szczepańskiego, relację mistrz-uczeń, która doskonale widoczna jest w opowieściach naszych rozmówców.

W przedstawionych poniżej fragmentach wywiadów obrazy nauczyciela-mistrza pojawiają się w różnych kontekstach: dysput akademickich, sytuacji dydaktycznych, sporów intelektualnych bądź tych związanych z organizacją życia akademickiego, sytuacji życiowych odnoszących się do kwestii rodzinnych, problemów dnia codziennego, trudności życiowych, czy wreszcie anegdot ukazujących różne cechy charakteru opisywanych postaci. W wielu przypadkach opowiadający odnoszą się do osób, które wywarły jeśli nie decydujący, to znaczący wpływ na ich życie naukowe

\footnotetext{
${ }^{5}$ Jan Szczepański, Problemy i perspektywy szkolnictwa wyższego w Polsce, Wiedza Powszechna, Warszawa 1968, s. 81.
} 
(i nie tylko). Możemy wtedy mówić o ,pełnej” relacji mistrz-uczeń w scharakteryzowanym przez Znanieckiego sensie. Ich odzwierciedlenie, choć nie jest to regułą, widać w bardziej rozbudowanych opowieściach. Nadany tej części tytuł „Wędrówka z Mistrzem” należy potraktować jako metaforę oznaczającą wspólne podążanie drogą wiedzy, rodzaj Buberowskiego „spotkania Innego", które przydarza się na drodze życia i doświadczenia dwóch osób, czy sokratejskiej dysputy niekiedy odbywającej się dosłownie $w$ drodze do domu, poza murami uczelni. ,Jak pisał Florian Znaniecki, jakość naszego życia zależy od tego, czy spotkamy w nim Mistrza"”.

Przejdźmy teraz do relacji naszych rozmówców:

\section{Profesora Adama Szpunara ${ }^{8}$ wspomina Biruta Lewaszkiewicz-Petrykowska}

Profesor Adam Szpunar był promotorem mojej pracy doktorskiej. Został przeniesiony do Łodzi w okresie, w którym zaczęto rozganiać Jagiellonkę. Było to chyba na początku 1949 roku. Początkowo profesor zachował jeszcze jakieś zajęcia w Krakowie. Przez pierwsze chyba trzy lata tylko trzy lub cztery dni był w Łodzi. Początkowo mieszkał w YMCE, na Moniuszki. Potem wynajmował pokój gdzieś na Gdańskiej. A później, kiedy już została wybudowana Biblioteka Uniwersytecka i, mniej więcej w tym samym czasie, dom tuż obok Biblioteki, to w nim właśnie otrzymał mieszkanie, w którym mieszkał aż do śmierci. Był dziekanem (1951/52-1952/53), a później został wybrany rektorem, dwa razy. Pierwsze po wojnie wybory rektora miały miejsce w 1956 roku, był to okres pewnego rozluźnienia. Prof. Szpunar był pierwszym wybranym rektorem. Zresztą jakiś czas tylko stan taki się utrzymywał, bo wkrótce znowu wróciło obsadzanie rektorów przez odgórne nominacje. Wtedy kadencje były trzyletnie. Szpunar był rektorem przez dwie kadencje, do 1962 roku. I trzeba powiedzieć, że z punktu widzenia Uniwersytetu jego wielką zasługą było to, że on w tym okresie wprowadził tradycyjny ceremoniał i zwyczaje akademickie dotyczące promocji doktorskich, inauguracji i tak dalej. Wprowadzono też togi oraz insygnia rektorskie i dziekańskie. Przyszedł z Krakowa, wychowany przez UJ, gdzie te sprawy, ten cały wielowiekowy rytuał był zawsze ściśle przestrzegany. Pamiętam, jak po raz pierwszy miały się odbyć na Uniwersytecie Łódzkim uroczyste promocje i ślubowania doktorskie. Rektor zarządził zebranie, taki spęd wszystkich samodzielnych pracowników naukowych i tych

${ }^{6}$ Zob. Martin Buber, Ja i Ty: wybór pism filozoficznych, thum. i wstęp Jan Doktór, Instytut Wydawniczy PAX, Warszawa 1992.

${ }^{7}$ Mirosława Nowak-Dziemianowicz, Edukacja i wychowanie w dyskursie nauki i codzienności, Oficyna Wydawnicza Impuls, Kraków 2012, s. 160.

${ }^{8}$ Adam Szpunar (1913-2002) - profesor prawa, specjalista w zakresie prawa cywilnego, w latach 1956-1962 rektor Uniwersytetu Łódzkiego. 
ewentualnych doktorów. Profesor Szpunar [śmiech] był wtedy rektorem, a zawsze był człowiekiem dosyć niecierpliwym. A zatem najpierw bardzo uprzejmie pytał profesorów, jak, ich zdaniem, uroczystość ta powinna przebiegać, a każdy z odpowiadających mówił o czym innym, jak to zwykle bywa. W pewnym momencie Szpunar wstał i mówi: „No tak, dziękuję, a zatem będzie tak” [śmiech] i powiedział po kolei, jak to wszystko ma przebiegać. Z tym, że wtedy myśmy składali ślubowanie pojedynczo po łacinie, ślubując na berło Uniwersytetu. To się w ten sposób odbywało [śmiech]. Mam gdzieś takie zdjęcie. Nie występowaliśmy w togach. Senat był w togach, a ślubujący doktorzy nie.

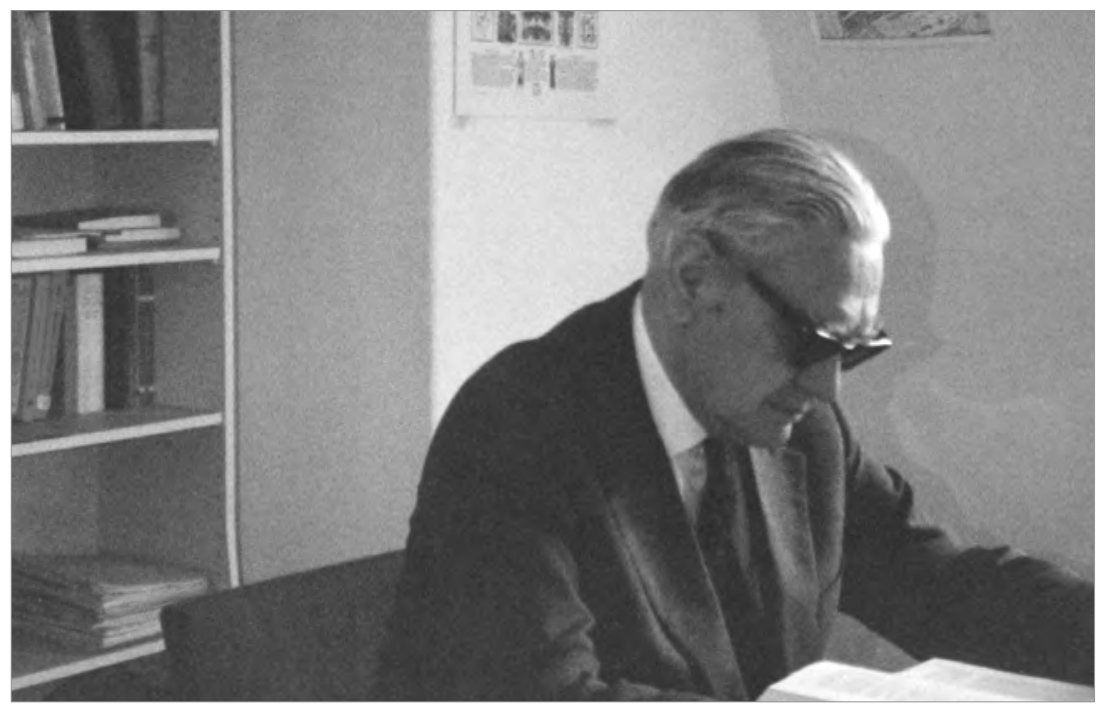

Fot. 40. Adam Szpunar

Więc on rzeczywiście tradycje akademickie na UŁ przeszczepił. Profesor Szpunar miał jedną ważną cechę - kiedy powiedzmy jako dziekan, czy potem rektor miał o czymś decydować, to podejmował decyzje szybko. Po drugie, miał zaufanie w stosunku do ludzi. I zawsze uważał, że najważniejsze sprawy Uniwersytetu to są sprawy osobowe i te trzymał bardzo mocno w garści. Na przykład, ściągnął do Łodzi Wróblewskiego ${ }^{9}$. Wróblewski niebywale zdolny, typ teoretyka, bardzo wybitny. To było chyba w 1950, 1952 albo może trochę później, w pięćdziesiątym którymś roku, kiedy ściągnął Wróblewskiego z Krakowa do Łodzi aby objął wykład pt. „Wstęp do prawoznawstwa”, to się tak nazywało. A potem była to też, z powrotem wprowadzona, „Teoria prawa”. Rektor Szpunar w ogóle bardzo zabiegał o przywrócenie zlikwidowanych

${ }^{9}$ Jerzy Wróblewski (1926-1990) - teoretyk prawa, profesor Uniwersytetu Łódzkiego i jego rektor w latach 1981-1984. 
w poprzednim okresie kierunków (np. filologia angielska, germańska i klasyczna) i mu się to udało. On bardzo dużo zrobił dla Uniwersytetu od tej strony. Poza tym był szefem Katedry Prawa Cywilnego, w której byłam. Ileż to lat z nim przepracowałam. Poznałam go, jak wykładał na drugim roku Prawa na Uniwersytecie Jagiellońskim. Nie u niego zdawałam egzamin z prawa cywilnego, tylko u profesora Gwiazdomorskiego ${ }^{10}$ i na drugim i na trzecim roku. Tak wypadło, chociaż u nas wszyscy cyrklowali, żeby zdawać u Szpunara. To dziekanat decydował, kto tam przychodził. Gwiazdomorski był bardzo surowy na egzaminach i taki w ogóle ostry w pytaniu. Z mojego punktu widzenia profesor Szpunar był o tyle szefem idealnym, że absolutnie nigdy nie narzucał własnych poglądów. Ja zawsze byłam dość niezależna w tym, co robiłam i nie mogłabym pracować z kimś, kto by mi kazał powtarzać jak za panią matką pacierz, to, co tam sobie wykoncypował. Więc od tej strony był szefem idealnym. Natomiast trzeba go było bardzo pilnować, głównie jeżeli chodziło o wszystkie sprawy administracyjne związane z katedrą. To właściwie najczęściej spadało na mnie. Musiałam trzymać papierki, przypominać profesorowi, że to czy tamto musi albo napisać, albo podpisać, jak musieliśmy składać jakieś sprawozdania czy inne tego typu rzeczy. Bo jak przychodziły papiery tego typu, to profesor najchętniej wyrzucałby je do kosza [śmiech], więc trzeba było go pilnować. Poza tym na stare lata profesor bardzo złagodniał. Jak był młodszy, to był niesłychanie wybuchowy, więc zdarzało się, że potrafił obrugać kogoś od góry do dołu [śmiech]. Ja zawsze żartowałam, że spełniam w katedrze rolę bufora. Byłam w tej katedrze i później, gdy byłam już docentem, potem profesorem nadzwyczajnym, profesorem zwyczajnym, nigdy nie przychodziło mi do głowy, żeby wydzielać osobny zakład. Czasem gdy patrzę na niektórych młodych kolegów, to mi się śmiać chce. Im się wydaje, że jak będą kierownikami zakładu, to zyskają autorytet, a nie na tym to polega. W każdym razie śmiałam się, że spełniam rolę bufora, bo jak asystenci coś naknocili, to przychodzili do mnie i ja pośredniczyłam między nimi i profesorem. A jak profesor miał o coś do nich pretensje czy był wściekły, to zawsze najpierw dzwonił do mnie i wylewał żale [śmiech]. Ponieważ zawsze mówił bardzo głośno przez telefon jak był zirytowany, moja córka jako dziecko poznawała go po głosie i mówiła: „No co, profesor Szpunar zły na kogoś?” [śmiech]. Profesor był wybitnym cywilistą o ogromnej wiedzy. On żył prawem cywilnym i Uniwersytetem. Wykładał bardzo jasno i bardzo donośnym głosem, mikrofon był mu zupełnie niepotrzebny. W całym budynku słychać było, jak [śmiech] Szpunar miał wykłady. Miał taką małą słabostkę, szczególnie dawniej, jak miał katar, to był nie do wytrzymania [śmiech]. Do tego stopnia, że pamiętam, jak woźny

${ }^{10}$ Jan Gwiazdomorski (1899-1977) - prawnik, specjalizował się w prawie zobowiązań, prawie spadkowym i prawie rodzinnym, wieloletni profesor Uniwersytetu Jagiellońskiego. 
z budynku na ulicy Kopernika, taki starszy pan Ciesielski, przyszedł do mnie (ja jeszcze wtedy nie miałam doktoratu) i powiedział: „Pani magister, ojej, dzisiaj profesor ma katar" [śmiech]. To wtedy wszystko było źle [śmiech].

\section{Profesora Aleksandra Kamińskiego ${ }^{11}$ wspomina Olga Czerniawska}

Aleksander Kamiński jest postacią wielowymiarową i kontrowersyjną w takim pozytywnym tego słowa znaczeniu i nie każdy ma prawo mówić o nim czy w ogóle jakoś go charakteryzować. To, co ja powiem, będzie bardzo osobiste, moje doznania w kontaktach z Aleksandrem Kamińskim. Nie będę go charakteryzować jako polityka czy nawet jako pedagoga, tylko powiem o spotkaniu z Aleksandrem Kamińskim w moim życiu.

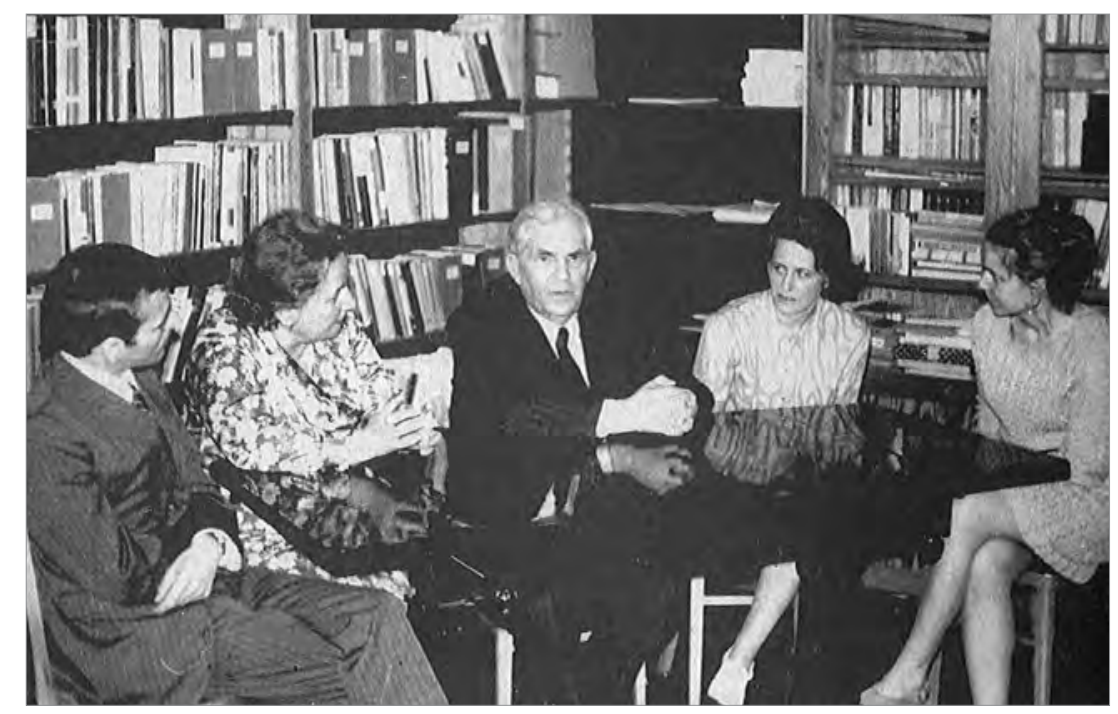

Fot. 41. Katedra Pedagogiki Spolecznej przy ulicy Uniwersyteckiej 3 Przy stole „Chippendale” siedza od lewej: Jan Badura, Irena Lepalczyk, Aleksander Kamiński, Olga Czerniawska, Ewa Marynowicz-Hetka

Jako nauczycielka przeniosłam się do szkoły dla pracujących i tam, ucząc historii, po prostu stwierdziłam, że moim powołaniem jest edukacja dorosłych - nie historia, ale właśnie edukacja dorosłych, w tym się będę specjalizować. I wobec tego szukałam seminarium $\mathrm{z}$ tego zakresu. Najpierw pojechałam do Warszawy, ponieważ tam można było studiować pedagogikę, więc stwierdziłam, że może skończę studia pedagogiczne. Poszłam do dziekana, który

${ }^{11}$ Aleksander Kamiński (1903-1978) - pedagog, harcmistrz i wychowawca młodzieży, zatrudniony na Uniwersytecie Łódzkim do 1950 roku, odsunięty od nauczania z przyczyn ideologicznych, od 1958 roku ponownie zatrudniony. 
zajmował się studiami pedagogicznymi, profesor Pasierbiński ${ }^{12}$, specjalista od analfabetyzmu w Polsce. On przyjął mnie, powiedziałam mu, że jestem magistrem historii, na co on mówi: „Pani tak dobrze z oczu patrzy, po co pani będzie szła na te studia, tam są takie same niedouki, pani ma wyższe studia skończone, niech pani robi doktorat, a nie sobie zawraca głowę pedagogiką. Pani skończyła historię, to jest dobra nauka, to jest pani przygotowana do pracy naukowej”. Tak mi powiedział i dodał: „W Łodzi jest docent Kamiński, który rozpoczyna pracę na Uniwersytecie - bo on został przywrócony - niech pani do niego idzie na seminarium doktorskie". Tak mnie skierował i ja wróciłam do Łodzi. Zaczęłam szukać protekcji do profesora Kamińskiego i znalazłam ją u księdza Króla ${ }^{13}$, salezjanina, który mnie znał, a drugą osobą była chyba pani doktor nieżyjąca już Aleksandra Majewska ${ }^{14}$. W każdym razie te osoby mnie zaprotegowały do Kamińskiego, ponieważ to nie było takie proste. Kamiński najpierw wywiad przeprowadził: jaka kariera moja na historii, co ja umiem, czego nie umiem. W każdym razie przyjął mnie. Wtedy Aleksander Kamiński był po habilitacji, a habilitował się, pisząc historię stowarzyszeń społecznych, począwszy od tych przed uzyskaniem niepodległości, w zaborach, po zaborach - także bardzo szerokie spektrum. To były badania archiwalne, historyczne i na Uniwersytecie habilitował się chyba Warszawskim, bo Uniwersytet Łódzki nie miał uprawnień do habilitacji. A na Uniwersytecie Łódzkim przyjął go najpierw do siebie profesor Jan Szczepański ${ }^{15}$ i na socjologii on miał wykłady. Miał wykład - takie były wykłady do wyboru - o czasie wolnym. Czas wolny to była wtedy problematyka pionierska, tym się nikt nie zajmował w Polsce. I on pierwszy zajął się tym, napisał książkę Społeczne problemy czasu wolnego i przeprowadził taką analizę literatury - to wiadomo, że musi być - a więc przede wszystkim francuską literaturę. Wtedy najwybitniejszą osobą, która się zajmowała badaniami nad czasem wolnym był Joffre Dumazedier ${ }^{16}$, francuski socjolog, który przeprowadził badania w małym miasteczku granicznym mię-

${ }^{12}$ Tadeusz Pasierbiński (1901-1968) - pedagog i działacz oświatowy. Studia ukończył na Uniwersytecie Jagiellońskim. Większość swojego zawodowego życia związany z Wyższą Szkołą Pedagogiczną w Warszawie.

${ }^{13}$ Ks. Józef Król SDB (1916-2000) - urodzony w Stanach Zjednoczonych, salezjanin. Od 1948 roku przebywał w Łodzi, gdzie przy kościele św. Teresy prowadził pracę oratoryjną. Podjął tutaj studia z pedagogiki społecznej na Uniwersytecie Łódzkim, które ukończył w 1952 roku. Znany ze swojego antykomunistycznego zaangażowania.

${ }^{14}$ Aleksandra Majewska (1907-1990) - pedagog społeczny, studia z tego zakresu ukończyła na Uniwersytecie Łódzkim, następnie doktoryzowała się na Uniwersytecie Warszawskim. Wychowanka prof. Heleny Radlińskiej. Przez wiele lat pracowała w Poradni Wychowawczo-Zawodowej w Łodzi.

${ }^{15}$ Jan Szczepański (1913-2004) - wybitny polski socjolog, urodzony w Ustroniu, przez wiele lat związany z Uniwersytetem Łódzkim (1945-1970), którego był profesorem a później także rektorem, członek PAN.

${ }^{16}$ Joffre Dumazdier (1915-2002) - francuski socjolog zajmujący się czasem wolnym. 
dzy Francją a Szwajcarią, Annecy - ja to miasteczko nawet odwiedziłam, byłam tam po wielu latach, przypadkowo, bo byłam w Genewie na konferencji. Organizatorzy stwierdzili, że taniej ich będzie kosztowało, jak pojedziemy do Annecy i tam w restauracji zjemy uroczystą kolację, więc ja się znalazłam w tym Annecy. I co ciekawe, jak przyjechaliśmy, kolejka szalona, okazało się, że będzie pokazywany film jakiś science fiction i ludzie stoją w kolejce, żeby się na to dostać - czyli czas wolny, śmieszne, prawda? A miasteczko się okazało takim miasteczkiem z jednej strony emerytów, którzy tam się osiedlali, bo pięknie położone: $\mathrm{z}$ jeziorem, górami, lasami naokoło, a z drugiej strony miasteczkiem granicznym, w którym Szwajcarzy kupowali różne rzeczy, bo było taniej, modniej - czyli takie ciekawe miejsce. Kamiński robił badania, opisując wszystkie stowarzyszenia, które tam funkcjonowały i to, jak ludzie spędzają czas wolny. Tak powstała książka francuska o czasie wolnym - chyba gdzieś jest w Polsce - Le semi-loisir czyli Czas wolny, taki „pół-wolny”. Poza tym było też stare pojęcie „wczasy” - i taka książka, którą niestety gdzieś zgubiłam, Badania polskie nad wczasami. On to wszystko porównał, opisał i ukazał pewne zjawiska. Zjawiska niekorzystne nazywał „nadkompensacją” - gdy ktoś nic nie robi czy w ogóle nie wykorzystuje tego czasu wolnego. Wyróżnił odpoczynek, zabawę i taki czas wykorzystany na własny rozwój, samokształcenie, poza tym prace domowe - w zależności od motywacji - jak je ktoś lubi, to owszem, a natomiast jak nie lubi, to to nie jest to czas wolny, tak samo opieka nad dziećmi, spacery z dziećmi. Natomiast uczenia się w instytucjach nie uważał za czas wolny. Tak więc bardzo była interesująca ta jego książka, odkrywcza. Następnym tematem, który Kamiński wprowadził, a którego nie było wcześniej, były problemy ludzi starszych, gerontologia społeczna. On był prekursorem koncepcji wychowania do starości. Właściwie pierwszy to w polskiej literaturze podjął. I szczerze mówiąc, w takim ujęciu tego też nie było w Europie. Teraz mam tutaj habilitację mojego doktora, który wynalazł w Stanach Zjednoczonych jakiegoś Amerykanina i porównuje tego Amerykanina z Kamińskim, że też podobne poglądy miał, że do starości trzeba się przygotować. Teraz to jest dosyć powszechne, ale w tym czasie, kiedy on o tym mówił, to było wyjątkowe. Czyli jedną z cech Kamińskiego, którą chciałabym wyróżnić, była umiejętność wyszukiwania nowych tematów, i to takich tematów wychowawczych, które zasiewały w Polsce Ludowej ziarno demokracji. Zrobił na przykład badania nad spółdzielczością szkolną, nad samorządami w szkole. To były badania zespołowe i powstała książka Samorząd szkolny. Spółdzielczość - zbiorowa, bo jego cechą były badania w zespole. Był zespół uczniów, profesor każdemu przydzielał temat i każdy coś tam badał, to były „zespoły samokształceniowe”. Ja wtedy miałam przydział „szaradziści”, tak - zresztą sama sobie wybrałam zespół szaradzistów. No i badałam tych szaradzistów w Łodzi w ŁDK-u i w Polsce. Ciekawe to było. Różne tam były zespoły w tej pracy zbiorowej: muzykujące, teatralne, jakieś różne hobbystyczne. $\mathrm{Z}$ tego 
powstała jakby teoria czasu, łączyło się to z czasem wolnym, ale także i z samokształceniem. Profesor pojechał z referatem na kongres do Jugosławii. Wygłosił taki referat oparty o badania. To było ewenementem, ponieważ badań się nie za wiele robiło, to, jak on to robił, to była rzadkość. Czyli jego cechą było tworzenie zespołów badawczych, publikacja tych badań i podejmowanie takich tematów, które wywoływały pewne zachowania; pojęcia demokratyczne. Jego zasługą także było opracowanie po wojnie podręcznika, Pedagogiki spotecznej. I tak w tej Pedagogice społecznej omówił między innymi trzy metody społeczno-wychowawcze. To była metoda indywidualnego przypadku - bardzo ważna. A w okresie, kiedy nie mówiło się o jednostce, on ją przypomniał: Helenę Radlińską ${ }^{17}$, Mary Richmond ${ }^{18}$ i Niewidzialny przypadek. Druga metoda: metoda grupowa, i tutaj powołał się też na taką amerykańską badaczkę, ją przytoczył i jeszcze tam innych badaczy. I trzecia metoda, najważniejsza, bo wymagająca struktur demokratycznych, to była metoda organizacji środowiska społecznego. Więc ona wymagała żywych relacji, wyszukania liderów, następnie współdziałania całego teamu, diagnozy, takiej lustracji środowiska: co tam się dzieje i kto czego potrzebuje; grup funkcjonalnych - czy ich potrzeby są zaspokajane. I właściwie w Polsce Ludowej to nie mogło być robione, dlatego że w diagnozie brały udział osoby partyjne i rządzące - więc nikt siebie nie skrytykuje, prawda? Poza tym postawią taką diagnozę, jak będą chcieli, a nie taką, jaką należy postawić. Więc Kamiński w jakiś sposób opracował to, co jest takie ważne dla demokracji - umiejętność samorządu lokalnego, współżycia organizacji, akceptowania wszystkich potrzeb mieszkańców, i to się znalazło w jego podręczniku. Ten podręcznik był podstawą do pracy socjalnej i kulturalno-oświatowej, do szeroko pojętego wychowania demokratycznego. Ponieważ ja u profesora robiłam doktorat, a przecież pedagogiki jako takiej nie studiowałam, to chodziłam do niego na wykłady. Odbywały się one wtedy w Instytucie Historii na Lindleya. Profesor przechodził przez ulicę i był szalenie taki czuły, jeśli chodzi o wykład, bo trzeba było siedzieć, uważać i przychodzić regularnie: jak raz nie byłam, to musiałam się mocno thumaczyć, dlaczego nie byłam na tym wykładzie, tylko że ja byłam wolontariuszem [wolnym słuchaczem] - przecież nie musiałam przychodzić, ale: „A, taki ważny wykład, a pani nie była. Co to się dzieje?". Więc był pod tym względem niezwykle skrupulatny. Zapamiętał negatywnie żonę mojego siostrzeńca: ona studiowała socjologię, a do niego przychodziła na wykład jako wolontariuszka - na ten taki wybrany [fakultatywny] - że kiedyś na jednym wykładzie ona czytała gazetę, to w ogóle nie chciał nic słyszeć, jak się mu coś mówiło, był tak zrewoltowany - coś niesamowitego! Po wykładach zawsze przeprowadzał

${ }^{17}$ Helena Radlińska (1879-1954) - profesor pedagogiki, stworzyła pedagogikę społeczną w Polsce, w 1945 roku po przyjeździe do Łodzi uruchomiła na Uniwersytecie Łódzkim Zakład Pedagogiki Społecznej. Jej współpracownikami byli m.in. Aleksander Kamiński i Irena Lepalczyk.

${ }^{18}$ Mary Richmond (1861-1928) - amerykańska pionierka pracy społecznej. 
dyskusje, pytania, a następnie nawet robił jakieś takie sprawdziany. Na konwersatorium też trzeba było być. Nieraz się spóźniłam, no to jakieś krzesło się przesunęło, to w ogóle rewolta niesłychana, wystawiam to krzesło - hałas, więc straszna rzecz. Bardzo bliski kontakt utrzymywał, do niego się telefonowało, rozmawiało się z nim, ale w godzinach odpowiednich, bo wiadomo było, że profesor rano pracuje, więc nie można mu przeszkadzać od którejś do którejś, potem jest „Dziennik” - to święta sprawa, bo on musiał obejrzeć „Dziennik” w telewizji, więc trzeba było bardzo delikatnie zacząć rozmowę: „Przepraszam. Dzień dobry. Czy mogę rozmawiać?”. Ja go odwiedzałam w domu, przychodziłam do niego do domu, na Kamińskiego, tam jest tablica. To było piękne mieszkanie, bo dom z dwudziestolecia, więc wielki hol, wchodziło się do holu, leżały takie specjalne szmatki, na których się wjeżdżało, bo to były pięknie utrzymane parkiety. On mieszkał razem z żoną, nie mieli pomocy, więc to było rzeczywiście dobrze, że się wjeżdżało na tych szmatkach - ja też miałam takie szmatki. U nas butów się nie zdejmowało, ale w wielu domach się zdejmowało buty. Profesor miał pięknie gabinet urządzony meblami z „Ładu”. „Ład” to była taka przedwojenna spółdzielnia plastyków, którzy pewną ideę realizowali, mianowicie ludowość, ale nie taka nachalna „cepelia”, tylko prostota połączona z funkcjonalnością. I to było białe drzewo, nie na połysk, i biurko; wielki wygodny stół i krzesła wyściełane, wyplatane; fotel twardy wyplatany i wysokie, jasne regały. Także on miał ten gabinet z „Ładu”, bardzo ładnie urządzony, jego żona lubiła kwiaty, więc było dużo kwiatów, amarylis między innymi, i zawsze kwitły tam amarylisy na wiosnę. I do profesora się zawsze przychodziło z kwiatami - on je bardzo lubił. Wtedy nie było za wiele kwiatów, frezje czy coś takiego. Biblioteka była wspaniała, wszystko było pilnie uporządkowane: pisma, archiwum badań, które prowadził. Miał też bardzo serdeczny stosunek do swoich uczniów. Czuwał nad nimi, czuł się za nich odpowiedzialny, ale dawał dużą swobodę: można było badać to, co się chciało. Na konwersatorium się przedstawiało te wybrane tematy badań. Profesor był zaangażowany w ruch harcerski i przez jakiś czas po październiku 1956 był jakby przywrócony harcerstwu, ale to się szybko skończyło, ponieważ to harcerstwo starano się upolitycznić, on się na to nie zgodził, więc go „czmychnęli” - już nie był w harcerstwie. Więc działał w Towarzystwie Wolnej Wszechnicy Polskiej i tam przy tym Towarzystwie w Łodzi - w Łodzi może mniej, ale jak do Warszawy się przeniósł po przejściu na emeryturę (tam córka jego mieszkała), to był czynny tam i część badań robił, potem jakieś seminaria tam robił, takie czasopismo było, więc w tym czasopiśmie też mógł wydawać jakieś numery specjalne. Jeden numer na przykład miał tytuł Jednostkowe sity społeczne. Żona była profesorem archeologii tu w Łodzi. Z żoną bardzo byli zaprzyjaźnieni i był podział prac domowych: profesor często obiad wstawiał, pilnował, zmywał. Gdy już mieszkał w Warszawie, to byłam tam zapraszana na obiad. Jeszcze w Łodzi to byliśmy czasem zapraszani na jakieś 
posiedzenie zespołu, zawsze kawa i ciasta, bo on lubił słodkie rzeczy, zresztą na każdym zebraniu musiało być; coś się piło - bo to było rytualne - herbatę czy soki, no i ciasteczka były na seminariach, to zawsze tak właśnie wyglądało. W czasie jak on pisał ten podręcznik, dawał nam fragmenty do przeczytania, żebyśmy dopisali uwagi. Miał też taką zasadę, że jak już napisał, to umiał przerwać: mówił „basta!”, już nie dodawał. Pamiętam, jak raz byłam w Warszawie. W Pałacu Kultury była taka księgarnia międzynarodowa i tam czasami można było ciekawe rzeczy znaleźć. Kilka książek ja dla bibliotek łódzkich kupiłam, fenomenalnych! I tam właśnie znalazłam też książkę dotyczącą stowarzyszeń społecznych, ponieważ on się zajmował stowarzyszeniami, i mu o tym powiedziałam, a on: „Już więcej nie, bo już ją napisałem” - bo uważał, że trzeba umieć przerwać, nie można doskonalić w nieskończoność, bo to się nigdy nie wyjdzie z tego; nigdy nie będzie tak, że wszystko zacytowane, wszystko zrobione. Ja też tak mam: że nigdy nie będzie tak, że człowiek w pełni zadowolony i że dzieło jest doskonałe. Ale profesor równocześnie był skrupulatny, a więc błędy wszystkie trzeba było poprawić elegancko. Pamiętam, że kiedyś telefonował do mnie, że ja coś źle napisałam, nie tak a inaczej powinno być, dlaczego ja tak napisałam itd., także bardzo mnie wtedy zdenerwował, zmartwiłam się, bo to już nie było do poprawienia i to był wyrzut bardzo duży. Profesor nie był dobrego zdrowia, po konwersatoriach z nim szłam w tę samą stronę, więc go odprowadzałam. Razem szliśmy, rozmawiało się i te rozmowy były takie bardzo, bardzo szczere. To były czasy między innymi wojny izraelsko-arabskiej, więc jedni byli za tym, inni za tym, a profesor też miał swoje sympatie. Tutaj „Węzel”19 się tworzył, więc go zapraszali, miał jakąś pogadankę. Ale - jak powiedziałam - bał się o tę pedagogikę, żeby broń Boże jej nie zamknęli, więc powiedział, że owszem, może być, ale nie za często, raz i koniec na tym. Żeby, broń Boże, nie powiedzieli, że on współpracuje z tym duszpasterstwem. Także czasy były trudne, złożone i on musiał bardzo uważać, bo był zapraszany za granicę. Nie miał zdrowia, miał liczne różne choroby, między innymi na płuca chorował, jakieś takie uczulenia miał. Kiedy ja u niego robiłam doktorat, to egzamin musiałam zdawać z filozofii. Promotor jest na egzaminie. Naprzeciwko jego domu, w Instytucie Historii miał się odbyć ten egzamin, a moim egzaminatorem był profesor Amsterdamski ${ }^{20}$. On był wtedy prodziekanem. Profesor Amsterdamski to bardzo wyjątkowa postać i ja cho-

${ }^{19}$ „Węzel” - Duszpasterstwo Akademickie przy kościele św. Teresy w Łodzi, utworzone w 1964 roku.

${ }^{20}$ Stefan Amsterdamski (1929-2005) - profesor filozofii; zaraz po wojnie rozpoczął studia chemiczne na Politechnice Łódzkiej, stopień doktora i doktora habilitowanego z zakresu filozofii zdobył na Uniwersytecie Warszawskim. Od 1954 roku pracował na Wydziale Filozoficzno-Historycznym Uniwersytetu Łódzkiego. W 1966 roku objął stanowisko dziekana tego wydziału. W konsekwencji wydarzeń marcowych w 1968 roku został usunięty z uczelni. Pracował później w Polskiej Akademii Nauk. Członek PZPR w latach 1948-1968, a od 1980 roku członek „Solidarności”, internowany w stanie wojennym. Uczestnik obrad Okrągłego Stołu. 
dziłam do niego na seminaria takie przygotowujące do egzaminu i muszę pani powiedzieć, że tak zabawnej sytuacji jak na tym seminarium, to już nie przeżywałam. Profesor Amsterdamski cały przejęty tym, co mówił, pisał na tablicy, kreda się sypała i był brudny od tej kredy. A audytorium specyficzne, trochę młodych ludzi, ale też było kilka takich pań starszych, które siedziały tak i zadawały mu pytania, a on się od nich oganiał jak od much: „Niech panie notują tylko to, co ja tu mówię" - bo uważał, że one i tak nic nie rozumieją, pewno miał rację [śmiech]. A te swoje: a jeszcze tu panie profesorze, niech pan jeszcze to, a tamto, jeszcze coś. Więc było humorystycznie na tych seminariach. Ale teraz o egzaminie: no więc ja się przygotowałam do egzaminu, profesor przyszedł na ten egzamin, ale profesor Amsterdamski się spóźnił. I profesor Kamiński patrzył na zegarek i pięć minut może, dziesięć może, ale piętnaście to już nie bardzo, żeby się spóźnić, poza tym on nie będzie czekał na tego Amsterdamskiego. Więcej jak piętnaście minut minęło, to on się zawinął, poszedł do domu. A profesor Amsterdamski się zjawił - bo ja musiałam czekać do skutku - i jak się zjawił, to mówię, że profesor zdenerwował się i poszedł: „Ojejku! Może się obrazi na mnie, co? Muszę zatelefonować i go przeprosić”. A to nie była epoka telefonów komórkowych, więc on musiał gdzieś tam iść, zadzwonić, przeprosić go. A ja czekałam no i miałam ten egzamin, a po egzaminie profesor Kamiński zadzwonił i ja też musiałam sprawozdanie złożyć, jak to wszystko się odbyło. Więc wie pani, był bardzo uczulony na takie różne formy. To, czego dzisiaj nie ma pewno. Pewne obyczaje powinny obowiązywać, a tych obyczajów dzisiaj nie ma, obyczajów uniwersytetu, poszły sobie te dawne, których profesor Kamiński bezwzględnie przestrzegał, uważał, że tak powinno być, np. punktualność. Poza tym też w czasie jego pracy powstał tom, też zbiorowy, Metodologia badań pedagogicznych. Był bardzo uczulony i każdy termin trzeba było bardzo dokładnie omówić, dlaczego tak, a nie inaczej, co to znaczy, żeby właściwie go używać. Czystość nauki i taki szacunek do słowa, do tego, co się mówi - on tego bardzo przestrzegał. Także uważam, że był człowiekiem wyjątkowym i rzeczywiście zostawił po sobie dużą bardzo spuściznę teoretyczną. Niestety w ludziach to już tak się nie pokazało. Instytucje zostały zniszczone, on przecież stworzył ruch oporu i ideologię ruchu oporu, prawda, te książki, które żyją i Wielka gra - pani czytała to czy nie? Wielka gra, no tę całą literaturę harcerską i powojenną sagę Zośka i Parasol czy wcześniej Kamienie na szaniec, a z drugiej strony Pedagogikę społeczna, monografię Czas wolny, bardzo istotną, potem takie pisma jego zebrane, artykuły, w których była gorąca walka z przypalaniem papierosów, ochrona zdolnych uczniów, o samorządzie, o spółdzielczości szkolnej. Więc wszystko to były badania niezwykle ważne, dla pedagogiki, dla demokracji, dla kultury politycznej w Polsce. No i muszę powiedzieć, że praca z nim była nadzwyczajna, bo on jak kiedyś dawałam artykuły, to on z boku pisał na marginesie ołówkiem uwagi, czytał strona po stronie i miał taki zwyczaj, że więcej jak trzydzieści 
stron dziennie takiego tekstu nie czytał. Pamiętam, jak pracę moją habilitacyjną mu dałam czy tam jakąś inną, no i te uwagi potem też dyskutowało się, poprawiało się, nanosiło się. Więc u niego robiłam doktorat, a poza tym był takim opiekunem mojej pracy habilitacyjnej i brałam udział w tych zespołach jego badawczych. Jego zainteresowaniem było stowarzyszenie społeczne i wprowadził do pedagogiki takie pojęcie pomiaru, bo to wtedy była ta twarda pedagogika, wszystko musiało być obliczone, wskaźniki, tak dalej, żeby się nikt nie przyczepiał. Więc jeżeli chodzi o stowarzyszenie społeczne, to był taki pomiar aktywności i w ogóle żywotności stowarzyszenia społecznego, a więc tak: pierwsza wiedza o historii stowarzyszenia, prawda, czy ktoś wie, jak ono powstało, kiedy powstało, jaka jest struktura. Drugim elementem tego pomiaru było aktywne uczestniczenie w działalnościach, więc pełnienie jakichś funkcji. Następnie liczba członków. O, i tutaj też profesor był, w tej chwili może już tak nie jest, ale ja jeszcze jestem uczulona na kwestię używania dwóch pojęć „ilość” i „liczba”. Więc „ilość” do rzeczy, a „liczba” do ludzi. Jak się ktoś pomylił, to bardzo było to źle przyjęte. Poza tym w ogóle język. Kiedyś pamiętam, coś referowałam i powiedziałam ,partner seksualny”, no to powaliło go to, jak to można w ogóle takiego słowa używać. Tak, inna epoka. A wracając do pomiaru, to liczba członków i jeżeli było za mało członków, to elitarne, a natomiast jeżeli frekwencja na tych zebraniach była duża, a więc jeżeli wszyscy byli, to też było podejrzane. No i był pomiar, jakiś procent to było aktywne, średnio aktywne i nieaktywne. No pomiar środowiska rodzinnego: czy jest dobrze, jakoś tam rokuje wychowawczo, czy nie. No więc liczba osób w rodzinie tutaj (bo on uważał, że troje dzieci, zresztą tak jest w tej chwili, bo to tak jest, to jest rodzina wielodzietna). Ja uważałam, że nie, bo miałam troje dzieci, to dla mnie to nie była rodzina wielodzietna.

Katarzyna Waniek: A on miał jedną córkę?

Olga Czerniawska: Jedną. Więc wielodzietna rodzina, następnie to praca obojga rodziców, czy na zmiany, czy nie, kiedy matka pracowała na zmiany, to nie było to zbyt korzystne. Poza tym bezrobocie. W PRL-u nie było bezrobocia. Następnie jakieś patologie $\mathrm{w}$ rodzinie, no więc alkoholizm, narkomania wtedy, jeżeli była, to się nie mówiło. W każdym razie źle rokujące. I co może panią zaciekawić, to ostatnio też było podnoszone, to znaczy liczba izb a liczba mieszkańców. Były takie badania we Francji robione, stwierdzono, że przy drugoroczności dzieci przy niepowodzeniach szkolnych te dzieci miały złe warunki mieszkaniowe i albo było za mało tych pokojów, w tym izba, kuchnia się nie liczyła jako izba. Albo jak za duże mieszkanie też niedobrze, to nam to nie groziło, ale ci francuscy badacze też pokazywali, że gdzieś jakiś pałac, to korytarze i to dziecko, pokój dziecinny był tam hen, hen, prawda, na pięterku czy gdzieś z dala, za siódmym korytarzem, to dziecko się bało. Albo zimno, bo przecież nie było centralnego ogrzewania, więc przez zimne salony, 
pokoje ewentualnie do tych rodziców biegło. Także liczba izb a liczba osób - to wszystko było mierzone i to marksizmowi się podobało. I trzeba było to robić i ze stowarzyszeniami też, wszystko miało pomiar.

KW: A proszę mi powiedzieć, a jak to się w ogóle stało, że on się znalazł w Lodzi?

OC: Jak się to stało? On był z Warszawy, gdzieś chyba zatrzymał się - to pani w jego życiorysach zobaczy - w Skierniewicach, bo tam była rodzina żony. I potem znalazł się w Łodzi u Radlińskiej, zaczął pracować na uniwersytecie przed skasowaniem pedagogiki społecznej, doktoryzował się przecież, bo właściwie jego wejście w życie naukowe było po wojnie, bo on pozostawił działalność organizacyjną na rzecz działalności naukowej. To się dokonało na Uniwersytecie Łódzkim w latach czterdziestych, jeszcze przed zlikwidowaniem pedagogiki społecznej. Tu po wojnie przyjechał do Radlińskiej ${ }^{21}$. No i chyba dostał wtedy mieszkanie jako pracownik naukowy - tego dokładnie nie wiem. Zresztą ja chcę pani powiedzieć, że ja z tej pracy habilitacyjnej żony korzystałam, ponieważ kiedy studiowałam historię, to u profesora Zajączkowskiego $^{22}$ zajmowałam się miejscowościami na ziemi łęczyckiej i sieradzkiej. Przeglądałam kodeks, różne dokumenty notacyjne, nadania łacińskie i między innymi tam wynotowane były miejscowości. Potem to sprawdzałam w jednym słowniku, w drugim i ta praca pani Kamińskiej też była potrzebna, bo ona pisała z zakresu archeologii o tych miejscowościach, więc też były tam one wymienione. I pierwszy raz profesora poznałam, kiedy siedziałam w gabinecie profesora Zajączkowskiego, razem żeśmy przeglądali te karty i wszedł profesor Kamiński, który zajmował się Jaćwieżą - bo on też był historykiem $\mathrm{z}$ wykształcenia. Tak zostałam przedstawiona. Nie chodziłam do niego na wykłady ani na zajęcia, dopiero w 1960 roku zaczęłam, zostawiłam już tą historię, stwierdziłam, że tam nic się nie zrobi i jakoś mnie uczenie historii dorosłych ludzi zainteresowało, edukacja dorosłych. Tak weszłam w tą inną dziedzinę.

KW: Żona pana profesora Kamińskiego była archeologiem i tak, jak zrozumiałam z pani opowieści, to oni bardzo się dzielili obowiązkami domowymi. A jaki był pani osobisty odbiór tej osoby?

OC: Bardzo sympatyczna, miła, oddana mężowi, otwarta osoba, bo ona, wie pani, przeżyła męża. Całe archiwum to jest jej zasługa, że ono powstało. Potem córka to przejęła. A w tej chwili to nie wiem, kto ma to archiwum. Tutaj w jakieś -lecie była konferencja na Uniwersytecie Łódzkim, profesor

${ }^{21}$ Zob. przypis $17 \mathrm{w}$ tym rozdziale.

${ }^{22}$ Stanisław Zajączkowski (1890-1977) - historyk, mediewista. Absolwent Uniwersytetu we Lwowie. Od 1945 roku związany z Uniwersytetem Łódzkim, kierownik Katedry Historii Średniowiecznej. W latach 1946-1948 dziekan Wydziału Humanistycznego, dwukrotnie dziekan Wydziału Filozoficzno-Historycznego (1956-1958, 1958-1960). 
Marynowicz-Hetka ${ }^{23}$ zorganizowała tę konferencję. Więc ja zamówiłam mszę w „Węźle” i też była sprawa, czy informacja o mszy ma się znaleźć w zaproszeniach konferencji jakoś tam oficjalnie, czy nie. Jak pani wie, to są niełatwe kwestie, więc nie znalazło się. Ja zaprosiłam osobiście niektóre osoby i niektóre przyszły, to znaczy przyszła żona, matka, córka. Już nie pamiętam, kto był duszpasterzem, któremu opowiedziałam życiorys profesora, więc miał kazanie. I córka powiedziała, że prawie świętego z niego zrobił. Byli jego doktoranci-nie wszyscy, część była, i jeszcze jakieś inne osoby. Więc tu mieliśmy tę mszę w „Węźle”. Córka była zadowolona. To wszystko było bardzo złożone i trudne. Mówiłam pani, że profesor nie bardzo chciał, żeby go identyfikowano z duszpasterstwem, bo trzeba być ostrożnym, a wiedział, że ja jestem w tym duszpasterstwie, więc to też było pouczenie dla mnie, żeby się za bardzo nie wychylać. Ale przede wszystkim on bardzo respektował przekonania innych. W gabinecie profesora wisiał, nie pamiętam, to nie był święty Tomasz z Akwinu, chyba święty Albert, filozof, więc wszyscy też patrzyli na to, że jak to tak może wisieć. Krzyż kiedyś ktoś powiesił w sali wykładowej, o to była cała afera: „ojej, krzyż wisi, co to zrobić, trzeba zdjąć”. Bardzo uważał, żeby broń Boże się nie przyczepili do pedagogiki społecznej, nie zamknęli. No i akurat wracaliśmy z profesorem, ja go odprowadzałam, potem on mnie kawałek odprowadzał, tak się odprowadzaliśmy, bo dość blisko siebie mieszkaliśmy. I była dyskusja o pedagogice, o tych metodach twardych - że ma być wyliczone itd. I on mi powiedział, że on uważa, że prawdziwe wychowanie, prawdziwa edukacja jest procesem jednostkowym, jakościowym, i że taki indywidualny przypadek, analiza na indywidualnych przypadkach, badania biograficzne, że to jest bardzo ważne i właśnie to jest sens, jakby esencja wychowania. Ale że on tego głośno nie powie, bo to idealistyczne, bo to nie jest mierzone, nie takie. Także od tego się odcinał. Owszem, była analiza indywidualnych przypadków, monografia instytucji, ale najlepiej, jak wszystko było pomierzone, i bardzo się w sądach diagnostycznych pilnował, żeby to wszystko było porządnie zrobione.

KW: A proszę mi powiedzieć, czy on wracał do czasów wojny, czy o tym się raczej nie mówiło?

OC: On stracił wielu swoich uczniów. Napisał pracę, dziś ta praca jest mało znana, ale on prześledził losy tych swoich uczniów ostatnich. Ale nie chcieli mu tego opublikować, historii tych, co przeżyli z Szarych Szeregów, gdzie oni zginęli, co się z nimi stało, jak oni byli prześladowani. Poza tym napisał kilka biografii, te, które nie były w Polsce wydane albo były wydane w podziemiu, albo były w Londynie, za to miał kilka odznaczeń, ale to wszystko były odznaczenia i nagrody zagraniczne. Tutaj jedynie mu dali chyba Medal Edukacji

${ }^{23}$ Ewa Marynowicz-Hetka (ur. 1946) - profesor w Katedrze Pedagogiki Społecznej Uniwersytetu Łódzkiego. 
Narodowej, to jedynie to. On nie był profesorem, tylko był docentem, a potem był profesorem nadzwyczajnym. Koniec na tym. Na Uniwersytecie był uważany za ,świętą naiwność”. Jak był podział pieniędzy, profesor nie chciał pieniędzy, bo on jeździł za swoje pieniądze, na nic nie brał, sam się opłacał, bo dostaje pensję, to nie będzie, mówił, za niego uniwersytet opłacał. I nam nie pozwolił. To już było gorzej. Więc nie miał pieniędzy na działalność, na badanie. Wszystko, proszę pani, szło z jego własnej kieszeni. Ja na doktorat dostałam dzięki prorektorowi, bo on przydzielił bez starania się profesorowi Kamińskiemu jakieś tam pieniądze i ja potem je dostałam na zbieranie wywiadów do pracy doktorskiej. Także był idealistą, nieprzygotowanym zupełnie do rzeczywistości, w której żył. A o przeszłości nie mówił, bo po co. To była tajemnica, po co miał mówić. Nigdy nigdzie się o tym nie wspominało.

\section{Profesora Wacława Szuberta ${ }^{24}$ wspomina Michał Seweryński}

Wie pani, co na prawie najbardziej przemawia do wyobraźni człowieka? Prawo karne. Ja zresztą pisałem pracę magisterską z procedury karnej, ale tam nie było stypendium doktorskiego. Profesor Wacław Szubert miał to stypendium, o czym zresztą powiedział mi mój przyjaciel. I on mnie na to namawiał. Po jakiejś tam rozmowie, po rocznym okresie próbnym ja to stypendium dostałem i już tu zostałem. Profesor Szubert prowadził także wykłady z polityki społecznej i ja na te wykłady chodziłem. To było jeszcze ciekawsze, pomyślałem sobie, że to by mnie ciekawiło, że ja bym chciał to robić, ja bym chciał się w tym jakoś bliżej zorientować, głębiej wejść w to wszystko. Kiedy się dowiedziałem o tym stypendium, poszedłem do niego na rozmowę. On to chował, ukrywał to, bo bał się, żeby mu tam partia nie nasłała kogoś swojego, kogo on by nie chciał. Zaufanym osobom mówił, bo szukał kogoś, żeby ewentualnie zaproponować to stypendium. A ja niestety nie byłem w kręgu tych, których on by szukał, bo to był jeden z moich egzaminów najmniej udanych. Nie dostałem dwójki, ale to był egzamin, który wspominam do dzisiaj jako bardzo nieudany. Profesor miał taki zwyczaj, że pytał przed terminem chętnych. Ja się oczywiście do wszystkiego przygotowywałem lepiej czy gorzej, tam nie było jakiegoś sensownego podręcznika, właściwie to były same wykłady. A ja dostałem takie bardzo niewygodne pytanie. Broniłem się na wszystkie sposoby, ale widziałem, że profesor jest niezadowolony i ja też byłem niezadowolony. Jakąś tróję dostałem, pomyślałem sobie, że nigdy już nie będę więcej miał z tym do czynienia, a potem nagle się okazało, że jednak tak. Sprawa tej oceny z egzaminu jakoś tam pewnie gdzieś wypłynęła. Był rok próbny. [Profesor] zaprosił mnie, żebym przychodził na seminarium. On prowadził seminarium doktorskie i ja na nie chodziłem, jakiś referat nawet raz zrobiłem. Miałem o sobie takie

${ }^{24}$ Wacław Szubert (1912-1994) - prawnik, specjalista prawa pracy, profesor Uniwersytetu Łódzkiego, dziekan Wydziału Prawa w latach 1953-1955 oraz 1965-1969. 
mniemanie, że potrafię pisać, bo mi zawsze w szkole mówiono, że dobre wypracowania miałem. Ja ten referat napisałem. I profesor ze mną usiadł i potem zaczęliśmy razem to analizować. Okazało się, że z tą umiejętnością pisania to grubo przesadzona sprawa. Ale od niego się też nauczyłem pisania, takiego jasnego wyrażania myśli. Obca mu była tendencja do pseudonaukowej mowy, żargonu. To wszystko, co masz powiedzieć, powiedz najprościej, jak potrafisz. Również wywód logiczny był bardzo ważny w tych pracach, które się pisało. Ja to do dzisiaj mam w pamięci i tego wymagam od innych. To jest niezmiernie trudne, ale w takich dziedzinach konwencjonalnych jak pani socjologia czy moje prawo dyscyplina języka jest niezmiernie ważnym narzędziem, to jest nasz ratunek, żeby nie powiedziano, że my się obracamy w obłokach jakiejś metafizyki, a nie zdyscyplinowanej wiedzy. Więc tak to było: był jakiś okres próby, który jakoś przeszedłem, a potem dostałem to stypendium i cztery lata przygotowywałem pracę doktorską i następne. Coraz bardziej mi się to podobało, był moment krytyczny po ukończeniu tych studiów doktorskich, bo jak pani wie, to jeszcze nie ma gwarancji zatrudnienia. Potem się dowiedziałem, że był taki dramatyczny moment, bo każdego, kto aspirował do pracy na uczelni, musiała pozytywnie ocenić partia. Ja jako notoryczny bezpartyjny miałem niestety niedobrą opinię. A pewien sekretarz, skądinąd żyjemy teraz w przyjaznych stosunkach, mówi: „No tak, ale on nie daje nam gwarancji, że się zapisze do partii”.

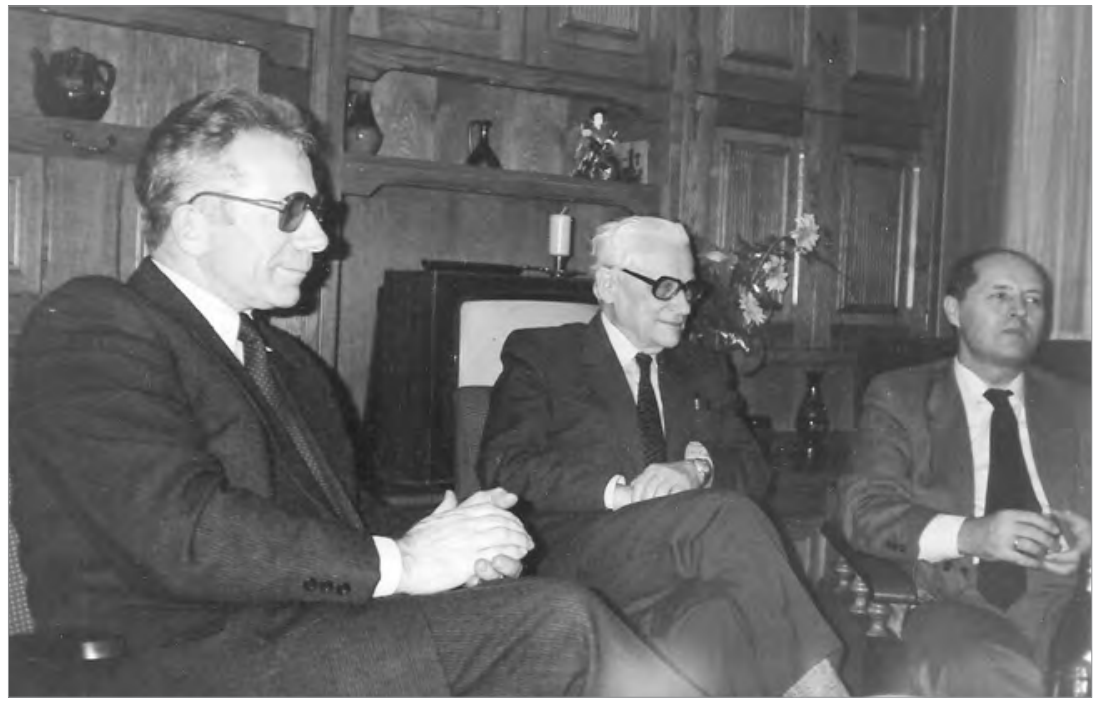

Fot. 42. Od lewej: Henryk Lewandowski ${ }^{25}$, Wacław Szubert i Michat Seweryński

${ }^{25}$ Henryk Lewandowski (1933-2013) - prawnik, specjalista prawa pracy, profesor na Wydziale Prawa i Administracji Uniwersytetu Łódzkiego, w latach 1987-1990 dziekan tego wydziału. 
Na szczęście profesor Szubert był wtedy dziekanem. I on jakoś przeforsował, żeby mi ten etat asystenta dali, i tak zostałem na uczelni, właśnie dzięki mojemu mistrzowi, który nie tylko zaufał mi i moim zdolnościom, ale nadto prowadził mnie jak prawdziwy mistrz. To jest taka relacja, która rodzi się z tego, nie waham się powiedzieć, zachwytu tym człowiekiem, który imponował wiedzą, ale nie tylko. W miarę jak go poznawałem, jego życiorys był coraz bardziej imponujący. Myślę, że w pewnym stopniu spłaciłem dług wobec niego za to, że mnie do tej nauki wprowadził, że mi drzwi na świat otworzył, bo tylko dzięki niemu też dostałem potem jako bezpartyjny stypendium do Francji. Ale spłaciłem także w ten sposób, że dwa lata temu wydałem jego pisma pośmiertnie, książkę wspomnieniową ${ }^{26}$, którą on pisał w tajemnicy, bo to był człowiek, który od początku był w ruchu oporu, w AK. Najpierw pracował w radiu powstańczym, a potem został dyrektorem w podziemnym Departamencie Pracy i Polityki Społecznej. Z tych jego wspomnień dowiedzieliśmy się, jak wyglądało działanie rządu podziemnego w czasie okupacji w Polsce. Na przykład była udzielana pomoc socjalna, były pieniądze na ten cel. I na przykład tym rodzinom, które potraciły swoich bliskich, albo innym osobom represjonowanym, wybitnym intelektualistom, artystom, uczonym udzielano takiej zapomogi. To działało w całej Polsce, cała utajniona sieć. To jest wspaniała książka. Profesor to trzymał wszystko w swoich papierach i bał się to ujawnić, na krótko przed śmiercią opublikował jeden rozdział w „Przeglądzie Historycznym”. I ja gdzieś czytając wspomnienie na stulecie jego urodzin, znalazłem ten ślad. Z córką Profesora zaczęliśmy drążyć jego bibliotekę, i w ten sposób z papierów pośmiertnych złożyliśmy ostatnią jego książkę. Więc niech pani nie wierzy marksistom, że ,jedynica wzdor, jedynica nul”, jak pisał Majakowski - „Jednostka - zerem, jednostka - bzdurą, sama - nie ruszy pięciopudowej kłody, choćby i wielką była figurą, a cóż dopiero podnieść dom pięciopiętrowy", bo okazuje się, że historię tworzą jednostki. Wybitne osoby mogą pchnąć historię ludzi, świata na inne tory. I w życiu wielu, bardzo wielu z nas jakaś jedna osoba może odegrać decydującą rolę. W moim życiu taką rolę odegrał mój mistrz. Dlatego tak dużo o nim pani opowiadam, bo kilkadziesiąt lat u jego boku pracowałem, jeździłem po kongresach razem z nim. Nawet siedzieliśmy razem w jednej ławce i uczyliśmy się języka włoskiego, tutaj w Łodzi. Profesor był wykładowcą w Międzynarodowej Szkole Prawa Pracy w Trieście i załatwił mi tam stypendium. Dostałem dwa dolary kieszonkowego od Uniwersytetu na drogę, a tam dostałem jeden posiłek i nocleg. Pojechałem. To były trzy tygodnie czy sześć tygodni, już nie pamiętam. Obaj stwierdziliśmy, że ponieważ to jest we Włoszech, gdzie otoczenie jest takie inspirujące i język nam się spodobał, to trzeba się tego języka poduczyć - chociaż wykłady były po francusku.

${ }^{26}$ Wacław Szubert, Problemy pracy w koncepcjach programowych Delegatury Rzadu na Kraj (1941-1945), red. Michał Seweryński, Wydawnictwo Uniwersytetu Łódzkiego, Łódź 2012. 
I potem przyjechawszy do Łodzi, szukaliśmy jakiegoś lektoratu i znaleźliśmy lektorat na Uniwersytecie, pani docent [Anna] Rynkowska na historii prowadziła ten lektorat. I myśmy siedzieli wtedy z Profesorem w jednej ławce, on już był wtedy blisko sześćdziesięcioletni, i razem uczyliśmy się tego języka. Pamiętam nawet pierwsze zdanie: „Andiamo a casa dove la mamma aspetta...”. On się zawsze dziwił: „Niech pan powie, panie Michale, jaki to jest dziwny język, jak tak można zdanie konstruować”. Ja mówię: „Panie profesorze, nie trzeba się temu dziwić, trzeba brać taki, jaki jest" [śmiech]. A przecież mówił i pisał w czterech językach, włoski byłby piąty. Też mi to trochę po nim zostało - zainteresowanie językami.

Agata Zysiak: Mam wrażenie, że ta relacja mistrz-uczeń trochę już ginie.

Michał Seweryński: Nie, niech pani w to nie wierzy. Jeśli jest mistrz, to będą zachwyceni uczniowie. Tylko nie każdy ma ten talent, nie każdy ma ten dar przyciągania uczniów. W kościele nazywa się to charyzmatem. Kiedy pojawi się prawdziwy mistrz, osoba pobudzająca wyobraźnię, zainteresowanie, pociągająca za sobą, to pojawiają się uczniowie, którzy chcą naśladować mistrza. Krótko mówiąc, światło musi być dostatecznie silne, żeby przyciągało. Co o tym decyduje? Nawet nie sama wiedza. Zwłaszcza nie w naszej dziedzinie. To jest także charakter. Jak już profesor był starszy i ja byłem trochę starszy, to się ta nasza więź osobista coraz bardziej zacieśniała . Miałem z nim dwa seminaria. Jedno oficjalne, a drugie prywatne, kiedyśmy sobie chodzili i rozmawiali - zwłaszcza po tym, jak przeniósł się do Warszawy i został dyrektorem Instytutu Pracy, a do Łodzi dojeżdżał. Ja go odprowadzałem tutaj na Tkacką do naszego domku uniwersyteckiego na nocleg. Sam mieszkałem w pobliżu. Po drodze rozmawialiśmy. To było takie prywatne seminarium. I tam rozpatrywaliśmy pytania najważniejsze. Na przykład takie: „Jak pan myśli, panie Michale, do czego właściwie w komunizmie służy prawo?". Fundamentalne pytanie. $\mathrm{Na}$ żadnym seminarium takich pytań nikt nie zadawał. A on zadawał. I razem staraliśmy się na to odpowiedzieć. Najogólniej mówiąc, jego odpowiedź była taka, że to prawo to jest takie teatrum, to są zaklęcia - jak ,władza klasy robotniczej" i podobne. To są wszystko zaklęcia ideologiczne, które przykrywają istotę rzeczy. Ona jest inna. To wszystko jest oparte na fałszu. A prawo jest po prostu narzędziem przemocy, która służy do utrzymania tej władzy przez pewną grupę, czyli służy do legitymizowania tego systemu. Ale mówiłem o charakterze, bo pytał: „Jak pan myśli, panie Michale, czy żeby zostać profesorem na uniwersytecie, trzeba mieć więcej wiedzy czy więcej charakteru?”. Ta sprawa w sposób jawny albo domyślny wypływała potem jeszcze nie raz, na przykład kiedy w stanie wojennym pisaliśmy założenia nowego sprawiedliwego prawa pracy na przyszłość, po obaleniu komunizmu. Spotykaliśmy się w jego domu w niewielkiej grupie. Wynikały na tym tle spostrzeżenia, które były rezultatem naszych postaw - różnych, ale cel był jeden. Spostrzeżenia 
te były odzwierciedleniem różnych osobowości ludzi, którzy tam wtedy się spotykali i coś proponowali, a przez to dawali wyraz swoim przekonaniom, poglądom i wyobrażeniom, jak ten system powinien być zbudowany w przyszłości. Mógłbym zatem powiedzieć, że wpływ mojego mistrza na mnie był wielostronny. Nie tylko taki, że inspirował, zachęcał mnie do pracy naukowej, a potem oceniał te prace. Był kiedyś taki moment, w którym powiedział: „No to panie Michale, trzeba pomyśleć o profesurze”. Ja mówię: „Panie profesorze, ja nie mam książki profesorskiej. - Ale to, co pan napisał, to wystarczy”. Ja już miałem publikacje za granicą. Gdzieś tam już jeździłem. Ale jego ocena była dla mnie ważniejsza niż dziesięć książek.

\section{(...)}

Miałem taki moment w życiu, w którym stanąłem na rozdrożu. Za sprawą profesora, ponieważ przyszedł i powiedział tak: „Panie Michale, jest wolne miejsce dla pracownika polskiego w Genewie, w Międzynarodowej Organizacji Pracy. Czy pan by się chciał tam przenieść?”. Nie wiem, który to był rok. Ale jeszcze przed „Solidarnością”. Jakoś tak. Zacząłem się zastanawiać. Mówię: „Muszę się namyśleć trochę. - No to niech się pan zastanowi”. Następnego dnia przyszedłem i powiedziałem: „Panie profesorze, to ja się decyduję". Byłem już po habilitacji wtedy, to był tam wtedy warunek nawet. A on wtedy spojrzał na mnie z zawodem i mówi tak: „A ja myślałem, że pan zostanie profesorem". Widziałem wyraźnie, że mu sprawiłem zawód tą wypowiedzią. Nie powiedział, jakie są jego preferencje. Potem był taki moment, w którym pojawiła się wolna katedra $\mathrm{w}$ jednym z polskich uniwersytetów i zrobili mi propozycję w tej sprawie. Ja się wahałem, właściwie bardzo krótko, i powiedziałem, że to mnie nie interesuje. I wtedy zaprosił mnie na rozmowę, mówi tak: „Panie Michale, to może być jakaś szansa dla pana”. Ja mówię tak: „Panie profesorze, ja naprawdę nie mam takich ambicji. Szczerze mówiąc, ja naprawdę wolałbym tu jeszcze z panem posiedzieć, bo mi tu jest dobrze. Takich rozmów jak z panem profesorem to ja gdzie indziej prowadzić nie będę. Wiem, że kiedyś to może trzeba będzie zrobić, ale póki jeszcze nie muszę, to ja wolę tu”. No to on mnie zaczął przekonywać, mówi: „Wie pan, przecież będziemy się kontaktować. Możemy na różne sposoby, myśl pokonuje granice, to jeszcze będzie tak, że będziemy coś razem robić". Ja powiedziałem, że nie. Mówię: „Poza tym wie pan, ja tu mam swoje groby. Tak łatwo się od nich nie odjeżdża. Poza tym to byłaby jakaś rewolucja w życiu mojej rodziny". I pomyślałem sobie, że ja bym stracił te seminaria na ulicy po drodze do hotelu. To mi się wydawało dużo ciekawsze. Niewątpliwe profesor był to dla mnie osobą opatrznościową. 


\section{Profesora Mieczysława Wallisa ${ }^{27}$ wspomina Wanda Nowakowska}

Mieczysław Wallis był niesłychanie ciepły i miły, bo doskonale wychowany, ale to był uczony jak określiłam, gabinetowy. To nie był ten profesor, który potrafi ze studentami na kawę iść, potańczyć nawet. To zupełnie inny typ uczonego $-\mathrm{z}$ dystansem, zawsze pomocny, ale do pewnej granicy. I profesor nie poświęciłby dla nas swojego czasu za dużo. To była ta granica. Student musiał pisać, musiał pracować, a profesor, owszem, pomagał, ale bardzo konkretnie, bardzo krótko. Powtarzał zawsze: ,Jak doktorat pisałem u profesora Kotarbińskiego $^{28}$, to ustaliliśmy temat, napisałem pracę, zaniosłem, a profesor Kotarbiński przejrzał, przyjął i była obrona. Koniec!”. A do tego to trzeba było też specyficznego sposobu reagowania tych, którzy chcieli robić u niego doktorat. Bo tu nie było niczego absolutnie z prowadzenia za rączkę. Nic z tych rzeczy! Dlatego profesor nie miał zbyt wielu doktorantów. Więc był ten pierwszy, Adam Więcek ${ }^{29}$, który przyjeżdżał z Wrocławia, zrobił ten doktorat i to było bardzo ładne.

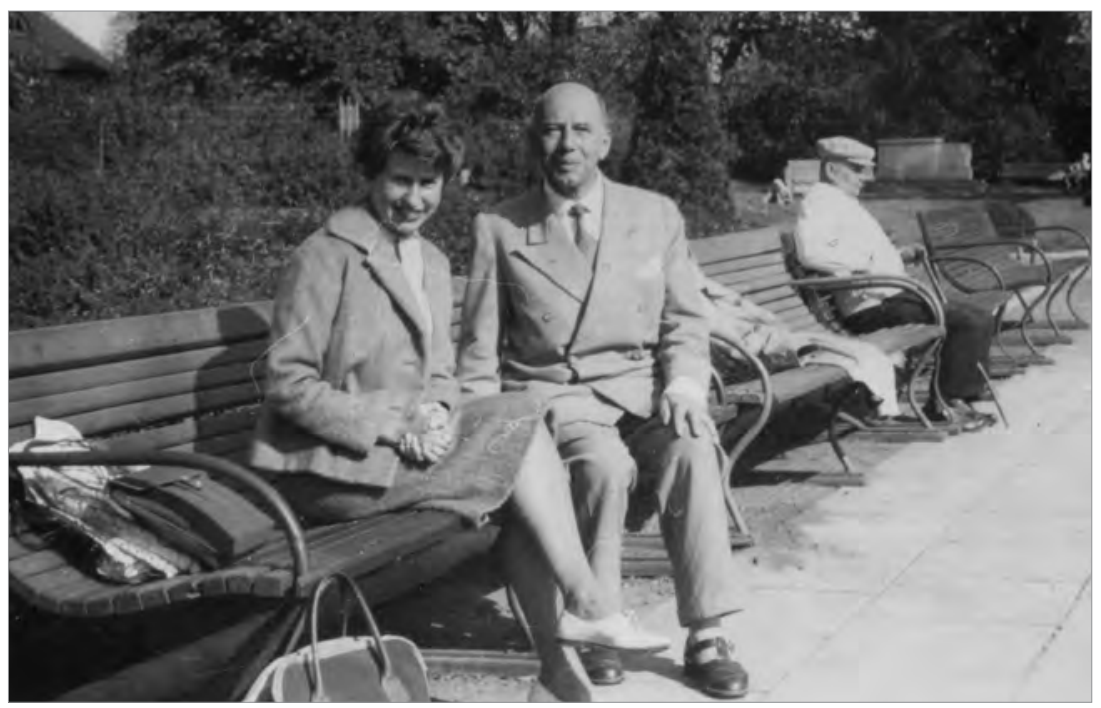

Fot. 43. Mieczysław Wallis z Wanda Nowakowska w parku imienia Jana Matejki w Łodzi. Pierwsza połowa lat sześćdziesiatych

${ }^{27}$ Mieczysław Wallis (1895-1975) - estetyk, teoretyk i historyk sztuki, kierował Katedrą Historii Sztuki, w latach 1955-1956 pełnił funkcję dziekana Wydziału Filozoficzno-Historycznego Uniwersytetu Łódzkiego.

${ }^{28}$ Tadeusz Kotarbiński (1886-1981) - profesor filozofii, logik, współzałożyciel Uniwersytetu Łódzkiego i pierwszy rektor uczelni.

${ }^{29}$ Adam Więcek (1923 -2002) - historyk sztuki, twórca i wieloletni dyrektor wrocławskiego Muzeum Sztuki Medalierskiej. Autor publikacji na temat muzealnictwa, medalierstwa i filatelistyki. 
Ja pamiętam akurat ten moment, jak byłam u profesora $\mathrm{w}$ domu, on wtedy mieszkał na Wierzbowej - w tym domu akademickim na rogu Narutowicza, i rozmawialiśmy o moich planach doktoratu i był telefon: profesor odbiera, przy mnie rozmawia, później po odłożeniu słuchawki powiedział: „To dzwonił właśnie mój doktorant Adam Więcek z Wrocławia, bo on jutro przyjedzie na obronę". I to była taka bardzo serdeczna rozmowa: profesor mówil, żeby on się wyspał, zjadł śniadanie, bo na drugi dzień miała być ta obrona. To był pierwszy doktorant, a druga byłam ja. Raptem dwie osoby z tego dużego grona dwudziestu osób. A to były naprawdę szalenie zdolne, świetne, pracowite osoby. Wieloletnia asystentka profesora Irena Popławska ${ }^{30}$ zrobiła u niego doktorat później. Ale powiedziała mi szczerze, że ona z trudem współpracowała z profesorem, że jako asystentce było jej łatwiej, bo miała w każdej chwili kontakt załatwiony i tak dalej. A potem ja pytałam kolegów, którzy naprawdę powinni byli robić doktorat, bo byli świetni, czemu tego nie robią, a oni mówili, że nie, bo oni się boją, że z profesorem nie będzie takiego kontaktu, jaki oni by chcieli. Bo oni sobie wyobrażali prowadzenie za rączkę. Ja to wiem. A u mnie było też tak: ustaliliśmy temat, on się zgodził. To ja mówię: „To ja będą rozdziałami profesorowi dawała". A skąd! I tak jak wspomniałam, profesor znowu powtarza: „Jak ja robiłem doktorat, to z Kotarbińskim ustaliliśmy temat, a potem zaniosłem mu pracę". Taka była mowa. I tak było. Ja napisałam całość! Nic, żadnych, żadnych w ogóle nie było kontaktów. Poza tym jak oczywiście pytałam, czy coś tam trzeba ewentualnie zmienić, ale to było ze dwa, trzy razy zaledwie w całym toku tych kilku lat. Ale przeczytał dokładnie, porobił uwagi i oddał mi. Ja zapytałam, co mam dalej robić, a on: „Pani poprawi i już. Ja teraz wyjeżdżam do Stanów i wrócę w październiku”. Struchlałam, ale poprawiłam pracę, złożyłam w dziekanacie, profesor wyznaczył recenzentów, do których moja praca została wysłana i tyle. Na obronie promotora zastępował dziekan Leon Błaszczyk ${ }^{31}$. Zimny wychów? Myślę, że raczej wiara w siły i umiejętności podopiecznego, dlatego że profesor Wallis nie miał zmysłu do ryzyka, a ta sytuacja mogła przecież tego wymagać. On po prostu we mnie wierzył i ta jego wiara, która znalazła też naoczny wyraz w opinii o mnie, którą kiedyś napisał, a którą sobie odczytywałam i nadal odczytuję w chwilach zwątpienia, wraz z wiarą moich rodziców pomagała mi zawsze w pokonywaniu kolejnych „wysokich progów”. A szczególnie ważny i wzruszający do głębi był moment, gdy jako kierownik Katedry Historii Sztuki jeszcze na Matejki usiadłam za starym biurkiem Mojego Profesora! No i też, kiedy pisałam jego biografię dla Łódzkiego Towarzystwa Naukowego, uświadomiłam sobie ponownie, że był

${ }^{30}$ Irena Popławska (1924-1995) - historyk sztuki, historyk architektury łódzkiej, działaczka społeczna. Zawodowo związana z Uniwersytetem Łódzkim i Politechniką Łódzką.

${ }^{31}$ Leon T. Błaszczyk (ur. 1923) - profesor historii, wybitny znawca starożytności, dziekan Wydziału Filozoficzno-Historycznego w latach 1964-1966, a w latach 1966-1968 dyrektor Instytutu Historii UŁ. Usunięty z Uniwersytetu Łódzkiego w marcu 1968 roku. 
więźniem w oflagu Woldenberg, gdzie wykładał historię sztuki. (...) Muszę powiedzieć, że profesor w stosunku do mnie był nadzwyczajny. Ale trzeba było zgodzić się na jego warunki. Na jego sposób, na jego styl bycia. Ja się zgodziłam i nie bałam się tej samodzielności po prostu. Ale to trzeba było się zdobyć na tę odwagę, na tę samodzielność i wtedy było dobrze. I tak go zapamiętałam. A poza tym on mówił zawsze takim spokojnym, wyważonym głosem. On był szalenie taki dżentelmeński, to była jedna kultura, jedna subtelność. I był tak ceniony, tak poważany jego głos, jego sąd na Uniwersytecie. Pamiętam, kiedy zabierał głos w jakichś sprawach, to był niepodważalnym autorytetem - jako osobowość, jako uczony. Chociaż nie było historyków sztuki, wokół niego było dużo innych profesorów, ale oni uważali, że on jest autorytetem naukowym, moralnym. Jako człowiek po prostu. I właśnie jako ten wzór, użyję tego słowa, dżentelmena po prostu. To był tego typu człowiek. Dlatego właśnie ważny był każdy jego sąd, każda jego opinia, każdy kontakt. Ja osobiście całe życie czułam się obarczona jego wiarą we mnie.

\section{Profesor Stefanię Skwarczyńską i ${ }^{32}$ profesora Bolesława Lewickiego ${ }^{33}$ wspomina Ewelina Nurczyńska-Fidelska}

Nieodłączonymi postaciami w mojej biografii była dwójka profesorów: profesor Stefania Skwarczyńska i profesor Bolesław Lewicki. Pani profesor Skwarczyńska pojawiła się na Wydziale Filologicznym po 1956 roku jako kierownik Zakładu Teorii Literatury, który to zakład w minionych latach był jako placówka naukowo-dydaktyczna zamknięty. Niezależnie od zajęć prowadzonych przez panią profesor i jej pierwszych współpracowników, między innymi młodziutką wówczas panią profesor Teresę Cieślikowską ${ }^{34}$, pana profesora Stanisława Kaszyńskiego ${ }^{35}$, pani profesor zorganizowała takie seminarium dla studentów. Dziś nazwalibyśmy je takim seminarium interdyscyplinarnym. Już propozycja uczestniczenia $\mathrm{w}$ tym seminarium prowadzonym przez panią profesor Skwarczyńską była wielkim zaszczytem dla każdego z nas - pani profesor tych studentów sobie wybierała, bo w końcu zdawaliśmy u niej różne egzaminy, między innymi na pewno historię literatury powszechnej, a późniejsze

32 Stefania Skwarczyńska (1902-1988) - teatrolog, teoretyk i historyk literatury, przed wojną związana z Uniwersytetem im. Jana Kazimierza we Lwowie, po 1945 roku profesor Uniwersytetu Łódzkiego i doktor honoris causa tej uczelni.

${ }^{33}$ Bolesław W. Lewicki (1908-1981) - teoretyk filmu, krytyk i pedagog. Urodził się we Lwowie, gdzie ukończył polonistykę na Uniwersytecie Jana Kazimierza. Od początku jego pasją był film i wiedza o filmie. Jest uznawany za twórcę polskiego filmoznawstwa. W 1959 roku utworzył Zakład Wiedzy o Filmie na Uniwersytecie Łódzkim; w późniejszych latach profesor Państwowej Wyższej Szkoły Filmowej w Łodzi.

${ }^{34}$ Teresa Cieślikowska - patrz biogramy rozmówców.

${ }^{35}$ Stanisław Kaszyński (1935-1988) - wybitny teatrolog, tłumacz dramatów i poezji, poeta, popularyzator wiedzy o teatrze i literaturze. 


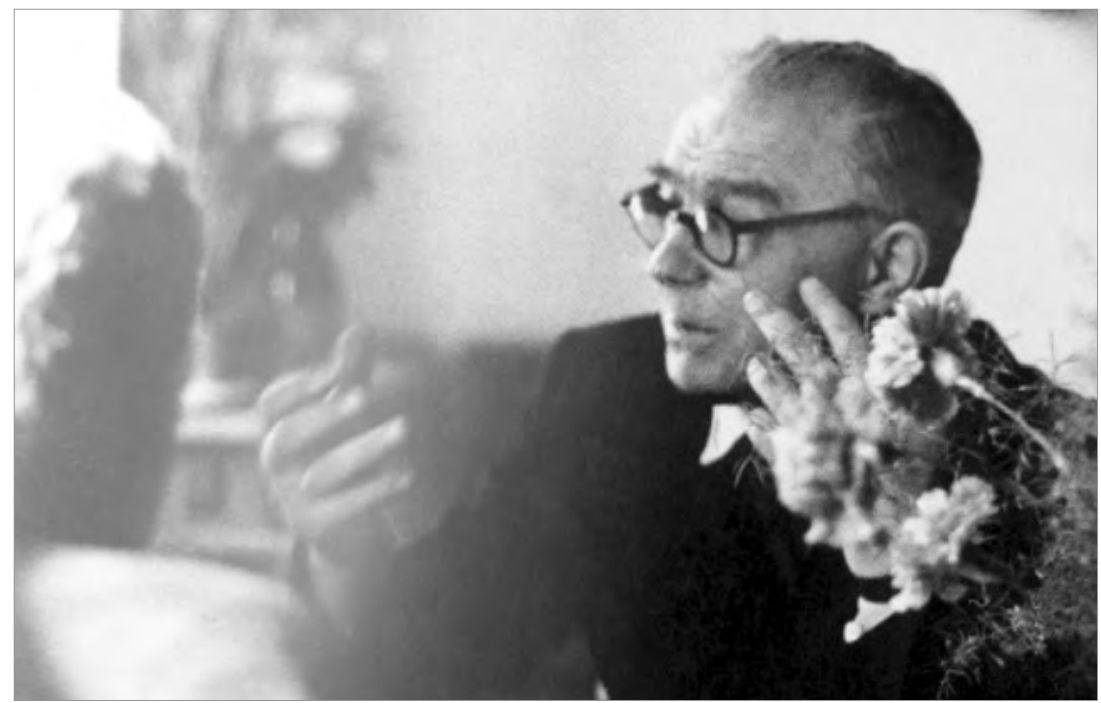

Fot. 44. Bolesław Lewicki

już roczniki także teorię literatury - i wśród tych studentów uczestniczących w seminarium pojawiło się parę osób, które później także zostały pracownikami naszego uniwersytetu, między innymi Elżbieta Wróblewska, Krystyna Ratajska, Ryszard Wierzbowski ${ }^{36}$ i inni, a więc koledzy tak naprawdę głównie z mojego roku. Pani profesor Skwarczyńska tworząc taki nowy zespół, oczywiście sondowała nasze zainteresowania i wówczas to zwierzyłam się publicznie, że moją pasją poza studiami polonistycznymi jest sztuka filmowa, że marzy mi się praca, która umiałaby łączyć moje kompetencje polonistyczne z moimi wówczas jeszcze nieistniejącymi kompetencjami filmoznawczymi. W drugim roku tych zajęć pani profesor Skwarczyńska oświadcza mi: „Słuchaj Ewuniu, będziesz miała chyba szansę realizować swoje plany, ponieważ w tym roku zajęcia u nas podejmuje profesor Szkoły Filmowej w Łodzi i Instytutu Sztuki PAN w Warszawie, pan profesor Bolesław Lewicki”. To był rok akademicki 1960, a więc pierwszy rok, w którym pojawił się wśród nas pan profesor Lewicki. Spotkał mnie więc zaszczyt, że to właśnie pani profesor Skwarczyńska przedstawiła mnie profesorowi Lewickiemu jako tę studentkę, która pasjonuje się kinem a pan profesor później przez wiele lat, a właściwie do końca mówił, że byłam jego pierwszą studentką. Taka jest prawda o naszym pierwszym kontakcie, ale ja nie pisałam pracy magisterskiej u profesora Lewickiego, bo kiedy powołał pierwsze seminarium przez siebie prowadzone, ja byłam już na piątym roku, więc nie mogłam pisać pracy u profesora. Pan profesor Lewicki wraz ze swoim przyjściem na Uniwersytet w roku 1959/1960,

${ }^{36}$ Elżbieta Wróblewska (1938-1980) - badaczka prac Brunona Schultza, Krystyna Ratajska i Ryszard Wierzbowski to profesorowie Uniwersytetu Łódzkiego. 
przy wsparciu profesor Stefanii Skwarczyńskiej utworzył Zakład Wiedzy o Filmie. W zakładzie tym początkowo pracował on i wówczas doktor Pola Wertowa $^{37}$. I ten rok, o którym wspominam, jest początkiem dziejów uniwersyteckiego filmoznawstwa, nie tylko w Łodzi, ale w całej Polsce. To była pierwsza naukowo-dydaktyczna placówka akademicka, bo jak wspominałam, w Instytucie Sztuki w Warszawie była placówka badawcza filmoznawcza, która nie prowadziła dydaktyki. Wraz z inicjatywą profesora Lewickiego na Uniwersytecie Łódzkim rozpoczęły się więc nie tylko w środowisku młodzieży i pracowników akademickich działania badawcze, ale także dydaktyczne. Nie mogłam w nich partycypować, w tym okresie pracowałam, jak mówiłam, w liceum, potem zostałam doktorantem w Instytucie Sztuki Polskiej Akademii Nauk w Warszawie, ale uczestniczyłam także w seminarium doktoranckim, które profesor otworzył po trzech latach swojej obecności na uczelni. W 1969 roku profesor Lewicki zaproponował mi asystenturę w swoim Zakładzie na Wydziale Filologicznym UŁ. Byłam w tej sytuacji troszkę rozdarta, w IS PAN doktorat nieskończony, tutaj ta propozycja, a przecież nigdy nie było łatwo zostać pracownikiem akademickim. Po różnych naradach z profesorem Lewickim, z profesorem Toeplitzem ${ }^{38}$ i Alicją Helman ${ }^{39}$ jednak podjęłam decyzję, że zawieszam tam studia doktoranckie, a podejmuję pracę jako asystent u profesora Lewickiego w Zakładzie Wiedzy o Filmie na UŁ, tak on się wówczas nazywał. Od tego 1969 roku już byłam pracownikiem akademickim, pokonując kolejne szczeble kariery naukowej. Obronę mojej pracy doktorskiej pod tytułem Andrzej Munk miałam na Uniwersytecie Śląskim, w którym odnalazłam się za sprawą profesor Alicji Helman w 1975 roku. Oczywiście jednym z recenzentów był pan profesor Lewicki. Moją rozprawę habilitacyjną była książka pod tytułem Edukacja filmowa na tle kultury literackiej, związana $\mathrm{z}$ moimi innymi niż historia filmu zainteresowaniami badawczymi. (...) $\mathrm{W}$ roku 1980 pan profesor Lewicki musiał przejść na emeryturę, nie chcę tu wchodzić w szczegóły, opowieści personalne, ale już na emeryturze, czy to był rok przed emeryturą, już nie pamiętam, pan profesor podjął decyzję, że będzie tworzył filmoznawstwo na Uniwersytecie Gdańskim. Tam już studia teatrologiczne prowadził pan profesor i teatrolog z naszego Instytutu, profesor Stanisław Kaszyński ${ }^{40}$, i on namówił profesora Lewickiego na przejście do pracy w Gdańsku. I tam Bolesław Lewicki jako profesor emerytowany rzeczywiście tworzył

${ }^{37}$ Pola Wertowa (1925-1987) - docent na Uniwersytecie Łódzkim, w latach 1959-1984 pracowała w Zakładzie Wiedzy o Filmie, zajmowała się telewizyjnymi widowiskami teatralnymi.

${ }^{38}$ Jerzy Toeplitz (1909-1995) - historyk filmu i krytyk filmowy; twórca Wyższej Szkoły Filmowej w Łodzi i rektor tej (kilkakrotnie w swojej historii zmieniającej nazwę) uczelni w latach $1957-1968$.

${ }^{39}$ Alicja Helman (ur. 1935) - teoretyk i historyk filmu związana z Uniwersytetem Śląskim, a od 1986 roku z Uniwersytetem Jagiellońskim.

${ }^{40}$ Zob. przypis $35 \mathrm{w}$ tym rozdziale. 
filmoznawstwo gdańskie, ale to był już 1979/1980 rok. (...) Niestety w lipcu 1981 roku pan profesor Lewicki nagle zachorował na nieuleczalną chorobę i zmarł. Poczuliśmy się bardzo osieroceni bo wówczas do czasu strajku studenckiego w 1981 roku zakładem kierowała pani docent Pola Wertowa. Nieobecność profesora wśród nas była po jego śmierci, dla jego wychowanków, ogromnym przeżyciem. Byliśmy związani z profesorem nie tylko jako z mistrzem dyscypliny, którą uprawialiśmy od początków filmoznawstwa w Polsce, ale przede wszystkim byliśmy z nim głęboko związani uczuciowo. Profesor był wspaniałym człowiekiem, patronem nas wszystkich, po prostu go uwielbialiśmy. Wszystkim, którzy kiedykolwiek mieli do czynienia z profesorem, towarzyszy wspomnienie tego człowieka, nie tylko mądrego, ale i niezwykle życzliwego ludziom, inicjującego najróżniejsze nasze działania i naukowe, i społeczne, i towarzyskie; zawsze pogodnego, zawsze uśmiechniętego, który spotykał się z nami oczywiście także poza uczelnią. Nie tylko wówczas, kiedy już nie pracował, ale również wcześniej. Pamiętam, że takim miejscem głównych spotkań profesora z jego uczniami, najczęściej takich w cztery oczy, ale i więcej, bo wtedy się najlepiej gawędziło, plotkowało, był Klub Plastyków, utworzony gdzieś tam w tych właśnie siedemdziesiątych latach. Było takie trochę inne miejsce na tle łódzkich kawiarń, nie mówiąc o restauracjach, bo te były straszne; w Klubie Plastyków spotykała się taka łódzka elita intelektualna i artystyczna. Profesor bardzo sobie to miejsce upodobal. No i my tam bywaliśmy z nim razem. Nasze kontakty z profesorem były nie tylko prywatne, ale także oczywiście wewnątrzuniwersyteckie. Pan profesor wciągał swoich wychowanków w pewne działania społeczne i kulturalne, które nie tylko nas aktywizowały, pokazywały nam jeszcze inne pozauniwersyteckie formy uczestnictwa w kulturze. On po prostu był duchem sprawczym tych działań, bo, na przykład, nie wszyscy pamiętamy o tym, że pan profesor Lewicki był przewodniczącym Krajowej Rady Kin Studyjnych. I jeszcze o czymś wspomnę: jeżeli pamiętamy profesora Lewickiego i jego obecność nie tylko w Uniwersytecie, ale także w życiu kulturalnym całej Polski, ale oczywiście i Łodzi, to on zaraził mnie problemami edukacji filmowej, którym jestem do dziś dnia wierna. Jesienią 2015 roku organizuję XXV Konferencję Filmoznawczą adresowaną do nauczycieli z całej Polski oraz jubileusz 30-lecia Centralnego Gabinetu Edukacji Filmowej w Łodzi. Przy obu tych formach edukacyjnych działań pan profesor współpracował z nami. Był od początku na konferencjach zwanych „Borki”, bo odbywały się w miejscowości Borki nad Zalewem Sulejowskim. Od czterech lat konferencje te odbywają się pod auspicjami PISF ${ }^{41}$ w Radziejowicach pod Warszawą. Tam, gdzie była edukacja, gdzie była młodzież, gdzie byli nauczyciele, gdzie były festiwale, tam był profesor Lewicki,

${ }^{41}$ PISF - Polski Instytut Sztuki Filmowej został założony w 2005 roku, jego celem jest rozwój i promocja polskiej kinematografii. 
a my przy nim, tak nas w to wszystko wciągał. Po śmierci profesora Lewickiego pani doktor Stolarska ${ }^{42}$ i ja wydałyśmy obszerną bibliografię profesora Lewickiego - bo objęłyśmy ją również lata trzydzieste aktywności pana profesora we Lwowie. To bycie po jego śmierci w domu profesora, $w$ jego archiwum znajdującym się pod opieką jego żony, pani Zofii Lewickiej, sprawiło, że doszłyśmy z panią doktor do wniosku, że naukowe i popularyzatorskie teksty profesora są bardzo rozproszone, że profesor nie był autorem dużej formy, choć w pamięci studentów pozostanie na pewno Wprowadzenie do wiedzy o filmie ${ }^{43}$, które istnieje jako książka. Natomiast temperament profesora Lewickiego chyba nie pozwalał mu siedzieć i pisać dzieła obszerne. W latach trzydziestych i później pisywał bardzo, bardzo dużo tekstów z różnymi zresztą wątkami filmoznawczymi, pisał teksty teoretyczno-filmowe, pisał teksty historycznofilmowe, teksty wspomnieniowe, krytyczno-filmowe. Także ta jego skala zainteresowań była taka bardzo szeroka i uznałyśmy, że naszym obowiązkiem jako jego uczennic - przecież pani doktor też była jego uczennicą, choć już doktoratu pod jego opieką nie zdążyła zrobić, napisała go potem pod patronatem profesor Teresy Cieślikowskiej - jest wydać zbiór jego pism. I to nam się udało, to była olbrzymia praca, te poszukiwania tekstów pana profesora rozsypanych po najróżniejszych miejscach, od gazet codziennych po duże książki zbiorowe. Wybór pism profesora Lewickiego pod tytułem O filmie wyszedł w Wydawnictwie Uniwersyteckim w roku $1995^{44}$. To duża książka, byłyśmy z panią doktor bardzo szczęśliwe, że mogłyśmy to opracować i wydać. Ja jeszcze miałam dużą przygodę intelektualną i emocjonalną związaną z panem profesorem, kiedy pisałam bardzo duży szkic do książki Polska kultura filmowa do 1939 roku, która wyszła w Szkole Filmowej pod redakcją Jolanty Lemann ${ }^{45}$. Zamieszczony tam szkic dotyczył wyłącznie obecności profesora Lewickiego w czasach lwowskich, gdzie był krytykiem literackim, znakomitym krytykiem teatralnym i krytykiem filmowym, inicjatorem działań na rzecz edukacji filmowej dzieci i nauczycieli, członkiem seminarium doktoranckiego Romana Ingarden $\mathrm{a}^{46} \mathrm{w}$ Uniwersytecie Jana Kazimierza we Lwowie i prezesem Klubu Filmowego „Awangarda”. Nam, jego uczniom, wychowankom, wyda-

${ }^{42}$ Bronisława Stolarska (ur. 1944) - specjalistka w dziedzinie historii polskiego kina oraz teorii filmu dokumentalnego. Aktualnie pracuje w Zakładzie Historii i Teorii Filmu UŁ.

${ }^{43}$ Bolesław Lewicki, Wprowadzenie do wiedzy o filmie, Zakład Narodowy im. Ossolińskich, Wrocław 1964.

${ }^{44}$ Tegoż, O filmie: wybór pism, red. Ewelina Nurczyńska-Fidelska, Bronisława Stolarska, Wydawnictwo Uniwersytetu Łódzkiego, Łódź 1995.

45 Jolanta Lemann-Zajiček (red.), Polska kultura filmowa do 1939 roku, Państwowa Wyższa Szkoła Filmowa, Telewizyjna i Teatralna, Łódź 2003.

${ }^{46}$ Roman Ingarden (1893-1970) - filozof, uczeń fenomenologa Edmunda Husserla. Zajmował się przede wszystkim zagadnieniami z zakresu epistemologii, ontologii i estetyki. Był profesorem Uniwersytetu Lwowskiego, Uniwersytetu Mikołaja Kopernika w Toruniu oraz Uniwersytetu Jagiellońskiego. 
wało się, że my znamy mistrza, jego wielkości i słabości na wylot. Po czym ja pierwsza uświadomiłam sobie, że tak niewiele o nim wiedzieliśmy. Tak naprawdę Lwów - wspomnienia o nim były bardzo ważnym miejscem w jego życiu, choć nigdy profesor po wojnie nie był już we Lwowie. Jego głęboka przyjaźń właśnie ze Stefanią Skwarczyńską, z profesorem Janem Trzynadlow$\mathrm{skim}^{47}$, z profesorem Stefanem Kawynem ${ }^{48}$, specjalistą od romantyzmu z naszego wydziału, to były wszystko przyjaźnie lwowskie. Oni później trafiwszy do Łodzi, jakoś byli ze sobą związani, ale kto tam z nas w latach sześćdziesiątych myślał o Lwowie i o takich rzeczach dowiadywaliśmy się już post factum, właśnie czytając i tamte czasopisma, tamte gazety, odkrywając profesora, którego nie znaliśmy. Ale innym odkryciem osobowości profesora, odkryciem, które nas wszystkich poraziło, była wydana w 1974 roku książka profesora, nieduża, pod tytułem Wiesz jak jest ${ }^{49}$, która jest zbiorem wspomnień z pobytów profesora w pięciu obozach koncentracyjnych, od Oświęcimia po Gross Rosen, skąd Amerykanie go wyzwolili. Profesor Lewicki nigdy nie wspominał, że miał 840 numer oświęcimski, należał więc do pierwszej grupy więźniów Oświęcimia, a potem do 1945 roku przechodził przez kolejne obozy. Nigdy nie wspominał lat obozowych, a nikt z nas nie miał odwagi go o to pytać, na szczęście tyle lat minęło, kiedy zdołał jakby te swoje wspomnienia spisać i napisał tę niedużą niestety książkę Wiesz jak jest. W archiwum profesora znalazłyśmy z panią doktor Stolarską listy od profesora Aleksandra Jackiewicza ${ }^{50}$, od profesora Aleksandra Kamińskiego, tego pedagoga - oni też się przyjaźnili, obaj w tych listach pisali o tym, że dla nich ta książka jest najwybitniejszym z dokumentów, śladów tamtego ludzkiego doświadczenia.

\section{Profesor Stefanię Skwarczyńską ${ }^{51}$ wspomina Teresa Cieślikowska}

Przeszłam z bibliotekoznawstwa na polonistykę, którą ukończyłam w 1952 roku. Napisałam wówczas pierwszą rozprawkę wystawioną w konkursie prac przez profesor Skwarczyńską, bowiem pod jej kierunkiem wówczas studiowałam. Rozprawka została później opublikowana w „Pracach Polonistycznych”. Profesor Skwarczyńska prowadziła Katedrę Teorii Literatury, Teatru i Filmu,

${ }^{47}$ Jan Trzynadlowski (1912-1995) - teoretyk i historyk literatury. Ukończył Uniwersytet Jana Kazimierza we Lwowie. W latach 1945-1950 pracownik Uniwersytetu Łódzkiego, po roku 1950 związany z Uniwersytetem Wrocławskim.

${ }^{48}$ Stefan Kawyn (1904-1968) - historyk literatury polskiej, od 1954 roku profesor Uniwersytetu Łódzkiego.

${ }^{49}$ Bolesław Lewicki, Wiesz jak jest [1974], wyd. 2, PWSFTviT-Uniwersytet Łódzki, Łódź 2012. W 1988 roku Grzegorz Królikiewicz zrealizował film pełnometrażowy poświęcony Lewickiemu pod tytułem Wiesz jak jest (Stowarzyszenie Artystyczne, Łódź 1988).

${ }^{50}$ Aleksander Jackiewicz (1915-1988) - teoretyk i krytyk filmu, profesor Państwowej Wyższej Szkoły Filmowej w Łodzi oraz Instytutu Sztuki PAN.

${ }^{51}$ Zob. przypis $27 \mathrm{w}$ tym rozdziale. 
mieszczącą się przy ulicy Lindleya. W tej katedrze zostałam zatrudniona w roku 1957 jako asystent. Chciałabym podkreślić, że profesor Skwarczyńska była osobą, której bardzo dużo zawdzięczam jeśli chodzi o opiekę nad przebiegiem moich studiów, wieloraką pomoc, niekiedy również materialną gdy byłam w jakichś kłopotach na przykład, czy staraniach o mieszkanie. Wiele korzystałam z jej instruowania i pomocy. Wiem też, że profesor Skwarczyńska pomagała nie tylko mnie ale też innym, także moim kolegom, nieraz o tym słyszałam. Po śmierci profesor Skwarczyńskiej w 1988 roku mój kolega, profesor Staszek Kaszyński ${ }^{52}$ zorganizował poświęconą jej konferencję.

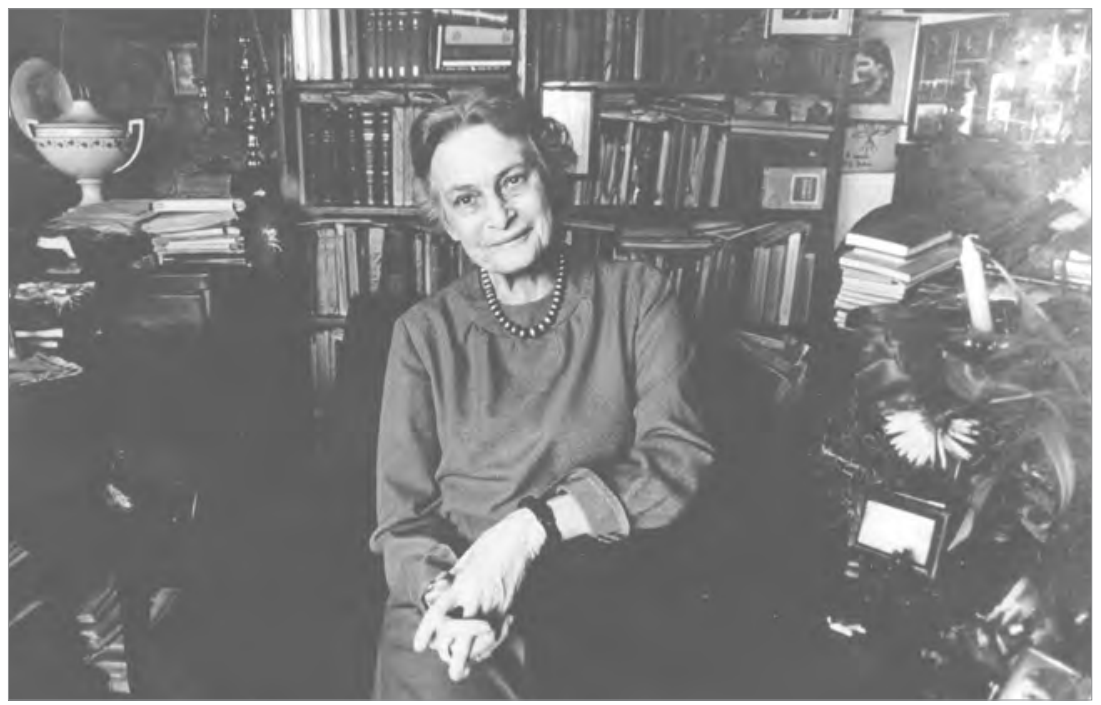

Fot. 45. Stefania Skwarczyńska

Efektem tej konferencji była publikacja książkowa, której przedmiotem były prace badawcze, działalność dydaktyczna i wychowawcza profesor Skwarczyńskiej.

\section{Profesor Antoninę Kłoskowską ${ }^{53}$ wspomina Zbigniew Bokszański}

Moja praca magisterska mieściła się w ramach takich powiedziałbym socjaldemokratycznych czy socjalistycznych, które w jakiejś mierze, w jakimś stopniu profesor Kłoskowska również reprezentowała, ponieważ skierowała moją uwagę na zagadnienia i na proces, który nazwaliśmy ruchliwością kulturową,

${ }^{52}$ Zob. przypis $35 \mathrm{w}$ tym rozdziale.

${ }^{53}$ Antonina Kłoskowska (1919-2001) - socjolog, absolwentka Uniwersytetu Łódzkiego, profesor na Uniwersytecie Łódzkim i Uniwersytecie Warszawskim, w latach 1989-1994 przewodnicząca Polskiego Towarzystwa Socjologicznego, członek PAN. 
przez analogię do mobilności, społecznej mobilności w strukturze. Zainteresowaliśmy się ludźmi, którzy odrywają się od pewnych wzorów recepcji kultury, kontaktów z kulturą, które są właściwe ich środowiskom, i realizują jakieś inne wzory. Stąd powstała moja praca magisterska o robotnikach, czytelnikach literatury elitarnej. Po czym postanowiłem, też zresztą w porozumieniu z profesor Kłoskowską, która bardzo mądrze skierowała mnie w stronę teorii socjologicznej, żeby oderwać się od tych takich stosunkowo prostych zagadnień empirycznych i skierowała moją uwagę na, z jednej strony, Znanieckiego, $\mathrm{z}$ drugiej strony na Parsonsa ${ }^{54}$. Zacząłem w sposób bardzo systematyczny, taki dość gruntowny przede wszystkim jak myślę, z jakimś tam stopniem [śmiech] rozumienia czytać trudne lektury socjologiczne, już takie bardzo profesjonalne. Poza tym musiałem się trochę, o czym też pani wspominałem już, nauczyć się języka niemieckiego tak, żeby móc czytać. Nie było Webera tłumaczonego, a koniecznie trzeba było Webera, do tej książki kilkadziesiąt stron przeczytać. No więc to była praca doktorska, którą w roku 1970 udało mi się obronić. Recenzentami byli chyba profesor Chałasiński, który już był wtedy w Warszawie, i profesor Szczepański ${ }^{55}$. Rozpocząłem przygotowania do habilitacji, która pięć lat po doktoracie została przygotowana. To był powrót znów do tych zagadnień ruchliwości kulturowej. Przy czym teraz starałem się przyjrzeć temu, jak wygląda, jakie są korelaty ruchliwości społecznej, tej tradycyjnej.

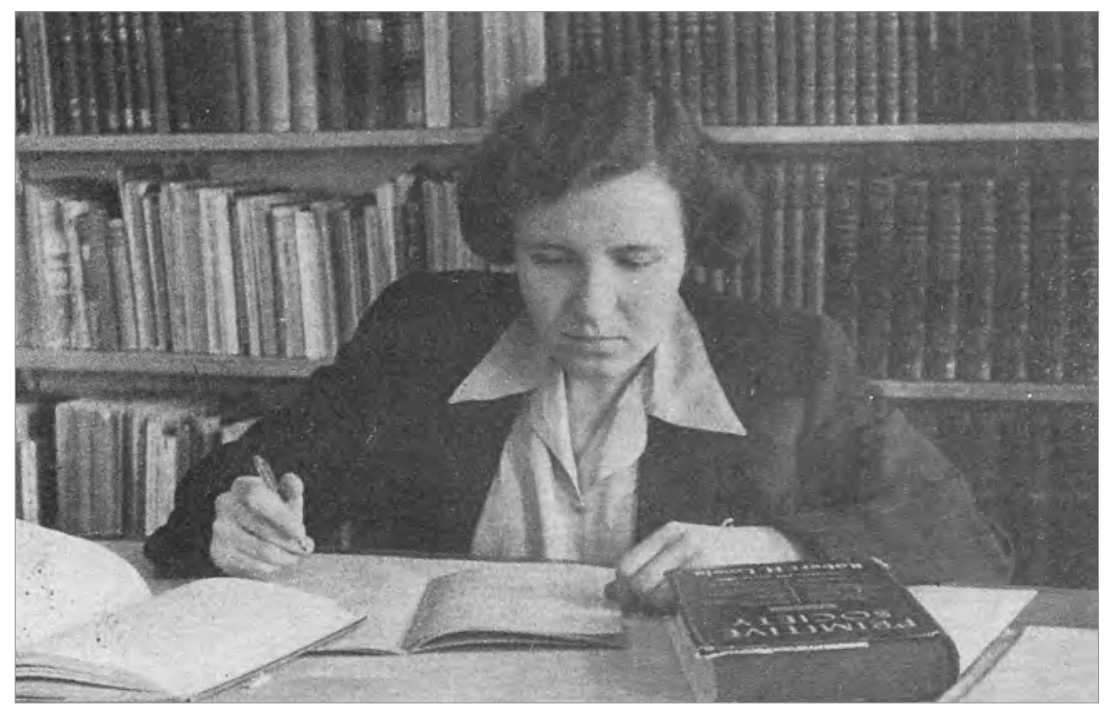

Fot. 46. Antonina Kłoskowska przy pracy w budynku na Uniwersyteckiej 3

${ }^{54}$ Talcott Parsons (1902-1979) - amerykański socjolog, twórca funkcjonalno-strukturalistycznej teorii systemów społecznych.

${ }^{55}$ Józef Chałasiński (1904-1979) - profesor socjologii, jeden z założycieli Uniwersytetu Łódzkiego i rektor tej uczelni w latach 1949-1952, członek PAN. Zob. przypis $15 \mathrm{w}$ tym rozdziale. 
Czy z nią są związane, czy ona znajduje swoje odzwierciedlenie w zmianie horyzontów kulturalnych ludzi, czy pójście w górę, taki upgrading właśnie. I to, czy przesuwanie się właśnie w przestrzeni społecznej ma jakieś echa, odzwierciedlenia i czy się przenosi na ruchliwość w jakiejś przestrzeni kulturalnej gustów, upodobań. Powstała oczywiście książka, musiała powstać, bo habilitację tak się przecież przygotowuje. Miałem kontakty z kolegami z Francji. Byłem zresztą na stypendium we Francji w związku z tą książką, ponieważ Francuzi byli też zainteresowani tymi kwestiami. Powróciłem do krótkich takich, ale bardzo intensywnych kontaktów z profesorem Bourdieu ${ }^{56}$, ale akurat jego te zagadnienia nie pasjonowały, ponieważ on o żadnej ruchliwości nie chciał słyszeć, ponieważ koncepcja habitusu u niego dość wyraźnie ludzi wiązała $\mathrm{z}$ pewnym miejscem w strukturze społecznej i z tym miejscem związane było wszystko. To, czy rybę się je widelcem, czy nożem, i czy się słucha dziewiątej symfonii Beethovena, czy raczej Beatlesów, i w ogóle o ruchliwości tam mowy być nie mogło. Dyskusje dwie takie miałem z profesorem Bourdieu, który posiał we mnie dość istotną wątpliwość co do tej perspektywy, którą właśnie przyjąłem w pracy i którą myśmy tu w Łodzi reprezentowali. Mianowicie takiej, że człowiek może podjąć próbę takiego zdystansowania się wobec zasadniczych celów swojego położenia społecznego. Tutaj argumentacja Bourdieu była taka, mówił mi: „Proszę pana, może pan się zajmować takimi" - zresztą on używał takiego określenia miraculeuse, cudownymi, sam był takim cudownym dzieckiem i cudownym człowiekiem, który się wyrwał $\mathrm{z}$ takich warstw umiarkowanie niskich w społeczeństwie francuskim i doszedł do Katedry w Collège de France, znał całą tę drogę z wszystkimi jej prawda zawiłościami i subtelnościami - ale mówił: ,przecież my zajmujemy się jako socjologowie dużymi populacjami, a w dużych populacjach ma pan habitus, proszę pana, i tam się nic nie zmienia. Tam są pewne struktury, których zmienić się nie da". Co zresztą było przedmiotem ciągłych i ustawicznych dysput, które Bourdieu i Kłoskowska ze sobą toczyli wtedy, kiedy mieli okazję się spotkać. To było widać na przykład w Jabłonnej, w której byliśmy na trzydniowym spotkaniu. I profesor Kłoskowska przedstawiała nam też jakieś referaty swoje na różnych spotkaniach międzynarodowych i reakcje Bourdieu właśnie relacjonowała. No więc taki trochę byłem w tej pracy powiedziałbym rozdwojony w tej swojej habilitacyjnej. Starałem się znaleźć jakieś uzasadnienie, podkreślając tutaj jednak duże różnice, jeżeli idzie o strukturę społeczną i kryteria uwarstwienia i procesy ruchliwości społecznej w Polsce i we Francji.

\section{(...)}

Ja uważam, że zawdzięczam profesor Kłoskowskiej niesłychanie wiele i z ogromną, z ogromną zawsze atencją, życzliwością, bardzo ciepło ją wspominam.

${ }^{56}$ Pierre Bourdieu (1930-2002) - wybitny francuski socjolog, filozof i antropolog. Zajmował się przede wszystkim socjologią kultury i wychowania oraz sferą znaczeń dzieł sztuki. 
Wdzięczny jej jestem po pierwsze za to mądre pokierowanie wszystkimi meandrami w karierze naukowej. Bo takie mądre pokierowanie i jakieś wsparcie i nietracenie czasu na jakieś plątanie się, wymyślanie jakichś tam tematów, pól zainteresowań, badań, wsparcie kogoś starszego i dysponującego autorytetem i wiedzą było tutaj bardzo znaczące. Przy czym profesor Kłoskowska przeniosła taki wzór bardzo rzeczowego traktowania, przy całej życzliwości i zrozumieniu była takim właśnie mentorem, który i wymagał sporo, i równocześnie nie zadowalał się jakimiś osiągnięciami, że tak powiem, miernymi. Przy czym ta jej presja na jakieś rezultaty była związana i ostatecznie jednak także uzasadniania wielkim jakimś zainteresowaniem tym, co pracownicy młodsi, bo nie tylko ja, ale i koledzy młodsi, tym, co czynią i jakiego rodzaju produkty tej pracy naukowej tworzą. Proszę wyobrazić sobie, że przez bardzo długi okres profesor wszystkie artykuły, które dawaliśmy do druku, a było ich coraz więcej, bardzo uważnie czytała: „Przegląd Socjologiczny”, „Kultura i Społeczeństwo”, potem „Studia Socjologiczne”. A szczególnie w początkowym okresie profesor Kłoskowska po prostu prosiła o maszynopis. I z tych rozmów, które toczyliśmy, wynikało, że bardzo gruntownie czytała te nasze teksty, więc była niezwykle odpowiedzialną osobą i traktowała nas jako osoby oddane pod jej władzę, pieczę, kontrolę, życzliwość także. Mieliśmy oczywiście także przez rok czy nawet więcej, chyba przez trzy semestry wizytacje na zajęciach, które prowadziliśmy. Już nie pamiętam, z jakich przedmiotów te zajęcia miałem. To było chyba przed doktoratem jeszcze, tak. Zostałem starszym asystentem. Bo najpierw uczestniczyłem w jej zajęciach, jej seminarium wprowadzającym do wstępu do socjologii. To już mi się nie zdarzyło nigdy, żeby ktokolwiek z pracowników przez cały semestr na przykład przychodził na zajęcia i bardzo uważnie słuchał. To nie znaczy, że profesor sobie jakichś notatek nie robiła, ale potem szliśmy tutaj do niej do pokoju i od czasu do czasu profesor sporo takich uwag, i to krytycznych uwag także formułowała pod moim adresem. Taka już, jak myślę, była natura tego terminowania. Myślę, że to jest dobre określenie chyba, bo ja się troszeczkę czułem jak taki terminujący pracownik. Przy czym to było niesłychanie ważne, bo z jednej strony to było trochę stresujące - ciągła obecność zwierzchnika, w dodatku człowieka bardzo wysoko notowanego w hierarchii socjologicznej. Przy czym profesor Kłoskowska to był naprawdę profesor na poziomie światowym i myśmy bardzo prędko się o tym dowiedzieli. Więc taka para oczu w człowieka wlepionych i para uszu, do tego niesłychanie sprawny mózg, to było rzeczywiście stresujące. Ale to była szkoła, która bardzo mi się przydała. Także chyba przez trzy semestry, dwa na pewno, a być może i trzy semestry, co tydzień miałem gościa w postaci profesor Kłoskowskiej i od czasu do czasu dłuższe czy krótsze rozmowy na temat tego, co tam się na tym seminarium działo. Więc te dwie rzeczy, to znaczy taka czujność i uwaga, i powiedziałbym ogromne poczucie obowiązku, które profesor przejawiała. A z drugiej strony, to mądre sterowanie rozwojem intelektualnym. Przy czym to było jeszcze 
o tyle atrakcyjne, że to nie była forma jakichś wskazówek. To było po prostu uczestnictwo w konferencjach, w seminariach, w kontaktach z kolegami z zagranicy.

\section{Profesor Kazimierę Zawistowicz-Adamską ${ }^{57}$ wspomina Bronisława Kopczyńska-Jaworska}

Dlaczego akurat pani profesor Kazimiera Zawistowicz znalazła się w Łodzi? Otóż ja bardzo blisko pracowałam z profesor, ona nie miała rodziny tu na miejscu i właściwie towarzyszyłam jej przez kilkadziesiąt lat. I dużo mi bardzo opowiadała o rzeczach, które się dzieją na uniwersytecie itd., ale zdałam sobie sprawę, że nie przypominam sobie, żebyśmy rozmawiały o tym, kto ją tutaj do Łodzi ściągnął i dlaczego. Przypuszczam, że była w dużej zażyłości z profesor Heleną Radlińską ${ }^{58}$ przypuszczam, że profesor Radlińska tu przyjechała i ściągnęła profesor Zawistowicz do Łodzi. Nie wiem, na jakim szczeblu i w jakich okolicznościach powstała idea założenia tej Katedry Etnografii, znaczy wówczas Zakładu jeszcze, bo pani profesor nie była jeszcze profesorem Zakładu. Ja byłam studentką, ale już od czerwca 1946 roku zostałam zastępcą asystenta. Pani profesor Zawistowicz-Adamska miała doktorat zrobiony przed wojną na Uniwersytecie Jagiellońskim u Jana Stanisława Bystronia ${ }^{59}$ i wobec tego była zastępcą profesora, bo nie miała habilitacji. Nasze pierwsze badanie i nasze pierwsze prace, to właśnie z tych prac powstała praca habilitacyjna. Ona miała napisaną pracę habilitacyjną przed wojną, bo ona w 1931 roku robiła doktorat czy w 1932, a potem pracowała dalej i miała przygotowaną pracę. Ona w pra-

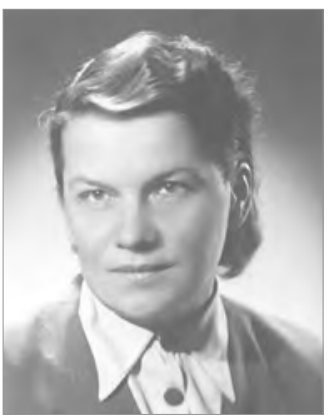

Fot. 47. Kazimiera Zawistowicz-Adamska cy doktorskiej zajmowała się małżeństwem: takie małżeństwo przez wkupno, małżeństwo z wolnego wyboru. I ona napisała drugą pracę o tym małżeństwie, jako pracę habilitacyjną, ale maszynopis tej pracy spłonął w powstaniu, został z niej tylko ślad w postaci odczytu wygłoszonego w Polskiej Akademii Umiejętności w Krakowie, oni drukowali na dwóch czy trzech stronach streszczenie i to było, ona miała na wiosnę 1939 ten wykład tam. To było wydrukowane i starsi profesorowie proponowali jej, że zaświadczą, że ta praca była, żeby ona dostała habilitację na tej podstawie. Bardzo wiele osób, może nie bardzo wiele, ale sporo dostało habilitacje za takie prace, które

${ }^{57}$ Kazimiera Zawistowicz-Adamska (1897-1984) - profesor etnologii, w 1945 roku założyła na Uniwersytecie Łódzkim Zakład Etnografii.

${ }^{58}$ Zob. przypis $17 \mathrm{w}$ tym rozdziale.

${ }^{59}$ Jan Stanisław Bystroń (1892-1964) - etnograf i socjolog, badacz kultury polskiej, folkloru i twórczości ludowej. Profesor na uniwersytetach w Poznaniu, Krakowie i Warszawie, członek Polskiej Akademii Nauk. 
poprzepadały albo były niepełne. Ale pani profesor się uniosła honorem, że ona nie będzie na podstawie świadectw niczego załatwiać, tylko że szybciutko napisze następną pracę. Wobec tego wyhabilitowała się normalnym tokiem, w 1951 roku czy 1952 zgłosiła Pomoc wzajemna i współdziałanie w kulturach ludowych ${ }^{60}$ jako pracę habilitacyjną. Miała normalną recenzję, przewód, egzamin na Uniwersytecie Jagiellońskim, jej recenzentami był profesor Kazimierz Moszyński i profesor Kazimierz Dobrowolski ${ }^{61}$, i spotkało się dwóch nielubiących się profesorów nad tą pracą. Egzamin się odbył i w tym momencie znieśli habilitację, także ona już nie dostała na rękę żadnego dowodu, że ma habilitację. Dopiero po 1956 roku jakoś jej tam ją zatwierdzili. Także pani profesor była zastępcą profesora, a ja byłam zastępcą asystenta. Od pewnego czasu w naszej katedrze były prowadzone, to pani profesor jeszcze zainicjowała, takie badania na terenie miasta Łodzi nad kulturą miejsko-robotniczą. Miałam wielką ochotę się do tego przyłączyć. Jak już zrobiłam habilitację, pani profesor przeszła na emeryturę, ja samodzielnie już wtedy pracowałam na uniwersytecie i zaczęłam zmierzać do organizacji większych badań nad kulturą robotniczą.

\section{Profesorów Tadeusza Kotarbińskiego, Tadeusza Krońskiego ${ }^{62}$ i Bronisława Baczko ${ }^{63}$ wspomina Ryszard Panasiuk}

Mimo, iż studia moje na Uniwersytecie Warszawskim przypadły na czas dla życia duchowego społeczeństwa niełatwy ${ }^{64}$, czas propagowania treści, które miały formować studenta jako posłusznego wyznawcę oficjalnej ideologii, to przecież zdarzało się w gronie kadry nauczającej spotkać ludzi godnych szacunku, dystansujących się wobec oficjalnej doktryny lub przynajmniej usiłujących poddawać ją pewnym próbom intelektualizacji. Miałem to szczęście, że wśród kadry nauczającej natrafiłem na takich ludzi i jednym z nich był prof. Tadeusz Kotarbiński. W czasach moich studiów tak zwana władza ludowa traktowała go z dystansem, podejmowano też krytykę jego poglądów filozoficznych. Spośród uczonych, którzy kształtowali kulturę filozoficzną

${ }^{60}$ Kazimiera Zawistowicz-Adamska, Pomoc wzajemna i współdziałanie w kulturach ludowych, 1950.

${ }^{61}$ Kazimierz Moszyński (1887-1959) - etnograf, slawista, profesor Uniwersytetu Stefana Batorego w Wilnie a po wojnie Uniwersytetu Jagiellońskiego. Kazimierz Dobrowolski (1894-1987) - etnolog i socjolog, profesor Uniwersytetu Jagiellońskiego, członek Polskiej Akademii Nauk.

${ }^{62}$ Tadeusz Kroński (1907-1958) - filozof zajmujący się głównie myślą Hegla i Kanta, uczeń Tadeusza Kotarbińskiego i Władysława Tatarkiewicza. Uznawany za jednego z głównych ideologów okresu stalinowskiego. Wykładał filozofię marksistowską w Instytucie Kształcenia Kadr Naukowych. Znany jako „Tygrys” z Rodzinnej Europy Czesława Miłosza.

${ }^{63}$ Bronisław Baczko (1924) - filozof i historyk myśli społecznej, profesor na Uniwersytecie Warszawskim, współtwórca tzw. Warszawskiej szkoły historyków idei.

${ }^{64}$ Ryszard Panasiuk studiował w latach 1952-1957. 
w okresie międzywojennym, właściwie tylko jemu pozwolono być czynnym nauczycielem. Jednakże jego aktywność nauczycielską ograniczono jedynie do wykładania logiki, ta była bowiem względnie apolityczna. Z prawdziwym sentymentem wspominam udział $\mathrm{w}$ prowadzonym przezeń seminarium, gdzie przy analizach podstawowych problemów logicznych dawało się odczuć tchnienie ducha najświetniejszej w naszych dziejach szkoły lwowsko-warszawskiej, dokonań filozofów i logików, których działalność zapoczątkował jeszcze przez I wojną światową Kazimierz Twardowski ${ }^{65}$, a w dorobku której Kotarbiński miał znaczny udział. Uczestnictwo w prowadzonym przezeń seminarium miało dla mnie znaczenie nie tylko dlatego, że mogłem poznać przekazywaną przezeń wiedzę, ważniejszą może nawet była możliwość obcowania bezpośrednio z nim jako człowiekiem, który swoją niezależną postawą połączoną z wybitnym talentem nauczycielskim, był w stanie formować postawy moralne swoich uczniów. Prof. Kotarbiński był dla mnie autorytetem i mistrzem nie jedynie $\mathrm{w}$ obszarze nauki, ale także moralności. Nie tylko wiele się odeń nauczyłem, ale także spotkałem się z życzliwością i pomocą w momentach dla mnie trudnych. Następną z kolei postacią, której oddziaływanie jako mistrza i nauczyciela wyraźnie odczułem, był prof. Tadeusz Kroński. Wiadomo, że był przyjacielem Miłosza ${ }^{66}$ i pamiętam jak kiedyś zaprosił nas z przyjacielem do swojego skromnego mieszkania i nagle odzywa się w sposób podniosły i tajemniczy: „Był u mnie Miłosz”, obaj nie bardzo zrozumieliśmy o co właściwie chodzi, bowiem ów poeta był nam, prawdę mówiąc, nieznany. A był to moment kiedy Miłosz wpadł do kraju na chwilę i następnie udało mu się szybko wyjechać,

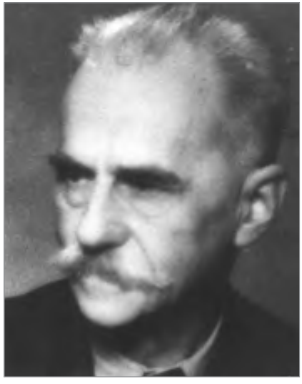

Fot. 48. Tadeusz Kotarbiński by już całkowicie zerwać z systemem komunistycznym. Kroński to postać na tle naszych ówczesnych nauczycieli osobna. Po przyjeździe z Francji do kraju zgłosił akces do komunizmu, ale czuł, jak się zdaje, głęboki dyskomfort swojej sytuacji. Jako człowiek wysokiej kultury musiał razić go prymitywizm powszechnie propagowanych treści oficjalnej doktryny. Stan ten próbował rozładować swoim osobliwym zachowaniem, dystansując się z pomocą ironii, żartów i niekonwencjonalnego sposobu wysławiania się wobec prawd oficjalnie głoszonych. Na seminarium, na które uczęszczałem przez dłuższy okres czasu,

${ }^{65}$ Kazimierz Twardowski (1866-1938) - filozof i psycholog, twórca lwowsko-warszawskiej szkoły filozofii.

${ }^{66}$ Czesław Miłosz (1911-2004) - polski poeta, prozaik, eseista, historyk literatury, tłumacz, od roku 1951 do 1989 przebywał na emigracji początkowo we Francji, potem w Stanach Zjednoczonych. W 1980 roku otrzymał Nagrodę Nobla w dziedzinie literatury. Był profesorem Uniwersytetu Kalifornijskiego w Berkeley i Uniwersytetu Harvarda. Kawaler Orderu Orła Białego, wyróżniony również tytułem Sprawiedliwy wśród Narodów Świata. 
przygotowując pod jego kierunkiem rozprawę magisterską, tworzył atmosferę swobodnej dyskusji, dopełnioną częstokroć ironicznymi komentarzami na temat bieżącej sytuacji politycznej w kraju. W kraju, w którym wiele się działo, jako że był to rok 1956. Był zafascynowany niemiecką kulturą duchową wieków XVIII i XIX, w szczególności filozofią okresu klasycznego, gdzie Hegel miał wyraźnie wyróżnione miejsce. Odnosiło się wrażenie, że tak jakby u tego myśliciela poszukiwał klucza do zrozumienia tej tak pogmatwanej współczesności, w której przyszło mu żyć. Przyznam, że to właśnie dzięki niemu zwróciłem się w swoich zainteresowaniach ku tej właśnie filozoficznej tradycji i pozostałem jej wierny właściwie przez cały okres mojej aktywności naukowo-badawczej. Zainspirowany przez Krońskiego kierunek moich zainteresowań po krótkim pobycie w Lublinie, gdzie nauczałem logiki i po przeniesieniu się do Łodzi uległ pogłębieniu. Stało się to dzięki temu, że włączyłem się do społeczności bardzo żywego intelektualnie grona badaczy dziejów myśli filzoficzno-społecznej oraz politycznej i religijnej, skupionych wokół prof. Bronisława Baczki. To pod jego przewodnictwem zbierało się grono w Instytucie Filozofii i Socjologii PAN w Pałacu Staszica w ciągu lat około dziecięciu, aż do roku 1968, niesławnego roku wydarzeń marcowych. W kręgu badaczy z tej społeczności, znanych także poza granicami Polski jako warszawska Szkoła Historii Idei powstały tak znakomite dzieła jak wspomnianego inicjatora owych spotkań prof. Baczki Rousseau: samotność $i$ wspólnota ${ }^{67}$, Kołakowskiego Świadomość religijna i więź kościelna ${ }^{68}$, Walickiego $W$ kręgu konserwatywnej utopi ${ }^{69}$ - by wymienić publikacje najważniejsze i najbardziej znane. Dla mnie osobiście, jako uczestnika wspomnianego seminarium, a następnie autora rozprawy doktorskiej poświęconej gronu młodszych uczniów Hegla, prof. Baczko, mój promotor, jawi się w kręgu społeczności wspomnianego seminarium jako postać pierwszoplanowa, jemu przede wszystkim zawdzięczam zarówno ukierunkowanie badawcze, jak też uzyskane rezultaty. Mam też powód do satysfakcji, że to czego nauczyłem się w tym tak inspirującym metodologicznie środowisku intelektualnym, mogłem w miarę możliwości przekazać uczestnikom prowadzonego przez mnie seminarium w Instytucie Filozofii UŁ. Dorobek ich, jak sądzę, stanowi udany przeszczep na nasz uniwersytecki grunt metod badawczych wypracowanych przez uczestników seminarium z pałacu Staszica.

${ }^{67}$ Baczko Bronisław, Rousseau: samotność i wspólnota, Państwowe Wydawnictwo Naukowe PWN Warszawa 1964.

${ }^{68}$ Kołakowski Leszek, Świadomość religijna i więź kościelna, Państwowe Wydawnictwo Naukowe PWN, Warszawa, 1965.

${ }^{69}$ Walicki Andrzej, $W$ kręgu konserwatywnej utopii: struktura i przemiany rosyjskiego stowianofilstwa, Państwowe Wydawnictwo Naukowe PWN, Warszawa 1964. 


\section{Profesora Ludwika Straszewicza ${ }^{70}$ wspomina Stanisław Liszewski}

Studiowałem w Katedrze Geografii Ekonomicznej pod kierunkiem profesora Ludwika Straszewicza, którego uważam za mojego mistrza. Wszędzie powtarzam, że to jest postać dla mnie bardzo, bardzo ważna z dwóch powodów. Po pierwsze, był to człowiek dużej klasy i wiedzy, a po drugie, był człowiekiem bardzo życzliwym i tworzącym atmosferę rodzinną. Myśmy wykonywali różne prace, profesor nam w tym bardzo pomagał. Była to dla mnie wielka szkoła. Profesor miał swoje poglądy ukształtowane w młodości, pochodził z rodziny warszawskiej, tam się urodził. Jego studia w Szkole Głównej Handlowej przerwała wojna. Po wojnie we Wrocławiu skończył studia i tam też obronił pierwszy po wojnie doktorat z geografii ekonomicznej. Miał zainteresowania geograficzno-ekonomiczne, co mi bardzo odpowiadało. A co do jego poglądów, to były silnie narodowe, ponieważ jego ojciec był piłsudczykiem i to pozostało mu gdzieś we krwi. Był bardzo wielkim patriotą. Ale miał cechę, którą chciałbym, żeby mieli wszyscy wielcy ludzie. Nie narzucał swoich poglądów nikomu. Nigdy nie pytał, jak my na to patrzymy, czy się zgadzamy, czy nie, zresztą nie było takich dyskusji. Po obronie mojej pracy magisterskiej rozstaliśmy się. Podjąłem pracę, w Katedrze Geografii Ekonomicznej. Pracę miałem formalnie podjąć w październiku, a ponieważ Katedra, w której byłem, prowadziła na Opolszczyźnie zlecone badania na użytek pracowni urbanistycznej, to profesor zaproponował mi, żebym się do nich włączył w czasie wakacji. Badania prowadzono wówczas w małym miasteczku Kiecz na granicy czesko-polskiej. Kiedy mi to mówił, musiałem zrobić jakąś dziwną minę, bo profesor zapytał: „Pewnie pan nie ma pieniędzy na wyjazd”. Odpowiedziałem zgodnie z rzeczywistością: „Panie profesorze, no nie mam”, bo mi się nie przelewało.

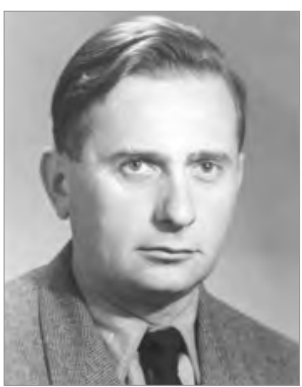

Fot. 49. Ludwik Straszewicz Profesor wyjął jakieś pieniądze i mówi: „Jak pan zarobi, to pan mi odda". I wie pani, to są gesty, które się pamięta do końca życia. I oczywiście wyjechałem. Z 1968 roku pamiętam strajk, jaki był zorganizowany wtedy na Kościuszki 21. I pamiętam także konsekwencje roku 1968, którymi było między innymi pozbawienie w 1970 roku kierownictwa katedry mojego profesora. Profesor zdecydował wtedy wyjechać za granicę. Wyjechał na wykłady do Francji. Wszystko tak trwało chyba do 1974 czy 1973 roku, kiedy zmarł profesor Jan Dylik ${ }^{71}$. Nie znam kulis tego, ale domyślam się, że wdowa po profesorze Janie Dyliku, profesor

${ }^{70}$ Ludwik Straszewicz (1916-1987) - ekonomista, geograf, od 1956 roku związany z Uniwersytetem Łódzkim, założyciel Oddziału Łódzkiego Polskiego Towarzystwa Urbanistycznego.

${ }^{71}$ Jan Dylik (1905-1973) - geograf, geomorfolog, od 1947 roku profesor Uniwersytetu Łódzkiego, w latach 1956-1972 przewodniczący Międzynarodowej Unii Geograficznej. 
Anna Dylikowa ${ }^{72}$ nawiązała wtedy kontakt z profesorem Straszewiczem, zapraszając go do powrotu. W każdym razie profesor wrócił i poproszono go, żeby podjął się dyrektorowania instytutem. Profesor Straszewicz przyjął tę propozycję, ale zapowiedział, że to będzie tylko trzy lata, że on nie ma ochoty na więcej. I przez trzy lata był dyrektorem instytutu. A moje dalsze losy były takie: w 1978 roku, jak na tamte czasy bardzo szybko, zrobiłem habilitację, wydałem książkę na temat terenów miejskich Łodzi, i w oparciu o tę pracę dostałem stopień doktora habilitowanego i stanowisko docenta.

\section{Profesora Konrada Jażdżewskiego ${ }^{73}$ wspomina Jerzy Kmieciński}

Zaczynałem studia na UJ-ocie w Krakowie w 1948 roku na kierunku historia sztuki, u profesora Wojsława Molé. ${ }^{74}$ Obowiązywał wtedy jeszcze tradycyjny przedwojenny system, charakteryzujący się mniejszą ilością egzaminów i dość dużą swobodą wyboru dyscyplin pomocniczych. Po dwóch latach studiów trzeba było mieć zdane co najmniej dwa egzaminy, zaś pozostałe - przeważnie sześć - do końca studiów. Zapisywało się od razu na określone seminarium, do konkretnego profesora, który stawał się mentorem, takim pater familias, który potem prowadził przez całe studia. Profesor Molé był specjalistą w dziedzinie sztuki starochrześcijańskiej. Jego wykłady były niezwykle interesujące, a przy tym prowadzone w sposób nietypowy. Nie zapomnę tego wykładu, kiedy mówił o baroku. Zaprowadził nas do kościoła św. Anny niedaleko Collegium Maius i tam demonstrował w jaki sposób ten kierunek w sztuce się rozwijał. Wnętrze tej świątyni zawierało kolejne etapy rozwoju baroku: a więc wczesny barok, następnie w rozkwicie, na koniec rokoko. Wszystko jest tam widoczne w wystroju wnętrza, w stiukach, w malarstwie ścian itd. Uważam, że taka metoda prowadzenia zajęć jest niezmiernie instruktywna i dydaktycznie skuteczna. Profesor Molé kontaktował się też ze środowiskiem archeologów, co dla mnie stało się przyczyną zmiany nie tyle zainteresowań, co kierunku studiów. Otóż Kraków odwiedził z grupą swoich studentów wybitny archeolog, profesor Uniwersytetu Łódzkiego Konrad Jażdżewski. Byłem zauroczony jego wykładem o początkach państwa

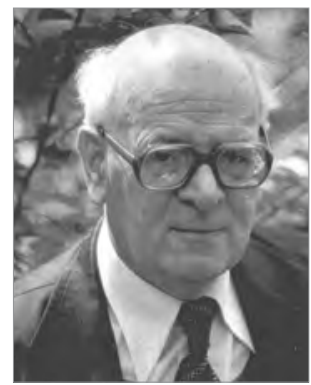

Fot. 50. Konrad Jażdżewski

${ }^{72}$ Anna Dylikowa (1912-2000) - geograf i geomorfolog. Komendantka żeńskiej komendy łódzkiej chorągwi harcerek ZHP w latach 1937-1939. Od 1965 roku profesor Uniwersytetu Łódzkiego. Żona Jana Dylika, profesora geografii na Uniwersytecie Łódzkim.

${ }^{73}$ Konrad Jażdżewski (1908-1985) - archeolog. Studia ukończył w Poznaniu pod kierunkiem prof. Józefa Kostrzewskiego; badacz prehistorii, od 1945 roku profesor Uniwersytetu Łódzkiego.

${ }^{74}$ Wojsław Molé (1989-1973) - słoweński historyk sztuki, od 1925 do 1960 (z przerwą w okresie wojennym) roku wykładał historię sztuki na Uniwersytecie Jagiellońskim. Umarł w USA, gdzie przeniósł się w 1966 roku. 
polskiego i jakoś dołączyłem do tego towarzystwa, wybrałem się nawet z nimi na objazd stanowisk archeologicznych wokół Krakowa. Brałem też udział w badaniach powierzchniowych. Zapałałem wtedy nieprzepartą chęcią przeniesienia się na archeologię, oczywiście do grupy seminaryjnej profesora Konrada Jażdżewskiego na Uniwersytecie Łódzkim.

Profesor stał się dla mnie takim jakby drugim ojcem, ponieważ - jak pani wiemojego ojca straciłem na początku drugiej wojny światowej. Z matką w czasie wojny rzadko żeśmy się spotykali, a bezpośrednio po wojnie uczęszczałem do szkoły średniej w Piotrkowie Trybunalskim do słynnego gimnazjum i liceum „Chrobrego", mieszkając u krewnych. Mama wówczas pracowała jako lekarz w Połczynie Zdroju, a następnie w Szczecinie. Byłem więc takim niby sierotą. Dla mnie więc, w tym czasie, właściwie najistotniejszą edukację nie tylko naukową, ale powiedziałbym życiową zawdzięczam profesorowi Konradowi Jażdżewskiemu. Przy każdej też okazji, czy to na konferencjach, czy innych wystąpieniach, zawsze o tym mówię i zawsze przypominam Mistrza. Bardzo wiele mu zawdzięczam. Bardzo często prosił mnie do swojej pracowni i tam dzielił się ze mną swymi przemyśleniami. Zżymał się na mnie też, bo często ośmielałem się mieć inne zdanie w różnych kwestiach. Nie to żeby nie pozwalał mieć innego zdania, bo był bardzo tolerancyjny, ale w takiej bezpośredniej wymianie myśli mawiał [zmienionym głosem]: „Ty to zawsze musisz wynajdywać jakieś „,ale”, nigdy nie możesz przyznać mi racji”. Ja na to: „Ale Panie profesorze, przecież sam pan wbija nam do głów, że konieczną cechą naukowca winna być początkowo refleksja wątpiąca (krytyczna)". Nie znaczyło to, że uczył nas jakieś złośliwego krytykowania, ale zalecał spokojny, obiektywny krytycyzm. „Jeśli się jakąś tezę bierze się na warsztat - mawiał do nas Mistrz - to pierwszą intelektualną czynnością jaką należy wykonać jest ostry atak na nią wszelkimi możliwymi antytezami. Jeśli mimo to pierwotna teza ostoi się przed kontrargumentami, to istnieje prawdopodobieństwo jej słuszności”. Więc argumentowałem Mistrzowi: ,Ja nic innego nie czynię tylko to czego nas Pan, Mistrzu nauczył” [zmienionym głosem]: „O właśnie ty zawsze znajdziesz jakieś wyjście” - ripostował. Z bardziej zabawnych sytuacji pamiętam jedną związaną z jego kłopotami zdrowotnymi z sercem. W czasie ożywionej dyskusji poczuł się gorzej i powiada: „Wiesz, dasz mi moich kropelek i ja się położę”. Miał taki fotel rozkładany. Mówi więc do mnie: „Rozłóż ten fotel, a ja się trochę położę, ale zamknij drzwi”. Więc ja na to: „Panie profesorze lepiej nie zamykać. A niech by ktoś wszedł i zobaczy rozłożoną leżankę". Reakcja Mistrza była gwałtowna: „O tak synku otwórz, otwórz szerzej drzwi” [śmiech]. 


\section{Profesora Jana Wojciechowskiego ${ }^{75}$ wspomina Jan Ziomek}

W późniejszych latach, po przejściu profesora Feliksa Różyckiego ${ }^{76}$ na emeryturę, zostałem zatrudniony, to znaczy skierowany do pracowni mineralogiczno-petrograficznej, do profesora Jana Wojciechowskiego. Profesor Jan Wojciechowski był absolwentem Uniwersytetu Stefana Batorego w Wilnie, ukończył tam chemię. Poza tym profesor Wojciechowski uczył mnie mineralogii i krystalografii. Pod okiem profesora Wojciechowskiego organizowałem szlifiernię, polernię, kupowałem mikroskopy do badań mineralogicznych i pierwsze moje prace były związane, powiedziałbym, z czystą mineralogią. Później zdecydowaliśmy z profesorem, że pracę doktorską będę pisał z kopalń rejonu łęczyckiego, dlatego że był to rejon najbliżej położony Łodzi. I to jest ten etap mojej pracy z profesorem Wojciechowskim. Chciałbym tutaj zwrócić jeszcze uwagę na to, że profesor Wojciechowski był żołnierzem Armii Krajowej, pseudonim „Kolarz”, gdyż był dywersantem, wysadzał pociągi niemieckie, które szły z bronią na wschód. Był niemile widziany, żadną polityką się nie zajmował, był człowiekiem skromnym, znającym kilka języków: niemiecki, francuski, bo wykładał w języku francuskim na Uniwersytecie w Lubumbasie [Lubumbashi] w Zairze. Miał znajomość języka niemieckiego, bo tłumaczył Złoża rud Hansa Schneiderhohna z niemieckiego. Znał język litewski, język rosyjski. Także znajomość tych języków dawała mu możliwość, bo pracował jako robotnik w Instytucie Geologicznym w Wilnie w czasie wojny i w związku z tym mógł podsłuchiwać i Litwinów, i Niemców, no i innych, którzy nie domyslali się, że robotnik Wojciechowski może znać tyle języków: i rosyjski biegle, bo tu NKWD, i język niemiecki, bo w Instytucie pracowali Niemcy. Władze tego instytutu wtedy były niemieckie. Także profesor jeździł w teren, na otwory wiertnicze, bo robił dokumentację cegielń, gdyż Niemcy potrzebowali do celów budowlanych różnych materiałów. W związku z tym niepozorny człowiek stworzył tak dużo. Jeszcze jedną bardzo ważną cechą profesora jest to, że był stypendystą uniwersytetów we Francji, w Rumunii, w Czechach, w Czechosłowacji dawnej - Słowacja i Czechy - i stamtąd miał kontakty, a poza tym przy-

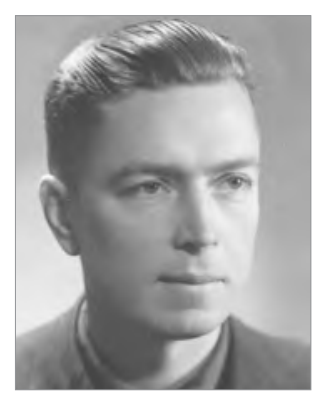

Fot. 51. Jan Wojciechowski woził minerały.

${ }^{75}$ Jan Wojciechowski (1887-1981) - geograf i geolog, profesor UŁ, pracował w Katedrze Mineralogii i Krystalografii, następnie w Katedrze Geologii prowadził pracownię mineralogiczno-petrologiczną.

${ }^{76}$ Feliks Różycki (1887-1981) - wybitny geograf i geolog. Od 1945 związany z Łodzią. Współtwórca i profesor Wydziału Matematyczno-Przyrodniczego Uniwersytety Łódzkiego. 


\section{Profesora Witolda Janowskiego ${ }^{77}$ wspomina Zbigniew Jakubowski}

Ja na przykład wspominam profesora Janowskiego, który był moim promotorem i który był głównym mistrzem moim. Przed wojną już pracował w Uniwersytecie Warszawskim, w sierpniu 1939 roku był w Zakopanem, bo lubił Tatry, tata go odnalazł, bo przyszła karta mobilizacyjna. On szukał swojej jednostki i znalazł się na Pomorzu. Dostał się potem do oflagu. Opowiadał różne rzeczy o tym oflagu, to był oflag Woldenberg 2, to jest za Krzyżem, na obecnych terenach polskich. Na szczęście dla profesora ten oflag był zarejestrowany w Międzynarodowym Czerwonym Krzyżu, więc tam Niemcy ich nie zabijali. Ale na przykład pisze się często o tym, że tam zorganizowano tajne nauczanie i między innymi były przedmioty matematyczne. Gdy oflag został wyzwolony, to przedtem jeńców Niemcy ewakuowali i na sankach można było coś zabrać, to profesor Janowski zabrał co? - ileś zeszytów, w których były wyniki egzaminów, kolokwia, jakieś inne rzeczy. Z tym przyjechał do Łodzi.

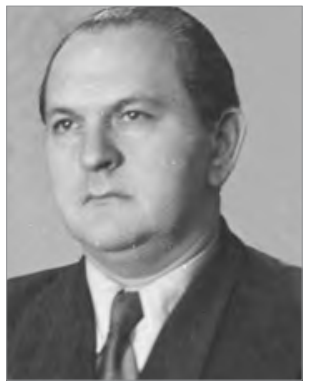

Fot. 52. Witold Janowski

\section{Profesor Annę Chrząszczewską ${ }^{78}$ wspomina Romuald Skowroński}

Pani profesor Chrząszczewska - popularna Babcia - to była niezwykle barwna postać, która działała w Wolnej Wszechnicy Polskiej przed wojną. Tutaj była jedną z twórczyń wydziału chemicznego na Uniwersytecie. Ja dopiero

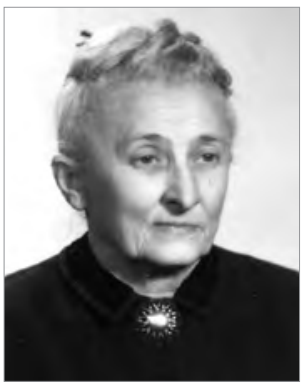

Fot. 53. Anna Chrzaszczewska potem, będąc z nią bardzo blisko, dowiedziałem się o jej działalności konspiracyjnej w Warszawie, bo ona się tym specjalnie nie chwaliła. Jej mąż był inspektorem do spraw zbrojeń w armii polskiej. Ona była drobniutka, pochodziła ze szlacheckiej rodziny wołyńskiej, natomiast Józef Chrząszczewski, jak wrócił z zachodu, w 1948 albo 1949 roku, to był bardzo przystojny wysoki mężczyzna z taką twarzą patrycjusza rzymskiego. Chrząszczewscy organizowali dla swoich najbliższych współpracowników przyjęcia w ich mieszkaniu przy Uniwersyteckiej 3, na drugim piętrze. Właśnie w okresie starania się o asystenturę dostałem wiadomość od profesor Chrząszczewskiej, że mamy kłopoty

${ }^{77}$ Witold Janowski (1912-1972) - matematyk, związany w okresie powojennym z Politechniką Łódzką, wieloletni profesor Uniwersytetu Łódzkiego, na obu uczelniach pełnił wiele funkcji naukowo-organizacyjnych, specjalista w zakresie ekstremalnych zagadnień teorii funkcji analitycznych.

${ }^{78}$ Anna Chrząszczewska (1889-1988) - chemik, specjalizująca się w chemii organicznej, od 1945 roku profesor Uniwersytetu Łódzkiego. 
z przyjęciem. Ja wtedy natychmiast wsiadłem do samolotu, bo już wtedy było połączenie lotnicze Gdańsk-Łódź. Jak na moją kieszeń to było dużo, ale przyleciałem natychmiast. Okazało się, że sekretarz partii wtedy powiedział, że nie można się zgodzić na przyjęcie mnie do pracy, bo ja jestem podejrzany, bo byłem w AK, byłem majorem AK. Cholernie byłem dumny, ja, gówniarz, bo owszem, byłem kawalerem podchorążym, a tu od razu „major AK”. Na ówczesne czasy, to był, muszę powiedzieć, niebywały akt odwagi, jaki wykazała profesor Chrząszczewska, która na Radzie Wydziału powiedziała: „Jeżeli ten młody człowiek zrobi jakieś głupstwo, to ja za niego ręczę i ja będę winna". I to oświadczenie wystarczyło, zostałem przyjęty. Profesor Chrząszczewska dała mi brulion swojego męża z takimi notatkami dotyczącymi jego działalności przed wojną, jeżeli chodzi o różne rodzaje broni, amunicji i tak dalej. To był rarytas, ale i taki wielki dowód zaufania profesor Chrząszczewskiej, że to akurat dostałem w prezencie.

Zaprezentowane w mniej lub bardziej rozbudowanej formie wspomnienia o profesorach, których nasi rozmówcy uznają za swoich mistrzów, są bardzo osobiste. Co ciekawe, wszystkie one mają wspólną cechę - w opowieść o mistrzu wplecione zostały elementy własnej, czasem nie tylko naukowej, biografii. Pokazuje to formacyjny charakter więzi, której efektem stało się dalsze twórcze i samodzielne rozwijanie zainteresowań kształtowanych wcześniej pod okiem mistrza. Jednocześnie, jak widzieliśmy w przedstawionych opowieściach, więzi te były bardzo różne - zależały od osobowości i temperamentów zarówno mistrza, jak i ucznia, zakresu wspólnych zainteresowań czy światopoglądu, stylów modelowania ucznia - od samej obecności i towarzyszenia po kierowanie rozwojem naukowym z sugerowaniem prac badawczych.

Ideałem wykładowcy uniwersyteckiego (...) byłby człowiek z jednej strony władający przedmiotem jak samodzielny myśliciel i badacz, z drugiej strony jak nauczyciel umiejący zaszczepić swoim uczniom ducha badań naukowych i przyciągnąć najbardziej uzdolnionych z nich do uczestnictwa w pracy naukowej. Do spełnienia tych warunków konieczne są: erudycja, czyli bogaty zasób wiedzy naukowej, i doskonałe opanowanie metod naukowych oraz zdolność patrzenia na rzeczy z właściwego punktu widzenia i wnoszenia w pracę naukową własnych idei. (...) Lecz jeszcze jedno trzeba założyć. Zgodnie ze znanym określeniem Katona - orator est vir dicendi peritus - profesor uniwersytetu powinien być człowiekiem wysokiej moralności, umiejącym zaszczepić w dusze uczniów wysokie dążenia, a przede wszystkim dążenie do zrozumienia istoty rzeczy, dumną 
niezależność myśli, szlachetną skromność przejawiającą się w braku pychy i próżności... ${ }^{79}$

Słowa Friedricha Paulsena, niemieckiego filozofa i pedagoga przełomu XIX i XX wieku, traktujemy jako podsumowanie tego rozdziału. Przedstawione $\mathrm{w}$ nim opowieści o mistrzach pokazują, że każda z przywołanych postaci wpisuje się w zarysowany przez Paulsena obraz, choć robi to w indywidualny, ,autorski” sposób, co również potwierdza jej wyjątkowość i charyzmę.

${ }^{79}$ Friedrich Paulsen, Die deutschen Universitäten und das Universitätsstudium, A. Asher, Berlin 1902, s. 59, cyt. za: Jan Szczepański, Socjologiczne zagadnienie wyższego wykształcenia, Państwowe Wydawnictwo Naukowe PWN, Warszawa 1963, s. 230-231. 


\section{Rozdzial III. Biografia naukowa}

W nauce to człowiek nigdy się nie czuje po fajrancie, tylko zawsze ma coś do
zrobienia. Nawet jak wróci z pracy do domu, to tam wyrywa każda godzine,
żeby usiąść przy biurku czy przy stole i czytać, pisać, notować, robić coś.

$\mathrm{Z}$ wywiadu z profesorem Romualdem Olaczkiem

W tym rozdziale spróbujemy wyodrębnić kluczowe momenty oraz najważniejsze aspekty biografii naukowej. Wyznaczały one kolejne etapy rozwoju akademickiego i osobistego oraz tworzyły codzienność pracy akademickiej. Nasi rozmówcy niemalże całe swoje życie związali z uniwersytetem i pracą naukowo-dydaktyczną. Na poprzednich stronach mogliśmy prześledzić te etapy ich życia, w których kluczową rolę odgrywał szeroko ujęty proces zdobywania wykształcenia i formacji intelektualnej. W tym rozdziale skoncentrujemy się na charakterystyce ścieżki zawodowej, która w przypadku narratorów, niezależnie od reprezentowanej przez nich dziedziny wiedzy, przebiegała według wzoru określającego karierę akademicką. Tok ich kariery został zatem ukształtowany z jednej strony przez specyficzne dla tej grupy zawodowej zasady: etos akademicki, kontekst historyczny, wymogi formalne ścieżki zawodowej, a z drugiej strony także przez wiele przygodnych czynników. Choć, jak to zostało pokazane w rozdziałach I i II, różne są środowiska społeczne, z których pochodzili rozmówcy, inne są dyscypliny nauki, którymi się zajmowali, odmienne specjalizacje, konstelacje wpływu ludzi, instytucji i osobistych wyborów, to jednak można próbować nakreślić pewną powtarzającą się sekwencję zdarzeń w ich naukowej biografii.

Co wydawać się może oczywiste, lecz warte jest podkreślenia, to to, że narratorzy brali pod uwagę i rozważali możliwość pozostania na uczelni, wiązali z nią plany własnego rozwoju naukowego oraz zawodowego i otrzymali taką możliwość. Trudno jest opisać karierę zawodową naukowca, unikając uproszczeń i rutynowych charakterystyk. Z jednej strony jest ona wpisana w szczeble awansu naukowego, podejmowane funkcje, aktywność dydaktyczną itp., z drugiej strony naznaczona jest niepowtarzalnością każdej ludzkiej biografii. Przebieg kariery akademickiej jest 
wynikiem określonych społeczno-biograficznych uwarunkowań, a kolejne progi wyznaczane są takimi formalnymi kryteriami jak: zdobywanie stopni naukowych, osiągnięcia badawcze, publikacje, wyjazdy zagraniczne, wkład w budowę i rozwój uniwersytetu itp.

We współczesnym świecie akademii wymienione kryteria stanowią pewien stały a nawet sformalizowany (jeśli weźmiemy pod uwagę konstrukcję tzw. kwestionariusza oceny pracownika) zakres aktywności naukowca. Trzeba więc zaznaczyć, że z perspektywy naszych rozmówców określone działania nie były tak oczywiste (np. wymóg ciągłego publikowania tekstów podlegających ocenie parametrycznej) ani tak łatwo osiągalne jak współcześnie (np. technologia badania, dostęp do publikacji zagranicznych). Trzeba pamiętać także, że wyjazdy zagraniczne czy udział w międzynarodowych konferencjach nie były wówczas z różnych względów, najczęściej politycznych, sprawą prostą. Te ostatnie zresztą tworzyły wiele paradoksalnych i nieoczywistych z dzisiejszej perspektywy sytuacji (będzie o nich mowa szerzej w kolejnych dwóch rozdziałach).

O ile też początkowa część biografii akademickiej związana była zazwyczaj z figurą mistrza (zob. rozdział II), to z czasem coraz większego znaczenia zaczynała nabierać rola środowiska akademickiego oraz przekazywanie wiedzy uczniom i studentom, a nawet budowa własnej szkoły naukowej. Kwestie te były podejmowane przez rozmówców zazwyczaj pod koniec narracji, kiedy chcieli pokazać sposoby uwieńczenia swojej naukowej biografii. Warto w tym miejscu odnotować, że nie były to wyłącznie opowieści o spełnieniu i sukcesie, ale także o wątpliwościach i trudnościach wynikających na przykład z konieczności wycofania się z życia akademickiego. Uwieńczeniem kariery nie zawsze stawała się profesura czy stanowiska kierownicze, które można uważać za społecznie uznawane kryteria sukcesu zawodowego. Wśród zebranych narracji kilka z nich należy do osób, które poświęciły swoje naukowe życie dydaktyce, budowie instytucji czy nawet uczelnianej infrastruktury, w konsekwencji mniej uwagi poświęcając prowadzeniu własnych badań.

W niniejszym rozdziale przedstawiamy zatem początki kariery akademickiej, odwołując się do opowieści o momencie podjęcia pracy na uniwersytecie. Punktem zwrotnym przesądzającym o wkroczeniu na ścieżkę naukowej biografii był zazwyczaj moment zatrudnienia na uczelni, a przynajmniej otrzymanie takiej propozycji - otwarte konkursy nie były wówczas metodą rekrutacji. W okresie powojennym, w latach czterdziestych, pięćdziesiątych i sześćdziesiątych, kiedy nasi rozmówcy rozpoczynali pracę naukową, bezpośrednia propozycja zatrudnienia na uczelni 
składana przez profesora była właściwie jedyną drogą wkroczenia w świat nauki. Nie znaczy to jednak, że zawsze było to przejście łatwe i przedstawiane jako naturalne. Wręcz przeciwnie, okres przed rozpoczęciem regularnej pracy na uczelni bywał dla narratorów i ich rodzin czasem wielu wątpliwości.

Także pierwsze lata pracy nie były ich pozbawione. Był to czas, kiedy nasi rozmówcy musieli sprostać różnym, często niespodziewanym i trudnym wyzwaniom - dla ich opisu używamy metafory „bycia rzuconym na głęboką wodę". Od młodych pracowników naukowych wymagano wówczas daleko idącej samodzielności i odpowiedzialności w prowadzeniu badań naukowych i zajęć dydaktycznych. Nie bez znaczenia jest tu trudna sytuacja powojenna (i jej szczególny kontekst polityczny, społeczny, a także kulturowy), w której naszym rozmówcom przyszło rozpoczynać pracę na Uniwersytecie Łódzkim. Wymagała ona od nich często ogromnej dozy uporu, pomysłowości, dyscypliny, a nawet odwagi.

Kierując się logiką opowieści naszych rozmówców, pokażemy dalej rolę środowiska naukowego jako naturalnej przestrzeni społecznej dla rozwoju naukowego, intelektualnego oraz prowadzenia badań itp. Relacja z mistrzem, jak pokazał rozdział II, pozostawała często istotnym, a nawet najważniejszym punktem odniesienia, ale szerokie sieci kontaktów, grupy dyskusyjne, wspólne badania stanowiły równie znaczącą ramę działalności naukowej. Przedstawiane tu uniwersyteckie biografie ujawniają zarówno wpływ przedwojennych środowisk i nestorów danej dyscypliny, jak i znaczenie badaczy z tego samego pokolenia, pracujących także poza ich macierzystymi katedrami czy instytutami.

Sama działalność naukowa, to znaczy wybrana tematyka i podejmowane czynności badawcze determinowały codzienność życia naukowego. Jego rozwój przedstawiamy zatem poprzez przykłady opowieści o zainteresowaniach badawczych i teoretycznych - niektóre z nich zadziwiały drobiazgowością i skrupulatnością opisu, inne jedynie skrótowo charakteryzowały pole zainteresowań. Co interesujące, fragmenty dotyczące treści badań nie zajmowały tyle miejsca, co te dotyczące ich formy. Nie powinno to dziwić, jeśli weźmiemy pod uwagę, że charakterystyka przedmiotu zainteresowań czy stosunkowo wąskiego zakresu specjalizacji często wymaga niezbędnego profesjonalnego żargonu, znanego obojgu uczestnikom wywiadu - a ten warunek nie zawsze był w naszych rozmowach spełniony. Nie jest chyba do końca prawdą, że wszystko da się opisać w sposób zarówno krótki jak i przystępny. 
Bardzo ważnym elementem życia akademickiego - o czym niejednokrotnie wspominają nasi rozmówcy - był i jest kontakt ze światem nauki także poza granicami kraju, dlatego osobny podrozdział poświęcimy podróżom zagranicznym. Nauka to także komunikacja - wymiana pomysłów, ciągłe aktualizowanie stanu badań i dostępnej wiedzy oraz dyskusje i polemiki.

Wreszcie, w końcowych partiach tego rozdziału przedstawimy passusy dotyczące uczniów i studentów. Taki podział wyłonił się z samych wywiadów, w których narratorzy wyraźnie odróżniali dziesiątki słuchaczy wykładów czy uczestników ćwiczeń od węższego grona własnych uczniów. $\mathrm{Ci}$ ostatni to osoby, które nasi rozmówcy niejako wyłaniali z tłumu, otaczali szczególną opieką, włączali we własne prace badawcze, wspierali ich zainteresowania naukowe i pasje poznawcze, czasem nawet widzieli jako swoich następców i kontynuatorów. Jak wiele poprzednich etapów biografii naukowej, także i ten nie był wolny od wątpliwości, napięć i utraconych nadziei.

\section{Początki pracy naukowej}

W przypadku niektórych narratorów, przede wszystkim pierwszego pokolenia absolwentów Uniwersytetu Łódzkiego, praca na uczelni często zaczynała się jeszcze w okresie studiów. Ówczesne środowisko naukowe - a mowa tu o drugiej połowie lat czterdziestych, a nawet latach pięćdziesiątych - mierzyło się z tragicznymi konsekwencjami II wojny światowej, które manifestowały się w niedoborze kadry akademickiej i ogromnych niedostatkach materialnych (lokalowych, wyposażeniowych, książkowych). Z pewnością był to jeden z najważniejszych czynników wpływających na tak ogromny popyt na specjalistów w odbudowującym się i rozwijającym kraju, o których zresztą rywalizowały stare i nowe ośrodki akademickie. Industrializacja i urbanizacja oraz pierwsze próby stworzenia masowego systemu szkolnictwa wyższego spowodowały, że - zwłaszcza w dziedzinach badań związanych z przemysłem i edukacją - istniało potężne zapotrzebowanie na wykładowców i dydaktyków.

Jeszcze w latach pięćdziesiątych brakowało osób, które mogłyby prowadzić zajęcia z zakresu nauk ścisłych i dlatego zdolnym studentom szybko powierzano obowiązki dydaktyczne i zatrudniano ich na uczelni. Tak było w przypadku matematyków, o czym opowiadają kolejno Zbigniew Jakubowski oraz Ryszard Jajte: 


\section{Zbigniew Jakubowski:}

To jest 15 sierpnia 1954 roku: profesor Charzyński i Janowski ${ }^{1}$, nas kilkoro zatrudniają na Politechnice Łódzkiej. To jest między innymi Tadek Świątkowski, Włodek Waliszewski, Heniek Taładaj, Rysiek Guzek², i ja Zbyszek Jakubowski. My jesteśmy na czwartym roku, czyli na ostatnim, do lutego pełnimy obowiązki asystentów. W lutym, mimo że nie mamy magisterium, ówczesne rady wydziału zatrudniają nas na stanowisku asystenta. W czerwcu bronimy prace magisterskie, pozostajemy nadal na Politechnice i w 1961/62 roku wchodzi ustawa czy zarządzenie ministra, trudno mi jest powiedzieć, zakazująca dwóch miejsc pracy. Profesorowie mają czas na decyzję. I teraz co robi profesor Charzyński i Janowski? Zostawiają Politechnikę Łódzką i przenoszą się na Uniwersytet. I teraz doktorantka wie [zwracając się do swojej rozmówczyni], że jak profesor się przeniesie, to lepiej się przenieść z profesorem. To raz. A dwa, matematyka jest tu na Uniwersytecie Łódzkim, tam [na Politechnice Łódzkiej] wówczas matematyki nie było jako kierunku, był tylko przedmiot. Dla osoby, która ma ambicje i chce się kształcić jako matematyk, to prowadzenie zajęć na kierunkach matematycznych było korzystniejsze. I w 1962 roku ja przeszedłem na pełen etat na Uniwersytet.

Ryszard Jajte:

Zaraz po egzaminie magisterskim przyjęty zostałem jako asystent. Z tym, że jeszcze rok wcześniej, będąc na studiach, pracowałem na Politechnice. Ponieważ nie mogłem być asystentem, byłem pomocnikiem asystenta, tak to się wówczas nazywało. To był zakład, który stworzył profesor Włodarski ${ }^{3}$, tam pracował również profesor Zygmunt Zahorski ${ }^{4}$ W tym zakładzie pracowali moi koledzy. I to nie był zakład dydaktyczny, tylko zakład usługowy stworzony

${ }^{1}$ Zygmunt Charzyński (1914-2001) - matematyk, profesor Uniwersytetu Łódzkiego, wieloletni kierownik Zakładu Funkcji Analitycznych i Równań Różniczkowych Instytutu Matematyki Uniwersytetu Łódzkiego; Witold Janowski (1912-1972) - matematyk, związany w okresie powojennym z Politechniką Łódzką, wieloletni profesor Uniwersytetu Łódzkiego, na obu uczelniach pełnił wiele funkcji naukowo-organizacyjnych, specjalista w zakresie ekstremalnych zagadnień teorii funkcji analitycznych.

2 Tadeusz Świątkowski (1933-1994) - matematyk specjalizujący się w funkcjach rzeczywistych, absolwent Uniwersytetu Łódzkiego, uczeń Zygmunta Zahorskiego, pracę rozpoczął na Politechnice Łódzkiej, gdzie został profesorem. Włodzimierz Waliszewski (1934-2014) - matematyk, profesor Uniwersytetu Łódzkiego. Henryk Taładaj - matematyk, prowadził ćwiczenia z matematyki na Politechnice Łódzkiej. Ryszard Guzek - matematyk, pracownik naukowy Politechniki Łódzkiej.

${ }^{3}$ Lech Włodarski (1916-1997) - matematyk, absolwent Uniwersytetu Poznańskiego, w 1945 roku podjął pracę równolegle na Uniwersytecie Łódzkim oraz Politechnice Łódzkiej, w pierwszym miejscu pracował do przejścia na emeryturę, w drugim do 1958 roku. Specjalizował się w analizie funkcjonalnej.

${ }^{4}$ Zygmunt Zahorski (1914-1998) - matematyk, uczeń Stefana Banacha, jednego z twórców lwowskiej szkoły matematycznej, profesor Uniwersytetu Łódzkiego. 
dla inżynierów, którzy chcieliby skorzystać z pomocy. Dla mnie było to wielkie wyzwanie, bo musiałem się pilnować, żeby się nie skompromitować, że jestem w zakresie matematyki źle wykształcony.

Podjęcie pracy jeszcze w okresie studiów wiązało się często z koniecznością prowadzenia zajęć dla równolatków, a nawet osób starszych, co - jak poniżej pokaże Zbigniew Jakubowski - wymagało negocjowania swoistej relacji ze studentami. Swoją opowieść wieńczy on jednak anegdotycznie, opowiadając o tym, jak upływ czasu nie zmienił jego nastawienia do słuchaczy w czasie, gdy on sam był już znacznie starszy, a studenci rekrutowali się z idących normalnym trybem edukacyjnym roczników:

Nas profesorowie zatrudnili na Politechnice już na czwartym roku, dlatego że po prostu było dużo kandydatów na studia. Oni byli starsi od nas, ale chcieli się uczyć, a często mieli braki. W związku z tym przygotowałem taką wypowiedź, którą uznałem za bardzo dobrą: „Drodzy, przepraszam was bardzo, bo widzicie, że jestem bardzo młody, ale ja bym chciał, żeby były między nami stosunki koleżeńskie, ale wymagający będę". I coś jeszcze dodawałem o tym, że część osób to straciła dużo w czasie wojny. W którymś momencie na studiach wieczorowych na Politechnice powtarzam to, patrzę i myślę sobie: „Zbyszku, coś jest nie tak”. Bo cała moja wypowiedź dla nich jest niezrozumiała. A dlaczego? Bo mnie przybyło te siedem lat, a przyszły roczniki w miarę normalne, więc ja im się thumaczyłem, że jestem dla nich za młody, a byłem już od nich starszy.

Prowadzenie zajęć ze studentami stanowiło chrzest bojowy dla niejednego młodego naukowca. Owo ,wrzucenie na głęboką wodę" było sprawdzianem jego umiejętności nie tylko przez przełożonego (często mistrza), ale też przez niego samego. Właśnie tej metafory używa Władysław Welfe, opowiadając o początkach swojej pracy dydaktycznej i zatrudnieniu na uczelni:

Okazało się, że pan profesor Rosset ${ }^{5}$, w owym czasie jeszcze nie członek Akademii, ale już bardzo znany statystyk i demograf, zainteresował się mną. Na Wydziale Prawa prowadził zajęcia ze statystyki i mnie, studentowi czwartego roku powierzył taką asystenturę, wolontariat. Muszę powiedzieć, że to była nauczka na całe życie, którą „odsprzedawałem” potem moim młodszym kolegom, polegająca na tym, że na czwartym wykładzie pan profesor się nie zjawił. Dzwonię, pytam się: „Co się dzieje?”. „Ach, panie Władysławie, źle się czuję, niech pan sam poprowadzi te zajęcia". I od tego czasu prowadziłem zajęcia sam. Także zostałem „wrzucony na głęboką wodę" i jakoś się z tej wody

${ }^{5}$ Edward Rosset (1897-1989) - demograf, związany z Łodzią już w międzywojniu jako naczelnik Wydziału Statystycznego Zarządu Miejskiego, później profesor Uniwersytetu Łódzkiego, członek PAN, organizator i wieloletni redaktor „Studiów Demograficznych”. 
wydostałem, dlatego że w następnym roku zostałem już przyjęty do Wyższej Szkoły Ekonomicznej, gdzie profesor Rosset miał katedrę, i tak zostałem najpierw asystentem, a potem szybko adiunktem, przeskoczywszy chyba starszego asystenta. Także tak się zaczęła moja kariera akademicka.

Zazwyczaj jednak warunkiem podjęcia pracy na uczelni był stopień magistra. Wyróżniający się studenci przyciągali uwagę profesorów, a podczas seminariów magisterskich rodziły się już często relacje mistrz-uczeń. Jednak, jak pokazuje przypadek Stanisława Liszewskiego, nie zawsze było tak, że tylko mistrzowie chcieli zatrudniać swoich zdolnych uczniów. Czasem musieli oni niemalże konkurować z innymi profesorami:

Napisałem pracę magisterską na temat, na który chciałem napisać, to znaczy o rozwoju sieci dróg $\mathrm{w}$ województwie łódzkim. To była na tyle interesująca praca, że potem ją opublikowano w dwóch artykułach w centralnych czasopismach. Po zakończeniu studiów i magisterium, które zdawałem na ulicy Curie-Skłodowskiej $11 \mathrm{w}$ tym pałacyku, w którym była siedziba instytutu całego rozstaliśmy się z profesorem Straszewiczem ${ }^{6}$. Ja chyba dwa dni później miałem telefon od profesora Wereszyńskiego ${ }^{7}$ z Politechniki Łódzkiej, który był geodetą, a na geografii wykładał geodezję i astronomię, $\mathrm{z}$ ofertą podjęcia pracy na Politechnice, w geodezji. Wtedy poprosiłem, żeby dał mi szansę do zastanowienia się. I profesor powiedział: „Dobrze, to ja za tydzień do pana zatelefonuję" - czy „pan do mnie”, już nie pamiętam. I w tym właśnie tygodniu znalazł mnie mój profesor Ludwik Straszewicz i mówi: „Panie Staszku, mam dla pana etat, czy pan by podjął pracę?”. Oczywiście wybór był jednoznaczny, pani rozumie.

Scenariusz, w którym rozpoczęcie pracy w akademii jest przedłużeniem etapu studiowania i następuje niemalże zaraz po obronie pracy magisterskiej, stanowi - można powiedzieć - idealny i pożądany przez wielu rozwój sytuacji. W taki właśnie bezproblemowy, związany z możliwością kontynuacji pracy badawczej sposób zatrudnienie na uczelni uzyskał Jan Ziomek:

Po ukończeniu studiów, napisaniu pracy magisterskiej na temat Budowa geologiczna pólnocnej części Łęczycy ze szczególnym uwzględnieniem stratygrafii pod kierunkiem profesora Feliksa Różyckiego ${ }^{8}$, egzamin magisterski zdałem 25 czerwca 1958 roku. Po zdaniu egzaminu profesor Różycki zaproponował

${ }^{6}$ Ludwik Straszewicz (1916-1987) - ekonomista, geograf, od 1956 roku związany z Uniwersytetem Łódzkim, założyciel Oddziału Łódzkiego Polskiego Towarzystwa Urbanistycznego.

${ }^{7}$ Jan Stanisław Wereszyński (1914-1991) - geodeta, kierownik Katedry Geodezji, Kartografii Środowiska i Geometrii Wykreślnej Politechniki Łódzkiej.

${ }^{8}$ Feliks Różycki (1887-1981) - geograf i geolog. Od 1945 związany z Łodzią. Współtwórca i profesor Wydziału Matematyczno-Przyrodniczego Uniwersytety Łódzkiego. 
mi pracę w Zakładzie Geologii nr 2, na stanowisku laboranta. I od tej pory, bo zatrudniony zostałem 1 października 1958 roku, a dziś jest już rok 2012, bez przerwy pracuję w Uniwersytecie Łódzkim.

Swoją przyszłość z uczelnią wiązał już w czasie studiów geograficznych Romuald Olaczek - pragnął zostać w instytucie, którym kierował jego promotor. Ten jednak, ze względów, których narrator nie chciał ujawnić, nie dał mu takiej możliwości. Cień żalu i rozgoryczenia wobec owego profesora pozostaje nadal żywy, co widać w poniżej cytowanym fragmencie. Jednak szczęśliwie dla naszego rozmówcy pracę na uniwersytecie zaproponował mu profesor Jakub Mowszowicz ${ }^{9}$ - biolog i botanik. Dla Romualda Olaczka oznaczało to konieczność zmiany profilu naukowego i uzupełnienia wiedzy:

Kończąc studia, miałem chęć i nadzieję, że zostanę zatrudniony w Instytucie Geografii, ale stało się inaczej. Nie będę się zwierzał, dlaczego. Profesor, u którego pisałem pracę magisterską, nie żyje już od lat, inni także. Powiem nieskromnie, że poznał się na mnie profesor Mowszowicz i on mi zaproponował pracę. Jakoś życie wtedy biegło szybko, było bardzo intensywne. Miałem 23 lata, byłem już po studiach, żonaty, z dwójką dzieci. [Opowiada o przychodni, do której chodził z synem i właśnie tam rozegrała się scena, o której mówi dalej]. Drewniane schody i słyszę za mną człapanie, tupot po schodach i sapanie. Profesor Mowszowicz był dosyć korpulentnym starszym panem. Widział mnie, jak szedłem z dzieckiem, gonił mnie i na tych schodach przychodni na Moniuszki: „Panie kolego, ja właśnie dostałem etat, czy pan by nie chciał się u mnie zatrudnić?" [śmiech]. Nie wiedziałem, czy się cieszyć, czy dziękować. Podziękowałem profesorowi, powiedziałem, że się najpierw porozumiem z żoną i dam mu odpowiedź. Żona już była po studiach, już miała pracę. Zgodziłem się i od 1 maja 1956 roku miałem zatrudnienie, jeszcze przed moim egzaminem magisterskim nawet. Tak zacząłem pracę w Katedrze Systematyki i Geografii Roślin, krótko mówiąc w Katedrze Botaniki, nie mając o botanice, o roślinach pojęcia. Bo akurat w mojej kochanej szkole pedagogicznej w Łowiczu biologii uczył entuzjasta, ale wzbudzał entuzjazm, natomiast niespecjalnie pogłębiał wiedzę [śmiech]. Miałem obeznanie z przyrodą takie, że w dzieciństwie i w młodości dużo czasu spędzałem nad rzeką, w lesie. Przyrodę znałem, rozumiałem, ale nie umiałem jej nazywać. A botanika to jest przede wszystkim umiejętność rozpoznawania i nazywania roślin oraz wiedzy o biologii tych roślin. Przez wakacje trochę się już sam dokształciłem,

${ }^{9}$ Jakub Mowszowicz (1901-1983) - urodzony w Wilnie biolog i botanik, profesor Uniwersytetu Łódzkiego. Doktorat uzyskał na tamtejszym Uniwersytecie Stefana Batorego. Badał florę regionu łódzkiego. Był jednym z założycieli łódzkiego Ogrodu Botanicznego. Przez wiele lat sprawował funkcję dziekana Wydziału Biologii i Nauki o Ziemi na Uniwersytecie Łódzkim. 
po wakacjach zacząłem uczestniczyć w zajęciach. W katedrze profesora pracowały dwie jego koleżanki, jeszcze z Wilna, pani magister Anna Niekrasz i pani mgr Helena Pekszyna. Obie mi sporo pomogły. One prowadziły ćwiczenia, ja byłem pomocnikiem, przy nich się uczyłem. Po jakimś czasie już trochę tej wiedzy botanicznej opanowałem, więc z kolei ja prowadziłem ćwiczenia, a przy mnie młodsi się kształcili.

Jeszcze bardziej skomplikowane były losy młodej absolwentki prawa Biruty Lewaszkiewicz-Petrykowskiej. W przypadku jej naukowej biografii kontekst polityczny odegrał ważną, jeśli nie kluczową rolę. Ze względu na orientację światopoglądową oraz śmiałe i krytyczne wypowiedzi naszej rozmówczyni dotyczące nowej organizacji państwa przyjazd z Krakowa (uważanego za wyjątkowo nieprzychylny nowym władzom ośrodek akademicki) do Łodzi i podjęcie pracy na „robotniczym uniwersytecie” były swoistą ,ucieczką do przodu":

Zaraz po ukończeniu studiów, profesor Szpunar ${ }^{10}$ zaproponował mi przejście do Łodzi. Szpunar był moim profesorem w Krakowie. Sytuacja wyglądała następująco: na drugim roku Szpunar prowadził wykład z części ogólnej prawa cywilnego, na trzecim roku utworzono z nas, studentów, wyselekcjonowaną, z tych co bardzo dobrze się uczyli, jedną grupę ćwiczeniową około dwudziestoosobową. Dostaliśmy świetną obsadę prowadzących z nami ćwiczenia. Szpunar prowadził, już jako docent, ćwiczenia z prawa cywilnego dla nas. Koniec moich studiów w Krakowie zbiegł się z okresem, w którym władze rozpoczęły rozsiedlanie profesury UJ. ${ }^{11}$. Trzeba pamiętać że po wojnie na Uniwersytecie Jagiellońskim, mówię o prawie, znalazło się wielu profesorów ze Lwowa, z innych miast. Rozpoczęto przesuwanie profesury do innych ośrodków, Wrocław, Toruń, Łódź itd. Jednocześnie na uniwersytecie a w pewien sposób również w mieście, panowały nienajlepsze, że tak powiem, nastroje. Wiązało się to z historią 3 maja $1946 \mathrm{r}$. i z tym, co się działo po 3 maja 1946 roku $^{12}$. Tak czy owak ja wprawdzie miałam propozycję pozostania w Krakowie, ale

\footnotetext{
${ }^{10}$ Adam Szpunar (1913-2002) - profesor prawa, specjalista w zakresie prawa cywilnego, w latach 1956-1962 rektor Uniwersytetu Lódzkiego.

${ }^{11} \mathrm{~W}$ okresie powojennym, wraz z nastaniem stalinizmu, działania władz centralnych były szczególnie skoncentrowane na ośrodku akademickim w Krakowie, uchodzącym wówczas za najbardziej zwarte i sceptycznie nastawione wobec nowego porządku środowisko naukowe.

123 maja 1946 roku w Krakowie studenci Akademii Górniczo-Hutniczej, chcąc uczcić dzień uchwalenia Konstytucji 3 maja, wyruszyli za zgodą rektora, na Mszę św. do Kościoła Św. Anny. Po mszy pokojowy pochód ruszył w stronę Collegium Novum i został zablokowany przez funkcjonariuszy UB. Doszło do krwawego starcia między milicją a studentami. Marsz został rozpędzony. Między innymi UB wdarło się do jednego z Domów Akademickich, aresztując wszystkich obecnych. Tego dnia zatrzymano w Krakowie ponad 2 tysiące osób, przed sądem stanęło 12 osób - Proces 12. Kraków 3 maja 1946, Wydawnictwo Maraton, Warszawa 1984.
} 
żadnych szans na jej realizację, ponieważ miałam nienajlepszą opinię polityczną [śmiech]. I taką też opinię o mnie tutaj przysłali [śmiech], śmiać się można teraz z tego wszystkiego. Tak czy owak, Szpunar zaproponował mi, żebym przyjechała do Łodzi. Ja z Krakowem nie byłam związana, bo się wprawdzie urodziłam w Krakowie, ale nigdy tam, poza studiami, nie mieszkałam. Było mi nieco wszystko jedno. Rodzice moi mieszkali wtedy we Wrocławiu. Przyjechałam przeto do Lodzi. A tu Uniwersytet i nasz wydział były właściwie w stanie tworzenia. Pamiętam, że dziekanem był wtedy profesor Namitkiewicz $^{13}$. Profesor Namitkiewiecz był specjalistą z zakresu prawa handlowego. W okresie międzywojennym pracował naukowo na Uniwersytecie Warszawskim, był profesorem, a od 1932 r. także sędzią Sądu Najwyższego. U niego się zameldowałam po raz pierwszy, żeby się przedstawić. Jak weszłam do dziekanatu, do jego gabinetu, to Namitkiewicz krzyknął: „Ależ pani jest nieprzyzwoicie młoda!" [śmiech]. Ja zawsze wyglądałam na mniej lat niż miałam w rzeczywistości. Ale w każdym razie tu mnie przyjęli.

Nie wszyscy jednak zaraz po studiach rozpoczynali karierę uniwersytecką. Często kilka pierwszych miesięcy czy lat po uzyskaniu tytułu magistra pracowali w takich miejscach jak np. szkoły czy biblioteki. Dla jednych był to świadomy wybór, dla innych konieczność wynikająca z braku możliwości zatrudnienia na uczelni. O tym pierwszym wypadku opowiada Michał Seweryński:

Pod koniec studiów otrzymałem propozycję od jednego z profesorów naszego Wydziału, żeby zostać asystentem, ale odmówiłem, bo uważałem, że nie mam do takiej pracy dostatecznych kwalifikacji, zwłaszcza językowych. Poszedłem więc z kilkoma kolegami na aplikację prawniczą w prokuraturze, bo ta była relatywnie krótka, a ponadto interesowała mnie procedura karna, z której zrobiłem magisterium. Kiedy jednak zobaczyłem z bliska komunistyczny wymiar sprawiedliwości, to od razu wiedziałem, że to praca nie dla mnie. Myślałem więc, żeby po aplikacji przenieść się do zawodu radcy prawnego, wykonywanego w jakimś przedsiębiorstwie. Na szczęście, krótko po aplikacji dostałem stypendium doktoranckie i z ulgą przeniosłem się na Uniwersytet Łódzki. Po studiach doktoranckich, które zakończyłem doktoratem w roku 1969, nie było gwarancji zatrudnienia na uczelni, ale ja już sobie nie wyobrażałem innego zajęcia niż praca naukowa. Co więcej, w czasie studiów doktoranckich wpływ profesora Szuberta ${ }^{14}$ na moje zainteresowania i poglądy bardzo się umocnił, bo imponował mi nie tylko jako uczony, lecz także jako człowiek - swoim pięk-

${ }^{13}$ Jan Namitkiewicz (1880-1958) - prawnik i sędzia, profesor na Uniwersytecie Łódzkim i dziekan Wydziału Prawno-Ekonomicznego w latach 1948-1950.

${ }^{14}$ Wacław Szubert (1912-1994) - prawnik, specjalista prawa pracy, profesor Uniwersytetu Łódzkiego, dziekan Wydziału Prawa w latach 1953-1955 oraz 1965-1969. 
nym życiorysem i godną postawą wobec trudnych wyzwań, przez które Uniwersytet Łódzki przechodził. Bardzo chciałem więc pracować dalej pod jego kierunkiem. Ostatecznie, dzięki zdecydowanemu poparciu profesora Szuberta, wówczas dziekana Wydziału Prawa i Administracji UŁ, pomimo poważnych zastrzeżeń ze strony wydziałowych władz partyjnych - byłem bezpartyjny dostałem etat asystenta na tym Wydziale.

Jak zatem widzieliśmy, podobnie jak w wypadku Biruty Lewaszkiewicz-Petrykowskiej, także w przebiegu kariery Michała Seweryńskiego konteksty polityczne miały niebagatelne znaczenie.

Jak to ilustruje biografia Ryszarda Panasiuka, zapotrzebowanie na absolwentów uniwersytetów w Polsce w połowie lat pięćdziesiątych nie malało. Po napisaniu pracy magisterskiej skorzystał on z możliwości podjęcia pracy na Uniwersytecie im. Marii Curie-Skłodowskiej w Lublinie. W jego przypadku o powrocie do Łodzi zdecydowały względy rodzinne:

Pod sam koniec studiów był już taki nastrój wyraźnej rewolty intelektualnej. Ale co potem? Nie bardzo było wiadomo. Różni chłopcy poszli do jakiejś tam działalności politycznej, a ja nie bardzo wiedziałem, co robić. Ale profesor Kotarbiński ${ }^{15}$ otrzymał list od profesora Łubnickiego ${ }^{16} \mathrm{z}$ Lublina, czy nie miałby kogoś do nauczania logiki. Więc zapytałem profesora, czy jak bym mógł się nadawać. A on mówi: „Ależ oczywiście!”. Pojechałem więc do Lublina i tam byłem z półtora roku i uczyłem logiki, ale ponieważ moja małżonka, która jest lekarzem, mieszkała w Lodzi, to w pewnym momencie doszedłem do wniosku, że tam nie ma co robić i przyjechałem do Łodzi. Po jakimś czasie zostałem asystentem na Wydziale Filozoficzno-Historycznym.

Czasem losy przyszłych profesorów były bardziej skomplikowane i obejmowały szereg różnych doświadczeń zawodowych, związanych co prawda z profilem wykształcenia, ale niekoniecznie z akademickim charakterem kariery. Tak właśnie było w przypadku Wandy Nowakowskiej:

Po studiach od razu wskoczyłam w pierwszą pracę zawodową w Muzeum Sztuki. Zaczęły się zawodowe sprawy, jak pamiętam. To był już etap kompletnie inny, przerażająco dla mnie wtedy samodzielny, bo to był dział oświatowy i trzeba było oprowadzać wycieczki. To się dla mnie zaczęło w Muzeum w momencie, kiedy tam były takie szkolenia dla nas, robił je dyrektor z kustoszami -. takie seminaria naukowe. On mnie zainteresował twórczością Stanisława Witkiewicza, ojca, nie Witkacego, i ja tam przygotowałam referat. Zaczęło

${ }^{15}$ Tadeusz Kotarbiński (1886-1981) - profesor filozofii, logik, współzałożyciel Uniwersytetu Łódzkiego i pierwszy rektor uczelni.

${ }^{16}$ Narcyz Lubnicki (1904-1988) - filozof, profesor Uniwersytetu im. Marii Curie-Skłodowskiej w Lublinie, specjalizował się w historii filozofii i metodologii nauki. 
mi się to podobać. To był początek naukowych rzeczy. Jednocześnie wiązało się to też z przygotowywaniem wystaw, scenariuszy wystaw. Zaczęłam pisać artykuły i pamiętam pierwszy naukowy, który napisałam nosił tytuł: Stanisław Witkiewicz w listach do Henryka Sienkiewicza i innych. Wysłałam go do „Życia Literackiego". I pamiętam, jak przyszła odpowiedź, że: tak, będzie wydrukowane! Wtedy pamiętam, jak weszłam do kiosku i na pierwszej stronie było: „Wanda Nowakowska, Stanistaw Witkiewicz...” i tak dalej. Kupiłam wszystkie egzemplarze, jakie były w tym kiosku, poszłam do następnego, kupiłam wszystkie! A za całe honorarium nabyłam u modystki 6 kapeluszy... I potem już zaczęłam drukować naukowo i zaczęłam myśleć o doktoracie z tego Witkiewicza. Później była już książka, której się wstydziłam kupować. Dostałam jakieś egzemplarze autorskie, ale mi ich zabrakło, więc poszłam do księgarni i jak mam powiedzieć: „Poproszę książkę Wandy Nowakowskiej”?

W przedstawionym fragmencie widać stopniowe zbliżanie się narratorki do pola naukowego. Po wypróbowaniu różnych zajęć decyduje się ona rozwijać samodzielnie swoje zainteresowania naukowe. W jej wypadku publikacja artykułu naukowego stała się punktem zwrotnym i stanowiła pretekst do przemyślenia planów związanych z biografią zawodową. Wanda Nowakowska ostatecznie zdecydowała się na podjęcie pracy nad doktoratem, który przygotowywała jako asystent w Państwowej Wyższej Szkole Teatralnej i Filmowej, wykładając jednocześnie na obecnej Akademii Sztuk Pięknych oraz Akademii Muzycznej w Łodzi, a po jego obronie została zatrudniona na Uniwersytecie Łódzkim.

Pierwsze kroki naukowe, o czym już kilkakrotnie mogliśmy się przekonać, oznaczały podjęcie szczególnego wyzwania - tak było zarówno w przypadku konieczności wypełniania obowiązków dydaktycznych, jak i realizacji pierwszych projektów naukowych. Od młodego pracownika naukowego wymagano dojrzałości, samodzielności i zaradności. Wątek „sprostania zadaniu i oczekiwaniom” pojawia się w wielu narracjach i zazwyczaj zostaje przedstawiony jako pokonanie wielu piętrzących się przeszkód, które - choć początkowo wydają się ogromne - zostają pokonane. Dodatkowym motywem jest tu na ogół brak doświadczenia czy dostatecznej wiedzy. Wszystkie te niedociągnięcia zostają jednak szybko opanowane przez naszych rozmówców, co przekonuje ich zazwyczaj o dobrym przygotowaniu do pełnienia trudnych obowiązków i utwierdza w słuszności dokonanego wyboru.

Przyjrzyjmy się jednej z takich relacji, w której Jerzy Kmieciński opisuje wyzwania, przed jakimi musiał stanąć jeszcze jako student archeologii. Powierzono mu wówczas samodzielne prowadzenie wykopalisk 
i nadzorowanie dość trudnej grupy pracowników. Cała historia zaczęła się niewinnie:

Latem 1949 roku zaczęliśmy badania wielokulturowego, skomplikowanego metodycznie, stanowiska archeologicznego w Lutomiersku pod Łodzią. Profesor Jażdżewski wystarał się o dotację na badania z Urzędu Miejskiego w Konstantynowie. Burmistrz Konstantynowa zastrzegł jednak, że ta dotacja ma być zużytkowana na paromiesięczne opłacenie 60 bezrobotnych z Konstantyno$\mathrm{wa}^{17}$. Kierownictwo pracami powierzył nasz Mistrz Olkowi Gardawskiemu ${ }^{18}$, wówczas świeżo upieczonemu magistrowi i asystentowi Zakładu Prehistorii UŁ. Do pomocy Olkowi dodał Mistrz mnie, adepta archeologii po jednym semestrze studiów na kierunku archeologia. Zamieszkaliśmy w starym drewnianym budynku szkolnym, wtedy już nieużywanym. Po pierwszym dniu badań Olek Gardawski oświadczył mi, że on nazajutrz zaczyna pracę w Państwowym Muzeum Archeologicznym w Warszawie, a mnie zostawia, abym dalej prowadził badania. Świeć Panie nad Jego Duszą, ale tchórzyła nic nie powiedział Mistrzowi, że zostawia ekspedycję w trudnej sytuacji. Mistrz Jażdżewski przyjechał co prawda za kilka dni. Pienił się straszliwie i wykrzykiwał: „Ja go tutaj urządzę! Ja go nauczę! Ja mu pokażę!”. Ale finał awantury był taki, że Mistrz oświadczył: „Ty, synku już badałeś ze mną Gdańsk, to dasz sobie radę. Rzucam cię na szerokie wody" i pojechał. Ja tymczasem zostałem z 60-osobową grupą kieszonkowców, sutenerów, recydywistów, panienek z zawodem najstarszym w świecie, do tego jeszcze z 20 robotnikami z Lutomierska (też podejrzanej konduity). Dałem sobie radę. Z satysfakcją też muszę stwierdzić, że tak dobrych pracowników w czasie moich kilkudziesięciu lat badań wykopaliskowych nie miałem.

Pełna napięć i rozterek sytuacja, która zostaje przedstawiona niezwykle sugestywnie i drobiazgowo (przez co rozmówca podkreśla dramatyzm wspominanych wydarzeń), kończy się jednak szczęśliwie. Co więcej, umiejętne poradzenie sobie z powierzonym mu zadaniem nie tylko naukowym, ale także organizacyjnym, legitymizuje Jerzego Kmiecińskiego jako dobrze przygotowanego i rzetelnego badacza.

Niełatwe zderzenie $\mathrm{z}$ pracą $\mathrm{w}$ terenie opisuje także Bronisława Kopczyńska-Jaworska, opowiadając o badaniach nad Polskim atlasem etnograficznym, w które włączyła się jako młody doktor, kiedy w okresie stalinowskim straciła etat na uniwersytecie:

${ }^{17}$ Konstantynów - niewielkie miasto (obecnie wchodzące w skład aglomeracji łódzkiej), którego centrum oddalone jest od śródmieścia Łodzi o ok. $20 \mathrm{~km}$. Od 1911 roku oba miasta połączone są linią tramwajową.

${ }^{18}$ Aleksander Gardawski (1917-1974) - student archeologii na Uniwersytecie Łódzkim, późniejszy profesor archeologii na Uniwersytetu im. Marii Curie-Skłodowskiej w Lublinie. 
Bohaterskie wspomnienia mam z tych badań. Podzielono Polskę na kwadraty, w każdym kwadracie był punkt badawczy i tam zbierano materiały. Wszystkie kraje europejskie miały atlasy etnograficzne, a Polska nie miała, więc postanowiono zrobić taki atlas. Tylko jak robiono te kwadraty, to się nie zastanowili, że w jednym kwadracie było powiatowe miasteczko, a w drugim była wieś, która należała do tego powiatu. Wobec tego w terenie to było strasznie uciążliwe, dlatego że ja odwiedzałam wsie, które były oddalone od siebie o trzydzieści kilometrów - taka była odległość między tymi punktami - a żeby dojechać do następnej wsi, musiałam wracać do miasta powiatowego i jechać autobusem w zupełnie innym kierunku. To były rok akademicki 1953-1954. Szczęśliwie miałam punkty na północny zachód od Warszawy, a rodzice moi mieszkali w Warszawie, więc miałam bazę u nich. Tam zostawiałam synka, który miał wtedy pięć czy sześć lat, i jechałam mężnie w teren z plecakiem, w którym miałam śpiwór, potem mi mama uszyła taki worek z dużego prześcieradła, dlatego że dwa dni były na miejscowość. Wobec tego szłam do sołtysa i mówiłam, że przyjechałam tutaj na badania naukowe, mam papiery itd. i proszę o nocleg $\mathrm{z}$,szarwarku”, to znaczy z przydziału. Prawie z reguły, tak jak wspominam teraz [śmiech], sołtys odpowiadał: „A to świetnie, bo tu wczoraj geometra był, to pani pójdzie do tych samych gospodarzy, tam łóżko dawali geometrze". To dostawałam łóżko razem z pościelą po geometrze, wobec tego to wszystko było obrzydliwe i mama mi uszyła taki worek, wchodziłam w ten worek, zaciągałam na głowę i już mi było wszystko jedno, ilu geometrów w tym łóżku przede mną spało. Kłopoty tylko były z higieną w takiej podróży, bo wsie polskie z reguły nie posiadały urządzeń sanitarnych. Pamiętam w jakiejś wsi, że kawałek drogi od autobusu było i obtarłam sobie piętę, bolała mnie, więc poprosiłam o miednicę ciepłej wody. Gospodyni bardzo miło przyszykowała, postawiła na środku kuchni, ja moczyłam nogi, a cała rodzina siedziała dookoła. Obserwowała, co ja takiego ciekawego robię [śmiech]. To rzeczywiście były bohaterskie lata jeszcze. Woziłam ze sobą chleb, kartki; tych sklepów z jedzeniem nie było jeszcze wtedy po tych wsiach. Pamiętam, że w Rypinie czy innym większym miasteczku była restauracja w rynku i tam poprosiłam, czy kawę mogę dostać, i usłyszałam potem jakiś brzdęk - okazało się, że oni tam w moździerzu thuką ziarnka kawy i takie duże ziarnka kawy zalali wodą i przynieśli mi to w charakterze czarnej kawy. Potem jakieś miejscowości, w Sierpcach chyba wtedy nocowałam, w hoteliku miejscowym, w którym jeszcze oprócz mnie miały dwie osoby nocować, to klucza nie było w drzwiach [śmiech]. To były rzeczywiście niesłychane wyprawy, ale dzięki temu pierwszy raz w życiu jechałam motocyklem. Byłam w jakiejś wiosce, już zmrok zapada, wyszłam na drogę, na przystanek autobusowy. Autobusu ni widu, ni słychu. Deszcz zaczął mżyć, ciemno się robiło, to był koniec października i ja stoję w szczerym polu przy tym patyku [śmiech]. Wtedy zajeżdża ktoś takim dużym motocyklem, starodawnym, co to miał dwa siedzenia i rączkę pomiędzy tymi siedzeniami, 
no i zatrzymał się jakiś dobry człowiek, że jedzie do Nasielska, a autobus to chyba dzisiaj nie pojedzie, bo on go nie widział po drodze, czy pani to jeździła motorem? „To niech pani wsiada, to ja panią podrzucę”. To co ja będę nocować na tej drodze, trudno, niech dzieje się, co chce, wsiadam na ten motocykl i jadę. Wsiadłam za tym facetem, trzymałam się rączki tak kurczowo, że jak dojechaliśmy do Nasielska, to nie mogłam rąk otworzyć, miałam powbijane paznokcie ze strachu, ale dojechałam. Nie ma jak badania etnograficzne.

Rzecz jasna, nie tylko badania etnograficzne i archeologiczne dostarczały tylu emocji. Wyjście w teren i stawienie czoła opornej rzeczywistości stanowiło chrzest bojowy także dla badaczy reprezentujących inne dyscypliny nauki. Interesujący opis zmagań, które towarzyszyły pracy nad doktoratem, przedstawia biolog Andrzej Piechocki. Przede wszystkim podkreśla, że jego mistrz - profesor Leszek Pawłowski - miał taki styl pracy, który wymagał ogromnej samodzielności od jego uczniów. Dawało to często poczucie całkowitej niezależności czy autonomii. Te jednak, wykorzystane nadmiernie, mogły narazić ich na srogą reakcję nauczyciela-mentora:

Karierę naukową zrobiłem zgodnie z przyjętym trybem, to znaczy nie opóźniłem wykonania doktoratu. Temat pracy był związany z zoologią systematyczną i po części ekologią, dotyczył mięczaków, ślimaków i małży, rzeki Grabi. Grabia i jej dorzecze były od lat poligonem doświadczalnym Katedry Zoologii Ogólnej, w której pracowałem. Wraz z profesorem jeździliśmy przynajmniej raz w tygodniu $\mathrm{w}$ teren, zbieraliśmy materiały. Dzięki kontaktom profesora z Łódzkim Towarzystwem Naukowym mieliśmy zapewniony samochód i bardzo wytrawnego kierowcę, który bezbłędnie trafiał w każde miejsce i bez protestów znosił nasze wielogodzinne badania. Badania terenowe i realizacja doktoratu trwały cztery lub, pięć lat. Praca została szybko opublikowana w dobrym czasopiśmie, w całości. Profesor był niewątpliwie mistrzem, którego można nam było zazdrościć, ale jednocześnie, muszę podkreślić, że pozwalał nam na dużą samodzielność. Przyglądał się nam, oceniał, dyskretnie podsuwał koncepcje. Pisałem swoją pracę po kawałku wspominając inspirujące pomysły i rozmowy z Mistrzem. Gdy przedstawiłem profesorowi rękopis, wtedy czytało się rękopisy w dosłownym tego słowa znaczeniu, do których wklejało się fotografie i mapy, muszę powiedzieć, że doznałem wielkiej satysfakcji słysząc, że przygotowałem rozprawę zgodną z jego wysokimi wymaganiami. Nieliczne poprawki dotyczyły zaledwie kilku zdań. Szybka publikacja rozprawy doktorskiej w warszawskim czasopiśmie wiązała się z niemiłym dla mnie nieporozumieniem. Przekazując maszynopis tamtejszemu redaktorowi, myślałem o wstępnej ocenie i czekających mnie poprawkach. On jednak uznał, że praca nie wymaga jakichkolwiek zmian i nie zawiadamiając mnie skierował ją do druku. Moja praca ukazała się więc bez konsultacji z promotorem, co 
profesor w niemiłej dla mnie rozmowie uznał za przejaw niesubordynacji. Żałuję niezawinionego incydentu związanego z publikacją pracy wykonanej pod kierunkiem profesora, którego zachowałem we wdzięcznej pamięci.

$\mathrm{Z}$ relacji tej jasno wynika, że wejście w świat akademii wymaga także umiejętnego balansowania na pograniczu autonomii i swoistej zależności od mistrza - odpowiedniego wpisania się w jego styl pracy i relacji z podwładnymi i ze środowiskiem.

Warto w tym miejscu podkreślić rzecz, która wydawać się może oczywista - nasi rozmówcy to osoby, które uporały się z różnego typu problemami i wyzwaniami, jakie na swojej drodze mógł napotkać młody naukowiec podejmujący pracę na uniwersytecie. Wielu, nawet utalentowanym młodym ludziom, z różnych powodów jednak się to nie udało - zabrakło im najczęściej nie tyle umiejętności, ile wsparcia, kompetencji wyniesionych z domu, determinacji czy odwagi. Należy też wspomnieć o tych, którym ówczesny system społeczno-polityczny uniemożliwił kontynuowanie studiów lub podjęcie czy kontynuację pracy naukowej. Z dzisiejszej perspektywy opowieści o „rzuceniu na głęboką wodę” wydają się niemal heroiczne, ale warto pamiętać, że słuchamy głosu tylko tych osób, które przeszły przez te próby zwycięsko.

Wiemy już z relacji naszych rozmówców, że ówczesny model uczelni wymagał samodzielnego studiowania i autonomii zarówno w odniesieniu do prowadzonych badań, jak i do zajęć dydaktycznych. Sięgał on nadal mimo niestrudzonych działań ówczesnych władz komunistycznych - do praktyk i wzorów wypracowanych w obszarze przedwojennego elitarnego kształcenia uniwersyteckiego, które koncentrowały się na kierowaniu zainteresowaniami studenta, rozwijaniu jego ciekawości poznawczej i stawianiu mu wymagań, nie zaś wyłącznie na nauczaniu czy szkoleniu kompetencji. Z biegiem czasu ,elitarny uniwersytet” został przekształcony w uczelnię o bardziej egalitarnym i masowym charakterze - wykładowcy w coraz mniejszym stopniu mieli podejmować dyskusję nad określonym problemem ze swoimi studentami i uczyć ich krytycznego spojrzenia świat, a coraz bardziej musieli się koncentrować na przekazywaniu określonych pakietów (zideologizowanej) wiedzy i egzekwowaniu ich znajomości.

$\mathrm{Z}$ jednej strony więc odgórna reforma uniwersytetów oraz wymogi modernizującego się kraju wymagały powszechnej edukacji wyższej, z drugiej strony jednak kadra profesorska broniła tradycyjnego modelu, zwłaszcza wówczas, gdy nie chodziło już o „masową produkcję magistrów”, a o pracę na uniwersytecie. Funkcjonowanie uniwersytetu według dwóch 
odmiennych wzorów - elitarnego i egalitarnego - mogło (i może) prowadzić do sytuacji, które pod znakiem zapytania stawiają wartość studiowania, zdobytej wiedzy i ukształtowanej postawy. Ten dylemat towarzyszy wielu pracownikom uniwersytetu także dzisiaj.

\section{Środowisko akademickie}

Rzecz jasna, kariera akademicka nie rozwija się w próżni, a jej przebieg jest rezultatem oddziaływania wielu splatających się ze sobą czynników i uwarunkowań. W zgromadzonych opowieściach możemy zaobserwować, jak wraz z upływem czasu poszerzał się krąg kontaktów i sieci współpracy młodego pracownika nauki i jak wpływ środowiska naukowego w coraz większym stopniu kształtował jego orientację biograficzną związaną ze światem akademii. Nasi rozmówcy byli członkami zespołów katedr, instytutów, wydziałów. Budowali relacje wewnętrzne i interdyscyplinarne. Jak ważny był to proces w odniesieniu do całej uczelni, która w odczuciu narratorów winna stanowić wspólnotę uczonych a nie tylko sprawnie działającą instytucję naukowo-dydaktyczną, pokażemy w zakończeniu. Obecnie natomiast pragniemy wyeksponować wątki związane z opisem tworzącego się środowiska naukowego w nowo powstającej i budującej swój prestiż uczelni. Zilustrujemy to, przywołując kilka przypadków tworzenia się środowiska akademickiego w różnych obszarach nauki - tak, jak zapamiętali je nasi rozmówcy ${ }^{19}$.

Przez długie lata Łódź znana była z silnego środowiska matematyków. Wpływ grupy wybitnych profesorów, którzy po wojnie związali się z tutejszym uniwersytetem, na ukierunkowanie naukowych zainteresowań narratorów czy ich sposób myślenia o uprawianej dyscyplinie był ogromny. O genezie tego wybitnego grona matematyków, które jednocześnie legitymizowało i nadawało rangę działaniom swoich uczniów, opowiada przedstawiciel tych ostatnich - Zbigniew Jakubowski:

Janusz Staliński, Romuald Zawadzki i Witold Janowski ${ }^{20}$ byli jeńcami w oflagu w Woldenbergu. Janusz Staliński przez lata budował statki, po wojnie

\footnotetext{
${ }^{19}$ Historię powstania zakładów, katedr, instytutów skupiających uczonych poszczególnych dziedzin znaleźć można m.in. w opracowaniach Bohdana Baranowskiego, Pierwsze lata Uniwersytetu Łódzkiego: 1945-1949, Wydawnictwo Uniwersytetu Łódzkiego, Łódź 1985 czy Jarosława Kity i Stefana Pytlasa, Uniwersytet Łódzki w latach 1945-1995, Wydawnictwo Uniwersytetu Łódzkiego, Łódź 1996 oraz Wiesława Pusia, Zarys historii Uniwersytetu Eódzkiego 1945-2015, Wydawnictwo Uniwersytetu Łódzkiego, Łódź 2015.

${ }^{20}$ Janusz Staliński (1916-1985) - inżynier budowy okrętów, profesor Politechniki Gdańskiej Romuald Zawadzki (1910-1974) - matematyk, profesor Politechniki Łódzkiej. Zob. przypis 1 w tym rozdziale.
} 
wykładał na Politechnice. Gdańskiej. Był jej rektorem. Spotykali się na różnych polach. Te przeżycia negatywne, obozowe, dały uboczny efekt, ale też oczywiście dały efekt pozytywny. Romek Zawadzki po wojnie znalazł się w Łodzi. Ja nie umiem odtworzyć tego okresu powojennego: czy profesor Janowski napisał do niego list, czy on do Janowskiego, ale fakt jest faktem, że po wojnie z Warszawy do Łodzi przyjechał Charzyński, z krótkiego okresu pobytu, chyba półrocznego w Łowiczu przyjechał Janowski, z suwalskiego przyjechał Romek Zawadzki. Spotkali tutaj Włodzimierza Krysickiego ${ }^{21}$, który studiował przed wojną, i jeszcze kilka innych osób. Tak zaczęło „fermentować” środowisko matematyczne w Łodzi. Oczywiście do tej „fermentacji” były potrzebne nazwiska matematyków, którzy tuż po wojnie tu podstawy organizowali - myślę o Pogorzelskim ${ }^{22}$ na przykład w Politechnice, o Edwardzie Otto w Politechnice, o Stanisławie Mazurze ${ }^{23}$ w Uniwersytecie Łódzkim. Oni byli tutaj przez kilka lat i myślę, że ich działalność spowodowała, że coś się zaczęło w matematyce łódzkiej kręcić. Ale potem przyjeżdża ta druga ekipa i ona na serio wiąże się z Łodzią, z matematyką, organizuje ileś rzeczy i tak rozpoczynają się badania.

O niebagatelnym wpływie na dalsze losy poszczególnych dyscyplin jakie miało przedwojenne pokolenie naukowców - którzy nie tylko uczyli swoich studentów, ale także kształtowali u nich określone postawy moralne - opowiada także fizyk - Leszek Wojtczak:

Założycielami fizyki na Uniwersytecie Łódzkim byli profesorowie: Marian Grotowski, Feliks Joachim Wiśniewski, Tadeusz Tietz i Aleksander Zawadz$\mathrm{ki}^{24}$. Byli to ludzie o wielkim sercu i niezmiernie pogodnym usposobieniu. Uczyli nas szacunku dla pracy naukowej, życzliwości dla studentów, skromności i bezinteresownego dochowania wierności swym zasadom. Z czasów

${ }^{21}$ Włodzimierz Krysicki (1905-2001) - matematyk, profesor Politechniki Łódzkiej. Zob. przypis $1 \mathrm{w}$ tym rozdziale.

${ }^{22}$ Witold Pogorzelski (1895-1963) - matematyk, profesor Politechniki Warszawskiej, współtwórca Wydziału Mechanicznego Politechniki Łódzkiej i kierownik Katedry Matematyki Politechniki Łódzkiej.

${ }^{23}$ Edward Otto (1908-1986) - urodzony we Lwowie matematyk, profesor Politechniki Warszawskiej. Do 1950 roku łączył wykłady na Politechnice Warszawskiej z pracą na Politechnice Łódzkiej, gdzie piastował stanowisko kierownika Katedry Matematyki na Wydziale Chemicznym; Stanisław M. Mazur (1905-1981) - urodzony we Lwowie matematyk, do 1948 roku pracował na Uniwersyteckie Łódzkim, później na Uniwersytecie Warszawskim.

${ }^{24}$ Marian Grotowski (1882-1951) - fizyk, przed wojną profesor Wolnej Wszechnicy Polskiej, współorganizator i prorektor Uniwersytetu Łódzkiego; Feliks Joachim Wiśniewski (1890-1963) fizyk, profesor Wolnej Wszechnicy Polskiej, a po II wojnie światowej profesor Uniwersytetu Łódzkiego i Politechniki Łódzkiej; Tadeusz Tietz (1920 - 1996) - matematyk, profesor Uniwersytetu Łódzkiego, kierownik Katedry Fizyki; Aleksander Zawadzki (1918-1997) - fizyk, profesor Uniwersytetu Łódzkiego. 
studenckich wspominam, że pasjonowało nas, jak do takiej rangi dorastać. Fizyka tworzona na Uniwersytecie Łódzkim w pierwszym okresie jego powstawania miała dwa oblicza: fizyki doświadczalnej budowanej przez profesorów Grotowskiego i Zawadzkiego, oraz fizyki teoretycznej tworzonej przez profesorów Wiśniewskiego i Tietza w zakresie statystycznej teorii atomu. Ten podział jednocześnie odzwierciedla filozoficzny charakter fizyki - dynamika pomiędzy teorią i eksperymentem prowadzi do poprawnego obrazu rzeczywistości.

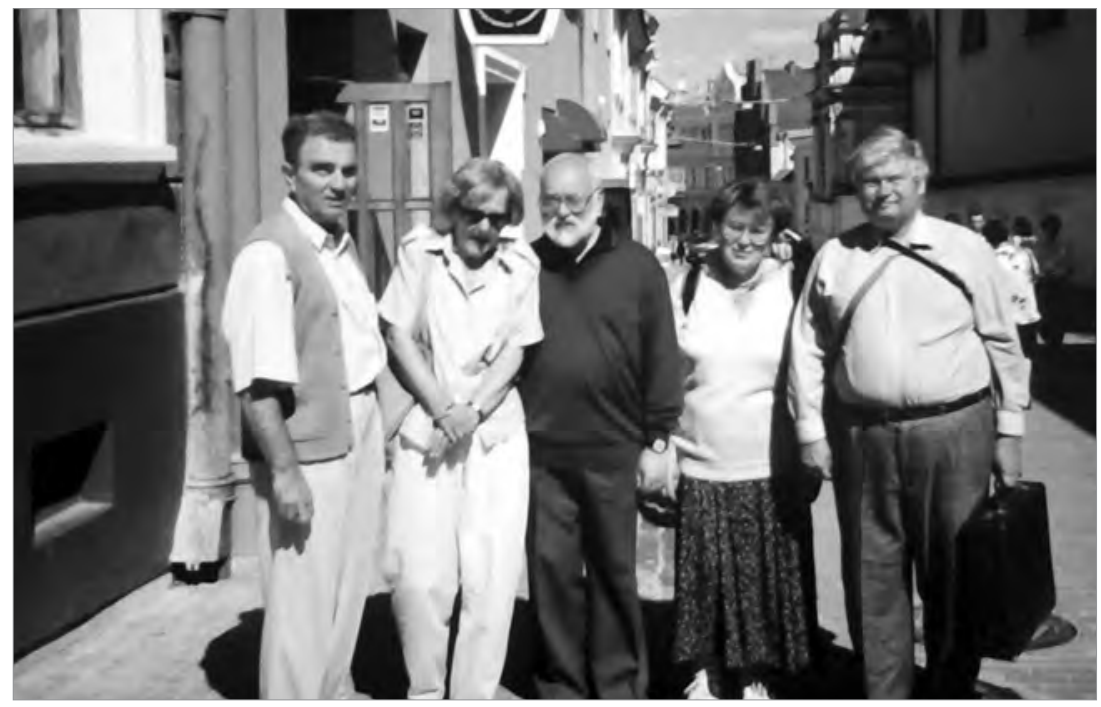

Fot. 54. Matematycy i fizycy na wspólnym wyjeździe do Wilna Od lewej stoja profesorowie: Ryszard Jajte, Leszek Wojtczak z żonami oraz Julian Lawrynowicz

Opis siły środowiska naukowego, tym razem w obszarze nauk humanistycznych i społecznych, znajdziemy także w relacji filozofa Ryszarda Panasiuka. Możemy w niej dostrzec, że rozwój tej dyscypliny (również ze względu na kontekst społeczny i polityczny) przebiegał w sposób skomplikowany. Akcenty zostają tu rozłożone nieco inaczej - rola pierwszego „założycielskiego" pokolenia zostaje, co prawda, wyraźnie podkreślona, ale narrator ogromną wagę przywiązuje również do relacji międzypokoleniowych i międzydyscyplinarnych.

Także to było takie środowisko raczej nieduże i skromne. A to łódzkie też się dopiero formowało. Państwo Pawłowscy ${ }^{25}$ byli tak jakby trochę z boku,

${ }^{25}$ Ija Lazari-Pawłowska (1921-1994) - etyk i filozof, twórczyni Katedry Etyki na Uniwersytecie Łódzkim; Tadeusz Pawłowski (1924-1996) - logik i filozof. Absolwent i profesor Uniwersytetu Łódzkiego. 
nie angażowali się. Pawłowski zajmował się logiką, oni oboje należeli do tego pierwszego okresu, kiedy studia w Łodzi były takie żywe i był wtedy Kołakowski ${ }^{26}$, Przełęcki i jeszcze inni. Oni wszyscy wyjechali: Kotarbiński ${ }^{27}$, Chałasiński ${ }^{28}$, wszystkich wyniosło do Warszawy, a oni zostali dwoje. I tak jakoś trwali i byli tak troszkę może nie do końca akceptowani ze względu na to, że byli zdystansowani do istniejącego porządku i ich kariery szły bardzo powoli. A to, co tam było z kadry Amsterdamskiego ${ }^{29}$, to byli młodzi ludzie. Był jeszcze kolega Gromczyński ${ }^{30}$, który był i ciekawy, i oryginalny, i zabawny człowiek, studiował w Moskwie. Także ci ludzie jakoś się potrafili odbić od tego formowania doktrynalnego i dawali sobie radę, ale bardzo powoli się to środowisko formowało. Trochę pomagały kontakty zagraniczne. A kontakt z socjologami był, bo i ja często uczestniczyłem w zebraniach u socjologów, profesora Lutyńskiego ${ }^{31}$ znałem dobrze, panią Kłoskowską ${ }^{32}$, profesor Szczepańskii3 przecież też, tylko go nie znałem, już go nie było wtedy, kiedy ja się zjawiłem w Łodzi. Ale pani Kłoskowska i Lutyński, i jeszcze paru innych bardzo aktywnych - takie ładne środowisko, silniejsze niż filozoficzne. Tak jakoś bardziej przetrwało. Potem pani Kłoskowska się przeniosła do Warszawy, profesor Lutyński zmarł, ale to środowisko trwa.

${ }^{26}$ Leszek Kołakowski (1927-2009) - wybitny współczesny filozof, zajmujący się przede wszystkim historią idei i historią filozofii. Studiował w Łodzi. Marian Przełęcki (1923-2013) - logik i filozof, absolwent Uniwersytetu Łódzkiego, profesor Uniwersytetu Warszawskiego.

${ }^{27}$ Zob. przypis $15 \mathrm{w}$ tym rozdziale.

${ }^{28}$ Józef Chałasiński (1904-1979) - profesor socjologii, jeden z założycieli Uniwersytetu Łódzkiego i rektor tej uczelni w latach 1949-1952, członek PAN.

${ }^{29}$ Stefan Amsterdamski (1929-2005) - profesor filozofii; zaraz po wojnie rozpoczął studia chemiczne na Politechnice Łódzkiej, stopień doktora i doktora habilitowanego z zakresu filozofii zdobył na Uniwersytecie Warszawskim. Od 1954 roku pracował na Wydziale Filozoficzno-Historycznym Uniwersytetu Łódzkiego. W 1966 roku objął stanowisko dziekana tego wydziału. W konsekwencji wydarzeń marcowych w 1968 roku został usunięty z uczelni. Pracował później w Polskiej Akademii Nauk. Członek PZPR w latach 1948-1968, a od 1980 roku członek „Solidarności” internowany w stanie wojennym. Uczestnik obrad Okrągłego Stołu.

${ }^{30}$ Wiesław Gromczyński (1931-2009) - filozof, w latach 1951-1956 studiował na Uniwersytecie Moskiewskim; późniejszy pracownik Instytutu Filozofii Uniwersytetu Łódzkiego.

${ }^{31}$ Jan Lutyński (1921-1988) - socjolog i metodolog, profesor Uniwersytetu Łódzkiego, Dyrektor Instytutu Socjologii UŁ, kierownik Zakładu Metod i Technik Badań Społecznych. Ekspert i doradca struktur związkowych „Solidarności”. W 1981 r. podczas strajku studenckiego na UŁ pełnił funkcję doradcy komitetu strajkowego.

${ }^{32}$ Antonina Kłoskowska (1919-2001) - socjolog, absolwentka Uniwersytetu Łódzkiego, profesor na Uniwersytecie Łódzkim i Uniwersytecie Warszawskim, w latach 1989-1994 przewodnicząca Polskiego Towarzystwa Socjologicznego, członek PAN.

${ }^{33}$ Jan Szczepański (1913-2004) - wybitny polski socjolog, urodzony w Ustroniu, przez wiele lat związany z Uniwersytetem Łódzkim (1945-1970), którego był profesorem, a później także rektorem, członek PAN. 
Jeszcze bardziej złożony przykład trudności w tworzeniu się środowiska naukowego określonej dyscypliny i jej celowej marginalizacji ukazuje opowieść Wandy Nowakowskiej, która skrupulatnie odtwarza losy historii sztuki na naszym uniwersytecie:

Dzieje Katedry Historii Sztuki Uniwersytetu Łódzkiego są bardzo burzliwe i nietypowe. Zakład Historii Sztuki powstał w ramach powołanego do istnienia Uniwersytetu Łódzkiego w roku 1945 i tu od razu trzeba zaznaczyć, że do roku akademickiego 1952/1953 były tylko zakłady, a dopiero od tej daty zaczęły funkcjonować katedry, w skład których wchodziły mniejsze jednostki czyli zakłady. Tak więc w roku akademickim 1945/1946 rozpoczęli studia pierwsi adepci historii sztuki w Łodzi. Twórcami kierunku byli profesor Wacław Husarski $^{34}$ i Mieczysław Wallis ${ }^{35}$. Profesor Husarski był od 1945 roku kierownikiem Zakładu Historii Sztuki a profesor Wallis Zakładu Estetyki, ale po śmierci profesora Husarskiego w 1951 roku Wallis objął kierownictwo Zakładu Historii Sztuki a Zakład Estetyki został wówczas zlikwidowany. W roku 1952 studia historii sztuki zostały na naszym uniwersytecie zarządzeniem władz państwowych zlikwidowane jako nieprzystające do robotniczego wizerunku miasta, a zajęcia z historii sztuki, głównie wykłady, prowadził profesor Wallis jako fakultatywne dla studentów różnych innych kierunków jak np. historia czy filologia polska. W roku 1965, po odejściu profesora Wallisa na emeryturę przemianowano Zakład Historii Sztuki na Zakład Historii Kultury i Sztuki, którego kuratorem został ówczesny dziekan Wydziału Filozoficzno-Historycznego docent Leon Błaszczyk ${ }^{36}$ a zajęcia fakultatywne $\mathrm{z}$ historii sztuki prowadziły na różnych kierunkach dwie doktorantki profesora - jego wieloletnia asystentka dr Irena Popławska ${ }^{37}$ i ja. A ja byłam zatrudniona od roku 1965 w Instytucie Filozofii, bo magisterium zrobiłam z estetyki ${ }^{38}$ więc wykładałam tam estetykę i historię filozofii. Po wyjeździe profesora Błaszczyka zagranicę w 1968 roku Zakład został zlikwidowany a dr Popławska została przeniesiona do Instytutu Filozofii i nadal prowadziła razem ze mną wykłady dla różnych kierunków studiów. Zaprzestano wówczas zakupów do naszej biblioteki, ale księgozbiór

${ }^{34}$ Wacław Teofil Husarski (1883-1951) - historyk sztuki, krytyk artystyczny, malarz. Od 1945 roku profesor Uniwersytetu Łódzkiego.

${ }^{35}$ Mieczysław Wallis (1895-1975) - estetyk, teoretyk i historyk sztuki, kierował Katedrą Historii Sztuki, w latach 1955-1956 pełnił funkcję dziekana Wydziału Filozoficzno-Historycznego Uniwersytetu Łódzkiego.

${ }^{36}$ Leon T. Błaszczyk (ur. 1923) - profesor historii, wybitny znawca starożytności, dziekan Wydziału Filozoficzno-Historycznego w latach 1964-1966, a w latach 1966-1968 dyrektor Instytutu Historii UŁ. Usunięty z Uniwersytetu Łódzkiego w marcu 1968 roku.

${ }^{37}$ Irena Popławska (1924-1995) - historyk sztuki, historyk architektury łódzkiej, działaczka społeczna. Zawodowo związana z Uniwersytetem Łódzkim i Politechniką Łódzką.

${ }^{38}$ Opowieść o tym w jakich okolicznościach Wanda Nowakowska zrobiła magisterium z estetyki przedstawiona zostanie w rozdziale V, w części “Ingerencje władz w proces edukacyjny”. 
pozostał nienaruszony i mieścił się w dotychczasowej siedzibę Zakładu w Bibliotece Uniwersyteckiej. Tak więc Zakładu w tym czasie nie było. Dopiero w październiku 1975 roku decyzją ówczesnego rektora Romualda Skowrońskiego $^{39}$ utworzono Zakład Historii Sztuki na Wydziale Filozoficzno-Historycznym UŁ jako jednostkę niezależną, pełniącą funkcje usługowe zgodnie z potrzebami różnych wydziałów. Kuratorem Zakładu został dziekan profesor Waldemar Michowicz ${ }^{40}$ a obsadę znów stanowiłyśmy my czyli przeniesiono nas z Instytutu Filozofii dr Irenę Popławską i mnie. Ja prowadziłam wykłady z historii sztuki dla studentów z innych kierunków. Irka pracowała u nas na pół etatu od 1978 roku objęła cały etat w Instytucie Architektury i Urbanistyki na Politechnice Łódzkiej. W październiku 1979 roku Zakład Historii Sztuki został włączony w Instytut Historii UŁ, a od stycznia 1980 otrzymałam funkcję kierowniczki tego Zakładu. W 1983 roku odbyło się moje kolokwium na Uniwersytecie Jagiellońskim, jak wtedy powiedziałam - najpiękniejszy dzień mojego życia. W 1984 roku otrzymałam stanowisko docenta na UŁ, potem wkrótce stanowisko profesora nadzwyczajnego, a w grudniu 2000 roku zostałam profesorem zwyczajnym tzw. belwederskim. No i co w tym czasie działo się z Zakładem? O bardzo dużo. W styczniu 1992 roku Zakład Historii Sztuki wyodrębnił się z Instytutu Historii stając się samodzielną jednostką na Wydziale Filozoficzno-Historycznym, a od roku akademickiego 1992/93 ówczesny rektor Michał Seweryński ${ }^{41}$ reaktywował, po czterdziestoletniej przerwie, kierunek studiów z historii sztuki na naszym uniwersytecie. Rektor przydzielił od razu niezbędne etaty, aktywnie wspierał nas też ówczesny dziekan Wiesław Puśt ${ }^{42}$, późniejszy rektor. I trzeba było „stworzyć wszystko od nowa”! Był to więc niewątpliwie najciekawszy i najbarwniejszy okres mojego życia. Oczywiście każdy etap obfitował $\mathrm{w}$ niecodzienne przeżycia i szokujące czasem wydarzenia, ale w zorganizowanie Katedry i prowadzenie kierunku studiów z historii sztuki byłam zaangażowana, jeśli tak można powiedzieć od podstaw, od początku. To była kreacja z niczego - a ja zawsze najbardziej kochałam w życiu takie sytuacje, tak jak z urządzaniem domu - a przeprowadzek w swoim życiu miałam niemało. Tak więc z pasją zabrałam się do odpowiedzialnej pracy, która uratowała mnie zresztą przed depresją. Miałam wtedy umierającą matkę, która po siedmiu latach absolutnego unieruchomienia w łóżku, odeszła 3 listopada 1992 roku a w październiku ruszył nowy kierunek. Podczas tych

\footnotetext{
${ }^{39}$ Romuald Skowroński - patrz biogramy rozmówców.

${ }^{40}$ Waldemar Michowicz (1929-2005) - historyk, specjalizował się w historii dyplomacji, profesor Uniwersytetu Łódzkiego. Inicjator powołanego w 1994 roku Instytutu Studiów Międzynarodowych, na bazie którego w 2000 roku powstał Wydział Stosunków Międzynarodowych i Politologicznych UŁ.

${ }^{41}$ Michał Seweryński - patrz biogramy rozmówców.

${ }^{42}$ Wiesław Puś (ur. 1940) - historyk, profesor Uniwersytetu Łódzkiego, rektor uczelni w latach 2002-2008.
} 
trudnych lat opieki napisałam dwie książki, które stały się podstawą mojej profesury belwederskiej, a w momencie jej śmierci przyszło to nowe wyzwanie, więc Pan Bóg wie co robi!... Tak więc wzięłam się do pracy, trzeba było stworzyć kadrę i nowy program od podstaw. A byłyśmy trzy: starsza asystentka, dziś już profesor, Eleonora Jedlińska, ja jako kierownik Zakładu i Irena Popławska na pół etatu. Dołączyli do nas Krzysztof Stefański - późniejszy profesor, światowej sławy konserwator, wówczas docent, Ewa Marxen-Wolska, dojeżdżający z Warszawy profesor Jerzy Malinowski oraz trzej asystenci: Krzysztof Cichoń, Piotr Gryglewski, Robert Wróbel. Zajęcia na naszym kierunku prowadzili też profesorowie Grzegorz Sztabiński - kierownik Katedry Estetyki, Leszek Kajzer - kierownik Katedry Archeologii, nasze koleżanki, łódzkie historyczki sztuki: dr Teresa Kmiecińska-Kaczmarek i kustosz Muzeum Sztuki w Łodzi mgr Janina Ładnowska ${ }^{43}$.

Środowiska naukowe przeobrażały się wewnętrznie, przenikały się czy oddziaływały na siebie wzajemnie. Powstawały nowe ramy instytucjonalne, które nie zawsze oparte były na kryteriach merytorycznych. Wszystkie te okoliczności miały wpływ na przebieg biografii naukowych naszych narratorów. O czynnikach istotnych dla jego kształtu opowiada ekonomista Jerzy Dietl:

Trochę osób ściągnąłem z uczelni poznańskiej, czasami to było bardziej a niekiedy mniej udane. Wszyscy jednak moi młodzi koledzy z Poznania uzyskali tytuły profesorskie i wzmocnili Uniwersytet Łódzki. Muszę jednak podkreślić, że katedra którą przejąłem nie była taką katedrą, że mógłbym pod każdym względem być dumny. Jak się pani domyśla, jeśli gdzieś ktoś się chciał kogoś pozbyć, to go przenosił do mojej katedry przed moim przyjazdem. Uzyskałem więc taki, powiedzmy, remanent nie najlepszy, ale część z tych osób obroniła doktoraty. Trochę doktoratów było też z zewnątrz, potem kilka habilitacji. Tak więc mogę powiedzieć, że w zakresie tzw. rozwoju młodej kadry jakoś wszystko szło naprzód. Byłem przeciwnikiem oddzielenia się Wydziału Zarządzania od Wydziału Ekonomiczno-Socjologicznego. Chciałem jednak, by powstało coś w rodzaju Business Administration czy Business Economics w ramach

${ }^{43}$ Eleonora Jedlińska (ur. 1943) - historyk sztuki nowoczesnej i współczesnej, profesor i wykładowca w UŁ; Krzysztof Stefański (ur. 1955) - historyk sztuki, specjalizujący się w historii architektury polskiej XIX i XX wieku, kierownik Katedry Historii Sztuki UŁ; Ewa Marxen-Wolska (1924- 2013) - historyk sztuki, współtwórca i wykładowca Katedry Historii Sztuki na Uniwersytecie Łódzkim, światowej klasy konserwator zabytków; Jerzy Malinowski, historyk sztuki, w latach 1992-1995 prof. nadzw. UŁ; Krzysztof Cichoń (ur. 1966) - historyk sztuki, pracownik Katedry Historii Sztuki UŁ; Piotr Gryglewski - historyk sztuki, dr hab., od 1992 zatrudniony w Katedrze Historii Sztuki UŁ; Robert Wróbel - historyk sztuki; Leszek Kajzer (ur. 1944) - archeolog, profesor na UŁ, specjalista w dziedzinie budownictwa i architektury obronnej; Teresa Kmiecińska-Kaczmarek, historyk sztuki; Janina Ładnowska (1934-2006) wieloletni kustosz Muzeum Sztuki w Łodzi. 
tamtego wydziału, ewentualnie jako odrębny wydział. Ale powstał wydział o istotnych brakach, bo ci, którzy tam mieli jakieś kwestie personalne, to się oddzielili, a ci, którzy nie mieli, pozostali. W konsekwencji Wydział Zarządzania znajduje się w nowym pięknym budynku przy ulicy Matejki, składa się w części z katedr, które powinny pozostać na Wydziale Ekonomiczno-Socjologicznym, przy równoczesnym braku reprezentacji pewnych dziedzin, np. mikroekonomii, statystyki, ekonometrii, handlu zagranicznego.

Jednym z ważnych czynników tworzących środowisko akademickie są sieci relacji interdyscyplinarnych. Przedstawione poniżej przykłady odnoszą się przede wszystkim do takich konfiguracji w dziedzinie nauk społecznych i humanistycznych, w których socjologia zajmuje niepoślednie miejsce, choć wielość odwołań do niej w zgromadzonej kolekcji z pewnością nie jest przypadkowa. Ma to, jak przypuszczamy, dwa źródła. Jedno z nich to bez wątpienia fakt, że w Uniwersytecie Łódzkim pracowało wielu wybitnych socjologów, którzy często sprawowali doniosłe funkcje (jak na przykład rektorzy Józef Chałasiński czy Jan Szczepański) czy odznaczali się szczególną postawą moralną (jak na przykład Jan Lutyński). Drugie to, jak wspomniano wcześniej, sytuacja wywiadu, w której osoba go prowadząca zazwyczaj kojarzona była jako socjolog, co skłaniało naszych rozmówców do eksploatacji tego wspólnego pola odniesień. Przyjrzyjmy się przede wszystkim pierwszemu, „obiektywnemu” uwarunkowaniu, które sprzyjało temu, że w tworzone sieci relacji i wzajemnych powiązań zawsze niemalże wchodziło grono socjologów. Od samego początku środowisko to było budowane w Łodzi przez wybitnych przedstawicieli tej dyscypliny. Choć niektórzy z nich przenieśli się do Warszawy, to utrzymywali z Uniwersytetem Łódzkim stały kontakt (dojeżdżając na zajęcia, kontynuując współpracę naukową czy badawczą), a często też pozostawiali tu swoich uczniów, którzy kontynuowali rozpoczęte dzieło kształtowania środowiska socjologicznego ${ }^{44}$. Nie bez znaczenia dla budowania relacji i tworzenia areny dyskusji miało też zaplecze materialne w postaci budynku przy ulicy Uniwersyteckiej $3^{45}$. Ta wspólna przestrzeń stała się miejscem krytycznej, polemicznej i konstruktywnej konfrontacji przedstawicieli wielu dyscyplin. Krystyna Lutyńska, najpierw z perspektywy studentki, potem młodej

${ }^{44}$ Należy pamiętać, że łódzka socjologia, jak i inne nauki społeczne, ma trudną historię związaną zwłaszcza z okresem stalinizmu, kiedy jako nauka „burżuazyjna” została zlikwidowana. Szerzej na ten temat piszemy w kolejnym rozdziale. Zob. przypisy 28,31 i 33 w tym rozdziale.

${ }^{45} \mathrm{O}$ roli przestrzeni oraz szczególnym znaczeniu budynku przy ulicy Uniwersyteckiej 3 piszemy dokładniej w rozdziale VI. 
asystentki na socjologii, wspomina spotkania naukowców, których łączyła wspólna przestrzeń oraz pasja dyskusji akademickiej:

$\mathrm{Na}$ początku, zanim ja zaczęłam studia, a mąż [Jan Lutyński] był już na socjologii, to byli jeszcze w Łodzi Ossowscy ${ }^{46}$. Mąż został zwolniony z obozu w Rosji 1946 roku, przyjechał do Polski, tylko przywitał się z rodziną i tak był spragniony, żeby dalej uczyć się, studiować, że od razu przyjechał do Łodzi. W Łodzi uniwersytet był już tak w pełni, więc przyjechał tutaj, podobno najpierw zapisał się na prawo, ale potem na socjologię. Bardzo szybko tę socjologię ukończył i został asystentem Chałasińskiego. I wtedy gdy mąż przyszedł na uniwersytet, to byli oboje Ossowscy, był też etnolog, etnograf, Obrębski ${ }^{47}$, bardzo ciekawa postać. Bo przecież nie było Uniwersytetu Warszawskiego i bardzo wielu tych ludzi przyjechało albo do Łodzi, albo do Poznania - tam, gdzie te miasta były mniej zniszczone, do Krakowa, ale tu w Łodzi byli głównie warszawiacy. Stąd Kotarbiński ${ }^{48}$ z żoną. I Kotarbińscy mieli swój zakład piętro niżej. Socjologia była na czwartym piętrze na Uniwersyteckiej 3, a zakład Kotarbińskich był na trzecim. Także ci asystenci Kotarbińskich bardzo byli zaprzyjaźnieni ze studentami Chałasińskiego ${ }^{49}$ i Szczepańskiego ${ }^{50}$. Chociaż między Kotarbińskim a Chałasińskim był można powiedzieć, konflikt, wojna, bo Kotarbiński miał Chałasińskiemu za złe wiele rzeczy, między innymi to pójście $\mathrm{z}$ ówczesnymi władzami na ugodę. Bo Kotarbiński się nie angażował tak jak i Ossowski, on miał takie sztywne zasady i to był bardzo prawy człowiek. Ija Pawłowska, Przełęcki ${ }^{51}$, to byli jego najstarsi uczniowie, bardzo mądrzy i bardzo sympatyczni ludzie. I oni wszyscy przesiadywali u socjologów. Wszyscy spotykali się na zebraniach PTS -u czy na zebraniach Polskiego Towarzystwa Filozoficznego. Najpierw Polskie Towarzystwo Socjologiczne powstało przecież jako sekcja Polskiego Towarzystwa Filozoficznego, potem się wyodrębniło. Była też na Uniwersyteckiej 3 pedagogika społeczna i pani profesor Radlińska ${ }^{52}$. Chyba na pierwszym piętrze była pedagogika, był

${ }^{46}$ Stanisław Ossowski (1897-1963) - socjolog, profesor Uniwersytetu Łódzkiego w latach 1945-1947 oraz Uniwersytetu Warszawskiego; Maria Ossowska (1896-1974) - etyk, teoretyk i socjolog moralności, profesor Uniwersytetu Łódzkiego w latach 1945-1948, a następnie Uniwersytetu Warszawskiego oraz Instytutu Filozofii i Socjologii PAN.

${ }^{47}$ Józef Obrębski (1905-1967) - socjolog i etnolog, absolwent Uniwersytetu Jagiellońskiego, uczeń Bronisława Malinowskiego, związany z Wolną Wszechnicą Polską, po wojnie pracował krótko na Uniwersytecie Łódzkim, aż do wyjazdu z kraju i kontynuowania kariery zawodowej za granicą.

${ }^{48}$ Zob. przypis $15 \mathrm{w}$ tym rozdziale.

${ }^{49}$ Zob. przypis $28 \mathrm{w}$ tym rozdziale.

${ }^{50}$ Zob. przypis $33 \mathrm{w}$ tym rozdziale.

${ }^{51}$ Zob. przypis 25 i $26 \mathrm{w}$ tym rozdziale.

52 Helena Radlińska (1879-1954) - profesor pedagogiki, stworzyła pedagogikę społeczną w Polsce, w 1945 roku po przyjeździe do Łodzi uruchomiła na Uniwersytecie Łódzkim Zakład Pedagogiki Społecznej. Jej współpracownikami byli m.in. Aleksander Kamiński i Irena Lepalczyk. 
profesor Truchim ${ }^{53}$. I oczywiście Aleksander Kamiński ${ }^{54}$ przyszedł. Kamiński ciągle siedział u socjologów. To był przesympatyczny człowiek, z nim to można było dyskutować, opowiadać do upadłego.

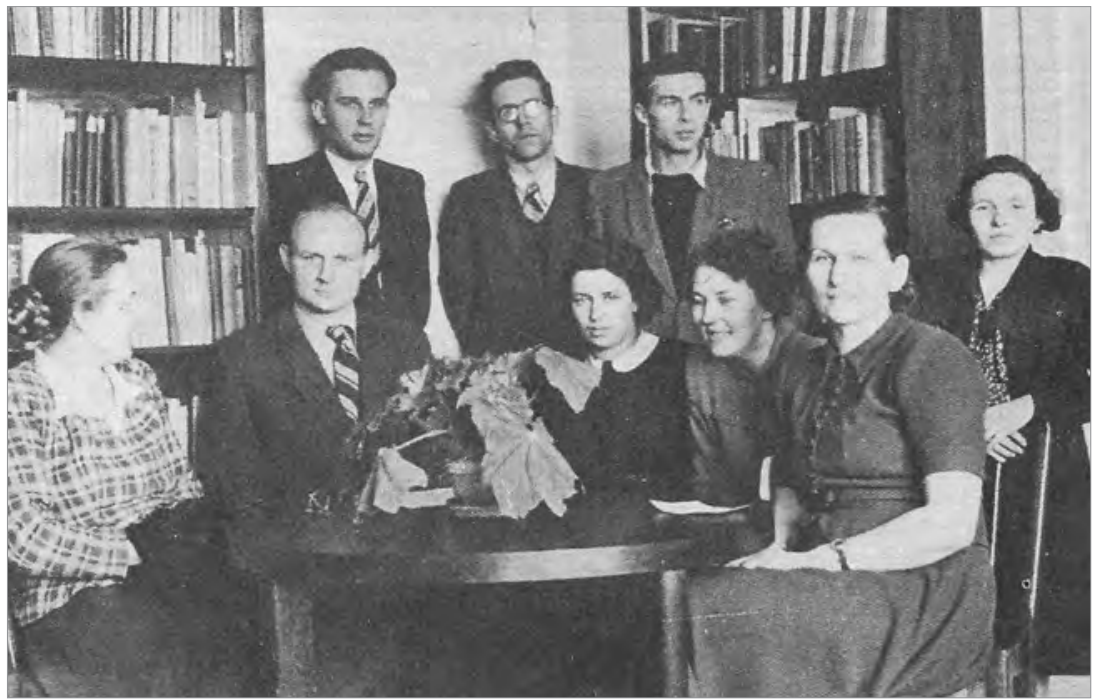

Fot. 55. Od lewej siedza: Krystyna Chałasińska, Jan Szczepański, Renata Szwarc-Tuli, Jolanta Kulpińska, Janina Kremky-Salony. Od lewej stoja: Zygmunt Gostkowski, Jan Lutyński, Wacław Piotrowski i Antonina Kłoskowska. Zdjęcie wykonano w budynku przy ulicy Uniwersyteckiej 3

Z nieco innej perspektywy budowanie relacji między etnografami a pedagogami i socjologami opisuje Bronisława Kopczyńska-Jaworska:

Zakład Etnografii powstał na Wydziale Humanistycznym. Z moich obserwacji wynikało, że pani profesor Zawistowicz ${ }^{55}$ nie miała $\mathrm{z}$ historykami jakichś szerszych kontaktów. No może z profesor Gąsiorowską-Grabowską ${ }^{56}$ gdzieś tam w Warszawie, ale tak to nie bywali u nas w katedrze, nie czuło się takich bliskich kontaktów z nimi. Myśmy na pewno mieli kontakty z pedagogiką

${ }^{53}$ Stefan Truchim (1896-1967) - historyk kultury i oświaty, od 1945 roku profesor Uniwersytetu Łódzkiego.

${ }^{54}$ Aleksander Kamiński (1903-1978) - pedagog, harcmistrz i wychowawca młodzieży, zatrudniony na Uniwersytecie Łódzkim do 1950 roku, odsunięty od nauczania z przyczyn ideologicznych, od 1958 roku ponownie zatrudniony.

${ }^{55}$ Kazimiera Zawistowicz-Adamska (1897-1984) - profesor etnologii, w 1945 roku założyła na Uniwersytecie Łódzkim Zakład Etnografii.

${ }^{56}$ Natalia Gąsiorowska-Grabowska (1881-1964) - historyk, badacz dziejów ruchu robotniczego, profesor Uniwersytetu Łódzkiego i Uniwersytetu Warszawskiego, profesor i rektor Wyższej Szkoły Pedagogicznej w Łodzi. 
społeczną, z profesor Heleną Radlińską ${ }^{57}$. Dla mnie to było bardzo naturalne, ponieważ ja znałam to środowisko. Od nich dostaliśmy pieniądze na pierwsze badania, na publikację, i potem prowadziliśmy badania. W ramach tych badań nad pomocą społeczną i współdziałaniem był cały zespół seminaryjny, a seminarium było duże, dlatego że na etnografię jako na przedmiot poboczny chodzili pedagogowie społeczni, historycy sztuki, geografowie, później też socjologowie itd., i była spora grupa, dwadzieścia parę osób siedziało. Pani profesor od pierwszego momentu zainicjowała te prace: w 1945 roku zaczęła właśnie pracować nad tą pomocą wzajemną i współdziałaniem, zostały zorganizowane badania, koncepcję badań pani profesor Zawistowicz opracowała i opublikowała w takiej małej książeczce, którą wydał Instytut Izby Społecznej, to był taki instytut, w którym babcia Radlińska to organizowała. Profesor Zawistowicz-Adamska ${ }^{58}$ nawet się o to obrażała, że koledzy etnografowie mówili, że ona uprawia nie etnografię, tylko socjologię. Ponieważ ona, że tak powiem, relatywizowała zjawiska kulturowe do zjawisk społecznych i jeżeli znalazła zależności, uwarunkowania społeczne, to na tym poprzestawała. Tłumaczyła strukturą społeczną, formami życia rodzinnego, sąsiedzkiego itd. i to jej wystarczało. To nie było takie hasło, którym w tej chwili antropologia szafuje, nie było thumaczenia kultury przez kulturę.

Jerzy Dietl z kolei opowiada o relacjach z socjologami, które miały zarówno wartość naukową, jak i społeczną, a jak pokazały wydarzenia z dekady lat osiemdziesiątych, również i polityczną:

W Łodzi zaprzyjaźniłem się bardzo z socjologami, z Jankiem Lutyńskim ${ }^{59}$, bardzośmy mieli serdeczne stosunki i z Jolantą Kulpińską ${ }^{60}$, ale też z młodszymi, z Ilonką Przybyłowską ${ }^{61}$. Razem realizowaliśmy nawet pewne badania, bo ja byłem bowiem między innymi w komitecie Badań Rejonów Uprzemysławianych PAN i socjologowie rozpoczęli w jego ramach badania w okolicach Włocławka, objęły również Puławy i jeszcze Polkowice. Ja prowadziłem badania od strony rolniczej, zajmowałem się rynkiem rolnym, jeżeli w ogóle można to nazwać rynkiem, chociaż były takie resztki rynku na wsi, czy może raczej początki. Zresztą badania w regionach uprzemysławianych prowadziłem jeszcze w Poznaniu, w powiatach konińskim, kolskim i tureckim. Nie potrafię wymienić wszystkich nazwisk socjologów, ale bardzo to było sympatyczne.

Jak zatem można dostrzec w przytoczonych powyżej fragmentach, tak dziś ceniona interdyscyplinarność i tworzenie pól możliwego spotkania

\footnotetext{
${ }^{57}$ Zob. przypis $52 \mathrm{w}$ tym rozdziale.

${ }^{58}$ Zob. przypis $55 \mathrm{w}$ tym rozdziale.

${ }^{59}$ Zob. przypis $31 \mathrm{w}$ tym rozdziale.

${ }^{60}$ Jolanta Kulpińska - patrz biogramy rozmówców.

${ }^{61}$ Ilona Przybyłowska (ur. 1945) - socjolog, pracownik Katedry Metod i Badań Społecznych UŁ.
} 
naukowców, na których prezentują oni swoje czasem skrajnie odmienne spojrzenia na określony problem, ma na uniwersytecie swoje wieloletnie i ugruntowane tradycje.

\section{Zainteresowania naukowe}

Podjęcie określonej tematyki pracy naukowej to decyzja o niebagatelnych konsekwencjach - nie tylko przesądza o tysiącach godzin poświęconych dociekaniom wokół często wąskiego zakresu zagadnień, ale niejednokrotnie waży na rozwoju dalszej kariery akademickiej, określa sieci koniecznych kontaktów czy możliwości rozwoju naukowego. Nasi rozmówcy, co ciekawe, nie tak często opowiadali o samym przedmiocie swoich zainteresowań. Być może i o tym decydował fakt, że osoby przeprowadzające wywiady reprezentowały zazwyczaj inne niż narratorzy dyscypliny naukowe, co powstrzymywało tych ostatnich od sięgania po żargon własnej dziedziny.

Treść swojej codziennej pracy badawczej (nieraz kompletnie niezrozumiałej dla laika) nasi rozmówcy starali się prezentować, jak to ujął Ryszard Jajte: „na poziomie inteligentnego licealisty”, odwołując się czasem także do bardziej złożonych kwestii. Wszystkie opisy, jak zobaczymy dalej, wyróżnia jedna wspólna cecha - przebija z nich pasja. Zacznijmy od relacji wspomnianego już Ryszarda Jajtego:

Niektórym się wydaje, że matematyka polega na tym, że ma się tam już jakieś fakty i z tych faktów dedukuje i drogą dedukcji dochodzi do nowych faktów. Nic mniej prawdziwego. Matematyk, jeżeli jest coś naprawdę niebanalnego, to najpierw to wymyśla, odkrywa, to znaczy myśli, że może tak właśnie jest i wtedy stara się to udowodnić. Nieraz jest tak, że udowodni, a nieraz nie udowodni. Tak było na przykład z tak zwanym pewnikiem Euklidesa w matematyce najstarszej chyba, ale nie najprostszej. On postawił taki postulat, tak zwany pewnik, że przez prostą i punkt poza nią leżący przechodzi dokładnie jedna prosta równoległa. Myślano, że to powinno się dać wywieść z innych pewników. Próbowali, nie udało się. W końcu doszło do tego, że stwierdzono, że tego się nie da wywieść. To znaczy ten pewnik jest niezależny od pozostałych. I w ten sposób ludzie stworzyli geometrie nieeuklidesowe. Oznacza to, że jeśli zaprzeczy się pewnikowi Euklidesa, to znaczy przyjmie się np. za pewnik, że przez punkt poza prostą można poprowadzić nieskończenie wiele do niej równoległych, to otrzyma się inną geometrię, równie ważną jak ta poprzednia. Także widać, że próby dowodzenia czegoś, co się najpierw próbowało jakoś odgadnąć, prowadzą do takiej na przykład sytuacji. Ale właśnie taka jest praca matematyka, że najpierw coś odgaduje, a dopiero potem próbuje dopasować dowód. I często jest tak, że odgaduje i publikuje bez dowodów. Tak było 
z niektórymi dowodami wielkich twierdzeń, że najpierw było twierdzenie bez dowodu, a dopiero potem ktoś podał dowód. Także to jest taka droga odgadnięcia czegoś, a potem dopasowania dowodu.

\section{( ...)}

Pisałem matematykę cały czas i lubiłem to. Robiłem to z pasją. Starałem się pisać dobrze, to znaczy nie po to, żeby napisać pracę i umieścić w czasopiśmie, którego nikt nie czyta, tylko w takich pismach, które czytają, w dobrych pismach o zasięgu międzynarodowym. I tak napisałem w moim życiu troszkę ponad sto prac, w tym dwie monografie wydane u Springera ${ }^{62} \mathrm{w}$ Niemczech. To tyle jeżeli chodzi o moją matematykę. Gdyby były osoby zainteresowane, co to jest matematyka w ogóle, to proponuję mój wykład inauguracyjny w roku 1987 - miałem zaszczyt wygłosić na inaugurację roku akademickiego wykład „O paradoksach w matematyce”, przystępny, ponieważ na sali byli nie tylko matematycy, ale i biolodzy, i socjolodzy, i wszyscy inni, więc starałem się napisać to na poziomie inteligentnego licealisty, żeby był zrozumiały i chyba jest.

Równie przystępnie, choć o zupełnie innym, odległym od matematyki przedmiocie naukowych i badawczych zainteresowań opowiada Olga Czerniawska - andragog:

Poza tym wymyśliłam temat habilitacji, ponieważ zajęłam się poradnictwem i byłam pionierką $\mathrm{w}$ tym zakresie. Jeździłam na seminaria do Wrocławia, bo tam się moja koleżanka tym zaczęła zajmować, i zrobiłam habilitację z poradnictwa. Poradnictwo to bardzo rozwinięta dziedzina, bo było poradnictwo zawodowe, ale tym się nie zajmowałam, poradnictwo edukacyjne, to jak najbardziej, poradnictwo życiowe. We Wrocławiu był profesor, który mówił o poradnictwie życiowym: więc różnego rodzaju kryzysy, sprawy, także poradnictwo pośrednie i bezpośrednie. Moje było poradnictwo bezpośrednie na przykład, z tego miałam kilka doktoratów wypromowanych, poradnictwo dla rodziców, poradnictwo małżeńskie. Także to jest, że tak powiem, wyspecjalizowane. Poradnictwo dla wdów na przykład, następnie poradnictwo pośrednie, przez środki masowego przekazu, przez prasę, różne media. Było też takie poradnictwo przez telefon, początki telefonu zaufania, poradnictwo gerontologiczne, profesjonalne, nieprofesjonalne. Tego jest sporo. Ja w tej chwili odeszłam prawie od tego, chociaż ostatnio miałam recenzję z bardzo ciekawej habilitacji z poradnictwa i jeszcze czasami do mnie to przypływa. Ta moja koleżanka z uniwersytetu we Wrocławiu, pani profesor Alicja Kargulowa ${ }^{63}$ się tym zajęła bardziej, mówi o poradoznawstwie, napisała o tym podręczniki, niewątpliwie jest to dziedzina ważna, i taką miałam habilitację.

\footnotetext{
${ }^{62}$ Springer-Verlag - jeden z największych domów wydawniczych w Niemczech i Europie.

${ }^{63}$ Alicja Kargulowa (ur. 1936) - pedagog, andragog, profesor w Dolnośląskiej Szkole Wyższej.
} 
Jak już to kilkakrotnie zaznaczono w tej publikacji, wybór zainteresowań naukowych naszych rozmówców uwarunkowany był wieloma czynnikami - niejednokrotnie wpływem mistrza, nieraz aktualnymi badaniami, w które zaangażowana była cała katedra, czasami nawet odgórnie zdefiniowanym zapotrzebowaniem, ale bywało i tak, że był on podyktowany przede wszystkim własnymi zainteresowaniami jednostki. W przypadku przedstawicieli nauk humanistycznych i społecznych nasi narratorzy podkreślali swoją wrażliwość na i zaangażowanie w sprawy społeczne, które zapewne w dużej mierze zaważyło na wyborze kierunku studiów. Zainteresowania naukowe Zbigniewa Bokszańskiego są bez wątpienia wypadkową sugestii mistrza - prof. Antoniny Kłoskowskiej ${ }^{64}$ - i kierunku jego własnej ciekawości poznawczej:

Zainteresowaliśmy się ludźmi, którzy odrywają się od pewnych wzorów recepcji kultury, kontaktów z kulturą, które są właściwe ich środowiskom, i realizują jakieś inne wzory. Stąd powstała moja praca magisterska o robotnikach, czytelnikach literatury elitarnej. Ponieważ takie białe kruki owszem się znajdowały i postanowiliśmy przyjrzeć się temu, kim są ci ludzie i co z tych lektur, nie wiem Kafki, Gide'a ${ }^{65}$ oni wynoszą. W środowisku robotniczym czytało się, jeżeli się czytało, Kraszewskiego czy tego typu literaturę. To był ten problem, który nas interesował, ciekawy zresztą. Okazało się, że są to po prostu ludzie, którzy w swoim środowisku byli głównie outsiderami jakimiś i z różnych powodów przerastali to swoje środowisko. Niekiedy pojawiały się tam problemy natury psychologicznej, można tak to nazwać. Po czym postanowiłem, też zresztą $\mathrm{w}$ porozumieniu z profesor Kłoskowską, która bardzo mądrze skierowała mnie w stronę teorii socjologicznej, żeby oderwać się od tych takich stosunkowo prostych zagadnień empirycznych i skierowała moją uwagę na, z jednej strony, Znanieckiego, z drugiej strony na Parsonsa ${ }^{66}$, po to, żeby, jak myślę też $\mathrm{w}$ części, co sobie w trakcie przygotowywania tej pracy coraz bardziej uświadamiałem, żeby pokazać łączność, która istniała między rozwojem myślenia teoretycznego w Polsce z tym głównym mainstreamem socjologicznym, który w latach sześćdziesiątych dawał się zauważyć. Stąd była

${ }^{64}$ Zob. przypis $32 \mathrm{w}$ tym rozdziale.

${ }^{65}$ Franz Kafka (1883-1924) - przez całe życie związany z Pragą tworzący po niemiecku pisarz pochodzenia żydowskiego. W swojej twórczości zajmował się przede wszystkim napięciami i dramatami jednostki w zderzeniu z instytucją. André Gide (1869-1951) - światowej sławy francuski prozaik, laureat Nagrody Nobla, autor m.in. „Fałszerzy”, „Lochów Watykanu” czy „Immoralisty”. Jego literatura opiewała skrajny indywidualizm i odejście od ograniczających norm moralnych. Jego zachwyt nad komunizmem zrewidowała podróż do ZSRR.

${ }^{66}$ Florian Znaniecki (1882-1958) - filozof i socjolog, ojciec założyciel socjologii w Polsce. Talcott Parsons (1902-1979) - amerykański socjolog, twórca funkcjonalno-strukturalistycznej teorii systemów społecznych. 
ta cała koncepcja działania w teoriach Parsonsa i Znanieckiego. Praca, która mi bardzo wiele dała. Zacząłem w sposób bardzo systematyczny, taki dość gruntowny przede wszystkim jak myślę, z jakimś tam stopniem [śmiech] rozumienia czytać trudne lektury socjologiczne, już takie bardzo profesjonalne.

Jolanta Kulpińska, socjolog, opowiada, co zdecydowało o tym, że zajęła się badaniem społeczeństwa. Podkreśla przy tym swoje zainteresowania polityką i pragnienie zmiany świata na lepsze - typowe zresztą dla pokolenia, którego dzieciństwo i młodość przypadły na lata wojny:

Także dość wcześnie zaczęłam współpracować z profesorem Szczepańskim ${ }^{67}$, $\mathrm{w}$ takim tym programie badań nad klasą robotniczą i inteligencją. $Z$ tym że ja się bardziej interesowałam niewątpliwie z powodów też ideologicznych klasą robotniczą. Ale to mi właściwie zostało. To zainteresowanie było wczesne i do końca jakoś ta problematyka mnie interesuje. Może też jakąś rolę myślę odgrywały te moje doświadczenia pracy przymusowej w Niemczech. Szczególnie, że Szczepański zawsze bardzo pomagał, ale nie narzucał swojego zdania.

Prawnik Michał Seweryński także odwołuje się do swoich zainteresowań prospołecznych, gdy wyjaśnia czemu specjalizował się w prawie pracy:

A co więcej, poczułem się zainteresowany, zafascynowany prawem pracy. Ma ono taki mocny wydźwięk społeczny, to bardzo prospołeczna nauka, takie podejście, które profesor Szubert ${ }^{68}$ propagował, rozwijał tu w Lodzi i nie tylko. I działo się coś więcej aniżeli z jakąś jedną ciasną dziedziną prawa, jak na przykład prawo karne. On miał takie żartobliwe powiedzenie, że ,prawo karne jest dla przestępców, a prawo pracy dla przyzwoitych ludzi”. Ono pozwalało dostrzegać te wszystkie uwarunkowania powiązane ściśle z pracą ludzką: polityczne, gospodarcze, społeczne, moralne.

Co ciekawe, czasem niespodziewane zewnętrzne ograniczenia decydowały o wyborze przedmiotu badania, jak w przypadku Jerzego Dietla, który uczestniczył $\mathrm{w}$ badaniach uprzemysławianych terenów wiejskich. Jego zainteresowania dotyczyły zachowań rynkowych, co w okresie PRL ograniczało znacznie pole eksploracji i właśnie na marginesach socjopolitycznej gospodarki próbował on realizować swoje cele:

Jako ten ,jajogłowy" coś tam próbowałem robić, musiałem przestawić się w ogóle, jeśli chodzi o badania empiryczne. Starałem się realizować badania w rejonach wiejskich, nie dlatego, że wieś mnie interesowała, tylko dlatego, że to było jedyne miejsce, gdzie można było to robić. Bo gdzie indziej takie wywiady czy inne wymagały jakichś szczególnych zezwoleń. Poza tym dla

\footnotetext{
${ }^{67}$ Zob. przypis $33 \mathrm{w}$ tym rozdziale.

${ }^{68}$ Zob. przypis $14 \mathrm{w}$ tym rozdziale.
} 
mnie jako ekonomisty nawet jakiś szczątkowy rynek był bardziej interesujący niż cokolwiek innego. Poza tym byłem związany z przemysłem lekkim, także z tego zakresu żeśmy prowadzili różne badania.

Bywało i tak, że praca badawcza obfitowała w zdarzenia, które przez lata powtarzane były w postaci anegdot, tworzących szczególną aurę danej dyscypliny, ale też świadczących o zaangażowanym stosunku rozmówcy do przedmiotu jego zainteresowań. Zobaczmy, jak barwnie o zbieraniu żab, które później służyły jako eksponaty dla studentów, opowiada biolog Edward Tranda:

Jeździło się po żaby w takie okolice podłódzkie, gdzie można było do worków nałowić tych płazów. Jeździliśmy na przykład do lasów tuszyńskich i któregoś razu wracaliśmy z tych lasów tuszyńskich tramwajem dojazdowym, w którym ławki były wzdłuż okien, ścian wagonu. I te worki oni związywali i wrzucali pod siedzenie, i tam sobie leżały, czasem kumkały te żaby, rechotały i tak dalej. Ale któregoś dnia zrobiła się draka niesamowita, bo jeden ten worek się rozwiązał i płazy powyłaziły z niego i zaczęły skakać po tramwaju [śmiech], wywołując popłoch wśród kobiet jadących z Tuszyna czy ze Rzgowa do Łodzi. A ci biedacy, łowcy tych zwierząt, pod ławkami, na czworakach wyłapywali te biedne płazy. Więc się cały czas zaśmiewaliśmy z tej ich przygody. Dzisiaj to się po prostu kupuje płazy u dostawców. Zakłady wtedy były biedne, to trzeba było samemu pojechać i przywieźć. Ja je łowiłem.

Skrótowo przedstawiony opis badań może brzmieć niczym relacja z filmu przygodowego. Kiedy Krzysztof Jażdżewski opowiada o wyprawach polarnych, nurkowaniu i rejsach na dalekie morza, praca zoologa wydaje się ciągiem przygód; niestety, jak sam stwierdza:

Moja praca magisterska o budowie małej ryby - strzebli, to była dosyć nudna taka praca, bo polegała na mierzeniu iluś tam dziesiątków ryb. Mierzeniu wszystkiego, co im się da zmierzyć: policzyć promienie w płetwach, policzyć różne długości, różne odcinki ciała, bo to jest takie badanie, jakie się na wszystkich właściwie organizmach prowadzi. Potem zająłem się morfologią i ekologią skorupiaków.

Krzysztof Jażdżewski zaangażowany był także w obiecujący program badawczy nad krylem, mający podratować polską gospodarkę lat siedemdziesiątych, a może i uchronić ludzkość przed głodem - niewtajemniczeni w problematykę kryla znajdą szczegółowy jej opis w wypowiedzi profesora: 
Na wyprawie „krylowej” na statku „Profesor Siedlecki”“99 właśnie ciągnęliśmy taki włok, sieć, tak na głębokości kilkudziesięciu metrów. To oczywiście w tej chwili już echosondą można wyczuć, bo te ławice widzi się na ekranie. Przez osiem minut ciągnięcia tego trału wydobyto już pełną sieć na pokład, ja mam takie zdjęcia nawet. I to, co wyrzucono na pokład po ośmiu minutach, zaciągu ważyło około dwudziestu pięciu ton, a jeden taki skorupiak ma wielkość [pokazuje długość kilku centymetrów]. Waży od jednego do dwóch gramów, więc teraz jeśli po ośmiu minutach ciągnięcia dostaje się taki ładunek, to to pokazuje, jak dużo jest tego zwierzęcia, bo tak jak mówię, w kilogramie kryla jest tysiąc sztuk tego zwierzaka, a dwadzieścia pięć ton... Samica duża, jeszcze z jajami w jajnikach, to większa, cięższa troszeczkę. To oczywiście wszystko zależy od tego, czy one są bardziej dorosłe, czy młodsze, czy starsze, więc jeden, dwa gramy to są już taka waga graniczna, dorosłe. Krótko mówiąc, tego organizmu jest bardzo dużo w Oceanie Południowym, który jest niesłychanie żyzny. Tam kryl ma co jeść, je mikroskopijne organizmy, okrzemki. To bardzo ciekawy system i wtedy się wydawało właśnie, że jak tego kryla się nałowi, to się zaraz zrobi w fabrykach białko bezpostaciowe. A białko bezpostaciowe to może nie wszyscy wiedzą, ale się dodaje do każdych prawie przetworów mięsnych w tej chwili. Ono nic nie szkodzi, że tak powiem, ale jak się doda za dużo, to kiełbasa może być niesmaczna. Ale przeważnie się dodaje jakieś pięć procent $z$ tej całej masy, to nikt tego nie poczuje. Ja na tej technologii żywności się nie znam, ale Polacy dużo w tym kierunku robili. Tylko dla nas to jest nie interes, bo to jest za daleko. Kryl to jest bardzo szybko psujący się produkt, wobec tego musi być natychmiast mrożony albo natychmiast przetwarzany, a na statku nie ma fabryki, więc jeżeli Polakom by się opłaciło, to łowić i szybko sprzedawać komuś: Argentyńczykom, Hindusom, tym, co są na południu. Oni sami już się tym troszkę zajmują. Poza tym, poza mięsem, poza tym białkiem, taki kryl ugotowany, świeżutko zrobiony jest pyszny, bo to jak krewetki, kryl to jest właściwie taka krewetka, a w smaku delikatniejszy nawet. Tyle tylko, że sporo do łuskania, bo to jest mała kreweteczka.

Jak widać, efekty pracy naukowej mogły mieć niebagatelne konsekwencje. Niejednokrotnie naukowcy podejmowali przecież współpracę z przemysłem i pracowali nad rozwiązaniami mającymi wpływ na środowisko pozaakademickie. O próbach powiązania ustaleń z uniwersyteckich laboratoriów z produkcją przemysłową i praktycznych zastosowaniach osiągnięć naukowych dla społeczeństwa opowiada Eugeniusz Czerniawski:

${ }^{69}$ RV „Profesor Siedlecki” - polski statek przeznaczony do badań oceanologicznych, ichtiologicznych i hydrobiologicznych prowadzonych przez Morski Instytut Rybacki w Gdyni. Został zbudowany na początku lat siedemdziesiątych w Gdańskiej Stoczni im. Lenina. 
Mieliśmy między innymi współpracę z Polfą pabianicką przy sterinolu. Oni wyprodukowali sterinol - odpowiednik zephirolu, mała różnica w budowie. I miał sterinol być przygotowany do odkażania kotłów do wody pitnej na statkach. W Pabianicach osiągnięto bardzo dobre wyniki. Może jeszcze powiem, że w naszych badaniach jedna osoba nic nie zrobi, tu musi być zaangażowanych bardzo dużo osób z zakładu, ba, nawet z instytutu. Bo przy określaniu wielkości promieniowania jonizującego na przeżywalności bakterii myśmy przebadali ponad dwadzieścia pięć tysięcy klonów drobnoustrojów - bakterie, grzyby izolowane ze sprzętu przeznaczonego do sterylizacji i z pomieszczeń produkcyjnych. I na tej podstawie określiliśmy stopień przeżywalności badanych drobnoustrojów w zależności od wielkości dawek. Na tym polegała cała sztuka. I ten sterinol zaczął funkcjonować, ale bakterie są złośliwe. I pałeczka okrężnicy - Escherichia coli zaczęła się rozwijać jakby zadomowiła się. W handlu był dziesięcioprocentowy sterinol i trzeba było go do trzech procent rozcieńczyć żeby go użyć, ale okazało się, że pałeczka okrężnicy uodporniła się na sterinol. Dlatego na zjeździe Polskiego Towarzystwa Mikorobiologów w Szczecinie - a wcześniej ze sterinolem myśmy wystąpili, że dobry jest - ale na tym zjeździe postawiłem wniosek, żeby sterinol wycofać z produkcji.

\section{Eugeniusz Czerniawski opowia-} da nie tylko o współpracy z przemysłem, która jest jedną z sytuacji wymagających dostosowania sposobu przekazywania wiedzy do odbiorcy spoza środowiska naukowego, ale też o szczególnym adresacie przekazu naukowego, jakim jest szerokie grono publiczności filmów oświatowych:

Polskie Towarzystwo Badań Radiacyjnych organizuje takie szkoły jesienne czy letnie dla różnych instytucji w Polsce, zainteresowanych sprawami radiacyjnymi. Na przykład sterylizacja radiacyjna sprzętu medycznego, radiacyjna konserwacja żywności i inne. Ja tam miałem wykłady co kilka lat, bo Państwowy Zakład Higieny i różne takie instytucje, fabryki, jeżeli tematyka ich dotyczy, prosiły o takie

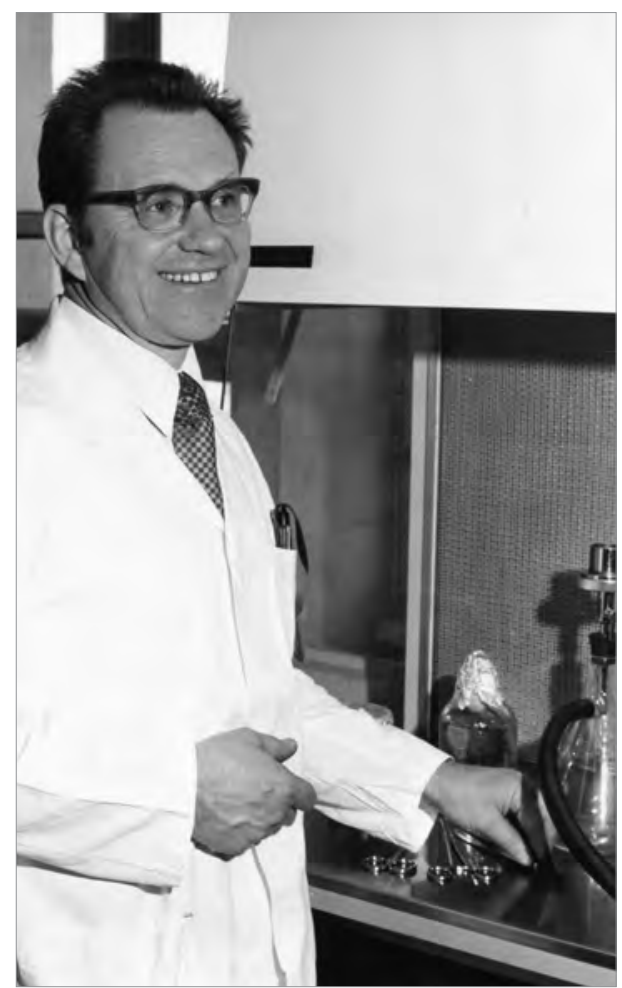

Fot. 56. Eugeniusz Czerniawski przy pracy 
wykłady. Także to jest bardzo ciekawe Towarzystwo. Ta technika radiacyjna jest bardzo ciekawa. A z innych ciekawostek to dwa scenariusze dydaktyczne napisałem do filmów o bakteriach. Tutaj trzeba było zbudować taką komorę, ktoś od filmów trochę podpowiedział, że chodzi o to, jak poklatkować zdjęcia. Jak rozwijają się bakterie, komórka, to trzeba zrobić tak, żeby ona cały czas była widoczna i nie można nic ruszyć. To z osiem godzin trwa, bo tyle musi trwać to doświadczenie. I okazuje się, że płytka mosiężna na posiew się nie nadaje, bo bakterie nie chcą rosnąć, trzeba inną, więc musiałem wymyślić, jaką. Taki film bardzo ładny mi wyszedł. A drugi był o fagocytozie, trzeba było to zrobić na żywo. I na WAM-ie robili, i na Akademii Medycznej. Nie wyszło. Marnowali masę królików, świnek morskich, bo pobierali krew, ale na tym materiale nie było pozytywnych wyników. Na to ja mówię: może my ten temat weźmiemy, i zaczęliśmy. Ja byłem wtedy na wakacjach i koleżanka napisała list, że niestety nie wychodzi. Mają nowoczesne metody immunologiczne, ale nie wychodzi. Pomyślałem sobie - zmiana cieplna. I odpisałem, żeby wzięła leukocyty od żaby - i wyszło. Przecież w mikroskopie nie widać, czy to ludzkie, czy nie [śmiech]. Później napisała: „,wyszło, bardzo dobrze”. A te bakterie, okazało się, w zależności od gatunku inaczej się dzielą. Inaczej E coli, inaczej laseczki przetrwalnikujące itd., w zależności od gatunku. Zanim to poszło do wytwórni filmów, to ja to wszystko musiałem w laboratorium zrobić.

Tematyka filmów oświatowych pojawia się także w wypowiedzi Eweliny Nurczyńskiej-Fidelskiej. Jej relacja o własnych zainteresowaniach badawczych staje się jednocześnie opowieścią o tworzeniu ram popularyzacji wiedzy o filmie:

Mój doktorat, a później habilitacja, były skoncentrowane na zagadnieniach, które jakby równolegle towarzyszyły moim zainteresowaniom historyczno-filmowym, czego przykładem był właśnie doktorat. Moja habilitacja była związana z tym drugim nurtem moich zainteresowań, które wywodzę z pierwszych szkolnych doświadczeń, kiedy byłam nauczycielem w liceum. To były moje prace związane z tak zwanym filmoznawstwem stosowanym, a ściślej z zagadnieniami dydaktyki filmu, edukacji filmowej itd. I moją habilitacją była książka pod tytułem Edukacja filmowa na tle kultury literackiej. Tym przedsięwzięciom patronował mój mistrz, profesor Lewicki ${ }^{70}$, który wciągał mnie we wszystkie prace związane $\mathrm{z}$ programowaniem form edukacji filmowej przez instytucje oświatowe, a głównie przez Ministerstwo Oświaty, tak to się chyba wówczas nazywało. Edukację filmową na różnych etapach programów

${ }^{70}$ Bolesław W. Lewicki (1908-1981) - teoretyk filmu, krytyk i pedagog. Urodził się we Lwowie, gdzie ukończył filozofię na Uniwersytecie Jana Kazimierza. Od początku jego pasją był film i wiedza o filmie. Jest uznawany za twórcę polskiego filmoznawstwa. W 1960 roku utworzył Zakład Wiedzy o Filmie na Uniwersytecie Łódzkim; w późniejszych latach profesor Państwowej Wyższej Szkoły Filmowej w Łodzi. 
szkolnych wprowadzano powoli za sprawą uczestnictwa w tych programach profesora Lewickiego i mego skromnego, wówczas także wprowadzano do programów szkolnych elementy wiedzy o filmie i telewizji. One wpisywane były w ówczesnych koncepcjach przede wszystkim w przedmiot język polski, ponieważ mieliśmy świadomość, że polonista jest w szkole osobą najbardziej predestynowaną do podejmowania zagadnień sztuk audiowizualnych. Pewne rzeczy w obrębie tych sztuk są sobie bliskie: gatunki konstrukcja fabuły itd. Nie tylko byliśmy w działach eksperckich jak Ministerstwo Oświaty czy Ministerstwo Kultury, ale także prowadziliśmy badania naukowe, najpierw jeszcze pod auspicjami profesora, później już prowadziłam je sama. To były badania paroletnie $\mathrm{w}$ różnych okresach, lata siedemdziesiąte, potem osiemdziesiąte, prowadzone w łódzkich szkołach, gdzie wedle określonych koncepcji nauczyciele poloniści prowadzili lekcje filmowe z uczniami w szkole podstawowej, $\mathrm{w}$ liceum, a nawet $\mathrm{w}$ technikum. Sprawdzaliśmy problemy recepcji filmu przez dzieci i młodzież oraz szukaliśmy metod dydaktyki szkolnej. Także na to otrzymywaliśmy granty, jak to dziś powiemy, dwukrotnie, raz w latach siedemdziesiątych, raz w osiemdziesiątych.

Gdy mowa o biografii naukowej, na szczególną uwagę zasługują wyjazdy zagraniczne, o których nestorzy naszej uczelni opowiadają chętnie i dużo. Temu wątkowi w ich relacjach poświęcimy kolejny podrozdział.

\section{Wyjazdy zagraniczne}

Żadna dyscyplina nauki nie może rozwijać się w izolacji, bez możliwości kontaktu i dialogu z jej przedstawicielami w innych ośrodkach - także tych zagranicznych. Niezbywalnym warunkiem budowania idei universitas, o której szerzej piszemy w rozdziale zamykającym tę książkę, jest poszerzanie i weryfikacja horyzontów poznawczych, metod badawczych czy sposobów myślenia poprzez konfrontację z odmiennymi wzorami logiki naukowej, koncepcjami teoretycznymi czy praktykami naukowych poszukiwań. Jednak nie zawsze założenie to może być w pełni realizowane. W powojennej historii wielu krajów byłego bloku sowieckiego miały miejsce takie okresy, kiedy nauka była poddawana presji ideologicznej, a jej rozwój podporządkowany wizji (często reżimowej) władzy, która starała się kontrolować i ograniczać kontakty naukowców ze światem. Dynamikę tego procesu możemy prześledzić w przytaczanych poniżej opowieściach naszych rozmówców.

Zanim jednak przejdziemy do ich prezentacji, przyjrzyjmy się owej kwestii z jeszcze innej perspektywy - potocznych wyobrażeń na temat możliwości zagranicznych wyjazdów naukowych czy badawczych (poza kraje tzw. demokracji ludowej, choć i o nich będzie tu mowa) w okresie 
PRL. Nader często możliwości opuszczenia kraju są bowiem przedstawiane jako niezwykle ograniczone, restrykcyjnie nadzorowane, zazwyczaj powiązane z kryterium ideologicznym i współpracą z aparatem partyjnym. Można w tym miejscu zaryzykować nawet tezę, że im mniej okres życia danego pokolenia „zachodzi” na epokę PRL (lub w ogóle nie ma z nią nic wspólnego), tym bardziej ówczesna Polska jawi się mu jako hermetycznie zamknięty kraj, z którego wyjechać mogli tylko nieliczni. Tymczasem obraz tych lat był znacznie bardziej zróżnicowany i wielowymiarowy. Choć szczegółowy i rzetelny opis ówczesnej rzeczywistości nie jest tutaj naszym celem, musimy wspomnieć o kilku aspektach kreślących ramę społeczno-historyczną, w której osadzone są doświadczenia naszych rozmówców. Przede wszystkim należy zaznaczyć, że polskie uniwersytety na tle uczelni z innych państw bloku wschodniego wyróżniały się względną otwartością i dużą powściągliwością wobec bezkrytycznej implementacji modelu radzieckiego, co miało również wpływ na możliwość wyjazdów zagranicznych $^{71}$. Co może wydawać się zaskakujące, wśród zgromadzonych przez nas opowieści nie ma żadnej, w której nie znalazłby się choćby jeden epizod związany z naukowym wyjazdem zagranicznym ${ }^{72}$. Słowem: wszyscy nasi rozmówcy, bez względu na zajmowaną na uniwersytecie pozycję i zaangażowanie polityczno-ideologiczne, mieli możliwość zdobywania, poszerzania czy dzielenia się wiedzą w innych krajach. Drugą ważną kwestią, która wymaga komentarza, jest jednak fakt, że aparat państwowo-partyjny na przestrzeni lat w różnym stopniu rozchylał poły żelaznej kurtyny, za którą w wyniku ustaleń jałtańskich znalazła się Polska. I tak przed rokiem 1956 podstawowym założeniem władz było kształcenie polskich uczonych u źródła (a zatem najlepiej w Związku Radzieckim), co miało się wiązać z przyjęciem przez nich prawomyślnej ideologicznie postawy, z indoktrynacją marksizmem-leninizmem oraz z przyswojeniem światopoglądu materialistycznego. Polityka ta nieco zelżała w latach sześćdziesiątych i Polska coraz bardziej zaczęła otwierać się na świat. Największą liberalizację w tej kwestii przyniosła epoka gierkowska, w czasie której ingerencja władzy państwowej w wyjazdy zagraniczne naukowców i kontakty międzynarodowe uczelni znacznie zmalała. Niestety wraz z wprowadzeniem w Polsce

${ }^{71}$ Por. dla przykładu: Ryszard Herczyński, Spętana nauka: opozycja intelektualna $w$ Polsce 1945-1970, Wydawnictwo Naukowe Semper, Warszawa 2008 czy Kristie Macrakis, Dieter Hoffmann (red.), Science under Socialism: East Germany in Comparative Perspective, Harvard University Press, Cambridge, MA 1999.

${ }^{72}$ Oczywiście musimy przy tym pamiętać, że wielu naukowcom ze względu na swoje zaangażowanie polityczne i krytyczną postawę wobec ówczesnego systemu uniemożliwiono kontynuowanie kariery (choćby przez blokadę możliwości wyjazdu za granicę). 
stanu wojennego proces ten został zahamowany, a wszelkie kontakty z Zachodem zostały drastycznie ograniczone. Wreszcie, mając przede wszystkim na uwadze kontekst polityczny, należy wspomnieć o różnicy między naukami humanistycznymi i przyrodniczymi oraz ścisłymi. Te pierwsze z założenia były definiowane jako, ,ideologiczne” i stanowiły (ze względu na przedmiot swoich zainteresowań) zagrożenie dla ,programowej linii politycznej”, podczas gdy te drugie miały spełniać raczej służebną rolę wobec systemu i ze swej natury nie powinny być uwikłane w żadne kontrowersje natury światopoglądowej.

Zarysowane wyżej warunki społeczno-polityczne mające wpływ na możliwości wyjazdów i otwarcie granic znajdują swój ślad w relacjach naszych narratorów, w których odnaleźć możemy liczne, niezwykle szczegółowe a nierzadko barwne relacje z pobytów zagranicznych - także w krajach Europy Zachodniej czy w Stanach Zjednoczonych. Nie chcemy jednak pozostawić Czytelnika z wrażeniem, że wyjazdy te odbywały się bezproblemowo. Drobiazgowość narracji może przy tym stanowić dowód nie wprost, że, po pierwsze, wyjazdy wcale nie były oczywistą możliwością, a po drugie, że wiązała się ona z różnorodnymi komplikacjami i często absurdalnymi zabiegami.

Zagraniczne wyjazdy naukowe czy ekspedycje badawcze przedstawiane są przez naszych narratorów w pierwszym rzędzie jako możliwości uczenia się (często od wybitnych przedstawicieli określonych dyscyplin), poszerzenia własnych horyzontów poznawczych, podpatrywania ,warsztatu" innych naukowców, dostępu do literatury, aktywności na międzynarodowych arenach wymiany myśli, transferu wiedzy i doświadczeń. Niebagatelną rolę odgrywają przy tym międzynarodowe kontakty nawiązane i podtrzymywane albo jeszcze przez przedwojennych profesorów, albo przez kolegów czy znajomych, którzy opuścili Polskę tuż po wojnie (lub później), albo też z własnej inicjatywy. Znajdziemy tu zatem wiele opowieści o poznanych ludziach - często wybitnych postaciach świata nauki - oraz ich wpływie na kariery naukowe naszych rozmówców.

\section{Trudności z wyjazdami}

Zacznijmy zatem od trudności, na jakie napotykali uczeni, chcąc wyjechać w celach naukowych czy poznawczych na Zachód, szczególnie wówczas, gdy ich postawa ideologiczna budziła wątpliwości władzy. Przytoczymy tu trzy opowieści: Biruty Lewaszkiewicz-Petrykowskiej, Jolanty Kulpińskiej i Jana Ziomka. 
Biruta Lewaszkiewicz-Petrykowska, prawnik, która jako uznany specjalista w swojej dziedzinie wielokrotnie zapraszana była do Strasburga na wykłady, podkreśla, jak kuriozalny i śmieszny z dzisiejszej perspektywy (a wówczas groteskowy i poniżający) był system przyznawania paszportów, odmawiania możliwości wyjazdu czy kontroli granicznej w różnych okresach PRL. Pojawia się tu też wątek wieloletniej współpracy Uniwersytetu Łódzkiego z francuskim uniwersytetem w Lyonie, która wówczas - jak podkreśla Lewaszkiewicz-Petrykowska - była niezwykle cenna ze względu na dostęp do literatury.

Wydział się bardzo szybko rozwijał. Mieliśmy bardzo rozwinięte stosunki z różnymi uniwersytetami: umowy z Lyonem, później ze Strasburgiem i z innymi ośrodkami. Jeśli chodzi o wyjazdy, to różnie to bywało. Ja współpracowałam bardzo długo z Uniwersytetem w Strasburgu. Co roku wykładałam na Międzynarodowym Wydziale Prawa Porównawczego odpowiedzialność cywilną w prawie porównawczym i tam jeździłam - chociaż ile razy miałam anulowany paszport, to już nie naliczę [śmiech]. Czasem się zastanawiałam, bo to aż śmiesznie wyglądało. W latach sześćdziesiątych - dostawaliśmy paszporty i jak się wyjeżdżało, to się odbierało te paszporty w Ministerstwie. Ministerstwo Szkolnictwa Wyższego je załatwiało, uniwersytety tych spraw nie prowadziły. Bywało pod tym względem bardzo różnie, bo oni tych spraw zwyczajnie nie załatwiali bardzo często i koniec. Pamiętam taką sytuację, jak mi powiedziała baba w Ministerstwie: „Co pani sobie wyobraża, że będzie pani jeździć, kiedy pani będzie chciała?”. Takie przygody, właściwie wszyscy w jakiś sposób mieli. A potem - w latach siedemdziesiątych - było o tyle prościej, że uniwersytet sprawy paszportów służbowych załatwiał. Mam do tej pory kopie tego, co wypisywałam w odwołaniach, bo nieodmiennie było tak, że odmawiają mi paszportu ze względu na bezpieczeństwo Państwa, takie tam bzdury.

Kaja Kaźmierska: Paragraf chyba piąty.

Biruta Lewaszkiewicz-Petrykowska: Artykuł czwarty, tak. Pisało się wówczas odwołanie, ale ono niewiele dawało. Ja zawsze się zastanawiałam o co im właściwie chodzi. W latach osiemdziesiątych dostawałam stale ten sam paszport służbowy, do jednokrotnego przejazdu w tę i z powrotem, i na tej granicy ten, co go sprawdzał, brał do ręki i pierwsze anulowane, następna kartka - anulowane, aż wreszcie znalazł, gdzie zgoda jest. Po prostu sami się wygłupiali w ten sposób, prawda? To idiotycznie wyglądało. Myśmy mieli współpracę z Lyonem - nawet taką dość ożywioną w latach siedemdziesiątych, ze Strasburgiem także. Profesor Natalia Gajlowa ${ }^{73}$, która wtedy, przez wiele lat, była

${ }^{73}$ Natalia Gajl (1921-1998) - prawnik i ekonomista, sędzia Trybunału Konstytucyjnego w latach 1985-1989. W pierwszych latach po transformacji ekspert Sejmu i Rady Ministrów. Pierwsza kobieta w Polsce, która została docentem prawa finansowego. 
dziekanem Wydziału Prawa, bardzo dbała o kontakty z uniwersytetami zachodnimi. Dużo z tych kontaktów zostało właśnie w tym czasie nawiązanych. To dawało możliwości przede wszystkim dostępu do literatury, przecież wtedy nie było łatwo sprowadzać książki z zagranicy.

Jan Ziomek, geograf, który z ogromną pasją opisuje swoje niezwykłe ekspedycje i wyjazdy (do których powrócimy później), opowiada o polityce ówczesnych władz wobec wyjazdów naukowych (czego najlepszą egzemplifikacją jest zdanie: „Oni doskonale wiedzieli, kto się zajmuje polityką"), problemach związanych z wydawaniem paszportów i niechęcią pracowników polskich ambasad wobec polskich badaczy i studentów:

Najtrudniejsze, jeśli chodzi o wyjazdy, to były lata pięćdziesiąte, sześćdziesiąte. W latach siedemdziesiątych już trochę pofolgowano i wyjazdy młodzieży studenckiej nie były tak kontrolowane jak inne wyjazdy. Zapewne dlatego, że nawet ci bonzowie, którzy mogli nam zabronić, sami sobie zdawali sprawę $\mathrm{z}$ tego, że my tam wdawać się w politykę nie będziemy, bo się nawet na tym nie znamy. Ale nie było to wcale łatwe, dlatego że na placówkach dyplomatycznych był wielki opór. Ci wszyscy, którzy byli konsulami czy urzędnikami, bardzo źle na nas patrzyli. Ja nigdy nie zapomnę, że jak byłem w Egipcie ze studentami, to na dziedzińcu, w ogrodzie Ambasady Polskiej w Kairze widziałem bunt taki, bo Ruskich wtedy wyganiali z kraju, bo była wojna i nas Arabowie też chcieli wywalić, bo myśleli, że jesteśmy Ruskimi, więc my krzyczeliśmy „Bulanda” [Polska] i nam nie robili krzywdy. Chciałem chronić naszych studentów i poprosiłem sekretarza ambasady, żeby pozwolił nam w ogrodzie, bo było gorąco, pod drzewami mangowymi do wieczora przeczekać. Na to sekretarz powiedział, że absolutnie nie, że o drugiej muszę opuścić ambasadę i po prostu nas wyrzucił. To było nieludzkie, dlatego że zachował się w sposób okrutny i chamski. Oni po prostu nie chcieli mieć z nami kłopotów. W ogóle stosunek ambasad był niedobry, był po prostu wściekły, wrogi. Oni pytali się, na jakich papierach my tu przyjechaliśmy. Także to były takie bardzo nieprzyjemne sprawy. Nie chcieli w ogóle z nami rozmawiać. Natomiast jeśli chodzi o paszporty, to najgorzej miałem z paszportem do Kanady, a bilet mogłem kupić dopiero gdy miałem paszport. Wszyscy już dostali paszporty, wszyscy kupili bilety, a ja w ostatnim dniu dopiero dostałem paszport.

Jolanta Kulpińska, socjolog, sugeruje, że po okresie stanu wojennego ,nastąpiło duże otwarcie na kontakty zagraniczne, bo nas zapraszano po prostu. Uczelnie miały taką politykę, akceptowaną przez wyższe władze, że jeżeli koszty ponosi strona zapraszająca, to proszę bardzo". Mówi 
jednak także o problemach paszportowych, z jakimi musiała się zmagać, chcąc wyjechać do Finlandii, i w których pomogli jej partyjni koledzy ${ }^{74}$.

Podkreślmy raz jeszcze, że jednak wielu osobom - szczególnie za brak subordynacji - odmawiano wydania paszportu i tym samym uniemożliwiano wyjazd zagranicę.

\section{Różnorodność doświadczeń a dyscypliny nauki}

Przyjrzyjmy się teraz szerokiemu spektrum i różnorodności doświadczeń naszych rozmówców, którzy reprezentują różne dziedziny i dyscypliny nauki:

Jolanta Kulpińska opowiada o swoim wyjeździe na Uniwersytet im. Łomonosowa w Moskwie na studia doktoranckie, wówczas - po wprowadzeniu radzieckiego modelu akademii - zwane kandydackimi. Akcentuje ona swoisty paradoks wynikający z założeń ówczesnej władzy (dodajmy, że aspirantura naszej rozmówczyni odbywała się w latach 1951-1955), która z jednej strony była przekonana, że jadąc do Moskwy, młodzi naukowcy w pełni przyswoją - niejako u źródła - ducha marksizmu-leninizmu, a z drugiej (do tego wątku wrócimy później) miała nadzieję, że pobyt na Zachodzie pozwoli im na zdobycie swoistego „,materiału do krytyki” kapitalistycznej formacji społecznej. Tymczasem, jak to zaraz pokaże Jolanta Kulpińska, rzeczy miały się odwrotnie:

Stwierdziłam, że ja jednak powinnam zapoznać się porządnie z marksizmem u źródła i wobec tego, ponieważ była taka rekrutacja, postanowiłam pojechać do Moskwy na studia - czyli na aspiranturę, na studia doktoranckie czy kandydackie. A Chałasiński ${ }^{75}$, to taka ciekawostka, z jednej strony wykorzystał to, ponieważ przy jakiejś okazji publicznie pochwalił się, że on posyła swoich asystentów na studia do Moskwy, ale z drugiej strony trochę się czuł obrażony, że ja właściwie powiedziałam mu o tym, że ja chcę jechać. Nie zapytałam go o zgodę - może o to chodziło. A może po prostu uznał, że to jest jakaś taka deklaracja i nie bardzo miał ochotę mieć ze mną do czynienia. Także kiedy wróciłam z Moskwy, to nie od razu się znalazłam z powrotem na tej socjologii, chociaż chciałam, tylko na filozofii, a właściwie w Katedrze Podstaw Marksizmu-Leninizmu, to się tak wtedy nazywało. Kierował nią wówczas Henryk Katz ${ }^{76}$, który wyemigrował, potem był w Anglii i już od jakiegoś czasu

\footnotetext{
${ }^{74}$ Zob. rozdział V.

${ }^{75}$ Zob. przypis $28 \mathrm{w}$ tym rozdziale.

${ }^{76}$ Henryk Katz (1914-1998) - historyk. Urodził się we Lwowie, gdzie studiował ekonomię. Studia kontynuował w Paryżu i Londynie. W czasie wojny służył w armii brytyjskiej. Zajmował się historią międzynarodowego ruchu robotniczego. W 1949 roku został zatrudniony na Uniwersytecie Łódzkim, w roku 1956 został mianowany docentem, a w roku 1968 musiał odejść z uniwersytetu.
} 
nie żyje. A potem w Katedrze Filozofii, którą kierował Jakub Litwin ${ }^{77}$ z IFiS-u, a tam z kolei był mój przyjaciel i z wcześniejszych czasów, i z późniejszych, czyli Stefan Amsterdamski ${ }^{78}$. Okres moskiewski był oczywiście pod różnymi względami interesujący, najmniej pod względem naukowym, co bardzo szybko odkryłam. Ale było to niewątpliwie ciekawe doświadczenie, w towarzystwie ciekawych kolegów z Polski, także to były całkiem interesujące trzy lata. Wróciłam do Polski w 1955 roku i od razu, niezależnie od tego, jaki miałam ten przydział formalny, zaczęłam zerkać w stronę socjologii, bo zaczęły być możliwe jakieś badania empiryczne i to mnie właśnie najbardziej interesowało.

Trzy lata po powrocie ze Związku Radzieckiego Jolanta Kulpińska wyjechała do Francji, której środowiska akademickie - jak wiemy - miały i mają po dziś dzień silnie lewicujący profil. O ile studia w Moskwie nasza rozmówczyni ocenia jako marne i rozczarowujące, to pobyt w Paryżu pozwolił jej na nawiązanie niezwykle znaczących i intelektualnie inspirujących kontaktów z wybitnymi postaciami świata nauki.

Dla mojego pokolenia 1956 rok to jest niesłychanie wyraźna granica. Dla socjologii również - od razu wiadomo było, że robimy badania i wracają studia. Jednocześnie otworzyły się możliwości stypendialne wyjazdów na Zachód i ja wyjechałam na rok do Francji w 1958 roku. Do Francji dlatego, że znałam ze szkoły francuski i były te stypendia rządu francuskiego. One były dość marne, Polska dopłacała, ale dzięki temu znalazłam się we Francji, w Instytucie Nauk Społecznych o Pracy, takim instytucie przyuniwersyteckim właściwie, a potem w tej sekcji szóstej, badawczej ${ }^{79}$. Na zajęcia chodziłam na przykład do Georges'a Friedmanna ${ }^{80}$ i osób bardzo ważnych w tamtej epoce we Francji. Potem uczęszczałam też na seminarium Alaina Touraine'a ${ }^{81}$. To była ta grupa socjologów, którzy wówczas zajmowali się socjologią pracy. Był też Jean-Daniel Reynaud ${ }^{82}$, z którym właściwie do końca utrzymywałam kontakt. Z Tourain'em też jakiś kontakt co jakiś czas miewałam, niespecjalnie bliski,

77 Jakub Litwin (1920-1984) - filozof, historyk ruchu politycznego, Absolwent socjologii na UŁ. Doktorat napisany pod kierownictwem Tadeusza Kotarbińskiego obronił w 1951 roku na UW.

${ }^{78}$ Zob. przypis $29 \mathrm{w}$ tym rozdziale.

${ }^{79}$ Szósta sekcja badawcza - wydział nauk społecznych w jednej z najbardziej prestiżowych instytucji naukowych i badawczych we Francji - École Pratique des Hautes Études (EPHE). Sekcja ta odłączyła się w 1975 roku, tworząc École des Hautes Études en Sciences Sociales (Wyższą Szkołę Nauk Społecznych).

${ }^{80}$ Georges Friedmann (1902-1977) - francuski socjolog; po II wojnie światowej stworzył podwaliny socjologii pracy skoncentrowanej przede wszystkim na relacji między robotnikiem a maszyną. Krytyk tayloryzmu wierzący w postęp techniczny.

${ }^{81}$ Alain Tourain (ur. 1925) - francuski socjolog zajmujący się przede wszystkim socjologią pracy i ruchów społecznych.

82 Jean-Daniel Reynaud (ur. 1922) - francuski socjolog specjalizujący się w socjologii organizacji i konfliktów. 
ale miałam. W każdym razie w kręgu takich ludzi się obracałam. Ostatnie badania, w których uczestniczyłam, organizował Claude Durand, którego z tamtych czasów znałam. Współpracowałam też z Marcem Mauricem ${ }^{83}$. Wszyscy mniej więcej w moim wieku albo niewiele młodsi ode mnie, więc wszyscy już, jeżeli żyją, to są na emeryturze i stąd te moje kontakty się trochę pourywały, ale w każdym razie były one dosyć trwałe.

Jolanta Kulpińska komentuje również wyjazdy zagraniczne swoich kolegów, w sposób szczególny uwidaczniając napięcie między oczekiwaniami reżimowej władzy a rzeczywistymi konsekwencjami pobytów na (wówczas traktowanych jako wrogie) zachodnich uniwersytetach. Wszyscy intelektualiści, których wymienia, stali się ostatecznie krytykami systemu społeczno-politycznego w ówczesnej Polsce ${ }^{84}$.

Władysław Welfe, ekonomista, swoją zagraniczną przygodę rozpoczął od wyjazdu do Moskwy w 1957 roku, gdzie zupełnie przypadkiem miał możliwość uczęszczania na cotygodniowe spotkania zespołu profesora Niemczynowa ${ }^{85}$. Następnie, przebywając w ramach stypendium Forda w Cambridge, zetknął się z późniejszym noblistą Richardem Stone'em ${ }^{86}$ Wreszcie najbardziej owocny okazał się wyjazd do Stanów Zjednoczonych, gdzie miał możliwość współpracy z kolejnym przyszłym noblistą Lawrence'm R. Kleinem ${ }^{87}$ i poznał inny sposób pracy badawczej.

W tym czasie [mowa o okresie 1963-1964, kiedy Władysław Welfe czekał na recenzje swojej pracy habilitacyjnej] zabiegałem o stypendia międzynarodowe, bo uważałem, że trzeba trochę przewietrzyć się i zobaczyć, jak wygląda ten zachodni świat. Otrzymałem stypendium Forda i mając do wyboru Stany

${ }^{83}$ Claude Durand (ur. 1927) - francuski socjolog przemysłu; Marc Maurice - francuski socjolog pracy.

${ }^{84}$ Zob. rozdział IV.

${ }^{85}$ Wasilij Niemczynow (1894-1964) - ekonomista, wybitny radziecki specjalista w dziedzinie statystyki gospodarczej.

${ }^{86}$ Fundacja Forda (Ford Foundation) - założona 1936 roku Henry’ego Forda i jego syna Edsel Bryanta prywatna fundacja amarykańska, która początkowo finansowała rodzinne przedsięwzięcia (jak szpital czy muzeum), a po śmieci obu założycieli w 1943 zmieniła profil swojej działalności skupiając się przede wszystkim na wsparciu finansowym (przez przydzielanie stypendiów i grantów) dla zdolnych osób chcących podjąć wyższe studia; finansowaniu badań naukowych; wspieraniu działań na rzecz rozwoju społeczeństwa obywatelskiego; pomocy krajom rozwijającym się; działaniach na rzecz ochrony środowiska; itp. John Richard Stone (1913-1991) - brytyjski ekonomista nagrodzony w 1984 roku nagrodą Nobla za opracowanie systemu rachunku dochodu narodowego oraz rachunkowości społecznej w oparciu o dane statystyczne.

${ }^{87}$ Lawrence Robert Klein (1920-2013) - amerykański ekonomista, laureat nagrody Nobla, którą otrzymał w 1980 roku za stworzenie modeli ekonometrycznych i ich zastosowanie do analizy fluktuacji polityki gospodarczej. W 1990 roku otrzymał tytuł doktora honoris causa Uniwersytetu Lódzkiego. 
Zjednoczone i Wielką Brytanię, wybrałem Wielką Brytanię, choć koledzy się dziwili. To stypendium w sensie finansowym to było stypendium British Council. W każdym razie trafiłem do dość znakomitego ośrodka, ponieważ w Uniwersytecie w Cambridge działał wtedy profesor Richard Stone, który został później laureatem nagrody Nobla i znany był z tego, że skonstruował ogromny model gospodarki Wielkiej Brytanii. Ale Nobla otrzymał za coś innego, a mianowicie za propozycję konstrukcji systemów rachunków narodowych, który to system został przyjęty przez ONZ i po dzień dzisiejszy funkcjonuje, oczywiście z pewnymi modyfikacjami. Także siedząc w Wielkiej Brytanii, doszedłem do wniosku, że chcę się czegoś nauczyć i muszę partycypować w procesie badawczym, który tam był w pełnym toku. Tak się rzeczywiście stało. Mam kilka publikacji z tamtego czasu, które w tym projekcie się ukazały. Uzyskałem też ogromną przyjaźń tegoż profesora Stone'a i jego przeuroczej małżonki, którą była księżniczka włoska. Autentyczna księżniczka włoska, która się przeniosła do Wielkiej Brytanii. Wcześniej jeszcze otrzymałem stypendium, o które też się normalnie starałem, do Związku Radzieckiego. Wiedziałem, że to fordowskie stypendium mi nie ucieknie, natomiast tę szansę mógłbym stracić. Zatem przed wyjazdem do Wielkiej Brytanii wyjechałem do Moskwy [w roku 1957], gdzie spędziłem pół roku. Też w zupełnie nie najgorszym ośrodku, w Moskiewskim Instytucie Ekonomiczno-Statystycznym. Tam byli najlepsi statystycy usytuowani, z tym, że nie powiem, aby tam się można było zbyt wiele nauczyć. Ja akurat miałem szczęście dlatego, że w tym samym czasie w Akademii Nauk Związku Radzieckiego powstało konkurencyjne wobec konserwatywnego Instytutu Nauk Ekonomicznych laboratorium zastosowań matematyczno-ekonomicznych i jego szefem był pan profesor Niemczynow, bardzo znany uczony. I oni mieli cotygodniowe spotkania poświęcone właśnie nowoczesnej, zmatematyzowanej ekonomii. Zamiast siedzieć w tym Instytucie Matematycznym, przychodziłem na te spotkania i dlatego mogę powiedzieć, że nie zmarnowałem czasu, ale to przez przypadek w gruncie rzeczy. Gdybym wyjechał pół roku później czy rok wcześniej, to by do tego nie doszło. Proszę sobie wyobrazić, że w tamtym czasie rozmowę $\mathrm{z}$ domem można było zamawiać na kilka dni wcześniej na Głównej Poczcie w Moskwie i zapłacić z góry za określoną liczbę minut. Natomiast mowy nie było o tym, żebym mógł w trakcie tego pobytu przyjechać do kraju czy żona do mnie. Już w tym czasie był na świecie mój syn Aleksander, ale mowy nie było o częstym kontakcie z rodziną. To były czasy stalinowskie, takie bardzo niesympatyczne, autorytarny był charakter tego wszystkiego. Kiedy byłem w Wielkiej Brytanii, to szczerze mówiąc, odetchnąłem. Wróciłem do kraju, byłem już po habilitacji, zostałem docentem, kierowałem Wydziałem ${ }^{88}$. Jak się skończył ten okres, to doszedłem do

${ }^{88}$ Przypomnijmy, że w latach 1965-1966 Władysław Welfe był prodziekanem Wydziału Ekonomiczno-Socjologicznego, a następnie w latach 1966-1969 dziekanem Wydziału Ekonomiczno-Socjologicznego Uniwersytetu Łódzkiego. 
wniosku, że trzeba jeszcze przed wzięciem na siebie innych administracyjnych obowiązków pojechać do Stanów Zjednoczonych, a powód był merytoryczny. Taki mianowicie, że od czasu mojego pobytu w Wielkiej Brytanii interesowałem się głównie popytem konsumpcyjnym w takim bardzo nowoczesnym wydaniu. W PWE wyszła trylogia, która dotyczyła modeli rynku, a de facto ten pierwszy tom to była teoria ekonometrii, drugi tom to były modele oparte na badaniach budżetów gospodarstw domowych, a trzeci tom dotyczył badań na szeregach czasowych odnoszących się do rynków, analizy rynków ${ }^{89}$. I to były wszystko badania ekonometryczne, których ja byłem współautorem, ale było wielu współpracowników. Kiedy zakończyłem ten etap badań, doszedłem do wniosku, że warto się zająć uogólnieniami, to znaczy modelowaniem całej gospodarki narodowej. W tym czasie wzorców nie było w Polsce. Więc [w $1971 \mathrm{roku}$ ] wyjechałem do Ameryki do profesora Kleina z Uniwersytetu Pensylwańskiego w Filadelfii. To była instytucja, którą można było nazwać Mekką i Medyną tych, którzy zajmowali się modelowaniem gospodarki narodowej w różnych krajach. On rozpoczął swoją działalność naukową jeszcze w latach drugiej wojny światowej, zaraz po niej. Był keynesistą ${ }^{90}$. Wpadł na pomysł, że można za pomocą układu kilku równań opisać funkcjonowanie gospodarki amerykańskiej. Nie był prekursorem, ponieważ prekursorem był profesor Tinbengen ${ }^{91} \mathrm{z}$ Holandii, natomiast on zdołał wokół siebie zgromadzić zespół osób, które z nim pracowały. I rzeczywiście ci, którzy dla swoich krajów konstruowali modele, przyjeżdżali po prostu do niego, żeby uzyskać radę. No i między innymi pojawiłem się ja. Zabrałem ze sobą bazę danych i tam powstał pierwszy model gospodarki polskiej, który przywiozłem stamtąd i tu został dopracowany i wydany. Tak zaczęła się ta historia makromodelowania, którą się trudnię nieprzerwanie od 1970 roku. Muszę powiedzieć, podobnie jak w Wielkiej Brytanii, doszedłem do wniosku, że tylko partycypacja w pracach tamtego ośrodka pozwalała wniknąć w pewne szczegóły dotyczące tego, czego w literaturze się nie znajdzie, a uczestnicząc w procesie budowy takich modeli, można było podpatrzeć po prostu pewne techniczne sprawy albo znaleźć pewne uzasadnienia dla rozwiązań, których próżno szukać w podręcznikach. Ten mój pobyt był zatem bardzo udany. Przywiozłem stamtąd i model, i sporo koncepcji, które potem były w naszym ośrodku realizowane. Tak właściwie co dwa lata powstawała nowa wersja modelu oparta o te pierwowzory.

${ }^{89}$ Chodzi tu o następujące publikacje: Władysław Welfe (red.), Metody ekonometryczne. Ekonometryczne modele rynku: analiza - prognozy - symulacja, t. 1, Państwowe Wydawnictwo Ekonomiczne PWE, Warszawa 1977; tegoż (red.), Modele konsumpcji. Ekonometryczne modele rynku: analiza - prognozy - symulacja, t. 2, Państwowe Wydawnictwo Ekonomiczne PWE, Warszawa 1978; tegoż (red.), Modele popytu konsumpcyjnego i równowagi rynkowej: analiza - prognozy symulacja, t. 3, Państwowe Wydawnictwo Ekonomiczne PWE, Warszawa 1982.

${ }^{90}$ Określenie zwolenników makroekonomicznej szkoły Johna Maynarda Keynesa.

${ }^{91}$ Jan Tinbengen (1903-1994) - holenderski ekonomista i ekonometryk. 
Indywidualne - niezwykle owocne - doświadczenia Władysława Welfego związane ze zdobywaniem wiedzy i praktyczną nauką warsztatu badawczego zagranicą sprawiły, że zaangażował się instytucjonalnie (jak twierdzi, za namową kolegów) w rozwój współpracy międzynarodowej Uniwersytetu Łódzkiego:

Kiedy wróciłem, koledzy mnie namówili, abym przyjął posadę w Rektoracie i tak zostałem Prorektorem do spraw Nauki i Współpracy z Zagranicą i byłem nim przez dwie kadencje. Muszę powiedzieć, że do moich sukcesów mogę zaliczyć to, że kiedy obejmowałem ten urząd, to Uniwersytet miał tylko jedną umowę międzynarodową z Uniwersytetem w Tbilisi, a po ośmiu latach, gdy opuszczałem urząd, to było ich ponad czterdzieści. Już nie pamiętam, czterdzieści sześć czy czterdzieści osiem, więc $\mathrm{w}$ pewnym sensie uczestniczyłem w otwarciu Uniwersytetu na świat i to nie tylko na Zachód, ale też i na Wschód.

Przyglądając się biografii naukowej Władysława Welfego, należy wspomnieć o jego niezwykłym doświadczeniu mobilności, w dużej mierze wynikającym z uczestnictwa w projekcie LINK (który powstał z inicjatywy wspomnianego wyżej amerykańskiego profesora Lawrence’a R. Kleina). Celem tego projektu było powiązanie modeli poszczególnych gospodarek narodowych w jeden ogólny model gospodarki.

Mogę jeszcze powiedzieć, że w ramach tego projektu LINK zwiedziłem cały świat. Mieliśmy posiedzenia dwa razy do roku. Raz w ONZ w Nowym Yor$\mathrm{ku}$, a drugi raz to za każdym razem gdzie indziej: to w Bangkoku, to w Manili, to w Paryżu, to w Moskwie, to w Południowej Afryce, to w Meksyku, w Azji dość często, dlatego że to były kraje dość szybko rozwijające się, które dysponowały środkami finansowymi. Mogę powiedzieć, że zwiedziłem pół świata.

Liczne podróże ekonomisty Jerzego Dietla i tworzone przez niego międzynarodowe sieci powiązań i kontaktów z różnymi środowiskami naukowymi przełożyły się na rozwój nie tylko jego własnej kariery, ale też karier wielu młodych badaczy:

Zawsze byłem snobem, jeśli chodzi o wyjazdy za granicę, bo moim marzeniem były podróże. Oczywiście starałem się w miarę możliwości zdobyć tam jakieś doświadczenie. Pamiętam, że zaraz po doktoracie, a doktorat obroniłem w 1959 roku, wyjechałem do Hagi na pół roku. Pomógł mi w tym Krzysztof Skubiszewski ${ }^{92}$, który miał tam kontakty i mnie zaprotegował, profesor Bohdan

${ }^{92}$ Krzysztof Jan Skubiszewski (1926-2010) - profesor prawa międzynarodowego na Uniwersytecie im. Adama Mickiewicza w Poznaniu, w latach 1989-1993 minister spraw zagranicznych. 
Winiarski ${ }^{93}$, który był wtedy przewodniczącym Trybunału Haskiego, którego znała moja rodzina, udzielił mi rekomendacji. To było pierwsze moje pół roku w Holandii na przełomie roku 1959 i 1960. A potem, ponieważ zająłem się rolnictwem $^{94}$, w 1962 roku uzyskałem stypendium do FAO ${ }^{95}$. Byłem w niezłym miejscu na świecie, ponieważ FAO znajduje się przy ulicy delle Terme di Caracalla w Rzymie. Byłem tam 3-4 miesiące i potem pojechałem do Brukseli na miesiąc i miałem tam praktykę w $\mathrm{OECD}^{96}$. We Włoszech prowadziłem studia nad planem Vannoniego ${ }^{97}$ dotyczącym rozwoju południowych Włoch, takiej interwencyjnej polityki inwestycyjnej, głównie w rolnictwie. Bardzo to sobie chwaliłem, to pozwoliło mi zwiedzić dokładnie Sycylię, być przyjmowanym na różnych uniwersytetach, mieć rozmowy z Włochami, którzy zajmowali się tą problematyką. Zacząłem korespondencję, trochę publikowałem za granicą i nawiązałem wiele kontaktów naukowych. Potem zaczęły się te kontakty z Giessen w związku z umową, którą miał uniwersytet. Nie chciano mnie tam puścić, ale, proszę sobie wyobrazić, ówczesny, niestety już zmarły tamtejszy rektor Karl Alewell ${ }^{98}$, powiedział, że on zerwie kontakty, jeśli mu nie dadzą partnera $\mathrm{z}$ jego dziedziny. A on kierował właśnie katedrą marketingu. Bardzo się zaprzyjaźniliśmy. To był jeden z moich prawdziwych przyjaciół. Miałem tam dużo także innych przyjaciół, sporo wykładów. Jeździłem też z wykładami do Francji, do Stanów Zjednoczonych oraz innych krajów. Miałem seminarium w Harvardzie, a także w Warton School w Filadelfii i w North Western i w Chicago, Illinois. No i oczywiście w uniwersytecie, który miał kontakty z Uniwersytetem Łódzkim, Urbana-Champaign, dokąd często jeździli socjologowie. Mój wuj Florian Znaniecki ${ }^{99}$ był tam profesorem w czasie wojny. Kiedy poszedłem do biblioteki, to wszystko, co tam opublikował, było w niej dostępne. I w Europie oczywiście, w czasach socjalizmu jeszcze jeździłem do demoludów. Potem, kiedy założyłem Towarzystwo Gospodarcze, a także Fundację Rozwoju Przedsiębiorczości, miałem dobrą passę. Margaret Thatcher nam pomagała i chyba z czterdzieści albo pięćdziesiąt osób z Uniwersytetu wysłałem na różne stypendia do Francji i do Anglii. Od Francuzów też bardzo

${ }^{93}$ Bohdan Stefan Winiarski (1884-1969) - prawnik specjalizujący się w prawie międzynarodowym, członek Międzynarodowego Trybunału Sprawiedliwości w Hadze, a w latach 1961-1964 jego przewodniczący.

${ }^{94}$ Ściślej rzecz ujmując: ekonomiką rolnictwa.

${ }^{95}$ FAO - Food and Agriculture Organization of the United Nations, pol. Organizacja Narodów Zjednoczonych do spraw Wyżywienia i Rolnictwa.

${ }^{96}$ Organizacja Europejskiej Współpracy Gospodarczej.

${ }^{97}$ Plan Vannoniego - dziesięcioletni plan ekonomicznej reformy Południowych Włoch (19541964), mający przeciwdziałać bezrobociu oraz wzmocnić ekonomiczny rozwój tej części kraju.

${ }^{98}$ Karl Alewell (1932-2012) - profesor ekonomii, rektor Uniwersytetu w Giessen w latach 1978-1986.

${ }^{99}$ Zob. przypis $66 \mathrm{w}$ tym rozdziale. 
dużo pomocy dostawałem. Pomagał nam też Jaques de Chalendar ${ }^{100}$, który był pierwszym prezesem Fondation France-Pologne ${ }^{101}$ w Paryżu i dzięki niemu też dostaliśmy dość dużo stypendiów. Była też współpraca z Lyonem, gdzie zostałem zaszczycony doktoratem honoris causa, co trochę pomagało w kontaktach i wysłałem tam z Łodzi sporo ludzi ze sfery gospodarczej, takich młodych przedsiębiorców czy quasi-przedsiębiorców, którzy znali francuski. Obracałem się też w towarzystwie międzynarodowym badania opinii publicznej i marketingu. Nie kocham marketingu, reklamy i promocji, ale cóż było robić. Przez to jednak mogłem tutaj wielu profesorów sprowadzić, kilka konferencji międzynarodowych zorganizować i zyskać dość znaczące kontakty. Dzięki temu mogłem na przykład Bohdana Gregora ${ }^{102}$ czy później mojego ostatniego doktoranta Kozielskiego ${ }^{103}$ wysłać na stypendium Fulbrighta. Mnóstwo ludzi wysyłałem na praktyki do profesora Simona ${ }^{104}$, który jest jedną z największych sław, jeśli chodzi o business administration na świecie, o pierwszym miejscu $\mathrm{w}$ cytowaniach w literaturze zagranicznej. On niedawno dostał doktorat honoris causa, byłem recenzentem jego dorobku. Wiele kontaktów miałem też $\mathrm{z}$ uniwersytetami skandynawskimi, między innymi byłem profesorem wizytującym w Turku w Finlandii.

Olga Czerniawska, pedagog i andragog, pokazuje, jak wiele zawdzięcza swoim stażom zagranicznym (we Francji i Czechosłowacji). Mówi tu przede wszystkim - podobnie jak cytowani wcześniej narratorzy - o możliwościach nawiązywania niezwykłych kontaktów naukowych i znajomości z ciekawymi osobowościami, dzięki którym otwierają się nowe pola inspiracji i zainteresowań badawczych. Mówi też o tym, jak została wciągnięta w działalność międzynarodowego towarzystwa naukowego, które stało się niezwykle istotnym elementem jej kariery naukowej:

Pracując już na uniwersytecie, w ramach współpracy pojechałam do Lyonu i tam poznałam panią profesor Reboul ${ }^{105}$, która w Lyonie założyła studia z zakresu gerontologii. To ona mnie wprowadziła w gerontologię. Nauczyłam się

${ }^{100}$ Jaques de Chalendar - francuski prawnik, Generalny Inspektor Finansów Francji, prezes Fundacji Polska-Francja.

${ }^{101}$ Fundacja Francja-Polska - organizacja dotowana przez rząd francuski, mająca na celu wspieranie rozwoju demokracji w Polsce m.in. poprzez programy wymiany studentów.

102 Bogdan Gregor (ur. 1943) - ekonomista, kierownik Katedry Marketingu na Wydziale Zarządzania Uniwersytetu Łódzkiego, obecnie prorektor ds. ekonomicznych UŁ.

${ }^{103}$ Robert Kozielski (ur. 1968) - profesor UŁ w Zakładzie Strategii Marketingowych Uniwersytetu Łódzkiego.

${ }^{104}$ Hermann Simon (ur. 1947) - wybitny niemiecki profesor i specjalista w dziedzinie teorii rynku i marketingu.

${ }^{105}$ Hélène Reboul (ur. 1929) - francuska psycholog i gerontolog, związana z Uniwersytetem Lyon 2, wieloletnia przewodnicząca AIUTA (Zob. przypis 106). 
tej gerontologii, a następnie weszłam w AIUT-ę ${ }^{106}$, czyli Międzynarodowe Stowarzyszenie Uniwersytetów Trzeciego Wieku, gdzie byłam w radzie administracyjnej od 1984 roku, a działała tam też pani profesor Szwarcowa ${ }^{107}$. Poza tym wymyśliłam temat habilitacji. Zajęłam się poradnictwem i byłam pionierką w tym zakresie. Jeździłam na seminaria do Wrocławia, bo tam się moja koleżanka zaczęła się tym zajmować. Napisałam tę habilitację z poradnictwa. Potem wyjeżdżałam na stypendia do Czechosłowacji, byłam i w Czechach, i na Słowacji, na Uniwersytecie Karola i na uniwersytecie w Bratysławie. Na Uniwersytecie Karola byłam u takiego profesora Livečki, bardzo ciekawa postać, był chyba Rosjaninem z pochodzenia, ale dobrze mówił po francusku, po niemiecku, po angielsku. Jak jeździł, to za nim jeździł jakiś profesor partyjny, który go śledził niemalże. Bardzośmy się zaprzyjaźnili z tym profesorem Livečką. Ciekawy był ten pobyt w Pradze. A w Bratysławie poznałam profesora Jozefa Koščo ${ }^{108}$, który zajmował się poradnictwem. I muszę powiedzieć, że spopularyzowałam jego pracę, przywiozłam jego podręcznik. Niestety samego profesora Koščo nie udało mi się sprowadzić do Polski - jemu nie pozwalali przyjeżdżać, bo on był nieprawomyślny. Przywiozłam i zaabonowałam wtedy również takie czasopismo o poradnictwie. A ponieważ Czesi mieli bardzo dużo rozwodów, więc wymyślili poradnie małżeńskie i ja widziałam te wszystkie poradnie. Pisałam na ten temat, sporo materiałów przywiozłam.

Nieco dalej Olga Czerniawska opowiada o swoich wyjazdach do Włoch w roku 1978 i 1987. Motywacją dla pierwszego z nich była chęć poznania uznanej profesor pedagogiki, której artykuł narratorka przeczytała swego czasu w periodyku naukowym. W jej relacji poza doświadczeniami związanymi z nauką (możliwością zdobywania literatury czy podpatrywania sytemu edukacji dorosłych) znajdziemy też opis codziennego życia przebywających zagranicą naukowców i pozostałych Polaków (wówczas $\mathrm{z}$ trudnością mogących utrzymywać kontakt z krajem).

Kiedy byłam we Francji, poznałam profesor Genevieve Latreille ${ }^{109}$, która organizowała poradnictwo na uniwersytetach dla studentów. Ja miałam doktorat z tego zakresu. Także to poradnictwo, od którego nieco odeszłam, to niewątpliwie jest dziedzina ważna. Potem pojechałam do Włoch, bo krajom demokracji ludowej oferowano różne stypendia, między innymi możliwość stypendium

${ }^{106}$ AIUTA - Association Internationale des Universités du Troisième Age.

${ }^{107}$ Halina Szwarc (1923-2002) - profesor medycyny, gerontolog, założycielka pierwszego w Polsce Uniwersytetu Trzeciego Wieku.

${ }^{108}$ Emil Livečka (1919-1985) - czeski pedagog, andragog profesor Uniwersytetu Karola w Pradze. Jozef Koščo (ur. 1920) to słowacki psycholog i nauczyciel akademicki, który przyczynił się do rozwoju psychologii doradztwa, zwłaszcza poradnictwa biodromalnego.

${ }^{109}$ Genevieve Latreille (1929-1982) - psycholog społeczny, prekursorka poradnictwa edukacyjnego i zawodowego we Francji, prof. uniwersytetów w Paryżu i Lyonie. 
we Włoszech. Ponieważ ja zwykle czytałam różne czasopisma zagraniczne, w tym było takie czasopismo, które wychodziło w Pradze: „Czas wolny i coś tam". I w tym czasopiśmie w Pradze znalazłam artykuł profesor z Włoch, Anny Lorenzetto ${ }^{110}$, na temat edukacji permanentnej. Przeczytałam ten artykuł i bardzo mi się ta osoba spodobała. Więc kiedy miałam się kwalifikować do wyjazdu do Włoch, to ją umieściłam jako osobę, która ma się mną opiekować. Ona była w Rzymie, Uniwersytet Sapienza. Zdziwiła się niesłychanie, skąd jakaś taka osoba o niej wie. A moje kwalifikacje do tych studiów były dosyć marne, tylko trzeba było mieć tego profesora, a potem odbywała się taka niby rozmowa w Instytucie Włoskim w Warszawie, na ulicy Foksal. Niby to miało być po włosku, ale ja mówiłam po francusku, tamten coś się spytał, spojrzał na mnie i pojechałam do tych Włoch. To było tuż po tym, jak papieżem został Jan Paweł II, więc Polska była we Włoszech bardziej kojarzona. Muszę powiedzieć, że strach niesłychany, ale ta profesor okazała się przyzwoitą osobą, bo na lotnisko wydelegowała swoją asystentkę - panią doktor Antoniettę Leggeri, bardzo oryginalną osobę, córkę malarza. Ona okazała się taką bardzo życzliwą, poczciwą osobą. Ona pracowała dla bardzo bogatej i prężnej organizacji, której prezesem była profesor Lorenzetto, a jej celem była organizacja walki $\mathrm{z}$ analfabetyzmem. Miała duży lokal w Rzymie, w EUR - to jest taka część budowana przez Mussoliniego, wysokie budynki. Tam w jednym z bardzo eleganckich lokali oni mieli swoją siedzibę; mieli bardzo duże zaplecze, samochód. Pani profesor Lorenzetto się mną nie interesowała, po prostu mnie zostawiła swoim asystentom. Sama była osobą dosyć specyficzną. Po latach się zorientowałam, że ona była lesbijką. Ale jeśli chodzi o umysłowość i działalność, to była wybitna osoba, elegancka. Miała piękne mieszkanie, do którego mnie zaprosiła. Ale, jak mówię, ,zleciła” mnie swojej zacnej Antonietcie oraz takiej asystentce, która się mną specjalnie nie przejmowała, ale mnie tolerowała. Gdy pierwszy raz byłam we Włoszech, to stypendium wynosiło trzysta dolarów. Było liche. To znaczy, nie było źle, bo po pierwsze, wtedy oni byli jeszcze otwarci na stypendystów i jakoś się nimi opiekowali. Wyznaczyli taki ośrodek, w którym można było mieszkać. To był ośrodek prowadzony przez siostry, one tam mówiły po włosku, także ja nie bardzo rozumiałam. Miały dom na przedmieściach Rzymu, część domu była wynajęta na szkołę prywatną, a część to były pokoje do wynajęcia. Jak na tamte czasy, to był dla mnie ekstra hotel - piękny pokój, urządzony, przedpokój, ze sprzątaczką, która przychodziła, wymieniała pościel i wszystko robiła raz w tygodniu; piękna łazienka, wszystko marmury, z ubikacją, łóżko, szafa, stół, na dole był telefon, z którego można było korzystać, choć nam nie pozwalali korzystać, była kaplica - chodziłam na msze, więc one mnie dobrze traktowały, kuchnia do

${ }^{110}$ Anna Lorenzetto (1914-2001) - włoska pedagog zajmująca się edukacją dorosłych i zagadnieniami uczenia się przez całe życie. 
wspólnego użytku i lodówka. Ja to wynajęłam, opłaciłam za trzy miesiące i miałam swoje lokum. To było dosyć daleko, trzeba było jechać na Uniwersytet jakieś pół godziny przez cały Rzym, bo to było pod Watykanem. Ale tam było pięknie. Jak się okno otworzyło, to kwitła mimoza, było słychać dzwony, ta msza mi bardzo odpowiadała. Odprawiali ją biedni studenci - księża z Meksyku, którzy ledwo mówili po włosku, natomiast siostrom to nie przeszkadzało i za to dostawali śniadanie. Wstawałam na mszę, jadłam śniadanie, potem jechałam autobusem, wysiadałam koło kościoła San Giovanni i przyjeżdżała ta moja opiekunka, Antonietta Leggeri, a dalej jej samochodem jechaliśmy. Potem ona mnie odstawiała, ja sobie coś kupowałam, gotowałam obiad i jadłam. Czytałam różne książki, szczęśliwie kupiłam sobie jedną książkę po francusku o edukacji we Włoszech, to mogłam przeczytać bez kłopotu, a te inne rzeczy to ze słownikiem, który kupiłam we Włoszech, mam go do dzisiaj. I jakoś tam sobie radziłam. To był mój pierwszy pobyt: zapoznałam się z różnymi instytucjami włoskimi. Poza tym miałam zapewnione dwie podróże, które ministerstwo opłacało: jedna była do Asyżu, gdzie mi bezpłatny pobyt zapewniono, a drugą - nie pamiętam dobrze - odbyłam na południe i to była taka podróż drogami tego stowarzyszenia. Pojechałem do tego stowarzyszenia, tam mi urodziny elegancko zorganizowali, hotel wynajęli. Witały mnie bezrobotne panie, które za wolontariat w tym stowarzyszeniu miały zapewnione pierwsze miejsca na listach szukających pracy. I tam zwiedzałam instytucje prowadzone przez to stowarzyszenie dla dorosłych. A w samym Rzymie, z jednej strony też się zainteresowałam poradnictwem, więc mu się przyglądałam, ale z drugiej również stowarzyszeniom, religijnym i innym, np. stowarzyszeniu dla emigrantów. Moją książkę profesorską napisałam właśnie o oświacie dorosłych we Włoszech. Odwiedzałam redakcje różne, książki od nich dostałam, czasopisma. Byłam na Uniwersytecie Sapienza, tam poznałam profesora Susi ${ }^{111}$, który mnie zaprosił na seminarium. On prowadził takie badania nad cudzoziemcami. Dziwili się, dlaczego Polacy nie uczestniczą w tych badaniach. Poznałam też profesora Duccio Demetrio ${ }^{112}$, potem rozpropagowałam jego prace i były thumaczone na język polski, no i profesora Gelpiego ${ }^{113}$ - uroczy człowiek, niestety przedwczesnie zmarł. Zwiedziłam Instytut Polski w Rzymie wydali sporo książek, między innymi po francusku monografię Wałęsy, którą przywiozłam wtedy do Polski. I taki to był wspaniały pobyt. Ja byłam wtedy w pełni sprawna, więc chodziłam, jeździłam, zwiedzałam. I pierwszy raz byłam w Muzeum Watykańskim. Jak wracałam z tego muzeum, to padałam jak nieżywa na łóżko, taka byłam zmęczona. Tam też zachorowałam na bardzo ciężką grypę. Poznałam tam Polkę, z którą się zaprzyjaźniałam. Ona potem

${ }^{111}$ Francesco Susi - włoski pedagog Profesor Uniwersytetu La Spienza.

${ }^{112}$ Duccio Demetrio - włoski pedagog, filozof edukacji, założyciel Wolnego Uniwersytetu Autobiograficznego w Anghiari.

${ }^{113}$ Ettore Gelpi (1933-2002) - włoski pedagog, współpracował z UNESCO. 
wyszła za Włocha i mieszkała w Rzymie, ale tylko z tą jedną się przyjaźniłam, bo Polki za granicą nie są sympatyczne - Polacy dla Polaków są wrodzy, bo każdy grosz się liczy. Poznałam też panią, z którą byłam w dobrych relacjach, ona wpadła w taką depresję przez ten długi pobyt za granicą, bo to telefonu nie było, list szedł sześć tygodni albo więcej. Także trzeba było być samemu, z marną znajomością języka. Dobrze, że była ta Antonietta, ale to postać tragiczna, bo ona jest alkoholiczką. Weszłam z nią w przyjaźń i kiedy znów po dziesięciu latach pojechałam do Włoch na następne stypendium, to już mieszkałam u niej, bo mnie zaprosiła. Wtedy moim patronem był profesor de Sanctis $^{114}$ z Florencji, wybitny uczony. Ja się z nim spotkałam w Paryżu na międzynarodowej konferencji oświaty dorosłych. Tambyła taka sekcja „Stowarzyszenie Przyjaciół Śródziemnomorskich" i na nią poszłam. On się bardzo zdziwił, po co ja do niego poszłam. Powiedziałam, że się interesuję Włochami, tam jeszcze poznałam jednego profesora z Bolonii i z nim zaczęłam rozmawiać. Była też profesor Lorenzetto, która była delegatem włoskim na tę konferencję. W każdym razie jakoś z nimi doszłam do porozumienia i jak drugi raz jechałam, to powołałam się na profesora de Sanctisa i zostałam przypisana do Florencji, ale mieszkałam w Rzymie. Mieszkałam właśnie u Leggeri, która odziedziczyła piękne mieszkanie, takie jak muzeum w śródmieściu Rzymu. Ileś tam pokoi w amfiladzie, każdy pokój urządzony w innym stylu, coś w ogóle niesłychanego, blisko Campo di Fiori. Więc u niej byłam, potem pojechałam do Florencji, mieszkałam u profesora w jego mieszkaniu. Z Florencji pojechałam do Turynu. Tam byłam już z Uniwersytetami Trzeciego Wieku, bo mnie zaprosili. Potem pojechałem do Trydentu. Po drodze zbierałam dalej materiały do książki. Potem jeszcze spotkałam we Włoszech panią profesor Martynę Lani-Bayle ${ }^{115} \mathrm{z}$ Nantes i weszłam z nią we współpracę. Zaprosiłam ją do Polski, ona się zajmuje badaniami biograficznymi, więc przysłała mi swoją książkę Historia szkoły. Miała takie seminarium związane z opowieściami o szkole, wspomnienia o szkole. Dzięki niej byłam w Nantes na kilku konferencjach.

Bronisława Kopczyńska-Jaworska, etnograf, również przywołuje w pamięci swój pierwszy międzynarodowy kongres, na który wyjechała, jak się zdaje, zupełnie przypadkowo:

Jeździłam na takie wielkie kongresy, które mamy co cztery lata. Mieliśmy takie światowe Kongresy Nauk Antropologicznych i Etnologicznych za profesora Welfego właśnie. W związku z tym byłam w Indiach, w Ameryce. Pierwszy raz byłam na kongresie w Moskwie. To było zabawne, bo byłam świeżo po doktoracie, a formowana była wówczas delegacja państwowa. Radzono, kto ma pojechać, kto ma nie pojechać, bo wielu miało na to ochotę. I ktoś

${ }^{114}$ Filippo de Sanctis - włoski pedagog, andragog, profesor Uniwersytetu we Florencji.

${ }^{115}$ Martine Lani-Bayle (ur. 1950) - profesor nauk o wychowaniu na uniwersytecie w Nantes. 
powiedział: „Niechże pojedzie choćby jeden doktor” [śmiech]. No i pojechałam „za doktora” na kongres do Moskwy.

Wanda Nowakowska, historyk sztuki, opowiada o swoich licznych zagranicznych wyjazdach, ale też o współpracy z Akademią Sztuk Pięknych we Lwowie i wyjazdach na Ukrainę.

Na Zachód jeździłam głównie za własne pieniądze, choć swoje pierwsze stypendium dostałam w związku z wyjazdem do Włoch. To było stypendium rządu włoskiego, a drugie to było stypendium pani profesor Lanckorońskiej, miesięczne. Obydwa te stypendia były bardzo ważne. Pamiętam, że w stanie wojennym sam rektor Wojtczak ${ }^{116}$ wziął za mnie odpowiedzialność, że na pewno wrócę i dał mi pismo, że wywożę notatki dotyczące wyłącznie sztuki! W sumie moich dwadzieścia siedem podróży poświęconych głównie zwiedzaniu muzeów i zabytków zaowocowało cyklami wykładów na naszym Uniwersytecie, ale także na Uniwersytecie Trzeciego Wieku, gdzie wygłosiłam ponad sto trzydzieści odczytów, czy w moim ostatnim miejscu pracy Akademii Humanistyczno-Ekonomicznej w Łodzi ${ }^{117}$. To był też doskonały materiał do moich książek i artykułów. Z tym, że u nas w Katedrze głównie się jeździło po Polsce: Kraków, poznańskie, śląskie. Była też podpisana umowa między Katedrą Historii Sztuki UŁ a Akademią Sztuk Pięknych we Lwowie. W każdym roku były tak zwane objazdy naukowe, na które się bardzo krzywiła uniwersytecka księgowość, bo to bardzo dużo kosztowało. Studenci zawsze mieli w planie wyjazdy i zwiedzanie, ale jeździli nie tylko po Polsce, były też wyskoki na parę dni do Lwowa, gdzieś za granicę. Tak się jakoś zadzierzgnęły więzy właśnie z Akademią Sztuk Pięknych we Lwowie. Myśmy wspólnie zrobili taką sesję w Łodzi, uwieńczoną potem księgą naukową. Zgromadzili ogromny zespół zdjęć, bardzo ciekawy. Później zaprosili nas do Lwowa na drugą sesję. Ja tam z jakichś względów nie pojechałam, ale potem byłam indywidualnie zaproszona i pojechałam do nich z takim odczytem Piękno ziemi lwowskiej, piękno ziemi ukraińskiej w obrazach malarzy polskich. Chełmoński, Brandta, co prawda branki i jasyry trzeba było jakoś delikatnie przedstawić - ja położyłam nacisk na piękno pejzażu: Dniepr, Dniestr i tak dalej. Byłam goszczona nieprzytomnie, przepięknie w tym Lwowie. Poznałam wtedy miasto. Byłam też w Gruzji, w Tbilisi, bo dwie dziewczyny zrobiły u mnie magisterium, a potem szły dalej z Uniwersytetem Gruzińskim, z Akademią Sztuk Pięknych we Lwowie.

We wspomnieniach Romualda Skowrońskiego, chemika, znajdziemy kilka interesujących, wartych wyeksponowania wątków: przede wszystkim możliwość wykorzystania sieci kontaktów i powiązań zagranicznych

${ }^{116}$ Leszek Wojtczak - patrz biogramy rozmówców.

${ }^{117}$ Akademia Humanistyczno-Ekonomiczna - niepubliczna uczelnia wyższa istniejąca w Łodzi od 1993 roku. 
stworzonych przez polskich naukowców, którzy w czasie wojny lub tuż po niej znaleźli się na Zachodzie. Jego opowieść rozpoczyna się od wyjazdu w 1957 roku na stulecie Francuskiego Towarzystwa Chemicznego, gdzie spotkał swojego znajomego, który zaproponował mu pracę u znanego francuskiego profesora. Tak Romuald Skowroński trafił do Centre National de Recherche Scientifique (CNRS), gdzie w latach 1958-1962 prowadził badania naukowe uwieńczone tytułem Docteur ès sciences Universite de Paris (Sorbona).

W 1957 roku było stulecie Francuskiego Towarzystwa Chemicznego. Została zorganizowana taka wielka międzynarodowa konferencja. A ponieważ brat mojej żony, profesor Michalski ${ }^{118}$, to bardzo znana postać w polskiej chemii, powiedziałem żonie: „Wiesz co, to my też pojedziemy do tego Paryża”. Zwróciłem się do rodziny w Stanach, do Margaret Zachwatowicz [córka brata matki] i napisałem do niej, że jest szansa wyjazdu do Paryża na ten kongres. I ona natychmiast przysłała pieniądze. Tak pojechaliśmy przez Wiedeń, przez Szwajcarię do Paryża. To była podróż naszego życia. I muszę powiedzieć, że wtedy delegacja polska na tym kongresie była najliczniejsza. To były trzydzieści dwie osoby. Polacy w tym okresie, jeżeli chodzi kontakty naukowe, ze wszystkich „demoludów” mieli najlepsze. Myśmy byli najmłodszymi uczestnikami tej konferencji. W czasie inauguracji na tej wielkiej auli Sorbony słyszę z tyłu głos: „O Romek, Romek!”. Odwracam się, a tam cztery rzędy za mną siedział Michał Siemiatycki ${ }^{119}$, a właściwie Silmalti. On pochodził z takiej inteligenckiej rodziny pochodzenia żydowskiego, człowiek niezwykłej kultury, który w 1948 roku wyjechał, bo wtedy, szczególnie jeżeli chodzi o kierunki ścisłe, była możliwość wyjazdu za granicę, bo zagranica oferowała stypendia. Wyjechało wtedy wielu fizyków, biologów, chemików. Tam zrobili doktoraty i potem olbrzymie kariery. Wszyscy prawie też zostali profesorami. I to było o tyle korzystne, że oni pamiętali o swoich korzeniach i mnóstwo ludzi z Polski było potem przez nich zapraszanych do ich ośrodków naukowych. Właśnie ten Michał mówi: „Wiesz co, pójdziemy do profesora Willemarta ${ }^{120}$, to taka wybitna postać nauki francuskiej. Ja ciebie przedstawię i może byś tutaj na staż przyjechał". Ja nie znałem wtedy francuskiego. Znałem tylko dobrze

118 Jan Michalski (ur. 1920) - chemik, specjalista w dziedzinie chemii związków fosforoorganicznych. W 1945 roku został asystentem na organizującej się Politechnice Łódzkiej, gdzie pracował przez wiele lat. Od 1971 pracował w Centrum Badań Molekularnych i Makromolekularnych PAN w Łodzi, które zorganizował i którego został pierwszym dyrektorem. Swoją pracę tam zakończył w 1990 roku.

${ }^{119}$ Później Michał Simalty.

${ }^{120}$ Antoine Willemart - francuski profesor chemii, przez długie lata pracował w założonym w 1939 roku Krajowym Centrum Badań Naukowych (Centre National de la Recherche Scientifique - CNRS). 
niemiecki i angielski. Poszliśmy do profesora Willemarta i rozmawiałem z nim po niemiecku. Willemart powiedział: „Proszę bardzo, chętnie pana przyjmę. Może pan zostać natychmiast”. „O - mówię - bardzo dziękuję, panie profesorze, ale ja muszę załatwić formalności”, bo wiedziałem, czym by się to skończyło dla żony, dla rodziny, gdybym się zdecydował zostać. Wróciłem do kraju. W 1958 roku pojechałem do Francji i dostałem etat w CNRS-ie, czyli w Centre National de Recherche Scientifique właśnie u profesora Willemarta. To jest taki odpowiednik Polskiej Akademii Nauk, który ma swoje ośrodki badawcze, naukowe i tak dalej. I tam naprawdę znalazłem znakomite warunki do pracy naukowej, bardzo przyjazną atmosferę, kolegów. Tam się ciężko pracowało. Zresztą miałem ambicję, żeby się wykazać. Z wielkim strachem na Sorbonę się jedzie. Teraz Sorbona to jest École Nationale Supérieure Recherche, bardzo znana, elitarna szkoła w Paryżu. No i [śmiech] wtedy ja dokonałem pewnego wyczynu, bo - tu się muszę pochwalić - w ciągu czterech lat uzyskałem tytuł Docteur ès sciences. W tej chwili ten tytuł nie istnieje, teraz jest doktor uniwersytetu, tak jak na całym świecie. Więc dostałem ten stopień Docteur ès sciences. To były cztery lata ciężkiej harówki. Z tym, że ja wtedy miałem możliwość przyjeżdżania na urlop do Polski, żona do mnie potem też przyjeżdżała. Potem zresztą żonie załatwiłem staż i przyjechała do Francji na dwa lata, bo też jest chemikiem. Nawiązałem mnóstwo przyjaźni, bardzo dużo moich kolegów z laboratorium z tego okresu zostało potem profesorami w wielu ośrodkach naukowych. Proszę sobie wyobrazić, że potem schedę po profesorze Willemarcie przejął profesor Cadiot ${ }^{121}$, niezwykle uroczy człowiek i dobry chemik. Byliśmy w bardzo dobrych układach. Był w Polsce kilka razy, także na moje osiemdziesięciolecie. Myśmy z żoną nawet byli w tym roku wiosną u niego, bo Cadiot organizował takie spotkanie swoich uczniów z tego laboratorium. Zjawiło się około pięćdziesiąt osób, jeszcze się rozpoznawaliśmy [śmiech]. Było tam już dużo młodsze pokolenie, ale to było niezwykle sympatyczne spotkanie. A po powrocie do kraju [w 1962 roku] to może była przesada ze strony Rady Wydziału, ale rzeczywiście były takie przepisy, że ja ten Docteur ès sciences - najwyższy tytuł naukowy we Francji - musiałem w Polsce nostryfikować [śmiech]. Miałem tam wtedy siedem publikacji. Musiałem je przetłumaczyć na język polski i odbyła się nostryfikacja tego [śmiech] mojego dyplomu. Moja pozycja w katedrze i na uczelni bardzo wzrosła.

Ryszard Panasiuk, filozof, zwraca także uwagę na to, że początkowo oczekiwania władzy ludowej były takie, aby rozwój kariery naukowej odbywał się w Związku Radzieckim, co w wypadku nauk ścisłych mogło mieć jeszcze sens, bowiem wielu rosyjskich naukowców prezentowało

\footnotetext{
${ }^{121}$ Paul Cadiot - francuski chemik, doktorant i współpracownik Antoine’a Willemarta w CNRS.
} 
naprawdę wysoki, światowy poziom (teza ta zostanie później potwierdzona w relacji Ryszarda Jajtego). W naukach humanistycznych - w tym szczególnie w filozofii - terror ideologiczny był ogromny i dlatego nie mogły one stanowić wiarygodnej ramy odniesienia czy swobodnej areny wymiany myśli. Opowiadając o kontaktach zagranicznych, Ryszard Panasiuk kładzie nacisk na swoje zaangażowanie i działalność w międzynarodowych towarzystwach oraz podkreśla życzliwość naukowców z zachodnich ośrodków badawczych:

Oczywiście były kongresy i współpraca z uczelniami zagranicznymi, ale ja przede wszystkim brałem udział w Kongresach Heglowskich. To było takie Międzynarodowe Towarzystwo Heglowskie, którego byłem członkiem. Było też takie Międzynarodowe Towarzystwo Feuerbachowskie [śmiech] i w nie też byłem zaangażowany. Pisywałem na ten temat i wydałem też taki zbiór publikacji Feuerbacha w „Bibliotece Klasyków Filozofii”. Była współpraca z Giessen, z Nantes i z Lyonem. Bardzo dobrze się współpracowało z tymi ludźmi, którzy byli nam bardzo życzliwi, przyjeżdżali, udzielali nam różnych rad i też łatwo tam było wyjechać na jakiś krótszy czy dłuższy pobyt. Było wsparcie przy innych poważnych stypendiach, jak Humboldta na przykład. Także to wszystko dobrze funkcjonowało i bez specjalnych problemów, bo taka była polityka w tym okresie.

Na rolę kontaktów międzynarodowych nawiązanych przez swoich wielkich poprzedników zwraca także uwagę matematyk Zbigniew Jakubowski. Owe areny wymiany myśli naukowej mają ogromne znaczenie - wszak żadne pole badawcze, o czym była wcześniej mowa, nie może rozwijać się w izolacji. Przyjrzyjmy się, jak kwestię tę przedstawia nasz rozmówca:

Jeśli chodzi o środowisko międzynarodowe, to jest temat złożony. W gruncie rzeczy można mówić o pozycji matematyków z poszczególnych działów, na przykład analiza zespolona, teoria prawdopodobieństwa czy sterowanie optymalne. Wtedy jest łatwiej porównać, łatwiej umiejscowić. Ale myślę, że jedną z głównych zasług naszych nauczycieli jest to, że nie zapomnieli o tym, że nie ma rozwoju nauki bez zaglądania do sąsiadów bliższych czy dalszych i nawiązywania kontaktów. To robiono. I myślę, że gdy mówimy o mojej dziedzinie, a więc wywodzącej się od Charzyńskiego i Janowskiego ${ }^{122}$, to oni mieli kontakty z Finami, ze Stanami Zjednoczonymi. Ja mam kilkanaście prac wykonanych wspólnie z nieżyjącym niestety Jaroslavem Fuką ${ }^{123} \mathrm{z}$ Pragi. Ze względu na to, gdzie byliśmy osadzeni, to nie zawsze było proste z różnych względów,

${ }^{122}$ Zob. przypis $1 \mathrm{w}$ tym rozdziale.

${ }^{123}$ Jaroslav Fuka (ur. 1929, zm. 2000) - czeski matematyk, profesor czeskiej Akademii Nauk i Uniwersytetu w Usti. 
trochę tu polityka wchodziła w grę, ale też finanse. Zresztą nadal wchodzą. Ale te kontakty były i przypisywałbym tu główną rolę naszym poprzednikom. To oni dali podstawy do tego, żeby z matematyką wyjść poza Łódź i gdzieś tam wyjrzeć przynajmniej przez jakieś małe okienko, żeby zobaczyć, co inni robią i pokazać: „słuchaj, ale my mamy taki piękny wynik tutaj”. I to po części się działo.

W opowiadaniu Ryszarda Jajtego, również matematyka, na uwagę zasługują - wysuwające się na plan pierwszy - kontakty ze Stanami Zjednoczonymi i naukowcami hinduskimi (także w Indiach). Wspomina on dodatkowo swój mający miejsce w połowie lat sześćdziesiątych, niezwykle owocny pobyt w Moskwie, gdzie miał możliwość kontaktu z wybitnymi matematykami.

Na dłuższy pobyt zagranicą wyjechałem dopiero w roku 1977 do Stanów Zjednoczonych. Pracowałem tam przez rok jako visiting professor na Wayne State University w Detroit. To takie miasto ciemne i czarne. Ale mam bardzo miłe wspomnienia. Potem wyjechałem jeszcze do University of Tennessee, University of North Carolina i do Rzymu też. Także to wszystko razem zajęło jakieś trzy i pół roku. Odwiedzałem także na krótko kilka innych uniwersytetów. Niełatwo było wyjechać. Przede wszystkim płaciłem bardzo wysoki haracz. Był to tak zwany fundusz stypendialny - w domyśle dla osób, które miały tatusiów w różnych komitetach; w skali rocznej porównywalny do ceny dobrego samochodu. Spędziłem rok na stażu w Moskwie. To był chyba rok 1964/1965. Tam byłem stażystą w katedrze kierowanej przez Andrieja Kołmogorowa $^{124}$, jednego z najwybitniejszych matematyków ubiegłego stulecia. Był to już wtedy starszy pan i nie zajmował się specjalnie stażystami, choć miałem okazję i zaszczyt rozmawiać z nim kilkakrotnie. Natomiast uczęszczałem na wspaniałe seminaria i wykłady Sinaja ${ }^{125}$, potem Gelfanda ${ }^{126}$ i Dobrushina ${ }^{127}$. To były znakomite wykłady, znakomite seminaria i bardzo dużo tym ludziom zawdzięczam. Bardzo wiele zawdzięczam też Hindusom: mój pierwszy wyjazd do USA - na zaproszenie Hindusa Barucha-Reidajazd, do Knoxhill (Tennessee) na zaproszenie Balrama Rajputa, też Hindusa, potem wyjazd do Północnej

124 Andriej Kołmogorow (1903-1987) - rosyjski matematyk, twórca współczesnej teorii prawdopodobieństwa.

${ }^{125}$ Yakov Sinai (ur. 1935) - wybitny rosyjski matematyk, od 1960 przez trzydzieści lat pracował na Uniwersytecie im. Łomonosowa w Moskwie. Obecnie jest profesorem w Princeton University, New Jersey, USA.

${ }^{126}$ Izrail Moisiejewicz Gelfand (1913-2009) - wybitny matematyk rosyjski. Od 1940 roku profesor uniwersytetu im. Łomonosowa w Moskwie. Ostatnie lata życia spędził w Stanach Zjednoczonych, gdzie wykładał na Rutgers University.

${ }^{127}$ Roland Lvovich Dobrushin (1929-1995) - matematyk rosyjski specjalizujący się w teorii prawdopodobieństwa. 
Karoliny na zaproszenie G. Kalliarnpura ${ }^{128}$. Potem wyjeżdżałem wielokrotnie do Szwajcarii zapraszany też przez Hindusa, S.D. Chatterjiego. Odwiedzałem w Stanach bardzo wybitnego profesora hinduskiego Massaniego. I byłem potem na jego jubileuszu w Indiach, w Kalkucie, miałem okazję zobaczyć Indie. Dla mnie to była rzecz niezwykle ciekawa, bo to jest kraj niezwykłych kontrastów. A jednocześnie ta matematyka hinduska świetnie stoi, bo Hindusi są rozproszeni po całym świecie i jest ich wielu na uniwersytetach amerykańskich. Także tyle zawdzięczam niechrześcijanom krótko mówiąc, co zawsze podkreślam w rozmowach z katolickimi przyjaciółmi.

Eugeniusz Czerniawski, mikrobiolog, rozpoczyna swoją opowieść od podróży, które wiązały się z jego działalnością w Komisji RWPG do Spraw Pokojowego Wykorzystania Energii Jądrowej. Dalej koncentruje się na stworzonej przez siebie recepturze uniwersalnej pożywki dla bakterii pokazując absurdy przepływu wiedzy i pomysłów w ówczesnych krajach socjalistycznych. Wreszcie widzimy tu też znaczenie weryfikacyjne czy konfrontacyjne międzynarodowego forum wymiany myśli (w poniższym opowiadaniu rolę tę pełni sympozjum w Brnie), pozwalającego na ustalenie faktycznego autora danej koncepcji czy pomysłu badawczego.

Byłem członkiem ekspertów delegacji PRL w stałej Komisji RWPG do Spraw Pokojowego Wykorzystania Energii Jądrowej. W latach 1961-1977 uczestniczyły w tym Polska, NRD, Czechosłowacja, Węgry, Rumunia. Posiedzenia odbywały się w różnych miejscach: w Baku, w Suhumii, w Moskwie, w Leningradzie, w Brnie, w Niemczech. Wyrzuciłem niestety, ale miałem do niedawna protokół posiedzenia w Baku. To były takie posiedzenia robocze. Pierwsze odbyło się w Bad Brambach w NRD. A w Baku, na przykład, budzą nas w hotelu o czwartej nad ranem i dają do przeczytania protokół, czy wszystko jest w porządku [śmiech]. Rosjanie byli bardzo pilni. Ta delegacja wyglądała tak, że ja byłem jedynym ekspertem z zakresu mikrobiologii. Zajmowaliśmy się stworzeniem pożywki uniwersalnej do badania stopnia jałowości czy zanieczyszczenia bakteriami, bo sprzęt kierowano do sterylizacji. I ja taką pożywkę przygotowałem. To było przygotowane w Polsce nawet z możliwością eksportu. Zostało przyjęte $\mathrm{z}$ wielkim zainteresowaniem, ale wiązało się $\mathrm{z}$ dużymi problemami. Zawiozłem to w słoiku do Związku Radzieckiego, ale to duży kraj, więc zabrali i prosili jeszcze. Więcej znowuż profesor Zabłocki ${ }^{129} \mathrm{z}$ koleżanką

${ }^{128}$ Wśród wielu wymienianych przez prof. Ryszarda Jajtego hinduskich naukowców jest Gopinath Kallianpur (ur. 1925) - wybitny matematyk i statystyk pochodzenia hinduskiego, który pracował na takich amerykańskich uczelniach jak: Michigan State University, University of Minnesota, czy University of North Carolina.

${ }^{129}$ Bernard Zabłocki (1901-2002) - mikrobiolog i immunolog, od 1946 roku kierownik Katedry Mikrobiologii Uniwersytetu Łódzkiego. 
Michną, jak pojechali do Mińska, to wzięli trochę tej pożywki ze sobą, żeby dalej przekazać, ale tam nie chcieli tego wziąć. W końcu przez kuriera specjalnego do Moskwy to zawieźli, oficjalnie. Drugie badania, które były tam prowadzone, dotyczyły wielkości danych sterylizujących w zależności od stopnia zanieczyszczenia drobnoustrojami. Stworzyłem tabelę zgodną z normami WHO: dopuszczalna jest jedna jałowa sztuka na milion sterylizowanych. I Rosjanie przedstawili to jako swoje, $\mathrm{z}$ tych moich tabel zrobili swoje. Ale kiedy byłem w Brnie i przedstawiłem moje wyniki biologom na sympozjum, gdzie na sali było pięćset osób, to profesor z Moskwy bardzo się tłumaczył, że to maszyny i tak dalej - a ja nie wiedziałem, dlaczego tak się thumaczy. Na koniec tylko powiedziałem „Dekuji pekne na pozor” i tak dalej. Czesi bili mi brawo. Dopiero potem się okazało, że był kongres w Bombaju i ci Rosjanie zrobili plagiat, przywłaszczyli to sobie i podali jako swoje. Ja organizatora zjazdu powiadomiłem o tym, że to jest plagiat. A co ciekawsze, Rosjanie nie wiedzieli, że ja to miałem opublikowane w aktach „Mikrobiologia Polonica” o zasięgu międzynarodowym [śmiech].

\section{Co dzieje się za żelazna kurtyną?}

$\mathrm{Z}$ jednej strony polscy naukowcy, w tym nasi rozmówcy, z wielkim zainteresowaniem przyglądali się temu, jak rozwija się nauka w Europie i na świecie, a z drugiej zachodni badacze i intelektualiści z wielką ciekawością spoglądali na to, co dzieje się w krajach, które ograniczyły swoim uczonym możliwości pełnego uczestnictwa w forach wymiany myśli, krytycznego namysłu nad powstającymi teoriami czy dyskusji nad nowymi osiągnięciami i odkryciami naukowymi. Niejednokrotnie przyjeżdżający zza żelaznej kurtyny naukowcy stawali się emisariuszami, którzy zdawali relację z wydarzeń mających tam miejsce, do których dostęp był ograniczony. Wątki te znajdziemy w opowieściach Zbigniewa Bokszańskiego i Michała Seweryńskiego.

Zbigniew Bokszański, socjolog, wspomina swój pierwszy wyjazd na Kongres Socjologiczny, w czasie którego miał możliwość spotkania wybitnych postaci dotychczas znanych mu jedynie z pisanych przez nie artykułów czy książek. Akcentuje przy tym szczególną, można by rzec uprzywilejowaną - pozycję Polski wśród krajów bloku socjalistycznego oraz zainteresowanie zachodnich intelektualistów tym, czym zajmują się socjologowie za żelazną kurtyną.

Przy okazji mojej habilitacji miałem okazję być za granicą, na Kongresie Socjologicznym w Uppsali. Tam miałem okazję poznać Garfinkla ${ }^{130}$ i całą jego

\footnotetext{
${ }^{130}$ Harold Garfinkel (1917-2011) - amerykański socjolog, twórca etnometodologii.
} 
świtę, tę sektę etnometodologów - Smelsera ${ }^{131}$, Margaret Archer ${ }^{132}$, która była niesłychanie miła i bardzo życzliwa. Był Lipset ${ }^{133}$, Bendix ${ }^{134}$ - wszyscy ci ludzie, których książki czytaliśmy, na których się uczyliśmy języka angielskiego czy amerykańskiego. Oczywiście były to króciutkie spotkania. Oni byli bardzo ciekawi i chcieli się dowiedzieć, co się w Polsce w ogóle robi. Wtedy właściwie Polacy byli jedynymi partnerami, jeżeli idzie o ten obóz wschodni, w odniesieniu oczywiście do kwestii socjologicznych, do statusu socjologii czy badań socjologicznych. W Rosji ta socjologia dopiero zaczynała się jakoś kształtować i cały czas była jeszcze bardzo zideologizowana. W innych krajach właściwie jej nie było. Czesi się dopiero podnosili po tych kłopotliwych przeżyciach z roku 1968. Mówiąc krótko, to były bardzo ciekawe lata, mimo że te wyjazdy były rzadkie i trzeba było je przygotowywać z nieprawdopodobnym mozołem, z sześciomiesięcznym wyprzedzeniem. Tutaj akurat ci krytycy i czarnowidzowie PRL-owscy mają rzeczywiście trochę racji.

Michał Seweryński, prawnik, wspomina swoje wyjazdy do Francji, szczegółowo opowiadając o pierwszym stypendium w tym kraju, o którym dowiedział się od swojego mistrza, profesora Wacława Szuberta ${ }^{135}$. W jego relacji znajdziemy nie tylko opis sposobu rekrutowania kandydatów, ale także wyjaśnienie, dlaczego w okresie PRL takie wyjazdy w ogóle były możliwe (szczególnie jeśli chodzi o osoby nierealizujące linii partyjnego myślenia). Bez wątpienia niezwykle ważnym doświadczeniem w jego naukowej, choć nie tylko, biografii jest wykład na temat porozumień gdańskich, który w okresie karnawału „Solidarności” wygłosił w Pałacu Sprawiedliwości w Paryżu.

Mój mistrz miał wcześniej kontakty międzynarodowe, brał udział w międzynarodowym życiu naukowym, odgrywał w nim pewne role. Jakąś drogą powziął informację, że są stypendia rządu francuskiego. Pojechałem na spotkanie w ambasadzie dowiedzieć się, jak to wszystko wygląda. Języka nie znałem, bo francuskiego się nigdy nie uczyłem. Ale że ta procedura musiała trwać jeszcze rok, więc ja szybko, choć zacząłem się wcześniej uczyć niemieckiego, przerzuciłem się na francuski. I przez ten rok podciągnąłem się

${ }^{131}$ Neil Smelser (ur. 1930) - amerykański socjolog zajmujący się m.in. socjologią zachowań zbiorowych i socjologią ekonomiczną.

${ }^{132}$ Margaret Archer (ur. 1943) - angielska socjolog, której zainteresowania koncentrują się głównie na relacji między strukturą a (jednostkowym) sprawstwem.

${ }^{133}$ Seymour Martin Lipset (1922-2006) - amerykański socjolog zajmujący się ruchami społecznymi, stratyfikacją społeczną, społeczeństwem obywatelskim i socjologią polityki.

${ }^{134}$ Reinhard Bendix (1916-1991) - niemiecko-amerykański socjolog, który starał się łączyć europejską i amerykańską myśl socjologiczną. Przedmiotem jego rozważań były przede wszystkim siły oddziałujące na społeczeństwo i działającą jednostkę.

${ }^{135}$ Zob. przypis $14 \mathrm{w}$ tym rozdziale. 
znacznie, choć potem mi powiedzieli w tej ambasadzie, że oni niekoniecznie biorą takich, którzy są biegli w języku, bo zakładają, że już na miejscu można będzie się douczyć. Po roku udało mi się, bezpartyjnemu, dostać to stypendium, chyba dlatego, że to nie była decyzja polskiego ministerstwa czy Uniwersytetu Łódzkiego. Uniwersytet chyba zresztą takich stypendiów nigdy nie dawał. Profesor Szubert dał mi rekomendacje do jednego z najwybitniejszych francuskich profesorów prawa pracy, swojego przyjaciela, który w Paryżu nade mną czuwał. To jest taka dawna cechowa metoda wprowadzania kogoś do zawodu, i taka, moim zdaniem, powinna pozostać. We Francji zaczęła się moja naukowa przygoda zagraniczna. Spotkałem tam kilka ciekawych postaci, o otwartych umysłach. Można było z nimi rozmawiać o różnych sprawach. Wcześniej byłem wprawdzie krótko na szkole letniej prawa pracy w Trieście, ale prawdziwe studia porównawcze odbyłem we Francji. Pojechałem tam zaraz po habilitacji i tam byłem najdłużej, bo aż sześć czy siedem miesięcy. Tam mogłem się oddać niezakłóconym studiom, chodziłem też na różne wykłady, także z amerykańskiego prawa pracy. Zapraszano mnie też do prywatnych domów, gdzie odbywały się ciekawe dyskusje. Kiedy wybuchła „Solidarność”, nastąpił ciąg dalszy, bo wtedy jeden z tamtejszych moich przyjaciół zaprosił mnie, żebym przyjechał na wykład o „Solidarności”. Wygłosiłem wykład o Porozumieniu Gdańskim dla prawniczego świata francuskiego w Palais de Justice w Paryżu, obok jednego z najświętszych miejsc we Francji - kaplicy świętego Ludwika. Przyszło wielu profesorów i innych prawników, bo ludzie byli bardzo ciekawi tego co się dzieje w Polsce. Po wykładzie dostałem zaproszenie na wykładów na Uniwersytecie w Bordeaux i tak się zaczęła moja przygoda profesorska z Francją.

\section{(...)}

Kiedy wyjeżdżałem na Zachód, miałem taki wykład komparatystyczny, dotyczący porównania komunistycznego prawa pracy z prawem zachodnim, które pozostało zakorzenione w zachodniej kulturze, w rzymskiej filozofii prawa. Ich to bardzo interesowało. Oni takiego wykładu ode mnie oczekiwali. Chętnie na niego przychodzili, bo chcieli się dowiedzieć, jaka właściwie jest ta koncepcja komunistycznego prawa. Tym bardziej byli ciekawi, że ja swój wykład osadzałem w uwarunkowaniach politycznych, ekonomicznych i społecznych ustroju komunistycznego. Trzeba dodać, że po powstaniu „Solidarności” zainteresowanie Polską było we francuskich kręgach akademickich bardzo rozbudzone. W moich wykładach ponownie musiałem podjąc pytanie: do czego służyło prawo w komunizmie? Do dzisiaj to robię w historycznej części wykładu. 


\section{Ekspedycje naukowe}

Nieco inną specyfikę miały ekspedycje badawcze, którym przyjrzymy się przez pryzmat doświadczeń biologa Krzysztofa Jażdżewskiego i geografa Jana Ziomka.

Zacznijmy od relacji Krzysztofa Jażdżewskiego, z ogromną pasją opowiadającego o swoich wyprawach badawczych na Antarktydę, które nie tylko ukierunkowały jego zainteresowania badawcze, ale również obudziły w nim pasję nurkowania.

Ogromne znaczenie w mojej karierze miało zaproszenie mnie przez profesora Suszczewskiego ${ }^{136}$, wtedy jeszcze doktora, do udziału w polarnej wyprawie antarktycznej w 1973 roku. To była wyprawa czterech Polaków dołączona do radzieckiej ekspedycji antarktycznej nr 19 na ich stacje Mołodiożnaja. Towarzysze radzieccy ją tam założyli, żeby się przeciwstawić Amerykanom, którzy mieli tam już kilka stacji. Wtedy to współpraca polsko-radziecka była podstawą jakichkolwiek egzotycznych wypraw i w tej 19. SAE czyli Soviet Antarctic Expedition brała udział trzecia grupa polskich biologów. Tak to się formalnie nazywało: Trzecia Grupa Polskich Biologów, jako cząstka SAE. I myśmy byli trzy miesiące na radzieckiej stacji Mołodiożnaja, która leży na Antarktydzie Wschodniej, na Ziemi Enderby, nad samym morzem. To było moje pierwsze zetknięcie się z rejonami polarnymi. Trochę zebraliśmy tam materiałów naukowych, w bardzo prymitywny sposób, bo ta stacja była wyłącznie lądowa - badali różne rzeczy wyłącznie na lądzie, może nawet i pingwiny liczyli, chociaż nie pamiętam dokładnie, ale jakieś obserwacje robili, raczej nauki o ziemi uprawiali, czyli glacjologię, może meteorologię, nawet trudno mi powiedzieć, które specjalności tam dominowały. Mam bardzo szczegółowe zapiski z każdej z tych moich wypraw. Najwięcej było w każdym razie geologów, glacjologów było trochę i meteorologów. A myśmy byli biologiami i usiłowaliśmy coś tam żywego zdobyć. Tam jest troszkę takich mikroorganizmów i tam, gdzie jest gleba, gdzie nie ma lodu, znajdzie się coś malusieńkiego, mikroskopijnego dosłownie. Natomiast w morzu jest ogromne bogactwo, ale do morza się dobrać nie mogliśmy, bo nie było tam żadnej łódki, nic. Zrobiliśmy tratwę na czterech pustych metalowych beczkach zakręcanych, żeby powietrze w nich było, i takie dostaliśmy bale, które żeśmy przymocowali jako tratwę na linie. Lina miała chyba jakieś pięćdziesiąt metrów, może nawet nie, i tylko tyle od brzegu można było odpłynąć i jaką́s dragą [urządzenie połowowe do dennych połowów morskich] trochę żeśmy zdobyli z dna organizmów. Tego tam jest dużo, w morzu jest wielkie bogactwo. W każdym razie to była moja pierwsza

${ }^{136}$ Stanisław Rakusa-Suszczewski (ur. 1938) - polarnik, biolog, oceanograf, jeden z twórców polskiego programu polarnego, założyciel Polskiej Stacji Antarktycznej im. Henryka Arctowskiego na Wyspie Króla Jerzego w Zachodniej Antarktyce. 
wyprawa antarktyczna, przełom 1973 i 1974 roku. Z drogą to trwało około pół roku, bo tam trzeba płynąć dość długo. Płynie się ponad miesiąc w jedną stronę. To jest wspaniała rzecz, przygoda niesłychana, bo pomijając, że ta droga ciekawa, bo się zahacza po drodze o Wyspy Kanaryjskie, Urugwaj, Wyspę Króla Jerzego, to na miejscu też jest niezwykłe spotkanie z tą szczególną przyrodą. Potem w roku 1975 i 1976 była pierwsza wyłącznie polska ekspedycja morska. Na statku „Profesor Siedlecki”. Dostałem zaproszenie już jako doświadczony polarnik [śmiech]. W każdym razie to była taka wyprawa krylowa. Bo wtedy kryl się zrobił modny i wydawało się, że z tego kryla coś można wyciągnąć korzystnego dla upadającego reżimu gierkowskiego. Oczywiście kryla się da jeść i to jest smaczne nawet, a na dodatek tego strasznie dużo, tyle że transport $\mathrm{z}$ tak daleka jest bardzo trudny. Nie jest to ratunek dla całego świata, ale jest to ciekawe źródło białka. To jest być może najliczniejszy gatunek zwierzęcia na kuli ziemskiej. Ta wyprawa, o której zacząłem mówić, polegała na tym, żeby się z tym krylem zapoznać, nawet parę publikacji z tego powstało, moich czy przy moim współudziale. To była głównie wyprawa morska, myśmy tam lądowali na różnych stacjach, ale jeszcze wtedy polskiej stacji nie było, bo taka powstała dopiero w 1977 roku i została założona właśnie na wyspie King George. U nas mówią Króla Jerzego, ale prawidłowa nazwa to jest jednak wyspa King George. Tam jest przepiękna stacja polska im. Henryka Arctowskiego ${ }^{137}$, w której wielu moich uczniów było i nawet zimowało, np. mój uczeń Jacek Siciński ${ }^{138}$. On jest obecnym kierownikiem tej katedry. I w sumie ludzi z naszej katedry na polskiej stacji antarktycznej było na pewno około dziesięciu, w tym moja córka. To już jest sporym osiągnięciem, że jest tutaj w Łodzi Zakład Biologii Polarnej i Oceanologii, który założyłem przed wielu już laty, bo pracownia o takiej nazwie pojawiła się w 1983 roku. Po tej mojej drugiej wyprawie antarktycznej była trzecia w 1981 roku. To była taka międzynarodowa wyprawa FIBEX, czyli First International Biological Experiment. Wiele państw wysłało swoje statki i był wśród nich polski statek „Profesor Siedlecki”. To było takie międzynarodowe badanie Oceanu Południowego. I potem w roku 1988 byłem po raz czwarty w Antarktyce. To była dwunasta polska wyprawa na stację Arctowskiego. Na zimę wtedy jechał dr Presler, mój doktorant, a ja pojechałem tam na lato ponurkować. Pierwszy raz nurkowałem w Antarktyce w 1981 roku. To było jeszcze bardzo takie, jak to powiedzieć, nieprzygotowane: ciach, wskoczyć na 15-20 minut i w byle jakim kostiumie. A zimno było wtedy [śmiech]. Ale to były wielkie emocje. I potem w 1988 roku z kolegą Jurkiem Żychlińskim, nurkiem z naszego klubu „Tryton”, już

${ }^{137}$ Henryk Arctowski (1871-1958) - podróżnik, geograf, oceanolog, geolog, glacjolog i podróżnik. W latach 1897-1899 przebywał na Antarktydzie, gdzie prowadził liczne badania naukowe.

138 Jacek Siciński - biolog, którego głównymi obszarami zainteresowań są limnologia i oceanobiologia, Kierownik Katedry Zoologii Bezkręgowców i Hydrobiologii oraz Zakładu Biologii Polarnej i Oceanobiologii Uniwersytetu Łódzkiego. 
zbieraliśmy materiały, nurkując gdzieś tak do trzydziestu metrów. Schodziłem i pobierałem takim czerpakiem, żeby z odpowiedniej powierzchni zebrać dno i policzyć wszystkie zwierzaki, jakie tam są. Siedemnasta Polska Wyprawa była w 1994 roku, kiedy byłem po raz piąty, i wtedy z Jurkiem Żychlińskim żeśmy trochę ponurkowali. I wreszcie w 2007 roku był Międzynarodowy Rok Polarny - IPY, International Polar Year; i wtedy siedem osób z naszej katedry, już pod wodzą Jacka Sicińskiego tam pojechało na krótki rejs. Badaliśmy Zatokę Admiralicji, gdzie leży nasza stacja, i zebraliśmy piękne, ciekawe materiały. $\mathrm{Z}$ nich między innymi moja córka doktorat zrobiła o skorupiakach obunogich Zatoki Admiralicji. To było chyba naprawdę największe osiągnięcie - być z własną córką w Antarktyce. To dosyć niesamowite. Cieszę się, że akurat to się jej spodobało i nie widziałem żadnych przeszkód. Miałem też szczęście, bo mogłem tak bardziej wakacyjnie, mniej naukowo być w Arktyce, na Spitsbergenie, bo tam przyjaciół naukowców mamy z Sopotu, z Instytutu Oceanologii. Tam pracuje mój przyjaciel, nie mogę nazywać go uczniem, ale recenzowałem jego doktorat, habilitację i profesurę, profesor Marcin Węsławski ${ }^{139}$, z którym jestem bardzo zaprzyjaźniony, i on tam na wyprawy polarne północne mnie zaprosił dwukrotnie, więc widziałem też Arktykę i tam również miałem okazję dwa razy nurkować. Tym się bardzo pysznię, bo w roku 1997, czyli dwanaście lat temu byłem pierwszym Polakiem, który nurkował i w polarnych rejonach południowych, i w północnych. Już teraz nie jestem jedynym, ale jakiś czas byłem pierwszym i jedynym. Bardzo to sobie cenię, bo jako mały chłopiec to byłem taki beksa i słabowity w sensie fizycznym, koledzy mnie zawsze wyszturchali [śmiech]. Także jeżeli się z czegoś lubiłem pysznić, to z tych fizycznych przewag, a nie $z$ tych naukowych, bo tam mi dobrze szło i lekko.

Jan Ziomek opowiada o niezwykłych zagranicznych wyprawach naukowych, które odbył (najczęściej wraz ze studentami) w latach siedemdziesiątych. Mowa tu będzie o „egzotycznych” eskapadach do miejsc takich jak Egipt, Afganistan czy Afryka Północna, ale też o niezwykłej podróży po Kanadzie i Stanach Zjednoczonych. Wszędzie, gdzie się znalazł, nasz rozmówca gromadził, rzecz jasna, eksponaty do swojego muzeum.

Rozpocząłem później taką wędrówkę na staże naukowe. Z tym już nie było problemu, dlatego że byłem zapraszany. Pisałem artykuły dotyczące hydrotermalności, które były nośne. Nieraz były krytykowane, ale niektórzy zapraszali mnie na stypendia. Ja wtedy wyjeżdżałem, na przykład na Uniwersytet Gorkiego, do Charkowa. Tam byłem chyba ze trzy razy. Byłem też na Uniwersytecie Arystotelesa w Grecji, później na Uniwersytecie w Segedzie. To były takie niedługie, dwutygodniowe wyjazdy na staże krótkoterminowe. Oni

${ }^{139}$ Jan Marcin Węsławski (1955) - oceanograf, profesor biologii, kierownik Zakładu Ekologii Morza w Instytucie Oceanologii Polskiej Akademii Nauk w Sopocie. 
później do nas przyjeżdżali. Po prostu te władze doskonale wiedziały, kto się zajmuje polityką, kto coś może czy kto ma kontakty. My nie mieliśmy żadnych takich kontaktów. Więc co ja mogłem powiedzieć komuś z ambasady czy jakiemuś ubowcowi, skoro my zbieraliśmy korale, różnego rodzaju małże, skały. Tam polityki w ogóle nie było. Naszą ostoją były uniwersytety. Na przykład Uniwersytet Aleksandryjski całe boisko sportowe nam oddał, żebyśmy mogli sobie postawić namioty i mieszkać przez długi czas na stadionie. I dlatego chyba nikt $\mathrm{z}$ ambasady o nas nie wiedział. Poza tym, gdy byliśmy w Luksorze na przykład, to było schronisko, w którym były pluskwy. Tam nikt z tych dygnitarzy by nie przyszedł, bo kto mógł przyjść. Brałem również udział albo byłem szefem, organizatorem wypraw naukowo-poznawczych, na przykład do Egiptu. To był chyba rok 1970 i była taka ekspedycja, w której uczestniczyło dziewiętnastu studentów. Zawiozłem zbiory polskie do Uniwersytetu Aleksandryjskiego, a Senat i rektor zorganizowali mi wycieczkę do oazy w Kharga i Dakhla, na Saharę. W Dakhla były kopalnie fosforytów, które zwiedzałem. Później polecieliśmy samolotem z Khargi do Luksoru. Tam się zatrzymałem, wypożyczyłem rower i mieszkałem w takim skromnym schronisku międzynarodowym za parę groszy. Rowerem pojechałem do Kolosu Memnona i stamtąd do Doliny Królów i Doliny Królowej. Później był Kair i też dosyć długi pobyt, a najdłużej byłem w Aleksandrii. Ta podróż czy wędrówka trwała trzy miesiące. Studenci, którzy ze mną tam byli, to byli geografowie i biologowie. Biologowie zbierali tam jeżowce, kraby i inne zwierzęta morskie. Natomiast ja z geografami głównie skały i skamieniałości. Drugą taką ekspedycję zorganizowałem bodajże w 1972 roku do Afganistanu wraz z moim studentem, który stamtąd pochodził i znał język. Wtedy to było Królestwo Afganistanu, więc miałem wizę królewską. Tam też byłem trzy miesiące i zebrałem dosyć dużo skał i trochę kamieni szlachetnych. To wszystko przywiozłem do Polski, do muzeum. Następna wyprawa to była Afryka Północna, też ze studentami. Dziesięciu ich było. Jechaliśmy samochodem przez kraje europejskie na południe, na Sycylię i tam promem z Trapani do Tunisu. Później przez Tunis, Algierię, Maroko, Hiszpanię, Francję, Niemcy do Polski. Stamtąd też przywiozłem dużo okazów do muzeum. Kolejna kilkumiesięczna ekspedycja to był zdaje się rok 1973 czy 1974, mój kilkumiesięczny pobyt w Kanadzie i Stanach Zjednoczonych. Płynąłem wówczas „Stefanem Batorym” dwanaście dni do Montrealu z ogromną ilością skał, minerałów i skamieniałości zebranych w Polsce. Zapakowałem to na „Stefana Batorego” i w Departamencie Górnictwa i Geologii w Ottawie zorganizowałem wystawę minerałów polskich. Podarowałem Departamentowi tę wystawę, za co otrzymałem od nich czternaście pojemników z zawartością skał i minerałów z Kanady. I z Kanady, już autobusami, takimi greyhoundami ${ }^{140}$ jechałem do Stanów Zjednoczonych.

\footnotetext{
${ }^{140}$ Chodzi tu o Greyhound Lines - amerykańską firmę przewozową.
} 
Miałem bilet kupiony na trzy miesiące, a to były samochody, które non stop kursowały do wielu dużych miast, można było w nich spać, więc nie trzeba było wydawać pieniędzy na hotel. Po drodze trafiłem do Akademii Górniczo-Hutniczej w Dudley w Kolorado. Tam był mój znajomy, który dokumentował kiedyś z profesorem Wyżykowskim ${ }^{141}$ miedź lubińsko-głogowską. Znaliśmy się jeszcze przed jego wyjazdem, więc on mnie tam bardzo serdecznie przyjął i zapewnił mi niezłe warunki mieszkaniowe. Potem znowu ze Stanów Zjednoczonych tym greyhoundem do Kanady, stamtąd wojażerem do Montrealu i znowu „Stefanem Batorym” z Montrealu do Polski. Kanadyjczycy zapłacili cło, żeby w Polsce uniwersytet mógł odebrać zbiory, które zostały podarowane właśnie przez Departament Górnictwa i Geologii w Ottawie. Ja natomiast miałem zezwolenie na wejście do każdej kopalni na terenie Kanady. Także było to bardzo interesujące, gdyż miałem list polecający, żeby wszędzie udostępnili mi zwiedzanie, a poza tym mieszkanie w hotelach górniczych, za darmo. Za darmo też dostałem samochód terenowy, którym nie bardzo umiałem jeździć. Ale jak opanowałem jazdę do przodu i do tyłu, to mogłem się spokojnie poruszać i tak objechałem różne miasta górnicze.

\section{Studenci i uczniowie}

W zebranym materiale uchwycić można dwie kategorie wychowanków: uczniów i studentów. Ci pierwsi to węższe grono osób o wspólnych zainteresowaniach, współpracujących a często kontynuujących badania profesora. Ci drudzy stanowią ogół uczestników zajęć, kursów czy praktyk, uczestniczą w ogólnym procesie nauczania akademickiego.

Dydaktyka, przez niektórych uznawana za konieczny acz nie zawsze przyjemny dodatek do prowadzonej pracy naukowej, dla wszystkich stanowiła wyzwanie. Byli też i tacy, dla których była ona tak wciągającym i wymagającym obszarem działan, że ich własna kariera - w tym zdobywanie stopni naukowych - zdawało się schodzić na drugi plan. Tak właśnie stało się w wypadku Janiny Tobery:

Moje główne zatrudnienie to były seminaria magisterskie na zaocznych studiach pedagogicznych, dlatego że od 1975 roku, kiedy miała wejść dziesięciolatka, wszyscy nauczyciele już pracujący mieli zdobyć stopień magisterski. I wobec tego był taki nacisk na wszystkich nauczycieli pracujących, żeby uzupełniali studia. Rozbudowano zatem zaoczne studia pedagogiczne. W przedszkolach, w szkołach podstawowych, wszystkie te panie musiały zdobyć tytuł magistra, pani sobie to wyobraża? Na Wydziale Nauk o Wychowaniu podjęto na Radzie Wydziału taką uchwałę, że ze stopniem doktora można prowadzić

${ }^{141}$ Jan Wyżykowski (1917-1974) - z wykształcenia inżynier górnictwa, wybitny specjalista w zakresie geologii złóż rud miedzi. 
seminaria magisterskie. A ponieważ tam nie mieli tych ludzi ze stopniem doktora wystarczająco dużo, to mnie jak gdyby tam wynajmowano. Także ja mam na swoim koncie przeszło sto pięćdziesiąt prac magisterskich. Mąż mówił mi: „po co ci to, ty rób swoje”. Kariera mało mnie obchodziła, bo ja miałam naprawdę rok w rok zajęcia na tych zaocznych studiach pedagogicznych. Tam były osoby pracujące, $\mathrm{z}$ dziećmi, $\mathrm{z}$ rodzinami, i jeszcze na głowie te prace magisterskie. Miałam takie przypadki, że jak seminaria magisterskie trwały dwa lata, to przez pierwszy rok przychodziły różne osoby i musiałam ciągle tłumaczyć: „Ale niech pani się nie boi, pani jakoś napisze tę pracę”, bo one mówiły: „Ale ja nie napiszę”. Jak już doszła do tego czwartego roku, niechże napisze. Były takie osoby z przedszkoli, które matury nie miały. To były osoby po takim trzyletnim studium dla wychowawczyń, miały niby to średnie wykształcenie i potem musiały iść na studia zaoczne. Ja miałam naprawdę urwanie głowy z tymi kobietami.

W pracy ze studentami liczyła się nie tylko kwestia rzetelnego przekazywania wiedzy, ale również osobiste zaangażowanie w ich sprawy, a w okresie PRL także określenie swoich poglądów politycznych. O spektrum możliwych kontaktów ze studentami (zależnych także od pełnionych na uniwersytecie funkcji) opowiada Biruta Lewaszkiewicz-Petrykowska:

Zawsze było tak, że studenci do mnie przychodzili ze swoimi różnymi sprawami: domowymi, takimi, siakimi. I to było zabawne, bo oni strasznie się bali egzaminu z prawa cywilnego u mnie. Krążyły na ten temat niesamowite legendy. Ja rzeczywiście byłam wymagająca. Mówiłam zresztą studentom zawsze na pierwszym wykładzie: „Żeby nie było nieporozumień, wymagam więcej niż tytułów rozdziałów. Musi być w sposób przyzwoity sprawa przedstawiona." Oni się tego egzaminu bali, ale z drugiej strony, zresztą nie tylko studenci, ale czasem i pracownicy przychodzili do mnie z różnymi sprawami. Na przykład, kiedy byłam prodziekanem do spraw studenckich, miałam taką sytuację: mamy oto przed sobą podanie dziewczyny o stypendium socjalne a do tego oczywiście musi być złożone potwierdzenie zarobków matki i ojca. To jest małżeństwo rozwiedzione, ona mieszka z matką, ale gdy chodzi o stypendium socjalne, to jest też sprawa zarobków ojca. W wyroku rozwodowym są zasądzone jakieś minimalne alimenty, bo ten wyrok jest sprzed wielu lat. Ale ona musi podać przecież, z czego ojciec żyje, co aktualnie robi. Ojciec, okazuje się, pracuje w Wytwórni Filmów Fabularnych, nie pamiętam już, czy jest operatorem, czy reżyserem, ale ma ogromne zarobki. Rzecz działa się w roku 1973, 1974 i jemu się bardzo dobrze powodziło. Komisja oczywiście nie mogła przyznać stypendium socjalnego, sprawa upada. Ja wzywam tę dziewczynę, rozmawiam z nią. Ona nie chce się upominać. Zasądzone były alimenty 100 złotych czy coś takiego, kompletnie śmieszna suma, której i tak 
nie płacił. Więc ja jej tłumaczę, że ona dostała się na studia, studiuje stacjonarnie i może wystąpić przeciwko ojcu, że oczywiście my jej pomożemy napisać pozew itd. Ona jednak nie chciała. Przeto ja mówię do niej, że w takim razie spróbuję tę sprawę załatwić inaczej. Co zrobiłam? Dzwonię do pana reżysera czy tam operatora, przedstawiam się i mówię, jaka jest sytuacja. Mówię do niego, że „to jest jednak, pan się zgodzi, skandal, że pan się nie interesuje i nie pomaga córce, że jej warunki są bardzo trudne, że ona nie chciałaby, ale jeżeli my mielibyśmy jej przyznawać stypendium, to musimy ją najpierw skłonić do tego, żeby wystąpiła przeciwko panu o alimenty, a tego ona nie chce. A zresztą jeżeli ona nie wystąpi, a my jej przyznalibyśmy stypendium, to my będziemy od pana regresować. I nie wiem, czy to byłoby takie dobre, żeby przy pana nazwisku, pozycji, sprawa o alimenty wyszła na jaw. Sądzę, że pan powinien to z córką w jakiś sposób załatwić". No i on oczywiście spotkał się z tą córką, uzgodnił, ile on jej będzie płacił. Ja mu powiedziałam jeszcze to, co rzeczywiście wynikało z orzecznictwa, że dziecko ma prawo korzystać z sytuacji majątkowej swoich rodziców, że to nie jest tak, że jej się należy tylko tyle, żeby wystarczyło jedynie na chleb i mleko. Jeżeli można pomóc, to dlaczego tego nie zrobić? To powodowało, że potem studenci przybiegali z najróżniejszymi swoimi sprawami do mnie. Ale to nie była moja jakaś specjalna zasługa, tylko, widzi pani, ja przez szereg lat byłam adwokatem, potem zabronili łączyć adwokaturę z pracą na uniwersytecie. Ponieważ miałam już gotową habilitację, wybrałam uniwersytet. Trzeba było wybrać. Więc wobec takich problemów to zaraz ten taki adwokacki pstryk się człowiekowi w głowie po prostu otwiera [śmiech]. To zresztą pomagało mi w wielu trudnych sytuacjach na Wydziale, na przykład w stanie wojennym jak studenci powiedzieli o pewnych sprawach, na przykład strajku, mogłam im powiedzieć: „Uważajcie na to czy owo, nie dajcie się sprowokować" itp. A przecież takie rzeczy zdarzały się w stanie wojennym.

Praca ze studentami mogła stać się źródłem ogromnej satysfakcji jak i ważną miarą własnej wartości jako uczonego, o czym opowiadają kolejno Wanda Nowakowska, Zbigniew Jakubowski oraz Jan Ziomek:

Wanda Nowakowska:

Moi studenci od początku odpłacali mi się wielkim sercem i niezwykłą pamięcią w postaci listów i życzeń, wieloletnich dowodów pamięci i wdzięczności. Za co? Tak naprawdę nie wiem, chociaż mi o tym piszą, czy mówią, bo ja tylko robiłam to, co kocham w życiu i może to właśnie, czyli takie spontaniczne, niewymuszone działanie, wywołuje taką reakcję? 
Zbigniew Jakubowski:

Jeden z tych absolwentów pamięta o mnie do tej pory i na każde święta, na każdego Zbigniewa i na każdy Nowy Rok dostaję pocztówki z życzeniami i z opisem, co się dzieje u niego w rodzinie. Niestety zmarł. Myślę, że tego typu przypadki dla nauczyciela są dużo ważniejsze niż odznaczenia, nagrody, wyróżnienia. Ja bardzo lubię, jak gdzieś jadę autobusem i ktoś się przepycha przez autobus, „Czy ja dobrze poznaję, pan docent Jakubowski, ile to czasu temu było, a ja byłam u pana na seminarium, kiedyś pan mnie obsztorcował, bo nie przygotowałam się solidnie". Jest bardzo przyjemnie słuchać tego typu wypowiedzi byłych studentów, byłych uczniów, doktorantów. Oczywiście ja sobie zdaję sprawę, że część osób, która niezbyt dobrze wspomina naszą współpracę, to po prostu nie biegnie przez autobus, ale ci, co biegną, dają nam satysfakcję.

\section{Jan Ziomek:}

Później już rozpocząłem pracę jako asystent, uczyłem studentów, miałem zajęcia z geologii dynamicznej, z geologii historycznej, a także z geologii regionalnej Polski. W czasie pracy ze studentami uczestniczyłem z nimi w różnego rodzaju wycieczkach po regionie i razem z nimi zbierałem okazy dla muzeum. Mam już takich studentów, którzy teraz są profesorami Uniwersytetu. Nie będę nazwisk ich wymieniał.

Anna Rawicka: Nie no, proszę!

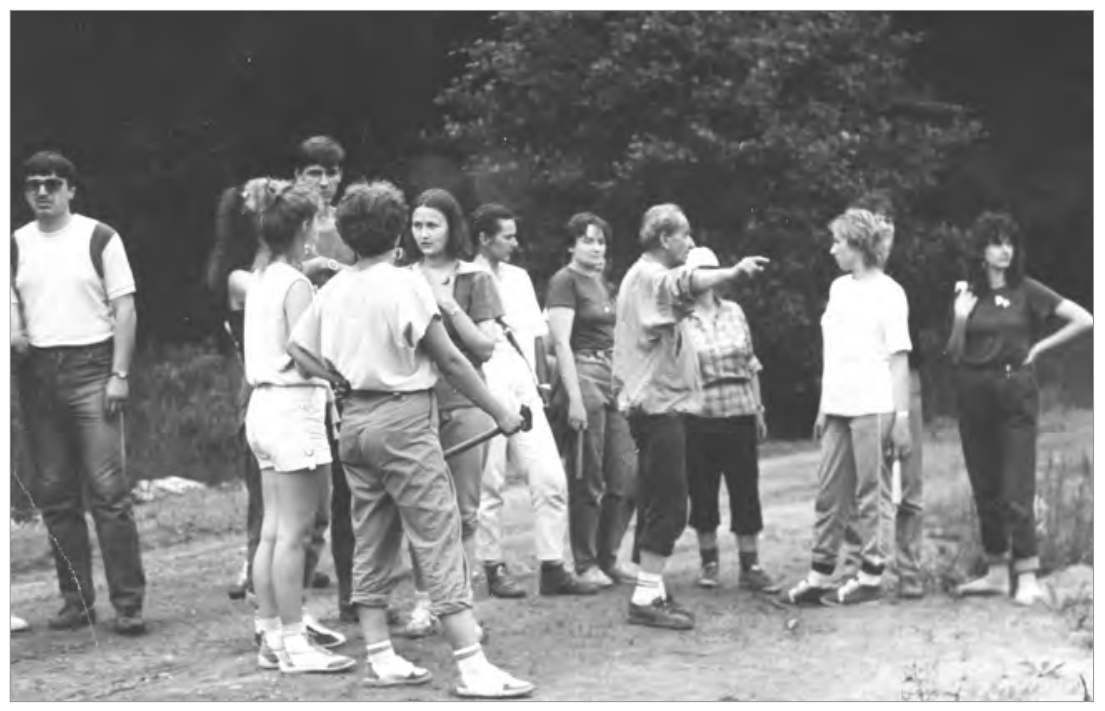

Fot. 57. Jan Ziomek ze studentami na ćwiczeniach terenowych 
Jan Ziomek: Mogę wymienić kilka nazwisk. To jest pani profesor Ławrynowicz ${ }^{142}$, która jest specjalistką od grzybów, później był profesor Markowski ${ }^{143}$, później profesor Niesiołowski ${ }^{144}$ także był moim studentem, z którym byłem też na ćwiczeniach $w$ terenie. Był studentem bardzo odpowiedzialnym, pilnym, który bardzo dobrze się spisywał.

Jednak nie zawsze praca ze studentami przebiegała gładko. Wielu z naszych rozmówców wskazywało na zmiany w podejściu do studiowania, jakie zaszły w ciągu ostatnich lat. Romuald Olaczek komentuje owe zmiany następująco:

Dzisiejsi studenci są traktowani jak dzieci, jak przedmioty, i przyznam się, że sam jestem po trochu współsprawcą takiego zinfantylizowania studentów. Jako wieloletni nauczyciel akademicki poddałem się temu ogólnemu trendowi, żeby studenci byli tylko uczniami, a nie rzeczywistymi partnerami. Mimo że w teorii ciągle nauczyciele akademiccy wszyscy mówiliśmy i głosiliśmy, że powinny być stosunki partnerskie, że od studentów się oczekuje samodzielności, odpowiedzialności, to nie tworzyliśmy pola, gdzie oni mogliby tę odpowiedzialność i samodzielność wytwarzać.

Ryszard Panasiuk zauważa podobne trudności na polu filozofii:

Teraz jest inny mechanizm wstępowania na studia. Niektórzy tak wędrują po różnych kierunkach, aż nareszcie lądują gdzieś na filozofii czy na pedagogice, czyli takich pobrzeżnych ze względu na charakter tych kierunków studiów, i wtedy się okazuje, że ta studenteria to jest wyjątkowo marne towarzystwo, o ile ja się orientuję. Choć trafiają się, ale tak zawsze było, pojedynczy ludzie, którzy coś potrafią i są naprawdę bystrzy, coś czytają, a reszta to jest takie sobie towarzystwo. Próbuje się to tak zrobić, żeby było jakoś przydatne, żeby można było wejść do różnych form pracy, ale mnie to już przestało zupełnie interesować.

Jednym z wielu pytań, jakie towarzyszyło nam w czasie czytania zgromadzonych historii życia i ich analizy, jest to dotyczące przyczyn, dla których nasi rozmówcy prawie nie podejmują wątku swoich uczniów. Co takiego zadziało się w ich własnych biografiach, albo, co jak mniemamy, ważniejsze - w sferze przemian kulturowych, społecznych i politycznych, że więź mistrz-uczeń, którą tak bardzo cenili, zaczęła zanikać? Wśród zebranych

${ }^{142}$ Maria Lawrynowicz (ur. 1934) - biolog, sprawuje funkcję kierownika Katedry Algologii i Mikologii oraz kierownika Zakładu Mikologii na Wydziale Biologii i Ochrony Środowiska Uniwersytetu Łódzkiego.

${ }^{143}$ Janusz Markowski (ur. 1947) - biolog, zoolog, pracuje w Zakładzie Dydaktyki Biologii i Badania Różnorodności Biologicznej UŁ.

${ }^{144}$ Stefan Niesiołowski (ur. 1944) - zoolog i polityk, po 1989 roku poseł i senator. Absolwent i wieloletni pracownik UŁ. 
przez nas wywiadów mamy przeto do czynienia z wieloma rozbudowanymi passusami poświęconymi (często bardzo trudnym, lecz wartościowym) relacjom z mistrzami, i znacząco mało (zazwyczaj lakonicznych, czasem przepełnionych rozczarowaniem) opowieści o własnych uczniach.

W naszej kolekcji jest jednak kilka relacji, w których pojawiły się wypowiedzi poświęcone wychowankom i młodemu pokoleniu akademików potencjalnych kontynuatorów i następców. Przyjrzyjmy się im nieco bliżej.

Tak o swoich uczniach opowiadają kolejno Ryszard Jajte i Teresa Cieślikowska:

Ryszard Jajte:

Miałem szczęście do zdolnych uczniów. Muszę powiedzieć, że najpierw doktoryzowałem same dziewczyny. Było ich chyba na początek pięć. Kiedy wyjeżdżaliśmy na konferencje organizowane przez Uniwersytet Wrocławski, to tam ktoś powiedział, że to łódzka żeńska szkoła probabilistyczna przyjeżdża. Potem się nikt nie chciał do tego przyznać. Później pojawili się utalentowani chłopcy, dziś ci chłopcy to już są mężczyźni, którzy są dziadkami, ale są wybitnymi matematykami. Najwybitniejszym moim uczniem jest profesor Adam Paszkiewicz ${ }^{145}$. Mówi się, że uczeń powinien przewyższać mistrza $\mathrm{i}$ tu się to absolutnie zgadza. Absolutnie jest to matematyk, który opiera się o genialność, myślę, że tak mogę powiedzieć. Bardzo wybitni są pozostali uczniowie - trzeba wymienić profesora Stanisława Goldsteina ${ }^{146}$, profesora Andrzeja Luczaka ${ }^{147}$. Obecnie w katedrze pozostali pracownicy to ich uczniowie.

\section{Teresa Cieślikowska:}

Pośród moich byłych podopiecznych kontynuujących badania teoretyczno-literackie ceniłam sobie zwłaszcza doktor habilitowaną Danutę Szajnert ${ }^{148}$ jako odpowiedzilną i obiektywna w pracach badawczych a także profesora doktora habilitowanego Jarosława Płuciennika ${ }^{149}$.

${ }^{145}$ Adam Paszkiewicz (ur. 1952) - matematyk i fizyk, obecnie kierownik Katedry Prawdopodobieństwa i Statystyki Uniwersytetu Łódzkiego.

${ }^{146}$ Stanisław Goldstein (ur. 1952) - matematyk, aktualnie kierownik Katedry Informatyki Stosowanej Wydziału Matematyki i Informatyki Uniwersytetu Łódzkiego.

${ }^{147}$ Andrzej Łuczak (ur. 1948) - matematyk, specjalista w dziedzinie teorii prawdopodobieństwa. Pracuje w Katedrze Teorii Prawdopodobieństwa i Statystyki Uniwersytetu Lódzkiego. Wybitny szachista.

${ }^{148}$ Danuta Szejnert - kulturoznawca, specjalizuje się w historii i teorii literatury, pracuje w Katedrze Teorii Literatury UŁ.

${ }^{149}$ Jarosław Płuciennik (ur. 1966) - kulturoznawca i literaturoznawca, kierownik Katedry Teorii Literatury UŁ, obecnie prorektor ds. programów i jakości kształcenia. 
Wanda Nowakowska, nie wymieniając wprawdzie nikogo z imienia i nazwiska, wspomina o życzliwej pamięci o jej dorobku wśród obecnych pracowników swojej Katedry:

W tym roku, w maju pracownicy „mojej” Katedry zrobili mi wielką niespodziankę: opublikowali o mnie książkę z bardzo pięknymi i wzruszającymi wspomnieniami. Wręczyli mi ją podczas zorganizowanej dla mnie uroczystości w Łódzkim Towarzystwie Naukowym, gdzie została opublikowana. Myślę, że warto jest żyć dla takich chwil, które zawdzięczam przecież pracy na Uniwersytecie.

Choć relacja mistrza wobec ucznia winna być obopólnie uczciwa i oparta na zaufaniu i szacunku, nie zawsze tak się działo. Nasi rozmówcy nieraz wspominali o rozczarowaniach, braku kontynuacji określonej szkoły naukowej czy o pewnym zawodzie, jaki spotkał ich ze strony własnych wychowanków. Są to kwestie, które pojawiają się kolejno w wypowiedziach Jerzego Dietla, Jolanty Kulpińskiej oraz Władysława Welfego:

Jerzy Dietl:

Reszta [uczniów] nie zawsze była najwyższych lotów, chociaż kilka osób ma tytuły profesorskie. Ukończonych doktoratów pod moją opieką było w sumie 28, nie tylko tutaj, bo już pewnym doktoratom patronowałem w Poznaniu. Na ogół te wszystkie doktoraty broniły osoby profesjonalnie związane $\mathrm{z}$ uczelniami. Miałem tylko jednego doktora, który nie był z uczelni, nawet nie był błyskotliwy, ale był tak uparty i pracowity, że napisał i obronił rozprawę doktorską.

Jolanta Kulpińska:

Kiedy przeszłam na emeryturę, w 1999 roku, to jeszcze najpierw zgodnie z przepisami miałam niby pół etatu, potem ćwierć, potem jedną ósmą, ale to stało się już zbyt kosztowne dla Instytutu, a w końcu z tego tytułu mogłam mieć jedno seminarium, więc to $\mathrm{w}$ ogóle już nie miało sensu. Tak więc zrezygnowałam i właściwie to poniosłam pewną klęskę. Dlatego że w mojej katedrze moje zainteresowania w niewielkim stopniu były kontynuowane i pojawiły się takie napięcia między kolegami i w stosunku do mnie również. Był jakby problem sukcesji i ja postawiłam na Krzysztofa Koneckiego ${ }^{150}$, uważając, że jest najzdolniejszy, miał wtedy właśnie ten świetny doktorat, uważam, że to jest jego najlepsza praca. To się nie podobało innym, starszym kolegom, którzy uważali, że zasada „seniority” jest tutaj istotna i to spowodowało takie dosyć

${ }^{150}$ Krzysztof Konecki (ur. 1958) - socjolog, przede wszystkim zajmujący się socjologią jakościową w tym teorią ugruntowaną. Obecnie sprawuje funkcję kierownika Katedry Socjologii Organizacji i Zarządzania UŁ. 
mocne napięcia. Mniejsza o to, tyle tylko, że jednocześnie właśnie Krzysztof absolutnie zmienił kierunek, odcinając się dosyć wyraźnie ode mnie. Zaczęło się to od nazwy Katedry ${ }^{151}$, ale nie tylko. Jesteśmy w dobrych kontaktach, zapraszają mnie i tak dalej, ale to już jest tylko grzecznościowe, nie ma żadnego znaczenia. I to trochę dla mnie bolesne przeżycie takiego zakończenia, bo w rezultacie bardziej współdziałam jakby i szukam oparcia w innych kolegach. Na przykład w redakcji „Przeglądu Socjologicznego” i to jest coś, co nie tylko lubię robić, ale też lubię być z tymi ludźmi. Jakoś tutaj się to lepiej kształtuje. $\mathrm{Z}$ różnymi ludźmi ciągle sobie coś tam recenzujemy czy piszemy, a z Katedrą najmniej. Bo też i inne zainteresowania, dość wyraźnie, nieinteresujące mnie w ten sposób, także nie ma obowiązku się do mnie zwracać. Czas leci tak szybko, to już przecież prawie dwanaście lat. Tak samo zresztą przyjęłam zasadę, żeby się nie wtrącać w sprawy Instytutu.

Władysław Welfe:

Udawało mi się w tym czasie łączyć administrację z pracą naukową, co więcej, stanąłem na czele Instytutu Ekonometrii i Statystyki. To te Instytuty powstały z połączenia katedr w roku 1970, o ile dobrze pamiętam, i nasz Instytut Ekonometrii i Statystyki rozrósł się bardzo - moi uczniowie jak zostawali profesorami, to się, że tak powiem, usamodzielniali. Początkowo były dwie katedry, a jak odchodziłem na emeryturę, to chyba ich było osiem czy dziewięć, to był rezultat takiego awansu i muszę powiedzieć, że chyba większość z nich to byli moi doktorzy, nie mogę się przyznawać do habilitacji, jako że każdy na własną rękę działał, ale tym niemniej, więc Instytut się bardzo rozrósł dzisiaj. Tylko mogę nad tym ubolewać, że na skutek rozmaitych niemerytorycznych przyczyn rozpadł się na Instytut Ekonometrii, w którym to nasza Katedra tkwi, i Instytut Statystyki i Demografii ${ }^{152}$, a poza tym dwóch profesorów się wyprowadziło do innych Instytutów. Także w pewnym sensie uważam to dzieło za zmarnowane, ale co zrobić. Sam partycypowałem w emancypacji młodszych kolegów i powinienem był to przewidzieć, zajmuję się prognozowaniem od lat, a w tej materii nie zdałem egzaminu. Natomiast poza pracą naukową uczestniczę od lat w takich aplikacjach polegających w głównej mierze na prognozowaniu rozwoju gospodarczego Polski - aktualizujemy te prognozy co kwartał, publikujemy je w świecie i w kraju i to jest taka przyjemna odskocznia, która niespecjalnie wymaga wysiłku naukowego, natomiast wymaga uczestniczenia w życiu gospodarczym lub obserwacji stałej, także muszę być zorientowany w tym, co się w kraju dzieje, żeby móc potem zobaczyć, czy prognoza na podstawie modelu ma ręce i nogi, czy można ją podtrzymać, czy należy ją

151 Katedra Socjologii Przemysłu została zmieniona na Katedrę Socjologii Organizacji i Zarządzania.

${ }^{152}$ Katedra Modeli i Prognoz Ekonometrycznych wchodzi od 2008 roku w skład Instytutu Ekonometrii, powstałego po odłączeniu się Instytutu Statystyki i Demografii. 
zmienić. Poza tym, jak pani widzi, nie próżnuję. Najlepszym tego dowodem jest książka ${ }^{153}$, która się ukazała, teoretycznie w zeszłym, a praktycznie w tym roku. To jest zarys historii makromodelowania w skali światowej. Napisałem ją w ciągu ostatnich trzech lat, jeszcze drugą część do niej dorabiam.

Praca naukowa nigdy się nie kończy, nigdy nie ma czasu od niej wolnego. Słowa Romualda Olaczka zdają się niezwykle trafnie oddawać tę właściwość biografii naukowca-badacza-dydaktyka: „W nauce to człowiek nigdy się nie czuje po fajrancie, tylko zawsze ma coś do zrobienia. Nawet jak wróci z pracy do domu, to tam wyrywa każdą godzinę, żeby usiąść przy biurku czy przy stole i czytać, pisać, notować, robić coś”. W pierwszej części ksiażki próbowałysmy uchwycić pewne względnie stałe elementy konstytuujące przebieg kariery akademickiej. Jednak poza owymi uniwersalnymi wymiarami większości biografii akademickich, często wspólnymi dla wielu pokoleń naukowców, indywidualne losy każdego z nich splecione były ze szczególnymi okolicznościami historycznymi i politycznymi danego czasu - tym dwóm tematom poświęcone są następne dwa rozdziały.

${ }^{153}$ Władysław Welfe, Macroeconometric Models, Springer, Berlin-Heidelberg 2013. 


\title{
Rozdzial IV. Konteksty historyczne
}

\begin{abstract}
Jak pani widzi, nie poruszam tematu polityki, ale nie jest tak, że ja nie mam pogladu na sytuacje, w jakiej studiowatem. To nie byta normalna sytuacja. Natomiast mam obawy, czy nasze indywidualne opinie $w$ tej sprawie sq miarodajne, czy nie trzeba poczekać trochę, troszkę to wypośrodkować, bo żyło nam się bardzo trudno, materialnie również, a te sytuacje zwiąane z polityka nie były zupetnie proste. (...) Ale czy ktoś wymyślit taki świat, taki ustrój, gdzie by było wszystko idealnie? Myślę, że nie.
\end{abstract}

$\mathrm{Z}$ wywiadu z profesorem Zbigniewem Jakubowskim

W tej części książki chcemy przyjrzeć się procesom społecznym i wydarzeniom historycznym z perspektywy indywidualnych doświadczeń osób, które w nich uczestniczyły i chciały o nich opowiedzieć. Zazwyczaj były to wspomnienia wynikające $\mathrm{z}$ dynamiki opowieści (narracji) lub $\mathrm{z}$ dodatkowych pytań osoby prowadzącej wywiad (odwołujących się do już podjętych przez narratora, lecz pobieżnie opracowanych wątków lub do uprzednio przygotowanych przez badaczki zagadnień). Należy przy tym pamiętać, że większość tych wydarzeń miała miejsce w epoce socjalizmu, której obrazy i interpretacje do dziś są bardzo zróżnicowane, a postawy osób - szczególnie należących do elit symbolicznych, których częścią byli nasi rozmówcy - są przedmiotem wielu sporów i kontrowersji. Nie jest jednak naszym celem poddanie analizie czy ocenie postępowania naszych narratorów, lecz rekonstrukcja tworzonych przez nich społecznych, kulturowych i politycznych obrazów rzeczywistości, w której przyszło im żyć, podejmować decyzje, rozpoczynać i rozwijać swoje kariery naukowe. Staramy się też nie komentować i nie analizować sposobu prezentacji ich własnych działań i tworzonych obrazów siebie (sposobu, w jaki chcieliby być widziani zarówno przez osobę słuchającą, jak i przez wyobrażonego czytelnika ich opowieści). Tym samym, nawet wówczas, gdy określone fakty są inaczej przedstawiane na kartach historii, nie weryfikujemy relacji naszych rozmówców, a jedynie w niektórych przypadkach zestawiamy opowieści różnych osób, w których dane wydarzenia są odmiennie rozumiane $\mathrm{i}$ interpretowane. Wyjątkowo sięgamy też tutaj do relacji świadków z innych znanych nam kolekcji wywiadów czy książek. 
Jak wspomniano we wstępie, aranżacja wywiadu (w dużej mierze inspirowana techniką autobiograficznego wywiadu narracyjnego) polegała na tym, że rozmówca sam decydował o tym, które wydarzenia ze swojej historii życia odtworzy i w jaki sposób to zrobi. Mógł on zatem swobodnie kształtować swoją opowieść zazwyczaj bez ingerencji i ukierunkowania (np. w postaci dodatkowych pytań) ze strony słuchacza. Tym samym czytelnik może odnieść wrażenie, że wśród cytowanych i omawianych poniżej fragmentów wypowiedzi dotyczących określonych wydarzeń społeczno-historycznych nie zostały zachowane właściwe proporcje: po pierwsze, nie wszystkie relacje naszych rozmówców zostały przytoczone, po drugie, określone wydarzenia zostały przez nich pominięte, a po trzecie, nie zostały one wystarczająco a nawet, jak mogą twierdzić niektórzy, właściwie odtworzone (przekłada się to zarówno na długość, jak i na treść wypowiedzi). Powtórzymy raz jeszcze, że ma to swoje uzasadnienie w swobodzie i spontaniczności relacji autobiograficznej: jedni po prostu pewnych wątków nie podejmowali, inni przedstawiali je z własnej perspektywy i umieszczali je w swojej własnej hierarchii jako kwestie mniej lub bardziej doniosłe biograficznie, sytuując punkt ciężkości być może w innych miejscach niż to jest powszechnie przyjęte czy niż by tego oczekiwał słuchacz lub czytelnik. Mówiąc krótko, narratorzy rzadko kiedy relacjonują te wydarzenia społeczno-historyczne, w które nie byli bezpośrednio uwikłani lub zaangażowani, mimo że są one przełomowymi momentami w powojennej historii Polski. Wspomnijmy przy tym, że jest to prawidłowość, którą już wcześniej udało nam się zaobserwować w kolekcji autobiograficznych wywiadów narracyjnych przeprowadzonych z osobami urodzonymi tuż po wojnie, co wiązało się z tym, że pierwsza połowa ich życia zawodowego przypadła na okres PRL, a druga na czas transformacji ustrojowej ${ }^{1}$.

Ramę biograficznych doświadczeń naszych rozmówców stanowią zatem takie zbiorowo-historyczne okresy czy wydarzenia jak: czas powojennej odbudowy, reforma szkolnictwa wyższego zapoczątkowana w 1948 roku, epoka stalinizmu, wydarzenia roku 1956, rok 1965 z ideologicznie motywowanym połączeniem socjologii z ekonomią, niepokoje i dramaty, które miały miejsce w 1968 roku, wypadki grudniowe na Wybrzeżu w 1970

\footnotetext{
${ }^{1}$ Mowa tu o projekcie badawczym prowadzonym w Katedrze Socjologii Kultury Uniwersytetu Łódzkiego oraz przez Uniwersytet w Magdeburgu w latach 2012-2014: „Doświadczenie biograficzne w PRL i NRD oraz jego przepracowanie w powojennym pokoleniu 1945-1955: porównanie socjologiczne na podstawie analizy biograficznej”, który był finansowany przez Polsko-Niemiecką Fundację na Rzecz Nauki.
} 
roku, okres gierkowski, rok 1981 - z którego częściej wspominano strajk studencki niż stan wojenny (do czego wrócimy później), lata osiemdziesiąte i festiwal „Solidarności”, przełom 1989 roku. Kwestię społeczno-kulturowych przeobrażeń uniwersytetu w sprawnie działające wolnorynkowe „przedsiębiorstwo" (czego widomym znakiem stało się zamknięcie Biblioteki Socjologicznej im. Józefa Chałasińskiego) omawiamy w rozdziale VI oraz w Zakończeniu.

Raz jeszcze podkreślmy, że poniższy tekst zmierza do uchwycenia przeżyć biograficznych i doświadczeń społecznych narratorów, dla których ramą były społeczno-polityczne wydarzenia w powojennej Polsce, a nie do systematycznej rekonstrukcji historii. Dodajmy jeszcze, że podjęte tu kwestie korespondują z treścią kolejnego rozdziału zatytułowanego „Konteksty polityczne”, w którym staramy się pokazać wzajemną relację między indywidualną biografią a sytuacją polityczną w peerelowskiej rzeczywistości. Tam też osobny podrozdział poświęcamy czasowi stalinizmu. Z kolei okres powojennej (od)budowy związany z powstaniem naszej uczelni przedstawiony został w rozdziale I, aby pokazać Czytelnikowi kontekst doświadczeń biograficznych rozmówców, wówczas młodych ludzi wstępujących w progi uniwersytetu. W związku z powyższym prezentację kontekstów historycznych zaczynamy od Października 56'.

\section{Odwilż gomułkowska - październik 1956}

Stalinowski terror, którego początek datuje się na rok 1948, wygasał wraz z nadejściem gomułkowskiej odwilży. Po okresie niemalże pełnej zależności Polski od Związku Radzieckiego i - jak pokazuje Andrzej Friszke - wymuszonego przejęcia od Moskwy „wzoru dla twórczości literackiej, artystycznej i badań naukowych"² październik 1956 przyniósł ze sobą nowe nadzieje - przede wszystkim te związane z odzyskaniem autonomii i niezależności. Nadzieje tym większe, że krytyka dotychczasowych poczynań władzy była sromotna, przez co wydawała się autentyczna.

Krystyna Lutyńska, która, jak sama otwarcie przyznaje, początkowo sama była ,pod urokiem komunistycznych idei”3 wspomina wystąpienie

\footnotetext{
${ }^{2}$ Andrzej Friszke, Spór o PRL w Trzeciej Rzeczpospolitej, „Tygodnik Powszechny” 2002, nr 16, 21 kwietnia 2002.

${ }^{3}$ Ten cytat zaczerpnięty z wywiadu z Krystyną Lutyńską wymaga komentarza. By właściwie zrozumieć wypowiedź naszej rozmówczyni, należy odczytać ją w kontekście innego fragmentu udzielonego przez nią wywiadu. Oto on: „W ostatnich dwóch klasach liceum zetknęłam się z dziewczętami, które były już w organizacjach młodzieżowych. Jeszcze wtedy był OMTUR i ZWM [Organizacja Młodzieży Towarzystwa Uniwersytetu Robotniczego, Związek Walki Młodych]. Dziewczęta te były bardzo inteligentne, przebojowe, oczytane i bardzo mi imponowały, a z niektórymi
} 
Władysława Gomułki w październiku 1956 roku jako szokujące i, co zresztą odzwierciedla panujące wówczas w Polsce nastroje, niosące wiarę w nadchodzącą zmianę.

Byliśmy bardzo tym poruszeni. Powstawały takie Kluby Inteligencji Katolickiej, to byliśmy trochę w to zaangażowani. Ja wtedy wystąpiłam z ZMP4, referat Chruszczowa, który czytałam wcześniej niż inni, bo jeszcze byłam w organizacji, to był ten największy szok. To, że Chruszczow powiedział, ile osób wyginęło i zostało zamordowanych w Związku Radzieckim przez te wszystkie lata komunizmu i potem w obozach - to był wielki szok. Potem to było wydrukowane w gazetach, to się powielało, czytało, debatowało. Pierwsze przemówienia Gomułki otworzyły wielkie nadzieje. Bo on mówił, żeby skończyć z kolektywizacją wsi, bronit, że tak powiem, twardego stanowiska wobec Rosji. Dopiero potem to się wszystko zmieniło. Ale te pierwsze wystąpienia Gomułki to było coś nadzwyczajnego.

Wydarzenia października 1956 roku odegrały także ważną rolę w życiu młodego Stefana Banasiaka (późniejszego profesora historii), który po ukończeniu trzyletnich studiów ${ }^{5}$ wyjechał do Warszawy, gdzie na Wydziale Historycznym tamtejszego uniwersytetu podjął naukę na studiach

z nich się nawet zaprzyjaźniłam. I potem był problem, jakie studia wybrać. W moim domu to tak niekoniecznie pochwalano, żeby kobieta zdobyła wyższe wykształcenie, ale ja bardzo chciałam. Oczywiście rodzice byli z tego zadowoleni. Studia wtedy były bezpłatne, a w moim domu w tych pierwszych latach powojennych było naprawdę bardzo ciężko (...). Miałam trochę zdolności do rysunku, trochę mnie pociągała architektura (...). Ale miałam jednocześnie duże zainteresowania społeczne. Jednak wpływ marksizmu-leninizmu na moje pokolenie był bardzo duży. Ja w liceum pod wpływem koleżanek wstąpiłam do ZMP. Ja należałam do tego pokolenia, które w czasie wojny było jeszcze dziećmi i nie mogło walczyć o wolność Polski. Gdybym była może w Warszawie, to bym była jakąś łączniczką w harcerstwie, ale ja mieszkałam na wsi, więc nie brałam udziału w ruchu oporu. Po wojnie bardzo chciałam zmieniać ten świat - takie hasła jak: „bezpłatna nauka”, „bezpłatna służba zdrowia”, „równość”, ,jednakowe traktowanie”. Na wsi widziałam, jak traktowani byli parobcy - to wszystko jakoś tak przemawiało do mnie. Ja ten marksizm [śmiech] rozumiałam raczej nie jak klasycy marksizmu, tylko bardziej jak Mickiewicz, Oda do młodości. Ale byłam w ZMP. I w rezultacie zdawałam na pedagogikę społeczną. Ale to był ten rok, kiedy skasowano socjologię. To był rok 1949/1950. Ja w tym roku wstępowałam na uniwersytet i wtedy skasowano te wszystkie kierunki, między innymi socjologię i stworzono Nauki Społeczne.

${ }^{4}$ ZMP - Związek Młodzieży Polskiej, organizacja młodzieżowa działająca w okresie stalinizmu w latach 1948-1957 zrzeszająca organizacje młodzieżowe działające do roku 1948: OMTUR - Organizację Młodzieży Towarzystwa Uniwersytetu Robotniczego, ZMD - Związek Młodzieży Demokratycznej, ZMW - Związek Młodzieży Wiejskiej, ZWM - Związek Walki Młodych.

${ }^{5}$ Kierunek studiów, jakim były wówczas nauki społeczne (wprowadzony wraz z dwustopniowym systemem studiów w 1949 roku) miał mieć w założeniu charakter ideologiczno-propagandowy i opierać się przede wszystkim na filozofii marksistowskiej. Wprowadzono go w miejsce zlikwidowanych dyscyplin akademickich, które uznano za politycznie niepoprawne (jak np. socjologię). W kolejnym rozdziale „Konteksty polityczne” szerzej o specyfice tego kierunku mówi jego studentka - Krystyna Lutyńska. 
II stopnia. W tym samym czasie, o czym dowiadujemy się z jego oficjalnego biogramu umieszczonego na stronach Uniwersytetu Łódzkiego, ,rozpoczął pracę w Katedrze Podstaw Marksizmu-Leninizmu, a później Katedrze Historii Polski Najnowszej UŁ"6. W 1955 roku otrzymał nakaz pracy i został skierowany do Łodzi. Wspomina to tak:

I tak wróciłem na swój pierwotny uniwersytet w charakterze asystenta. Bez mieszkania, bez jakiegokolwiek zaczepienia. Ale to był już okres od strony społecznej o tyle ciekawszy, że był to już schyłkowy okres stalinizmu. Z tego, co pamiętam, to było duże zainteresowanie tym, jak rozprawiono się z Berią po śmierci Stalina. Później Gomułka, jakoś tak przemilczany. Kiedy byłem w szkole średniej, to Gomułka był wśród tych postaci, które były bardzo silnie propagowane. A oficjalnie na portretach szkolnych to był Bierut jako prezydent, Osóbka-Morawski, później Rokossowski, a przed nim Żymierski. Tak się moja asystentura zaczęła, a na historii tych zajęć było niewiele, bo później już skurczono rekrutację, także człowiek był zadowolony, jak jakieś zajęcia dostał. (...) I po tym wszystkim rozpoczęła się taka sprawa, to pamiętam gdzieś z jakiejś kroniki filmowej: pokazują Gomułkę w kronice filmowej, ale tak prywatnie i on nie wycofuje się zarzutów o odchylenie prawicowo-nacjonalistyczne, ale nie zamierza się pociągać do jakiejś odpowiedzialności sądowej czy administracyjnej. To był dość duży szok. Później, po roku chyba, nastąpiło rozwiązanie Urzędów Bezpieczeństwa Publicznego. I rozpoczął się ten okres, który w mojej mentalności nazywa się odwilżą. Chociaż współcześnie tak ludzie nazywają to, co było po 1956 roku, to mnie się bardziej to kojarzy z tym, jak następowały zmiany za formalnego stalinizmu, jeszcze za życia Bieruta, przed XX Zjazdem.

Następnie profesor Banasiak opowiada o swoim spotkaniu z funkcjonariuszami Urzędu Bezpieczeństwa, które miało miejsce tuż po wojnie:

Na ogół prowadziłem takie życie, że nie powinno ono wzbudzać żadnych zainteresowań, ale zaraz po wojnie, trudno mi powiedzieć, czy to był 1945 rok, raczej chyba 1946 albo 1947, ojciec był sołtysem i tam się zgłosił jakiś pan, który nie miał gdzie się zatrzymać. Wtedy istniały jakieś serwituty, jakieś obowiązki opiekowania się, naprawa dróg, pomoc milicji i jeżeli ktoś był bezdomny, to trzeba było wydać takie zaświadczenie i skierować do któregoś gospodarstwa, żeby dało tej osobie schronienie. Tym się zainteresowali jacyś ludzie, którzy przyjechali samochodem. Oczywiście nie pamiętam już, czy się dokładnie przedstawiali, czy nie, ale okazało się, że mieli zaświadczenie takie od ojca, to ja z upoważnienia ojca wystawiałem, i ten pan zawołał mnie, ponieważ rozmowa była prowadzona przed domem, na podwórku, chciał wyjść

\footnotetext{
${ }^{6}$ http://www.historia.uni.lodz.pl/instytut/dyrektorzy/banasiak_stefan.htm (10.07.2015).
} 
z mieszkania. On mnie tam wypytywał, bardzo grzecznie, muszę powiedzieć, ale to pozostawiło ślad na całe życie: mianowicie sięgnął do prawej kieszeni, wyjął magazynek od pistoletu, przełożył do drugiej ręki i schował go do drugiej kieszeni. Ja miałem szesnaście lat czy coś takiego, więc specjalnego wrażenia na mnie to nie zrobiło, ale do dnia dzisiejszego wspominam to jako taką próbę zastraszenia, odłączenia od rodziny, pokazania mi, że tutaj jest amunicja, w tym magazynku i tak dalej .

Dalej o znaczeniu roku 1956 w jego życiu i karierze akademickiej profesor Banasiak mówi tak:

Ten 1956 rok był o tyle ciekawy dla Uniwersytetu Łódzkiego, że na Uniwersytecie nastąpił swego rodzaju bunt, rewolucja polityczna. Szczegółów nie znam, bo byłem w Warszawie, ale te struktury partyjne były takie studenckie, dlatego że przedwojenna kadra profesorska nie angażowała się w te nowe struktury. Więc to byli głównie studenci, niektórzy już zaawansowani w latach, nie ci dziewiętnastolatkowie, ale powiedzmy 25 lat czy więcej, o różnych często doświadczeniach, nawet wojennych. Więc to była taka organizacja, która na dobrą sprawę nie bardzo była widoczna, liczyła się dla wtajemniczonych. W 1956 roku ja byłem już członkiem partii, bo w szkole średniej byłem w ,Wici" ${ }^{\prime \prime}$. Z tego powodu miałem trochę różne takie przytyki, ale nie można tego nazwać represją czy czymkolwiek. To mi nigdy nie szkodziło, ale zawsze mi wywlekano, że mam dwie dusze, że „Wici” opowiadały się w tych pierwszych wyborach po stronie Mikołajczyka, przeciwko władzy ludowej i tak dalej. Więc tu [na Uniwersytecie Łódzkim] zaangażowałem się w działalność polityczną w 1956 roku. I te zmiany to się już rozpoczęły w 1955 roku, na cztery miesiące przed XX Zjazdem, który był na początku 1956 roku. A później wydarzenia poznańskie, później ten słynny powrót Gomułki do władzy. Także ja się zacząłem wysuwać do takiej czołówki ludzi, którzy są zaangażowani w destalinizację Uniwersytetu. Jak to w takich sytuacjach bywa, awanse następują nieraz bardzo łatwo, więc ja wszedłem do jakichś władz dzielnicowych, a po dwóch latach czy po roku nawet do łódzkich. Bardzo dużo mi to dało satysfakcji, zadowolenia. Uważam, że odegrałem pozytywną rolę. I na tym skończyła się moja działalność. Później zostałem wezwany na dywanik, do komitetu łódzkiego, zakazano mi w ogóle zajmowania się polityką. Powiedziałem: „tak jest”. Poszedłem do archiwum i tam sobie byłem. Prowadziłem badania nad Ziemiami Zachodnimi, które stały się modne, nad repatriantami

${ }^{7}$ Relację Stefana Banasiaka z kolejnego spotkania z funkcjonariuszami UB można znaleźć w następnym rozdziale, poświęconym kontekstom politycznym.

${ }^{8}$ Związek Młodzieży Wiejskiej Rzeczpospolitej Polskiej „Wici” - działająca w latach 19281948 organizacja młodzieży wiejskiej, Od 1931 roku związana ze Stronnictwem Ludowym. W 1948 roku stała się częścią Związku Młodzieży Polskiej (ZMP). 
na Ziemie Zachodnie, później wysiedlaniem ludności niemieckiej z terenu Polski do Niemiec ${ }^{9}$.

Jan Ziomek, geograf, geolog, założyciel Muzeum Geologicznego, którym przez wiele lat kierował, opowiada o tym, jak z grupą studentów mieli styczność z wydarzeniami roku 1956. W jego pamięci zapisał się zatem strajk w Poznaniu pod koniec czerwca, strajk tramwajarzy w Łodzi, a także powstanie węgierskie będące próbą uniezależnienia się od Związku Radzieckiego.

W 1956 roku brałem udział w strajku. Byliśmy w Kłodzku na praktykach i wieczorem poszliśmy do Domu Kultury. W Domu Kultury siedzieli ludzie przy stolikach, pili kawę, wino, no i my studenci, tam nas było około czterdzieścioro, ci ludzie nas częstowali, bo mieliśmy białe czapki jako studenci i ludzie nam dawali wino. Niektórzy koledzy popili dosyć dużo i żeśmy nad ranem prawie szli do internatu. Wchodziliśmy nie głównym wejściem, tylko przez piwnicę, bo w piwnicy był węgiel i po węglu później się szło na górę, bo drzwi główne były zamknięte, ale te od piwnicy były uchylone. Uchyliliśmy specjalnie, bo chodziło o to, żeby asystenci i profesor, którzy spali w Liceum Chrobrego, wiedzieli, że my śpimy, bo się nie pali światło. Ale poszliśmy do Domu Kultury i tam żeśmy krzyczeli i skandowali o klasie robotniczej Poznania i różne historie wygadywaliśmy, a później szliśmy pieszo do tego internatu. Ci, co szli z przodu, to byli bardziej trzeźwi, a tam z tyłu chyba paru kolegów, co trochę wypili i UB ich złapało. Po cichu, cyk i do suki i na komisariat. I proszę pani, rano my jak nigdy nic, nawet nie wiedzieliśmy, że ci nasi dwaj czy trzej koledzy siedzą w pace [śmiech]. Rano idziemy na śniadanie, wchodzi profesor, wściekły na nas i na koleżanki, które były Bogu ducha winne, bo one były z nami, ale nie piły tego wina i zachowywały się elegancko. Ale profesor dosyć ostro je potraktował, a my ich nie broniliśmy, bo się baliśmy. Profesor wtedy powiedział, że w związku z tym, że jest taka sytuacja, pogranicze tutaj już czechosłowackie, więc wojska wokół już pilnują i że zbieramy się, ładujemy i wsiadamy do pociągu i jedziemy do Łodzi. Przyjechaliśmy do Łodzi i akurat był strajk. Wtedy tramwaje jeździły, bo przy każdym motorniczym stał żołnierz, milicjant chyba z karabinem, i on musiał jechać. My wtedy żeśmy przestawili wagon na placu Dąbrowskiego. Jak szedł tak prosto, to go w poprzek postawiliśmy i zrobiliśmy taką barykadę. Niech pani sobie wyobrazi, że wagon przestawić to była sztuka! [śmiech]. A później udaliśmy się do zakładów Marchlewskiego, by tam być z klasą robotniczą. Byliśmy frajerami, co krzyczeli to i tamto. Wpuścili nas, ale byli tam też UB-owcy, którzy skrzętnie nas później wyłuskali i do suki, i pozabierali nam legitymacje i wtedy była taka sytuacja, że niektórzy studenci zostali wyrzuceni z uczelni. Niektórzy dostali

${ }^{9}$ Więcej na temat konsekwencji podjęcia takiego tematu badawczego przez prof. Banasiaka można znaleźć w części rozdziału V poświęconej cenzurze. 
nagany za strajk. Ja naganę dostałem za strajk i wyrzucili mnie z partii, bo należałem już wtedy do partii. Z partii wyrzucał mnie profesor Krzemiński ${ }^{10} \mathrm{i}$ profesor Tylman ${ }^{11}$, moi koledzy [śmiech]. Tak więc takie były czasy i ja po dziś dzień z profesorem Tylmanem żyję w przyjaźni. Tylman ma jeszcze zajęcia, ale już ma kupę lat, starszy jest ode mnie, a Krzemiński już nie żyje, ale do mnie przychodził i rozmawialiśmy, a o tych sprawach żeśmy zapomnieli. Nie [śmiech], $\mathrm{z}$ tego powodu nie było mi smutno. Raczej ja ich obraziłem. Powiedziałem, że jak tak kochają tę partię, to oby jej nie zamordowali. I wyszedłem. Ale dobrze się stało, że mnie nie wyrzucili z uczelni, bo innych wyrzucili. Później była sprawa węgierska, w której też braliśmy udział - solidaryzacja z Węgrami, powstanie na Węgrzech. To było też działanie ruchu studenckiego: ogromne poparcie dla Czechów, dla Węgrów. Ruchy studenckie były, powiedziałbym, taką odskocznią od szarego, normalnego życia. Powiedziałbym, że nieraz były taką przygodą - „chodźmy porozrabiać”. Chociaż idee były bardzo wzniosłe, ale po prostu jako młodzi ludzie [śmiech] nie zawsze żeśmy sobie zdawali sprawę z tego, co może nas spotkać, z konsekwencji, które mogły być bardzo poważne.

\section{Losy niepokornej socjologii 1951-1965 ${ }^{12}$}

Nie bez lekkiej konfuzji przyznać musimy, że socjologia jako dyscyplina naukowa uprawiana przez naszych rozmówców jest w tej książce nadreprezentowana. Ma to dwa, zróżnicowane jakościowo, wytłumaczenia. Po pierwsze, same jesteśmy socjologami (dodajmy, że nie tylko z zawodu, ale i z pasji) i, siłą rzeczy, łatwiej nam było dotrzeć do przedstawicieli tej nauki, a ich opowieści były nam bliższe i tym samym bardziej zrozumiałe. Po drugie, chodzi o wyjątkową pozycję łódzkiej socjologii w powojennej Polsce. Dyscyplinę tę tworzyły i rozwijały wówczas tak znaczące postaci jak Józef Chałasiński ${ }^{13}$ (uczeń Floriana Znanieckiego ${ }^{14}$ i rektor Uniwersytetu Łódzkiego w latach 1949-1952), Jan Szczepański15 ${ }^{15}$ (rektor Uniwersytetu

${ }^{10}$ Tadeusz Krzemiński (1925-2009) - profesor geografii na Uniwersytecie Łódzkim, zajmujący się przede wszystkim badaniami środowiska geograficznego Polski środkowej.

${ }^{11}$ Janusz Tylman (ur. 1924 w Łodzi) - prawnik, profesor Uniwersytetu Łódzkiego, wieloletni dyrektor Instytutu Prawa Karnego UŁ.

${ }^{12}$ Szeroko sytuację socjologii jako nauki w powojennej Polsce analizuje Jan Lutyński. Zob. tegoż, Niektóre uwarunkowania rozwoju socjologii polskiej i ich konsekwencje, [w:] tegoż, Nauka i polskie problemy: komentarz socjologa, słowo wstępne Krystyna Lutyńska, Państwowy Instytut Wydawniczy PIW, Warszawa 1990, s. 229.

${ }^{13}$ Józef Chałasiński (1904-1979) - profesor socjologii, jeden z założycieli Uniwersytetu Łódzkiego i rektor tej uczelni w latach 1949-1952, członek PAN.

${ }^{14}$ Florian Znaniecki (1882-1958) - filozof i socjolog, ojciec założyciel socjologii w Polsce.

15 Jan Szczepański (1913-2004) - wybitny polski socjolog, urodzony w Ustroniu, przez wiele lat związany z Uniwersytetem Łódzkim (1945-1970), którego był profesorem, a później także rektorem, członek PAN. 
Łódzkiego w latach 1952-1956), Stanisław Ossowski ${ }^{16}$, a także Antonina Kłoskowska ${ }^{17}$ i Jan Lutyński ${ }^{18}$. Wszyscy oni byli wybitnymi intelektualistami, uznawanymi i cenionymi nie tylko w Polsce. A, co bodaj najistotniejsze, nawet tych spośród nich, którzy zaangażowali się ideologicznie w nowy system, bez wątpienia zaliczyć należy do umysłów niezależnych.

Wróćmy do wydarzeń z roku 1956, szczególnie ważnego dla socjologii, której wykładanie od 1949 roku było zabronione ${ }^{19}$. Zlikwidowano wówczas - powołany na Wydziale Filozoficzno-Historycznym w 1947 roku na mocy porozumienia trzech Katedr ${ }^{20}$ - Instytut Socjologiczny. Zanim jednak przyjrzymy się dynamice wydarzeń społeczno-politycznych, które miały wpływ na losy tego kierunku, przypomnimy krótko kontekst powstania Uniwersytetu Łódzkiego.

Uniwersytet powstający w robotniczym mieście miał stanowić sztandarowy przykład uczelni wolnej od podziałów klasowych (choć, paradoksalnie, promował robotników i chłopów), oczyszczonej z burżuazyjnych ideologii i propagującej założenia marksizmu-leninizmu ${ }^{21}$. Rzecz w tym, że tuż po wojnie władza ludowa nie dysponowała jeszcze wystarczającą „ideologicznie poprawną i zaangażowaną” kadrą naukową i, chcąc nie chcąc, musiała tworzyć uniwersytet na wzór przedwojenny, tj. w oparciu o przedwojenną strukturę administracyjną oraz o przedwojennych naukowców i profesorów. To wiązało się z pozostawieniem nadal sporego

${ }^{16}$ Stanisław Ossowski (1897-1963) - socjolog, profesor Uniwersytetu Łódzkiego w latach 1945-1947 oraz Uniwersytetu Warszawskiego. Maria Ossowska (1896-1974) - etyk, teoretyk i socjolog moralności, profesor Uniwersytetu Łódzkiego w latach 1945-1948, a następnie Uniwersytetu Warszawskiego oraz Instytutu Filozofii i Socjologii PAN.

${ }^{17}$ Antonina Kłoskowska (1919-2001) - socjolog, absolwentka Uniwersytetu Łódzkiego, profesor na Uniwersytecie Łódzkim i Uniwersytecie Warszawskim, w latach 1989-1994 przewodnicząca Polskiego Towarzystwa Socjologicznego.

${ }^{18}$ Jan Lutyński (1921-1988) - socjolog i metodolog, profesor Uniwersytetu Łódzkiego, Dyrektor Instytutu Socjologii UŁ, kierownik Zakładu Metod i Technik Badań Społecznych. Ekspert i doradca struktur związkowych „Solidarności”. W 1981 r. podczas strajku studenckiego na UŁ pełnił funkcję doradcy komitetu strajkowego.

${ }^{19}$ Uściślijmy, że zlikwidowano wówczas większość z utworzonych kierunków humanistycznych. Poza socjologią były to między innymi: filozofia, psychologia, pedagogika, etnografia, archeologia czy filologie (poza polską i rosyjską).

${ }^{20}$ Chodzi tu o powołane w 1945 roku: Katedrę Socjologii, na czele której stanął wtedy jeszcze doktor Józef Chałasiński, Katedrę Socjologii Szczegółowej, którą kierował Józef Obrębski, i Katedrę Teorii Kultury, z posiadającym wówczas stopień doktora Stanisławem Ossowskim jako kierownikiem.

${ }^{21}$ Szczegółowo pisze o tym Agata Zysiak w swojej pracy Uniwersytet w modernizującym się mieście przemysłowym: przypadek Łodzi (1945-1980) (w druku). 
obszaru autonomii ${ }^{22}$ i z rekonstrukcją przedwojennej przestrzeni mentalnej czy universitas. Nawet zasadniczo odmienne wizje uniwersytetu robotniczego propagowane przez pierwszego rektora Uniwersytetu Łódzkiego Tadeusza Kotarbińskiego i jego bezpośredniego następcę Józefa Chałasińskiego (przy wszystkich opisanych powyżej różnicach między nimi ${ }^{23}$ ) mogły być realizowane prawie wyłącznie przy pomocy rąk i umysłów przedwojennej kadry naukowej, osób wywodzących się w głównej mierze z uniwersytetów w Warszawie, Krakowie, Wilnie czy Lwowie, które w wyniku zawieruchy wojennej znalazły się w Łodzi oferującej, jak na tamte czasy, stosunkowo dobre warunki lokalowe - zarówno jeśli chodzi o możliwość znalezienia mieszkania, jak i prowadzenia wykładów. Krótko rzecz ujmując, tuż po wojnie Łódź zgromadziła i dała możliwość działania wielu wybitnym intelektualistom, naukowcom i myślicielom. Stworzono w ten sposób środowisko, któremu - w przypadku przedstawicieli nauk humanistycznych i społecznych - bliskie były problemy kondycji społeczeństwa i organizacji państwa, które krytycznie przyglądało się promowanej ideologii, raczej odtwarzając przedwojenny porządek niż budując zmodernizowany, ludowy uniwersytet, i które tym samym stawało się coraz większym zagrożeniem dla reżimowej władzy. Co ciekawe, ze względu na trudne warunki lokalowe wielu filozofów, socjologów czy pedagogów (choć nie tylko) zamieszkało w jednym miejscu - w kamienicy przy ulicy Uniwersyteckiej 3, gdzie znajdowały się zarówno mieszkania, sale seminaryjne, jak i biblioteka. Przestrzeń prywatna i oficjalna przenikały się, tworząc tym samym warunki do nieustającej dyskusji ${ }^{24}$.

W 1949 roku z Wydziału Humanistycznego Uniwersytetu Łódzkiego wyrugowano większość - uznawanych za burżuazyjne - kierunków, w tym między innymi socjologię ${ }^{25}$. Dopiero po odwilży gomułkowskiej w 1956 roku socjologia wróciła na Wydział Filozoficzno-Historyczny jako kierunek studiów. W 1961 roku przy współudziale socjologów powołany został Wydział Ekonomiczny (przez włączenie do Uniwersytetu Wyższej Szkoły Ekonomicznej), a wśród powstających katedr znalazły się również cztery

${ }^{22}$ Zob. John Connelly, The Foundations of Diversity: Communist Higher Education Policies in Eastern, 1945-1955 Europe, [w:] Kristie Macrakis, Dieter Hoffmann (red.), Science under Socialism: East Germany in Comparative Perspective, Harvard University Press, Cambridge, MA 1999, s. 134-135.

${ }^{23}$ Kamil Piskała, Agata Zysiak, Światynia nauki, fundament demokracji czy fabryka specjalistów?, „Praktyka Teoretyczna” 2013, nr 3, www.praktykateoretyczna.pl/PT_nr9_2013_Po_kapitalizmie/11.Piskala,Zysiak.pdf. (15.04.2015).

${ }^{24} \mathrm{O}$ Uniwersyteckiej 3 piszemy szerzej w rozdziale VI.

${ }^{25}$ Podobny los spotkał kierunki humanistyczne na wszystkich polskich uniwersytetach. 
katedry socjologiczne. W 1965 roku do Wydziału Ekonomicznego, którego formacja ideologiczna nie budziła zastrzeżeń władz państwowych, dokooptowano - nadal uważaną za wichrzycielską i niepokorną - socjologię. Stało się to przede wszystkim za sprawą Jana Szczepańskiego, który przekonywał ówczesne władze o wartości socjologii (mającej przecież w polu swoich zainteresowań badawczych kwestie związane z rozwojem i funkcjonowaniem przemysłu). Tak doszło do utworzenia istniejącego do dziś Wydziału Ekonomiczno-Socjologicznego, jedynego takiego wydziału w Polsce. Zasygnalizowane powyżej wydarzenia ciekawie prezentuje opowieść profesor socjologii Jolanty Kulpińskiej, która tak opisuje zmiany, jakie przyniósł ze sobą polski październik: „1956 rok to jest dla mojego pokolenia ta granica niesłychanie wyraźna i dla socjologii bardzo, bo zaczęło się od razu, wiadomo było, że robimy badania i wracają studia”. Kulpińska opowiada dalej o powrocie do nadzoru ideologicznego i narzucania obszarów zainteresowań naukowych i badawczych oraz o zachodzących później zmianach:

Kiedy wróciłam z Francji [w 1959 roku], to właściwie już tworzona była Katedra Socjologii II Szczepańskiego i ja już się w niej znalazłam. Tak wróciłam na Uniwersytecką, już jako adiunkt, do 1965 roku $^{26}$, bo to znowuż była taka bardzo ważna granica dla nas, ze względu na te pomysły reformatorskie, zewnętrzne, które z jednej strony były jakimś pomysłem zagospodarowania socjologii, też załatwienia sprawy ekonomii łódzkiej, bo dzięki nam Wydział Ekonomiczny wtedy dostał uprawnienia akademickie do doktoryzowania. Ale z drugiej strony, to była przecież kara za Chałasińskiego ${ }^{27}$, więc zawsze żeśmy się spierali. Wacek Piotrowski ${ }^{28}$ podkreślał bardziej to, że w ten sposób żeśmy wspomogli jakby Wydział Ekonomiczny, włączenie Wyższej Szkoły Ekonomicznej do Uniwersytetu, i że był to taki pozytywny dla rozwoju socjologii element, a Janek Lutyński ${ }^{29}$, ja, częściowo też chyba Tola Kłoskowska ${ }^{30}$, uważaliśmy, że tutaj ten główny element to była kara za Chałasińskiego czy rozwiązanie jakieś problemu socjologii, ale w kontekście bardziej konfliktu z Chałasińskim niż ze względu na jakieś poszukiwania rozwojowe. To było jednak w duchu odejścia od października. Czyli był już w tym element kontroli nad socjologią bardziej i w tym procesie uczestniczył Schaff ${ }^{31}$. Nie był jeszcze

${ }^{26}$ Zob. informacje dotyczące historii powstania Wydziału Ekonomiczno-Socjologicznego umieszczone na stronie: www.eksoc.uni.lodz.pl/is/historia.html (10.07.2015).

${ }^{27}$ Zob. przypis $13 \mathrm{w}$ tym rozdziale.

${ }^{28}$ Wacław Piotrowski (1924-1998) - socjolog, absolwent łódzkiej socjologii i późniejszy profesor socjologii na Uniwersytecie Łódzkim.

${ }^{29}$ Zob. przypis $18 \mathrm{w}$ tym rozdziale.

${ }^{30}$ Zob. przypis $17 \mathrm{w}$ tym rozdziale.

${ }^{31}$ Adam Schaff (1913-2006) - urodzony we Lwowie, profesor filozofii. Studia w tym zakresie ukończył na Uniwersytecie w Moskwie w 1945 roku. Tam też uzyskał stopień doktora i doktora 
rewizjonistą, tylko odwrotnie, był tym, który bronił przed burżuazyjną, czy tam w każdym razie niekontrolowaną socjologią. Trzeba powiedzieć, że dla tego naszego pokolenia - choć Janek [Lutyński] i Tola [Kłoskowska] trochę starsi ode mnie, ale byliśmy zawsze w bardzo bliskich kontaktach - to dla nas troska o rozwój socjologii była rzeczywiście jakąś życiową misją, to było dla nas niesłychanie ważne i to kształtowało nas, nasz stosunek do pracy i do nauczania, do badań i dyskusji wokół tego, co się robi.

(...)

No to... właśnie ta cezura, walka o utrzymanie socjologii to, żebyśmy... Rzeczywiście był problem. I myślę, że pewną rolę w tym może i odegrałam. Mianowicie idea była taka: przeniesienia nas na ten Wydział Ekonomiczny, żeby rozwijać socjologię pracy i kształcić socjologów zakładowych. Ale tą problematyką interesowało się $\mathrm{w}$ instytucie parę osób. Właśnie głównie zespół Szczepańskiego, który wtedy zresztą był w Ameryce. Natomiast i Lutyński, i Gostkowski ${ }^{32}$ i Kłoskowska interesowali się czym innym, ale mieli coś w tym „czym innym” do powiedzenia. Więc cały wysiłek polegał na tym, żeby nie tylko socjologią pracy się zajmować, żeby właśnie pozwolono na rozwijanie również i innych subdyscyplin, zarówno w dydaktyce - przede wszystkim w dydaktyce, bo w badaniach już wtedy nie byłoby takiego nacisku, że oni muszą koniecznie robić socjologię pracy. Zresztą mieli już doświadczenie zajmowania się historią czasopiśmiennictwa polskiego i też w tej sprawie zrobili coś interesującego dla historii kultury czy nauk społecznych w XIX wieku. Włożono spory wysiłek w szukanie sposobów do przekonania decydentów w Warszawie i Wydziału Nauki KC, który jednak o tym decydował, a także jakiegoś wsparcia w Ministerstwie. Tutaj rzeczywiście pomogły nam dobre relacje $\mathrm{z}$ komitetem łódzkim. Jakieś badania, które ich zainteresowały, nam w tym pomogły. Oni pomogli nam tak, że uznali, że socjologowie w Łodzi nie są niebezpieczni może, że można, warto rozwijać to szerzej. Początkowo było przecież tak, że kierunek nazywał się socjologia pracy, przez kilka lat, do 1965 roku. To była ta granica, wtedy odbyło się jakieś zebranie, na którym nie byłam, bo akurat byłam chora, ale na tym zebraniu ostatecznie uznano, że to powinien być Wydział Ekonomiczno-Socjologiczny, więc dowartościowano socjologię na Wydziale - nie tylko socjologię pracy, ale kierunek socjologia z różnymi zakładami, kierunkami, różnymi specjalizacjami. Niby początkowo to było tak, że tamte pozostałe miały być mniej liczne, ale potem już wszyscy zapomnieli o tych ograniczeniach, bo nadszedł 1968 rok.

habilitowanego. Od powrotu do Polski w 1948 roku członek Komitetu Centralnego Polskiej Partii Robotniczej i główny ideolog stalinizmu. Później krytyk dogmatycznego marksizmu.

32 Zygmunt Gostkowski (1926-2014) - profesor socjologii na Uniwersytecie Łódzkim, metodolog pracownik PAN. 
Utworzenie i funkcjonowanie Wydziału Ekonomiczno-Socjologicznego inaczej postrzegał i oceniał Władysław Welfe, ekonomista, profesor Uniwersytetu Łódzkiego:

W dawnej WSE ${ }^{33}$ uważano, że jestem dobrym administratorem. Jako zastępca profesora - magister, byłem dziekanem, najpierw Wydziału Handlu, a potem Wydziału Handlowo-Towaroznawczego. Niestety rozwój kadry był tak powolny, że żadna z tych Rad Wydziałów nie miała uprawnień do doktoryzowania. Także to w znacznej mierze przesądziło o tym, że WSE została połknięta. Miała miejsce fuzja z Uniwersytetem i powstał najpierw Wydział Ekonomiczny, a po roku Wydział Ekonomiczno-Socjologiczny, na którego czele stanął profesor Mujże ${ }^{34}$. Wtedy zdecydowano o mariażu ekonomistów z socjologami. $\mathrm{W}$ moim przekonaniu to było jedno z genialnych posunięć organizacyjnych, ponieważ taki twór jest unikalny w Polsce i w moim przekonaniu korzystny dla obu stron. Nie wiem, czy wszyscy podzielają ten punkt widzenia, ale tym niemniej żadne separatystyczne tendencje poważne nie miały miejsca, o ile dobrze pamiętam.

\section{Konsekwencje wydarzeń marcowych 1968}

Następstwem wydarzeń roku 1968 - począwszy od zdjęcia przez cenzurę inscenizacji Dziadów (o antyrosyjskiej w swej wymowie) w reż. Kaźmierza Dejmka, przez brutalnie stłumione przez MO i tzw. aktyw robotniczy demonstracje studentów domagających się powrotu tegoż spektaklu na afisz, relegowanie z uczelni studentów relacjonujących mediom francuskim owe zajścia (Adama Michnika i Henryka Szlajfera), wiece i strajki organizowane w ich obronie, po antysemickie nagonki i czystki - było zbiorowe załamanie się oczekiwań wobec dnia codziennego i powszechna dezorientacja. Miało to związek z upadkiem moralnym społeczeństwa polskiego, dramatycznym zachwianiem się podstaw relacji społecznych opartych na wzajemności oraz pogłębiającą się wzajemną nieufnością i podejrzliwością ${ }^{35}$. Dotychczasowe zasoby interpretacyjne i schematy odniesienia

${ }^{33}$ WSE - Wyższa Szkoła Ekonomiczna została utworzona w Łodzi w 1950 roku na bazie działającej już od pięciu lat filii Szkoły Głównej Handlowej.

${ }^{34}$ Jan Mujżel (1923-2006) - ekonomista, profesor Uniwersytetu Łódzkiego, zajmował się teorią ekonomii, w tym przede wszystkim teorią funkcjonowania gospodarki i przedsiębiorstw. Uczestnik obrad Okrągłego Stołu.

${ }^{35}$ Odwołujemy się tutaj do koncepcji trajektorii zbiorowej Fritza Schützego. Zob. np. Fritz Schütze, Pressure and Guilt: War Experiences of a Young German Soldier and Their Biographical Implications (Part 1), „International Sociology” 1992, nr 7, s. 187-208; tegoż, Analiza biograficzna ugruntowana empirycznie $w$ autobiograficznym wywiadzie narracyjnym: jak analizować wywiady narracyjne, [w:] Kaja Kaźmierska (red.), Metoda biograficzna w socjologii: antologia tekstów, Zakład Wydawniczy Nomos, Kraków 2012. 
przestały działać albo ich funkcjonowanie nabrało innego, zaskakującego charakteru: to, co kiedyś było ważne, straciło swoją wartość, a rzeczy dotąd nieistotne zaczęły się wysuwać na plan pierwszy. Ten proces można zrekonstruować w relacjach wielu profesorów, którzy opowiadają o wpływie ówczesnych wydarzeń na ich pracę, na zachowanie przełożonych, na odmienny, etnicznie i ideologicznie motywowany sposób patrzenia na ludzi i definiowania ich osiągnięćc ${ }^{36}$. Stefan Banasiak, historyk, ze swojego punktu widzenia - wówczas doktora habilitowanego - przedstawia doświadczenia tamtych dni:

Kiedy przyszła sprawa Dziadów i akcja przeciwko młodzieży, przeciwko studentom, rozpoczął się ruch - moim zdaniem przedwcześnie, niedojrzały, niepoważny. Ja z doświadczeniem z 1956 roku, a to się zakończyło tą rozmową, że mam być odsunięty za rewizjonizm, zdałem sobie sprawę, że od strony i historycznej, i socjologicznej to jest sprawa słabo przebadana, ale tak intuicyjnie wyczuwam, że tam był duży procent dzieci dygnitarzy Polski Ludowej o rodowodzie żydowskim. $Z$ jednej strony bunt młodych przeciwko starym rodzicom czy dziadkom, $\mathrm{z}$ drugiej duma $\mathrm{z}$ sukcesów Izraela. Jednocześnie Związek Radziecki nakazał, żeby zerwać stosunki dyplomatyczne z Izraelem, a u nas wszystko, co pochodziło z nakazów Rosji, jest zawsze niemile widziane, więc to był też bunt. I jest zrozumiałe, że to spowodowało ruch młodzieży. Przyglądałem się temu, prawie że uczestniczyłem, ale nie tak aktywnie, nie ideologicznie, tylko biernie. Co się działo w 1968 roku, to to, że władze uczelni w takich sytuacjach nakazywały głównie, żeby pracownicy dbali o majątek. To są różne sprzęty, pracownia fotograficzna. To było okupowane i ktoś musiał być, żeby widział, kto pobiera klucze, kto wchodzi, kto wychodzi, jak się $\mathrm{z}$ tego wszystkiego korzysta. Więc ja byłem w tym okresie wiele razy na terenie Instytutu i przysłuchiwałem się przemówieniom studentów. Doszedłem do wniosku, że oni nie mają w ogóle wyrobienia politycznego. Oni są strasznie mierni, strasznie słabi jako politycy, jako demagodzy, nie potrafią po prostu być trybunami. Zawsze stawiali taki argument, że musimy zachować twarz. Skoro występują studenci innych miast, to i Łódź nie może być gorsza i musimy występować. To wszystko byłoby niczym, gdyby nie to, że w Instytucie Historii 1968 rok odegrał dość znaczącą rolę. Bo tak: po 1968 roku wyrzucono z pracy rektora, profesora Piątowskiego ${ }^{37}$, prawnika, z którym byłem, mimo różnicy wieku i różnicy stanowisk, w takich dobrych układach. Na Wydziale

${ }^{36}$ Zainteresowanych dokumentami z tamtego okresu odsyłamy do tomu Marzec ' 68 w Łodzi, red. Sławomir M. Nowinowski, IPN, Łódź 2010.

${ }^{37}$ Józef Stanisław Piątowski (1914-1986) - profesor prawa, znawca prawa cywilnego, w latach 1965-1968 rektor Uniwersytetu Łódzkiego. 
u nas dziekanem był wówczas docent Amsterdamski ${ }^{38}$ Przed marcem 1968 roku on był już kierownikiem Katedry Filozofii Marksistowskiej na Uniwersytecie i kiedy przyszedł rok 1968, to wtedy wywleczono trzy sprawy z naszego środowiska. Środowisko wyciągnięto w sprawę dziekana Amsterdamskiego. Przyszli przedstawiciele z Politechniki, którzy wygłosili jakieś mowy, bo Amsterdamski studiował też chemię na Politechnice, i opowiadali o tym, co on wyprawiał na Politechnice. Druga postać to był Paweł Korzec ${ }^{39}$, docent zajmujący się ruchem robotniczym, który zrobił karierę na rewolucji 1905 roku. Postać do dnia dzisiejszego dosyć dziwna. Trzecia postać, która była też wyciągnięta, to był dyrektor Instytutu Historii, Leon Błaszczyk ${ }^{40}$. I faktycznie te trzy osoby były nie do uratowania. Przyszedł przedstawiciel komitetu łódzkiego, który zresztą wielokrotnie bywał u nas i który zagroził, że jeżeli ta sprawa nie zostanie załatwiona, to organizacja partyjna Uniwersytetu zostanie rozwiązana, więc była jakaś presja. Byli ludzie, którzy prowadzili akcje przeciwko syjonistom na Uniwersytecie. My doszliśmy do wniosku, że skoro oni angażują się w to wszystko, to trzeba się zorientować, jakie mają powiązania $\mathrm{z}$ agentami, kto jest agentem i tak dalej. Nie dali się podejść. Nic to nie dało, mimo że robiliśmy po prostu celowe prowokacje, żeby chcieli wpaść w to. Do tego dołączyli inni ludzie. Wyjechał jeszcze od nas Adam Leśniewski ${ }^{41}$, Henryk Katz ${ }^{42}$, Amsterdamski, profesor Piątowski, rektor. W rezultacie około 1968 roku odeszło z pracy ponad dziesięć osób. Po tych ludziach zostały etaty. I myśmy później musieli zatrudnić ludzi. Ta dzisiejsza kadra Instytutu Historii

${ }^{38}$ Stefan Amsterdamski (1929-2005) - profesor filozofii; zaraz po wojnie rozpoczął studia chemiczne na Politechnice Łódzkiej, stopień doktora i doktora habilitowanego z zakresu filozofii zdobył na Uniwersytecie Warszawskim. Od 1954 roku pracował na Wydziale Filozoficzno-Historycznym Uniwersytetu Łódzkiego. W 1966 roku objął stanowisko dziekana tego wydziału. W konsekwencji wydarzeń marcowych w 1968 roku został usunięty z uczelni. Pracował później w Polskiej Akademii Nauk. Członek PZPR w latach 1948-1968, a od 1980 roku członek „Solidarności” internowany w stanie wojennym. Uczestnik obrad Okrągłego Stołu.

${ }^{39}$ Paweł Korzec (1919-2012) - przed wojną pracował w Łodzi jako tkacz, zaraz po wojnie politycznie zaangażowany funkcjonariusz Milicji Obywatelskiej, członek PZPR, skazany w 1945 roku za zabójstwo na 5 lat więzienia, jednak zwolniony w tym samym roku. W 1948 roku podjął studia historyczne. Został na uczelni i pod okiem prof. Natalii Gąsiorowskiej napisał pracę doktorską poświęconą rewolucji 1905-1907 na ziemiach polskich. Docentem został w 1956 roku, a w roku 1969 opuścił Polskę.

${ }^{40}$ Leon T. Błaszczyk (ur. 1923) - profesor historii, wybitny znawca starożytności, dziekan Wydziału Filozoficzno-Historycznego w latach 1964-1966, a w latach 1966-1968 dyrektor Instytutu Historii UŁ. Usunięty z Uniwersytetu Łódzkiego w marcu 1968 roku.

${ }^{41}$ Adam Leśniewski (ur. 1923) - historyk, w czasie wojny działał w ruchu oporu zorganizowanym w getcie łódzkim, do 1968 roku pracownik Uniwersytetu Łódzkiego, gdzie w latach 1952 1956 kierował Katedrą Podstaw Marksizmu-Leninizmu.

${ }^{42}$ Henryk Katz (1914-1998) - historyk. Urodził się we Lwowie, gdzie studiował ekonomię. Studia kontynuował w Paryżu i Londynie. W czasie wojny służył w armii brytyjskiej. Zajmował się historią międzynarodowego ruchu robotniczego. W 1949 roku został zatrudniony na Uniwersytecie Łódzkim, w roku 1956 został mianowany docentem, a w roku 1968 musiał odejść z uniwersytetu. 
to jest przeważnie ta kadra, którą ja zatrudniałem jako asystent. Ja im się bardzo przyglądałem później, jak oni wylądują, czy tam nie zostały popełnione w tym napięciu politycznym jakieś wielkie błędy. Ona się sprawdziła i wydaje mi się, że zupełnie przyzwoicie się zachowuje, także wybór był poprawny. Tak wyglądał ten 1968 rok. To była, jak mówiłem, przedwczesna rewolucja studencko-inteligencja. A hasła robotnicze to były: ,,pisarze do piór, studenci do książek". My ciężko pracujemy, a wy macie się uczyć, a nie tutaj politykować. Studenci na parkanie naszego Instytutu wywiesili taki napis: „Prasa kłamie”, czego nie należy zapomnieć, bo jednak środki masowego przekazu spełniają bardzo służebną rolę. Jak nie temu panu, to innemu, ale zawsze się komuś wysługują.

O wewnętrznych napięciach w środowisku łódzkiej filozofii, wywołanych wydarzeniami marcowymi opowiada Ryszard Panasiuk - wówczas adiunkt w katedrze Filozofii Marksistowskiej. Jego perspektywa przedstawia się tak:

Jak wróciłem [z rocznego stypendium na paryskiej Sorbonie po obronie doktoratu], to już pomału tworzył się taki nastrój, narastanie takiej atmosfery nacjonalizmu, antysemityzmu. Powstał klimat napięcia i w pewnym momencie to eksplodowało. To jest nawet trochę odzwierciedlone w książce Marzec ' 68 $w \operatorname{Lodzi}^{43}$. To nasze środowisko znalazło się pod obstrzałem, dlatego że Amsterdamski, ci wszyscy ludzie partyjni byli, a on miał tak zwane niewłaściwe pochodzenie. I chociaż nie było się do czego przyczepić, postanowili go po prostu usunąć z uczelni. Usunęli też wtedy rektora [Józefa Piątowskiego], który nie miał złego pochodzenia, ale który się nie starał. Wyjechał na jakieś leczenie. To wszystko w tych dokumentach jest, choć one w dużym stopniu są kłamliwe. I powstała taka aura napięcia i taki klimat zaszczuwania ludzi, ataki w prasie i na zebraniach partyjnych, a ja występowałem w obronie tego człowieka, bo wydawało mi się, że to jest w ogóle skandaliczne działanie i jakieś takie szokujące na tle tego, co się mówiło na ten temat w ideologii marksistowskiej, która była taka internacjonalistyczna i nie akcentowało się pochodzenia czy czegokolwiek, a tutaj nagle taki klimat. On [Amsterdamski] miał jakieś $\mathrm{z}$ tego powodu okropne kłopoty, chociaż w tych dokumentach jest jeszcze, że ja tam byłem prawą ręką Amsterdamskiego i że brałem udział w takim jakimś spotkaniu, które wydaje się strasznie podejrzane, a to była naukowa dyskusja nad książką Schaffa Marksizm a jednostka ludzka w redakcji „Studiów Filozoficznych". Ja [śmiech] w tym brałem udział i to było jeszcze przed tymi wydarzeniami. Ale taki tworzono klimat szczucia ludzi i to się tak skończyło, że zostaliśmy bez kierownictwa. Ja miałem bardzo bliskiego przyjaciela,

${ }^{43}$ Zob. Marzec ‘68 w Lodzi... 
Aleksandra Orłowskiego ${ }^{44}$, który był starszy ode mnie i wydawało mi się, że on jakoś pokieruje tym towarzystwem, bo to raptem było nas tylko trzech doktorów w tym środowisku - ten Orłowski, ja i jeszcze Gromczyński ${ }^{45}$, który nie tak dawno zmarł. A ten mówi: ja już złożyłem papiery. Ja wcale nie wiedziałem, że on jest żydowskiego pochodzenia. Przez półtora roku nikt [śmiech] tym zespołem nie kierował, bo nie było kandydata i poszukiwano go gdziekolwiek, i w Warszawie, i gdzie indziej, i nie było chętnych albo nie było po prostu możliwości. Dopiero po półtora roku ja się zgodziłem przejąć to kierownictwo i od tej pory kierowałem tym zespołem aż do emerytury.

Stanisław Liszewski, polski geograf urbanista, w latach 1996-2002 rektor Uniwersytetu Łódzkiego, odwołuje się do sytuacji, która była rezultatem wydarzeń 1968 roku i bezceremonialnego obchodzenia się z osobami, których postawa nie odpowiadała władzy ludowej.

Z 1968 roku pamiętam strajk, jaki był zorganizowany wtedy na Kościuszki 21; były tam różne kierunki studiów: matematyka, psychologia, geografia i inne. Pamiętam, że jako pracownicy mieliśmy dyżury, siedzieliśmy dzień i noc. I pamiętam także konsekwencje roku 1968, którymi było między innymi pozbawienie kierownictwa katedry mojego profesora [Ludwika Straszewicza]. Profesor zdecydował wtedy wyjechać za granicę. Wyjechał na wykłady do Francji a katedrę przejął profesor z Wydziału Ekonomiczno-Socjologicznego, pan profesor Tadeusz Olszewski ${ }^{46}$. I mogę powiedzieć, co nie jest żadną tajemnicą, że profesor Olszewski chciał żebym z nim współpracował. Źle jednak zaczął tę współpracę, bo przyszedł do mnie i zaproponował zorganizowanie wyniesienia rzeczy pana profesora Straszewicza z gabinetu, bo on chce go zająć. Co oczywiste reakcja moja była jednoznaczna: nie. I tak moja współpraca z profesorem Olszewskim się zakończyła. Znaliśmy się oczywiście, byliśmy w jednej katedrze, on był moim szefem, więc nie można było inaczej, ale stracił wiele w moich oczach.

Olga Czerniawska, profesor pedagogiki, przywołując w pamięci strajk studentów z 1968 roku przedstawia perspektywę swojego mistrza - Aleksandra Kamińskiego ${ }^{47}$, który, przypomnijmy, w 1950 roku został usunięty ze względów ideologicznych z Uniwersytetu Łódzkiego. Powrócił na uczel-

${ }^{44}$ Aleksander Orłowski (1929-2007) - filozof, uczeń Bronisława Baczki, adjunkt na UŁ, profesor Uniwersytetu w Sztokholmie odkąd wyemigrował w 1968 roku.

${ }^{45}$ Wiesław Gromczyński (1931-2009) - filozof, w latach 1951-1956 studiował na Uniwersytecie Moskiewskim; późniejszy pracownik Instytutu Filozofii Uniwersytetu Łódzkiego.

${ }^{46}$ Ludwik Straszewicz (1916-1987) - ekonomista, geograf, od 1956 roku związany z Uniwersytetem Łódzkim, założyciel Oddziału Łódzkiego Polskiego Towarzystwa Urbanistycznego. Tadeusz Olszewski (1914-1990) - profesor ekonomii, specjalista w zakresie geografii ekonomicznej.

${ }^{47}$ Opowieść Olgi Czerniawskiej o Aleksandrze Kamińskim jako jej mistrzu została przytoczona w rozdziale II. 
nię dopiero osiem lat później, a od 1962 roku kierował Katedrą Pedagogiki Społecznej. Bardzo wyraźnie maluje się tutaj tragizm tej postaci, która wśród kadry naukowej postrzegana była często jako „dziwak-idealista”, którego wojenne i literackie dokonania były niewygodne dla narzuconej przez reżimowe państwo linii polityczno-ideologicznej, i, wreszcie, który był coraz bardziej marginalizowany i niedostrzegany przez współczesną mu młodzież ${ }^{48}$.

Muszę powiedzieć, że [Aleksander Kamiński] przeżywał sam pewien taki dramat, taki niepokój. Więcej niż jakieś niezadowolenie czy rozczarowanie, ponieważ kiedy był strajk studencki na uczelni w 1968 roku, to do niego nie przyszli, jego nie wybrali do takiego zespołu wspierającego ten strajk. Nie został wybrany i bardzo to przeżywał, że studenci nie przyszli do niego, że on nie jest już tym liderem, że jego przeszłość została zapomniana i to młode pokolenie już nie ma z nim kontaktu, nie może być dla nich ideałem. Ze mną o tym rozmawiał i bardzo był tym przejęty. Poza tym był przejęty, ponieważ on stracił swoich wszystkich wychowanków - zginęli ci z Szarych Szeregów, inni byli aresztowani, poginęli. Nie ma właściwie uczniów genialnych, nie ma kogo po sobie zostawić.

Michał Seweryński w 1968 roku był jeszcze młodym doktorantem na Wydziale Prawa. Po latach wspomina ten okres następująco:

Poza tym były jakieś wydarzenia par excellence polityczne, jak na przykład 1968 rok. Ja wtedy byłem doktorantem, który w ogóle nie prowadził żadnych zajęć, tylko raz na dwa tygodnie uczestniczyłem w seminarium doktorskim. Więc to mnie tak bezpośrednio nie angażowało. Nie miałem zajęć ze studentami. Ale w jakichś spotkaniach z kolegami brałem udział, bo się gotowało w całej uczelni. Jeszcze większy wpływ na życie uczelni wywołało powstanie „Solidarności”, a potem wprowadzenie stanu wojennego. Wiadomo, że to oddziałało na nas wszystkich, bo zamknęli Uniwersytet i nie było wiadomo, czy jeszcze go otworzą i kiedy.

Jolanta Kulpińska, profesor socjologii, odtwarza w pamięci, co wówczas działo się na Wydziale Ekonomiczno-Socjologicznym, mówi o napięciach między socjologami a ekonomistami i o tym, jak w wydarzenia te uwikłane zostało jej własne życie - ówczesnego członka PZPR, która

${ }^{48}$ Tymczasem w maju 1968 roku I zastępca komendanta miejskiego MO ds. SB w Łodzi płk. Leon Chruśliński raportuje: „Inne środowiska, które zazwyczaj nie wyrażały swojego poparcia dla aktualnej polityki partii i rządu (...), w okresie marca i kwietnia, w zasadzie poza nielicznymi wyjątkami, jak np. Aleksander Kamiński, kierownik Katedry Pedagogiki Społecznej UŁ, b. pracownik Biura Informacji i Propagandy AK, który solidaryzował się ze studentami, nie uczestniczyli w żadnych akcjach popierających ekscesy studenckie”. Zob. Marzec ‘68 w Łodzi..., s. 571. 
przebywając na stypendium w Paryżu, miała przelotny kontakt z „Kulturą” paryską i Jerzym Giedroyciem ${ }^{49}$, czym wzbudziła podejrzenia swoich partyjnych przełożonych i władzy ludowej.

Rok 1968 był bardzo ważny w Warszawie, ze względu na restrykcje, na usunięcie tych głównych rewizjonistów ówczesnych. W Łodzi tego nie było, ale też były różne pretensje, że niby my źle wychowujemy studentów. To było nawet pod takim hasłem na Radzie Wydziału. Trzeba powiedzieć, że wszyscy ci nasi ówcześni wrogowie nie żyją i prędko jakby zmarli, bez naszego oczywiście udziału [śmiech], ale jakoś w ten sposób też oczyściła się atmosfera. Bo właśnie takim sztandarowym przeciwnikiem był Janowski - były mąż profesor Zdzisławy Janowskiej ${ }^{50}$ i mieliśmy też takiego obrońcę, moczarowca, Kornobisa $^{51}$, który z kolei jakby bronił nas, ale trochę w związku z ówczesną pozycją Chałasińskiego ${ }^{52}$, który miał tych kilka tekstów własnych albo, jak uważano, inspirowanych przez niego tekstów naszych młodszych kolegów, o takim nacjonalistycznym charakterze. Ale jakoś nie stało się tak, żeby ktokolwiek w Instytucie taką pozycję moczarowską zajął. Także na szczęście nie było tutaj pod tym względem żadnych problemów. Ja miałam sprawę partyjną na Wydziale, to była taka komisja weryfikacyjna, miała do mnie różne dziwne, śmieszne z perspektywy pretensje. Po pierwsze, jak to się stało, że ja dokładnie w tym tygodniu w marcu 1968 wyjechałam do Szwajcarii, zamiast być tutaj, stać dzielnie przy towarzyszu Gomułce. A ja rzeczywiście wyjechałam na ten tydzień, bo pamiętam, że jeszcze byłam w Warszawie i w przeddzień wyjazdu widziałam zajścia na Uniwersytecie Warszawskim. To było takie nieduże seminarium, zajmowałam się partycypacją robotniczą i posłał mnie tam Zygmunt Rybicki, rektor Uniwersytetu Warszawskiego, który robił coś takiego. A myśmy się znali z Paryża, z czasów studiów. Sam nie mógł pojechać i zaproponował, czy ja nie pojadę. Ja oczywiście bardzo chętnie pojechałam i byłam tam tydzień, świetny tydzień z dala od spraw polskich, ale jak wróciłam to między innymi wymyślono mi taki zarzut. A drugi zarzut był taki, że ja miałam w czasie pobytu we Francji, dziesięć lat wcześniej kontakty z „Kulturą” paryską. Miałam rzeczywiście, nawet jadłam obiad u Giedroycia, ale to nie miało większego znaczenia, kontakt miał charakter prywatny i przelotny. Tyle tylko, że rzeczywiście Giedroyć wtedy szukał różnych kontaktów na Polskę i doszedł do wniosku, że musi załatwiać książki dla Polski. Między innymi zastanawiał się i pytał mnie też, pewnie nie tylko mnie, którą

49 Jerzy Giedroyć (190-2000) - publicysta, polityk i działacz emigracyjny, epistolograf, założyciel emigracyjnego miesięcznika „Kultura”. Działalność Giedroycia i „Kultury” miały ogromny wpływ na polską emigrację i inteligencję PLR-u.

${ }^{50}$ Zdzisława Janowska - ekonomista, profesor Uniwersytetu Łódzkiego, habilitacja zablokowana 11987 kierownik Katedry Zarządzania Zasobami Ludzkimi.

${ }^{51}$ Ryszard Kornobis - Sekretarz KU PZPR przy Uniwersytecie Łódzkim.

${ }^{52}$ Zob. przypis $13 \mathrm{w}$ tym rozdziale. 
placówkę socjologiczną wesprzeć. Nie pamiętam, co ja tam mówiłam, bo ani siebie nie traktowałam jako doradcę, ani jako kontakt ważny dla niego, ale posłałam mu jakąśs listę. A potem podziękowania, bo Instytut dostał wielką pakę książek z tego Kongresu Kultury Europejskiej, bo to była ta firma, że tak powiem, realizująca takie rzeczy. Wcale nie Giedroyć bezpośrednio oczywiście. Ale przecież już wtedy kontrolowano korespondencję i wobec tego rzeczywiście byłam wezwana na rozmowę w Komitecie Centralnym, w tym Wydziale Nauki, gdzie z kolei też byli moi dawni znajomi. Powiedziałam, na czym polegał mój kontakt, to oni uznali, że nie jest to kontakt polityczny ani trwały. Tyle tylko, że rzeczywiście nie bardzo mnie wysyłano za granicę przez parę lat. Ale też wtedy te wyjazdy były tak trudne do osiągnięcia, a ja byłam w końcu młodym adiunktem, któremu jeszcze daleko do jakiejś większej pozycji. Ale w 1968 roku to wyciągnęli jako zarzut na zebraniu partyjnym na Wydziale, pytano mnie o te kontakty z „Kulturą” paryską i książki - skąd, jakie one były i tak dalej. Natomiast prawdziwe zarzuty, jak sądzę, tak sądziłam również i wtedy, były takie, jakie były w 1968 roku. Nie robiono mi zarzutów ideologicznych, ale wiadomo było, że ja się bardzo przyjaźniłam ze Stefanem Amsterdamskim $^{53}$, który był wtedy w brzydki bardzo sposób potraktowany, i zarzucono mi, że ja się dobrze znam z tymi, których wyrzucono. Nie tyle formalny zarzut rewizjonizmu, bo to by mnie pogrążyło, tylko takie właśnie tam zarzuty trochę dziwaczne. Pierwotnie był wniosek o wyrzucenie, ale zreflektowali się, że gdyby mnie wyrzucono wtedy z partii, to by mnie musieli wyrzucić też z Uniwersytetu, bo przecież ja na socjologii nie mogłabym pracować - a na to jakoś nie chciano się zgodzić. Tu mnie zresztą uratował trochę Janek Woskowski ${ }^{54}$, który był w tej komisji weryfikacyjnej, także dostałam tylko naganę $\mathrm{z}$ ostrzeżeniem. $\mathrm{Z}$ punktu widzenia formalnego, statusu uczelnianego, nie było żadnych innych konsekwencji. Takim czyścicielem był tutaj Kortan ${ }^{55}$, też nieżyjący, który miał dużo do powiedzenia. On był nawet potem członkiem egzekutywy komitetu łódzkiego, więc rzeczywiście miał taką wysoką pozycję partyjną. W każdym razie ten 1968 rok był dosyć ciężki, tym bardziej, że ja wtedy właśnie drukowałam pracę habilitacyjną. I to jest taki też dosyć istotny element. 1968 rok był w ogóle dla naszego Instytutu dosyć ważny, bo odbywały się strajki studenckie z bardzo dużym udziałem naszych studentów, w tym także tych partyjnych. Większość z nich potem odeszła i z Wydziału, i z partii, ale wtedy to trochę jakby pomogło w utrzymaniu Wydziału. Bo ta nagonka na parę osób na socjologii, ale też na socjologię jako całość, była wynikiem tego, że niektórzy ekonomiści, nie wszyscy oczywiście, byli bardzo wpływowi

\footnotetext{
${ }^{53}$ Zob. przypis $38 \mathrm{w}$ tym rozdziale.
}

${ }^{54}$ Jan Woskowski (1922-2015) - socjolog edukacji, pracownik Instytutu Socjologii Uniwersytetu Łódzkiego, wieloletni kierownik Katedry Socjologii Ogólnej.

${ }^{55}$ Jerzy Kortan (1924-1998) - profesor ekonomii na Uniwersytecie Łódzkim, specjalizujący się w dziedzinie zarządzania przedsiębiorstwem. 
w organizacji partyjnej na Wydziale i szukali wroga, bo trzeba było zrobić jakąś aferę na Wydziale - to był ten mechanizm czystkowy w partii. Trudno by im było wskazywać na kolegów, z którymi byli blisko, a my byliśmy zawsze trochę z boku, więc się bardzo dobrze jako grupa, jako środowisko nadawaliśmy do tego. Ale trzeba było znaleźć zarzuty, więc były zarzuty, że u nas nie wychowuje się dobrze studentów. Na Radzie Wydziału takie zarzuty były postawione socjologii, a profesor Kłoskowska w imieniu socjologów wygłosiła mowę obronną. Trzeba było też znaleźć jakieś osoby, więc były pretensje do różnych osób poza mną, ale spośród starszych stopniem to ja się im dobrze nadałam z różnych powodów, np. tych „złych” przyjaźni czy znajomości, czy właśnie dlatego, że miałam korespondencję z Giedroyciem. Śmieszne po prostu. Ale muszę powiedzieć, że nigdy nie miałam żadnych kontaktów i żadnych wezwań ani problemów z SB. Wtedy interesował się nami facet, który potem awansował do Warszawy, miał to nazwisko służbowe, o ile dobrze pamiętam, Zdaniewicz i szczególnie dręczył Andrzeja Boruckiego ${ }^{56}$, bo się ciągle z nim umawiał. Ale właśnie wtedy, po tej mojej sprawie widocznie chciał mnie poznać, chciał wiedzieć, słyszał o mnie i przyszedł do mnie do domu, i żeśmy dość długo rozmawiali tak o niczym właściwie, on nawet prawie nie nawiązywał do tej historii partyjnej. Nawet poczęstowałam go kawą. Przyjaciel potem twierdził, że to właśnie strasznie głupio, bo wyszłam do kuchni, a on przecież mógł pluskwę w tapczan wsadzić, ale jakoś nie [śmiech]. Poza tym nigdy więcej żadnych problemów. Jeżeli miałam problemy paszportowe, to już, że tak powiem, jawne i niewynikające z tego, co się wydarzyło. Na pewno w Instytucie były osoby, które informowały. Niektórzy nawet mówili mi później, że wiedzą, kto, ale ja się nigdy nie chciałam tym interesować. Wiedziałam, że na pewno musi ktoś być taki, co najmniej jedna osoba. Ale nie chciałam o tym wiedzieć, bo potem bym nie była w stanie z tym kimś rozmawiać, więc lepiej tego nie wiedzieć.

W pamięci Janiny Tobery - socjolog, której prywatne życie w sposób szczególny splotło się ze strajkami studenckimi w Łodzi w 1968 roku - zapisał się pewien epizod, w którym główną rolę odegrał Jan Szczepański ${ }^{57}$.

Myśmy postanowili się pobrać w 1968 roku [z Piotrem Toberą ${ }^{58}$ i wtedy właśnie była kwestia tych wichrzycieli rozmaitych i Instytut nasz [Instytut

${ }^{56}$ Andrzej Borucki (1931-2003) - doktor socjologii, w latach 1976-1988 wicedyrektor Instytutu Socjologii Uniwersytetu Łódzkiego. Blisko związany z prof. Janem Lutyńskim, z którym wspólnie opowiadali się za niezależną myślą i autonomią uczelni. W marcu 1968 roku brał udział w strajku studenckim. Wspierał strajkującą młodzież w strajku studentów łódzkich w 1981 roku. Był działaczem „Solidarności”, organizował pomoc dla internowanych w stanie wojennym.

${ }^{57}$ Zob. przypis $15 \mathrm{w}$ tym rozdziale.

${ }^{58}$ Piotr Tobera (ur. 1939) - profesor socjologii na Uniwersytecie Łódzkim, wieloletni pracownik Katedry Socjologii Przemysłu. 
Socjologii] był traktowany jako takie źródło fermentu, bo Lutyński ${ }^{59}$ był jakoś źle oceniany. Ale była biblioteka (...) i byli docenci marcowi, którzy byli docentami, chociaż nie mieli habilitacji, jakby te zasługi marcowe powodowały, że oni awansowali. To stąd się wzięli ci docenci marcowi. Oni wtedy byli tacy aktywni. Profesor Szczepański na przykład przyjeżdżał, bo wtedy już nie mieszkał w Łodzi, tylko przyjeżdżał, w poniedziałki zawsze, i nie chciał rozmawiać w pokoju, tylko wychodził na ulicę, z tymi swoimi chłopakami. Wiadomo, że profesor wychodzi na spacer. Pod biblioteką uniwersytecką wiec studencki i wiadomo było, że on jest tak zwany legalny, bo były wiece legalne i nielegalne. Więc ten legalny był ogłoszony i akurat profesor przyjechał i chciał zobaczyć wiec. Więc idziemy. Poszli Piotrek mój, profesor i chyba [Włodzimierz] Jaśkiewicz. W każdym razie jakoś tak bokiem, od Pomorskiej czy dawniej Nowotki to się nazywało, jakoś tak doszli do Matejki, tamtędy przeszli, nie od Narutowicza, i znaleźli się, to wiem od mojego męża, w gronie tych zomowców i tej obstawy całej. A studenci podobno zaczęli śpiewać hymn Jeszcze Polska nie zginęla, więc profesor się tak obejrzał i powiedział „Panowie, zdejmujemy nakrycia z głów". No i profesor pierwszy kapelusz zdjął [śmiech]. Ci panowie, asysta jego też, więc ci ludzie [śmiech] nie mieli innego wyjścia, tylko musieli te czapki z głów zdjąć. I oni się tak jakby rozbroili poniekąd. Tam przy bibliotece uniwersyteckiej to była tylko taka obstawa, ale na Wydziale Prawa, to wiem, że były jakieś pogonienia.

Życie prywatne wielu pracowników Uniwersytetu Łódzkiego w tamtym okresie było przedmiotem zainteresowania PRL-owskich władz. Wspomina o tym Grażyna Kononowicz, która po ukończeniu studiów socjologicznych została pracownikiem biblioteki. Nieoczekiwanie jej wiedza i profesjonalizm stały się niewystarczającym warunkiem utrzymania tego stanowiska, a jej wiarygodność i kompetencje zawodowe okazały się bezwartościowe w obliczu zarzutów jakie wysuwano pod adresem jej ojca:

Dzięki mojemu kierownikowi ${ }^{60}$ nie wyleciałam z pracy w 1968 roku, ponieważ były jakieś takie partyjne zebrania pracowników Wydziału i chcieli mnie z pracy wyrzucić dlatego, że mój ojciec był w PAX-ie ${ }^{61}$. Więc pan kierownik wykazał się wyjątkową inteligencją, ponieważ powiedział, że, po pierwsze, to mój ojciec, a nie ja, a po drugie przecież PAX jest instytucją uznawaną przez państwo. Dali mi wtedy spokój. Mogłam wtedy bardzo [śmiech] spokojnie $\mathrm{z}$ winy tatusia wylecieć z pracy.

${ }^{59}$ Zob. przypis $18 \mathrm{w}$ tym rozdziale.

${ }^{60}$ Stanisław Szereda (1909-1985) - bibliotekoznawca, starszy kustosz dyplomowany, od 1964 kierował Biblioteką Socjologiczną.

${ }^{61}$ Stowarzyszenie PAX - utworzona przez Bolesława Piaseckiego w 1947 roku świecka organizacja katolicka, początkowo współpracująca z władzą komunistyczną, po roku 1956 próbująca odzyskać neutralność. W późniejszych latach część członków PAX-u była związana z „Solidarnością”. 
O wydarzeniach roku 1968 na ówczesnym Wydziale Biologii i Nauk o Ziemi opowiadają Eugeniusz Czerniawski, Jan Ziomek oraz Edward Tranda.

Eugeniusz Czerniawski przyjaźnił się z Gustawem Kerszmanem ${ }^{62}$, którego w 1968 roku odprowadzał na dworzec kolejowy. Na pytanie o znaczenie tej znajomości w jego życiu nie tylko kreśli sylwetkę kolegi, ale także pokazuje relacje panujące wówczas w Zakładzie Mikrobiologii:

Jego rodzice byli Żydami. Ojciec był lekarzem laryngologiem, Gestapo go zamordowało. No i była mama. A on się czuł Polakiem i teraz się czuje Polakiem. Ale on był w partii, bo jemu się wydawało, że to, co się działo przed wojną, to za dużo nie pamiętał, bo w Wilnie była bardzo duża tolerancja. Myśmy nie wyróżniali żyda czy prawosławnego. Naprawdę wielka tolerancja. Tego nie ma teraz, a szkoła nas tego nauczyła. Ja zawsze wyszukuję u ludzi coś dobrego i nie mylę się. Trudno się zaprzyjaźniam, ale jak zaprzyjaźnię się, to już wiem. Gustaw w zakładzie czuł się nieswojo. Przy nim wszyscy byli bardzo grzeczni, a on naszych spraw bronił przez swoją organizację, ale nie o to idzie. On mnie po kilku latach zapytał. Mówi: „Ja czuję, że niektórzy, jak jestem, to są serdeczni, a jednak czuję, że jestem tu obcy”. A ja mu odpowiadam: „Czy wiesz, że ty masz więcej Boga niż oni?”. I stąd ta przyjaźń. „Więcej Boga niż oni." Mnie ta szkoła przedwojenna nauczyła tolerancji i bronienia swego: jak jest racja, to ja nie ustąpię.

Jan Ziomek relacjonuje wydarzenia1968 roku w taki sposób:

Ten rok 1968 był na uczelni taki nieprzyjemny na tych kierunkach politycznych lekko - na historii, filozofii, na filologiach wszelkiego rodzaju, natomiast na naszym Wydziale niektórzy wyjechali. Kerszman wyjechał, mikrobiolog. Ale w zasadzie wyjechał, bo matka jego bardzo chciała wyjechać, a sam Kerszman niespecjalnie się palił do wyjazdu. Także myślę, że na tych kierunkach - na prawie, na ekonomii - były takie różne nagonki. Amsterdamski ${ }^{63}$ na przykład miał wykład i na katedrze położyli mu zdechłego wróbla. Wysłuchał wykładu i zdechł. Amsterdamski trzasnął swoją teczką w katedrę i wyszedł. Jego żona i teściowa - Summaczowa - wyjechały do Francji, do Paryża, a on został i z Łodzi przeniósł się do Akademii Nauk. To był dobrej klasy filozof. Był magistrem chemii, później studiował filozofię i ja chodziłem nawet na wykład do niego, kiedy wykładał filozofię dla doktorantów. Większość wcale nie robiła żadnych problemów z tego tytułu. Co mnie tam obchodziło, że Amsterdamski

${ }^{62}$ Gustaw Kerszman (1932-2014) - urodzony w Warszawie, mikrobiolog. Wychował się w Białymstoku. Po wojnie zamieszkał w Łodzi i do 1969 roku pracował w Katedrze Mikrobiologii. Po antysemickiej nagonce już jako doktor habilitowany opuścił Polskę i wyjechał do Danii, gdzie do 2002 roku prowadził zajęcia z mikrobiologii i genetyki na Uniwersytecie w Roskilde. Zmarł w Kopenhadze.

${ }^{63}$ Zob. przypis $38 \mathrm{w}$ tym rozdziale. 
jest Żydem, albo Summaczowa - bardzo piękna, elegancka kobieta, starsza, którą bardzo sobie ceniłem, lubiłem, była bardzo serdeczna. Co ja mogłem do niej mieć? Miałem podkreślać, że jest Żydówką? Także normalni ludzie mieli do Żydów stosunek pozytywny. I jeszcze profesor Mowszowicz ${ }^{64}$ był bardzo eleganckim człowiekiem, którego lubiliśmy na biologii przecież.

O tym, co w roku 1968 spotkało profesora Jakuba Mowszowicza, opowiada jego ówczesny student, Edward Tranda, biolog.

Profesor Jakub Mowszowicz to była też postać bardzo ciekawa: botanik z Wilna, Żyd. Zresztą wyczuwało się w akcencie trochę właśnie te jego [korzenie]. On szczęśliwie przeżył wojnę, ale przeżył też śmierć swoich bliskich. A jego samego ocalili koledzy z Uniwersytetu Wileńskiego i on przyjechał do Łodzi i tutaj miał zajęcia. Zresztą bardzo mnie lubił. W roku 1968, jak były te marcowe wydarzenia słynne, to zrobiono poszukiwania Żydów na wydziałach. Skłaniano ich do wyjazdu. Ja byłem we władzach organizacji partyjnej, myśmy nie dopuścili do tego, ja działałem w tym kierunku, żeby ktokolwiek nie zrobił im krzywdy. Myśmy poszli do Mowszowicza, poszliśmy do profesora Halicza ${ }^{65}$, który był botanikiem także, moim szefem i powiedzieliśmy: „Spokojnie panowie, pracujcie panowie, nikt wam krzywdy nie zrobi", bo takie zapewnienie otrzymaliśmy na Uniwersytecie, że nikt im nie zrobi nic złego. I rzeczywiście. Ale fakt, że myśmy w ten sposób postąpili, że myśmy ich osłaniali, nie dopuściliśmy do tego, żeby się nad nimi jakiś pętak wyżywał i głupoty plótł, więc profesor Mowszowicz „mój kochany kolego” mówił do mnie, ponieważ jak byłem szefem muzeum [Muzeum Przyrodniczego], to wcześniej mówił do mnie: „Panie drogi dyrektorze”. Lubił bardzo moją żonę, bośmy go odwiedzali. Także tego typu relacje też były między nami - takie przyjacielskie, koleżeńskie, serdeczne.

Antysemicka nagonka miała miejsce także poza Uniwersytetem. Ewelina Nurczyńska-Fidelska, nestorka łódzkiego filmoznawstwa, specjalizująca się w historii i teorii filmu, krytyk filmowy, opowiada o zwolnieniu Marii Kornatowskiej ${ }^{66} \mathrm{z}$ redakcji tygodnika „Odgłosy”, w którym pracowała jako krytyk filmowy, oraz o swoim odejściu zeń po tym, jak odmówiła napisania antysemickiego tekstu.

${ }^{64}$ Jakub Mowszowicz (1901-1983) - urodzony w Wilnie biolog i botanik, profesor Uniwersytetu Łódzkiego. Doktorat uzyskał na tamtejszym Uniwersytecie Stefana Batorego. Badał florę regionu łódzkiego. Był jednym z założycieli łódzkiego Ogrodu Botanicznego. Przez wiele lat sprawował funkcję dziekana Wydziału Biologii i Nauki o Ziemi na Uniwersytecie Łódzkim.

${ }^{65}$ Benedykt Halicz (1903-1997) - profesor biologii na Uniwersytecie Łódzkim i nauczyciel, specjalista w dziedzinie porostów.

${ }^{66}$ Maria Kornatowska (1935-2011) - urodzona w Warszawie, zmarła w Łodzi, polski krytyk filmowy, autorka wielu prac dotyczących filmu, wykładowca PWSFiT. 
Powiem, że o ile w naszym zakładzie czy naszej katedrze w tym momencie, w 1968 roku nic strasznego się nie stało, to straszne rzeczy stały się w rzeczonych „Odgłosach” ${ }^{\circ}$. Ja już tam coraz częściej pisałam dłuższe recenzje. Byłam wtedy też nauczycielką. Pracowałam w szkole, a potem jeszcze na studia doktoranckie trafiłam do Instytutu PAN, więc dla mnie ta możność oglądania filmów i pisania o nich była bardzo ważna. Już później często było tak, że co tydzień byłam w dziale sama. Maryla [Maria Kornatowska] wyfruwała na szerokie warszawskie wody i inne rzeczy, ale jeszcze też pisywała. Wtedy został naczelnym Wacław Biliński ${ }^{68}$, taki łódzki pisarz. Zawsze go miałam za bardzo kulturalnego pana, a on był wściekłym antysemitą. Wcześniej zaproponował Marysi etatową pracę w „Odgłosach”. A w 1968 roku po marcu, nie wiem czy pół roku później Maryla już tam nie pracowała. Wyrzucił ją po prostu z pracy. Marysia wtedy przestała pracować w szkole filmowej i przyszła do „Odgłosów”. I kto ją z powrotem natychmiast przyjął do pracy w Szkole Filmowej, jeszcze w 1968 roku? Oczywiście profesor Lewicki ${ }^{69}$, który był wtedy rektorem. Natomiast przeżyłam rzecz straszną, ponieważ pan Wacław Biliński zaprosił mnie do gabinetu i żąda ode mnie napisania dużej publicystyki na temat opanowania Szkoły Filmowej przez żydostwo. Ja powiedziałam: „Nie, panie redaktorze, ja tego nie napiszę" i nie napisałam. „A pani sobie zdaje sprawę z tego, że kończy się nasza współpraca?”. Ja mówię: „Domyślam się”. A wtedy, nie dość, że ja sobie w jakiś sposób doskonaliłam jeszcze warsztat krytyka filmowego, to byłam jeszcze w dość trudnej sytuacji osobistej i dla mnie te honoraria $\mathrm{z}$ „Odgłosów” to była bardzo ważna sprawa w moim życiu rodzinnym, z tym małym jeszcze wtedy dzieckiem. Straciłam tę pracę. Już nie powiem, kto napisał ten tekst, bo nie chcę, ale on został napisany. Kto jest zainteresowany, to może sprawdzić [śmiech]. A ja przestałam w „Odgłosach” pracować. Minęło chyba z półtora roku, może rok, już dziś nie pamiętam, dzwoni do mnie niejaki naczelny Biliński. Już się tak troszeczkę wyciszyły te rzeczy, już te ohydztwa przestały się tak pokazywać w gazetach i on do mnie zadzwonił z propozycją powrotu na stanowisko stałego recenzenta. To nie był etat od wierszówki tak zwanej. Powiedziałam wtedy: „Ale pod jednym warunkiem, panie redaktorze. Pan już nigdy nie każe mi pisać czegoś, czego domyślać się pan będzie, że ja nie będę chciała napisać”. „Przyrzekam pani”. No i wróciłam. On jeszcze jakiś

${ }^{67}$ „Odgłosy” - ukazujący się w Łodzi w latach 1958-1990 tygodnik społeczno-kulturalny.

${ }^{68}$ Wacław Biliński (1921-1999) - urodzony we Lwowie, zmarły w Łodzi, pisarz, autor powieści radiowych, scenarzysta filmowy. Przez długie lata był kierownikiem literackim zespołu filmowego „Profit”.

${ }^{69}$ Bolesław W. Lewicki (1908-1981) - teoretyk filmu, krytyk i pedagog. Urodził się we Lwowie, gdzie ukończył polonistykę na Uniwersytecie Jana Kazimierza. Od początku jego pasją był film i wiedza o filmie. Jest uznawany za twórcę polskiego filmoznawstwa. W 1959 roku utworzył Zakład Wiedzy o Filmie na Uniwersytecie Łódzkim; w późniejszych latach profesor Państwowej Wyższej Szkoły Filmowej w Łodzi. 
czas pobył potem. Na jego miejsce przyszedł [Jan] Koprowski ${ }^{70}$, bardzo zacny, dobry pisarz. Ale Biliński też był dobrym pisarzem. Według jego powieści powstał taki film Odznaczenia i ordery.

\section{Epoka gierkowska - lata siedemdziesiąte}

Hasło propagandowe epoki, której „patronem” stał się Edward Gierek: „Aby Polska rosła w siłę, a ludzie żyli dostatniej” miało wyrażać nowe cele społeczno-polityczne i przyspieszenie gospodarcze. Ich wprowadzenie wydawało się konieczne po brutalnej pacyfikacji przez MO i wojsko strajków na Wybrzeżu w grudniu 1970 roku (wywołanych ogromnymi podwyżkami cen) i odsunięciu od władzy Władysława Gomułki.

W zgromadzonej kolekcji wywiadów nie znajdziemy wielu relacji dotyczących tego okresu. Wyjątek stanowią opowieści profesorów Jolanty Kulpińskiej, Stefana Banasiaka i Romualda Olaczka. Pierwsza z nich brzmi następująco:

Jolanta Kulpińska:

Trzeba powiedzieć, że dla nas ten przełom 1970 roku i epoka Gierka była dobra. Dlatego, że był nacisk na badania społeczne. Oczywiście, był nacisk, żeby to miało jakąś etykietę marksizmu, stąd te pierwsze zdanie w różnych tekstach. Wiadomo było, że są możliwe badania empiryczne z wykorzystywaniem technik zachodnich. I zainteresowanie socjologią zachodnią także nie miało tylko charakteru krytycznego. Trochę złośliwie powiem, że Zygmunt Bauman $^{71}$ napisał swój doktorat i chyba habilitację o angielskich związkach zawodowych, Hirszowicz ${ }^{72}$ też o polityce angielskiej, Wiatr ${ }^{73}$ też na podstawie wyjazdów zagranicznych. To były krytyki burżuazyjnej socjologii, ale niezła też i informacja o tej burżuazyjnej socjologii i oni się wszyscy, że tak powiem, nawrócili. Ale wysłani byli po to, żeby zdobyć materiał do krytyki, prawda. Więc to takie dosyć paradoksalne, ale charakterystyczne też dla tej epoki, dla lat sześćdziesiątych. Lata siedemdziesiąte jakby już tego w takim stopniu nie

${ }^{70}$ Jan Koprowski - (1918-2004) - pisarz, publicysta, krytyk. W 1950 roku zamieszkał w Łodzi, gdzie był m.in. kierownikiem literackim Teatru Nowego oraz redaktorem pism literackich, takich jak „Łódź Literacka”, „Kronika”, „Odgłosy”.

${ }^{71}$ Zygmunt Bauman (ur. 1925) - socjolog, filozof, eseista, autor wielu książek na temat ponowoczesności. Jego działalność w służbach bezpieczeństwa Polski Ludowej przede wszystkim w epoce stalinizmu jest przedmiotem licznych kontrowersji. Usunięty z Uniwersytetu Warszawskiego w wyniku wydarzeń marcowych 1968 roku. przez wiele lat związany z Uniwersytetem w Leeds.

${ }^{72}$ Maria Hirszowicz (z domu Bielińska) (1925-2007) - docent socjologii na Uniwersytecie Warszawskim, zwolniona z pracy w konsekwencji wydarzeń marcowych w 1968 roku; pracę naukową kontynuowała na emigracji w Wielkiej Brytanii.

${ }^{73}$ Jerzy Wiatr (ur. 1931) - socjolog, znany i bardzo aktywny działacz komunistyczny w okresie PRL, silnie dbający o poprawność ideologiczną socjologii. 
potrzebowały i rzeczywiście mogliśmy robić różne rzeczy już jakby bez tych danin. Ale jednocześnie wydawało się, że właśnie to zainteresowanie możliwościami naukowymi, cała ta rewolucja naukowo-techniczna, że ona przyniesie również bardziej liberalną gospodarkę. Cały czas się szukało tej reformy gospodarczej i całe lata siedemdziesiąte i osiemdziesiąte ekonomiści nic, tylko szukali reformy gospodarczej, a socjologowie też ewentualnie byli zapraszani do jakiegoś tam udziału, od strony właśnie reakcji nie obywatelskich, ale społecznych. Tak najogólniej można to określić.

\section{Stefan Banasiak komentuje ów czas następująco:}

Przyszedł rok 1970. To było dla mnie następstwo oczekiwane. Przyszedł etap, gdzie robotnicy powinni wystąpić i wystąpili. Gomułka już był dokompromitowany - te wszystkie przesunięcia z Cyrankiewiczem, ze Spychalskim i tak dalej, to była już taktyka. Oczywiście nas jako środowisko dopadnięto, bo to się odbiło i na finansowaniu, i na wynagradzaniu. A następnie zlikwidowano wybory na uczelniach, a stanowiska były przydzielane według mianowania. Lata Gierka przez społeczeństwo były odbierane bardzo korzystnie. Przeze mnie źle. Dla mnie było źle, dlatego że to było niszczenie Polski. To zadłużanie, ta propaganda sukcesu, to rozdmuchanie inwestycji, które w planie sześcioletnim były i później nie miał ich kto dokończyć. Te gierkowskie inwestycje do dnia dzisiejszego w wielu częściach na peryferiach Łodzi stoją jeszcze jako betonowe słupy, bo nikt się tym zająć nie chce ani nikt nie chce wydać pieniędzy na rozebranie, ani na dokończenie tego wszystkiego. Chciano mnie zrobić dziekanem, ale ze względu na to, że moja żona zachorowała, odmówiłem przyjęcia funkcji.

Z kolei Romuald Olaczek patrzy na ten okres przez pryzmat rozwoju i rozbudowy Łodzi oraz ogólnej poprawy sytuacji w kraju:

Lata siedemdziesiąte to były lata wielkiej przebudowy Łodzi. Nie wszyscy łodzianie sobie z tego zdają sprawę, ale wystarczy pomyśleć: Teofilów, Retkinia, Widzew, bliski i dalszy Widzew Wschód i wiele innych osiedli. Żyją tam w sumie setki tysięcy ludzi. Gdzie ci ludzie czy ich rodzice w tej samej prawie liczbie mieszkali, gdy nie było tych osiedli? Czy w Łodzi wiele osób, a zwłaszcza polityków, śmie sobie kiedyś postawić takie pytanie? Gdzie mieszkało te 100 tysięcy ludzi z Teofilowa, 100 tysięcy ludzi z Widzewa, kiedy nie było ani Teofilowa, ani Widzewa? Pod mostami? W rurach kanalizacyjnych? Na ulicy? W parku? Nie, gnieździli się w tych czynszowych kamienicach, na strychach, często w suterenach, w ciasnych bardzo izbach. Wszelkie narzekania na blokowiska, na to budownictwo blokowe to jest wielka hipokryzja i to jest coś naprawdę niegodnego ludzi. Powiedzenie, że można było zbudować lepiej. Każdą rzecz można zrobić lepiej, ale to kosztuje zawsze drożej i zabiera więcej czasu. A tu trzeba było wyprowadzić te setki tysięcy ludzi z tych 
ciasnych mieszkań, z tych familijnych domów, gdzie w jednej izbie wieloosobowe rodziny musiały mieszkać, czasami 2-3 pokolenia w jednoizbowych mieszkaniach.

\section{Lata osiemdziesiąte i „Solidarność"}

Sierpień 1980 roku z pewnością nie był łatwy dla ówczesnego aparatu władzy - w wyniku strajków robotniczych, jakie miały miejsce na Wybrzeżu, doszło do podpisania porozumień sierpniowych, które oprócz spraw politycznych i ekonomicznych podnosiły kwestię rejestracji pierwszego Niezależnego Samorządnego Związku Zawodowego „Solidarność”. Jak wiadomo, nie tylko stał on na straży praw pracowniczych, ale do 1989 roku stanowił główny ośrodek opozycji wobec komunistycznej władzy. Skomplikowana i pełna napięć sytuacja społeczno-polityczna w kraju stała się także przedmiotem dyskusji wśród wielu pracowników naukowych Uniwersytetu Łódzkiego. Bez wątpienia też sierpniowe strajki na Wybrzeżu w 1980 roku i powstanie ,Solidarności” spotęgowały wśród młodzieży akademickiej potrzebę powołania niezależnej od władz państwowych i wolnej od wpływów ideologicznych organizacji studenckiej. Okres między podpisaniem porozumień sierpniowych a wprowadzeniem przez generała Wojciecha Jaruzelskiego (który po odsunięciu od władzy uważanego za nieskutecznego premiera Józefa Pińkowskiego 11 lutego 1981 roku objął jego stanowisko $)^{74}$ stanu wojennego - nazywany karnawałem „Solidarności” - przyniósł ze sobą niemal równolegle trwające strajki „Solidarności” Rolników Indywidualnych oraz Niezależnego Zrzeszenia Studentów, i w konsekwencji rejestrację obu tych organizacji.

Tak wspomina ten czas Jolanta Kulpińska:

Oczywiście 1980 rok. Tutaj pokazał się dosyć wyraźny podział w Instytucie, w środowisku. Ale właściwie taki obraz najogólniejszy był taki, że obrońcy starego systemu są w absolutnej mniejszości i jest takie ogólne poparcie dla „Solidarności”, chociaż nie bezwarunkowe. Jesienią 1980 roku wszyscy śledziliśmy to, co się działo na Wybrzeżu i potem cały ten wrzesień pełen był lokalnych strajków. Organizacja też, ale to było gdzie indziej. Strajki w Łodzi

${ }^{74}$ Warto przypomnieć, o czym dokładniej pisze Andrzej Czyżewski, że dokonana wtedy nieznaczna rekonstrukcja rządu miała jednak wpływ na decyzje podejmowane przez władze w odniesieniu do toczącego się strajku studenckiego. Minister Górski zachował swój urząd, ale zyskał wsparcie w postaci wicepremiera Mieczysława Rakowskiego. Zob. Andrzej Czyżewski, ,,Niemniej to jest farsa, która może być groźna": reakcja aparatu partyjno-państwowego, władz uczelnianych oraz NSZZ „, Solidarność” na strajk tódzkich studentów, [w:] Krzysztof Lesiakowski (red.), Łódzki strajk studencki. Styczeń-luty 1981: spojrzenie po latach, Wydawnictwo Uniwersytetu Łódzkiego, Łódź-Warszawa 2014, s. 178 i dalej. 
- owszem, ale jako echo, dosyć takie nawet wątłe, ubogie echo zdarzeń gdzie indziej zachodzących. Ale co na uczelni? Na uczelni to było trochę tak, że pewni ludzie byli aktywni w ZNP ${ }^{75}$ i na tej fali uznali, że właśnie jest to czas dla związku zawodowego, można powiedzieć, że w ZNP na uniwersytecie to był Seweryński ${ }^{76}$, był kiedyś przewodniczącym, potem Liszewski, a na wydziale Kropiwnicki ${ }^{77}$. I Kropiwnicki zorganizował niby zebranie ZNP, sytuację, która się przerodziła w powstanie „Solidarności” na wydziale. I Kropiwnicki, między innymi też przyszedł do mnie, że właśnie bardzo liczy na jakiś udział, a ja mu wtedy powiedziałam - to musiało być w listopadzie może? - że ruch solidarnościowy to bardzo dobrze, ale że „Solidarność” dla mnie jest trochę za bardzo przykościelna. Chyba nie użyłam tego sformułowania, ale że jakoś nie jestem pewna, czy chcę w tym uczestniczyć. Najpierw właśnie tak powiedziałam, bo rzeczywiście nie byłam pewna, a miałam wtedy jechać do Hanoi. Myśmy mieli umowę międzyuniwersytecką i byli ludzie od nas w Hanoi i był od nich u nas rektor tego uniwersytetu - nawet był dłużej, na nieszczęście dla kasy uczelnianej, bo nie można było znaleźć miejsca w samolocie MoskwaHanoi. Takie to były trudności. A przecież z powodów dewizowych musiała być tylko ta trasa. Ja akurat miałam jechać do tego Hanoi i ktoś mi powiedział, żebym się jednak pospieszyła, bo od nowego roku bardzo zdrożeją bilety i uniwersytet wtedy nie będzie w stanie mnie tam wysłać. Pojechałam w grudniu, tak żeby wrócić przed Bożym Narodzeniem, a nawet wcześniej. „Solidarność” wydziałowa organizowała taką konferencję programową i tam miałam mieć też wystąpienie właśnie o samorządności. Doszłam do wniosku, że przecież ja nie wiem, (...) że wszystko się może zdarzyć, że wrócę i tej „Solidarności” już nie będzie, bo będzie zakazana i wtedy właśnie się zapisałam do niej. Także wróciłam na tą konferencję z przygodami zresztą [natury podróżniczej]. I bardzo żeśmy się angażowali w 1981 roku. Chociaż trzeba powiedzieć, że właściwie nie aż tak, żeby to groziło jakimiś restrykcjami, bo właściwie w Instytucie internowana była tylko Ania Kubiak ${ }^{78}$ w Gołdapi i tak trochę nam się wydawało, że to jest taki sygnał, że jesteśmy jakoś na oku, ale niedostatecznie

${ }^{75}$ ZNP - Związek Nauczycielstwa Polskiego - istniejąca od 1905 roku organizacja zrzeszająca początkowo nauczycieli, którzy zobowiązali się do nauczania dzieci języka polskiego i wychowywania ich w duchu polskim. Obecnie jest niezależnym związkiem zawodowym pracowników oświaty i wychowania, szkolnictwa wyższego i nauki. W dniu wprowadzenia stanu wojennego w grudniu 1981 roku został zdelegalizowany przez ówczesne władze.

${ }^{76}$ Michał Seweryński - patrz biogramy rozmówców.

${ }^{77}$ Jerzy Kropiwnicki (ur. 1945) - dr ekonomii, polityk, jeden z założycieli NSZZ „Solidarność" Ziemi Łódzkiej, w stanie wojennym skazany na sześć lat więzienia, prezydent Łodzi w latach 2002-2010.

${ }^{78}$ Anna Kubiak (ur. 1951) - profesor socjologii zajmująca się metodologią badań społecznych, przez wiele lat współpracowała z Janem Lutyńskim, działaczka opozycji antykomunistycznej, członek NSZZ „Solidarność”, internowana na dwa miesiące w okresie stanu wojennego. Obecnie kierownik Katedry Metod i Technik Badań Społecznych Uniwersytetu Łódzkiego. 
zaangażowani politycznie. W latach osiemdziesiątych już te opcje polityczne, podziały polityczne ukształtowały się nieco inaczej. Ja wystąpiłam z partii po ogłoszeniu stanu wojennego i wiele osób z Instytutu, z młodszych pracowników. Właściwie została taka niewielka grupa. Ale jednocześnie, trzeba powiedzieć, że podziały nie spowodowały tego, żeby dotknęły kogoś prześladowania, kłopoty paszportowe ewentualnie tak, ale to jakby w innym trybie. A w różnych sytuacjach ta grupa partyjna, która była nieduża, ale z dostępem i do władz komitetu łódzkiego, i Komitetu Centralnego wiele razy, jeśli idzie o stopnie, o wyjazdy, pomagała.

O zmianach, jakie niosło ze sobą pojawienie się „Solidarności”, opowiada również Stanisław Liszewski, przyszły profesor geografii, wówczas przewodniczący Związku Nauczycielstwa Polskiego na UŁ:

Zostałem w 1980 roku prodziekanem Wydziału Biologii i Nauk o Ziemi i z natury powinienem się zrzec szefowania Związku [Nauczycielstwa Polskiego]. Odbyło się walne zgromadzenie i było zgłoszonych dwóch kandydatów na to stanowisko, pan doktor Kropiwnicki i pan profesor Seweryński. Obaj zresztą zrobili potem dużą karierę polityczną. Ja optowałem za Seweryńskim, którego znałem wcześniej. Uważałem, że jako prawnik nadawał się na tę funkcję i rzeczywiście on wygrał te wybory jakąśs niewielką liczbą głosów i został po mnie Przewodniczącym ZNP na UŁ. Nastąpiły lata osiemdziesiąte i muszę powiedzieć, że ponieważ z założenia wszystko, co było do tej pory, było złe i miało być wszystko nowe. To ja tak tego nie odbierałem. Jeżeli chodzi o działalność związkową, to uważałem, że ZNP dobrze spełniał swoje zadania, nie był sterowany przez partię. To potwierdzam, ponieważ nie byłem nigdy członkiem partii i nawet wtedy, kiedy byłem szefem Związku, nigdy nie miałem przypadków, żeby jakiś sekretarz mi coś kazał. Mówię to z pełną odpowiedzialnością, czegoś takiego nie było, zupełnie nie było. Potem odbywały się różne zebrania założycielskie „Solidarności” i ciekawe, bo chyba nigdzie nie wyciągano na tych zebraniach jakichś pretensji pod adresem Związku Nauczycielstwa. Może ja już nie wszystko pamiętam, ale w każdym razie mnie nie dotknęło nic, mogę zatem zaświadczyć, że nie było czegoś takiego, że ktoś mi robił jakąś krzywdę. W każdym razie późniejsza moja kariera była związana już z administracją, uczelnią, czyli wydziałem. I tu miałem ogromną satysfakcję, zostałem wtedy wybrany - wtedy były wolne już wybory, takie jak są teraz - dziekanem Wydziału Biologii i Nauk o Ziemi. A nie był to wydział łatwy. Na tym wydziale geografia stanowiła tylko $1 / 10$. Dominowali biolodzy i to biolodzy aktywni politycznie pokroju profesora Niesiołowskiego ${ }^{79}$, profesora Jażdżewskiego ${ }^{80}$.

${ }^{79}$ Stefan Niesiołowski (ur. 1944) - zoolog i polityk, poseł i senator. Absolwent i wieloletni pracownik UŁ.

${ }^{80}$ Krzysztof Jażdżewski - patrz biogramy rozmówców. 


\section{Strajk studencki 1980-1981: „, «Od solidarnościowego odruchu do ideologicznej determinacji» o silnym emocjonalnym podłożu"s1}

W coraz bardziej peryferyjnym (ze względu na systematyczne przejmowanie przez Warszawę dużej części najlepszych naukowców i studentów) i niezauważanym przez władze państwowe mieście, studenci „wzorowego" robotniczego uniwersytetu (oraz innych łódzkich uczelni) w styczniu 1981 roku podjęli strajk okupacyjny, który trwał 28 dni i w którym wzięło udział ponad 8 tysięcy osób. Profesor Jan Lutyński, wybitny socjolog, który wówczas nie tylko towarzyszył młodzieży, ale także był jednym z niewielu obdarzonych przez nią zaufaniem doradcą, pisząc o ambiwalentnym zewnętrznym odbiorze tego wydarzenia, powołuje się na słowa Pawła Gniazdowskiego, który sugeruje rzecz następującą:

Należy przede wszystkim uświadomić sobie specyfikę środowiska, które rozpoczęło i przeprowadziło akcję strajkową. Łódzkie środowisko akademickie - ilościowo jedno z najliczniejszych - funkcjonowało (przynajmniej w ostatnich latach) jako mały ośrodek prowincjonalny. Nie jest moim zadaniem szukanie źródeł regresu, czy wręcz upadku kultury studenckiej (...). Także stopień zainteresowania studentów polityką czy sprawami społecznymi był wyjątkowo niski, jak na tak duży ośrodek - nie powstawały tu SKS-y (Studenckie Komitety Solidarności), a nawet SZSP nie prowadził tu walki ideowej, a jedynie wycieczki w góry, nad jeziora i na dyskoteki. Stąd w chwili, gdy powstał NZS, na czele wybijał się problem przeciwstawienia się bierności środowiska, a nie - jak w Warszawie czy Krakowie - hasła ideowe ${ }^{82}$.

Temu wydarzeniu poświęcimy nieco większą uwagę z dwóch względów. Po pierwsze, to bodajże jedyny raz, kiedy Łódź jako ośrodek akademicki stała się centrum wydarzeń i skupiła uwagę całej Polski (prowadząc największy i najdłuższy strajk okupacyjny studentów w Europie). Paradoksalnie jednak, ówczesne strukturalne, polityczne, społeczne i kulturowe uwarunkowania ${ }^{83}$ wskazywały na to, że do takiego protestu nie miało prawa

\footnotetext{
${ }^{81}$ Zob. Jan Lutyński, Nauka i polskie problemy..., s. 229.

${ }^{82}$ Cyt. za: Jan Lutyński, Uwagi wstępne, [w:] Jan Lutyński (red.), Strajk studentów łódzkich '81 $w$ świetle analiz socjologicznych: praca zbiorowa, Wydawnictwo Uniwersytetu Łódzkiego, Łódź 2010, s. 13. Książka ta, dodajmy, po raz pierwszy ukazała się w niewielkim nakładzie w postaci tzw. druku wewnętrznego w 1988 roku.

${ }^{83}$ Można zaryzykować tezę, że prawie nie istniały takie przesłanki, które wskazywałyby na to, że strajk łódzkich studentów zostanie uwieńczony sukcesem. Składały się na to: z jednej strony, robotniczy (a nie akademicki) charakter miasta, jego peryferyjne położenie „w cieniu” Warszawy, jego pierwotna wizja jako „wizytówki” „postępowego” uniwersytetu, a z drugiej, ówczesne ulokowanie tego buntu na mapie politycznej (począwszy od jego bagatelizacji w pierwszych dniach przez
} 
tu dojść. Po drugie, o czym pisze między innymi Marek Czyżewski, jest to - z różnych względów - ,strajk zapomniany”, niesprawiedliwie pozbawiony swojej rangi i bagatelizowany w pamięci zbiorowej (nawet samych łodzian), dlatego też chcemy podkreślić jego wyjątkowość i znaczenie, tym bardziej, że dla wielu naszych rozmówców - świadków tamtych wydarzeń - ma on ogromną wagę ${ }^{84}$.

Przedstawimy najpierw w skrócie sekwencję wydarzeń, które doprowadziły do wybuchu strajku, jego rozwoju i wreszcie podpisania porozumień strajkowych i powołania NZS, by później móc je prześledzić w opowieściach profesorów. Odzwierciedlają one nie tylko przebieg wypadków, ich subiektywną ocenę, ale też postawy narratorów, które jednak przedstawimy tylko szkicowo, pozostawiając czytelnikowi pole do dalszych analiz i interpretacji.

Akcja protestacyjna rozpoczęła się znacznej wcześniej, bo już 10 grudnia 1980 roku, kiedy studenci Uniwersytetu Łódzkiego zrzeszeni w nowo powstałym, wówczas jeszcze niezalegalizowanym, Niezależnym Zrzeszeniu Studentów (NZS) ${ }^{85}$ i Socjalistycznym Związku Studentów Polskich (SZSP) wspólnie wystąpili o likwidację egzaminu z podstaw nauk politycznych, zniesienia obowiązkowego lektoratu języka rosyjskiego i praktyk robotniczych. Ponieważ władze uczelni, mimo wcześniejszych zapewnień, nie ustosunkowały się w żaden sposób do zgłoszonych postulatów, po świętach Bożego Narodzenia, w styczniu 1981 roku, studenci Wydziału Prawa i Administracji rozpoczęli akcję tzw. „Solidarnego Czekania”, do którego niebawem dołączyła młodzież z Wydziału Ekonomiczno-Socjologicznego. Ta forma protestu - zaproponowana zresztą przez studentów PWSzFTViT polegała na tym, że po zakończeniu zajęć studenci nie opuszczali budynków Uniwersytetu. Jednocześnie wywieszano flagi, plakaty, ogłaszano gotowość strajkową, formowano kierownictwo, poszukiwano ekspertów, a także wysuwano kolejne postulaty. Nadrzędną ramą roszczeń wysuwanych przez

aparat władzy w obliczu znacznie ważniejszych i groźniejszych w jej mniemaniu protestów robotników czy rolników, przez skrajną nieufność środowisk opozycyjnych - w tym przede wszystkim „Solidarności” i KOR-u - wobec ,anonimowych” inicjatorów strajku, na dodatek współdziałających z koncesjonowanym SZSP, po chęć „,zawłaszczenia” strajku przez warszawski NZS). O relacjach strajkujących studentów z tzw. światem dorosłych pisze Andrzej Czyżewski (tegoż, ,Niemniej to jest farsa, która może być groźna”...). Zob. też Marek Czyżewski, Społeczne i kulturowe aspekty strajków studenckich w Łodzi: zarys analizy, [w:] Krzysztof Lesiakowski (red.), Łódzki strajk studencki..., s. 277.

${ }^{84}$ Zob. Marek Czyżewski, Spoleczne i kulturowe aspekty strajków studenckich $w$ Łodzi.., s. $267-268$.

${ }^{85}$ Przedstawiciele niezależnych zrzeszeń i organizacji uczelni w wielu miastach Polski na zjeździe, który we wrześniu 1980 roku odbył się na Politechnice Warszawskiej, wybrali dla niej nazwę Niezależne Zrzeszenie Studentów (NZS). 
studentów była humanizacja (wyrażająca się między innymi w postulacie zastąpienia przedmiotów ideologicznych między innymi socjologią i filozofią) i demokratyzacja (manifestująca się np. w żądaniu możliwości wyboru ciał kolegialnych i rezygnacji z praktyki motywowanej ideologicznie obsady stanowisk) uczelni. Żądano przede wszystkim: rejestracji NZS-u, zniesienia przedmiotów indoktrynacyjnych, zniesienia cenzury, prawa do swobodnego wyjazdu za granicę, skrócenia służby wojskowej dla studentów, wprowadzenia niezależności uczelni w sprawach naukowych i dydaktycznych, wydłużenia czasu studiów do 5 lat, poszanowania autonomii uczelni przez MO i SB, poprawy sytuacji bytowej studiujących i absolwentów, a także uwolnienia więźniów politycznych oraz ukarania winnych stłumienia protestów robotniczych w grudniu 1970 i 1976 roku. Kiedy 21 stycznia 1981 roku zerwane zostały rozmowy prowadzone między studentami a delegacją władz państwowych na czele z wiceministrem Stanisławem Czajką ${ }^{86}$, rozpoczął się strajk okupacyjny. 29 stycznia 1981 roku podjęto negocjacje, w których, ze strony władz PRL, uczestniczyła wysłana z Warszawy Komisja Międzyresortowa pod przewodnictwem ministra Nauki Szkolnictwa Wyższego i Techniki prof. Janusza Górskiego (byłego rektora Uniwersytetu Łódzkiego), a ze strony studenckiej prowadziła je Międzyuczelniana Komisja Porozumiewawcza NZS, w skład której weszli m.in. Wojciech Walczak, Maciej Maciejewski, Marek Perliński, Wiesław Potoczny, Marcin Sobieszczański z Uniwersytetu Łódzkiego, Andrzej Bolanowski i Piotr Kociołek z Politechniki Łódzkiej, Stanisław Nowak i Krzysztof Sulik z Akademii Medycznej, oraz Jan Przybylski z Państwowej Wyższej Szkoły Muzycznej. 17 lutego 1981 roku po spotkaniu w Urzędzie Rady Ministrów w Warszawie z wicepremierem Mieczysławem Rakowskim oraz ministrami Stanisławem Cioskiem i Januszem Górskim z przedstawicielami studentów: Wojciechem Walczakiem, Markiem Perlińskim, Maciejem Godyckim-Ćwirko oraz wspierającym ich prof. Janem Lutyńskim, doszło do rejestracji Niezależnego Zrzeszenia Studentów.

Profesor Jan Lutyński, który wówczas pełnił rolę konsultanta studentów ${ }^{87}$, już w trakcie trwania samego protestu podjął analizę przebiegu tego

\footnotetext{
${ }^{86}$ Stanisław Czajka (1938 - 1990) - członek PZPR, pracownik etatowy KC PZPR (1973-1979): w tym zastępca kierownika Wydziału Nauki i Oświaty KC w okresie 1975-1979; w latach 19791981 podsekretarz stanu Ministerstwa Nauki, Szkolnictwa Wyższego i Technik.

${ }^{87}$ Należy podkreślić, że niemalże we wszystkich zebranych opowieściach uczestników strajku studenckiego w 1981 roku pojawia się postać Jana Lutyńskiego. Zawsze podkreślane jest jego niezwykle przychylne nastawienie wobec studentów oraz rozumiejąca postawa wobec ich działań i prowadzonych pertraktacji. Bez wątpienia Lutyński zapewnił wówczas strajkującej i nieufnej wobec kadry uniwersyteckiej młodzieży przekonanie, że wśród profesorów jest ktoś, komu można
} 
wydarzenia i negocjacji strajkowych ${ }^{88}$. Kwestia, która nas tu najbardziej interesuje, wiąże się z próbą wyjaśnienia, dlaczego strajkujący studenci nie zwrócili się o pomoc (a być może nawet nie brali jej pod uwagę) do profesorów, ale do adwokatów (do Karola Głogowskiego, a kiedy ten trafił do szpitala, do Adama Wojciechowskiego). Lutyński, podejmując punkt widzenia młodzieży, wskazuje na jej oficjalnie stanowisko, które sugeruje, że, po pierwsze, nauczyciele akademiccy „w obecności ministra będą się czuli skrępowani w swoich wypowiedziach" "89 i, po drugie, że profesorowie przywykli mówić językiem stosowanym przez aparat władzy i ,uznawali - przynajmniej pozornie - racje i system wartości władz (...) broniąc stanowiska zbliżonego do poglądów studentów"90.

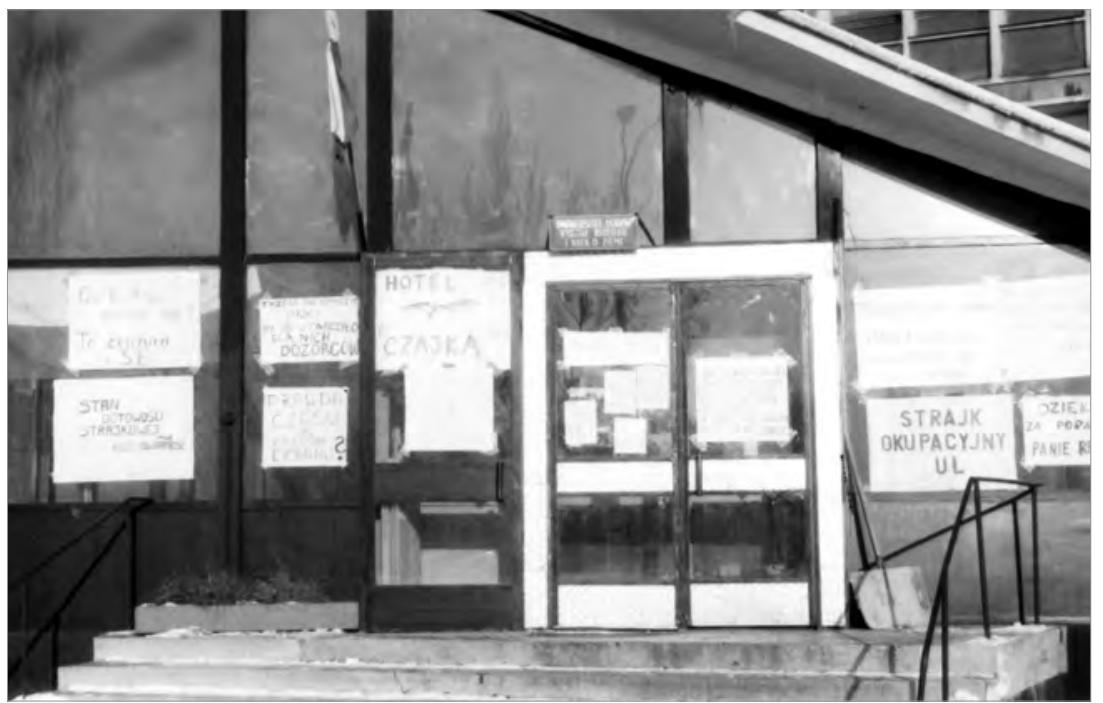

Fot. 58. Strajk studentów na Wydziale Biologii i Nauk o Ziemi

Lutyński podkreśla także, że część postulatów strajkujących studentów nie była aprobowana przez kadrę uniwersytecką, zwłaszcza przez profesorów. Chodzi tu przede wszystkim o żądania, aby ciała kolegialne uczelni w jednej trzeciej składały się ze studentów, młodszych pracowników naukowych i samodzielnych pracowników, aby były wybieralne i aby studenci

ufać, kto wyraźnie ich wspiera i kto chce im pomóc. W relacjach strajkujących, które, dodajmy, zebrane zostały po ponad trzydziestu latach od tego wydarzenia, szczególnie doceniona zostaje także postawa prof. Biruty Lewaszkiewicz-Petrykowskiej i prof. Romualda Skowrońskiego. Relacje obu tych postaci są tutaj omawiane.

${ }^{88}$ Jan Lutyński (red.), Strajk studentów łódzkich '81 w świetle analiz socjologicznych...

${ }^{89}$ Tamże, s. 234.

${ }^{90}$ Tamże, s. 235. 
mieli prawo zgłaszania votum nieufności wobec prorektora i prodziekana ds. studenckich na Radzie Wydziału i Senacie Uczelni ${ }^{91}$. Na marginesie wspomnijmy, że władze PRL przystały na ten postulat, ale studenci mieli ogromne problemy z uformowaniem delegacji stanowiącej trzydzieści procent władzy kolegialnej uczelni. Owa trzydziestoprocentowa reprezentacja, nazwana przez Piotra Bikonta w filmie Bunt na Łodzi Jacka Talczewskiego „hiperdemokracją”, jakiej nie było nigdzie na świecie, wynikała z „głodu demokracji i pragnienia wolności" nękającego młodych ludzi, którzy urodzili się i zostali wychowani w peerelowskiej rzeczywistości.

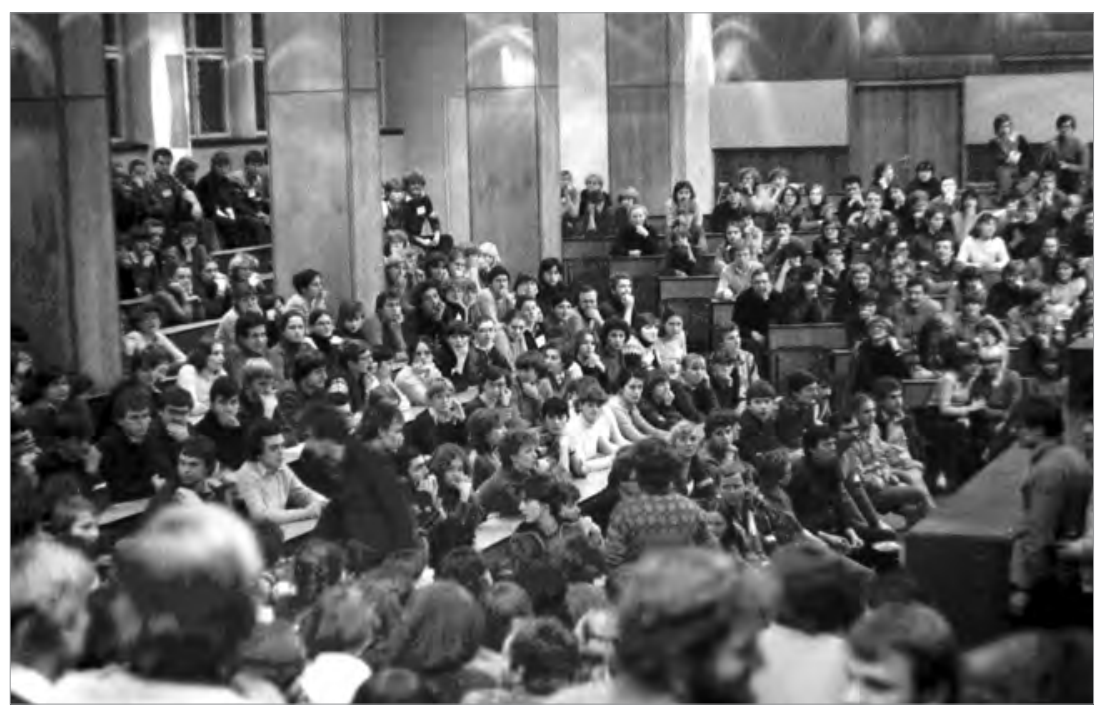

Fot. 59. „, Głód demokracji i pragnienie wolności”-strajk studentów na Wydziale Ekonomiczno-Socjologicznym

Wróćmy do rozważań Lutyńskiego, który przyglądając się roli doradców, pisze:

Postawa [profesorów] w stosunku do żądań młodzieży była więc - ogólnie rzecz biorąc - ambiwalentna. Przyczynił się do tego w pewnej mierze fakt, że sytuacja, w której studenci prowadzą rokowania z ministrem w sprawie uczelni (co dawno już zresztą zaaprobował minister), była traktowana przez wielu profesorów jako nienormalna, a stawiane przez młodzież akademicką żądania nierealne. Rzutowało to także na tych, którzy współpracę ze studentami w negocjacjach w zasadzie akceptowali ${ }^{92}$.

${ }^{91}$ Zob. np. Archiwum Ośrodka KARTA, Ustalenia negocjacyjne, postulaty - wersja robocza [nazwa red.], 1981, www.dlibra.karta.org.pl/dlibra/publication?id=14214\&tab=3, (18.02.2104).

${ }^{92}$ Jan Lutyński (red.), Strajk studentów łódzkich '81 w świetle analiz socjologicznych ..., s. 234. 
Lutyński uwzględnia także perspektywę profesorów, którzy niejednokrotnie byli schematycznie „obsadzani” przez strajkującą młodzież w roli opowiadających się ,po stronie władzy ludowej”, która z tego powodu mogła zachowywać się wobec nich agresywnie i lekceważąco ${ }^{93}$. Co więcej, niektórzy profesorowie wiedzieli znacznie mniej niźli studenci na temat kontekstu i uwarunkowań tego konfliktu ${ }^{94}$. To napięcie i podejrzliwość między studentami a kadrą uniwersytecką $\mathrm{w}$ wielu wypadkach wynikało jednak nie tyle ze „stania po dwóch stornach barykady”, co z odmienności perspektyw i wyobrażeń dotyczących, z jednej strony, ograniczonych struktur możliwości (związanych np. z ówczesnymi ograniczonymi kompetencjami rektora), a z drugiej, możliwych konsekwencji takich działań (np. w postaci brutalnej pacyfikacji uczelni). Z pewnością rację ma Andrzej Czyżewski pisząc, że władze uczelni (i większość kadry akademickiej) dążyły przede wszystkim do wyciszenia strajku i niedopuszczenia do eskalacji konfliktu przy jednoczesnej minimalizacji strat ${ }^{95}$, jednak wydaje się, że motywy takiego postępowania mogły być u różnych osób reprezentujących ową władzę inne.

Przyjrzyjmy się teraz nastawieniom i ocenom profesorów Uniwersytetu Łódzkiego wobec strajku studenckiego w 1981 roku. Dwoje z nich (Biruta Petrykowska i Romuald Skowroński) odegrało tu znaczącą, choć różną, rolę - profesor Petrykowska została wybrana przez studentów doradcą, Skowroński, ówczesny rektor Uniwersytetu Łódzkiego, z racji swojej funkcji został bezpośrednim adresatem postulatów studenckich, a później (ze względu na brak uprawień i możliwości podejmowania znaczących decyzji) pośrednikiem $\mathrm{w}$ negocjacjach z przedstawicielami władzy. Należą oni do tych akademików, którzy chcieli i potrafili uwzględnić punkt widzenia studentów, co niejednokrotnie wymagało od nich pokory i cierpliwości. Inaczej rzecz się ma w przypadku postępowania profesora Banasiaka, który „stanął na straży ładu i porządku publicznego” i tym samym zamanifestował zupełnie inną postawę wobec strajku i biorącej w nim udział młodzieży.

Biruta Lewaszkiewicz-Petrykowska (prawnik) wspomina:

Zaczęło się to żądaniami. Jeszcze zanim studenci zaczęli strajkować, na Wydziale Prawa odbyło ich spotkanie z prorektorem ds. studenckich i chyba

\footnotetext{
${ }^{93}$ Tamże.

${ }^{94}$ Tamże.

${ }^{95}$ Andrzej Czyżewski, „, Niemniej to jest farsa, która może być groźna”..., s. 166-167.
} 
z rektorem ${ }^{96}$, które nawiasem mówiąc do niczego nie doprowadziło. To już wtedy studenci mnie prosili, żebym jak gdyby mediowała między nimi a władzami uczelni. I ja brałam udział w tym zebraniu. Dyskusja dotyczyła głównie pewnych swobód dla studentów. Wtedy Głogowski ${ }^{97}$ im też doradzał, adwokat. Najpierw studenci zbierali się u nas i na innych wydziałach, a później odbyły te słynne rozmowy z Górskim ${ }^{98}$. Pierwszy na nie przyjechał Czajka ${ }^{99}$. On nic nie mógł. A potem przyjeżdżał Górski. On na początku był dość arogancki. Po jego stronie był wtedy $\mathrm{z}$ naszego Wydziału profesor Borkowski ${ }^{100}$ a po przeciwnej negocjowali sami studenci. Najpierw były podnoszone pewne kwestie związane ściśle z programem nauczania i z uczelnią, a później dopiero studenci zaczęli wysuwać pewne dalej idące postulaty. Edelman ${ }^{101} \mathrm{im}$ wtedy doradzał, on też tam przesiadywał na Kościuszki. Lazari-Pawłowska ${ }^{102}$ była też obecna przez jakiś czas.

Kaja Kaźmierska: I Lutyński od nas.

Biruta Lewaszkiewicz-Petrykowska: Lutyński, tak. O Lutyńskim pamiętam. U niego były zebrania. On mieszkał na Uniwersyteckiej 3. Jak ten strajk się zakończył, to przecież pani wie. Potem były wybory władz. Wróblewski wtedy został wybrany rektorem. I ja też właśnie w tych pierwszych wyborach byłam wybrana dziekanem. Ale wtedy już w powietrzu coś wisiało. To się czuło, że to tak nie będzie. Czy studenci sobie zdawali sprawę, jak to wyglądało? Myślę, że niekoniecznie. Byli pełni entuzjazmu i zresztą oni bardzo zręcznie prowadzili te rozmowy. Przecież myśmy tam w sam sposób formułowania się nie wtrącali. Doradzało się im w czasie przerw czy też na pewne rzeczy zwracało się uwagę, odpowiadało kiedy oni o pewne sprawy pytali. Ale trzeba powiedzieć, że studenci bardzo dobrze prowadzili rozmowy. „Solidarność” się za bardzo nie angażowała, jeżeli chodzi o ten tzw. długi strajk. Studenci wtedy uzyskali sporo, a na ile im przyrzeczono to czy owo w złej wierze, to inna sprawa. Bo przypuszczam, że pewne sprawy były przyrzeczone po prostu w złej wierze. W rozmowach z Górskim była podnoszona sprawa autonomii uczelni, zniesienia tej indoktrynacji, która przecież panowała - między innymi chodziło

${ }^{96}$ Chodzi tu o geologa prof. Tadeusza Krzemińskiego pełniącego w latach 1975-1981 funkcję prorektora ds. dydaktyki i wychowania oraz chemika prof. Romualda Skowrońskiego.

${ }^{97}$ Karol Głogowski (1933-2005) - znany łódzki adwokat broniący opozycjonistów.

${ }^{98}$ Janusz Górski (1929-1986) - profesor ekonomii, członek PZPR od 1968 roku, rektor Uniwersytetu Łódzkiego w latach 1972-1975, minister w Resorcie Nauki, Szkolnictwa Wyższego i Techniki w latach 1978-1981.

${ }^{99}$ Zob. przypis $87 \mathrm{w}$ tym rozdziale.

${ }^{100}$ Janusz Borkowski (1935-2012) - prawnik, sędzia Sądu Najwyższego, sędzia Naczelnego Sądu Administracyjnego. Absolwent i wieloletni pracownik Uniwersytetu Łódzkiego.

${ }^{101}$ Marek Edelman (1919-2009) - lekarz kardiolog, działacz polityczny i społeczny. Absolwent Akademii Medycznej w Łodzi. Od połowy lat siedemdziesiątych współpracownik KOR.

${ }^{102}$ Ija Lazari-Pawłowska - etyk i filozof, twórczyni Katedry Etyki na Uniwersytecie Łódzkim. 
o „nauki polityczne”, tak to się chyba nazywało.. Gdy chodzi o prawników, to przedmiot ten był kompletnie bez sensu. Nasi studenci na trzecim roku dostawali „,nauki polityczne”, kiedy to oni byli już po prawie konstytucyjnym, po prawie międzynarodowym i wiedzieli więcej niż ci, którzy do nich przychodzili. Nawiasem mówiąc, pamiętam takiego jednego, jeszcze w latach siedemdziesiątych - zawiadomiliśmy Wydział Ekonomiczno-Socjologiczny, bo on był stamtąd, że on prowadzi zajęcia z nauk politycznych w ten sposób, że przychodzi, przynosi magnetofon, otwiera go, puszcza nagranie zamiast wykładu, a sam je w tym czasie jabłka [śmiech]. I wieczne były awantury między tymi prowadzącymi zajęcia z nauk politycznych a naszymi studentami, bo studenci się wściekali. A jednocześnie na egzaminach wypadali dobrze. Oni się wygłupiali na zajęciach, gdy chodziło o sprawy związane z indoktrynacją. Natomiast gdy chodziło o wiedzę, to oni ją mieli, nie z tego, co ten im gadał, tylko z tego, co po prostu wiedzieli. To wszystko był dom wariatów, bez sensu zupełnie. O to się też upominali, żeby rosyjski nie był przymusowy. Na skutek tego, że musieli się go uczyć, to się nie uczyli - a jak nie musieli, to się uczyli. To tak to wszystko się odbywało. Ale później, już po wprowadzeniu stanu wojennego, gdy były dyskusje na posiedzeniach Senatu dotyczące nowych statutów, które uniwersytety musiały uchwalić według wytycznych z ministerstwa, to awantury były moralno-socjalistyczne [śmiech] na tym Senacie. I tak sobie myślę, że pewne ustępstwa były robione $\mathrm{w}$ złej wierze, że w pewnym momencie to się z powrotem przykręci i tak się zresztą stało. Ale wtedy młodzi na pewno w ten sposób nie myśleli, nie mieli doświadczeń. Zresztą ludzie sobie też nie ze wszystkiego zdawali sprawę.

Prof. Romuald Skowroński był rektorem Uniwersytetu Łódzkiego w latach 1975-1981, a w czasie jego drugiej kadencji doszło do strajku studentów w Łodzi. Przypomnijmy, że ze strony rządowej negocjacje ze studentami prowadził prof. Janusz Górski (rektor Uniwersytetu Łódzkiego do roku 1975, a zatem bezpośrednio przed Skowrońskim), wówczas minister Resortu Nauki, Szkolnictwa Wyższego i Techniki. Skowroński opisuje go jako ,pana dynamicznego, bardzo silnego". Zaraz potem opowiada, że sam za radą swoich przyjaciół z lat okupacji (a dodajmy, że w czasie wojny otrzymał stopień kaprala podchorążego AK i został odznaczony krzyżem partyzanckim) został członkiem PZPR i wyjaśnia:

Może to zabrzmi dziwnie, ale całe szczęście, że [wstąpiłem do partii], bo to dawało takie wielkie możliwości załatwiania różnych rzeczy, które czasami okazywałyby się niemożliwe. Nie wszyscy członkowie partii byli wredni, a to był taki okres, że partia liczyła dwa miliony osób. 
Oto jego relacja ze strajku:

Górski był takim, powiedziałbym, prężnym ministrem, ale nie był specjalnie lubiany. Ja za jego kadencji zostałem powołany na prorektora. Wtedy byłem rzeczywiście bardzo młodym człowiekiem. Jak on został powołany na ministra szkolnictwa wyższego, to wtedy dostałem p.o. rektora, a już jesienią zostałem chyba najmłodszym rektorem uniwersytetu w Polsce [miał wówczas 49 lat]. To było olbrzymie wyróżnienie, ale muszę powiedzieć, że i olbrzymia odpowiedzialność. Z tym, że ja dobrałem sobie bardzo zawodową ekipę, bo był w niej profesor Welfe ${ }^{103}$ - znakomity ekonomista o dużym autorytecie, profesor Szymczak ${ }^{104}$ - postać znana, autorytet, był profesor Tylman ${ }^{105}$, prawnik. Co tydzień robiłem tak zwane kolegia dziekańskie i prosiłem dziekanów i kolegialnie załatwialiśmy różne sprawy dla Wydziału. Jeżeli chodzi o sprawy finansowe, to był okres niezłej sytuacji nauki w Polsce. Na naukę przeznaczano więcej środków aniżeli teraz. To było naprawdę dwa procent PKB. A teraz nie wiem, czy osiąga choćby jeden. Wtedy zaczęła się też walka o bazę lokalową Uniwersytetu, nowe inwestycje. Byłem wtedy przewodniczącym kolegium rektorów i członkiem wielu komisji ministerialnych. A okres ten był naprawdę trudny, bo były przecież różne naciski, różne formy działalności opozycyjnej pracowników Uniwersytetu. Wielu ludzi, którzy dzisiaj te czasy wspominają, przychodziło do mnie z różnymi problemami, naprawdę mieli do mnie zaufanie. Natomiast opiekunowie z odpowiedzialnych służb przychodzili do mnie, żebym coś zrobił z tym czy innym, ale co ja mogłem zrobić. Mówiłem zawsze: „Jeśli działają niezgodnie z prawem i macie podstawy do ich zaaresztowania, to ich aresztujcie, ale nie radzę". Tak sobie szczerze rozmawialiśmy, ale jak mówię, to naprawdę nie był łatwy okres. Potem finałem tego mojego rektorowania były strajki studenckie. Widzi pani, dla mnie wtedy największym problemem było to, że ja się bałem prowokacji. Bałem się, żeby młodzież nie wyszła na ulicę, bo były takie próby kontestacji, wyjścia młodzieży na ulicę. To się zaczęło wszystko najpierw na Wydziale Prawa, w grudniu, a potem ten wielki strajk styczeń/luty, już w tym gmachu na Alei Kościuszki. Proszę mi wierzyć, ja siedziałem z tą młodzieżą dzień i noc, bezustanne dyskusje. Społeczeństwo było bardzo pomocne przez pierwsze dwa tygodnie - studenci mieli wszystko, co chcieli, ale po dwóch tygodniach hojność społecznika się skończyła. Przychodzą do mnie organizatorzy: „Panie rektorze, my jesteśmy głodni”. Ja mówię: „Moi drodzy, czy widzieliście pracodawcę, który żywi strajkujących

${ }^{103}$ Władysław Welfe - patrz biogramy rozmówców.

${ }^{104}$ Halina Mortimer-Szymczak (ur. 1926) - ekonomista, wieloletni pracownik i profesor Uniwersytetu Łódzkiego. W czasie strajku studenckiego sprawowała funkcję prorektora i brała udział w spotkaniach ze studentami z ramie władz uczelni.

${ }^{105}$ Janusz Tylman (ur. 1924) - prawnik, karnista. Absolwent Uniwersytetu Łódzkiego oraz jego wieloletni wykładowca. W czasie strajku studenckiego był prodziekanem i pierwszym zastępcą rektora. 
[śmiech]?”. Ale zorganizowałem w stołówce „wzmocnione” zupy i te posiłki dostawali. Dla młodzieży to było wielkie przeżycie - uczestniczenie w takim proteście. A tam oprócz demagogów było wielu bardzo zdolnych, inteligentnych ludzi. Były takie bardzo rzeczowe dyskusje i muszę powiedzieć, że jeżeli chodzi o zmiany w ustawie o szkolnictwie wyższym, to nie tylko ośrodek krakowski, ale uważam, że głównie łódzki miał największe zasługi. Byłem też z młodzieżą w delegacji u premiera [Mieczysława Rakowskiego] i mówiliśmy o sytuacji, która jest. Górski zajął bardzo twarde, nieprzyjemne stanowisko. Jemu się wydawało, że on reprezentuje władzę i tak dalej. Ja mu mówię: „Zastanów się. Zobaczysz, że nikt tego nie doceni, wręcz odwrotnie". I po tych wszystkich wydarzeniach jego odwołano. Zresztą to się dla niego źle skończyło, powiem szczerze, bo on to przypłacił zawałem serca. Był bardzo zaangażowany po stronie rządowej. Także to był sukces młodzieży, jeżeli chodzi o pewne rzeczy, które znalazły się w ustawie o szkolnictwie wyższym. Szkoda, że teraz jest taki mały rozłam intelektualny, jeżeli chodzi o te zasługi NZS-u. Każdy chce być bardziej bohaterem i mieć większe zasługi. A to była taka bardzo pozytywna rzecz. W każdym razie ta młodzież zdobyła ogromne doświadczenie. Ja miałem osobiście ogromną satysfakcję, bo kiedy byłem jakieś pięć lat temu na takim zjeździe NZS KWU, to młodzież dziękowała za moją postawę, za moją pomoc. Ale wie pani, dla mnie to było dużo więcej, trochę inna historia, bo ja miałem telefony nocne, żona była świadkiem: a to dzwonił biskup łódzki z gratulacjami, a to dzwonił ktoś z komitetu z groźbami - tych telefonów było mnóstwo i trzeba było naprawdę, mówiąc lapidarnie, lawirować albo mieć pewne zdolności dyplomatyczne, żeby jakoś z tego wybrnąć.

Choć niektórzy profesorowie, o czym już wcześniej w odwołaniu do Lutyńskiego była mowa, nie mieli pełnej wiedzy o okolicznościach wybuchu i przyczynach strajku, to często mieli znacznie szerszą perspektywę i wyobrażenie potencjalnego zagrożenia, z jakim może wiązać się bunt przeciwko opresyjnej władzy. Biograficzne doświadczenia Romualda. Skowrońskiego jako młodego naukowca, który we Francji spędził w sumie sześć lat (najpierw w latach 1958-1962 na studiach doktoranckich, potem w latach 1966-1967 jako profesor wizytujący) i który z relacji swoich najbliższych współpracowników na tamtejszej uczelni dokładnie znał przebieg i konsekwencje wydarzeń zapoczątkowanych przez strajki studenckie w maju 1968 roku w Paryżu (m.in. brutalne usunięcie przez policję protestujących studentów z Sorbony), z pewnością miały ogromny wpływ na jego postawę w tamtym czasie ${ }^{106}$. Ma też za sobą doświadczenie okresu stalinizmu, kiedy usunięto go ze stanowiska komendanta obozu

${ }^{106}$ Romuald Skowroński mówi o tym wyraźnie w dokumentalnym filmie Bunt na Łodzi, w którym Jacek Talczewski utrwala wspomnienia uczestników strajku studenckiego. 
młodzieżowego ${ }^{107}$. W tej perspektywie nie dziwi strach, który towarzyszy rektorowi Skowrońskiemu w okresie strajku, który nie jest w pierwszym rzędzie związany z obawą o swoje stanowisko czy karierę.

Przyjrzyjmy się jeszcze, jak postać Skowrońskiego zostaje przedstawiona w opowieści jego niegdysiejszego adwersarza - Wojciecha Walczaka ${ }^{108}$, jednego z czołowych przywódców strajku, wówczas studenta psychologii:

Pojawił się pan rektor Skowroński, którego do tej pory szanuję i uważam, że to wspaniały facet, ale co on mógł zrobić. Był uwikłany w ten układ i do głowy mu nie przyszło, że czterdzieści lat po wojnie ludzie mogą czegoś chcieć, a nie słuchać. Wobec powyższego rozmawialiśmy prawie przez całą noc i pan rektor robił to, co według niego było oczywiste i nie robił tego wcale źle. Mówił: „W zasadzie to ja bym się z wami zgodził, bo macie rację, ale tego się nie da, bo to musi minister". Mieliśmy zatem całe porozumienie, gdzie pan rektor na wszystko się zgadza, tylko nic nie może. I oczywiście jakby spojrzeć na historię, to on rzeczywiście nic nie mógł, bo wtedy, za przeproszeniem, żeby kichnąć, to trzeba było mieć zgodę sekretarza. Ale skoro on nie mógł, to znaczy, że strajk musi być i trzeba sobie przyprowadzić ministra.

Rozważmy teraz, jak w stosunku do strajkujących zachował się prof. Skowroński. Ponownie odwołam się tutaj do słów Lutyńskiego, który podkreśla, że inaczej niż w latach poprzednich, władze uczelni i administracja udzieliły materialnego wsparcia studentom ${ }^{109}$. Paradoksalną sytuacją było zatem to, o czym z uśmiechem opowiada prof. Skowroński, że władze uczelni pomagały studentom finansowo - udzielając kredytu na posiłki w stołówkach ${ }^{110}$. Nie bez znaczenia jest tu zatem pozornie błahy gest rektora, który zapewnia strajkującym (swoim zbuntowanym podwładnym) zupę $\mathrm{z}$,wkładką".

Dalej odpowiadając na pytanie o to, co działo się po strajkach studenckich z jego karierą jako rektora i jako pracownika, Romuald Skowroński odpowiada:

Ja nie poniosłem żadnych konsekwencji służbowych. Już wtedy zaczęła się trochę zmieniać atmosfera w kraju. Muszę powiedzieć, że wtedy znalazłem więcej czasu na wyjazdy zagraniczne i kontakty. Kiedyś w ministerstwie spotkałem się nawet z pewnym, jakby to powiedzieć, podziwem. Ktoś tam

${ }^{107}$ Ten epizod jest opisany także w rozdziale V.

${ }^{108}$ Wywiad ten został przeprowadzony przez Katarzynę Waniek i Andrzeja Czyżewskiego w ramach badań Andrzeja Czyżewskiego nad łódzkim strajkiem studenckim w 1981 roku.

${ }^{109}$ Jan Lutyński (red.), Strajk studentów tódzkich '81 w świetle analiz socjologicznych ..., s. 225.

${ }^{110}$ Ilona Przybyłowska i Krzysztof Kistelski mówią o tym wsparciu w rubryce zatytułowanej „Źródła finansowania strajku”, [w:] Jan Lutyński (red.), Strajk studentów tódzkich '81 w świetle analiz socjologicznych..., s. 80. 
powiedział: „Miał odwagę”. Dobrze. Może sobie nie zdawałem z tego sprawy, ale to wzbudziło pewnego rodzaju zdumienie, tak mi się wydaje, bo wielu rektorów na innych uczelniach w tym czasie się po prostu załamywało, nie wytrzymywało nerwowo. Ja po prostu jako młody człowiek wcześnie przecież zacząłem pracować, przede wszystkim w konspiracji. Rozpocząłem pracę w wieku szesnastu lat jako elektryk. Pracowałem w fabryce, o piątej rano wstawałem. Także ta szkoła życia swoje zrobiła.

Zgoła odmienną perspektywę ma Stefan Banasiak. Przyjrzyjmy się, co opowiada o strajku studentów, kiedy osoba z nim rozmawiająca wprost pyta go o tamte wydarzenia:

Sebastian Zaborowski: A jak wyglądał w Instytucie Historii czas „Solidarności”, a potem strajków studenckich? Jak pan profesor to wspomina?

Stefan Banasiak: Nie mam zielonego pojęcia. Przebywałem w Instytucie dużo ze względu na takie społeczne zainteresowanie tym, co się dzieje, jako wychowawca i jako pracownik. To wynikało też z obowiązku służbowego. Jest strajk, ale pensja jest, więc trzeba być na posterunku, i ze względu na mój 1956 rok, z którego jestem wręcz dumny, więc to obserwowałem. A pan pyta, jak to wyglądało ze studentami? Proszę pana: masówka; histeria. Nie byłem w kierownictwie, nie wiem, jak kto kierował, bo centrum było przy Zamenhoffa, na filologii, więc tam to się wszystko odbywało. U nas była sypialnia. Ławki były do samego sufitu poukładane, podłoga była, a na podłodze porozkładane nadmuchiwane materace, dziewczyny chodziły w piżamach po korytarzach Instytutu. Tłok ludzi na korytarzach. To był taki obrazek. Pamiętam reakcję profesor Barszczewskiej ${ }^{111}$ : „Co oni tu będą robić, że tu jest taka kupa pudeł z farbą?”. Przywieźli jakąś ciężarówkę dziesięciolitrowych wojskowych puszek, takich jednodaniowych posiłków z wkładką mięsa czy coś takiego. A potem studenci zadeklarowali na ulicy: „Żarcia mamy, wytrzymamy!”112. Studenci mieli magnetofony, mieli poprzywożone taśmy, bo co się tam ponagrywali, to kopiowali i tu sobie odtwarzali. Na tej sali nie przebywałem, nie narzucaliśmy się, przeważnie gdzieś tam w jednym pokoju się zbieraliśmy czy ze znajomymi studentami porozmawialiśmy, ale tam na sali studenckiej nie przebywaliśmy. Nadzorowaliśmy tylko, żeby tak do katedr nie wchodzili, żeby kuchni i pracowni fotograficznej nie porozwalano, kserografu, to wszystko. Nikt nic nie miał nam do powiedzenia, a myśmy też się nie mieszali. Byleby nie spalili budynku, żeby nic się złego nie działo. Matki przychodziły, to

${ }^{111}$ Alina Barszczewska-Krupa (1932-2001) - historyk, znawczyni tematyki Wielkiej Emigracji. Absolwentka i wieloletnia wykładowczyni Uniwersytetu Łódzkiego. W czasie strajku studenckiego pełniła funkcję dziekana i prodziekana Wydziału Filozoficzno-Historycznego.

${ }^{112} \mathrm{O}$ hasłach wywieszanych wówczas przez studentów pisze szeroko Krytyczna Lutyńska. Zob. Krystyna Lutyńska, Strajk studentów 1981 w opinii mieszkańców Łodzi, [w:] Jan Lutyński (red.), Strajk studentów łódzkich '81 w świetle analiz socjologicznych... 
próbowaliśmy z rodzicami pogadać. Matki przerażone, bo córka podlega dyscyplinie, musi, pakuje się jak na biwak, bierze szczoteczkę, a to, co z nią będą ci chłopcy robić, to tę matkę niepokoi. W sumie to tu była taka sypialnia, ktoś przekazywał jakieś plotki, jakieś informacje. Były zgłaszane te wszystkie postulaty, nie postulaty, no więc pracować nie będziemy, krótko będziemy pracowali: komunizm, po prostu był komunizm, że za Stalina jak właśnie mówiono o przyszłym komunizmie, to właśnie w ten sposób miało być, prawda, jakieś taki komunizm, tego jedzenia było, ten ekwipunek to był no nie uczelniany, tylko to prywatny to był, przynosili to wszystko. Incydentów specjalnie nie było. Trudno mi powiedzieć, jak to przeżywał profesor Baranowski ${ }^{113}$. Przypuszczam, że przeżywał, on był mało odporny, za bardzo sobie wyobrażał jako dyrektor Instytutu. Ja nie byłem dyrektorem, byłem po prostu szeregowym pracownikiem, profesorem nadzwyczajnym jeszcze wtedy, to starałem się dowiedzieć, zorientować, o co chodzi. A resztę to coś tam się w domu trochę posłuchało.

Inaczej codzienne życie strajkującej w budynku Wydziału Ekonomiczno-Socjologicznego młodzieży przedstawia Janina Tobera ${ }^{114}$ :

Wszystkie osoby należące do „Solidarności” były jakoś związane z tym strajkiem. Mamy nawet w domu taki znaczek, paragraf, na którym jest napisane: „Strajk uczelni”, nie „Strajk studencki”, więc to jest szersza formuła. Strajk uczelni - czyli pracownicy jak gdyby też w tym uczestniczyli. Myśmy [jako pracownicy] mieli takie nocne dyżury w tej starej auli, bo życie studenckie w nocy się toczyło. W ogóle były koszmarne warunki, materace, jakieś jedzenie, łazienki, a wszystko trwało 28 dni. Którejś nocy też solidarnie czekałam na rozwiązanie tej sprawy i w auli był występ Olka Grotowskiego ${ }^{115}$, takiego piosenkarza z Wrocławia. Olek Grotowski przyjechał, ludzi się tam zeszło bardzo dużo - na katedrze świece, on z gitarą, myśmy wszyscy na schodach siedzieli, a on śpiewał piosenki swoje, Andrzeja Waligórskiego i takie stare satyryczne, z Wrocławia. Ale poza tym jeszcze uczył piosenki o Piłsudskim

${ }^{113}$ Bohdan Baranowski (1915- 1993) - historyk, orientalista, regionalista, profesor Uniwersytetu Łódzkiego. Dyrektor Instytutu Historii w latach 1952-1956 i 1978-1981 oraz kilkakrotnie dziekan Wydziału Filozoficzno-Historycznego.

${ }^{114}$ Dodajmy, że Ilona Przybyłowska i Krzysztof Kistelski w swoim artykule pt. Organizowanie i kierowanie strajkiem studentów tódzkich zwracają szczególną uwagę między innymi na niewygody fizyczne, złe warunki noclegowe i sanitarne, jak i na zakłócony, całkowicie odwrócony rytm dnia i nocy (nocą prowadzono dyskusje, przepisywano teksty na maszynach, przygotowywano się do spotkań z przedstawicielami władzy. Zob. Jan Lutyński (red.), Strajk studentów tódzkich ' 81 w świetle analiz socjologicznych..., s. 82-83. Porównaj także: D. Kasprzyk, (Nie)codzienność strajkowa: studencki protest $w$ Lodzi ze stycznia-lutego 1981 r. z perspektywy antropologicznej, [w:] Krzysztof Lesiakowski (red.), Łódzki strajk studencki...

115 Olek Grotowski (ur. 1952) - kompozytor i wykonawca związany z wrocławskim środowiskiem kabaretowym i Studiem 202. 
takiej: „Jedzie, jedzie, na kasztance”. Powtarzaliśmy słowa, on grał i wszyscy śpiewali. Poza tym jeszcze taka historia: my na działce chcieliśmy mieć bardzo stół pingpongowy i ja gdzieś na Jaracza z ogłoszenia kupiłam taki stół. Ten stół jakoś za małe pieniądze ktoś nam dostarczył na Wydział i u mnie w pokoju on stał złożony. Jak był ten strajk, to któryś ze studentów przypomniał sobie o tym stole i stół został rozłożony. Niektórzy mieli klucze do naszego pokoju. Przecież studenci się tam zamęczali z nudów, bo ileż można siedzieć? Były rozmaite wykłady na sali gimnastycznej, było trochę zajęć sportowych, ale oprócz tego nie było nic. Nie można było wyjść, studenci stali na bramkach, okupacja trwała, trzeba było mieć przepustkę, żeby wyjść. Pamiętam, że na parterze ludzie oknami wychodzili choć na trochę, bo po prostu nie mogli wytrzymać. Na Uniwersyteckiej, gdzie miałam zajęcia na pedagogice, były pojedyncze ubikacje, takie oczka po prostu, bo łazienki zlikwidowano. Było kilka sal, materace porozścielane i jedna ubikacja po jednej stronie, a druga po drugiej. Negocjacje odbywały się na Wydziale Filologicznym i przedstawiciele wszystkich okupowanych gmachów chodzili przysłuchiwać się tym negocjacjom albo nagrywali i wieczorem rozchodzili się i relacjonowali studentom, co tam się działo. A na tej Uniwersyteckiej to wszyscy schodzili na klatkę schodową, żeby się spotkać i wysłuchać tych relacji. Ktoś stał na dole i krzyczał na te cztery piętra czy trzy. Naprawdę to było wielkie umęczenie tych studentów. I tak ja pamiętam ten postulat rosyjski bez przywilejów. I to było takie oczywiste przecież, prawda, że niech będzie język rosyjski, ale do wyboru. Podobno w związku z tym postulatem interweniował ambasador ZSRR, dlatego strajk trwał tak długo.

Krystyna Śreniowska, historyk, urodzona w 1914 roku we Lwowie absolwentka Uniwersytetu im. Jana Kazimierza, odpowiadając na pytanie prowadzącego wywiad „Jak wspomina pani strajki studentów w Łodzi na początku lat osiemdziesiątych?”, mówi:

Ja zawsze byłam po stronie młodzieży, bo mnie się wydawało, że jej rola polega na inicjowaniu czegoś nowego, że jej zadaniem jest tworzenie. Zawsze broniłam młodzieży. W każdym razie strajki akceptowałam na pewno. Byłam przekonana, że mają rację. Ja robiłam swoje - dydaktyka, wykłady, ćwiczenia - wszystko. Robiłam swoje, a tych, co się buntowali, wcale nie traktowałam gorzej, Boże broń!

Sięgnijmy jeszcze do wywiadu, który należy do przywoływanej wcześniej kolekcji wywiadów z osobami urodzonymi w latach 1945-1955 ${ }^{116}$ i przyjrzyjmy się relacji ówczesnego nauczyciela akademickiego, który opowiada o okupacyjnym strajku łódzkich studentów:

${ }^{116}$ Zob. przypis $1 \mathrm{w}$ tym rozdziale. 


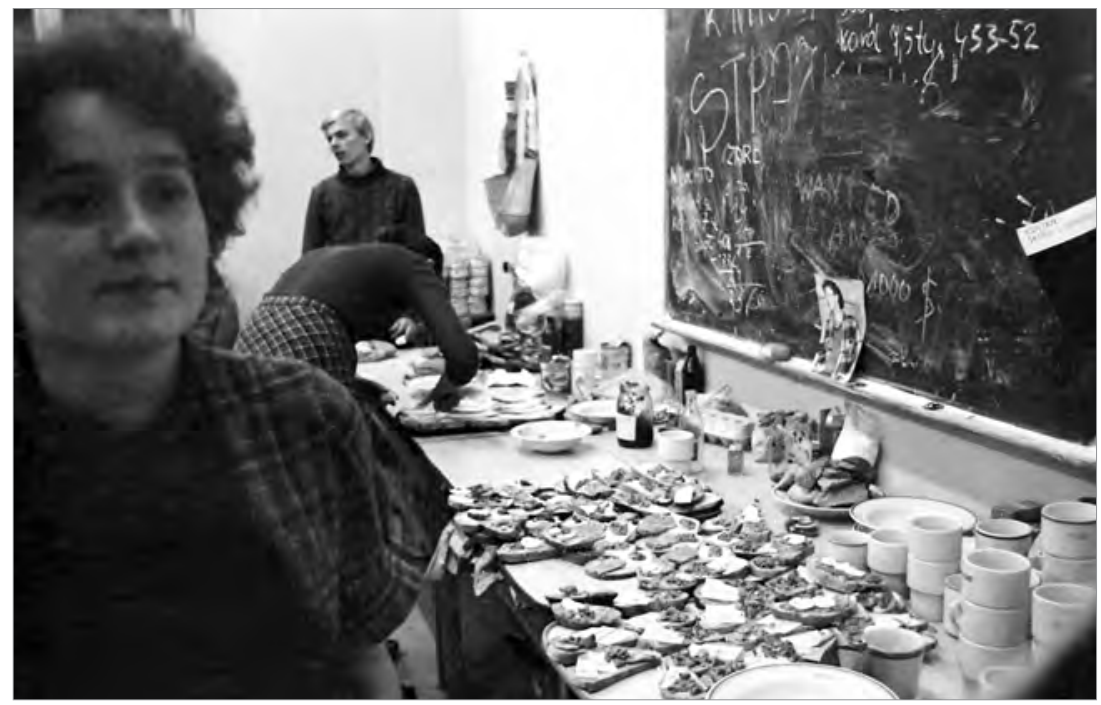

Fot. 60. Strajk studentów na Wydziale Ekonomiczno-Socjologicznym

Pani profesor wychodziła z takiego założenia, że tam, gdzie są uczniowie, tam powinni być nauczyciele i ponieważ ja byłem wśród tych nauczycieli, których studenci tolerowali, to ustaliśmy między sobą, że przyjeżdżałem na dyżury do studentów w nocy, ponieważ ja miałem małe dzieci. Nie ukrywam, że miałem wrażenie, jakbym uczestniczył w jakiejś wojnie i były to niesamowite sytuacje. Rano, tak byliśmy umówieni, składaliśmy sprawozdanie z tego, co się działo. A studenci zachowywali się bardzo porządnie, wbrew temu, co oficjalnie nagłaśniano. Ja wśród znajomych przynajmniej zaprzeczałem, że to nie jest tak, jak mówią. Myślę, że studenci nigdy tak nie jedli, jak w czasie strajku, bo ludzie przynosili zupy, jakieś pączuszki, jakiś tam kapuśniaczek, takie smakołyki. Natomiast nie było prawdą to, co w powszechnym obiegu rozgłaszano, że piją wódkę, alkohol, że dzieją się najprzeróżniejsze rzeczy. Uczestniczyłem w kilku takich nocnych dyżurach, a na jednym, nie ukrywam, że się bałem, bo robili jakąś mobilizację, bali się, że Uniwersytet będzie okrążany. Jeśli będzie to okrążenie, ta obława, to mieli taką instrukcję, jak się mają zachowywać. A ja się bałem, jak wrócę do mojej rodziny, do dzieci.

Na zakończenie części dotyczącej przebiegu strajku łódzkich studentów warto zasygnalizować, że zgromadzony materiał (również w ramach innych programów badawczych) nie pozwala nam na pełną rekonstrukcję wachlarza postaw kadry uniwersyteckiej w owym czasie, niemniej warto zarysować w tym miejscu przynajmniej niektóre z nich. Wspomnijmy zatem - odwołując się do prac brytyjskiego antropologa Victora Turnera 
- o postawie „strażników struktury" ${ }^{117}$ i tych, którzy w różny sposób towarzyszyli czy wspierali strajkującą młodzież akademicką w ich doświadczeniu communistas ${ }^{118}$ (spontanicznego wejścia w antystrukturę, któremu towarzyszy poczucie braterstwa, wspólnoty i mocy sprawczej wyrastające $\mathrm{z}$ relacji międzyludzkich a nie narzuconej powinności) ${ }^{119}$. Ci pierwsi postrzegali strajkową communitas jako swoiste zagrożenie dla porządku społecznego wynikające z "rozregulowania” normatywnych wzorów postępowania i ,zawieszenia” wymogu „zacności” ${ }^{120}$. Najczęściej wiązało się to z paternalistycznym traktowaniem studentów i postrzeganiem ich zachowania jako nierozważnego, nieprzewidywalnego, niebezpiecznego i, co za tym idzie, wymagającego nieustannej kontroli i nadzoru ${ }^{121}$. W zachowaniu drugich - w mniejszym lub większym stopniu stojących po stronie strajkujących - można dostrzec rozumienie communitas jako naturalnego procesu, który jest konieczny dla istnienia (w istocie kontestowanej) struktury, ale niesie ze sobą także potencjał dla przekształcania rzeczywistości. W tę sytuację wpisana jest - jak sądzą nauczyciele akademiccy - pewna doza ryzyka, przed którym chcieliby ochronić młodych ludzi lub przynajmniej dyskretnie pomóc im w przejściu tego etapu ${ }^{122}$.

Zwróćmy uwagę na jeszcze jedną kwestię związaną ze strajkiem łódzkich studentów w 1981 roku. Ewelina Nurczyńska-Fidelska pokazuje, jak w ich konsekwencji dokonała się tymczasowa zmiana personalna na kulturoznawstwie i ona sama została kierownikiem Zakładu Wiedzy o Filmie.

Cofnijmy się jeszcze. Nie ma stanu wojennego, jest rok 1980 - czas karnawału „Solidarności”, który oczywiście ogarnia także uczelnie. Do annałów akademickich wszedł wielki studencki strajk Uniwersytetu Łódzkiego, który odbywał się zimą 1981 roku. Studenci, wiadomo, żądali zmian programów, żądali wolności słowa, większych dotacji na szkolnictwo wyższe, ale żądali także pewnych zmian personalnych. I tak się wówczas stało, że po tym strajku

${ }^{117}$ Zob. Victor Turner, Proces rytualny: struktura i antystruktura, thum. Ewa Dżurak, Państwowy Instytut Wydawniczy PIW, Warszawa 2010.

${ }^{118}$ Communitas ma najczęściej miejsce w środkowej (zwanej marginalną czy liminalną) fazie rytuałów przejścia (opis których Turner zapożyczył od Arnolda van Gennepa) - a zatem po wyłączeniu ze „starego świata” a przed włączeniem do określonej grupy w nowej roli czy z nowym statusem społecznym (Victor Turner, Proces rytualny ..., s. 105).

119 Tamże.

${ }^{120}$ Marek Czyżewski, Repatrianci i wypędzeni: wzajemne uprzedzenia w relacjach autobiograficznych, [w:] Marek Czyżewski, Andrzej Piotrowski, Alicja Rokuszewska-Pawełek (red.), Biografia a tożsamość narodowa, wyd. 2, Katedra Socjologii Kultury, Łódź 1997, s. 170.

${ }^{121}$ Zob. Andrzej Czyżewski, ,, Niemniej to jest farsa, która może być groźna”...

${ }^{122}$ Postawy te (często mające też protekcjonalny charakter) mają swoje rozmaite odcienie, na omówienie których nie ma tutaj miejsca. 
studenckim, który toczył się głównie na Wydziale Filologicznym, na Kościuszki, gdzie studenci wszystkich łódzkich uczelni protestowali, wynikiem tych buntów studenckich było także odejście pani docent Wertowej ${ }^{123} \mathrm{z}$ funkcji kierownika zakładu. Wówczas ja, jako doktor jeszcze „niewyhabilitowany”, myślę że wskutek opinii pana profesora [Bolesława Lewickiego], zostałam mianowana przez rektora na kierownika zakładu i byłam nim przez prawie dwa lata, bo zimą 1981 roku przyszedł stan wojenny i pewne struktury i układy personalne powróciły do czasu przeszłego. Kierownikiem zakładu została na powrót pani docent Pola Wertowa. A ja funkcję kierownika już pełnoprawnego, „wyhabilitowanego” objęłam w 1990 roku.

\section{Okres stanu wojennego}

13 grudnia 1981 został w Polsce wprowadzony stan wojenny. Generał Wojciech Jaruzelski na mocy uchwały Rady Państwa zdecydował o oddaniu władzy w ręce administracji wojskowej „celem zaprowadzenia porządku publicznego" 124 . Rozpoczęły się internowania działaczy opozycji antykomunistycznej - przede wszystkim Komisji Krajowej „Solidarność”, ograniczono możliwość poruszania się na terenie kraju, wstrzymano wyjazdy za granicę, przerwano łączność telefoniczną, wprowadzono godzinę milicyjną, zaostrzono cenzurę oraz wzmożono kontrolę nad sferą kultury i nauki.

Eugeniusz Czerniawski w cytowanym poniżej fragmencie opowiada o swojej pierwszej reakcji na wieść o wprowadzeniu stanu wojennego, która jednocześnie ujawnia definicję sytuacji ${ }^{125}$, kierującą wówczas jego działaniem. Przede wszystkim jego poprzednie doświadczenia z władzą komunistyczną i świadome śledzenie sytuacji politycznej w Polsce, jak też krytyczne nastawienie wobec Związku Radzieckiego pozwoliły mu (nawet jeśli jego ówczesna wiedza na temat tego, co się właściwie dzieje, była niepełna) na wyobrażenie sobie potencjalnych konsekwencji wprowadzenia stanu wojennego. Definicja sytuacji, jaką wówczas posiadał narrator, wydaje się jasna: z pewnością wielu ludzi znalazło się w bardzo trudnym położeniu, a to oznacza, że należy im pomóc ${ }^{126}$. W ten sposób dowiadujemy

${ }^{123}$ Pola Wertowa (1925-1987) - docent na Uniwersytecie Łódzkim, w latach 1959-1984 pracowała w Zakładzie Wiedzy o Filmie, zajmowała się telewizyjnymi widowiskami teatralnymi.

${ }^{124}$ Przypomnijmy, że stan wojenny został zawieszony 31 grudnia 1982 roku, a zniesiony 22 lipca 1983 roku.

${ }^{125}$ Odwołujemy się tutaj do koncepcji Williama I. Thomasa, który pisał: „Jeżeli ludzie definiują sytuacje jako realne, to są one realne w swoich konsekwencjach" (William I. Thomas, Dorothy Swaine Thomas, The Child in America: Behavior Problems and Programs, Knopf, New York 1928, s. 572).

${ }^{126}$ To podstawowa zasada zdroworozsądkowej wiedzy: należy pomagać innym, jeśli tego wymagają okoliczności. Jak sugeruje Fritz Schütze: „W potrzebie ludzie udzielają sobie wzajemnie 
się także o systemie wartości narratora i jego hierarchii istotności. Zanim odwołamy się do jego słów, warto jeszcze zauważyć, że Eugeniusz Czerniawski zawsze bardzo mocno był związany z Kościołem katolickim i zaangażowany w jego działalność społeczną. Nie powinno być zatem zaskoczeniem, że od razu wykorzystuje tę sieć powiązań.

Jak ogłoszono stan wojenny? Rano w niedzielę włączam radio, słyszę Jaruzelskiego i jakie uczucie mi się przypomina? - wywózka z Wilna, kiedy ludzie wyjeżdżali, niektórzy tak jak stali. Wtedy pomyślałem, że trzeba coś zrobić. To była niedziela. We wtorek byłem u biskupa Rozwadowskiego. Powiedziałem, że chcę zrobić paczki dla rodzin osób internowanych. Paczki mają być świąteczne, żeby ich wzmocnić, żeby nie zostali sami. Biskup wyraził zgodę. Wobec tego poszedłem do pani doktor Majewskiej ${ }^{127}$ tutaj w kościele św. Teresy. Mówię, jak jest sprawa, muszę znaleźć miejsce. Ona na to, że przychodnię plebania tutaj na dole miała i ona ją udostępni. A w dodatku, ponieważ zajmowała się pijakami, to miała znaczek ormowski ${ }^{128}$ i się śmiała. Mówię: dobrze. Proboszcz się zgodził. Ja pojechałem syreną, dwa kursy zrobiłem z obecnym prorektorem Antosiem Różalskim ${ }^{129}$ i razem po tym śniegu przywieźliśmy worek mleka i różne produkty żywnościowe. Zrobiłem czterdzieści paczek. Na to mleko w pracowni z rękawa zrobiłem woreczki i mówię: tam gdzie są dzieci małe, obojętnie partyjne czy niepartyjne, to mleko ma być, a paczki muszą być dostarczone. Koleżanka z zakładu okazała się świetna: wyszukiwała adresy i zorganizowała kilka osób do roznoszenia. Niektórzy byli poza Łodzią, to trudno było, ale i tak paczki poszły. A później ta koleżanka trafiła do ojca Miecznikowskiego ${ }^{130}$, bo on przez ten czas też prowadził pomoc i potwierdzał,

pomocy, w każdym razie tak być powinno" (tegoż, Trajektorie cierpienia jako przedmiot badań socjologii interpretatywnej, „Studia Socjologiczne” 1997, nr 1, s. 41). Pomoc ta winna na dodatek przybrać „normalną formę”, która bazuje na: „interakcyjnej wzajemności i kooperacji” (tamże).

${ }^{127}$ Aleksandra Majewska (1907-1990) - doktor pedagogiki, przedwojenna działaczka społeczna, asystentka prof. Heleny Radlińskiej, organizatorka Izb Wytrzeźwień w Łodzi, związana z Zakładem Pedagogiki Społecznej Uniwersytetu Łódzkiego.

${ }^{128}$ Dr Majewska za swoją działalność społecznikowską otrzymała ORMO-wskie odznaczenie. Dodajmy, że była to organizacja, której działalność stała w całkowitej sprzeczności z jej światopoglądem. Przypomnijmy, że ORMO - Ochotnicza Rezerwa Milicji Obywatelskiej, to w zamierzeniu ochotnicza paramilitarna forma wsparcia dla Milicji Obywatelskiej i reżimowego systemu mająca na celu kontrolę i nadzór nad społeczeństwem. Członkowie ORMO rekrutowali się zazwyczaj z robotników i członków PZPR.

${ }^{129}$ Antoni Różalski (ur. 1952) - mikrobiolog, immunobiolog bakterii, professor na Wydziale Biologii i Ochrony Środowiska. Obecnie prorektords. nauki UŁ

${ }^{130}$ Stefan Miecznikowski ( 1921-2004) - jezuita, kapelan łódzkiej „Solidarności”. Po wprowadzeniu stanu wojennego, podjął szereg inicjatyw na rzecz opozycji: powołał do życia Ośrodek Pomocy Uwięzionym i Internowanym, sporządzał listy aresztowanych i internowanych, organizował pomoc dla rodzin zatrzymanych i samych aresztowanych, odwiedzał ich w ośrodkach odosobnienia, 
że ona jest świetna do wyszukiwania. Nikt nie wiedział, co ja reprezentuję. $\mathrm{Z}$ „Solidarności” kwiaty dostałem i takie różne rzeczy.

Biruta Lewaszkiewicz-Petrykowska, znana ze swojej nonkonformistycznej postawy manifestującej się w dystansie i ironii wobec reżimu komunistycznego i ówczesnej władzy, wspomina o dwóch epizodach związanych z okresem stanu wojennego:

Potem wprowadzono stan wojenny. Ten strajk to znana sprawa [mowa o strajku okupacyjnym budynku Wydziału Prawa i Administracji, który rozpoczął się 14 grudnia 1981 roku z inicjatywy NZS], potem pacyfikacja naszego Wydziału [przez milicję i oddziały ZOMO 15 grudnia 1981 roku]. O tym, jak bili w rektoracie ${ }^{131}$, to przecież też pani wie ${ }^{132}$. Niepotrzebnie zamknięty był ten rektorat. Zawsze jak wpadną wtedy tacy, to leją kogo popadnie. Nawiasem mówiąc, I Sekretarz Egzekutywy oberwał. Studenci zresztą wszyscy uciekli wtedy. Część wyszła z biskupem [Bejzem] ${ }^{133}$, a ci, którzy zostali, potem zdążyli uciec tyłem przez nasz dziekanat. A potem było ponowne otwarcie zajęć. Były bramki. Sprawdzało się legitymację studencką, czy ktoś spoza studentów nie wchodzi. Ja pamiętam taką sytuację, jak u nas ustawiono te bramki i na parterze kłębią się studenci, którzy weszli, część z nich już wchodzi na górę i raptem widzę, że po cywilnemu oczywiście idzie pan kapitan i jakaś dwójka z nim. On wchodzi. Ja wtedy powiedziałam głośno, tak żeby wszyscy studenci usłyszeli: „Panie kapitanie, a cóż pana do nas sprowadza?”. Studenci stanęli, natychmiast wszyscy się odwrócili. Błyskawicznie się zorientowali, o co

wspomagał osoby pozbawione pracy i środków do życia. Regularnie odprawiał msze za Ojczyznę w łódzkim kościele oo. jezuitów. w 1992 otrzymał także honorowe obywatelstwo miasta Łodzi.

${ }^{131} \mathrm{~W}$ tym miejscu warto wyjaśnić tym, którzy nie znają topografii miasta i lokalizacji poszczególnych budynków Uniwersytetu, że między ówczesnym gmachem Wydziału Prawa i Administracji przy ulicy Składowej a znajdującym się na rogu równoległej ulicy Lindleya i prostopadłej ulicy Narutowicza budynkiem, który do jesieni 2015 roku był rektoratem UŁ, wybudowano w 1976 roku tzw. ,jamnik" - długi, blaszany budynek (biegnący wzdłuż ulicy Narutowicza), który miał służyć coraz to liczniejszym rocznikom studentów prawa. Co istotne dla tej opowieści, z owego ,jamnika" można było dostać się do obu budynków.

${ }^{132}$ Sięgamy tutaj do wspomnień ówczesnego studenta prawa Krzysztofa Strausa opublikowanych na stronie www.uml.lodz.pl/get.php?id=433 (15.03.2015), który tak opisuje rolę prof. Petrykowskiej w strajku z grudnia 1981 roku: ,, Z panią profesor mieliśmy bliższe spotkanie podczas solidarnego czekania. W tej akcji uczestniczyło kilkunastu ludzi z Wydziału. Byliśmy zupełnie nieprzygotowani do okupacji budynku, bez sprzętu do spania i bez jedzenia. Gdzieś koło godziny 19-20 przyszła do nas pani profesor, a my zebraliśmy się wokół niej. Wtedy ona zaczęła przekonywać nas, że ze względów bezpieczeństwa powinniśmy wrócić do akademika. Nie wytrzymał tego Wiesiek Urbański, który zwrócił się do pani profesor ze słowami: «I kto to mówi? Żołnierz AK, uczestnik powstania warszawskiego». Pani profesor zapytała, skąd to wszystko wiemy, a po chwili oświadczyła, że zostaje z nami. W takiej małej kobiecie tyle bohaterstwa - od tej pory zacząłem inaczej patrzeć na prawo cywilne.

${ }^{133}$ Biskup Bohdan Bejze przekonał dużą część młodzieży do opuszczenia budynku. 
chodzi. Stanęli tacy nastroszeni. On miał strasznie głupią minę, tłumaczył, że oni do dziekanatu, tutaj koledzy chcą przedłużenie. „No to pan kapitan nie wie, że dziekanat jest na Lindleya? Tutaj, z tej strony nie ma tam wejścia. Proszę wrócić". Wyszli. [śmiech]. Zdarzały się sytuacje komiczne [śmiech]. Pamiętam z czasu stanu wojennego wykład na studiach zaocznych i widzę, że w ostatniej ławce siedzi jakiś bubek i lekko sobie przysypia [śmiech]. Mam niezłą pamięć, wprawdzie ich tam była setka na tych zaocznych, ale człowiek mniej więcej twarze pamięta i ten coś mi się wydał podejrzany. Więc skończyłam temat, a mówiłam o odpowiedzialności cywilnej i myślę sobie, że zaraz się przekonam, kto to jest ten, co przysypia, bo inni notują, a ten nie notuje. I mówię: „A teraz, proszę państwa, skończyliśmy to zagadnienie, więc porozmawiamy sobie o solidarności”. Powiedziałam bardzo głośno. I w tym momencie widzę jak tamten się obudził. I ja mówię: „W przypadku wyrządzenia szkody przez kilka osób zgodnie z artykułem takim i takim odpowiedzialność jest solidarna" [śmiech]. Ta jego mina! Oni rzeczywiście przysyłali różnych swoich. Myśmy nawet w pewnym momencie protestowali.

Odwołajmy się raz jeszcze do relacji cytowanego wcześniej nauczyciela akademickiego, który był naocznym świadkiem wydarzeń, jakie rozegrały się na Uniwersytecie po wprowadzeniu stanu wojennego:

Przyjechałem na dyżur, to była środa. Stan wojenny został ogłoszony trzynastego, w nocy z soboty na niedzielę. Ja w środę miałem dyżur i przyjechałem. Studenci wywiesili wielki transparent informujący o strajku i moje koleżanki tam też stały. Ja postanowiłem do nich dołączyć, tylko wszedłem najpierw do budynku, żeby zostawić jakieś klamoty. I oczywiście nie zdążyłem. Kiedy wszedłem, ZOMO ze wszystkich stron okrążyło budynek. Niesamowite to było, bo myśmy ludzi przypadkowych zupełnie uratowali, wybawili z opresji. Jakiegoś mężczyznę i kobietę, którzy nie wyglądali absolutnie jak rewolucjoniści. Wpuściliśmy ich do budynku na Uniwersyteckiej 3 i zabarykadowaliśmy ten budynek jakąś ławką. Po drodze kolega kazał im się rozbierać, a więc rozbieraliśmy ich tam z kożuchów, z ich odzienia i kolega udzielał im instrukcji, żeby w razie czego mówili, że oni tu są pracownikami. Jakieś klucze wyrzuciliśmy do kosza, których potem nie mogłem znaleźć. A samo natarcie: staliśmy w oknie, a tam są takie galeryjki i jakaś kobieta, która zabłąkała się, nie miała wyjścia, bo ze wszystkich stron nacierali zomowcy, z Uniwersyteckiej, z Narutowicza z jednej strony i od strony placu Dąbrowskiego. I ta kobiecina chciała przejść na drugą stronę, tam jest taki wieżowiec, a oni na nią lali wtedy wodę, było minus 16 stopni, to na niej to odzienie tylko fruwało! Ktoś wybiegł z bramy, z przeciwnej strony i ją wciągnął tak za ręce do tej bramy. Pani profesor wtedy wygłosiła taką sentencję: „,widzicie, to są też ludzie, a waszym zadaniem, bo wy jesteście wychowawcami, jest rozbroić tych ludzi bez użycia 
sił. To jest zadanie wychowawcze". Sytuacja była [wzruszenie] niesamowita. Ja myślałem, że będę wracał na pieszo do domu, telefony nie były czynne, więc tu koledzy już oferowali mi nocleg, a ja mówię: ,a w życiu nie, ja jadę do domu". Jeszcze na dworcu czuć było gaz łzawiący. Drzwi do budynku uniwersytetu wyrąbane. Ja o tym wydarzeniu opowiadałem później w domu i mówię: „Ci zomowcy będą mogli napisać, że byli na Uniwersytecie”. Oni podobno wtedy wygarnęli wszystkich, łącznie z sekretarzem partii, tak jak wszyscy stali. Podobno tak było, ale tego świadkiem nie byłem. Natomiast świadkiem ataku byłem. I gdyby mieli inną komendę, bo oni wiedzieli, że myśmy wbiegli do tego budynku na Uniwersyteckiej 3, to oni by nas tam wszystkich wygarnęli i nie wiem, co by się stało, ale była inna komenda i myśmy tam w tym budynku przeczekali, widząc, co się dzieje, jak lano wodą, jak bito ludzi. Ale było też coś, co nas cieszyło. To było zdumiewające, taka radość się we mnie zrodziła, kiedy ludzie odrzucali petardy w tłum tych zomowców. Popłoch był niesamowity, a we mnie radość jakaś. To pamiętam z okresu strajku w stanie wojennym. Przejrzeli nam wszystkie biurka. Wtedy wielkie, chwalebne zadanie miała do spełnienia nasza pani profesor, która była prodziekanem do spraw studenckich: ona odwiedzała tych studentów aresztowanych w stanie wojennym, organizowała tam ich, wzmacniała i wpierała - to było takie piękne.

\section{Obrady Okrągłego Stołu i transformacja ustrojowa: „ziścił się sen, ale zapowiadała się droga przez mękę"...}

Przyjrzyjmy się teraz, jak Jerzy Dietl (ekonomista i członek ,Solidarności”, w latach 1989-1991 senator Ziemi Łódzkiej) opowiada o tym, jak doszło do tego, że stał się uczestnikiem obrad Okrągłego Stołu, jak ocenia reformy Balcerowicza i przebieg transformacji ustrojowej, oraz jak wraz z Cezarym Józefiakiem ${ }^{134}$ próbował do nich przekonywać łódzkich robotników.

To była fundacja ${ }^{135}$, a dokładniej taka fundacja in spe - nie było wtedy podstaw prawnych do jej utworzenia, ale były propozycje otrzymania dość dużych funduszy z Austrii i Niemiec, głównie za pośrednictwem „organów kościelnych”, tzn. przy pomocy prymasów i episkopatów tych krajów, jak również dużych

${ }^{134}$ Cezary Józefiak (1932-2007) - ekonomista, wieloletni pracownik i profesor Uniwersytetu Łódzkiego, doradca „Solidarności”, senator I kadencji w wyborach w czerwcu 1989 roku.

${ }^{135}$ Mowa tu o Fundacji Rolniczej Episkopatu Polski działającej w latach 1981-1987, która na mocy porozumienia z episkopatami krajów zachodnich miała nieść pomoc polskim rolnikom. W skład Komitetu Organizacyjnego Fundacji Rolniczej powołanej w kwietniu 1984 roku przez Józefa Glempa, ówczesnego Prymasa Polski, weszli m.in. ks. Alojzy Orszulik, Andrzej Sołtysiński, Wiesław Chrzanowski, Jerzy Dietl, Jan Górecki, Janusz Haman, Maria Radomska, Witold Trzeciakowski, a na jej czele stanął Andrzej Stelmachowski. Zob. więcej na: www.encyklopedia-solidarnosci. pl/wiki/index.php?title=T01567_Fundacja_Rolnicza_Episkopatu_Polski. (18.04.2015). 
funduszy ze Stanów Zjednoczonych w okresie prezydentury Reagana, na to, żeby stworzyć coś w rodzaju rynku rolnego - wieś miała otrzymać bardzo dużą pomoc finansową. Myśmy mieli koncepcję i właściwie ja byłem jej głównym autorem - ta pomoc w dużej mierze miała przyjść w postaci produktów, również maszyn, nawozów, nierozdawanych jako dary, tylko sprzedawanych. Zyski miały zostać przeznaczone na infrastrukturę rolną. To był jeszcze okres Breżniewa, także to spaliło na panewce, ale później powstały dwie takie fundacje. W tej chwili w dalszym ciągu jest Fundacja Wspomagania Wsi, gdzie jestem ,wiecznym” członkiem tej rady. Spiritus movens był tam Andrzej Stelmachowski ${ }^{136}$, który był z nami w komitecie Badania Regionów Uprzemysłowionych, z którym się bardzo zresztą przyjaźniłem, bo w Poznaniu dwa lata u nas mieszkał. To on mnie właściwie wciągnął do obrad Okrągłego Stołu. Tam były te stoliczki, ja byłem przy stoliku rolnym. Pani zapewne wie, że byłem aktywny w tym okresie, kiedy był wprowadzany plan Balcerowicza i jeśli się mnie pyta, kto jest moim guru, to mogę powiedzieć, że Leszek Balcerowicz ${ }^{137}$. Niesłychanie go ceniłem i cenię nadal. Uważam go za człowieka wyjątkowej uczciwości i szlachetności, wielkiego patriotę. Byłem przewodniczącym nadzwyczajnej komisji w Senacie do wprowadzania tych reform, dlatego referowałem dość znaczną liczbę ustaw, które plan Balcerowicza wprowadzał w życie, tak to można nazwać.

Agata Zysiak: A po latach jak pan ocenia transformację? To bardzo trudny proces.

Jerzy Dietl: Transformację oceniam bardzo dobrze, tzn. uważam, że była ona jedynym rozsądnym rozwiązaniem. Boleję natomiast nad tym, że nie została ona ukończona. W dalszym ciągu nasze państwo jest nadmiernie zetatyzowane. Reformy są niedokończone i będziemy za to płacić. Również nie dokończono reform, które by pobudziły indywidualną przedsiębiorczość. Na pewno nie jestem krytyczny w stosunku do obecnego rządu [PO], bo uważam, że w obecnej sytuacji nic lepszego nie jest osiągalne. A poprzedniej władzy [PiS] nie uważam za lepszą, tylko za gorszą. W każdym razie jestem bardzo optymistycznie nastawiony i uważam, że powinniśmy sobie zdawać sprawę, że ziścił się ten sen, który w moim pokoleniu był tylko snem. A oczywiście, jak myśmy z Czarkiem Józefiakiem uczestniczyli w spotkaniach z robotnikami, większość z nich odbywała się w fabrykach, to jak dziś pamiętam, że mówili: „Co tam pan profesor mówi, wystarczy tych komuchów wywalić i już. Wszystko będziemy mieli, Ameryka nam pomoże". Na każdym takim posiedzeniu z Czarkiem

${ }^{136}$ Andrzej Stelmachowski (1925-2009) - prawnik i polityk, nauczyciel akademicki, marszałek Senatu I Kadencji, minister edukacji narodowej w rządzie Jana Olszewskiego.

${ }^{137}$ Leszek Balcerowicz - ekonomista i polityk, pracownik akademicki, wiceminister i minister finansów w rządach Tadeusza Mazowieckiego, Jana Krzysztofa Bieleckiego i Jerzego Buzka, prezes Narodowego Banku Polskiego. 
mówiliśmy, że to będzie droga przez mękę. Tu nie ma nic innego jak droga przez mękę, która i tak była mniejsza niż myśmy się spodziewali, bo mieliśmy ciągle dług, którego nam połowę podarowali.

Michał Seweryński, podsumowując czas transformacji, mówi:

Wszyscy przyjęli transformację $\mathrm{z}$ otwartymi ramionami. Kiedy ja zostałem rektorem i od ' 90 roku weszła nowa ustawa o szkolnictwie wyższym, która dawała pewne ramy prawne, to nawet ci, którzy wcześniej byli apologetami komunizmu i PRL nie wypowiadali się krytycznie - przycichli, albo, jeśli tak można powiedzieć, nawrócili się na nową wiarę, zajęli postawę konformistyczną. Niektórzy nawet bardzo konformistyczną. Albo gdzieś wyjechali. Nawet ci, który nie byli w „Solidarności”, ci, którzy nie podnosili żadnych krytyk pod adresem dawniejszego systemu, uważali, że dobrze, że już się skończył, że w tym nowym będzie się żyło lepiej, lepiej pracowało. Najlepszy dowód to to, że jakichś dramatycznych odejść czy zerwania z Uniwersytetem ze względu na nowy porządek polityczny właściwie nie było. Pojawiły się prywatne rozmowy o charakterze rozliczeniowym, bo przecież otwarła się wolność mówienia i pisania, więc dowiadywaliśmy się o wielu sprawach, o których wcześniej nie wszyscy wiedzieli. Pojawiały się różne wypowiedzi oceniające te wcześniejsze lata. Taki był obraz uczelni po ' 89 roku. Ale nawet ci, którzy wcześniej deklarowali się jako komuniści, zostali, bo uczelniach nie było czystki politycznej. Lustracja była w pewnym momencie rozpoczęta, ale potem na skutek orzeczenia Trybunału Konstytucyjnego ona została zastopowana i już potem do niej nie wrócono. Nie było więc jakiegoś generalnego rozliczenia w skali całego kraju i na uczelni. Ale oczywiście przestrzeń swobody wypowiedzi się zwiększyła, zwłaszcza w naukach społecznych, filozoficznych, humanistycznych. Trzeba było wyrzucić stare wykłady i przygotować nowe. Niektórzy zrobili to z zadowoleniem, inni bez. Niektórzy musieli zmienić język. Wiele książek można było spalić...

Zamykając tę część naszej książki, w której podjęłyśmy próbę rekonstrukcji historycznych i społecznych wydarzeń wpisanych w indywidualne losy naszych rozmówców, raz jeszcze chcemy podkreślić, że żadną miarą nie było naszym celem ustalenie tzw. ,prawdy obiektywnej” czy ocena postaw poszczególnych osób. Dążeniem naszym było przede wszystkim ukazanie wielości możliwych postaw narratorów i współczesnych sposobów ich prezentacji przez nich samych.

Pozostawiając przeszłość za sobą, spójrzmy jeszcze przez chwilę oczyma profesorów Uniwersytetu Łódzkiego na współczesne wydarzenia i przemiany. 


\section{„Niepokojąca współczesność” 138}

Współczesne przemiany akademii napawają lękiem i rozgoryczeniem wielu nauczycieli uniwersyteckich, szczególnie tych, którzy mogą sięgnąć pamięcią do różnych okresów jej funkcjonowania i porównać, co było kiedyś i jak jest teraz. Społeczno-kulturowe zmiany zachodzące na uniwersytecie wielu naszym rozmówcom przywodzą na myśl dążenie do stworzenia zeń instytucji o zupełnie innym charakterze i odmiennych celach działania - sprawnie działającego wolnorynkowego ,przedsiębiorstwa”, dla którego najważniejszy jest „wizerunek” i „klient”, a nadrzędną wartością staje się bycie kreatywnym, przedsiębiorczym i konkurencyjnym. Zmierzymy się z tym problemem raz jeszcze w ostatnim, podsumowującym rozdziale tej książki, najpierw jednak oddajmy głos profesorowi biologii Uniwersytetu Łódzkiego Andrzejowi Piechockiemu:

Kończąc moją opowieść, zwrócę uwagę na to, że dla nas problemem jest, a przynajmniej ja tak uważam, żeby nie zgubić w obecnej sytuacji, prowadzącej do zurzędniczenia nauki, roli uniwersytetów w kultywacji badań naukowych. Uniwersytet staje się jedną z instytucji realizujących plany gospodarczo-państwowe, a zapomina się o tym, że głównym powołaniem uczelni typu uniwersyteckiego jest prowadzenie badań podstawowych. Dlatego powiem tak: pełny zespół naukowy powinien obejmować osobę menadżera, ale jednocześnie powinien skupiać ludzi, którzy na sprawach organizacyjnych może mniej się znają, ale za to mają głęboką wiedzę dotyczącą badanych zagadnień. Niewątpliwie dużo zyskaliśmy dzięki kontaktom zagranicznym. Te kontakty w naszej Katedrze się kultywuje, rozwija, przyjeżdżają do nas specjaliści z zagranicy, my wyjeżdżamy. Jest obecnie możliwość uczestniczenia w kongresach, konferencjach i seminariach. Znacznie się poprawiło finansowanie nauki w stosunku do lat, które ja pamiętam, chociaż nadal jest jeszcze niedostateczne. Mam natomiast osobiste zastrzeżenia co do priorytetów, które się przed nami stawia. Jest to zwłaszcza rygorystyczny wymóg publikowania w czasopismach $z$ listy filadelfijskiej, co jest rzeczą w zasadzie słuszną, ponieważ są to periodyki o wyrobionej renomie i światowym zasięgu. Ale powszechne i rygorystyczne spełnianie tej ,filadelfijskości” skazuje polskie wydawnictwa naukowe na upadek i lub marną wegetację. Jeżeli najlepsi specjaliści publikują wyłącznie w czasopismach zagranicznych, to dla polskich wydawnictw niewiele zostaje. Mało tego, my w ten sposób wygubimy kadrę fachowców którzy potrafią redagować teksty naukowe i mają osiągnięcia w tej dziedzinie. Byłbym tutaj ostrożny i nie wywyższał tej bez zastrzeżeń „międzynarodowości”. Uważam,

${ }^{138}$ Nawiązujemy tutaj świadomie do książki pod redakcją Anity Miszalskiej i Kazimierza Kowalewicza o takim właśnie tytule - Niepokojąca współczesność: zbiór, Instytut Socjologii Uniwersytetu Łódzkiego, Łódź 2001. 
że krajowe wydawnictwa też powinny a się rozwijać, zwłaszcza że stwarzają pole startu dla młodych naukowców, wybitnych amatorów i nauczycieli. Część $\mathrm{z}$ nich może być wydawana $\mathrm{w}$ języku angielskim także u nas, $\mathrm{w}$ tym nie ma nic złego. Warto przytoczyć przykład Holandii, gdzie takie serie wydawnicze jak „Nederlandse Fauna” wychodzą w języku niderlandzkim, co dziwi część specjalistów europejskich. Tymczasem praktyczni Holendrzy, wyznają zasadę że obok „rynku” międzynarodowego istnieje pole lokalne, przeznaczone dla tej społeczności, żyjącej w ich kraju. Warto zaznaczyć, że rola nauki polega m. in. na nadaniu temu, co lokalne, wartości uniwersalnych.

Biruta Lewaszkiewicz-Petrykowska tak mówi o nastawieniu współczesnego młodego pokolenia:

Jest inaczej, jest inne podejście. Wśród studentów zawsze są przodujący i lenie, to wiadomo. Jest między nimi spora konkurencja. Może dawniej bardziej współpracowali. To jest jedna sprawa. Natomiast jeśli chodzi o pracowników, w szczególności młodszych, też jest jakieś inne podejście. Widać, że ludzie zachłysnęli się konsumpcją, że jest ważna możliwość robienia pieniędzy. I akurat w pewnym momencie, gdy chodzi o prawo, to takie możliwości były spore. Dla wielu sprawy Uniwersytetu przestały być najważniejsze. To mnie zresztą wkurza, muszę powiedzieć.

Wydaje się, że w uwieńczeniu tego rozdziału przychodzi nam w sukurs nasz nauczyciel - Zbigniew Bokszański, socjolog, który wprowadzając swoją opowieść we współczesność, puentuje:

Jak słyszę dzisiaj, jak to nauczyciele akademiccy ubiegają się o miano najbardziej przyjaznego studentom wykładowcy, to myślę sobie, że to chyba w niewłaściwą stronę idzie. Szkoła wyższa nie jest miejscem, w którym się prawi komplementy, tylko po prostu się w sposób rzeczowy mówi, na czym polega ta gra, w którą się weszło, i stosuje się kryteria, które pozwalają spojrzeć i ocenić, co jest jakimś sukcesem większym czy mniejszym, a co jest po prostu niedociągnięciem bądź brakiem, który koniecznie trzeba przezwyciężyć. Szkoły wyższe stały się po prostu rodzajem stojącego na trochę wyższym poziomie, chociaż też nie zawsze, dobrego liceum, łącznie z nauczycielami, którzy po prostu sprawdzają te setki prac i patrzą bez przerwy na zegarek, na kalendarz. To jest jeszcze jedna uwaga, którą tu chciałbym wyeksponować, że im dalej sięgam wstecz, tym bardziej mam takie wrażenie, że byłem bardziej wolny jako człowiek. Wolny w tym sensie, że mogłem sam sobie wyznaczać lektury, zainteresowania. W tej chwili, jeżeli mam cztery programy zajęć, to one znakomicie mi załatwiają cały rok, ponieważ nawet przejrzenie notatek przed wykładem, a ja przynajmniej mam taką pamięć, że nie mogę odwołując się do swoich zajęć z ubiegłego roku, zważywszy, że program i lektury się zmieniają, 
nie mogę pójść na zajęcia, nie spędzając pół godziny w przeddzień na przeglądaniu notatek, uporządkowaniu, dopisaniu czegoś sobie, skreśleniu, dodaniu. Więc to wszystko jest rzeczywiście niesłychanie time consuming [śmiech] i chyba w przeszłości trochę więcej czasu mieliśmy. Nie było Internetu, który też pochłania bardzo wiele czasu. W ogóle przybyło informacji. Jesteśmy jednak zalewani nią i pozostała w nas jeszcze, szczególnie w starszym pokoleniu jak myślę, ta tendencja, żeby dokonać jakiegoś systematycznego przeglądu tego, co jest. Co jest straszliwą strategią. To jest niemożliwe do zrobienia dzisiaj. 


\section{Rozdzial V. Konteksty polityczne}

Sebastian Zaborowski: Potem, kiedy tutaj już w Lodzi zacząt się budować
Uniwersytet, to jak pani była ustosunkowana do tej nowej rzeczywistości
politycznej?

Krystyna Śreniowska: Proszę pana, no entuzjazmem nie pałałam, ale cóż, nie było innego wyjścia, prawda. Nie można wciąż żý́ w opozycji. Człowiek chce normalnie funkcjonować $i \dot{z} y c ́$.

Z wywiadu z profesor Krystyną Śreniowską

W ostatnim czasie powstaje wiele opracowań dotyczących okresu PRL, w różny sposób opisujących ideologiczne presje i uwikłania zwykłych ludzi, ale przede wszystkim elit symbolicznych w odniesieniu do różnych kontekstów życia społecznego ${ }^{1}$. Naszym celem nie jest ich systematyczna analiza, lecz ukazanie obrazu epoki socjalizmu z perspektywy naszych rozmówców, którzy po latach przytaczają i komentują różne sytuacje i wydarzenia z ich politycznym tłem. Należy przy tym pamiętać, że ponad czterdziestoletnią historię $\mathrm{PRL}^{2}$ charakteryzuje swoista dynamika

\footnotetext{
${ }^{1} \mathrm{~W}$ przypadku rozważanej tu problematyki na szczególną uwagę zasługuje książka Ryszarda Herczyńskiego Spętana nauka: opozycja intelektualna w Polsce 1945-1970, Wydawnictwo Naukowe Semper, Warszawa 2008, oraz zbiór tekstów Hanny Świdy-Ziemby, Człowiek wewnętrznie zniewolony. Mechanizmy i konsekwencje minionej formacji: analiza psychosocjologiczna, Instytut Stosowanych Nauk Społecznych, Warszawa 1997. Zob. również Maria Hirszowicz, Pułapki zaangażowania: intelektualiści w stużbie komunizmu, Wydawnictwo Naukowe Scholar, Warszawa 2001; Rafał Stobiecki, Historiografia PRL: ani dobra, ani mądra, ani piękna ... ale skomplikowana. Studia i szkice, Wydawnictwo Trio, Warszawa 2007; John Connelly, Zniewolony uniwersytet: sowietyzacja szkolnictwa wyższego w Niemczech wschodnich, Czechach i Polsce 1945-1956, thum. Witold Rodkiewicz, Instytut Historii Nauki, Warszawa 2014; Patryk Pleskot, Tadeusz P. Rutkowski (red.), Spętana akademia: Polska Akademia Nauk w dokumentach władz PRL, IPN, Warszawa 2009. Syntetyczny opis tych kwestii w odniesieniu do Uniwersytetu Łódzkiego zawierają artykuły Krzysztofa Lesiakowskiego: Lódź akademicka - powstanie, tendencje rozwojowe, znaczenie (1945-1980) i Zrewoltowana Łódź akademicka 1945-1980, zawarte w tomie Łódzki strajk studencki. Styczeńluty 1981: spojrzenie po latach (red. Krzysztof Lesiakowski), Wydawnictwo Uniwersytetu Łódzkiego, Łódź-Warszawa 2014.

${ }^{2}$ Określenia „PRL” używamy tu umownie dla charakterystyki okresu 1945-1989, w którym Polska stała się państwem satelickim ZSRR. Oficjalna nazwa państwa polskiego jako Polskiej Rzeczypospolitej Ludowej zamyka się w latach 1952-1989. Chodzi jednak o potoczne rozumienie tej nazwy i związane z nią konotacje.
} 
przemian i zdarzeń wyznaczających określone cezury dla życia politycznego, nacisków ideologicznych, swobód obywatelskich itp. Wydarzenia te nie ominęły przecież życia uniwersyteckiego. Były to punkty zwrotne w życiu społecznym, choć, jak to zostało pokazane w poprzednim rozdziale, niekoniecznie znacząco i wyraźnie wpisujące się w biografie rozmówców i dość rzadko spontanicznie przywoływane w opowieściach. Czas zawarty ,pomiędzy” owymi wydarzeniami to w różny sposób zmodyfikowane przez nie okoliczności polityczno-ideologiczne kształtujące życie społeczne, w tym życie akademickie. Niewątpliwie najbardziej mrocznym czasem, najbardziej upodabniającym Polskę do pozostałych państw bloku sowieckiego, był okres stalinizmu. Dlatego zostanie mu poświęcony odrębny podrozdział.

Trzeba też podkreślić, że Polska, w tym polscy naukowcy, zdołali wypracować sobie uprzywilejowaną pozycję w porównaniu z innymi krajami bloku sowieckiego, choć zawsze relatywnie, to jednak definiowaną jako przestrzeń swobody ${ }^{3}$. Z drugiej strony, w wielu przypadkach świadomość tej względnej autonomii nie niwelowała poczucia presji i zewnętrznego nadzoru. Np. Hanna Świda-Ziemba ${ }^{4}$ (absolwentka socjologii na Uniwersytecie Łódzkim, gdzie studiowała w latach 1948-1952) opisując własne „usytuowanie w okresie PRL”, stwierdziła:

Przez cały ten okres (wyłączywszy może lata 1955-1957) doświadczałam stanu zniewolenia. Czułam niewymowny ciężar funkcjonowania $\mathrm{w}$ tym systemie irracjonalnego fałszu i absurdu, systemie, który nie był przeze mnie odbierany jako „naturalny” kontekst moich zamiarów, dążeń, biografii. Rozdźwięk między moim ,ja” - a systemem, w którym przypadło mi żyć, był przeze mnie nieustannie doświadczany. Miało to znaczenie dla mego usytuowania społecznego. Pracowałam w szkołach średnich, a później przez wiele lat na Uniwersytecie Warszawskim. Zdobyłam stopnie naukowe i w żadnym okresie nie zostałam w sensie nieodwołalnym pozbawiona pracy (...). Do 1980 roku nie należałam też do zorganizowanej opozycji. Przy tym jednak usytuowana byłam stale na marginesie procesów charakterystycznych dla PRL, traktowana przez miejscowy ,aparat” jako ciało obce, podejrzane. Wielokrotnie w procesie pracy napotykałam na bariery systemu, które uniemożliwiły mi realizację jakichkolwiek zamierzeń. Wielokrotnie podlegałam też atakom dokuczliwego nękania czy spychania

${ }^{3}$ Podobny pogląd w odniesieniu do całego środowiska naukowego wyraża Ryszard Herczyński w książce pt. Spętana nauka ..., s. 9-10. Zob. też John Connelly, Zniewolony uniwersytet....

${ }^{4}$ Hanna Świda-Ziemba (1930-2012) - profesor socjologii, absolwentka Uniwersytetu Łódzkiego, od 1954 roku związana z Uniwersytetem Warszawskim. 
na margines. Jednocześnie jednak owo nękanie, choć subiektywnie uciążliwe, nie prowadziło do dramatów i - w mojej ocenie - było relatywnie na tyle łagodne, iż nie zasługuje na miano represji ${ }^{5}$.

Konsekwencją takiej postawy było uprawianie „szufladowej socjologii własnej”, którą Świda-Ziemba traktowała jako formę terapii:

W nieznośnej dla mnie sytuacji psychospołecznej uczyniłam natomiast terenem mojego autentycznego życia - właśnie wspomniane prywatne zapiski $^{6}$, dzięki którym mogłam sytuować się intelektualnie wobec systemu jako „zewnętrzny obserwator”, mimo że z konieczności stanowił on codzienny teren mojego życia. Umożliwiało mi to rodzaj wejścia w rzeczywistość jakby „pozasystemową" - co stanowiło formę osobistej terapii, czyniło życie mniej uciążliwym ${ }^{7}$

W rozdziale tym chyba najpełniej realizuje się sens pamięci komunikacyjnej, której nośnikiem jest uczestnik zdarzeń, osobiście ich doświadczający. Odbiorcą zaś jest ten, dla którego obraz opowiadanej przeszłości może być zbudowany jedynie dzięki jej wyobrażeniom, nieuchronnie zapośredniczonym przez opowiadającego ${ }^{8}$. Innymi słowy, podczas gdy można zbudować pewne wspólne pole interpretacyjne np. dla ówczesnego i współczesnego obrazu biografii naukowej, nie mogłyśmy sięgać do własnych doświadczeń, gdy nasi rozmówcy opowiadali np. o czasie stalinizmu czy kłopotach z cenzurą itp. Wydaje się nam, że właśnie z owych względów rozdział ten powinien zainteresować przede wszystkim tych Czytelników, dla których realia PRL, a zwłaszcza mrocznego okresu stalinizmu, nie są częścią ich biografii. Cytując fragmenty rozmów odnoszące się do rozważanej problematyki, staramy się przedstawić spektrum różnych (na pewno nie wszystkich) okoliczności wpływających na złożoność ówczesnej rzeczywistości. Zwłaszcza dziś, z perspektywy młodego (post)peerelowskiego pokolenia, postrzegana jest ona zero-jedynkowo, jakby istniały tylko dwie drogi, dobra i zła, pomiędzy ideologicznym zaangażowaniem a kontestacją. Takie uproszczenie tylko pozornie tłumaczy świat, zniekształcając wielowymiarową rzeczywistość. Tymczasem w większości wypadków

\footnotetext{
${ }^{5}$ Hana Świda-Ziemba, Człowiek wewnętrznie zniewolony...., s. 7-8.

${ }^{6}$ Materiały te Hanna Świda-Ziemba gromadziła na własny użytek przez cały okres PRL. Składały się na nie 1) przeprowadzane wywiady, 2) zapisy rozmów, 3) opisy makro- i mikrosytuacji, w których uczestniczyła, 4) analizy tekstów publikowanych w ówczesnych mediach, 5) przeprowadzane na bieżąco analizy mechanizmów i procesów społecznych. Zob. Hanna Świda-Ziemba, Człowiek wewnętrznie zniewolony..., s. 5-6.

${ }^{7}$ Tamże, s. 8.

${ }^{8}$ Koncepcja pamięci komunikacyjnej została przedstawiona we wstępie.
} 
konstelacja doświadczeń naszych rozmówców była bardziej skomplikowana, zwłaszcza jeśli weźmiemy pod uwagę sceptyczną orientację wobec nowego systemu. Naszym celem nie jest więc ocenianie perspektyw, stanowisk, postaw, czy też analizowanie argumentacji w przytaczanych wypowiedziach. Pokazujemy jedynie różne spojrzenia na ówczesną rzeczywistość, różne jej interpretacje ukształtowane przez i kształtujące biografie opowiadających. Punktem wyjścia są dla nas zacytowane w motcie tego rozdziału słowa Krystyny Śreniowskiej „Człowiek chce normalnie funkcjonować i żyć”. Choć, dodajmy, już samo zdefiniowanie „normalności” jest trudne i może być wieloznaczne. W przytoczonym zdaniu chodziło przede wszystkim o możliwość odbudowania normalności zakłóconej przez czas wojny. Jak mozolny i trudny był to proces, pokazuje rozdział I rysujący obraz powojnia i pierwszych lat funkcjonowania Uniwersytetu Łódzkiego. Normalne życie oznaczało więc życie w pokoju, bez poczucia zagrożenia i napięcia, możliwość powrotu do ról zawodowych ${ }^{9}$. Zapewne również w podobny sposób jak Krystyna Śreniowska ów aspekt normalności doceniali uczeni wspomniani przez Ryszarda Herczyńskiego, wówczas ideologicznie zaangażowanego studenta Uniwersytetu Łódzkiego:

Cieszyliśmy się na łódzkim uniwersytecie - niewielka grupka członków partii - chyba sympatią naszych nauczycieli, wśród których byli filozofowie Tadeusz Kotarbiński ${ }^{10}$ i Janina Kotarbińska ${ }^{11}$, językoznawcy [Henryk] Ułaszyn ${ }^{12}$ i [Jan] Oko ${ }^{13}$, fizycy Feliks Wiśniewski ${ }^{14}$ i Marian Grotowski ${ }^{15}$, socjologowie Maria i Stanisław Ossowscy ${ }^{16}$. Mieli wszelkie podstawy, by uważać nas za przeciwników, chyba jednak wierzyli, że nie kierujemy się oportunizmem, że

${ }^{9}$ Trzeba zauważyć, że w wypadku Krystyny Śreniowskiej napięcie to miało szczególny charakter, ponieważ jej mąż musiał ukrywać się w czasie wojny ze względu na pochodzenie żydowskie. Na niej spoczywał ciężar walki o bezpieczeństwo męża, walki ze szmalcownikami oraz zdobywania środków do życia.

10 Tadeusz Kotarbiński (1886-1981) - profesor filozofii, logik, współzałożyciel Uniwersytetu Łódzkiego i pierwszy rektor uczelni.

${ }^{11}$ Janina Kamińska-Kotarbińska (1901-1997) - filozof i logik, profesor Uniwersytetu Łódzkiego w latach 1945-1951, później profesor Uniwersytetu Warszawskiego.

${ }^{12}$ Henryk Ułaszyn (1874-1956) - językoznawca, slawista, profesor Uniwersytetu we Lwowie i Uniwersytetu Łódzkiego.

${ }^{13}$ Jan Oko (1875-1946) - filolog klasyczny, profesor Uniwersytetu Stefana Batorego w Wilnie, współtwórca wileńskiej szkoły filozoficznej, założyciel Katedry Filologii Klasycznej UŁ.

${ }^{14}$ Feliks Joachim Wiśniewski (1890-1963) - fizyk, profesor Wolnej Wszechnicy Polskiej, a po II wojnie światowej profesor Uniwersytetu Łódzkiego i Politechniki Łódzkiej.

${ }^{15}$ Marian Grotowski (1882-1951) - fizyk, przed wojną profesor Wolnej Wszechnicy Polskiej, współorganizator i prorektor Uniwersytetu Łódzkiego.

16 Stanisław Ossowski (1897-1963) - socjolog, profesor Uniwersytetu Łódzkiego w latach 1945-1947 oraz Uniwersytetu Warszawskiego. Maria Ossowska (1896-1974) - etyk, teoretyk 
nie „nadajemy” do policji. Może wierzyli, że zmądrzejemy. (...) Widzieliśmy życiowe trudności naszych nauczycieli. Wiśniewski, wysiedlony ze swojego majątku w Łazinie, mieszkał wraz z rodziną w małym, zaniedbanym pokoju hotelowym. Staraliśmy się pomóc. Nie zdawaliśmy sobie jednak sprawy, że to pokolenie uczonych, które zdobywało ostrogi naukowe na Sorbonie, w Getyndze, Heidelbergu czy Wiedniu, musi czuć się w nowych warunkach jak w klatce, odcięte od możliwości nawiązywania dawnych kontaktów naukowych z zachodnimi przyjaciółmi. Byliśmy tak blisko i zarazem daleko: blisko - ponieważ wierzyliśmy, że bierzemy udział w zachodzących przekształceniach, daleko - ponieważ prawdziwe motywy wielu politycznych decyzji nie były nam znane, a o profesorskim oporze wobec wprowadzanych zmian - były wśród nich również wymienione uprzednio osoby - nie wiedzieliśmy ${ }^{17}$.

Herczyński, podejmując po latach perspektywę profesorów, dostrzega zatem relatywny charakter obrazu ówczesnej rzeczywistości - dla jednych była to wizja budowy (lepszego) ładu społecznego, dla innych powojenna „normalność” wykreowana przez nowy porządek ideologiczny prowadziła do rozpadu ich świata. Dla przykładu, urodzona w Łodzi w 1930 roku Olga Czerniawska, po wojnie studentka historii, w ten sposób rozpoczyna swoją opowieść:

Nasz dom był taki bardzo tradycyjny, spokojny. Teraz jak myślę o dorosłości, to muszę powiedzieć, że przed wojną wszystko było poważne, to znaczy ludzie dorośli byli dorośli, dzieciństwo było dzieciństwem, wszyscy traktowali wszystko poważnie. To był okres, kiedy się wszystko traktowało z celebrą i poważnie. Jak było święto, to miało być święto, jak nie było święto, to nie święto, praca to była praca, sprzątanie to było sprzątanie. I tego już się nie uratowało - takiego poważnego traktowania życia. Wszystko musiało być wypracowane, zrobione, kołnierzyki przy koszulach były sztywne, krochmalone i tak dalej. Także to było zupełnie inne życie, moje dzieciństwo upłynęło właśnie w takiej rodzinie, która była prawdziwą rodziną, wszystko było prawdziwe. Ale wojna wybuchła i skończyło się dzieciństwo.

Niezależnie od konkretnego nastawienia, ukształtowanego swoistymi przeżyciami biograficznymi, każdy przyjęty sposób definiowania powojennego porządku musiał jednak przekładać się na realne doświadczenie powiązane z koniecznością życia w nowej, powojennej rzeczywistości. Jak pisze Świda-Ziemba:

i socjolog moralności, profesor Uniwersytetu Łódzkiego w latach 1945-1948, a następnie Uniwersytetu Warszawskiego oraz Instytutu Filozofii i Socjologii PAN.

${ }^{17}$ Zob. Ryszard Herczyński, Spętana nauka ... 
Odkąd tzw. „realny socjalizm” został u nas wprowadzony przemocą, nie istniał dla społeczeństwa - w pewnym zakresie - żaden margines wyboru. Jeśli ludzie chcieli zrealizować jakiekolwiek życiowe cele - czy to o charakterze osobistym (zdobyć środki utrzymania, dbać o zdrowie, kształcić się, zakładać rodziny, wychowywać dzieci) czy ponadosobistym (działać na rzecz innych, budować miasta, rozwijać naukę i sztukę) - zmuszeni byli grać kartami systemu - inaczej żadnych celów życiowych nie mogliby osiągnąć ${ }^{18}$.

W rozdziale tym staramy się zatem pokazać, jak można było bądź nie w różnych okresach i w różnych sytuacjach życia akademickiego próbować rozdawać karty systemu po swojemu.

\section{Stalinizm}

Z reguły za okres stalinizmu uznaje się lata $1948-1956^{19}$. Nasza książka nie jest opracowaniem historycznym, dlatego nie podejmujemy tu systematycznej charakterystyki tego czasu. Poprzestaniemy tylko na wyliczeniu niektórych cech stalinizmu (ujawniających się także w opowieściach naszych rozmówców) związanych między innymi z takimi aspektami jak: ograniczanie wolności, brutalna ideologizacja życia, rozbijanie więzi społecznych, obowiązek „czujności ideologicznej” usprawiedliwiającej donosy, prześladowania i represje, agitacja antyreligijna itp. Kilka z nich w sposób szczególny odnosiło się do życia uniwersyteckiego - np. kopiowanie instytucji z ZSRR przez zniesienie stopnia naukowego doktora i wprowadzenie stopnia „kandydata nauk”, uniemożliwienie jakichkolwiek kontaktów z Zachodem, ideologizacja nauki, „co oznaczało odejście od kryterium prawdy na rzecz «ideologicznej słuszności»" 20 , a w odniesieniu do nauk społecznych i humanistycznych skutkowało ich znacznym ograniczeniem włącznie z likwidacją kierunków studiów. W przedstawionych poniżej fragmentach Czytelnik spotka się ze wszystkimi wariantami wymienionych tu bardzo ogólnie cech. Celowo, odwołując się do funkcjonującego w świadomości społecznej obrazu, nie rozwijamy dalej opisu tej epoki społeczno-historycznej. Chcemy jedynie oddać głos świadkom tego czasu, przedstawiając różne sposoby jego widzenia i doświadczenia, przy czym interpretację poszczególnych głosów pozostawiamy Czytelnikowi. Jedynym kryterium porządkującym cytowane niżej wypowiedzi jest miejsce, jakie wtedy nasi

${ }^{18}$ Hanna Świda-Ziemba, Człowiek wewnętrznie zniewolony..., s. 32.

${ }^{19}$ Chociaż np. Świda-Ziemba pisząc socjologiczny esej Stalinizm i społeczeństwo polskie (w: Człowiek wewnętrznie zniewolony ..., s. 98-191), nazwę stalinizm przypisuje latom 1949-1955.

${ }^{20}$ Tamże, s. 100-101. 
rozmówcy zajmowali w społeczności akademickiej - czy byli wówczas studentami, czy młodymi pracownikami Uniwersytetu Łódzkiego (w tym drugim przypadku uwzględniamy również wspomnienia zapośredniczone - relacje o ówczesnych profesorach, ich reakcjach i postawach).

\section{Powojenne pokolenie studentów}

Wiele zostało napisane $\mathrm{w}$ poprzednich rozdziałach na temat pierwszej powojennej dekady i społeczno-politycznych warunków kształtujących życie uniwersyteckie. Poniżej pokazujemy, jak wpływały one na atmosferę studiowania z perspektywy ówczesnych studentów, których doświadczenie umieścić można na kontinuum pomiędzy przekonaniem, że: „Stosunki między ludźmi, muszę powiedzieć, były wtedy pełne...życzliwości” (Romuald Olaczek) a „Wie pani, muszę powiedzieć, że żyło się w poczuciu pełnej nieufności, było to jedną z bardziej charakterystycznych cech" (Teresa Cieślikowska). Jak dobrze widać po zaledwie dwóch wypowiedziach, nawet okres stalinizmu może być opisywany w różny sposób i rzeczywistość społeczna wymyka się prostym ocenom, zwłaszcza jeśli weźmie się pod uwagę kontekst wypowiedzi czy odniesienie do poszczególnych wspomnień i doświadczeń biograficznych. Poczuciu presji doświadczanej przez ówczesnych studentów, którym przyszło studiować w tym trudnym czasie, mogła jednocześnie towarzyszyć świadomość przywileju spotkania z wielkiej miary uczonymi; ostrożności we wchodzeniu w relacje społeczne w atmosferze inwigilacji i donosów przeciwstawić można doświadczenie budowania głębszych relacji przyjacielskich i uczuciowych. Wszak mroczny okres stalinizmu przypadał na czas najjaśniejszego etapu życia, jakim jest doświadczenie młodości. Autorzy przedstawionych niżej fragmentów koncentrują się raczej na eksponowaniu ciemnej strony tego czasu i taka perspektywa zdecydowanie przeważa w zebranych opowieściach.

\section{Atmosfera studiowania - relacje między wyktadowcami a studentami}

Ryszard Panasiuk wspomina studia filozoficzne na Uniwersytecie Warszawskim w latach 1952-1957:

To były ciekawe studia, choć... tonacja i orientacja była bardzo wyraźna, taka jak to powiedzieć można... no marksistowska. Na przykład socjologii w ogóle nie było. Niektórzy profesorowie byli odsunięci, na przykład profesor Tatarkiewicz ${ }^{21}$, który zaraz po wojnie reaktywował działalność, był odsunięty

${ }^{21}$ Władysław Tatarkiewicz (1886-1980) - wybitny filozof i historyk filozofii, etyk, aksjolog i estetyk, członek stworzonej przez Kazimierza Twardowskiego lwowsko-warszawskiej szkoły filozoficznej. Autor monumentalnego dzieła Historia filozofii i Historia estetyki. Po wojnie wykładał na 
i w ogóle nawet go nie widziałem. Profesorstwo Ossowscy ${ }^{22}$ też nie prowadzili zajęć, choć na Wydziale byli, bo to w pałacu Potockich była ta filozofia, zaraz przy Kościele Wizytek. Ale studia były w sumie ciekawe, dlatego, że tam interesujący ludzie wykładali, mimo wszystko, jak na przykład profesor Kotarbiński ${ }^{23}$, Kołakowski ${ }^{24}$ wtedy zaczynał swoją aktywną działalność. I sytuacja się zmieniała po śmierci Stalina. Potem zaczęła się rewolucja w umysłach, czytanie książek, do których dostęp był trudny. Ja uczestniczyłem w seminarium profesora Kotarbińskiego, a magisterium pisałem i też uczestniczyłem w seminarium profesora Krońskiego. ${ }^{25} \mathrm{~A}$ ta cała filozofia to było nauczanie marksizmu. I chociaż jeszcze za czasów studenckich to uczono historii WKP $(b)^{26}$. To była taka dziwna książka radziecka, kłamliwa i według niej uczono, doktryny. Ale po 1956 roku to zaprzestano tego, więc to takie nauczanie marksizmu polegało na tym, żeśmy uczyli historii filozofii, włącznie ze świętym Tomaszem. Także to nie był żaden problem, to nie była taka radykalna indoktrynacja przecież. Nie wiem, czy pani wie, ale taka była polityka w tym czasie, w czasie wcześniejszym nieco, żeby znaczną część młodzieży przygotowywać, posyłając ich na studia do Związku Radzieckiego, w różnych dyscyplinach. Niektórzy z tego korzystali, bo niektóre dyscypliny, szczególnie przyrodnicze, matematyczne, fizyczne, tam nie były złe. Ale filozofiato była rzecz koszmarna. I tam bardzo dużo ludzi studiowało filozofię. Mój przyjaciel Aleksander Orłowski ${ }^{27}$ też tam pojechał, właściwie studiować chemię, ale mu się nie podobało [śmiech] i zaczął studiować filozofię. Ale był na tyle inteligentny, że jakoś się od tego potrafił zdystansować i na seminarium u Krońskiego jak się pojawił, to Kroński tak patrzy na niego i mówi: „I ty byłeś w Persji?”. Bo nigdy nie mówił na Związek Radziecki inaczej jak Persja [śmiech], taki jakiś dziki, okropny kraj. Także on się tak ładnie do tego zdystansował. A niektórzy ludzie byli jakby uwięzieni w tym kanonie takiego

Uniwersytecie Warszawskim. W 1950 roku na mocy decyzji politycznej został odsunięty od pracy dydaktycznej.

${ }^{22}$ Zob. przypis $16 \mathrm{w}$ tym rozdziale.

${ }^{23}$ Zob. przypis $10 \mathrm{w}$ tym rozdziale.

${ }^{24}$ Leszek Kołakowski (1927-2009) - wybitny współczesny filozof, zajmujący się przede wszystkim historią idei i historią filozofii. Studiował w Łodzi.

${ }^{25}$ Tadeusz Kroński (1907-1958) - filozof zajmujący się głównie myślą Hegla i Kanta, uczeń Tadeusza Kotarbińskiego i Władysława Tatarkiewicza. Uznawany za jednego z głównych ideologów okresu stalinowskiego. Wykładał filozofię marksistowską w Instytucie Kształcenia Kadr Naukowych. Znany jako „Tygrys” z Rodzinnej Europy Czesława Miłosza.

${ }^{26}$ Krótki kurs historii WKP(b) - Historia Wszechzwiązkowej Komunistycznej Partii (bolszewików) - propagandowa publikacja radziecka stanowiąca oficjalną wykładnię historii i doktryny Komunistycznej Partii Związku Radzieckiego.

${ }^{27}$ Aleksander Orłowski (1929-2007) - filozof, uczeń Bronisława Baczki, adjunkt na UŁ, profesor Uniwersytetu w Sztokholmie, dokąd wyemigrował w 1968 roku. 
„klepania pacierza”, tak to nazwijmy. Trzymania się tych tekstów z akcentowaniem bardziej Lenina, niż Marksa i tak dalej.

Krystyna Lutyńska rozpoczęła studia w 1949 roku na kierunku nauki społeczne:

To był ten rok, kiedy skasowano socjologię, 1949/1950. Ja w tym roku wstępowałam na Uniwersytet i wtedy skasowano te wszystkie kierunki społeczne, między innymi socjologię, i stworzono nauki społeczne. To był taki twór, gdzie uczono nas wszystkiego: trochę socjologii, trochę myśli społecznej, historii, trochę psychologii i trochę statystyki i bardzo dużo marksizmu, leninizmu, ekonomii politycznej. Tę ekonomię wykładał Jan Mujżel' ${ }^{28}$, wysoki, przystojny facet, bardzo pewny siebie. Pamiętam, że wykładał w takiej wielkiej sali, gdzie przedtem była jakaś sala biologów czy coś takiego, w każdym razie był pulpit, z którego takie kurki wystawały i myśmy się z tego strasznie śmieli. Pewnego razu, na drugim roku Mujżel wykładał ekonomię polityczną, a potem w okresie lata Stalin ogłosił swój słynny artykuł o językoznawstwie ${ }^{29}$ i niestety bardzo się wszystko zmieniło. I wszystko to, co Mujżel nam mówił, okazało się złe. Więc trzeba było odkręcać na jesieni. Ci, co zdawali egzamin w sesji letniej, to zdawali jeszcze nieprawidłowo. A ci, co zdawali w jesiennej, to musieli się douczyć ze Stalina. Niektóre wykłady nie przebiegały tak przyjemnie i gładko. Na moim roku było kilku kolegów, którzy byli bardzo oddani partii. Przede wszystkim Janusz Kuczyński ${ }^{30}$, późniejszy słynny profesor, który bardziej stał się filozofem niż socjologiem. On uważał, że na każdym kroku trzeba walczyć o czystość ideologiczną, marksizm, leninizm. On potrafił na przykład przerwać wykład. Miał wykład monograficzny taki profesor historii, nie pamiętam, jak się nazywał, który dużo mówił o roli rozmaitych władców. I wtedy Janusz potrafił wstać i „Nie chcemy” - krzyczał - „nie chcemy takich wykładów ponieważ historią nie rządzą królowie, tylko lud, nie chcemy pana wykładów!”. To były takie historie, których byłam świadkiem. Również i na innych zajęciach ta młodzież była taka fanatycznie oddana komunizmowi i atakowała profesorów. I to nie było przyjemne.

Kaja Kaźmierska: A jak wtedy reagowali ci profesorowie?

${ }^{28}$ Jan Mujżel (1923-2006) - ekonomista, profesor Uniwersytetu Łódzkiego, zajmował się teorią ekonomii, w tym przede wszystkim teorią funkcjonowania gospodarki i przedsiębiorstw. Uczestnik obrad Okrągłego Stołu.

${ }^{29}$ W czerwcu 1950 roku w „Prawdzie” opublikowano roku artykuł Stalina W sprawie marksizmu w językoznawstwie, który został następnie wydany przez Książkę i Wiedzę pt. Marksizm a zagadnienia językoznawstwa.

${ }^{30}$ Janusz Kuczyński (ur. 1930) - filozof, obecnie emerytowany profesor Uniwersytetu Warszawskiego. 
Krystyna Lutyńska: Milczeli, milczeli. Nie pamiętam, co się stało z tym historykiem. W ogóle wtedy w Łodzi była taka grupa młodych - Woroszylski ${ }^{31}$ tam był właśnie, Kołakowski ${ }^{32}$, bo też wtedy studiował w Lodzi. Szereg innych, którzy byli tacy bardzo bojowi i bardzo fanatyczni, szerzyli ateizm, w taki sposób bardzo głośny. Pamiętam, że miałam taką koleżankę, bardzo zdolną, Teresę Górską. Ona jest profesorem psychologii w Krakowie, chyba jeszcze żyje, mam nadzieję, i ona była bardzo wierzącą katoliczką. Poszła zdawać egzamin do profesora Henryka Katza ${ }^{33}$, wyklepała wszystko, co wiedziała, znakomicie była przygotowana, więc profesor wpisuje piątkę, a ona wtedy mówi: „Panie profesorze, ale ja w to wszystko nic nie wierzę" [śmiech]. Ale on jej postawił tę piątkę [śmiech], nie wycofał się i żadnych konsekwencji nie było. Więc były i takie historie.

Sławomir Cieślikowski, student psychologii w latach 1947-1952, uczestniczył również w spotkaniach koła filozoficznego prowadzonego przez profesora Kotarbińskiego ${ }^{34}$ :

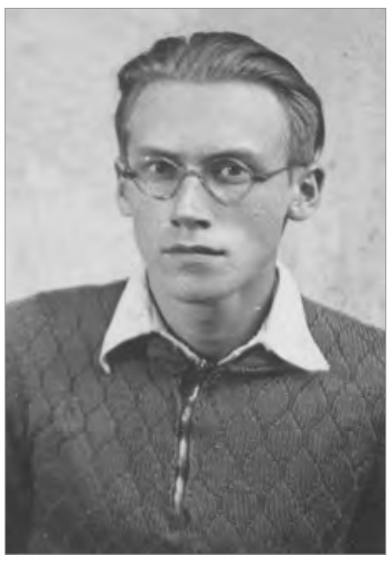

Fot. 61. Leszek Kolakowski jako kontestujacy student

Profesor Kotarbiński założył i prowadził koło filozoficzne. Jak to się nazywało, nie pamiętam, ale chyba „koło studentów filozofii” czy „kółko filozoficzne” i on miał tam zajęcia różnego rodzaju. Na dużej części z nich byłem. Ale ponieważ to nie było obowiązkowe, a ja miałem jeszcze mnóstwo innych rzeczy na głowie, w tym między innymi duszpasterstwo i Caritas, i takie inne historyjki o charakterze społecznym, to nieraz zdarzyło mi się pominąć te posiedzenia. Niemniej pamiętam, jak kłócił się z Kotarbińskim Leszek Kołakowski ${ }^{35}$, jak wymyślał Kotarbińskiemu, bo chodziło o to, że Kotarbiński powiedział czy użył zwrotu o tym, że podstawy etyki chrześcijańskiej, etyki katolickiej mają w dużej mierze - a może nawet w pełni, już nie pamiętam - charakter etyki naturalnej. Jakżeż się to szczenię wtedy zirytowało.

${ }^{31}$ Wiktor Woroszylski (1927-1996) - poeta, prozaik, w latach 1945-1947 studiował na Uniwersytecie Łódzkim. W 1956 roku, będąc naocznym świadkiem interwencji radzieckiej na Węgrzech, zmienił poglądy polityczne, w latach siedemdziesiątych. Związany był z opozycją, współpracował z KOR-em, internowany w stanie wojennym.

${ }^{32}$ Zob. przypis $24 \mathrm{w}$ tym rozdziale.

${ }^{33}$ Henryk Katz (1914-1998) - historyk. Urodził się we Lwowie, gdzie studiował ekonomię. Studia kontynuował w Paryżu i Londynie. W czasie wojny służył w armii brytyjskiej. Zajmował się historią międzynarodowego ruchu robotniczego. W 1949 roku został zatrudniony na Uniwersytecie Łódzkim, w roku 1956 został mianowany docentem, a w roku 1968 musiał odejść z uniwersytetu.

${ }^{34}$ Zob. przypis $10 \mathrm{w}$ tym rozdziale.

${ }^{35}$ Zob. przypis $24 \mathrm{w}$ tym rozdziale. 
Jak nawymyślało z marksistowskiego oczywiście punktu widzenia. I tak jak przedtem z Kołakowskim chętnie rozmawiałem, to od tego wybuchu nie przeprowadziłem z nim ani jednej rozmowy. Dość! No bo jak tak można?! Nie przeszło mi przez myśl, że to nie była indywidualna sprawa, że ci młodzi dostali instrukcje, że mają kwestionować starszych profesorów, bo profesorowie starsi, pozornie sympatyczni, niszczą młodych i nie dopuszczają ich do głosu. A młodzi powinni być górą. Stąd ten cały ruch wredny przecież. Część z tych ludzi nie wiedziała, czego to dotyczy. Ale część to byli agenci po prostu. Nie sądzę, żeby Kołakowski był agentem. Na pewno był na zebraniach partyjnych. Lata musiały minąć, zanim zmienił zdanie i swoje nastawienie, ale to musiały upłynąć lata, bo zaczadzenie było duże.

Olga Czerniawska, studentka historii w okresie 1948-1952, po latach profesor pedagogiki, opowiada o wybranym przez siebie kierunku studiów:

Historia na uniwersytecie była bardzo trudną dziedziną, dlatego że byli profesorowie przedwojenni. Profesor Stanisław Zajączkowski ${ }^{36}$ był chyba prorektorem czy kimś tam, ze Lwowa, specjalistą od średniowiecza i nauk pomocniczych. Na prawie był jego syn, niedawno przeszedł na emeryturę, też się tym zajmował. U profesora Zajączkowskiego byłam na seminarium i robiłam pracę magisterską. Był bardzo zacny, zasłużony, a ponieważ to był mediewista, to tak za bardzo ten marksizm go nie atakował. Ale już drugi profesor, profesor Serejski ${ }^{37}$, też wybitny uczony, też mediewista, zajmował się historią europejską, Karolem Wielkim i tym okresem, pisał na ten temat, i chociaż jego seminaria i ćwiczenia też związane były ze średniowieczem, to jednak starał się ukazać walkę klasową, ruchy chłopskie i już taki marksizujący był. W czasie moich studiów wszedł ten marksizm-leninizm i trzeba było go zdawać: baza, nadbudowa itd., i byli specjaliści różnego rodzaju. Byli tacy jacyś mądrzy, ale byli też tacy chyba z UB czy skądś i oni nas maltretowali. Jeden z nich był straszny, ale go zabili. Była cała historia, bo był zamach na niego. Tak idziemy na wykład, nie ma go, co się dzieje? Okazało się, że nie żyje. Wykończyli go, bo za bardzo się pastwił nad studentami. Był też profesor Katz ${ }^{38}$, on zajmował się historią gospodarczą. Od historii gospodarczej była taka pani profesor Natalia Gąsiorowska ${ }^{39}$, która była przedwojenną komunistką czy socjalistką. Ona

${ }^{36}$ Stanisław Zajączkowski (1890-1977) - historyk, mediewista. Absolwent Uniwersytetu we Lwowie. Od 1945 roku związany z Uniwersytetem Łódzkim, kierownik Katedry Historii Średniowiecznej. W latach 1946-1948 dziekan Wydziału Humanistycznego, dwukrotnie dziekan Wydziału Filozoficzno-Historycznego (1956-1958, 1958-1960).

${ }^{37}$ Marian Serejski (1987-1975) - profesor historii, mediewista. W latach 1948-1950 był dziekanem Wydziału Humanistycznego Uniwersytetu Łódzkiego.

${ }^{38}$ Zob. przypis $33 \mathrm{w}$ tym rozdziale.

${ }^{39}$ Natalia Gąsiorowska-Grabowska (1881-1964) - historyk, badacz dziejów ruchu robotniczego, profesor Uniwersytetu Łódzkiego i Uniwersytetu Warszawskiego, profesor i rektor Wyższej Szkoły Pedagogicznej w Łodzi. 
miała szalone poważanie, miała wykład w wielkiej sali na socjologii. Nuda! Nudy na pudy! Ona miała całe grono różnych asystentów, którzy potem zostali profesorami, był właśnie ten zakład marksizmu-leninizmu, bo ona najlepiej się na tym znała. I był tam profesor Katz, u niego można było zdawać. Ja zdawałam ten marksizm-leninizm tuż po urodzeniu syna, więc on jakoś mnie tak nie maltretował, ale przede mną zdawał profesor Pawłowski ${ }^{40}$, który miał marne szanse. Ale jakoś zdałam ten marksizm. To był straszny mechanizm, bo niektórzy ileś razy przychodzili i nie zdawali, zresztą to była bardzo poważna sprawa z tym egzaminem ${ }^{41}$.

Zbigniew Jakubowski był studentem matematyki w latach 1951-1955 i wspomina te czasy następująco:

Jak pani widzi, nie poruszam tematu polityki, ale nie jest tak, że ja nie mam poglądu na sytuację, w jakiej studiowałem. To nie była normalna sytuacja. Natomiast mam obawy, czy nasze indywidualne opinie w tej sprawie są miarodajne, czy nie trzeba poczekać trochę, troszkę to wypośrodkować, bo żyło nam się bardzo trudno, materialnie również, a te sytuacje związane z polityką nie były zupełnie proste. Ciężko było zrozumieć na przykład, jak nadawano informację o stanie zdrowia Stalina i część studentów miała łzy w oczach. Teraz żaden dziennikarz tego nie wypowie, bo to nie uchodzi, to się nie mieści w regułach, które w tej chwili obowiązują. Ale tak było. Jakie były pobudki tego, trudno mi jest powiedzieć, ale tak było. Na studiach duża część z nas, większość należała do ZMP ${ }^{42}$ czy może myśmy wszyscy musieli tam być, nie wiem, ale myślę, że część z nas szukała formy działania. A żeby szukać czegoś, to trzeba mieć ustalone, że my na przykład cię zawieziemy do konkretnego lasu w Spale i wydaje nam się, że tutaj są bunkry, poszukaj, może ty je znajdziesz w tym lesie. Ja myślę, że duża część z młodzieży, ale też część dorosłych chciała możliwie najwięcej zrobić w tym spalskim lesie. A więc w tych określonych ramach, które są. Myśmy byli po wojnie bardzo pokiereszowani. To wcale nie było takie oczywiste i proste. Na przykład mamie męża zamordowali Rosjanie, dokładnie NKWD, ale mimo to pracowała w rosyjskiej szkole w 1939-1941 roku. I pracowała potem po wojnie w białostockiem, w szkole, w której mogła pracować.

40 Tadeusz Pawłowski (1924-1996) - logik i filozof. Absolwent i profesor Uniwersytetu Łódzkiego.

${ }^{41} \mathrm{~W}$ kolejnych dekadach zmiękczoną wersją tego typu ideologizacji był również kończący się egzaminem przedmiot „nauki polityczne”. Jak przedstawione zostało w rozdziale III, jednym z pierwszych postulatów przedłożonych przez studentów prawa w grudniu 1980 roku władzom wydziału było żądanie zniesienia egzaminu z tego przedmiotu. Postulat ten stał się jednym z punktów ogniskujących protest studentów, który w styczniu 1981 roku przerodził się w strajk.

${ }^{42}$ ZMP - Związek Młodzieży Polskiej, organizacja młodzieżowa działająca w okresie stalinizmu w latach 1948-1957 zrzeszająca organizacje młodzieżowe działające do roku 1948: OMTUR - Organizację Młodzieży Towarzystwa Uniwersytetu Robotniczego, ZMD - Związek Młodzieży Demokratycznej, ZMW - Związek Młodzieży Wiejskiej, ZWM - Związek Walki Młodych. 
Teraz można powiedzieć „nie, tę szkołę zorganizowały władze przyniesione przez okupanta, ja w niej uczyła nie będę". Mama się od 1946 roku znajduje w Łodzi i w 1947 po urodzinach brata szuka możliwości pracy w szkole. W takiej, która działa w Łodzi i jest organizowana przez określone mechanizmy, a innych nie ma. Jej jedyne wyjście to podjąć pracę w takich narzuconych warunkach lub nie podjąć. Ja myślę, że jeśli chodzi o młodzież, to ona źle ocenia fakt, że cały naród odbudowywał Warszawę. Na zasadzie, że odbudowa była zła, bo prowadzona w złym okresie. Ten okres nie należy do najlepiej ocenianych. Ale to był fakt. Stolicy nie było, a chcieliśmy, żeby była. To jak inaczej można było to robić? Ja myślę, że świat jest bardzo pokomplikowany. Część z nas chciała w tych warunkach, które były, maksymalnie wpłynąć pozytywnie na coś. Coś wybudować, kogoś nauczyć. Często trzeba było iść na kompromisy. Często nie umieliśmy znaleźć tego najlepszego kompromisu. Często się przekraczało jakieś granice i szło się dalej. Czasami się trzeba było gdzieś zatrzymać, może nie umieliśmy tego zrobić. Czy ja chcę usprawiedliwić nas wszystkich? Nie. Bo myślę, że i w czasie studiów, i po studiach, częściowo też w marcu 1968 roku pewne rzeczy się robiło w dobrej wierze, bo wydawało nam się, że tak trzeba postąpić, a po upływie iluś lat człowiek sam by chciał odwołać, a nie może. Jeszcze raz chcę podkreślić - atmosfera w czasie studiów na pograniczu polityki była fatalna, nie ma co tłumaczyć. Ale na przykład żona jest po historii, u nich na historii było inaczej niż u nas na matematyce. U nas nie było podłoża dodatkowego do tych konfliktów. Ale kilka osób już wtedy było w partii. A tylko parę osób nie należało do ZMP. Teraz oczywiście się do tego nie przyznajemy, w moim życiorysie też pani nie znajdzie, że byłem członkiem tego czy tamtego. Może to źle. Możliwe, że nic mądrzejszego pani nie jestem w stanie odpowiedzieć na takie pytania. Oczywiście były donosy, ludzie siedzieli w więzieniach bez podstaw. Ale czy ktoś wymyślił taki świat, taki ustrój, gdzie by było wszystko idealnie? Myślę, że nie.

\section{Atmosfera studiowania - relacje między studentami}

Obowiązek czujności ideologicznej „usprawiedliwiającej” donosy oraz kontrola więzi społecznych skwapliwie sprawowana przez aktywistów wpływały na atmosferę studiowania i przekładały się na relacje w środowisku studenckim. Przez jednych stosunki te były doświadczane jako sytuacje opresyjne, inni eksponowali poczucie odpowiedzialności i dojrzałości środowiska studenckiego. We wspomnieniach nestorów Uniwersytetu Łódzkiego przywoływane są zwłaszcza obrazy zebrań, które w okresie stalinowskim miały szczególny charakter. Co charakterystyczne, ich opisy są dość podobne niezależnie od zaangażowania narratora, co pokazują dwa 
poniższe przykłady. Olga Czerniawska, która nie była członkiem ZMP, opisuje zebrania studenckie, w których wszyscy musieli uczestniczyć:

Były zebrania studenckie, obowiązkowe: samoocena, samokrytyka, dlaczego zdał, co zdał, a czego nie zdał itd. Ja byłam dobrą studentką, to mnie się nie mogli czepiać, bo zdałam w terminie. Ja i jeszcze taka moja koleżanka, myśmy obie zrobiły w cztery lata dyplom, napisałyśmy pracę magisterską, wszystkie egzaminy miałyśmy na piątkę. Natomiast inni nie mieli. Ale ja też się nie ustrzegłam, bo pożyczyłam jakąś książkę i nie oddałam jej w terminie, to mi powiedzieli, że to sabotaż - taki pan, bardzo partyjny, chyba ubowiec, bo sporo ich było w UB. On mi tak powiedział, że to jest sabotaż i że właściwie powinnam mieć sprawę kryminalną o przetrzymanie tej książki. To był jedyny taki incydent, który miałam.

Krystyna Lutyńska opisuje z kolei zebrania ZMP z perspektywy członka organizacji wymagającej bezwzględnej lojalności:

Jeszcze parę słów o tym, jak odbywały się zebrania ZMP-owskie na Uniwersytecie Łódzkim, co nie należy do przyjemnych wspomnień. Te zebrania odbywały się zwykle wieczorami i ciągnęły się długo do nocy. Nie pamiętam, czy tam były jakieś referaty. Zwykle chyba były jakieś referaty ideologiczne, ale potem bardzo często były takie sprawy personalne. Miano pretensje do studentów, wówczas zwanych bikiniarzami, którzy na przykład mieli za wąskie spodnie. Pamiętam takiego kolegę, Bogdana Szurgota, który nosił te wąskie spodnie i biedak był strasznie ochrzaniany, bo był uczesany w specjalny sposób, tak jakoś zaczesywał włosy do tyłu. Trzeba było składać publiczną samokrytykę. Ale gorsze były takie sprawy, jak na przykład jedna z koleżanek, która była w ZMP, wypowiadała się pozytywnie o AK. A wiadomo, że wtedy AK była bardzo potępiana. Jeżeli ktoś walczył z Niemcami, to Armia Ludowa. Ta dziewczyna chyba miała kogoś w rodzinie, kto należał do AK, ojca czy kogoś takiego. Ktoś się dowiedział, zarząd wyciągnął to jej publicznie, że ona pozytywnie mówi o AK. I była cała wielka dyskusja, nie wiem, czy jej nie wyrzucili. Bardzo często wyrzucano z organizacji, nawet za te wąskie spodnie czy za właśnie nieprawidłowe poglądy. O Katyniu to w ogóle się nie mówiło, a jeśli, to oczywiście zrobili Niemcy. Były takie broszury, które były podstawą do wygłaszania referatów. Także pewne rzeczy były tabu i można było mieć duże przykrości - przynajmniej wylecieć z organizacji i mieć zaszarganą opinię polityczną. A potem ta opinia była bardzo ważna, ponieważ zarządy organizacji ZMP wydawały opinie, jak chciało się gdzieś wyjechać czy dalej studiować, czy nawet pracować, to oni pisali te opinie i to było potwierdzane przez POP, czyli podstawową organizację partyjną. Tak sprawowano kontrolę nad poszczególnymi osobami. Tak starano się wychowywać. Te samokrytyki były bardzo nieprzyjemne. Pamiętam, jak byłam na obozie studenckim, bardzo 
fajnym, w Karpaczu. To był obóz ideologiczny. Ponieważ po pierwszym roku byłam jedną z przodujących studentek, wysłano mnie na taki obóz ideologiczny. Piękne miejsce, bo w Samotni mieszkaliśmy, ale strasznie dużo było tych szkoleń. A to był lipiec, tam trochę wyżej, nad Samotnią był taki lśniący lodowiec. Zostało trochę śniegu i lód. Kilka osób spośród nas się urwało, między innymi mnie też podkusiło. Jakoś wspięliśmy się na ten lodowiec, na ten śnieg [śmiech], bardzo przyjemnie czas spędziliśmy i wróciliśmy. Ale ktoś widocznie doniósł. Potem było zebranie całego obozu i w obecności wszystkich uczestników obozu kierownik kazał powiedzieć kto to. Oni wiedzieli, że ktoś się urwał, ale nie wiedzieli, kto, więc kazali się przyznawać. No, ja jednak pomyślałam, że nie ma co, trzeba się przyznać i wystąpiłam przed szereg i paru kolegów, którzy byli ze mną, też. I musieliśmy składać samokrytyki, że urwaliśmy się z tego szkolenia na tą [śmiech] wycieczkę.

Ten obrazowy opis młodzieńczej „niesubordynacji” Krystyna Lutyńska dopełnia szczegółami wskazującymi na siłę oddziaływania presji ideologicznej:

Pamiętam też z tamtych czasów jeżeli chodzi o kwestie studenckie, że większość roku należała do ZMP. Bardzo wielu zrobiło to dla wygody, ponieważ chcieli się dostać na studia i tak dalej. Byli ludzie, którzy jak się dostawali na studia, ukrywali swe pochodzenie. Jedna z moich koleżanek tak zrobiła. Miała ojca fabrykanta, napisała że ,,inteligencja pracująca”. Potem już po trzecim roku studiów wywalili ją z organizacji i ze studiów, była wielka awantura $i$ afera. Ja powiedziałam sobie, że nigdy nie będę ukrywała mego pochodzenia. A to nie było dobre. Ojciec - zawodowy oficer przedwojenny to było bardzo brzydkie. Ale jakoś nigdy tego nie ukrywałam. Tam trzeba było w tych ankietach wypisywać, czy się ma rodzinę za granicą, gdzie, stopień pokrewieństwa - makabra! Ja już wolałam wszędzie pisać prawdę, żeby nie było przykrości. A mój ojciec był na tyle mądry, że - zresztą był nastawiony bardzo anty-, bardzo cierpiał, uważał, że jesteśmy pod okupacją rosyjską - gdy namawiano go, żeby wstąpił do wojska polskiego, tego powojennego, to się nie dał. I dzięki Bogu, mądrze zrobił, bo potem była taka afera i ci przedwojenni oficerowie, którzy wstąpili do wojska, potem mieli proces i nawet kary śmierci. Ale jeszcze wracając do studentów, była też walka $\mathrm{z}$ religią. Ja sama byłam w takim rozkroku, ponieważ byłam wychowana w rodzinie religijnej, a tutaj to ZMP, więc miałam szereg takich momentów zawahań. Pamiętam, jak mnie przekonywano, jedna z tych aktywistek mówiła do mnie tak: „No jak to, przecież jak jesteś chora, to idziesz do lekarza, nie do znachora" [śmiech]. To miał być jej argument na to, że religia to jest tylko wymysł, to jest opium dla ludu. Potem jednak jak wychodziłam za mąż, to było już po trzecim roku, myśmy z mężem brali ślub kościelny. Ale ja uważałam, jeszcze wtedy byłam w ZMP, że muszę 


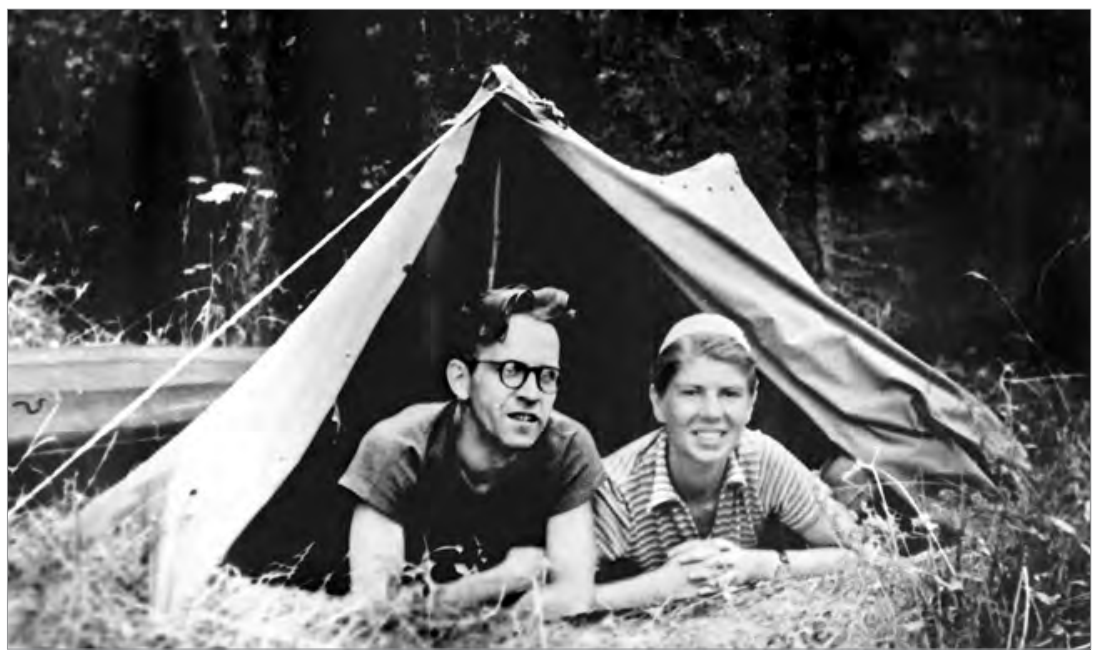

Fot. 62. Krystyna i Jan Lutyńscy

o tym powiedzieć w Zarządzie swego koła ZMP. Poszłam do nich i powiedziałam: „Słuchaj Włodek, ale ja będę brała ślub kościelny”. „No dobrze...” Więc takie to były wtedy [śmiech] różne dylematy, traktowane niezwykle serio, bo jeżeli człowiek był ideowy, to rzeczywiście było wtedy ważne. Zresztą to doskonale opisuje Kuroń w tej swojej Winie i karze ${ }^{43}$ - te problemy młodego człowieka, który o pewnych rzeczach wie np. o tym, że aresztowano i torturowano niewinnych ludzi i tak dalej, a jednocześnie jest pod szalonym urokiem haseł komunizmu. Ja to przeżywałam i wielu młodych ludzi. Dopiero 1956 rok to dla mnie i dla wielu było takie objawienie. Odwilż, rok 1956 był dla wielu wielkim szokiem, wielkim otwarciem oczu.

Romuald Olaczek, student geografii w latach 1952-1956, dziś emerytowany profesor biologii, eksponuje inne cechy ówczesnej rzeczywistości, podkreślając przede wszystkim kolektywny i więziotwórczy aspekt podejmowanych w grupie działań:

Gdzieś w połowie sierpnia 1952 roku przyjechałem do Łodzi. Dotarłem do gmachu rektoratu na rogu Lindleya i Narutowicza, odszukałem komisję rekrutacyjną, pokój, w którym dwóch, jak mi się wydawało, bardzo poważnych młodych mężczyzn za biurkiem siedziało. A to byli po prostu studenci trzeciego lub czwartego roku - Ignacy Gajewski z polonistyki ${ }^{44}$ i Jurek Nowicki z chemii! Ja do nich stereotypowo „Proszę panów, chciałem się dowiedzieć”. Pan Gajewski mi przerywa: „Kolego, tu nie ma panów. Wszyscy jesteśmy

${ }^{43}$ Chodzi o książkę Jacka Kuronia Wiara $i$ wina: do i od komunizmu, Niezależna Oficyna Wydawnicza, Warszawa 1989.

${ }^{44}$ Ignacy Gajewski - student polonistyki, w latach 50. Pełnił funkcję przewodniczącego ZSP. 
kolegami". To pierwsze spostrzeżenie, jak wtedy była zorganizowana uczelnia i jaką samodzielność i uprawnienia miała młodzież studencka. Całą tę procedurę formalną, przygotowanie papierów, przeglądanie, korespondencję prowadzili studenci starszych lat. Studenci kierowali stołówkami, studenci kierowali domami akademickimi, nie było etatowych administratorów. To wszystko robili studenci w ramach Zrzeszenia Studentów Polskich, które było prężną organizacją. Przewodniczący uczelnianego zarządu ZSP był członkiem Kolegium Rektorskiego ${ }^{45}$, studenci mieli reprezentację w senacie, w radach wydziału. Byli rzeczywistymi partnerami i to był rok 1952! Ale stosunki miedzy ludźmi, muszę powiedzieć, były wtedy pełne życzliwości. Dom akademicki, w którym mieszkałem na pierwszym roku, to był budynek na rogu Jaracza i Kilińskiego. Pamiętam taki epizod, że były jakieś wybory ${ }^{46}$. Już nie pamiętam, czy do sejmu, czy do rad narodowych. W szkole niedaleko Teatru Jaracza był lokal wyborczy. Któryś z chłopców przybiegł i mówi, że chuligani w tym lokalu rozrabiają. I momentalnie, nieagitowani przez nikogo, studenci, którzy w duchu mieli bardzo różne zapatrywania i nie zawsze entuzjastyczny stosunek do, jak to się wtedy mówiło, nowej czy obecnej rzeczywistości, czyli do Polski Ludowej, na wieść, że w lokalu wyborczym coś się dzieje, natychmiast wszyscy ruszyli na odsiecz. Zanim przybyła jakakolwiek milicja, z tymi chuliganami szybko się rozprawiliśmy i porządek został przywrócony. Taki był początek studiów. Skończyłem te studia w roku 1956, na ogół z niezłymi wynikami. Wszystkie egzaminy, jakie zdawałem - zdawałem na piątkę. Było nas takich dwie osoby. Rok był nieliczny. Na geografii na pierwszym i drugim roku było nas tylko dwadzieścia siedem osób. W czasie studiów działałem aktywnie i w ZSP, i w ZMP ${ }^{47}$, i w różnych ruchach studenckich. A życie studenckie wtedy było bardzo bujne. Każdego roku na uniwersytecie, który liczył około czterech tysięcy studentów, wiosną był przegląd amatorskiej twórczości artystycznej studentów. Trwał kilka dni. Każde popołudnie w auli uniwersytetu, zamienionej na widownię ze sceną, poszczególne grupy: śpiewaków, satyryków, poetów prezentowały swój dorobek i co ciekawe, zawsze była pełna widownia. Było też ożywione życie sportowe.

${ }^{45}$ Zrzeszenie Studentów Polskich (ZSP) - działająca od 1950 roku organizacja studencka założona w Warszawie. Jego programową działalnością miała być przede wszystkim pomoc studentom w kwestiach materialno-bytowych. Do1956 roku ZSP było jednak silnie uwikłane w polityczną działalność reżimowego państwa.

${ }^{46}$ Najprawdopodobniej chodzi o wybory do Sejmu PRL pierwszej kadencji, które odbyły się, jak mówią źródła historyczne, „w atmosferze terroru” 26 października 1952 roku. Zob. Jacek Wojsław, Kampania propagandowa towarzyszaca wyborom do sejmu z 26 października 1952 r., „Polska 1944/1945-1989: studia i materiały”, t. 9, Instytut Historii Polskiej Akademii Nauk, Warszawa 2010, s. 133-153.

${ }^{47}$ Zob. przypis $42 \mathrm{w}$ tym rozdziale. 


\section{Organizacje mlodzieżowe}

Przedstawione powyżej cytaty w dużej mierze pokazują relacje między studentami przez pryzmat działalności organizacji studenckich. Warto temu wątkowi poświęcić nieco więcej uwagi. We wspomnieniach najczęściej znajdujemy odniesienia do ZMP. Ponieważ w poprzednim podrozdziale znalazło się już kilka opisów działalności tej organizacji, tutaj przedstawimy tylko jeden cytat, zachowując w pamięci fakt, iż wielu naszych rozmówców wspominało, iż większość studentów należało właśnie do ZMP. Tym niemniej charakterystyczną cechą wszystkich poniższych opisów, w zasadzie niezależnie od profilu ideologicznego, jest upolitycznienie działalności studenckiej tego okresu. Konsekwencją walki ideologicznej była likwidacja wszystkich organizacji studenckich poza tymi kontrolowanymi przez władzę. Warto zauważyć, że ów ideologiczny monopol został podtrzymany do roku 1981, kiedy, jak to zostało pokazane w rozdziale III, w rezultacie strajku studentów łódzkich powstało Niezależne Zrzeszenie Studentów.

Romuald Skowroński studiujący chemię w latach 1948-1952 był członkiem „Bratniaka”:

Wtedy były różne organizacje młodzieżowe. Wzorem przedwojennych uczelni powstała Bratnia Pomoc ${ }^{48}$. Udzielała bardzo istotnej pomocy, jeżeli chodzi o sprawy ubioru młodzieży akademickiej, wyżywienia i tak dalej. Po prostu przez Bratnią Pomoc przechodziły dary UNRRA ${ }^{49}$. To była głównie pomoc amerykańska. Jeszcze wtedy to nie było tej pomocy Zachodu. Był rozdział odzieży, płaszczy, ubrań, butów z UNRRA. Nawet były takie dary, pamiętam, z Norwegii, narty - były buty i narty o długości dwa dziesięć, na których się bardzo trudno jeździło. Ale wtedy bardzo dużo się jeździło na nartach, szczególnie na Dolnym Śląsku. Były te nowo odkryte ziemie: Sudety, Szklarska Poręba i tak dalej. Bardzo modne tereny i dużo lepiej zagospodarowane, bo to były tereny wypoczynkowe, niemieckie. Było mnóstwo bardzo dobrze utrzymanych domów wypoczynkowych, które należały do różnych niemieckich związków zawodowych. Bardzo dużo było domów, które należały do takiego niemieckiego odpowiednika Związku Nauczycielstwa. To wtedy była forma

${ }^{48}$ Bratnia Pomoc „Bratniak” - studencka organizacja samopomocowa założona w połowie XIX wieku przy polskich uniwersytetach. Reaktywowana po wojnie, została upolityczniona w początkowym okresie stalinizmu, a potem zlikwidowana i zastąpiona Socjalistycznym Zrzeszeniem Studentów Polskich.

${ }^{49}$ UNRRA (United Nations Relief and Rehabilitation Administration) - organizacja międzynarodowa powstała w celu pomocy obszarom wyzwolonym po II wojnie światowej w Europie i w Azji. Większość pomocy UNRRA finansowana była przez USA, a Polska była jednym z największych beneficjentów tej pomocy. 
bardzo modnych obozów akademickich. Organizowało się wtedy zarówno obozy zimowe, jak i letnie. Tym właśnie zajmowała się Bratnia Pomoc. Jeździło się głównie na Mazury, bo one były bardzo atrakcyjne, jeżeli chodzi o jeziora. A poza tym myśmy tam prowadzili coś w rodzaju pracy społecznej. Ta miejscowa młodzież mówiła swoim dialektem i myśmy tam w czasie tych obozów po pierwsze, otworzyli wiele szkół, opiekowaliśmy się szkołami i uczyliśmy polskiego w wielu wypadkach. Pierwszy obóz urządziliśmy w Sorkwitach [mazurska wieś], nad pięknym jeziorem, gdzie był taki piękny pałac, bardzo zniszczony, bo tam kwaterowały wojska radzieckie. Wojna jak to wojna - nawet konie były wyprowadzane na pierwsze piętro, więc pierwszym celem było odremontowanie tego zamku, żebyśmy mieli gdzie mieszkać. Przez księdza poprosiliśmy, że potrzebujemy ludzi do pracy. Zgłosiło się tyle osób, że wszystkich nie byliśmy w stanie zatrudnić. Ja nie wiem, jak to się stało, ale widać miałem jakieś zdolności organizacyjne, bo cztery czy pięć razy byłem tak zwanym komendantem obozu, właśnie w tych Sorkwitach i na Dolnym Śląsku. Pamiętam, że elitarnym obozem miał być pierwszy obóz w Poroninie. Ja tam pojechałem na rekonesans do kolegi mojego ojca z Legionów. I tam w Poroninie takie dwa dość duże domy wynająłem. Piękna miejscowość, Tatry. Wtedy jako Bratnia Pomoc mieliśmy dwa auta wojskowe, bo najpierw trzeba było pojechać taką ekipą ośmiu, dziewięciu osób. Tam się jakoś złośliwie wydarzyło, powstała idea, że to ma być wzorowy obóz i muszą tam jechać najładniejsze dziewczyny. Chętnych było bardzo dużo i myśmy, że tak powiem, co ładniejsze dziewczyny [śmiech] wybierali. Obóz był bardzo przyjemny, jedzenie było bardzo dobre i poznawaliśmy Tatry, bo to zawsze ciężarówka podwoziła nas daleko do dolin. To był naprawdę bardzo udany obóz. Z tym się wiąże cała historia różnych wydawnictw, jak na przykład gazeta pod tytułem „Pchła”, gdzie były różne ciekawostki, a potem szczególnie „Wędrzyn”, na ziemi lubuskiej. Myśmy tam też zorganizowali obozy na byłych poligonach Wehrmachtu, więc były bardzo dobre warunki lokalowe, bardzo dobra stołówka. To był obóz ogólnouczelniany, więc tam byli koledzy z Uniwersytetu, Akademii Medycznej, która była wówczas jeszcze wydziałem Uniwersytetu, ale też z tych szkół artystycznych: muzycznej, teatralnej. I tam było potem wiele późniejszych sław aktorskich i muzycznych. Na tej ziemi lubuskiej byli osadnicy, którzy musieli wyjechać z ziem wschodnich, często z okolic Wilna. I myśmy, mając znakomitą ekipę, prowadzili bardzo bogatą akcję kulturalną. Mieliśmy występy w Zielonej Górze i w Sulęcinie, i w Bierszowie. Powodzenie mieliśmy ogromne. Sulęcin i Poronin to już było zupełnie co innego. To były lata 1949-1950, kiedy się zaczynał już ten prawdziwy terror stalinowski. Myśmy na przykład w Poroninie, tak żeby „Panu Bogu świeczkę, a diabłu ogarek", śpiewali Kiedy ranne wstaja zorze i Międzynarodówkę, żeby nikt nie miał pretensji. Ale wtedy zaczęły się wizyty z innych organizacji politycznych. Oczywiście z tego drugiego obozu w Poroninie mnie zdegradowano 
i odwołano mnie z funkcji komendanta. Już potem w latach pięćdziesiątych obozy akademickie w tej formie się skończyły, bo w latach 1952, 1953 był przeogromny terror polityczny.

\section{Eugeniusz Czerniawski działał w Caritas Academica:}

Ja pracowałem w Caritas Academica ${ }^{50}$, prowadziłem sekcję zdrowia, która była podzielona na dwie półsekcje. Jedna sekcja była medyczna: tu wchodziła stomatologia i medycyna, i farmacja była jeszcze, a druga sekcja udzielała pomocy studentom chorym w szpitalach. I była też stołówka w Caritas Academica, teraz to jest sala ks. Jerzego Popiełuszki w kościele u jezuitów ${ }^{51}$. I w tej stołówce szukałem ludzi do pomocy, np. mówię: „Kto jest tam z prawa, to się zgłaszać. W szpitalu leży student, trzeba do niego podejść", bo skryptów nie było, tylko notatki z zajęć. Leżał, skomplikowane złamanie nogi, i leżąc do egzaminu się przygotował. Mówię: „Warunek jeden, pomóc studentowi, który studiuje, ma legitymację studencką, niezależnie, czy należy gdzieś". Bo tam był jeden, co był chory, a należał do ZMP i jemu też pomogliśmy, on potem napisał taki bardzo miły list z podziękowaniami do Caritas Academica, bo mu te notatki przynosili do szpitala, żeby mógł uczyć się do egzaminu. A przychodzi też kiedyś ode mnie taki starszy kolega i mówi: „Kolego, jestem z Armii Krajowej z Nowogródka i potrzebuję opatrunków". A ja opatrunków nie miałem, tylko witaminy i inne rzeczy, a opatrunki nie, więc mówię: ,Jak się cieszę, że widzę tu kogoś z Nowogródka ${ }^{52}$, tak przyjemnie jest, ale ja nie mogę dać". Bo to była nie moja, a studentów własność. A później kiedy mnie wzywali na Anstadta ${ }^{53}$, widzę, że on idzie korytarzem - czyli to był ubek. I było mi bardzo „potrzeba” przed aresztowaniem właśnie pchać się w coś takiego, ale na szczęście nie dałem się wtedy nabrać. Jak byłem aresztowany i siedziałem tu na Anstadta, to wiedziałem, że szykuje się aresztowanie ojca Tomasza Rostworowskiego $0^{54}$. Na tych całych przesłuchaniach, to trwało całą dobę, od rana do rana, zorientowałem się, że ojca chcą aresztować, więc jak mnie puścili,

${ }^{50}$ Caritas Academica była częścią powołanej po wojnie przez Episkopat organizacji charytatywnej pod nazwą Caritas. Zadaniem Caritas Academica była pomoc studentom w zakresie materialnym, kulturalnym i duchowym. Uniwersyteckie koła Caritas Academica zaczęły powstawać w roku akademickim 1946/1947. W roku 1950 zawieszono działalność Caritas Academica, ale duszpasterstwa akademickie dalej zajmowały się działalnością charytatywną na rzecz studentów. Zob. www. encyklo.pl/index.php5?title=Caritas_Academica (20.07.2015).

${ }^{51}$ Kościół pw. Najświętszego Imienia Jezus przy ulicy Sienkiewicza 60.

${ }^{52}$ Rozmówca pochodzi z Wilna.

${ }^{53}$ W latach 1945-1959 mieściła się tam siedziba Wojewódzkiego Urzędu Bezpieczeństwa Publicznego, gdzie przetrzymywano więźniów politycznych i wykonywano egzekucje.

${ }^{54}$ Ojciec Tomasz Rostworowski (1904-1974) - jezuita. W 1945 roku oddelegowany do Łodzi, gdzie został duszpasterzem akademickim. Pełnił tę funkcję do roku 1950. Aresztowany przez UB zimą 1950 roku,a następnie skazany na 12 lat więzienia za rzekomą działalność antypaństwową. Został zwolniony w 1956 roku. 
poszedłem od razu do ojca i mu o tym powiedziałem. On tylko tak pokiwał głową, chyba się tego spodziewał.

\section{Olga Czerniawska opowiada o działalności w Sodalicji Mariańskiej:}

Jeszcze w okresie, kiedy byłam w szkole średniej, zaczęła się taka moja przygoda z Sodalicją Mariańską ${ }^{55}$. Już nie pamiętam, kto nas zwerbował, zorganizowane zostały w Zakopanym takie pierwsze rekolekcje dla młodzieży szkolnej, żeby odrodzić Sodalicję Mariańską, no i w 1946 roku jechałyśmy ze wszystkich gimnazjów łódzkich. To było dla dziewcząt, żeńska Sodalicja, jechałyśmy wynajętym wagonem pociągu. Zajmowały się nami siostry urszulanki, które były bardzo dobrze zorganizowane, jedna siostra urszulanka była przygotowana przez POW, czyli przysposobienie wojskowe kobiet, więc była taką energiczną siostrą i bardzo miłą osobą. Beczka z kapustą, worek mąki i tak nas wieźli do Krakowa. W Krakowie przetoczenie, bo były inne tory i tę beczkę z kapustą trzeba było przetoczyć do następnego wagonu i z powrotem. A myśmy też wszystko miały, kołdry i tym podobne, bo tak się wtedy jeździło. Pierwszy obóz był w Jaszczurówce, naprzeciwko był klasztor sióstr, a obok myśmy mieli lokum, willa taka była. Ksiądz, nieżyjący już, był moderatorem, ponieważ on miał jakieś kontakty z UNRRA, więc jedzenie było bardzo dobre, jakieś puszki z brzoskwiniami. Siostry prowadziły kuchnię, i to też też nie byle jaką, tylko wszystko musiało być akuratnie, jak się kroiło ziemniaki w plasterki, to musiała być marchew w plasterki, jak w kostkę, to w kostkę, nie tak byle jak. Myśmy zmywały, podawały do stołu. Do stołu były wazy, nakrycia, wszystko trzeba było podać elegancko, nie tak, że jakoś się rzucało i już. Na tę Sodalicję Mariańską jeszcze część przyjechała panienek z Krakowa ze swoim moderatorem i tak została założona Sodalicja Międzyszkolna. Nie wiem, co ten ksiądz we mnie widział, w każdym razie zaproponował, żebym ja była wiceprezeską tej Sodalicji, a moja koleżanka, która jest profesorem fizyki, obecnie już na emeryturze, została prezeską. Naszym zadaniem było prowadzenie Sodalicji Międzyszkolnej, więc prowadziłyśmy ją, ale także w każdej szkole miała być założona Sodalicja, więc u Czapczyńskiej ja założyłam Sodalicję i w poszczególnych innych szkołach też zostały założone Sodalicje. Ale potem był okres stalinizmu. Szkoła została upaństwowiona, przyszła komisja i pyta: „Jakie organizacje działają?”. No jakie organizacje? Był OMTUR ${ }^{56}$,

${ }^{55}$ Sięgające XVI wieku katolickie stowarzyszenie osób świeckich, o zadaniach formacyjnych i apostolskich, skierowane przede wszystkim do młodzieży, zwłaszcza studenckiej. Szybko odradzające się po wojnie struktury Sodalicji Mariańskiej zostały zawieszone w 1949 roku przez władze kościelne. Wiązało się to z wydanym przez władze nakazem rejestracji wszystkich stowarzyszeń i organizacji religijnych z podaniem list ich członków. Od 1948 roku działaczy Sodalicji zaczęły dotykać represje władz.

${ }^{56}$ OMTUR (Organizacja Młodzieży Towarzystwa Uniwersytetu Robotniczego) - założona przez PPS, po wojnie reaktywowana, w 1948 roku weszła w skład Związku Młodzieży Polskiej. 
bo miałam koleżankę, która to organizowała, siedziała ze mną w ławce. I to też było postępowe, bo ona była mężatką, była w ciąży, więc wyobraża sobie pani, w szkole dla dziewcząt kobieta w ciąży? A była. Ubierała się tak, że nie było tak widać tego brzucha, więc ona założyła OMTUR. I profesor Sadowski, który był w PPS-ie, opiekował się OMTUR-em, a Sodalicją opiekował się ksiądz. Więc jak przyszedł wizytator, to się wypytywał. Ten OMTUR nie był zbyt wysoko ceniony, bo to był PPS, a musiał być ZMP czy ZMS. W każdym razie musiała być taka komunistyczna organizacja, a tego u nas nie było. No i straszna afera, że co to jest - szkoła prywatna, nie ma tego, a jest Sodalicja! Myśmy robiły różne akcje pomocy, że się np. paczki robiło na wieś. Jedna z koleżanek mieszkała na wsi, więc napiekłyśmy ciastek, zrobiłyśmy paczki i to zostało na święta Bożego Narodzenia na tej wsi rozdane. To doszło do kuratorium i były prześladowania. Mówię o tym dlatego, że przy zdawaniu na uniwersytet oprócz egzaminu była rozmowa kwalifikacyjna i tam mnie pytali o tę Sodalicję. Ja się wyparłam, bo tam nie mieli takich dokładnych danych o mnie. O koleżankach innych mieli, to ich nie przyjęli, przecież one jeździły po Polsce i nie mogły się dostać na uniwersytet. W tej rozmowie kwalifikacyjnej je dyskwalifikowano. Koleżanka gdzieś tam po iluś rozmowach wreszcie się dostała na medycynę, ale miała duże problemy. A mnie się jakoś udało, wykpiłam się, że nie widzieli, że ja jestem w tej Sodalicji.

Powróćmy na koniec do wspomnień Krystyny Lutyńskiej, która z ZMP wypisała się w 1956 roku. Opowiada ona o wykorzystywaniu młodzieńczego zapału do działania i przemiany rzeczywistości w czasie agresywnej ideologizacji:

Jeżeli chodzi o młodzież ZMP-owską, to w pierwszych latach po wojnie, tam właśnie byli jeszcze bardzo wierzący komuniści. Wtedy były wielkie imprezy organizowane przez ZMP. Pamiętam, studenci szli na plac Wolności, robiliśmy takie wielkie koło i tańczyliśmy lambadę. To jest taka piosenka, w której coś tam było o Stalinie i to się jakoś tak tańczyło, nogi wysuwając. To było szalenie, szalenie wesołe [śmiech]. To nie było wcale ponure. A potem szło się na spacer czy na piknik. Tylko trzeba było być w tych koszulach. Jeszcze na początku, jak byli ci omturowcy i ZWM-owcy, to omturowcy mieli niebieskie koszule i czerwone krawaty, a ZWM-owcy mieli białe koszule i czerwone krawaty. Potem jeździłam też na takie studenckie obozy pracy, gdzie pomagaliśmy. To były obozy organizowane we wsiach skolektywizowanych albo w PGR-ach. Ja byłam na takim obozie gdzieś na Pomorzu, w PGR-ze. Byliśmy zakwaterowani w jakiejś ogromnej sali, kilkadziesiąt osób. Wychodziliśmy tam do prac polowych. A jeszcze przedtem były takie wyjazdy, zbieranie stonki na przykład, coś takiego, bo wiadomo, że stonkę zrzucają Amerykanie z samolotu [śmiech]. Ale na tym obozie było nie tylko uczestnictwo w pracach 
polowych - grabienie siana, żniwa czy co tam popadło - ale również trzeba było jeździć do pobliskich wsi i przekonywać chłopów, żeby się kolektywizowali. Wójt zwoływał chłopów do jakiejś świetlicy i przyjeżdżało dwóch takich nieszczęsnych studenciaków, którzy zostali wyznaczeni przez kierownictwo obozu i im tam opowiadało, ,jak to dobrze jest, żeby wieś się skolektywizowała, jaki to wielki dobrobyt i tak dalej”. Ja wspominam to bardzo przyjemnie, bo jechałam na tę wieś jakąś bryczką w towarzystwie bardzo przystojnego kolegi. Tylko potem, jak zobaczyliśmy tych chłopów, którym kazano przyjść na zebranie i wypowiedzieliśmy tę swoją prelekcję, po której było kompletne milczenie, to poczuliśmy się bardzo głupio i źle i szybko wróciliśmy. ZMP-owcy brali też udział w agitacji przedwyborczej. Niedawno mi się przypomniało, że nas organizowano w takie piątki i byliśmy w tych swoich koszulach i w każdej piątce byli tacy mocniejsi ideologicznie i w gębie, i słabsi - wszystkich angażowali. A ponieważ prawie cały rok należał do ZMP, więc to była kupa ludzi. Chodziło się tak od domu do domu. Ja pamiętam, że chodziłam w tej piątce w takiej dzielnicy domków kolejarskich. To nie była dzielnica willowa, tylko domki robotników. No i niech pani sobie wyobrazi: ludzie siedzą - to zwykle tak wieczorami się odbywało - przy kolacji siedzą i jedzą czy tam coś innego robią, a tu pakuje się piątka takich [śmiech] młodych ludzi pyskatych i jeden zaczyna perorować. Ale nawet tym, którzy milczeli, w tym mnie, było jakoś bardzo głupio, bo też straszyłam w jakiś sposób tych nieszczęsnych wyborców. Tak właśnie wyglądało wciąganie młodzieży w pewne akcje polityczne. Najprzyjemniejsze były bezpośrednio po wojnie, jak jeszcze do szkoły chodziłam, wyjazdy do Warszawy, do odgruzowywania. W Łodzi były też miejsca, które trzeba było odgruzować, np. tam gdzie było getto, gdzie teraz jest Park Śledzia - ten park myśmy, młodzież gimnazjalna, odgruzowywali i sadzili drzewa. W tym widziało się sens. Ale te akcje polityczne, to namawianie chłopów do kolektywizacji czy do głosowania w określony sposób, to nie było przyjemne, przynajmniej dla mnie, bo się bardzo głupio czułam. Pamiętam, jak w czasie którejś dyskusji jedna z członków partii, gdy była mowa o rewolucji i o tym, że wtedy krew się leje i wiele takich osób niewinnych ginie, to ona miała powiedzieć: „Trochę krwi więcej, trochę krwi mniej, co to szkodzi”. To było wypowiadane całkiem poważnie, bez cynizmu i bez ironii. Takie były czasy.

\section{Świadectwa moralności, inwigilacja i kontrola}

Zarówno na etapie rekrutacji, jak i monitorowania postaw studentów, proces studiowania kontrolowany był nie tylko przez ideologicznie zaangażowanych przedstawicieli ZMP, ale również, a w zasadzie przede wszystkim, przez Urząd Bezpieczeństwa. Studenci zdawali sobie sprawę, iż są inwigilowani, choć nie zawsze ich podejrzenia skierowane wobec konkretnych osób musiały się sprawdzać. Oto kilka przykładów. 
Wanda Nowakowska, studiująca na przełomie lat czterdziestych i pięćdziesiątych, pokazuje, jak ważne było odpowiednie pochodzenie wykazane w ankiecie. Można to wspomnienie skonfrontować z wcześniej przywoływanymi przez Krystynę Lutyńską (włącznie z jej własnym przypadkiem) przykładami dylematów związanych z ujawnianiem własnych „złych” korzeni.

Ja pamiętam tylko jedno, że jak zdawałam na uniwersytet, to był jakiś egzamin z wiedzy o Polsce, coś takiego. I ankieta była oczywiście, a tam: zawód ojca, pochodzenie. Jakie? No to oczywiście inteligencja pracująca. Zawód ojca przed wojną. Ja pytam: „Tatusiu, no co ja mam napisać?”. Przecież nie napiszę, że starosta, bo to już byłby koniec. A ojciec mówi: „Napisz urzędnik państwowy. - No pewnie!”. No i był ,urzędnik państwowy”. Ale przewodniczącym tej komisji był taki profesor Zajączkowski senior ${ }^{57}$, historyk świetny, który znał mojego ojca. On wiedział oczywiście, co i jak, ale miał przed sobą „urzędnik państwowy” i powiedział: „Bardzo dobrze”. Egzamin z tej historii Polski współczesnej też jakoś zdałam.

Eugeniusz Czerniawski opowiada, jak to się stało, że choć marzył aby zostać lekarzem, ostatecznie podjął studia na Wydziale Matematyczno-Przyrodniczym. Studiował biologię w latach 1948-1952:

W Wilnie do szkoły chodziłem, tam jeszcze były tajne komplety dla pracujących, dorobiłem maturę w 1948 roku i poszedłem na studia. Starałem się i nie mogłem się dostać, bo chciałem iść na medycynę. Spróbowałem na Wydział Matematyczno-Przyrodniczy - tam był kierunek biologiczny i mikrobiologia. Tutaj jako wolny słuchacz zaliczyłem rok i zostałem studentem. Ale wpadłem $\mathrm{w}$ tarapaty z bezpieką.

Katarzyna Waniek: Bo ta medycyna potem się pojawia, nawet jak pan jest na biologii, to czuć, że pan cały czas w tę stronę zmierza z tą pomocą studencką, to jak to było?

Eugeniusz Czerniawski: To dolne niech pani przeczyta.

KW: No tak, [czyta pokazany dokument]: „Odmawiam obywatelowi wydania świadectwa moralności. Decyzja niniejsza pozostawiona swobodnej ocenie władzy blebleble prezydenta Rzeczypospolitej z dnia o postępowaniu...". No tak. I to świadectwo było potrzebne do studiowania?

EC: Zaraz powiem. Ponieważ byłem wolnym słuchaczem na biologii, a koleżanka powiedziała mi, że wolnym słuchaczom też świadectwo moralności

${ }^{57}$ Stanisław Franciszek Zajączkowski (1890-1977) - historyk, studia ukończył na Uniwersytecie Lwowskim. Od roku 1945 związany z Uniwersytetem Łódzkim, gdzie kierował Katedrą Historii Średniowiecznej. 
jest potrzebne, więc ja je złożyłem. Później okazało się, że to świadectwo jest potrzebne, tylko jeśli była przerwa w nauce, a ja studiowałem. Wobec tego zaliczyłem rok i wziąłem dwa zaświadczenia identyczne, że jestem studentem drugiego roku. Jedno ze sobą nosiłem, a drugie schowałem poza domem. Później mnie wezwali, bo co jakiś czas wzywali na przesłuchanie i zostałem zatrzymany. A miałem iść na egzamin, bo złożyłem papiery w dziekanacie na Wydział Lekarski, który był na uniwersytecie na pierwszym piętrze, a biologia na parterze. Wobec tego papiery wszystkie złożyłem, ten drugi rok już zaliczyłem, ale cały czas nie byłem pewien swojej sytuacji. I mówię: „Jutro idę na egzamin". A zamiast na egzamin poszedłem do dziekanatu lekarskiego i mówię: „Chciałbym teczkę odebrać”. Kierowniczka mówi: „Proszę pana, wszystko wiem, ale to jest na sali egzaminacyjnej, wobec tego raniutko niech pan przyjdzie. Ja o wszystkim wiem, teczka zabezpieczona, schowana i ją panu oddam". No to było umówione. A dlaczego tak zrobiłem? Jak dostałem to świadectwo moralności, to żona jeszcze panną była i pyta: „Co, odwołujesz się?”. Mówię: „Nie jestem głupi. Jedziemy na kajaki tak jak było umówione i już.”. No i jednego dnia zostałem wezwany na przesłuchanie. Ono trwało bardzo długo, kilka razy trzeba było pisać życiorys. To szło od siódmej rano, do około piątej po południu. Ja byłem zmęczony. Przychodzi porucznik w mundurze. Życiorys to krótko, jeszcze takie przesłuchanie, po czym wyjmuje pistolet, otwiera szufladę, pistolet zostawia i wychodzi. Czekam z pół godziny może. Głodny byłem taki. Wchodzi. Zobaczył i od razu do współpracy. Ja mu odpowiadam: „Zgoda”. On mi daje do podpisania, ja mu mówię: „Nie podpiszę”. „To co ze mnie balona robisz? „Nie, jak zobaczę wroga ojczyzny, to zawiadamiam władzę, a jeżeli mój podpis ma tu coś decydować, to biedna Polska”. On chwycił za pistolet, nie pamiętam, czy włożył do kabury, czy w ręku miał i wyskoczył. Znowuż czekam, czekam, przychodzą, na korytarzu siadam. Czekam, poszli dalej do następnego gabinetu, a tam siedzi student, czapka z prawa, bo po sznurku poznaję, i ma znaczek Bratniaka. Zaczyna się. Ja mówię: „Jestem studentem”. - „A przecież nie daliśmy wam świadectwa moralności”. To ja mu odpowiadam: „Bo ja się do was nie zgłaszałem”. Mówi: „Jak to student! Myśmy was na medycynę nie wpuścili”. Mówię: „Bo ja studiuję biologię. Rozmyśliłem się i studiuję biologię”. I daję to zaświadczenie. „A kto tam dziekanem jest? A kto wam załatwił to?”. „Załatwił minister”. I on się zgubił. Ja mówię: „Minister wydał zarządzenie, że likwiduje się wolnych słuchaczy, a jeżeli ktoś zaliczył rok, to automatycznie staje się studentem, a takich jak ja na roku chyba z sześćdziesięciu jest”. Tutaj wyjaśniłem, dlaczego. Wiedzieli, że ja ich nabiłem w butelkę. Później tak jeszcze mówi: „Tutaj zgnijesz”. A ja mu odpowiadam: „To trudno”. Spokojnie. Wyszedł. Tamtego nie ma, nie ma - potem przychodzi, przynosi przepustkę i już. 
Stefan Banasiak, student historii w latach 1949-1952, był jedynie świadkiem zdarzenia, które głęboko utkwiło w jego pamięci, doskonale ilustrującego siłę ówczesnego terroru:

Kiedy byłem na studiach, przez dwa miesiące mieszkałem w takim prymitywnym akademiku i z kolegą po kolacji w stołówce studenckiej przychodzimy wieczorem, a pod drzwiami stoi dwóch panów. Pytają się o nazwisko trzeciego kolegi z pokoju. On był w środku i powiada, żebyśmy weszli do środka. Kazali mu ręce podnieść do góry i obrewidowali go, przeszukali jego dobytek, łóżko, te rzeczy, które uznał za swoje. Wobec nas dwóch pozostałych nie było żadnego zainteresowania. Po paru miesiącach, kiedy przybyli krewni, żeby zabrać te jego rzeczy z akademika, to się dowiedziałem, że wykryto jakąś grupę, która w klasie na portrecie Stalina dorysowała rogi. No i przesłuchiwali ich, trafili na niego, dostał osiem lat więzienia. Oczywiście ja i ten drugi kolega byliśmy zobowiązani do zachowania tego w ścisłej tajemnicy. Dzisiaj chyba jestem już zwolniony po upływie tylu lat z tej tajemnicy państwowej. Ale to są takie sprawy, które pozostawiają ślad na całe życie. I nieprzypadkowo po tylu latach to tkwi, pamiętam szczegóły, pamiętam ten obraz, to, w jaki sposób to rzutowało na mnie. Dlatego zastanawiałem się wiele razy: dorysowując rogi, wiele nie zwojowali, natomiast jego kariera jako młodego Polaka została zwichnięta. Nie było to zbyt rozważne postępowanie.

Warto skonfrontować powyższy cytat z narracjami, zebranymi na użytek innego projektu badawczego ${ }^{58}$, obejmującego osoby urodzone w latach czterdziestych, dla których okres stalinizmu przypadł na czas dzieciństwa lub lat szkolnych. Epizody z portretem Stalina „w tle” nie były chyba rzadkością, a motywacje do podejmowania takich działań mogły być różne: od aktów młodzieńczej kontestacji, poprzez dziecinne czy młodzieńcze „wygłupy”, po wyładowywanie negatywnych emocji. W każdym z tych przypadków konsekwencje działań były (mogły być) niewspółmierne do ich rzeczywistego znaczenia. Przyjrzyjmy się dwóm takim epizodom. Mężczyzna urodzony w 1940 roku wspomina lata szkolne przypadające na okres stalinizmu:

Profesor od języka polskiego był opiekunem biblioteki. Wybrał sobie z nas kilku uczniów i myśmy mu pomagali wypożyczać książki. Bardzo często zastępowaliśmy go w różnych jego pracach. Ale jeden raz na jego i nasze nieszczęście bardzo się naraziliśmy szkole, ponieważ 1 kwietnia wpadliśmy na

${ }^{58}$ Materiał pochodzi z przywoływanego już projektu „Doświadczenie biograficzne w PRL i NRD oraz jego przepracowanie w powojennym pokoleniu 1945-1955: porównanie socjologiczne na podstawie analizy biograficznej”. 
według naszej opinii wówczas znakomity pomysł. Na zapleczu biblioteki, która znajdowała się na trzecim piętrze w szkole, tak prawie na poddaszu, był taki magazynek akcesoriów, które uczestniczyły w uroczystościach pierwszomajowych, rewolucji październikowej i innych takich komunistycznych. Tam były portrety Lenina, Róży Luksemburg, hasła jakieś. I nie wiem, kto wpadł na ten pomysł, w każdym razie myśmy zaczęli te portrety spuszczać na sznurkach z trzeciego piętra na dół w szkole. Cieszyliśmy się przy tym bardzo. Brakowało nam sznurków, bo tych portretów było tam bardzo dużo. Potem okazało się, że była to sprawa bardzo tragiczna dla nas, bo rodzice wszyscy byli wzywani, myśmy byli zawieszeni w prawach ucznia. W ogóle to była wielka tragedia, której myśmy tak nie postrzegali zupełnie. Myśmy to postrzegali jako żart, natomiast rodzice przeżywali to bardzo. Mama płakała, w ogóle rozpacz. Posiedzenie rady pedagogicznej ileś tam godzin trwało, rodzice czekają na wyniki. My musieliśmy też czekać pod tym pokojem. Słyszeliśmy przez drzwi, jak ten nasz profesor, nasz wychowawca, mądry człowiek mówi: „Słuchajcie, przecież to dzieci! Co wy wyprawiacie? To nie można tak myśleć! Przecież oni sobie Prima Aprilis zrobili, to była zabawa, opamiętajcie się!". On krzyczał wtedy i to było słychać aż na korytarzu, więc myśmy mieli jakąś tam iskierkę nadziei, że może jakoś nam się upiecze. Chyba byliśmy wtedy przez dwa tygodnie zawieszeni, ale ten profesor jakoś nas tam wybronił, chociaż wszyscy byliśmy na cenzurowanym już do końca, że tak się naraziliśmy z tymi portretami. Mi się ten wygłup szkolny do tej pory podoba [śmiech].

A oto fragment narracji mężczyzny urodzonego w 1949 roku:

Jeszcze wrócę do takich dat, które w pamięci zostały. Pamiętam zarówno pogrzeb Stalina, co jest ciekawe, bo to był 1953 rok, więc ja musiałem mieć cztery lata. I tak mi w głowie utkwiło, że tam były jakieś salwy, ktoś strzelał. Pamiętam też taką sytuację, kiedy moja siostra poszła do szkoły i przyniosła pierwszy elementarz. To był Falskiego chyba elementarz i ostatnie kartki kończyły się tak: był herb Polski, orzeł bez korony, było coś tam jeszcze i był Stalin. Jedna z tych moich ciotek [z którymi mieszkaliśmy] oglądając ten elementarz, tak przeglądała, przeglądała i doszła do Stalina. Wpadła w furię, złapała widelec i wydłubała oczy temu Stalinowi. Więc ja byłem zdziwiony tym wszystkim. Siostra wpadła natychmiast w płacz, jak to siostra, że zniszczyła jej ten elementarz, natomiast moja mama nie straciła zimnej krwi, złapała ten elementarz i spaliła. To już powinno jakoś zadziałać na mnie, że ta atmosfera była jakaś dziwna. Później dopiero sobie to wytłumaczyłem, że za takie postępowanie ludzie po prostu siedzieli długie lata w więzieniu. Ale ta kobieta nawet nie myślała o tym, tylko tak na nią zadziałał ta postać Stalina w elementarzu. 
Sławomir Cieślikowski (student psychologii w latach 1947-1951) opowiada z kolei o swoich własnych doświadczeniach, które zaważyły na jego karierze edukacyjnej i zawodowej:

W domu wita mnie mama, że byli z UB, trzymali przez trzy dni tatę i zapowiedzieli, że jeżeli ja się nie zgłoszę, to tatę aresztują. A tata w 95\% inwalida. Wobec tego czym prędzej poszedłem na UB. Przygotowałem się odpowiednio, gdyby mnie aresztowano. W ten sposób zafiksowała się moja sytuacja polityczna i uczelniana. $\mathrm{Z}$ trudem zdobyłem dyplom, tylko dzięki uprzejmości na przykład profesor Janiny Kotarbińskiej ${ }^{59}$, która bez litości mnie wypytała w dwa miesiące chyba, po wyjściu z więzienia. Jak ja się mogłem z logiki przygotować w tym czasie czy przy tym typie egzaminów? ${ }^{60}$ Byle jak się mogłem tylko przygotować. Trójkę mi postawiła. Ale wiedziała, w jakiej sytuacji byłem - w ogóle dobrze, że mnie przyjęła. To był koniec marzeń o pracy, co się okazało bardzo szybko. Po wyjściu szukałem pracy. W każdej pracy, a było ich w ciągu trzech miesięcy ponad trzydzieści, był przebieg następujący: „Aha, studia, kończy pan studia, doskonale. Języki? O, to pan sporo zna i zachodnie nawet. Nie tylko starożytne, ale i zachodnie nawet. Co? I niemiecki też, no proszę! Dobra to niech pan zostawi pismo, jutro pan przyjdzie i podpisze zaangażowanie”. Następnego dnia albo za dwa dni przychodzę: „Nie ma etatów”. Bez thumaczenia. „Ale przecież...”. „To było wczoraj, dzisiaj nie ma etatu”. Zorientowałem się dość szybko, że to po prostu jest zwykła tendencja polityczna. Siedział na UB, nie wolno mu siedzieć w Łodzi i pracować, studiów nie skończył i nie skończy. Nie przewidzieli, że ja chyłkiem, chyłkiem będę załatwiał to inaczej, bo gdyby się domyślili, że robię dyplom, to bym tego nie zrobił.

\section{Ówcześni pracownicy}

Przechodzimy teraz do prezentacji perspektywy ówczesnych pracowników naukowych, z którymi do czynienia mieli wówczas nasi rozmówcy. Jak to już zostało podkreślone, w większości przypadków byli to przedwojenni uczeni - profesorowie bądź doktorzy lub młodzi asystenci rozpoczynający pracę w latach pięćdziesiątych po podjętych tuż po wojnie studiach. Niezależnie od stażu pracy wszyscy w równym stopniu musieli zmierzyć się z presją ideologiczną. Rozpoczynamy od relacji zapośredniczonych, tj. opowieści ówczesnych studentów lub młodych asystentów obserwujących zmagania z systemem swoich wykładowców, profesorów, mistrzów. Powróćmy do wspomnień Sławomira Cieślikowskiego, który rozwijając

\footnotetext{
${ }^{59}$ Zob. przypis $11 \mathrm{w}$ tym rozdziale.

${ }^{60}$ Rozmówca nawiązuje tu do swojej opowieści na temat sposobu przygotowania do egzaminów. Były one wówczas nieliczne, ale wymagały wiele nauki - zob. rozdział I.
} 
opowieść o konsekwencjach aresztowania i więzienia, mówi o trudnościach związanych ze zdobyciem dyplomu i w tym kontekście przedstawia sylwetkę profesora psychologii Eugeniusza Geblewicza ${ }^{61}$.

\section{Postawy profesorów}

Sławomir Cieślikowski:

Eugeniusz Geblewicz zapisał się w mojej pamięci jako człowiek wyjątkowo dużej klasy i odwagi. Gdzie jest ten indeks mój? Ach, tu jest. Aresztowano mnie w październiku 1950 roku, a wypuszczono w 1951 roku. Tu są daty [zagląda do indeksu] absolutorium i egzaminów. Magisterium zrobiłem pod koniec 1951 roku. A cały 1950 i 1951, czyli semestr dziesiąty czy dziewiąty, zakończyłem wtedy, kiedy byłem w więzieniu.

Kaja Kaźmierska [czytając]: „1950 rok, semestr letni”, tak jest napisane.

Sławomir Cieślikowski: Dobrze, semestr letni. Mnie nie ma - jestem w więzieniu. A co napisał Geblewicz?

KK: „Stwierdzam, że obywatel Sławomir Cieślikowski przygotowuje pracę magisterską pt. Wpływ elektrowstrząsów na bezpośredni zakres pamięci, 18 istopada 1951 rok".

SC: Tak. Dopiero wtedy. Ale za który rok? Za poprzedni. Za czas, który siedziałem. Odważny?

KK: No tak.

SC: Nie wiem, czy jest wielu profesorów w Łodzi, którzy odważyliby się coś takiego zrobić. Mam duży szacunek i duży dług wdzięczności w stosunku do profesora Geblewicza. Też ciekawy człowiek. Doktorat jego chyba był w Paryżu. Napisał dwie nieduże pracki, które w Paryżu opublikował, oczywiście po francusku. No i to moje zdumienie, bo on to opracował w połowie lat trzydziestych XX wieku. Pół wieku później dostałem do ręki angielską książkę z psychologii eksperymentalnej. Przeglądam bibliografię i jest Eugeniusz Geblewicz, obie prace! To sięgam do tekstów, gdzie to jest. I widzę, że autor powołuje się na jego wyniki prac i wyciąga wnioski, że Geblewicz pierwszy opracował to, to i to, a my teraz ciągniemy to dalej. Pół wieku później. To znaczy, że Geblewicz umiał wybrać temat, użyć nowoczesnych metod tak, że pół wieku później była wykorzystywana ta praca. Podkreślam to, dlatego że on wymyślił temat dla mnie. A to z tej przyczyny, że kiedy nie mogłem znaleźć po wyjściu z więzienia pracy, to mój kolega wicedyrektor zaangażował mnie do szpitala psychiatrycznego $100 \mathrm{~km}$ za Poznaniem, w Międzyrzeczu-Obrzycach.

${ }^{61}$ Eugeniusz Geblewicz (1904-1974) - psycholog, prakseolog, psycholog sportu, profesor Uniwersytetu Łódzkiego i Warszawskiego. 
I jak się Geblewicz dowiedział, że tam jestem, to „Niech pan się zajmie elektrowstrząsami”. A to była nowość wtedy w ogóle. W polskiej psychiatrii były wtedy tylko dwie prace na temat elektrowstrząsów. Takie poważniejsze jeszcze były trochę później. A o pamięci i elektrowstrząsach w ogóle nic. Więc wziąłem się za robotę, zrobienie badań w szpitalu. Geblewicz wpisywał mi to, a ja przygotowywałem w miejscu pracy pracę magisterską.

Z kolei Krystyna Lutyńska, przypomnijmy, wówczas studentka nauk społecznych, w taki sposób przedstawia zagmatwane losy Józefa Chałasińskiego $^{62}$ - jednego z wybitnych polskich socjologów, dodatkowo postaci niezwykle ważnej dla Uniwersytetu Łódzkiego:

Profesor Chałasiński to był nie tylko wielki autorytet naukowy, ale i jednocześnie dla swoich uczniów wielkie zmartwienie [śmiech], wielkie, stałe zmartwienie. Ponieważ Chałasiński na początku uznał, że w tych warunkach można albo nic nie robić i usunąć się tak jak Ossowski i zachować tę nieskazitelność, albo działać w zgodzie z partią. Ale Chałasiński nigdy nie był komunistą - ani Chałasiński, ani Szczepański. Jednak uznał, że trzeba coś robić, trzeba budować uniwersytet, a żeby budować uniwersytet w Łodzi, to trzeba iść na pewne ugody. Może on w tej ugodzie poszedł za daleko, ponieważ złożył zarówno samokrytykę ze swojego Młodego pokolenia chtopów ${ }^{63}$ - tu chodziło o metodę biograficzną, która była absolutnie niedopuszczalna przez marksistów. Pisał rozmaite artykuły o socjalistycznej Łodzi i tak dalej. W końcu jeździł do Moskwy na urodziny Stalina, było zdaje się coś takiego. A w dodatku miał takie bardzo apodyktyczne usposobienie, to mu przysparzało wielu wrogów i na uniwersytecie, i w ogóle w Polsce wśród opozycjonistów. W 1956 roku, pod wpływem odwilży, czy może w ogóle już miał dosyć tego wszystkiego, w każdym razie pojechał na Międzynarodowy Kongres Socjologiczny, który odbył się we włoskim mieście Stresa. Wygłosił tam wykład o stanie nauki w Polsce, który był strasznie krytyczny w stosunku do tego, co się działo w nauce w ustroju komunistycznym. Spotkały go z tego powodu wielkie represje. Stracił różne stanowiska, bo on piął się bardzo wysoko, był w Polskiej Akademii Nauk i tak dalej. Został odsunięty od nauczania młodzieży, pod jego kierunkiem nie wolno było pisać prac magisterskich ani doktoratów. Został przeniesiony karnie do Warszawy i dostał tam przy Polskiej Akademii Nauk Zakład Kultury Afrykańskiej.

${ }^{62}$ Józef Chałasiński (1904-1979) - profesor socjologii, jeden z założycieli Uniwersytetu Łódzkiego i rektor tej uczelni w latach 1949-1952, członek PAN.

${ }^{63}$ Józef Chałasiński, Młode pokolenie chłopów, t. 1-4, Ludowa Spółdzielnia Wydawnicza, Warszawa 1938 - dzieło na temat ruchów społecznych na wsi, uznane za najwybitniejszą pracę empiryczno-teoretyczną w dorobku tego socjologa oraz uznana jako jedna z najbardziej znaczących prac z zakresu polskiej socjologii wsi. 
Sytuacja nauk humanistycznych i społecznych była w tym okresie niesłychanie trudna: likwidowano kierunki, zwalniano pracowników naukowych. Olga Czerniawska opowiada o Aleksandrze Kamińskim ${ }^{64}$ :

Katarzyna Waniek: A co robił Aleksander Kamiński w tym okresie, kiedy zlikwidowano pedagogikę?

Olga Czerniawska: Kiepsko. To było tak, że kiedy pozwalniali profesorów, to przecież nie on pierwszy był wyrzucony. Był taki okres, kiedy sporo osób z Uniwersytetu straciło posadę. Wtedy koledzy się opodatkowywali i ich tam utrzymywali. Przecież i profesor Ułaszyn, i chyba jeszcze inni, i profesor Radlińska ${ }^{65}$ - wszyscy byli zwolnieni. Na polonistyce sporo osób, na historii, na psychologii. Kamiński pewnie też dostawał od kolegów pieniądze. Chorował, nie miał siły, a to, co miał, to pisał. Pisał do szuflady.

Kontynuując swoją opowieść, Olga Czerniawska zwraca uwagę, że fakt zlikwidowania kierunku wpłynął na postawę Aleksandra Kamińskiego w kolejnym okresie, kiedy ciągle musiał zmagać się z dylematem, jak pogodzić dystans wobec funkcjonującej ideologii z działaniami na rzecz podtrzymania aktywności akademickiej - również w wymiarze instytucjonalnym, czyli możliwości rozwoju pedagogiki jako kierunku.

To był czas, gdy pedagogika społeczna była zamknięta, potem wyrzucili Radlińską, podobnie Kamińskiego też usunęli. Po latach profesor wrócił na Uniwersytet, pedagogiki nie było, została reaktywowana dopiero po latach, ponieważ uważano, że to jest dyscyplina nienaukowa, niemarksistowska, idealistyczna, więc coś takiego nie może się pętać po uczelni. I profesor się tego bardzo bał i bardzo był ostrożny: umiejętnie kluczył między cenzurą, tą napaścią, tą krytyką, że to jest nauka idealistyczna, więc był bardzo delikatny i tak wszystko pisał, żeby wilk był syty i owca cała. Pokazywał między innymi, jakie te metody powinny być, ale nie wychylał się za bardzo, ponieważ inaczej by mu książki nie wydali i poza tym dalej by zlikwidowali tą pedagogikę. Trzeba było usta zamknąć w odpowiednim momencie - prawdę powiedzieć, ale tak powiedzieć, żeby ona była nie do podważenia. Miał wrogów, atakowali pedagogikę i jego, wiadomo - taki był okres.

${ }^{64}$ Aleksander Kamiński (1903-1978) - pedagog, harcmistrz i wychowawca młodzieży, zatrudniony na Uniwersytecie Łódzkim do 1950 roku, odsunięty od nauczania z przyczyn ideologicznych, od 1958 roku ponownie zatrudniony.

${ }^{65}$ Henryk Ułaszyn (1874-1956) - językoznawca, slawista, profesor Uniwersytetu we Lwowie i Uniwersytetu Łódzkiego. Helena Radlińska (1879-1954) - profesor pedagogiki, stworzyła pedagogikę społeczną w Polsce, w 1945 roku po przyjeździe do Łodzi uruchomiła na Uniwersytecie Łódzkim Zakład Pedagogiki Społecznej. Jej współpracownikami byli m.in. Aleksander Kamiński i Irena Lepalczyk. 
Bronisława Jaworska-Kopczyńska była już w tym czasie młodym pracownikiem naukowym. Współpracując z profesor Kazimierą Zawistowicz-Adamską ${ }^{66}$ przypatrywała się jej zmaganiom z systemem w sytuacji, gdy jej mistrzyni wyraźnie dystansowała się wobec nowej władzy. Jak trudne były to decyzje i jak brzemienne w skutki, sugeruje poniższy cytat:

Był pierwszy Kongres Nauki ${ }^{67}$, na którym odbyło się dramatyczne naprawianie ideologii nauki polskiej. Ja nie powiem dokładnie. To było w 1951 roku i na tym kongresie, to wiem z relacji profesor Zawistowicz, która była tam i opowiadała, że odbywały się tam straszliwe sądy - jacyś czołowi marksiści polscy grzmieli tam na profesorów Kotarbińskiego, Ossowskiego ${ }^{68}$, Ajdukiewicza ${ }^{69}$, że idealistyczną naukę uprawiają. Pani profesor barwnie opowiadała, jak Kotarbiński twierdził, że jest materialistą, ale nie marksistą, a tamci twierdzili, że nie można być materialistą i nie być marksistą itd. Odbywały się straszliwe dyskusje. Notabene to, co ja $\mathrm{z}$ tych opowiadań pani profesor pamiętam, a na co koledzy z socjologii inaczej patrzą, to kwestia Chałasińskiego ${ }^{70}$. Mianowicie pani profesor opowiadała, że Chałasiński też się straszliwie wypowiadał druzgocąco do tych, którzy nie chcieli pójść nową i prawdziwie słuszną drogą. Pani profesor przyjechała $z$ tego kongresu i jak dziś pamiętam - myśmy na trzecim piętrze na Uniwersyteckiej 3 mieli pokój naszego zakładu, z czasem nas z placu Wolności przeniesiono na Uniwersytecką - tak siadła przy stole i do mnie i do mojej młodszej koleżanki, która miała taki etat roboczy w katedrze, powiedziała: „Dziewczyny, ale chyba będziecie miały do mnie pretensje, bo to się źle skończy, ale ja się wstrzymałam od głosu, jak głosowano uchwały kongresu. Wstrzymał się Ajdukiewicz, Kotarbiński, Ossowski, Wallis ${ }^{71}$ " i wyliczyła parę nazwisk - „Ja tym ludziom ufam, jeżeli oni protestowali, to uważam, że się na tym znali. Nie znam się na filozofii, ale ja tym ludziom ufam, to są prawdziwi i uczciwi ludzie i nie mogłam głosować".

\section{Obowiazkowe szkolenia i egzaminy z marksizmu}

Nieco wcześniej przedstawione zostało wspomnienie ówczesnej studentki Olgi Czerniawskiej na temat egzaminu z marksizmu, teraz zaś pokażemy, jak wymóg zaliczenia tego przedmiotu wyglądał z perspektywy

${ }^{66}$ Kazimiera Zawistowicz-Adamska (1897-1984) - profesor etnologii, w 1945 roku założyła na Uniwersytecie Łódzkim Zakład Etnografii.

${ }^{67}$ I Kongres Nauki Polskiej odbył się 4 lipca 1951 roku.

${ }^{68}$ Zob. przypisy 10 i $16 \mathrm{w}$ tym rozdziale.

${ }^{69}$ Kazimierz Ajdukiewicz (1890-1963) - filozof i logik, był przedstawicielem szkoły lwowsko-warszawskiej.

${ }^{70}$ Zob. przypis $62 \mathrm{w}$ tym rozdziale.

${ }^{71}$ Mieczysław Wallis (1895-1975) - estetyk, teoretyk i historyk sztuki, kierował Katedrą Historii Sztuki, w latach 1955-1956 pełnił funkcję dziekana Wydziału Filozoficzno-Historycznego UŁ. 
ówczesnych pracowników, którzy byli systematycznie, choć nie zawsze skutecznie, poddawani procesowi indoktrynacji.

We wspomnieniach Biruty Lewaszkiewicz-Petrykowskiej, budowanych z dużym dystansem wobec systemu, widać wyraźną różnicę między sytuacją szkolenia a sytuacją egzaminacyjną. Podczas gdy w odniesieniu do tej pierwszej można było grać ironią czy wręcz groteską, kwestia egzaminu powiązana została z przebiegiem kariery naukowej i służyć miała nie tylko weryfikacji wiedzy zdającego, ale też jego postawy wobec systemu. Biruta Lewaszkiewicz-Petrykowska, dziś emerytowana profesor prawa, rozpoczęła pracę jako asystent na Wydziale Prawa Uniwersytetu Łódzkiego w 1949 roku:

W latach chyba 1953-1954 i potem zaczęli nam serwować szkolenia marksistowskie przez różne osoby prowadzone - to też była historia niezła. Potem pamiętam, że mieliśmy z tego egzamin. Szkolenia dla pracowników były prowadzone często przez innych pracowników Uniwersytetu. Niektórzy dzisiaj by się nie przyznali, jak gorliwie szkolili [śmiech]. U nas wtedy powinni byli chodzić wszyscy pracownicy, i asystenci, i profesorowie. Myśmy najbardziej lubili [śmiech], jak na szkolenia od czasu do czasu przychodził profesor Jan Namitkiewicz ${ }^{72}$, w szczególności jak to się odbywało dla całego wydziału albo miało być w ramach zespołu katedr. I najbardziej lubiliśmy, jak przychodził profesor Namitkiewicz w charakterze słuchacza, bo zawsze dochodziło do bardzo zabawnych sytuacji. Pamiętam taką, prelegent opowiadał o rewolucji 1905 roku i wdał się w dyskusję z kimś ze słuchaczy na temat zamachu na jakiegoś policmajstra, któremu bombę podłożono i na balkonie I-go piętra zawisła jego ręka czy noga [śmiech]. W pewnym momencie Namitkiewicz powiada: „A w ogóle ten Mikołaj II był głupi”. To już czuliśmy, że coś z tego będzie. Na to jeden ze słuchaczy - asystent, późniejszy sędzia Sądu Najwyższego, pyta się: „Ale dlaczego panie profesorze?”. A Namitkiewicz mówi: „No jak to dlaczego? To pan nie zna tej historii z tą tancerką, z tą jego kochanką?". Na to on powiada: „Ależ panie profesorze, przecież pan chyba nie uważa, że miłość przeszkadza?" [śmiech]. A na to Namitkiewicz: „Oczywiście, że nie, ale czy pan ją widział? Brzydka była” [śmiech]. „Ja ją widziałem, brzydka” [śmiech]. Jak były szkolenia dla całego wydziału i przychodzili ludzie tak bardziej z zewnątrz, to wtedy różnie bywało. Ja siedziałam na ogół na końcu, ze mną takich dwóch adiunktów, grali zawsze w wojnę morską [śmiech]. Potem musieliśmy zdać z tego egzamin. Pamiętam, że tej komisji przewodniczyła Gryzelda Missalowa ${ }^{73}$, ona

${ }^{72}$ Jan Namitkiewicz (1880-1958) - prawnik i sędzia, profesor na Uniwersytecie Łódzkim i dziekan Wydziału Prawno-Ekonomicznego w latach 1948-1950.

${ }^{73}$ Gryzelda Missalowa (1901-1978) - polska historyk. Razem z Janiną Schoenbrenner wydała w 1951 roku stalinowski podręcznik szkolny do nauki historii Polski. 
była profesorem na Wydziale Historii. Dziekan był przy tym obecny i ktoś tam jeszcze. Pojedynczo się wchodziło i te bzdury tam trzeba było opowiadać. Zresztą zdawaliśmy potem przecież przy przewodzie doktorskim to samo a nawet więcej, tylko wtedy to się zdawało w Warszawie. Pani nie wie, że tak było?

Kaja Kaźmierska: Nie, o tym nie wiem, czy to wszyscy musieli zdawać, czy tylko prawnicy?

Biruta Lewaszkiewicz-Petrykowska: Proszę pani, teraz abstrahując od Wydziału Prawa i historii naszego wydziału, w latach pięćdziesiątych otwarcie przewodu doktorskiego i zrobienie doktoratu było uwarunkowane zdaniem przedtem egzaminu z materializmu historycznego i z materializmu dialektycznego. Ten egzamin zdawało się w Warszawie, w Instytucie Marksizmu ${ }^{74}$. Oni wyznaczali termin x miesięcy wcześniej i tam trzeba było przyjechać i zdawać. To obowiązywało wszystkich: prawników, historyków, matematyków, pracowników Politechniki, lekarzy i tak dalej. Tak było w latach 1954-1955. Później to zniesiono. Był taki moment, że chcieli wprowadzić te całe kandydatury i taki system jak sowiecki. Ale tak czy owak trzeba było zdać ten egzamin z marksizmu. To się odbywało w ten sposób, że tam się wchodziło na określoną godzinę, wyciągało się pytania. Egzaminatorów siedziało tam ośmiu czy dziewięciu. Pamiętam, że na tym egzaminie pytał mnie Kroński ${ }^{75}$. Bez tego egzaminu nie mogło się posuwać postępowanie doktorskie. Tam się trzeba było przygotować samemu. Powiedzmy, dla prawników, historyków, filozofów to ostatecznie było to jakoś do opanowania. Natomiast na przykład dla inżynierów, lekarzy nauczenie się tego to była zupełna makabra. Jednocześnie zdarzało się, że po tym egzaminie w Warszawie, niezależnie od tego, jak go się zdało, nawet bardzo dobrze na przykład, powiadamiano dziekana, że taka czy inna osoba ma niezbyt prawomyślne [śmiech] poglądy i mnie to właśnie spotkało. Udało mi się zdać w pewnym sensie dzięki profesorowi Jerzemu Lande $^{76}$. On był profesorem teorii i filozofii prawa w Krakowie. Współpracowałam z nim w czasie studiów i prawdopodobnie gdyby nie zaczęli rozganiać Jagiellonki, to bym u niego została. Po egzaminie na pierwszym roku z teorii prawa prof. Lande zaprosił mnie na konwersatorium, które prowadził z filozofii prawa i teorii prawa. On je prowadził dla pracowników wydziału. Tam

${ }^{74}$ Instytut Kształcenia Kadr Naukowych - wyższa szkoła partyjna i marksistowska placówka badawcza, powołana w 1950 roku przez Adama Schaffa przy Komitecie Centralnym PZPR. W 1954 roku Instytut przekształcono w Instytut Nauk Społecznych przy KC PZPR. Zadaniem IKKN było kształcenie kierowniczych kadr naukowych w oparciu o sprawdzone wzory nauki radzieckiej (tzw. Instytut Czerwonej Profesury). Dorobek naukowy pracowników Instytutu ograniczał się do krytyki politycznej nauki Zachodu z pozycji marksizmu-leninizmu.

${ }^{75}$ Zob. przypis $25 \mathrm{w}$ tym rozdziale.

${ }^{76}$ Jerzy Lande (1886-1954) - wybitny prawnik, profesor teorii i filozofii prawa na Uniwersytecie Wileńskim i Uniwersytecie Jagiellońskim. 
przychodzili profesorowie, adiunkci i tak dalej. Ja byłam jedyną studentką. Nic na początku nie rozumiałam [śmiech], ale nauczyłam się dużo filozofii wówczas. Właśnie to mi zaprocentowało potem na egzaminie z marksizmu [śmiech]. Bo na tym egzaminie miałam taką metodę, dzięki której zdawałam bardzo dobrze, jak mi zadawali jakieś pytanie z marksizmu, to zaczynałam od Heraklita [śmiech]. Czasem to już nie mieli cierpliwości [śmiech] i puszczali mnie na zasadzie ,jak tamto wie tak dobrze, to musi też znać to" - co było całkowitym nieporozumieniem.

\section{Ideologizacja nauki a kariera akademicka}

Jak pokazują prezentowane dotychczas cytaty, od wszystkich oczekiwano ideologicznej kontrybucji na rzecz systemu. W sposób szczególny objęci nią byli młodzi pracownicy, mający stanowić przyszłe pokolenie naukowców, tzw. nową inteligencję ukształtowaną bez „bagażu” przedwojennego. Wątek ten eksponowany był zwłaszcza w opowieściach rozmówców, którzy próbowali grać kartami systemu w taki sposób, aby nie musieć podejmować wszystkich z góry narzuconych zasad owej gry. Kontekst tych działań był różny, zawsze jednak dotyczył przebiegu kariery akademickiej.

Krystyna Lutyńska opowiada o doktoracie swojego męża Jana Lutyńskiego:

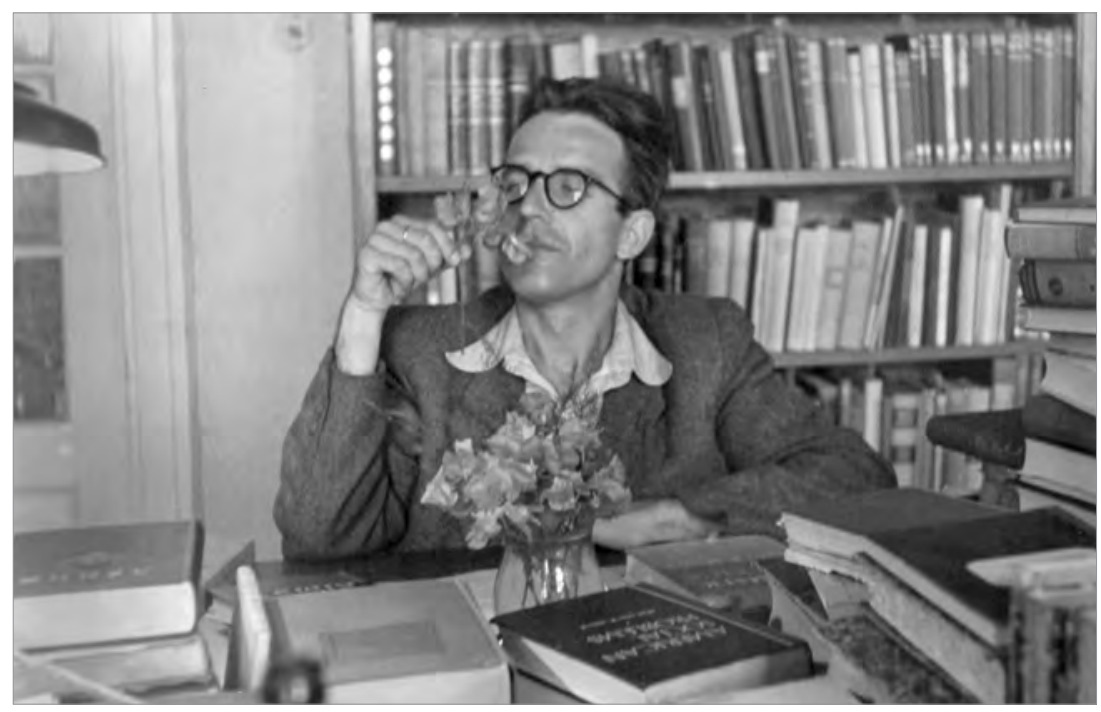

Fot. 63. Uniwersytecka 3. Jan Lutyński przy pracy 
W tym czasie starsi asystenci Chałasińskiego ${ }^{77}$ powoli porobili. Przy czym to też nie było takie proste. Mąż [Jan Lutyński] musiał zmieniać temat pracy doktorskiej; Chałasiński mu poradził, żeby zmienił. Ponieważ ten pierwszy temat, który on chciał, już nie pamiętam o czym mąż chciał pisać, ale on by nie przeszedł. Więc dlatego mąż pisał o etnografii radzieckiej.

Kaja Kaźmierska: Znam tę pracę.

Krystyna Lutyńska: Właśnie, ta jego książka ${ }^{78}$, która wyszła, to wie pani, że do tej pory jest czytana, etnologowie to mają w swoich lekturach.

Z kolei Bronisława Kopczyńska-Jaworska przyznaje, że pracę nad doktoratem powinna była podjąć kilka lat wcześniej, wówczas gdy wprowadzono na wzór radziecki stopień kandydata nauk. W taki sposób wspomina ona swoją strategię ,przeczekania” trudnego okresu nachalnej ideologizacji:

Po doktoracie długi czas nie robiłam habilitacji, zresztą ja długo doktoratu nie robiłam, dlatego że zniesiono doktoraty, były tylko egzaminy i ten tytuł kandydat nauk, a ponieważ nie miałam wielkiej ochoty zdawać marksizmu i leninizmu, bo był taki egzamin, więc się grzebałam z tym doktoratem, a lata płynęły. Były jakieś kursy, trzeba było chodzić, zaliczyć te wykłady z marksizmu i leninizmu, nie było to takie proste. Część kolegów, tych młodszych ode mnie, którzy byli w organizacji młodzieżowej ZMP, wyjechało na stypendium do Związku Radzieckiego, tak jak pani profesor Kulpińska ${ }^{79}$, potem wiem, że z Uniwersytetu to pani Mortimer-Szymczakowa ${ }^{80}$ była, chyba profesor Szymczak $^{81}$ też był. Oni byli na stypendiach w Moskwie i tam robili kandydatury. Ale oni byli zorganizowani wszyscy itd., a my byliśmy wszyscy nieuleczalnie bezpartyjni [śmiech], z panią profesor Zawistowicz ${ }^{82}$ na czele. Wobec tego ja zrobiłam doktorat dopiero w 1959 roku jak zniesiono kandydatury i przywrócono doktoraty. Mój doktorat ma numer jeden na Wydziale Historycznym. Byłam pierwszą osobą, która zdawała doktorat według nowych przepisów. To jeszcze nie były jakieś szczegółowe przepisy wykonawcze, w wyniku czego

\footnotetext{
${ }^{77}$ Zob. przypis $62 \mathrm{w}$ tym rozdziale.
}

${ }^{78}$ Jan Lutyński, Ewolucjonizm w etnologii anglosaskiej a etnografia radziecka, Zakład Narodowy im. Ossolińskich, Wrocław 1956. Autor dokonał tu sprytnego zabiegu - charakteryzując etnografię radziecką, w istocie koncentrował się przede wszystkim na etnologii anglosaskiej. Książka ta przez wiele lat służyła jako źródło rzetelnej, opartej o literaturę zachodnią wiedzy na temat początków angielskiej i amerykańskiej antropologii kulturowej.

${ }^{79}$ Jolanta Kulpińska - patrz biogramy rozmówców.

${ }^{80}$ Halina Mortimer-Szymczak (ur. 1926) - ekonomista, wieloletni pracownik i profesor Uniwersytetu Łódzkiego. W czasie strajku studenckiego sprawowała funkcję prorektora i brała udział w spotkaniach ze studentami z ramie władz uczelni.

${ }^{81}$ Tadeusz Szymczak (1923-2014) - prawnik konstytucjonalista, absolwent i wieloletni pracownik Uniwersytetu Łódzkiego.

${ }^{82}$ Zob. przypis $66 \mathrm{w}$ tym rozdziale. 
nie zdawałam ani ekonomii, ani filozofii jako przedmiotu nauk społecznych, tylko zdawałam socjologię u Jana Szczepańskiego ${ }^{83}$, a jako przedmiot główny zdawałam etnografię [śmiech]. Teraz przy okazji odnawiania doktoratu dowiedziałam się, że byłam pierwsza [śmiech] z tej nowej porcji doktorów. Po doktoracie stosunkowo szybko zrobiłam habilitację, w 1967 roku. Wtedy po habilitacji był taki stopień docenta, a docenta się mianowało profesorem państwowym, tak zwanym belwederskim. Ale to już była procedura dość mocno umaczana w sosie ideologicznym, więc ja dość długo czekałam na tytuł profesora - habilitacja w 1967, a profesura dopiero w 1981 roku. Ale przebił mnie chyba profesor Pawłowski ${ }^{84}$, on jeszcze dłużej czekał [śmiech] na ten awans.

Biruta Lewaszkiewicz-Petrykowska otwarcie kontestowała ówczesną rzeczywistość:

Ja myślę, że się wszyscy przyzwyczaili do tego, że ja mówię, co myślę.

Kaja Kaźmierska: A na przykład nie próbowano się, że tak powiem brzydko, pozbyć pani profesor z uczelni, żeby mieć święty spokój?

Biruta Lewaszkiewicz-Petrykowska: W 1952 czy 1953 roku rzeczywiście była taka historia na skutek tego, co nagadałam, że chcieli mnie usunąć. Ale jakoś to potem przyschło, dlatego że sami między sobą zaczęli się kłócić. Miałam wtedy referat na jakimś zebraniu, na które byli zaproszeni też goście z zewnątrz. Tam mnie zaatakowano, że nie cytuję „świętych marksistów” [śmiech]. I rzeczywiście nie cytowałam. Ja mam w ogóle niewyparzoną gębę, a oni mnie tam zezłościli. Najpierw tłumaczyłam spokojnie, a potem w pewnym momencie się wściekłam i powiedziałam, że „Jest mi bardzo przykro, ale ani Marks, ani Engels, ani Lenin, ani Stalin nie znali się na prawie cywilnym, a w szczególności na zagadnieniu winy, a trudno żebym cytowała «Proletariusze wszystkich krajów, łączcie się», a potem wina w rozumieniu artykułu 134 k.z. to jest to czy owo". A potem jeszcze poszło o taką pracę karnika radzieckiego X [wymienia nazwisko]. Powiedziałam, że on ściąga bez podania źródeł z nauki niemieckiej. I dość mało pochlebnie wyraziłam się o nauce prawa w ZSRR. Po tej całej dyskusji i po tym wszystkim profesor Szpunar ${ }^{85}$ wpadł do pokoju asystentów i wrzeszczał na mnie: „Wariatka! Wariatka! Panią powinno się zamknąć w Kochanówku”86 [śmiech]. „Co pani opowiada! [śmiech] Pani podcina gałąź, na której pani siedzi. Wariatka! Panią powinno się zamknąć w Kochanówku”.

${ }^{83}$ Jan Szczepański (1913-2004) - wybitny polski socjolog, urodzony w Ustroniu, przez wiele lat związany z Uniwersytetem Łódzkim (1945-1970), którego był profesorem a później także rektorem, członek PAN.

${ }^{84}$ Zob. przypis $40 \mathrm{w}$ tym rozdziale.

${ }^{85}$ Adam Szpunar (1913-2002) - profesor prawa, specjalista w zakresie prawa cywilnego, w latach 1956-1962 rektor Uniwersytetu Łódzkiego.

${ }^{86}$ Lokalna nazwa szpitala psychiatrycznego w Łodzi. 
I z tego zrobiła się wielka awantura. Byli tacy, co mówili, że ja jestem czynnikiem destrukcyjnym, bo opowiadam, co chcę. Ale potem Stalin umarł. Oni zaczęli się kłócić wszyscy między sobą i mieli inne sprawy na głowie. Ale wtedy to rzeczywiście napisali o opinię o mnie na Jagiellonkę, o moich rodzicach do Wrocławia, jakieś takie historie. Szpunar mnie bronił. W istocie to mnie obroniło to, że przestali się już interesować pewnymi sprawami.

\section{Ingerencje wladz $w$ proces edukacyjny}

$\mathrm{Na}$ zakończenie części poświęconej czasowi stalinizmu przedstawimy wybiegający również poza ów okres problem szeroko rozumianej ingerencji władz w proces edukacyjny dotyczący różnych poziomów kształcenia. Można tu wskazać zarówno na bezpośrednie interwencje przedstawicieli Ministerstwa, np. zamieszczona poniżej opowieść Biruty Lewaszkiewicz-Petrykowskiej o wizycie urzędników wyjaśniających przyczyny niskiego poziomu zdawalności egzaminów czy opisywane przez Bronisławę Kopczyńską-Jaworską sterowanie naborem na studia jako efekt decyzji o charakterze politycznym. Bardzo interesującym przypadkiem jest opisane przez Wandę Nowakowską nadzorowanie wskaźników limitów przyjęć na studia. Na szczególną uwagę zasługuje tutaj polityka edukacyjna rozwijana nie tylko w latach pięćdziesiątych wobec określonych grup społeczno-zawodowych. Przedstawimy tu dwa przykłady: wyrównywania deficytów edukacyjnych przez pracowników wymiaru sprawiedliwości w latach pięćdziesiątych-sześćdziesiątych oraz przez nauczycieli w latach siedemdziesiątych Przypadek pierwszy odnosi się do sytuacji obsadzania strategicznych politycznie ról zawodowych (wymiar sprawiedliwości zdecydowanie do takich należał) przez zaangażowanych popleczników reżimowego systemu. Drugi przykład związany jest z planowaną w czasach gierkowskich reformą oświaty mającą upodobnić polski system edukacji do systemu radzieckiego (wprowadzenie dziesięcioletniej szkoły podstawowej). Reforma szczęśliwie nie doszła do skutku, ale wielu nauczycieli uzupełniło swoje wykształcenie, zdobywając tytuł magistra, o czym opowiadała wcześniej Janina Tobera ${ }^{87}$.

Biruta Lewaszkiewicz-Petrykowska opowiada o interwencji Ministerstwa w działania Uniwersytetu w początku lat pięćdziesiątych:

Na początku lat pięćdziesiątych jeszcze zdarzały się takie sytuacje. Na przykład na trzecim roku załamała się sesja - to znaczy bardzo dużo osób musiało iść do repetowania. Wtedy profesor Szpunar ${ }^{88}$ był dziekanem. Zrobiła się dzika

\footnotetext{
${ }^{87}$ Zob. też rozdział III.

${ }^{88}$ Zob. przypis $85 \mathrm{w}$ tym rozdziale.
} 
awantura, przyjechała taka pani z Ministerstwa. Prawie wszyscy prowadzący zajęcia na trzecim roku byli wtedy postawieni nieomal w stan oskarżenia. To był taki sposób rozumowania, że jak nie zdają, to znaczy, że źle byli uczeni. Było takie zebranie u dziekana, Szpunar się wtedy tak wściekł, [śmiech] że w pewnym momencie, jak walnął pięścią w biurko, a tam była taka szklana płyta i pękła [śmiech] przy okazji tej awantury. Ja wtedy prowadziłam na trzecim roku ćwiczenia. Wszyscy prowadzący zajęcia na trzecim roku zostali wezwani do rektora. Był wśród nich też prof. Schaff. Schaff dojeżdżał z Warszawy i prowadził wykład z procedury karnej,. To nie ten od filozofii89. Nie wiem, czy to był jego brat.. W każdym razie doszło tam u rektora do ponownej awantury. W konsekwencji się jednak od nas odczepili. Tak to wszystko wyglądało. Natomiast ta pani po paru latach, kiedy był zjazd katedr cywilistycznych w Kazimierzu, przyjechała tam z ramienia Ministerstwa. Na dźwięk nazwiska Szpunar powiedziała: „Ooo, a to straszny człowiek”. To były pozostałości tej całej awantury.

Bronisława Kopczyńska-Jaworska w ten sposób opowiada o ciągnących się do lat siedemdziesiątych trudnościach w rekrutacji na etnografię:

Rzeczywiście pani profesor Zawistowicz ${ }^{90}$ miała rację, bo od jesieni 1951 roku wstrzymali nam zapisy na grafik. O to była polka nieustanna. Po 1956 roku przez dwa czy trzy lata mieliśmy zapisy, a potem już nie z powodów ściśle ideologicznych, tylko bardziej takich organizacyjnych i pewnych takich układów na miejsce etnografii powstała historia kultury materialnej i miało być tak, że zapisy na etnografię miały być na zmianę: Łódź - Wrocław - Poznań. Kiedy w następnym roku była nasza kolej, żeby mieć zapisy, to Wrocław narobił hałasu, że oni są na ziemiach odzyskanych, oni są na rubieży, oni walczą o polskość itd., i dano te zapisy Wrocławiowi. Potem myśmy walczyli przez lata całe: profesor jeździła, a ja za nią nosiłam teczkę po rozmaitych ministrach, komisjach, akademiach, sekretarzach itd. Gdzie tylko się dało, ciągle namawialiśmy [śmiech], prosiliśmy żeby uruchomili studia. I wreszcie kiedy profesor Kotełkowa ${ }^{91}$ była prorektorem, a pani profesor Zawistowicz była już na emeryturze, w 1972 roku zgodzono się, żeby uruchomić etnografię.

Agata Zysiak: Przez tyle lat nie było naboru?

${ }^{89}$ Chodzi o prawnika Leona Schaffa, autora m.in. książki Proces karny w Polsce Ludowej, PWN, Warszawa 1952. Na początku lat pięćdziesiątych kierował Katedrą Postępowania Karnego Uniwersytetu Łódzkiego. Później został wykładowcą Uniwersytetu Warszawskiego. Był młodszym bratem Adama Schaffa.

${ }^{90}$ Zob. przypis $66 \mathrm{w}$ tym rozdziale.

${ }^{91}$ Krystyna Kotełko (1920-2003) - mikrobiolog, absolwentka biologii na Uniwersytecie Łódzkim i późniejsza profesor na tym Uniwersytecie. 
Bronisława Kopczyńska-Jaworska: Wie pani, była jakaś krótka przerwa w środku między tym 1956 a 1972 rokiem, ale nie było tak, żeśmy zupełnie nie mieli studentów, bo to przecież przez pięć lat się uczyło. Więc te roczniki jakoś zachodziły na siebie, ale nie mieliśmy nowych studentów przez szereg lat. Wobec tego myśmy prowadzili cały czas badania i dzięki energii i urokowi osobistemu profesor seminarium cały czas pracowało. Byli cały czas chętni do prowadzenia badań. Zdobywało się jakieś fundusze skromne, na pokrycie kosztów i cały czas prowadziło się w Katedrze badania. Jak w 1956 roku pierwszy raz nam wrócili zapisy i powstała Polska Akademia Nauk i Instytut Kultury Materialnej, w którym to Instytucie jest Zakład Etnografii, to myśmy położyli na stół drugi tom opracowań tych naszych badań. Pierwszy tom „Biblioteki Etnografii Polskiej" to są nasze badania po 1956 roku wydane. Badania, które zostały zrobione w ten sposób, że koleżanka, nieżyjąca już profesor Kucharska $^{92}$, która miała dwa magisteria, z geografii i etnografii, pracowała w jakimś przedsiębiorstwie geodezyjnym, miała znakomitą posadę, wysoko płatną i na wszystkie urlopy jeździła na badania terenowe. Jak w 1956 roku ruszyła Katedra, to rzuciła to i przeszła do nas jako wykładowca. Także przez te wszystkie lata się z niczego coś robiło, to była taka szarpanina wieczna. Mieliśmy jedną zaletę w porównaniu z socjologami - nas trochę per noga traktowano i nie byliśmy jacyś strasznie ważni. Wobec tego pieniędzy nam nie dawali, mieliśmy perturbacje z tymi zapisami, ale w porównaniu z socjologami, którym dawano pieniądze, ale jednocześnie musieli się angażować w rozmaite historie, to myśmy taką suchą nogą przeszli przez ten cały okres PRL-u. Jedno co było, to dekoracja PRL-u za pomocą śpiewu, tańca i sztuki ludowej, więc odbywały się konkursy, pracowała Cepelia ${ }^{93}$, myśmy tam świadczyli dla nich rozmaite rzeczy. Pani profesor Zawistowicz zasiadała w tych wszystkich radach, Cepelii nie Cepelii, konkursach nie konkursach, i braliśmy udział w takich wojewódzkich przeglądach sztuki ludowej, zespołów folklorystycznych itd.

Wanda Nowakowska opisuje swoje perypetie związane z planem zmiany kierunku studiów w pierwszej połowie lat pięćdziesiątych. Na uwagę zasługuje tu zarówno absurdalność decyzji ministerialnych (pokazująca skądinąd ówczesny całkowity brak niezależności uniwersytetu), jak też przychylność wobec studentki i zaradność pracowników naukowych w obejściu procedury.

92 Jadwiga Kucharska (1922-1995) - polska etnograf, etnolog, profesor na Uniwersytecie Łódzkim.

${ }^{93}$ Cepelia - działająca w latach 1949-1990 i powołana na wniosek Ministerstwa Kultury i Sztuki Centrala Przemysłu Ludowego i Artystycznego zrzeszająca spółdzielnie rzemieślnicze związane z rękodziełem ludowym i prowadząca ich sprzedaż. Istnieje do dziś w formie fundacji i spółki o tej nazwie. 
Zaczęłam studiować równolegle historię sztuki u profesora Wallisa ${ }^{94}$, który mnie właśnie wtedy oczarował. Byłam głęboko znudzona psychologią, chociaż zdawałam te egzaminy. Zaczęłam już wtedy na drugim roku zdawać egzaminy równocześnie na historii sztuki. Jedne i drugie, dwa indeksy. Nie wiem, jak mi się to udawało, ale potem okazało się, że ja mam więcej na tej historii sztuki zdane niż na psychologii. Bo to były inne wydziały, nie tak jak teraz Filozoficzno-Historyczny - jeden był Filozoficzny a drugi Historyczny. Ja byłam na Filozoficznym, a historia sztuki była na Historycznym, dlatego dwa indeksy. Pojechałam do Warszawy, zabrałam oba indeksy, zamówiłam się przez telefon w ministerstwie u Ministra Szkolnictwa Wyższego, pamiętam, że był nim wtedy Adam Rapacki ${ }^{95}$, potem on był ministrem spraw zagranicznych. Ale wtedy przyszłam i powiedziano mi, że pana ministra nie ma, jest pani dyrektor Krasowska zastępująca go, więc weszłam. I mówię: „Proszę o pozwolenie zdawania egzaminu magisterskiego i przeniesienie mnie z psychologii na historię sztuki. Tu są moje indeksy, więcej egzaminów mam zdanych na historii sztuki niż na psychologii, więc nie widzę powodu, żebym była na psychologii, bo po prostu mnie to już nie interesuje i to widać po egzaminach". A ona powiada: „Bardzo mi przykro, ale to nie jest możliwe”. A ja mówię: „Dlaczego? - No pan minister się nie zgadza”. A ja: „Dlaczego pan minister się nie zgadza? - Bo by mu się limit psychologów nie zgadzał”. Dosłownie.

Agata Zysiak: No tak, wtedy zdaje się były już te wskaźniki, wszystkie limity przyjęć.

Wanda Nowakowska: Tak, wstałam, powiedziałam: „A ja i tak będę historykiem sztuki. Do widzenia!”. I wyszłam. Nie trzasnęłam drzwiami, bo mi [śmiech] dobre wychowanie nie pozwoliło. I pamiętam, jak szłam Krakowskim Przedmieściem z tego ministerstwa i tak mi łzy leciały jak groch, płakałam z wściekłości i żalu, i bezsilności. Wróciłam. Ale profesor Wallis, u którego byłam na wykładach i zdawałam egzaminy u niego z tej historii sztuki, z estetyki przede wszystkim, i profesor Jan Szczepański ${ }^{96}$, który był wówczas dziekanem, uroczy człowiek, we dwóch się naradzili, i profesor Wallis po prostu powiedział, że chce mnie. Więc profesor Szczepański znalazł wyjście - że przecież estetyka jest dyscypliną filozoficzną, a profesor Wallis miał katedrę estetyki, więc mogę u niego pisać pracę magisterską, tylko nie będzie ona u niego figurowała jako magisterska $\mathrm{z}$ historii sztuki, tylko z estetyki, ale będzie ten sam temat: Teoria wyrazu Leonarda da Vinci. A recenzentem był

${ }^{94}$ Zob. przypis $71 \mathrm{w}$ tym rozdziale.

${ }^{95}$ Adam Rapacki (1909-1970) - ekonomista, aktywista partyjny PRL, polityk, minister żeglugi (od 1950), minister szkolnictwa wyższego (także od 1950) - współorganizator I Kongresu Nauki Polskiej, minister spraw zagranicznych w rządzie Józefa Cyrankiewicza.

${ }^{96}$ Zob. przypis $83 \mathrm{w}$ tym rozdziale. 
mój profesor psychologii - Józef Pieter ${ }^{97}$, bo psychologia - teoria wyrazu i tak dalej. W ten sposób zrobiłam magisterium - jako jedyna! - z estetyki, co było oczywiście niesłychanie ważne w moich późniejszych losach.

Biruta Lewaszkiewicz-Petrykowska opisuje mechanizm podejmowania studiów przez tzw. działaczy, w tym wypadku osoby piastujące odpowiedzialne stanowiska w wymiarze sprawiedliwości. Fragment ten doskonale ilustruje siłę i rewolucyjny charakter powojennych przemian politycznych. Z kolei w pespektywie uniwersyteckiej, w opowieści tej odtworzona została pierwotna specyfika studiów zaocznych powstałych wówczas w celu wyrównywania wykształcenia przez osoby dorosłe, które dawno zakończyły swoją edukację - dziś ten sam typ studiów służy często zdobywaniu wykształcenia przez ludzi młodych w trybie płatnych studiów w sytuacji, gdy chcą oni podjąć pracę bądź nie dostali się na studia stacjonarne:

Wydział zaczął prowadzić studia zaoczne chyba w 1955 roku. W latach pięćdziesiątych i sześćdziesiątych to one były tutaj w ten sposób ustawione, że to były rzeczywiście studia dla pracujących. Przy czym jednocześnie była taka sytuacja, że przewodzili tam ludzie, którzy nie tylko pracowali, ale którzy zajmowali czasem bardzo wysokie stanowiska w administracji, w partii i wymiarze sprawiedliwości. To może się wydać dziwne, ale to było efektem tego, że po wojnie stworzono takie kursy prawnicze - była szkoła Duracza ${ }^{98}$, która zdaje się trwała dwa lata, po których oni szli do pracy i zostawali na przykład sędziami. Albo były też takie kursy po prostu sześcio- czy iluś tam-miesięczne, po których ci ludzie szli do wymiaru sprawiedliwości. W pewnym momencie tym, którzy byli w wymiarze sprawiedliwości szeroko pojętym, kazano zrobić studia. Tu bywały sytuacje bardzo różne, jeżeli chodzi o ludzi, którzy do nas przychodzili. Byli tacy, którzy powiedzmy skończyli te sześciomiesięczne kursy i potem gdzieś tam awansowali, a nie mieli nawet matury. Naprawdę! I im kazano zrobić maturę. Pamiętam takiego jednego, który pracował przed-

97 Józef Pieter (1904-1989) - psycholog i filozof, absolwent Uniwersytetu Jagiellońskiego. W roku 1949 otrzymał nominację na profesora nadzwyczajnego oraz katedrę psychologii rozwojowej na Uniwersytecie Łódzkim, gdzie pracował do roku 1953, kiedy został przeniesiony na Uniwersytet Warszawski. Organizator i wieloletni rektor Wyższej Szkoły Pedagogicznej w Katowicach, później (w latach 1968-1974) dyrektor Instytutu Pedagogiki i Psychologii Uniwersytetu Śląskiego w Katowicach.

${ }^{98}$ Centralna Szkoła Prawnicza im. Teodora Duracza w Warszawie (w skrócie CSP), potocznie zwana „Duraczówką” - polska szkoła prawnicza funkcjonująca w latach 1948-1953, utworzona zarządzeniem Ministra Sprawiedliwości z dnia 14 maja 1948 roku. Placówka ta zapewniała dalszą edukację absolwentom tzw. średnich szkół prawniczych, które przyuczały do wykonywania zawodów prawniczych osoby cieszące się zaufaniem ówczesnych władz. CSP oraz tzw. średnie szkoły prawnicze miały w szybkim tempie wykształcić nowe kadry dla stalinowskiego wymiaru sprawiedliwości. 
tem jako konduktor czy motorniczy, czy coś takiego, i był po tym kursie, a potem był prezesem sądu w jednym z miast. Kazano mu zrobić maturę, to ją bez większych kłopotów zrobił. Poza tym to był bardzo sympatyczny i inteligentny facet. Ale [śmiech] kazano mu dorobić studia i przyszedł do nas. On sądził w sprawach karnych tylko, do cywilnych takich już nie wpuszczali [śmiech]. Ale mieliśmy przecież na studiach na przykład człowieka, który był sędzią w Sądzie Wojewódzkim Rewizyjnym w Izbie Karnej. Nie miał przedtem studiów. I tam w tej grupie też byli bardzo różni ludzie. Byli tacy - to głównie ci, którzy mieli ważne stanowiska powiedzmy w administracji czy w partii - którzy uważali, że właściwie uniwersytet jest po to, żeby dać im papier. Byli też tacy, którzy rzeczywiście chcieli pracować i pracowali.

\section{$(\ldots)$}

Tak patrzyłam czasem na niektórych, to właściwie w pewien sposób zostali skrzywdzeni przez to, że byli tak wysunięci w wymiarze sprawiedliwości. A niektórzy z nich byli bardzo zdolni. Pamiętam takiego jednego, sędziego karnego, który był wybitnie zdolny i świetnie szedł. Ale zawsze był w otoczeniu tych innych. On skończył te studia. Nawiasem mówiąc, pamiętam nazwiska wielu z tych osób. Ich reakcje były zresztą bardzo różne. Przecież pamiętam takiego, co mi powiedział: „Coś podobnego! Przy moim stanowisku mam dostać niedostateczny?!" [śmiech]. Te zajęcia odbywały się w soboty i w niedziele. Oni musieli mieć skierowanie z miejsca pracy, więc była pewna grupa, która była zobowiązana to zrobić. Oni się oczywiście w przeciągu tych iluś tam lat pod koniec lat pięćdziesiątych i na początku sześćdziesiątych jak gdyby wyczerpali, bo zrobili albo nie byli w stanie zrobić studiów. Potem oczywiście tak samo bywali różni ludzie, którzy chcieli sobie powiedzmy zdobyć określony zawód lub taki czy inny tytuł. Ale gdy chodzi o sprawy związane z wymiarem sprawiedliwości, to nie było już tych, którym nakazano studia zrobić. Tak więc niektórzy z nich, którzy zaczynali pracować w wymiarze sprawiedliwości po szkole Duracza albo po jakichś tam kursach, potem zrobili u nas studia i świetnie funkcjonowali dalej w wymiarze sprawiedliwości. A byli też tacy, w szczególności z administracji albo z partii, którzy nie pokończyli, zwyczajnie wylecieli. Wiele lat to czasem trwało. Byli skreślani, to, tamto. Pamiętam takiego, który twierdził, że (oni zresztą mieli często wpisywane w indeksie, co robią, gdzie pracują) był jakimś ekspertem ds. umów w ramach RWPG ${ }^{99}$, a pojęcia nie miał o prawie [śmiech]. Tego też nie zapomnę. On mi na pytanie: „Co to jest oferta?”, odpowiedział: „To jeśli któś ma cóś na sprzedaj”. Cytuję

${ }^{99}$ Rada Wzajemnej Pomocy Gospodarczej - istniejąca w latach 1948-1991 międzynarodowa organizacja państw bloku wschodniego mająca na celu zapewnienie współdziałania w zakresie procesów gospodarczych (postępu technicznego, industrializacji, wydajności pracy i zwiększenia dobrobytu). 
dosłownie [śmiech]. Więc jedni skończyli, inni nie skończyli. Różnie to bywało. Ja nie stosowałam w stosunku do nich taryfy ulgowej.

Janina Tobera, adiunkt w Katedrze Socjologii Kultury, socjolog i pedagog społeczny, prowadziła seminaria magisterskie na pedagogice. Jej studentami byli m.in. uczący się dorośli:

Bo okazuje się, że wszystkie placówki dla dzieci musiały mieć osoby z wyższym wykształceniem pedagogicznym. I to było tak wymyślone, że każdy promotor na pedagogice opowiada czym się zajmuje i co będziemy robić na tych swoich seminariach magisterskich. Potem puszczamy listę i każdy się do jakiegoś promotora zapisuje. I do mnie przychodzi taki facet... Na ogół ci panowie to $\mathrm{w}$ garniturach, zwłaszcza ci z prowincji, bo oni się rzeczywiście bardzo starali... Był na przykład dyrektor jakiejś szkoły podstawowej. Albo przychodzi taki facet, fajny kostium, stójka taka czarna. „Co to za człowiek” - mówię, a on na to „Może ja bym się tu nadał?” „No niech pan siada”. I oczywiście, zawsze rozdawałam takie kartki, żeby mi napisali, jak się z nimi kontaktować, co oni robią w ogóle, poznać ich, żeby wiadomo było, gdzie pracują. No więc to był dyrektor Teatru Arlekin. I ja mówię: „No ale to pan musisz też?” „No tak". Zmusili go do tego, żeby skończył studia pedagogiczne. A on był lalkarz, wybitny lalkarz, i on w pewnym momencie mi mówi, że on jest docentem we Wrocławiu na wydziale lalkarskim. Awansowali go na docenta (śmiech) na wydziale lalkarskim, jeździł do Jugosławii na festiwale (śmiech), no w ogóle komedia jedna no!

\section{Po stalinizmie}

\section{Nauka a ideologia}

Odwilż 1956 roku zakończyła najtrudniejszy i bodaj najokrutniejszy okres w dziejach powojennych Polski, w tym również w życiu uniwersytetu. Nie oznaczało to jednak całkowitej niwelacji nacisków ideologicznych i uzyskania możliwości pełnej swobody w formułowaniu poglądów oraz tematów badawczych. Presja ciągle była silna i wymagała dużej rozwagi w podejmowaniu badań - zwłaszcza tych odnoszących się bezpośrednio do ówczesnej rzeczywistości społecznej czy ekonomicznej. Nieprzerwanie działała cenzura (o czym piszemy w innej części tej książki), opisane w poprzednim rozdziale naciski na łódzkie środowisko akademickie, zakończone połączeniem socjologii z ekonomią można, w świetle cytowanych w tamtym rozdziale wypowiedzi, też rozumieć jako jedną ze strategii ideologizacji nauki. Ciągle więc mieliśmy do czynienia z balansowaniem między ograniczeniami a działaniem w ramach stworzonych przez system 
struktur możliwości. Napięcie to doskonale widać w pokazanych poniżej cytatach, których autorzy wskazują na możliwości i ograniczenia.

Krystyna Lutyńska opowiada o rozwoju badań w latach sześćdziesiątych w zespole kierowanym przez Jana Szczepańskiego ${ }^{100}$ w łódzkim Instytucie Socjologii. Zaowocowały one szeregiem publikacji wydanych jako $Z$ Badań Klasy Robotniczej i Inteligencji w Ossolineum we Wrocławiu, popularnie nazwanych „białą serią” ze względu na wygląd okładki.

Potem Szczepański zaczął robić te badania nad inteligencją, nad rozmaitymi grupami inteligencji. Powstawały prace doktorskie i były wydawane jako książki - powstała „biała seria” licząca dwadzieścia kilka tomów. To były bardzo interesujące, dobre prace. Ja osobiście pisałam pracę doktorską Urzędnicy $w P R L-u^{101}$, ale koledzy pisali o dziennikarzach, o nauczycielach, o inżynierach i tak dalej. Jeszcze przed tym, zanim zaczęliśmy badać te grupy zawodowe, to pod kierunkiem Szczepańskiego badaliśmy losy absolwentów Uniwersytetu Łódzkiego, którzy studiowali w latach pięćdziesiątych. Andrzej Borucki ${ }^{102}$ napisał znakomitą pracę doktorską o absolwentach Gimnazjum Piłsudskiego. Więc ta „biała seria” i badania Szczepańskiego miały bardzo szeroki zasięg, bo to poszło na Zachód, ale również doszło do krajów socjalistycznych, w których dzięki nam pozwolono prowadzić badania socjologiczne. Ponieważ oczywiście ingerencja cenzury była szalona, nie wolno było pisać o pewnych sprawach. Taki pierwszy lepszy przykład: koleżance wyszło w badaniach, że studenci rusycystyki nie lubili swego kierunku, żałowali, że poszli na rusycystykę - to trzeba było wykreślić. Były tysiące ingerencji. Tak samo jak ja wydawałam swoją książkę o urzędnikach, to miałam bardzo dużo ingerencji. A w ogóle żeby przeprowadzić badania musiałam mieć pozwolenie od Komitetu Łódzkiego [PZPR]. Dobrze, że był tam jakiś kolega koleżanki, partyjniak, który mi to załatwił. Tatarkówna ${ }^{103}$ się wtrącała do prac socjologicznych, bo ona bardzo się interesowała kobietami łódzkimi. Więc broń Boże nie można było coś tam złego napisać o łódzkich włókniarkach.

Jolanta Kulpińska również nawiązuje do publikacji „,białej serii”, w której ukazała się jej praca habilitacyjna. W tej relacji znajdujemy ciekawe połączenie ogólnie panującej atmosfery nacisków ideologicznych tego czasu

${ }^{100}$ Zob. przypis $83 \mathrm{w}$ tym rozdziale.

${ }^{101}$ Dokładny tytuł książki brzmi: Krystyna Lutyńska, Pozycja społeczna urzędników w Polsce Ludowej: tódzcy urzędnicy w świetle badań socjologicznych, Zakład Narodowy im. Ossolińskich, Wrocław 1965.

${ }^{102}$ Andrzej Borucki (1931-2003) - doktor socjologii, wicedyrektor Instytutu Socjologii Uniwersytetu Łódzkiego (1976-1988). Jeden z najbliższych współpracowników prof. Jana Szczepańskiego.

103 Michalina Tatarkówna-Majkowska (1908-1986) - działaczka komunistyczna, w latach 1953-1964 I Sekretarz PZPR w Łodzi. 
z odniesieniami do konkretnych tematów badawczych oraz napięć między socjologami a ekonomistami:

W każdym razie ten 1968 rok był dosyć ciężki, tym bardziej, że ja wtedy właśnie drukowałam pracę habilitacyjną. To jest taki też dosyć istotny element. Oczywiście była ona związana z socjologią pracy, ale też z tymi problemami partycypacji, bo książka nazywa się „Aktywność społeczna pracowników przedsiębiorstwa przemysłowego". Była pracą opartą na jakiś badaniach i na szczęście dla mnie, ponieważ jak zawsze jestem oporna w pisaniu, już miałam wszystkie terminy przekroczone. Książka była wydawana w tej białej serii Szczepańskiego ${ }^{104}$ i redaktorem była pani profesorowa Hessenowa ${ }^{105}$. Ona mi prędko powiedziała, że mojego pierwszego rozdziału to cenzura nie przełknie. Bo tam była oczywiście cała problematyka alienacji pracy i tak dalej. Wobec tego, rzeczywiście na szczęście dla mnie, całą tę część usunęłam, nie było jej już w potem wydanej książce. Ale gdybym nie była taka opieszała, to by było i wtedy oczywiście nie zatwierdziliby mi habilitacji, bo to było absolutnie traktowane jako odstępstwo, rewizjonizm i tak dalej. Kolokwium miałam w czerwcu 1968 roku i oczywiście Kortan ${ }^{106}$ przygotował pytania, które

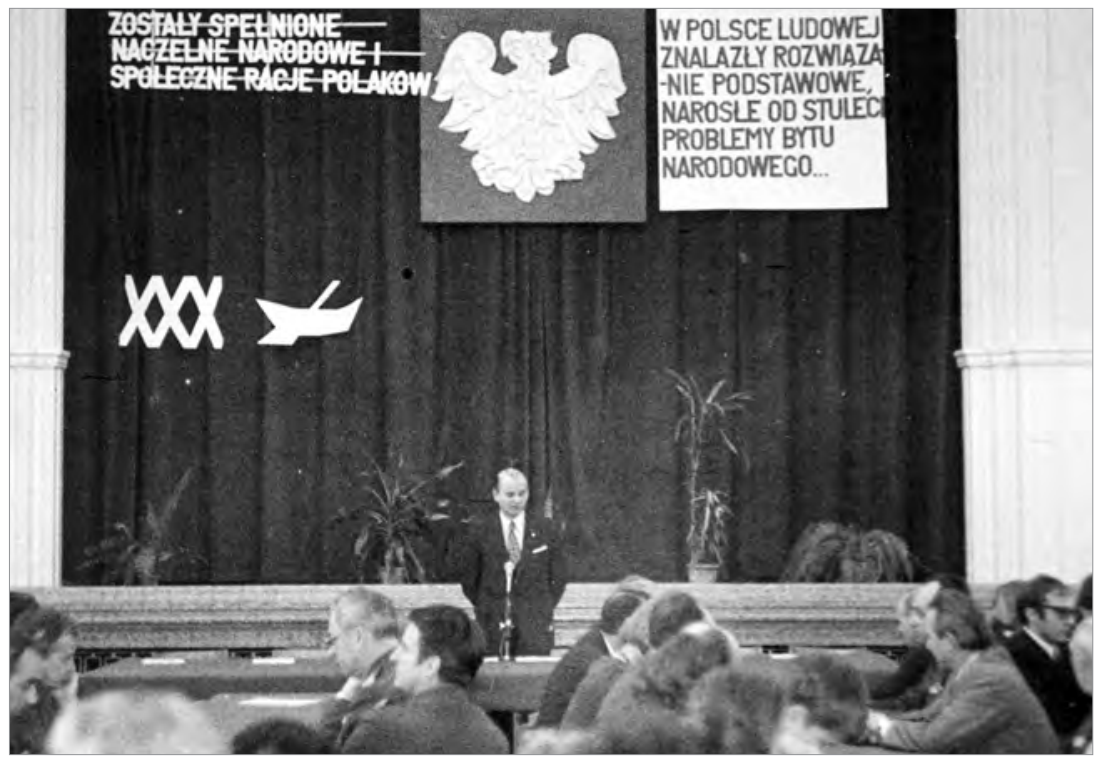

Fot. 64. Retoryka PRL-u. Zdjęcie wykonane podczas obchodów trzydziestej rocznicy powstania Ut

${ }^{104}$ Zob. przypis $83 \mathrm{w}$ tym rozdziale.

${ }^{105}$ Maria Niemyska-Hessen (1905-1986) - pedagog społeczny, zajmowała się przede wszystkim oświatą robotniczą. Była także redaktorem w wydawnictwie Ossolineum.

${ }^{106}$ Jerzy Kortan (1924-1998) - profesor ekonomii na Uniwersytecie Łódzkim, specjalizujący się w dziedzinie zarządzania przedsiębiorstwem. 
miały mnie pogrążyć. Jak czytam ten protokół, to jest aż śmieszne, dlatego że stanął w mojej obronie nieżyjący już, wpływowy profesor ekonomii. Oni zapytali, Kortan i jeszcze inny członek tej Rady Wydziału, że z moich badań wynika, że klasa robotnicza wcale nie jest taka aktywna, więc dlaczego, jak ja to thumaczę? Ja odpowiedziałam zgodnie z wynikami empirycznymi, a bez żadnych jakiś takich ideologicznych wstawek, że niby może wróg działa albo coś w tym rodzaju. A potem właśnie ten profesor już w części tajnej mówił: „Ależ to znakomicie, bo przecież to bardzo słusznie, dlatego że przecież wiadomo, że klasa robotnicza musi być przodującą siłą owszem, ale kierowanie gospodarką wymaga kwalifikacji, więc nie może być tak". Bronił mnie w gruncie rzeczy z pozycji menadżerskiej, a nie ideologicznej, i to nawet dosyć tak pokrętnie, ale w taki sposób, że tamci nie mogli tego wyjaśnienia nie przyjąć. W rezultacie oczywiście dostałam tę habilitację na Wydziale i dość prędko też była zatwierdzona. Superrecenzentem był Jerzy Wiatr ${ }^{107}$, który nawet tam mnie pochwalił, ale to już inna sprawa, i w ten sposób ten rozdział kariery również się skończył.

Władysław Welfe opowiada o możliwościach zastosowania analiz ekonomicznych w odniesieniu do realiów gospodarki socjalistycznej:

Kaja Kaźmierska: To jest wszystko bardzo ciekawe, a przede wszystkim nowe, bo ja jestem socjologiem, nie ekonomistą, więc bardzo wielu rzeczy się dowiedziałam. Nie wszystko jestem w stanie tak zupełnie pojąć jeśli chodzi o kwestie ekonomiczne, ale bardzo to jest ciekawe. I właśnie chciałam się zapytać o taką rzecz, bo pan profesor mówił o tych modelach ekonometrycznych dla kraju. A jak to było w czasach PRL, kiedy pan opracowywał te modele - czy było widać na przykład, że gospodarka ma się nie najlepiej i czy to miało jakoś przełożenie na rzeczywistość, czy też były to takie, powiedziałabym, ekspertyzy chowane do szuflady?

Władysław Welfe: To zależy, o jakim okresie mówimy, ponieważ w okresie PRL-u sytuacja ekonomiczna wcale nie była jednorodna. Na samym począt$\mathrm{ku}$ ta gospodarka była silnie scentralizowana i planowanie szło z góry do dołu, a przedsiębiorstwa miały bardzo ograniczoną swobodę działania, plany przedsiębiorstw były zatwierdzane przez Zjednoczenia, a Zjednoczeń jeszcze wyżej, przez Ministerstwa. Kolega, który był dyrektorem departamentu w Ministerstwie Przemysłu Lekkiego, miał dostęp do informacji dotyczących produkcji na przykład przędzy i był zorientowany, w jakim zakładzie i ile tej przędzy jest produkowane, i to on ostatecznie decydował o tym, jaka będzie produkcja w każdym z tych zakładów. Przy tego rodzaju planowej czy planowanej gospodarce modele mogły być używane w gruncie rzeczy tylko po

${ }^{107}$ Jerzy Wiatr (ur. 1931) - socjolog, znany i bardzo aktywny działacz komunistyczny w okresie PRL, silnie dbający o poprawność ideologiczną socjologii. 
to, żeby zbilansować zapotrzebowanie pochodzące z różnych jednostek czy, jak to się z angielska mówi, input-output. Te modele były w użyciu również i w Komisji Planowania, rzadziej w ministerstwach, także myśmy tylko teoretyzowali na temat tych modeli. W późniejszym okresie, kiedy odstąpiono od takiej ostrej centralizacji i bilansowano co najwyżej kilkanaście podstawowych wyrobów, a resztę już pozostawiano w dyspozycji przedsiębiorstw, to stało się możliwe konstruowanie modeli w taki sposób, że podstawowym narzędziem w tych modelach były funkcje produkcji. Nie wiem, czy pani to coś mówi [śmiech]. Funkcja produkcji to jest takie podstawowe narzędzie ekonometryczne, w ramach którego ustala się relacje między wynikiem, jakim jest produkcja, a nakładami czynników, tzn. zatrudnieniem a aparatem produkcyjnym, technologią, zużyciem surowcowym itd. To można scharakteryzować za pomocą pewnej funkcji wielu zmiennych, najczęściej nie liniowych. Tu się okazywało, że za pomocą tego rodzaju narzędzi, które występowały w modelach, mogliśmy przewidywać albo wielkość produkcji przy danym aparacie produkcyjnym i zatrudnieniu, albo wykonywać zadania odwrotne polegające na tym, że przy zerowej produkcji mogliśmy odpowiadać na pytanie, ile potrzeba do tego zatrudnionych, jak wielki aparat produkcyjny powinien być zaangażowany, żeby otrzymać tę produkcję. Czyli, krótko mówiąc, to już miało znaczenie praktyczne. Dopiero to w gruncie rzeczy się odnosiło do gospodarki PRL-u. W okresie późniejszym, kiedy wystąpiły ostre niedobory, tośmy musieli ostro te modele modyfikować, w szczególności jeśli chodzi o funkcje produkcji; musieliśmy uwzględniać ograniczenia wynikające z ograniczeń w bilansie płatniczym albo mówiąc dokładniej: ograniczenia wynikające z przydziału dewiz. Jeżeli te ograniczenia dotyczyły bananów - pal sześć, ale jeżeli dotyczyły surowców lub części zamiennych, to to wpływało na rozmiary produkcji. Musieliśmy rozbudowywać nasze modele tak, żeby to uwzględnić. Wielu instytucjom bardzo zależało na oszacowaniu popytu konsumpcyjnego, a w szczególności określeniu skali, w jakiej ten popyt nie jest zaspakajany, czyli oszacowaniu tak zwanego nadwyżkowego popytu, który nie może być zaspokojony na skutek ograniczeń albo produkcji krajowej, albo w imporcie. Do tego celu służą tak zwane funkcje popytu: w gospodarkach rynkowych popyt się uzależnia przede wszystkim od dochodów realnych, jeszcze innych czynników, ale te najważniejsze to są dochody realne. Otóż okazywało się, że jeżeli nie można zaspokoić popytu, to pozostają oszczędności zwane wymuszonymi i one w następnym czasie powiększają fundusze, z którymi wychodzą konsumenci na rynek, nie tylko dochody bieżące, ale te oszczędności wymuszone, więc to też trzeba było oszacować. Myśmy opracowali metodologię pozwalającą na szacunki tego właśnie typu i innych zjawisk, które występowały na rynku. Niekiedy nas wyśmiewano mówiąc: „Dlaczego nie pytacie o to, jak wielki jest popyt i nie liczycie tego popytu bezpośrednio, zapytując gospodarstwa domowe?". Myśmy odpowiadali, że to jest niesłychanie mylące. Proszę sobie wyobrazić, że pani chce kupić 
rękawiczki i schodzi pani całą Piotrkowską z góry w dół i nie mają tych rękawiczek, ale notują, że pani pytała. W takim razie popyt, który jest sumą tych wszystkich zapytań, jest fałszywą informacją. Także, krótko mówiąc, odrzucaliśmy możliwość wykorzystywania tego rodzaju informacji. Tak to wyglądało w okresie PRL-u, czyli krótko mówiąc, myśmy się nie nastawiali na to, żeby odwzorowywać sposób postępowania planistów, tylko raczej staraliśmy się poprzez te odpowiednie równania odwzorowywać mechanizmy, które naprawdę $\mathrm{w}$ tej gospodarce występują wbrew planom, albo jeżeli plany są realizowane, to zgodnie z planami. Także w tym sensie różniliśmy się od planistów.

Dla kontrastu przedstawiamy perspektywę matematyka. Ryszard Jajte argumentuje ideologiczną ,neutralność” matematyki, pokazując jednocześnie, że nie musiała być ona równoznaczna z ideologiczną „neutralnością” naukowca:

Agata Zysiak: Historia czy socjologia, w ogóle nauki humanistyczne w czasach PRL miały znacznie więcej do czynienia z władzą. Jak wyglądały takie uwikłania w matematyce?

Ryszard Jajate: Całe szczęście, że władze się na matematyce nie znały. Myślę, że poza tabliczkę mnożenia nie wychodzili i w związku z tym mieli przekonanie, że matematyk to jest bardzo mądry człowiek, który wiele rzeczy wie, ale politycznie jest z nim nie najgorzej. Jednak trzeba było być czujnym. Jako przykład mogę dać profesora Gelfanda ${ }^{108}$ w Uniwersytecie Moskiewskim, który był bardzo wysokiej klasy matematykiem, a za granicę nie wyjeżdżał, bo był nieprawomyślny. Ale tolerowany był w Uniwersytecie jako wybitny specjalista.

AZ: Czyli różnego rodzaju strajki 1968 roku matematykę zostawiały?

RJ: W miarę tak. To znaczy wszyscy byliśmy uwikłani jako inteligencja, ale matematyka, ze względu na swój abstrakcyjny charakter, broniła się.

Przedstawione powyżej wypowiedzi to pewne przykłady trudności w uprawianiu nauki (zwłaszcza w dziedzinach humanistycznych i społecznych) oraz radzenia sobie z nimi poprzez różne (z pewnością nie wszystkie tu wskazane) strategie ,rozgrywania kart systemu”. Jak ważnie były to dylematy i jak znaczące biograficznie decyzje, może wskazywać refleksja Jerzego Dietla, który podsumowuje swoją karierę naukową, odnosząc ją do wyborów dokonanych przez innych:

Ja np. twierdzę, że masę czasu zmarnowałem, bo mogłem zajmować się czymś innym, a próbowałem się w ramach tego zajmować tym, co nie byłoby zupełnie kompromitujące. Ale byli tacy, którzy potrafili jakoś inaczej postępować,

${ }^{108}$ Israel Gelfand (1913-2009) - rosyjski matematyk, autor pionierskich prac z wielu dziedzin matematyki i geometrii. 
np. Zbigniew Czerwiński ${ }^{109}$. Wywalili go z Uniwersytetu Poznańskiego jako asystenta profesora Taylora ${ }^{110}$, to przerzucił się do logiki formalnej, u profesora Ajdukiewicza ${ }^{111}$ był. Zrobił habilitację z zakresu hipotez statystycznych na pograniczu logiki i matematyki, więc można było, ludzie to robili. Mam poczucie takiego niesmaku, że ja tego nie robiłem, że ja próbowałem w tych naukach ekonomicznych coś tam robić, jakieś książki pisać itd. Choć twierdzę, że to nie było wysokich lotów, to myślę, że na Uniwersytecie miało to jakieś znaczenie. Miałem bardzo dużo kontaktów zagranicznych, po prostu starałem się.

\section{Na tle innych krajów bloku wschodniego}

Powyżej wyeksponowane były wspomnienia naszych rozmówców dotyczące ograniczeń i trudności w swobodnym uprawianiu nauki. Jednocześnie, powtórzmy raz jeszcze, polscy naukowcy na tle innych krajów Europy Środkowo-Wschodniej zdołali wypracować sobie pewien margines niezależności. Stanowili też częsty punkt odniesienia dla uczonych $\mathrm{z}$ innych krajów bloku wschodniego. Wyjazdy polskich naukowców ${ }^{112}$, zabieganie o dostęp do literatury światowej, budowanie relacji międzynarodowych i współpracy z uczonymi czy badaczami z zagranicy, pozwalały w niektórych dziedzinach, zwłaszcza ścisłych, utrzymać światowy poziom nauki, a w odniesieniu do nauk humanistycznych i społecznych zapewniały swobodę myślenia, która, choć nie zawsze w pełni mogła być odzwierciedlona w publikacjach naukowych, obecna była np. w dyskusjach seminaryjnych czy konferencyjnych. Wszystkie te okoliczności wpłynęły na relatywnie, ale jednak uprzywilejowaną pozycję polskich uniwersytetów, które w wielu przypadkach tworzyły w pełnym tego słowa znaczeniu społeczność naukową, w ten sposób charakteryzowaną przez Ryszarda Herczyńskiego:

Społeczność naukowa obejmuje wszystkie dziedziny wiedzy, jest wspólnotą uczonych różnych specjalności. Starają się ją utrzymać uniwersytety, angielskie koledże, amerykańskie i pozaamerykańskie kampusy. Tę społeczność spajają wspólnie uznawane autorytety naukowe i moralne,

${ }^{109}$ Zbigniew Czerwiński (1927-2010) - ekonomista specjalizujący się w ekonomii matematycznej i teorii podejmowania decyzji, związany z Poznaniem.

${ }^{110}$ Edward Taylor (1884-1964) - ekonomista, twórca tzw. poznańskiej szkoły ekonomicznej, związany z Uniwersytetem w Poznaniu, wykładał na Uniwersytecie Łódzkim.

${ }^{111}$ Zob. przypis $68 \mathrm{w}$ tym rozdziale.

112 Jak zostało to pokazane w rozdziale III, poza okresem stalinizmu łódzcy naukowcy, choć z różną dynamiką (pamiętajmy, że w konkretnych przypadkach wyjazdy nie zawsze były możliwe do zrealizowania ze względu na zakaz władz) wyjeżdżali w zasadzie do wszystkich krajów świata. 
wspólne - wykraczające poza ścisłą specjalność - zainteresowania. Nade wszystko łączy ją zadanie obrony etho su nauki, jej niezawisłości i godności, wolności badań i wypowiedzi, zadanie przeciwstawiania się naciskom zewnętrznym, troska o własną spoistość i poczucie wspólnoty uczonych wszystkich krajów ${ }^{113}$.

W warunkach PRL nie było to zadanie łatwe do zrealizowania, ale jak pokażą cytaty zawarte $\mathrm{w}$ tym i kolejnym podrozdziale („Przestrzenie wolności i konsekwencje niesubordynacji”), starano się bronić etosu nauki. Przyjrzyjmy się kilku przykładom.

Władysław Welfe, profesor ekonomii, charakteryzując status ekonomii jako nauki szczególnie poddanej presjom ideologicznym, komentuje, na czym polegała możliwość budowania pewnego marginesu niezależności w myśleniu na temat gospodarki i jak było to odbierane przez naukowców reprezentujących ośrodki naukowe z innych krajów bloku socjalistycznego. Jest to odpowiedź na postawione przez osobę przeprowadzającą wywiad pytanie o kwestię ideologicznej samodzielności ekonomii:

Muszę powiedzieć, że gros ekonomistów z czasów PRL to było jednak ideologicznie bardzo silnie powiązanych z nauką radziecką, aczkolwiek mieliśmy uczonych o międzynarodowej klasie, którzy liczyli się na Zachodzie, jak np. Oskar Lange ${ }^{114}$ - on siedział przecież w czasie drugiej wojny światowej w Stanach Zjednoczonych i był profesorem na którymś z uniwersytetów, chyba na chicagowskim, i pisywał, potem był przez jakiś czas po powrocie do kraju rektorem SGH. I on reprezentował niezależną myśl, ale też uważał, że jest marksistą. Michał Kalecki ${ }^{115}$ to jest drugi przykład uczonego, który ma światową renomę po dzień dzisiejszy, który napisał znakomite eseje dotyczące dynamiki krajów kapitalistycznych, a przyjechawszy do kraju, siedział w komisji planowania i tam robił przewidywania dotyczące wzrostu gospodarczego i napisał książkę o wzroście gospodarczym w krajach socjalistycznych. Także ukłon w stronę czy to marksizmu, czy to systemu gospodarczego niekapitalistycznego, to był charakterystyczny dla większości liczących się ośrodków w Warszawie. Tutaj w Łodzi profesor Mujżel ${ }^{116}$ reprezentował bardzo samodzielny punkt widzenia. Natomiast ekonometrycy byli postrzegani przez Rosjan jako ci, którzy wszczepiają zachodnie idee do obcej tkanki socjalizmu. To było o tyle

${ }^{113}$ Ryszard Herczyński, Spętana nauka ..., s. 10.

114 Oskar Lange (1904-1965) - ekonomista, wykładał m.in. na Uniwersytecie Jagiellońskim i uczelniach w Stanach Zjednoczonych, prominentny członek PZPR.

${ }^{115}$ Michał Kalecki (1899-1970) - ekonomista, wykładowca na kilku uniwersytetach w Wielkiej Brytanii, w latach pięćdziesiątych i sześćdziesiątych doradca ekonomiczny rządów m.in. Izraela, Meksyku, Kuby, PRL.

${ }^{116}$ Zob. przypis $28 \mathrm{w}$ tym rozdziale. 
śmieszne [śmiech], że tego rodzaju poglądy również występowały w Ministerstwie Nauki i wtedy, kiedy zablokowano w czasie stanu wojennego i zaraz po tym możliwości wyjazdu na Zachód, to to dotyczyło ekonomistów, natomiast nie dotyczyło ekonometryków. Więc z tego punktu widzenia to było różnie. Ja muszę powiedzieć, że tam w Związku Radzieckim były pewne odpryski nowoczesności. Byłem zaproszony do Erywania przez mojego przyjaciela, do złożenia wizyty w takim instytucie, który się zajmował propagowaniem informatyki. On był bardzo nowoczesny. Matematycy radzieccy byli bardzo nowocześni, informatycy też. Natomiast miałem odczyt w Instytucie Ekonomiki, gdzie byli sami konserwatywni, starsi panowie. I byli oburzeni tym, o czym ja ich tam informowałem, że my liczymy coś w rodzaju elastyczności popytu i odpowiadamy na pytanie, jaka jest skala popytu niezaspokajanego. „Co to takiego jest?" [śmiech]. Ja muszę powiedzieć, że nauczanie ekonomii podlegało takim rygorom niezbyt naukowym. Była ekonomia polityczna socjalizmu i kapitalizmu. Bywały okresy dość różne, ale muszę powiedzieć, że myśmy się odznaczali znaczną samodzielnością w stosunku do Wschodu czy też NRD. Myśmy organizowali rokrocznie konferencje naukowe, które mają kryptonim „Makromodele" 117 . Po dzień dzisiejszy są one organizowane, już jest chyba trzydziesta ósma. Na tych „Makromodelach” występowali z referatami przedstawiciele różnych nacji, międzynarodowa konferencja, język angielski. I proszę sobie wyobrazić, że przyjeżdżali do nas koledzy z NRD po to, żeby się tu spotkać ze swoimi kolegami z RFN-u. Bo inaczej nie mogli.

Bronisława Kopczyńska-Jaworska odnosząc się do wieloletnich badań nad kulturą karpacką prowadzonych m.in. w Bułgarii, opowiada z kolei o trudnej konfrontacji perspektyw polskich i bułgarskich etnografów:

Te nasze badania bułgarskie, które myśmy cztery czy pięć lat robili, rokrocznie po sześć tygodni tam siedzieliśmy, niestety nie doczekały się publikacji. Zrobiliśmy opracowania, a umowa była taka, że najpierw Bułgarska Akademia Nauki to publikuje. Oni siedli nad tym i im się to nie podobało ideologicznie. Leży to $\mathrm{w}$ archiwum w Sofii do dziś. Kapitalne materiały zostały zebrane, bardzo duże, bo ta Akademia dała środki, więc to wszystko było i sfotografowane, i narysowane; mnóstwo informacji zostało tam zebranych. Wszystko poszło do archiwum. Brałam udział w rozmowach, które się toczyły z dyrekcją tamtejszego instytutu, że właśnie nie mogą wydrukować, ponieważ wyraźnie widać w tych naszych opracowaniach polskich, że nam się nie podoba socjalizm. A dowodem na przykład w stosunku do mnie było to, że ani razu nie użyłam słowa „rewolucja socjalistyczna” w artykule na osiemdziesięciu stronach.

117 Coroczna konferencja organizowana od 1974 roku przez Wydział Ekonomiczno-Socjologiczny Uniwersytetu Łódzkiego dla naukowców zajmujących się modelami ekonometrycznymi, zob. http://www.macromodels.uni.lodz.pl (15.06.2015). 
Używałam słowa „zmiana”. Tam był jeszcze taki artykuł Jana Szczepańskiego ${ }^{118}$ o zmianie kulturowej, w ogóle społecznej, do którego się odwoływałam jako do autorytetu. Naturalnie Jan [Szczepański] też nie pisał ,rewolucja socjalistyczna" [śmiech]. Tłumaczyliśmy, że w Polsce w pracach naukowych nie używa się tego języka politycznego, że to nawet jest trochę takie rażące. Używa się takich bezstronnych określeń, ale nie przekonaliśmy ich. Oni strasznie byli gorliwi.

Krystyna Lutyńska mówi o szczególnej roli socjologii polskiej na tle państw bloku wschodniego. Warunkiem zbudowania tej pozycji było przede wszystkim otwarcie na świat i traktowanie uniwersytetu jako areny dyskusji nieograniczającej się tylko do perspektywy lokalnej ${ }^{119}$ :

Potem mówiono o Polsce, o polskich badaniach, że to one otworzyły okno dla tych krajów socjalistycznych na czele ze Związkiem Radzieckim, które zaczęły się od nas uczyć. Ja pamiętam też, nie wiem, który to był rok, jakiś 1958 czy 1959 - zaprosiliśmy Rosjan i wszystkich przedstawicieli nauk społecznych do Polski i uczyliśmy ich podstawowych metod i technik: wywiadu, obserwacji. Ale przede wszystkim były wtedy modne badania ilościowe, więc to leciało. W Warszawie wtedy powstał OBOP ${ }^{120}$, tam od nas z Łodzi poszedł do OBOP-u Stefan Szostkiewicz ${ }^{121}$, który był przez pewien czas jego dyrektorem. To był też wielki ewenement. W 1956 roku był pierwszy raz wyjazd za granicę, do Paryża. Akurat od nas pozwolono memu mężowi [Janowi Lutyńskiemu] ${ }^{122}$ i Toli [Antoninie Kłoskowskiej] ${ }^{123}$ tam pojechać. Coś się zaczęło dziać. Za-

${ }^{118}$ Zob. przypis $83 \mathrm{w}$ tym rozdziale.

${ }^{119}$ Otwartość polskiej socjologii na tle innych krajów socjalistycznych potwierdzają również opowieści socjologów reprezentujących różne uniwersytety z tych krajów. Zebrane w pracy pod redakcją Mike'a Keena i Janusza Muchy opowieści o ich karierze akademickiej wyraźnie pokazują różnicę między polskimi socjologami (mającymi dostęp do socjologii zachodniej dzięki wyjazdom, kontaktom z zapraszanymi do Polski naukowcami, ograniczonym, ale jednak dostępem do najnowszej literatury) a socjologami z NRD, ZSRR, Bułgarii, Czechosłowacji czy innych krajów bloku wschodniego. Zob. Janusz Mucha, Mike F. Keen (red.), Autobiografie czasu transformacji: socjologowie Europy Środkowej i Wschodniej, tłum. Janusz Mucha i in., Wydawnictwo IFiS PAN, Warszawa 2006.

${ }^{120}$ OBOP - Ośrodek Badania Opinii Publicznej, powstał w 1958 roku i jest najstarszym tego typu ośrodkiem w Polsce.

${ }^{121}$ Stefan Szostkiewicz (1926 -1988) - socjolog i metodolog. Inicjator powołania OBOP. Od momentu jego powstania w 1966 kierował pracami Ośrodka.

122 Jan Lutyński (1921-1988) - socjolog i metodolog, profesor Uniwersytetu Łódzkiego, Dyrektor Instytutu Socjologii UŁ, kierownik Zakładu Metod i Technik Badań Społecznych. Ekspert i doradca struktur związkowych „Solidarności”. W 1981 r. podczas strajku studenckiego na UŁ pełnił funkcję doradcy komitetu strajkowego.

${ }^{123}$ Antonina Kłoskowska (1919-2001) - socjolog, absolwentka Uniwersytetu Łódzkiego, profesor na Uniwersytecie Łódzkim i Uniwersytecie Warszawskim, w latach 1989-1994 przewodnicząca Polskiego Towarzystwa Socjologicznego. 
częła ta nauka zachodnia do nas docierać, książki zachodnie. Myśmy zaczęli promieniować na Wschód, a tutaj zaczęli przyjeżdżać profesorowie z Zachodu: Lazarsfeld, Merton ${ }^{124} \mathrm{i}$ inni. Powstało też stypendium Forda, zaczęli Polacy na nie wyjeżdżać do Ameryki, do Francji, ale przede wszystkim do Ameryki. To było niesłychanie dla nich pouczające. Od nas na stypendium Forda ${ }^{125} \mathrm{z}$ Łodzi był Lutyński i Gostkowski ${ }^{126}$. Wracali pełni idei. Przywożono książki. Zaczęło się jeździć na Międzynarodowe Kongresy Socjologiczne.

Niewątpliwie bardzo ważnym elementem włączającym naukę polską do społeczności naukowej były kontakty z zagranicą budowane nie tylko poprzez wyjazdy własne, ale też przyjazdy naukowców zagranicznych. Zbigniew Bokszański pokazuje, w jaki sposób budowało to poczucie wspólnoty uczonych:

Profesor Chałasiński ${ }^{127}$ był przecież znany bardzo szeroko w świecie, Napoleon polskiej socjologii, jak go nazywano z racji niskiego wzrostu, ale też temperamentu i energii. Dzięki niemu zresztą mieliśmy co miesiąc jakąś wizytę zagraniczną. Tu przyjeżdżali bardzo poważni ludzie, profesorowie tacy jak Touraine ${ }^{128}$ na przykład w początkach swojej kariery. Potem tę schedę ściągania naukowców przejęła profesor Kłoskowska ${ }^{129}$ i to głównie na jej zaproszenia tutaj różne znakomitości przyjeżdżały typu Pierre Bourdieu ${ }^{130}$ czy Boltanski ${ }^{131}$ na przykład. Przez trzy dni w Jabłonnej była taka konferencja, można było

${ }^{124}$ Paul F. Lazarsfeld (1901-1976) - wybitny amerykański socjolog austriackiego pochodzenia, zajmował się przede wszystkim metodologią nauk społecznych. Autor ogromnej liczby rozpraw naukowych. Przedstawiciel neopozytywizmu w socjologii. Robert K. Merton (1910-2003) - wybitny amerykański socjolog, przedstawiciel funkcjonalizmu. Zajmował się przede wszystkim problemami biurokracji, dewiacji społecznej, anomii i ról społecznych.

${ }^{125}$ Fundacja Forda (Ford Foundation) - założona 1936 roku Henry’ego Forda i jego syna Edsel Bryanta prywatna fundacja amarykańska, która początkowo finansowała rodzinne przedsięwzięcia (jak szpital czy muzeum), a po śmieci obu założycieli w 1943 zmieniła profil swojej działalności skupiając się przede wszystkim na wsparciu finansowym (przez przydzielanie stypendiów i grantów) dla zdolnych osób chcących podjąć wyższe studia; finansowaniu badań naukowych; wspieraniu działań na rzecz rozwoju społeczeństwa obywatelskiego; pomocy krajom rozwijającym się; działaniach na rzecz ochrony środowiska; itp.

${ }^{126}$ Zygmunt Gostkowski (1926-2014) - profesor socjologii na Uniwersytecie Łódzkim, metodolog pracownik PAN.

${ }^{127}$ Zob. przypis $62 \mathrm{w}$ tym rozdziale.

${ }^{128}$ Alain Tourain (ur. 1925) - francuski socjolog zajmujący się przede wszystkim socjologią pracy i ruchów społecznych.

${ }^{129}$ Zob. przypis $123 \mathrm{w}$ tym rozdziale.

${ }^{130}$ Pierre Bourdieu Pierre Bourdieu (1930-2002) - wybitny francuski socjolog, filozof i antropolog. Zajmował się przede wszystkim socjologią kultury i wychowania oraz sferą znaczeń dzieł sztuki.

${ }^{131}$ Luc Boltanski (ur. 1940) - francuski socjolog zajmujący się przede wszystkim socjologią polityki i moralności w odniesieniu do formacji społecznej kapitalizmu. 
spokojnie z profesorem Bourdieu porozmawiać. Były to rzeczy niesłychanie rozwijające. Dlatego jak słucham czasem jakichś wywodów młodych dziennikarzy czy młodych polityków na temat tych ciemności, które kryły ziemię w czasach PRL-u, to czuję się trochę nieswojo i niesłychanie krytycznie podchodzę do wszelkich historycznych materiałów. Muszę powiedzieć, że jestem wielkim sceptykiem, jeżeli idzie o tak zwane nauki historyczne, bo przyglądam się temu, co się pisze o PRL-u w tej chwili i jestem w stanie ocenić to, co było i zestawić to $\mathrm{z}$ opiniami, które pojawiają się w tej chwili na ten temat. Ja w każdym razie nie odczułem jakiegoś zapóźnienia. Być może inną skalę porównawczą przykładałem tutaj - młodego człowieka, który z poziomu bibliotek szkolnych i tego, co w księgarniach było, dostał się od razu w świat ludzi bardzo intelektualnie znaczących i tych różnorodnych zasobów książkowych, które dzisiaj mogą się wydawać już ubożuchne, ale wtedy stanowiły okno na świat po prostu. Od początku było uczestnictwo w konferencjach, w seminariach, w kontaktach z kolegami z zagranicy. Ja byłem głównym kurierem przez pewien czas, który odbierał ludzi albo z Warszawy, albo z Dworca Łódź Fabryczna. Miałem numer „Polish Sociological Bulletin”"132, tak to się wtedy nazywało. Zielona okładka, to był znak rozpoznawczy i ktoś wysiadający $\mathrm{z}$ pociągu wiedział, że ma szukać takiego chudego faceta $\mathrm{w}$ okularach z zieloną okładką „Polish Sociological Bulletin”. Właściwie co tydzień było coś. Przynajmniej dwa razy w miesiącu jak nie jakiś wyjazd, to przyjazd kogoś. Niesłychanie było to żywe.

Jednym z ważnych efektów budowania takich relacji była możliwość zapewnienia dostępu do zachodniej literatury. Jak pokazuje poniższy fragment, w którym Zbigniew Bokszański kontynuuje przedstawiony wyżej wątek, wymagało to wielu niełatwych zabiegów, które przynosiły pozytywny efekt. Opis budowanych sieci relacji i stwarzanych przez nie możliwości świadczy nie tylko o determinacji i zaradności polskich badaczy, ale też pokazuje, dlaczego polskie środowisko naukowe wyróżniało się na tle innych krajów bloku radzieckiego:

Joanna Wygnańska: Jeszcze może niech pan profesor opowie o współpracy między młodymi badaczami wtedy. Czy pan profesor miał jakieś kontakty, kolegów z zagranicy, którzy przysyłali książki, jakieś kserokopie?

Zbigniew Bokszański: Proszę pani, to jest niesłuchanie ważne. Ja bym w ogóle nie przygotował swojej pracy habilitacyjnej, gdybym nie miał książek i gdybym nie miał tej współpracy. Absolutnie tak. Jeżeli chodzi o artykuły z czasopism, to myśmy mieli w Łodzi w Bibliotece Uniwersyteckiej chyba tylko pięć, siedem tytułów, o ile pamiętam, przez długi czas. To znaczy „American

${ }^{132}$ Dzisiaj periodyk ten nosi nazwę „Polish Sociological Review”. 
Sociological Review”, „American Journal of Sociology”, „Sociological Abstracts" ${ }^{133}$ i to było źródło naszych niepokojów, bo czytaliśmy, że są takie artykuły, znaliśmy nazwiska autorów, ale to było takie window-shopping, czyli lizanie cukierków przez szybę po prostu. Wobec tego z każdego wyjazdu zagranicznego wracało się z jakimiś wizytówkami. Poza tym w trakcie każdego wyjazdu zagranicznego robiło się kserokopie. Ja miałem kolegę w Szwajcarii, kolegów w Niemczech, do Stanów Zjednoczonych wysyłałem bardzo oficjalne prośby, albo do autorów, albo do jakichś profesorów, których poznałem. Ale to były takie prośby właśnie do starszych kolegów, którzy jeżeli będą mieli czas, to i tak dalej, i tak dalej... Bo jeżeli przyjeżdżali ci profesorowie ze Stanów, to byli to ludzie już ugruntowani w środowisku akademickim, bardzo znane nazwiska. Więc pisanie do jakiegoś Lipseta ${ }^{134}$ czy do Millsa ${ }^{135}$, żeby kserokopie przysłał, to była jakaś taka arogancja, zwłaszcza że człowieka się nie znało osobiście. Można było się powołać, że „na tym seminarium, na którym pan profesor miał znakomity referat, ja też miałem okazję go wysłuchać" itd. na przykład George'a Ritzera ${ }^{136}$, tego od makdonaldyzacji, kiedy on zaczynał w ogóle się tym zajmować, też taką właśnie prośbę sformułowałem. Ale z reguły to się wysyłało do osób, które się znało. Ja miałem takich dwóch kolegów - jednego w Szwajcarii, drugiego w Niemczech. W Niemczech Zachodnich wszystko było. Oni poza tym dzięki sieciom mogli po prostu do bibliotek zaglądać, potem mieli już maile i był Internet, który u nas był jeszcze w powijakach. To była pomoc o zupełnie kapitalnym znaczeniu. Ja bym po prostu nie mógł pracować. Ja bym niczego nie mógł zrobić powyżej doktoratu bez tych kontaktów. Dlatego z ogromną życzliwością wspominam tych właśnie kolegów, którzy tracąc czas i pieniądze, przysyłali te sterty papieru tutaj do Polski. Na szczęście wszystko czy prawie wszystko dochodziło. Trwało to, trwało, ale jednak wszystko dochodziło. I tutaj nikt na poczcie nie interweniował. Akurat w moim przypadku to nie były jakieś rzeczy, które mogły być drażniące. Oczywiście spotykaliśmy się tutaj z nimi niekiedy, jak przyjeżdżali. $Z$ reguły to były wizyty w domach też, bo człowiek czuł się zobowiązany kogoś tutaj zaprosić. To były jakieś noclegi niekiedy i tak dalej. Ale z reguły było tak, że jak się za granicę wyjeżdżało, to się tam samemu sporo robiło. $Z$ reguły miało się przy sobie jakąś wizytówkę i prosiło się, żeby z życzliwością potraktowano nasze listy w przyszłości. Potem to byli już tacy starzy współpracownicy, którym się płyty wysyłało niekiedy, jakieś prezenty urodzinowe drobniutkie, które można

${ }^{133}$ Tytuły znanych amerykańskich czasopism socjologicznych.

${ }^{134}$ Seymour Martin Lipset (1922-2006) - amerykański socjolog zajmujący się ruchami społecznymi, stratyfikacją społeczną, społeczeństwem obywatelskim i socjologią polityki.

${ }^{135}$ Charles Wright Mills (1916- 1962) - wybitny socjolog amerykański, znany przede wszystkim ze swojej książki Wyobraźnia Socjologiczna.

${ }^{136}$ Georg Ritzer (ur. 1940) - socjolog amerykański, znany przede wszystkim ze swojej książki Makdonaldyzacja społeczeństwa. 
było przesłać pocztą. To była ogromna pomoc. Myślę, że wszyscy z mojego pokolenia by pani powiedzieli to samo. Po prostu nie bylibyśmy w stanie nawet połowy tego zrobić, co zrobiliśmy, bez pomocy szczególnie kolegów z Niemiec, z Francji, ze Skandynawii, ze Szwecji, z Finlandii. W moim przypadku miałem z Finami kontakty niesłychanie żywe i zachowuję Finlandię w bardzo wdzięcznej pamięci. Wprawdzie z opóźnieniem to wszystko się odbywało, bo oni też mieli zasoby takie skromne, biorąc pod uwagę ich potencjał taki akademicki. Ale dzięki kontaktowi z szerokim światem to się po prostu udawało. To jest rzecz niesłychanie ważna, ta nieprawdopodobna życzliwość kolegów z krajów zachodnich, którzy w znacznej mierze zdawali sobie sprawę $\mathrm{z}$ tego, że dla nich to jest piętnaście, dwadzieścia minut przy kserokopiarce, a dla nas to jest miesiąc pracy. Także jak wyjeżdżaliśmy za granicę, też ten papier przywoziliśmy, bo na nic więcej pieniędzy nie było.

\section{Przestrzenie wolności i konsekwencje niesubordynacji}

W okresie PRL, w odniesieniu do nauk społecznych, zwłaszcza w środowisku łódzkim zauważalne było nie tylko dążenie do rozwoju różnorodnych podejść badawczych i teoretycznych, ale też potrzeba kształtowania środowiska intelektualnego tworzącego możliwości poszerzania horyzontów poznawczych dzięki dostępowi do różnych (często zasadniczo odmiennych) koncepcji naukowych, podejść teoretycznych czy punktów widzenia. Było to w wielu przypadkach środowisko tworzące arenę debaty i sporu, dające możliwość artykulacji własnej opinii, twórczej krytyki i refleksji nad własnymi dokonaniami i dokonaniami innych osób. Efektem tych dążeń było tworzenie przestrzeni swobodnej dyskusji rozwijającej się od towarzyskich dysput przy kawie poprzez usystematyzowane refleksje seminaryjne czy referaty konferencyjne.

Krystyna Lutyńska wspomina, że ów proces budowania aren dyskusji rozpoczął się po 1956 roku. Warto poniższą wypowiedź umieścić w kontekście poprzednich cytatów pokazujących rolę odwilży październikowej:

W 1957 roku powstało Polskie Towarzystwo Socjologiczne Oddział w Łodzi. Chałasiński nam powiedział, że wszyscy muszą należeć, więc wszyscy należeli do Łódzkiego Oddziału PTS-u, przychodzili i naprawdę wtedy te zebrania oddziału były bardzo żywe, bardzo ciekawe. A gdy były wybory do zarządu, to bycie wybranym to był wielki zaszczyt. Teraz to zupełnie co innego - teraz trzeba wyciągać na siłę za włosy [śmiech]. A wtedy jak ktoś został wybrany do zarządu, to się liczyło, ile głosów zdobył. Zresztą też trochę się patrzyło w Warszawie, w Zarządzie Głównym, ilu partyjnych weszło, ilu bezpartyjnych. I była bardzo wielka radość, jak bezpartyjni przeważyli [śmiech]. 
Zbigniew Bokszański podkreśla znaczenie nieformalnych dyskusji przypominajacych klimat publicznych debat intelektualnych:

Kiedyś był tak zwany klub. Nie trzeba było parzyć kawy, nie trzeba było mieć naczyń, po prostu szliśmy sobie i można było niekiedy posiedzieć. Szczególnie w okolicy lat osiemdziesiątych, to znaczy koniec lat siedemdziesiątych i początek lat osiemdziesiątych, gdy te problemy natury politycznej się jakoś skumulowały. A poza tym w latach siedemdziesiątych byliśmy bardzo jednak ruchliwi, także w skali międzynarodowej. Wobec tego było o czym rozmawiać. Już się zaczęła ta lawina książek pojawiać w latach siedemdziesiątych i u nas w kraju, i także za granicą. Było o czym rozmawiać.

Krystyna Lutyńska niejako kontynuując wątek podjęty przez Zbigniewa Bokszańskiego, opisuje Zjazd Polskiego Towarzystwa Socjologicznego, który odbył się w czasie „karnawału Solidarności”. Do dziś jest on postrzegany jako jedno ze znaczących intelektualnie i politycznie wydarzeń w historii powojennej socjologii.

Z takich ważnych momentów w dziejach Łodzi, to już późniejsze lata - 1981 rok, zorganizowanie Ogólnopolskiego Zjazdu Socjologicznego w Łodzi. To był bardzo ciekawy zjazd. Zjechało się mnóstwo osób. Ja wtedy byłam w Zarządzie Oddziału PTS-u łódzkiego i zakwaterowaliśmy ich w kwaterach, ale ci ludzie nie mieli co jeść [śmiech] w Łodzi. Wtedy nawet po chleb były ogonki. Zrobienie jakiegoś przyjęcia czy czegoś takiego było prawie niewykonalne, zupełnie nie było co podać. Gdzieś tam dowiedzieliśmy się, że w Kutnie czy gdzieś można kupić dużo żółtego sera. Pojechało się na gwałt po ten żółty ser, nabijało się kosteczki na zapałki i tym się częstowało gości. Ale pod względem naukowym to był wielki sukces, bo były referaty, które były bardzo odważne, takie bez ograniczeń cenzuralnych. Ściągnęły ze sobą bardzo, bardzo wielkie thumy, wywołały duże zainteresowanie. Ale potem chcieliśmy to wydać, był przygotowany tom „Przeglądu Socjologicznego" ${ }^{137}$ z referatami, a cenzura nie pozwoliła. Przez długie lata znane było tylko sprawozdanie Andrzeja Gniazdowskiego ${ }^{138}$, który napisał dokładnie, co się działo na tym zjeździe. Dopiero dwa lata temu w „Przeglądzie” żeśmy wydali trochę tych referatów jako taką już właściwie ciekawostkę historyczną. Ale wtedy to było wielkie wydarzenie. Przyjechało wielu znanych

${ }^{137}$ Mowa tu o „Przeglądzie Socjologicznym” - najstarszym czasopiśmie socjologicznym wydawanym od 1930 roku. Zostało ono założone przez Floriana Znanieckiego w czasach, gdy pracował w Poznaniu.

${ }^{138}$ Andrzej Gniazdowski (1936-2013) - doktor socjologii, pracował w łódzkim Instytucie Socjologii w latach 1966-1985. 
opozycjonistów. Jadwiga Staniszkis miała referat i Stefan Nowak ${ }^{139}$, i taki drugi Nowak ${ }^{140}$, który wtedy wygłaszał referat o władzy, już szczegółów nie pamiętam. Tłumy były i to był chyba jeden z ciekawszych Ogólnopolskich Zjazdów Socjologicznych, właśnie w Łodzi.

Jerzy Dietl odnosi się do podobnego chronologicznie okresu początku lat osiemdziesiątych ale do innego czynnika kształtującego środowisko naukowe - nieformalnych seminariów samokształceniowych:

Tam prowadziliśmy te badania razem z socjologami. Nie potrafię wymienić wszystkich nazwisk socjologów, ale bardzo to było sympatyczne i muszę powiedzieć, że ta przyjaźń została mi z socjologami, bo później, kiedy zaczęły się takie wolnościowe ruchy i był stan wojenny, tośmy mieli takie tajne, choć pewnie wszyscy wiedzieli o tym, takie właśnie seminarium z Jankiem [Lutyńskim] ${ }^{141}$, z Jolą [Kulpińską] ${ }^{142}$, z Cezarym Józefiakiem ${ }^{143}$ oczywiście, z [Marcinem] Bielskim ${ }^{144}$, pani zna te nazwiska. Mieliśmy takie seminarium, dyskusje były, co dalej robić, w oparciu o rozmaite źródła. Na ogół tematem tych dyskusji była próba odpowiedzi na pytanie, kiedy ustrój upadnie. Robiliśmy różne prognozy, wszystkie były nieudane, bo upadł znacznie wcześniej niż żeśmy to przewidywali. Teraz tak na poważnie chciałem powiedzieć, że bardzo miło wspominam te seminaria, bo żeśmy się spotykali w naszych mieszkaniach. $\mathrm{Na}$ każdym seminarium jedna osoba miała referat i ten referat opracowywała na podstawie literatury zachodniej. Ja miałem wtedy dużo czasu, bo przez rok nie wolno mi było wykładać, co zresztą nawet dobrze wspominam, bo napisałem książkę i miałem więcej czasu. Tak, nie było to złe.

Budowanie przestrzeni wolności powiązane było jednak z koniecznością ponoszenia ewentualnych konsekwencji za działania interpretowane w kategoriach niesubordynacji, a niekiedy wręcz definiowane jako zagrożenia dla władzy. Mamy tu do czynienia z różnymi wariantami nękania oraz wiele dowodów na ciągłą inwigilację środowiska akademickiego przez Służbę Bezpieczeństwa (do 1956 Urząd Bezpieczeństwa Publicznego).

Jolanta Kulpińska opowiada o trudnościach w otrzymaniu paszportu jako formie kary za podpisanie protestu Rady Głównej Szkolnictwa Wyższego.

${ }^{139}$ Stefan Nowak (1924-1989) - socjolog zajmujący się metodologią nauk społecznych, profesor Uniwersytetu Warszawskiego.

${ }^{140}$ Leszek Nowak (1943-2009) - filozof, profesor Uniwersytetu Adama Mickiewicza w Poznaniu.

${ }^{141}$ Zob. przypis $122 \mathrm{w}$ tym rozdziale.

${ }^{142}$ Jolanta Kulpińska - patrz biogramy rozmówców.

${ }^{143}$ Cezary Józefiak (1932-2007) - ekonomista, profesor na Uniwersytecie Łódzkim, doradca Solidarności, senator I kadencji w wyborach w czerwcu 1989 roku.

${ }^{144}$ Marcin Bielski (1931-2002) - ekonomista, przed przejściem na emeryturę w 2001 roku kierował Zakładem Teorii Zarządzania. 
Ja miałam takie przeżycie znowu [śmiech], gdy inicjatorem pewnego protestu naukowców był Janek Lutyński jeszcze z kolegami z Wrocławia. Oni byli członkami z wyboru Rady Głównej Szkolnictwa Wyższego. Potem nawet niektórzy nazywali to protestem Rady Głównej, a to oczywiście dotyczyło tylko tej inicjatywy kilkuosobowej. To było właściwie echo innych protestów intelektualistów, dotyczących przede wszystkim cenzury, i oczywiście ja to podpisałam. Wszyscy ci, którzy podpisali, byli ukarani odmową paszportów. Nawet było dziwnie w ten sposób po raz pierwszy sformułowane, że to jest odmowa paszportu na dwa lata czy coś takiego. Nawet nie pamiętam, czy w moim przypadku to było tak określone, bo jednocześnie, w tym samym czasie, w latach osiemdziesiątych było bardzo duże otwarcie na kontakty zagraniczne, zapraszano nas, a uczelnie miały taką politykę, akceptowaną przez wyższe władze, że jeżeli koszty ponosi strona zapraszająca, to proszę bardzo. A że koszty ponosiła strona zapraszająca, to tych wyjazdów było dosyć sporo. Ja między innymi uczestniczyłam w takim programie międzynarodowym i właśnie z tego tytułu dostałam honorowy doktorat Uniwersytetu w Tampere. Oni tam mieli jubileusz i była duża grupa, razem ze mną prezydent Finlandii, potem zresztą podobno oskarżany o to, że był bezpośrednim agentem radzieckim, co mi się wydaje dosyć absurdalne. Ale to inna sprawa. Okazało się, że mam zaproszenie, koszty podróży ponoszą Finowie, a ja nie mogę, bo nie mam paszportu. Mam odmowę. Tutaj rzeczywiście koledzy interweniowali w KC, KC interweniował w Łodzi. Nerwówka była niesamowita, dlatego że samolot do Helsinek był raz w tygodniu, w sobotę, o ile pamiętam, a ja w czwartek nie miałam jeszcze paszportu. Już jest decyzja, że mam go dostać, a ja muszę pojechać po wizę do Warszawy. Decyzja jest, ale paszportu nie mam w ręku, bo zupełnie przypadkowo szef tego urzędu łódzkiego zachorował, nie było go w pracy, nie miał kto podpisać tego paszportu. To są takie rzeczy, które dzisiaj jak sobie człowiek przypomina, to brzmią [śmiech] groteskowo. Ale ktoś w kadrach naszych uniwersyteckich, zresztą osoba, jak się okazało, jakoś personalnie życzliwa, miała do niego dostęp. Dowiedziała się, że jest chory i miała do niego na tyle dostęp, że ten podpis w piątek rano był. Wsiadłam w taksówkę, pojechałam do Warszawy, zgłosiłam się do ambasady, pani konsul wyszła, żeby mnie zobaczyć, bo już właśnie wiedziała, że jest korespondencja pilna, czy ja pojadę, czy nie pojadę. Dostałam te wizy oczywiście. Taksówka czekała [śmiech], wróciłam do Łodzi. Dlaczego musiałam wrócić do Łodzi? Bo bilet był w Orbisie, a bez wizy nie mogłam tego biletu wykupić i trzeba było zdążyć przed zamknięciem. Zdążyłam [śmiech] i w sobotę pojechałam do Warszawy, do samolotu i poleciałam. To zwolniło, że tak powiem, mój paszport. I to była rzeczywiście interwencja [partyjnych] kolegów z naszego Instytutu. To była rzecz ważna, taki doktorat honoris causa zawsze w CV dobrze wygląda, ponieważ miałam do końca właściwie kontakty z tym uniwersytetem, później słabnące, bo ludzie, którzy wtedy mnie znali, też już odeszli z uczelni, więc to to 
taka naturalna sytuacja. Ale te kontakty były jeszcze przez właściwie całe lata dziewięćdziesiąte, jeszcze byłam parę razy na jakichś tam konferencjach. Taki był mój przypadek osobisty. Te lata osiemdziesiąte dla instytutu były właściwie pod względem naukowym nie najgorsze, bo Instytut dosyć dobrze był sytuowany w środowisku i to mniej więcej się utrzymało w różnych dziedzinach.

Krystyna Lutyńska opowiada o inwigilacji przez Służbę Bezpieczeństwa jej i jej męża, profesora Jana Lutyńskiego:

I do męża [Jana Lutyńskiego] ${ }^{145}$, i zresztą do mnie, jako do przewodniczącej Oddziału Łódzkiego Polskiego Towarzystwa Socjologicznego, przychodzili esbecy, tylko już tacy właśnie wykształceni. Do męża to pamiętam, że do mieszkania przychodził taki facet $\mathrm{w}$ randze majora. Taki w okularkach, o wyglądzie inteligenta. No i pamiętam te meble, które były w gabinecie męża. Pani nigdy tam chyba u nas nie była na Uniwersyteckiej 3 ?

Kaja Kaźmierska: Nie.

Krystyna Lutyńska: Do szkoły jeszcze pani chodziła [uśmiech]. No ale był ten fotel, a nad nim wisiał obraz [portret szlachcica z wąsami]. To jest bez autora, ale myśmy się zawsze wygłupiali i śmiali się, że to jest jakiś nasz przodek. No i mąż sadzał tego ubeka na fotelu i dyskutował z nim o Gorbaczowie. Przekonywał go o [śmiech] pieriestrojce. A do mnie też przychodził, w niższej randze, chyba jakiś porucznik i się bardzo interesował tym, kogo ja zapraszam na odczyty do PTS-u. „Bo jak to można taką jakąś Staniszkis ${ }^{146}$ czy Nowaka ${ }^{147}$, czy Strzeleckiego ${ }^{148}$ zapraszać, takich opozycjonistów - strasznie, be". Jakim cudem męża nie internowali, nie wsadzili w stanie wojennym, to nie wiem. Może ze względu na wiek? Ale u nas bywał na przykład Kropiwnicki ${ }^{149}$. Taka była sytuacja, że jak wypuścili za którymś razem Kropiwnickiego i Słowi$\mathrm{ka}^{150}$, to oni przyszli prosto $\mathrm{z}$ więzienia do nas, do mieszkania. No a ubecy szli za nimi. Potem nastąpiły represje, bo męża przestano puszczać w ogóle za granicę. Nawet na zaproszenie prywatne, miał ciocię w Anglii, to nawet na zaproszenie tej cioci nic, na żadne kongresy, absolutne tabu. Ossolineum chciało, żeby wydać podręcznik metodologiczny pod redakcją moją i męża

${ }^{145}$ Zob. przypis $122 \mathrm{w}$ tym rozdziale.

${ }_{146}$ Jadwiga Staniszkis (ur. 1942) - socjolog, absolwentka i wykładowczyni Uniwersytetu Warszawskiego.

${ }^{147}$ Zob. przypis $139 \mathrm{w}$ tym rozdziale.

148 Jan Strzelecki (1918-1988) - socjolog związany z IFiS PAN w Warszawie, internowany w czasie stanu wojennego.

${ }^{149}$ Jerzy Kropiwnicki (ur. 1945) - dr ekonomii, polityk, jeden z założycieli NSZZ „Solidarność" Ziemi Łódzkiej, w stanie wojennym skazany na sześć lat więzienia, prezydent Łodzi w latach 2002-2010.

${ }^{150}$ Andrzej Słowik (ur. 1949) - działacz „Solidarności” Ziemi Lódzkiej i opozycjonista w okresie PRL. 
o wszystkich metodach. Ale to zostało utrącone, ponieważ Lutyński był zakazany. Więc to były tego typu represje. Absolutnie nie wolno było go drukować. A przecież kiedy Kropiwnicki i Słowik bezpośrednio po więzieniu przyszli do nas i [śmiech] piliśmy wódkę na ich cześć, to nie wiedzieliśmy, jakie będą reperkusje z tej wizyty.

Krzysztof Jażdżewski opowiada z kolei jakie były konsekwencje jego kontestacji stanu wojennego:

Habilitowałem się w roku 1975. Chyba następnego roku dostałem stanowisko docenta, bo wtedy się zostawało docentem. Teraz nie ma docentów na uczelniach, wtedy byli. Natomiast tytuł profesora to się ciągnęło długo, trochę ze względów politycznych, bo mnie nie lubiło to UB i z tego powodu chociaż wniosek o tytuł został wystawiony w 1983 roku, to na sześć lat to zostało zablokowane. I o ile wiem, po profesorze Józefiaku ${ }^{151}$ byłem drugi w Łodzi, jeśli idzie o tę blokadę. To był taki okres, gdy mówiło się, że prawdziwy rektor to jest tam na ulicy Lutomierskiej, tam siedzi UB. Tam zaprosili mnie, kiedy ja Stefana Niesiołowskiego przyjąłem tutaj do katedry. Ostrzegali mnie, że to jest taki terrorysta i żebym uważał. To był zresztą mój pierwszy doktorant. Myślę, że z tą moją profesurą to była kara za to, że jego aresztowano i internowano w stanie wojennym i tam siedział rok, półtora roku, nawet na pogrzeb ojca go nie puścili. W każdym razie wtedy jak byli internowani ci wszyscy najdzielniejsi, to mnie chcieli dać jakieś takie odznaczenie uniwersyteckie, medal czy odznakę. To było w 1982 roku. Ja wtedy napisałem list do rektora, że bardzo jestem zaszczycony, ale póki moi koledzy siedzą w więzieniu, ja nie będę odbierał żadnych nagród. Rektor był trochę nieszczęśliwy: „Po co to panu?” i „Dlaczego?”. Przypuszczam, że to właśnie wtedy moje papiery do profesury poszły do szuflady na sześć lat. A może coś innego? W każdym razie dopiero jak przyszła ta prawdziwa wolność w 1989 roku, to akurat dosłownie w 1989 mi ten tytuł przyznano - nie pan Jaruzelski, bo wtedy jakoś nie wręczał tego prezydent, tylko jakiś minister te dyplomy przekazywał, ale podpis pewnie Jaruzelskiego na tym, bo on był wtedy pierwszym prezydentem w wolnej Polsce. Po tak zwanym okrągłym stole to Jaruzelski został prezydentem, a Mazowiecki był premierem. Takie były początki wolności.

$\mathrm{Na}$ koniec tego podrozdziału odwołamy się do epizodu, który dziś opowiedziany jest w formie anegdoty, a związany z doświadczeniami z czasów studenckich z lat sześćdziesiątych. Pod pozorną groteskowością sytuacji kryje się poczucie opresji do złudzenia przypominające praktyki stosowane w latach pięćdziesiątych. Grażyna Kononowicz, studentka socjologii w latach 1960-1965, później wieloletni kierownik Biblioteki Socjologicznej

${ }^{151}$ Zob. przypis $143 \mathrm{w}$ tym rozdziale. 
im. Józefa Chałasińskiego, opowiada o zdarzeniu związanym z praktykami studenckimi we Włocławku:

To też była sytuacja prześmieszna, bo ponieważ studenci biegali robić wywiady przez cały dzień, to spotkania pracowników ze studentami, jakaś wymiana uwag odbywały się zazwyczaj koło północy. A mieszkaliśmy w szkole, do której chodziła kiedyś Maryla Rodowicz. Ja sobie siedziałam, ponieważ akurat miałam trochę wolnego czasu, i pisałam pocztówki z pozdrowieniami dla moich znajomych, nie tylko szkolnych, ale i tych z duszpasterstwa akademickiego. Akurat do takich moich przyjaciół, którzy w Bydgoszczy mieszkali, pisałam pocztówkę, i tam między innymi na tej pocztówce, że jest północ, mamy zebranie i tak dalej, i tak dalej. Później się nagle po jakimś czasie okazało, że ten mój znajomy należał do tej organizacji Ruch ${ }^{152}$. Takiej, do której tu w Łodzi Niesiołowski ${ }^{153}$ też należał i wielu innych. Ja nie wiedziałam o tym, że oni należeli do tego, bo to była tajemnica wielka. I już po paru ładnych latach pracy zostałam wezwana do Komendy Milicji na Sienkiewicza. Przepytywali mnie, czy znam tego, a czy znam tamtego, a czy znam owego? Pokazywali całe albumy, więc kogo znałam, to znałam, przecież nie mogłam powiedzieć, że nie znam, jeżeli ludzi znałam [śmiech], i to niektórych bardzo dobrze. Dowiedziałam się, między innymi, dlaczego mnie wezwali. Otóż znaleźli tę pocztówkę, którą wysłałam do Bydgoszczy, do tych moich przyjaciół i uznali, że jak ja piszę, że jest północ i zebranie mamy, to widocznie jest to jakieś zebranie antypaństwowe i koniecznie chcieli [śmiech] się ode mnie dowiedzieć, co to było. Tłumaczyłam im co prawda, że przecież korespondencja prywatna to ich nie powinna interesować i z jakiej racji oni mają pocztówkę, którą ja wysłałam do znajomych. Poza tym bardzo gorliwie mnie wypytywali o tę organizację, ale ponieważ ja naprawdę wtedy nic nie wiedziałam, więc nie musiałam odgrywać bohaterki. Powiedziałam, że owszem, znam taką organizację, pracuję w bibliotece, i w Ruchu kupuję gazety, które dla biblioteki prenumerujemy. Pan milicjant myślałam, że mnie zabije wtedy. Ale ja zupełnie szczerze mówiłam [śmiech], jak było, więc długa była ta rozmowa na tematy różne. W każdym razie w końcu kazał mi podpisać protokół, który ktoś tam z boku pisał. Więc ja grzecznie przeczytałam, poprawiłam błędy ortograficzne bezczelnie i pożegnaliśmy się. Musiałam dostać jeszcze przepustkę, żeby mnie stamtąd wypuścili. Moja ówczesna kierowniczka była oburzona, że jak ja mogę mieć kontakty z milicją i tak dalej. Po czym jeszcze raz mnie wezwano i zaczęli mi zadawać te same pytania ponownie. Więc grzecznie powiedziałam, że ja na te wszystkie pytania odpowiadałam już jakiś czas temu i nie widzę powodu, żeby zmieniać zdanie. Długo się naradzali, poszli gdzieś tam, poszukali, znaleźli ten

${ }^{152}$ Ruch - organizacja konspiracyjna działająca w Polsce w latach 1965-1970.

${ }^{153}$ Stefan Niesiołowski (ur. 1944) - zoolog i polityk, po 1989 roku poseł i senator. Absolwent i wieloletni pracownik UŁ. 
protokół i dali mi od tej pory święty spokój. Ale moi koledzy z Ruchu w pace sobie posiedzieli trochę, ale takie to były czasy. Taka jest historia z moich praktyk we Włocławku.

\section{Cenzura}

Jednymi z najbarwniejszych fragmentów opowieści są passusy dotyczące zmagań z cenzurą w związku z publikacjami tekstów naukowych. Główny Urząd Kontroli Prasy, Publikacji i Widowisk ${ }^{154}$ dzielił się na oddziały wojewódzkie, zaś jego centrala mieściła się w Warszawie przy ulicy Mysiej. Instytucja ta została zlikwidowana wiosną 1990 roku. Jak pokażą cytowane fragmenty wywiadów, naukowcy podejmowali negocjacje zarówno ,na szczeblu centralnym", jak i w oddziałach, bezpośrednio, telefonicznie bądź też korzystając z mediacji osób trzecich. Niezależnie od podejmowanych w konkretnym przypadku strategii, trzeba tu podkreślić dwie okoliczności: po pierwsze, cenzurze podlegały wszystkie publikacje; ideologiczne i instytucjonalne zaangażowanie autorów tekstów pełniło funkcję drugoplanową wobec ocenianych treści. Innymi słowy, również członkowie partii i aktywni działacze polityczni mogli mieć na tym polu problemy, jeśli weszli na grząski grunt charakterystyki teraźniejszości czy przeszłości niewpisującej się, w mniemaniu cenzora, w ówczesną poprawność polityczną. Ocena była tu zawsze relatywna i podporządkowana wizji oceniającego. Po drugie, siłą rzeczy większe problemy miały tu nauki humanistyczne i społeczne. W naukach przyrodniczych i ścisłych, może oprócz czasu stalinizmu, łatwiej było formułować ideologicznie neutralne treści.

Cytowane poniżej przykłady doskonale pokazują, co mogło oznaczać granie kartami systemu. Należy czytać te anegdotyczne dziś opowieści ze świadomością, iż była to jednak gra na serio, a absurdalność racjonalizacji cenzorskich miała znaczący wpływ na rozwój nauk humanistycznych i społecznych.

Krystyna Lutyńska opowiada o badaniach socjologicznych:

Myśmy tu w Łodzi pierwsi - profesor Szczepański1 ${ }^{155}$ ze swoimi uczniami właśnie w okresie odwilży, kiedy socjologia wróciła na uniwersytety, zaczęli robić na szeroką skalę badania empiryczne. Zaczęło się, o tym koniecznie trzeba powiedzieć, od konkursu na pamiętniki dla młodych inteligentów. To jest też ewenement pewien, bo to był pierwszy konkurs, który został ogłoszony

${ }^{154}$ Od roku 1981 funkcjonujący pod zmodyfikowana nazwą jako Główny Urząd Kontroli Publikacji i Widowisk.

${ }^{155}$ Zob. przypis $83 \mathrm{w}$ tym rozdziale. 
po stalinizmie. Opracowywaliśmy - ja w tym bardzo czynnie uczestniczyłam - odezwę do młodej inteligencji i potem zbieraliśmy te materiały, ogromne materiały dostaliśmy, 766 tych pamiętników. Niektóre bardzo grube, bardzo ciekawe, bo ludzie w okresie odwilży się otworzyli. Pisali do nas o prześladowaniach, o okresie wojny, o prześladowaniach po wojnie. Byli akowcy, byli jacyś tam ziemianie. Oni się nagle otworzyli i pisali szczerze. Ale pisali również i ubowcy, bo po odwilży był taki krótki okres tendencji, żeby tych dawnych aparatczyków, którzy nie mieli wykształcenia, którzy byli tacy tępi, usuwać. Potem werbowano do tej tajnej służby takich $\mathrm{z}$ wykształceniem trochę mądrzejszych, więc pisali również i tacy dawni ci ubowcy, którzy się wyżalali. To było fantastyczne, ale niestety już nam potem nie pozwolono wydać tego jako książki.

Kaja Kaźmierska: I to nie zostało wydane?

Krystyna Lutyńska: Nie zostało wydane, a co gorzej, te materiały zginęły. Nie wiadomo jak. Ja wtedy nie mogłam tego przypilnować, bo zaszłam w ciążę, dużo musiałam leżeć w czasie ciąży, potem poród i tak dalej. I to niestety zginęło. Ale ten konkurs odbił się wielkim echem po całej Polsce i to był pierwszy nasz wyczyn. A w latach sześćdziesiątych, siedemdziesiątych dalej trwała nieustanna walka z cenzurą. Mąż [Jan Lutyński] ${ }^{156}$ ogromnie się tym przejmował. To były ciągłe pierepałki, ciągle cenzura nam coś kwestionowała. Wydawaliśmy „Przegląd Socjologiczny” po odejściu Chałasińskiego ${ }^{157}$, któremu odebrano też redakcję „Przeglądu [Socjologicznego]”, a po nim redaktorem został mój mąż. Artykuły, trzeba było kreślić wycofywać, kreślić, zastanawiać się, na ile można iść na ugodę, żeby coś tam puścić. To były dylematy, to nie było wszystko takie czarno-białe tak jak teraz się mówi, że jak autor czy redaktor poszedł na ugodę, coś tam skreślił - to już agent. A trzeba było kształcić tę młodzież i przemycać tę prawdziwą socjologię, mówić o tym, co jest na Zachodzie i tak dalej.

Biruta Lewaszkiewicz-Petrykowska charakteryzuje publikacje z zakresu prawa:

Do tego wszystkiego nigdy nie było wiadomo, co odstrzeli tym na granicy. Ja pamiętam, kiedy zatrzymała na granicy cenzura książkę francuską Umowa na rzecz osoby trzeciej. To są zagadnienia techniczno-prawne, niemające nic wspólnego z jakimikolwiek takimi czy innymi historiami. A tego nie można było temu facetowi wytłumaczyć, a w każdym razie było bardzo trudno wytłumaczyć. W ogóle z cenzurą bywały czasem przekomiczne historie. Nie pamiętam, czy to było przy okazji takiej mojej pracy o wadach oświadczenia woli, czy potem o wyrządzeniu szkody przez kilka osób, ale chyba o wadach oświadczenia woli. Dzwoni do mnie raptem z Wydawnictwa Prawniczego sekretarz

\footnotetext{
${ }^{156}$ Zob. przypis $122 \mathrm{w}$ tym rozdziale.

${ }^{157}$ Zob. przypis $62 \mathrm{w}$ tym rozdziale.
} 
tego wydawnictwa z Warszawy i powiada: „Zatrzymała pani pracę cenzura”. Jak to zatrzymała cenzura? Wady oświadczenia woli? Co to może być? I teraz moja rozmowa z tym łebkiem z cenzury: „Bo pani pisze «kodeks cywilny niemiecki». - Tak, piszę. - No ale jak to niemiecki? Przecież NRD. To nie można tak pisać, to trzeba zmienić”. Więc ja mu thumaczę: „Kodeks cywilny niemiecki wszedł w życie 1 stycznia 1900 roku, obowiązywał w Polsce na terenie poznańskiego i pomorskiego, pewne części do 1947 roku i obowiązuje w obu państwach niemieckich. - To niemożliwe" - on mi na to powiedział. Czterdzieści pięć minut trwała rozmowa z tym gościem. Puścił książkę pod warunkiem, że jak pierwszy raz mówię o tym kodeksie cywilnym niemieckim jako systemie rozwiązań prawnych to sprawę wyjaśnię. Zrobiłam przypis, w którym jest napisane, że obowiązywał tu i tu, wtedy i wtedy, taki i taki. Doszło do tego, że ja mu w pewnym momencie powiedziałam: „Proszę pana, ja się z panem zgadzam, że to może dziwne, tylko niech pan ma pretensje do parlamentu NRD, a nie do mnie, że nie uchwalili sobie kodeksu cywilnego". Bo oni uchwalili sobie odrębny kodeks dopiero w 1975 roku, a to było w 1972, przy mojej pracy o wadach oświadczenia. Więc oczywiście każdy, kto dobrze zna historię prawa polskiego, pomyśli sobie: „Co ona zwariowała, po co ten przypis, przecież każdy wie, o co chodzi”. Ale takie bywały czasem zabawne historie.

Władysław Welfe wspomina z kolei o źle widzianych tematach z zakresu ekonomii:

Muszę powiedzieć, że myśmy byli dość ostrożni w publikacjach. Książkę o nierównowadze na rynkach grup towarowych to mogłem opublikować dopiero w 1981 roku, a ona powinna się była ukazać w 1978. To mi mówiono: „A nie proszę pana, to będzie źle widziane”. Więc w pewnym sensie tak, były ograniczenia, ale cenzura na ogół uważała, że to, czym my się zajmujemy, jest tak odległe od zwykłego czytelnika, że nikt tego w zasadzie nie weźmie do ręki [śmiech].

Bronisława Kopczyńska-Jaworska opowiada o perypetiach z publikacją wyników badań etnograficznych nad tradycyjnymi formami wzajemnej pomocy gospodarczej i współpracy wśród ludu polskiego:

Dostaliśmy pieniądze na pierwsze badania, publikację i dzięki temu prowadziliśmy te badania. Przygotowywaliśmy opracowywania, pani profesor Zawistowicz swoją pracę habilitacyjną, a myśmy te fragmenty naszych badań opracowywali w formie artykułu czy prac magisterskich i powstało w ten sposób takie tomiszcze wyników tych badań. To zostało przygotowane do druku w serii prac i materiałów etnograficznych Polskiego Towarzystwa Ludoznawczego w 1955-1957 roku. I tutaj muszę powiedzieć, że wpadliśmy w oko cyklonu. To był czas rozwoju materializmu dialektycznego i historycznego, a jednocześnie 
dochodzenie do władzy coraz większej awangardy lewicowej, nie wiem, jak to nazwać. W każdym razie jak przygotowaliśmy ten tom do druku, to cenzura go zatrzymała. Powiedziała, że nie wydrukuje. Pamiętam takie rozmowy pani profesor Radlińskiej ${ }^{158} \mathrm{z}$ Zawistowicz ${ }^{159}$, gdzie obie panie, idealistycznie myślące, wychodziły z założenia, że przypomnienie o tym, iż istnieją tradycyjne formy wzajemnej pomocy gospodarczej i współpracy wśród ludu polskiego, może być przydatne w budowie zniszczonego kraju itd. A tu okazało się, że Lenin negatywnie odniósł się do współdziałania w Związku Radzieckim [śmiech] i wobec tego nasze współdziałanie też poszło pod topór i nikomu się nie podobało. Były to tragiczne momenty w moim życiu, ale też i prześmieszny incydent jest z tym związany. Mianowicie profesor moja się ciężko pochorowała. Miała jakieś kłopoty z żołądkiem i była operowana, miała resekcję części żołądka. Była w szpitalu, ciężko chora, kiedy przyszła wiadomość, że cenzura zakwestionowała, nie puszcza, nie ma mowy. A jeśli towarzystwo się chce odwoływać, to należy się zgłosić do profesora, który ma ideologiczny nadzór nad pionem, nie wiem, chyba kultury czy nauk społecznych. Był to mianowicie profesor Juliusz Starzyński, historyk sztuki, wieloletni dyrektor Instytutu Sztuki Polskiej Akademii Nauk ${ }^{160}$. Kiedy pani profesor leżała w szpitalu, przyszła wiadomość, że trzeba się zgłosić do tego profesora, thumaczyć się, dlaczego taką pracę chcemy opublikować. Wtedy pani profesor powiedziała: „No pani Bronko, ja nie mogę jechać, trudno, musi pani pojechać”. Ja mówię: „Ale pani profesor, na litość boską, co ja mam tam mówić, jak ja będę bronić tej pracy, nie dam rady". Ale pani profesor mówi, że trzeba, więc ja pojechałam do Warszawy. Moi rodzice mieszkali w Warszawie, nie wrócili po wojnie do Łodzi, może się to nie nadaje do nagrywania, ale moja mama powiedziała: „Pójdź do fryzjera, ładnie się ubierz i w razie czego udawaj idiotkę, co ty będziesz rozmawiać z tym profesorem". I rzeczywiście poszłam z bijącym sercem, to było w jakimś ładnym pałacyku w Warszawie, ładny lokal. Tam był piękny mahoniowy stół. Ja do dziś mam go przed oczyma, ponieważ ten profesor siedział naprzeciwko, ja się wpatrywałam w ten stół, a on grzmiał. Za dużo z tych jego ideologicznych wywodów nie zrozumiałam, ale grzmiał dalej. Między innymi mówił, że to jest titoizm i gomułkizm, ponieważ to było po aresztowaniu Gomułki i po obrażeniu się na Jugosławię, a ja miałam zielone pojęcie, o co w gruncie chodziło. Dowiedziałam się, że jacyś komuniści się ze sobą pożarli, nie byłam za bardzo zorientowana $\mathrm{w}$ polityce, miałam małe dziecko $\mathrm{w}$ domu [śmiech], więc nie miałam pojęcia,

${ }^{158}$ Zob. przypis $65 \mathrm{w}$ tym rozdziale.

${ }^{159}$ Zob. przypis $66 \mathrm{w}$ tym rozdziale.

${ }^{160}$ Juliusz Starzyński (1906-1974) - historyk sztuki, krytyk sztuki, profesor Uniwersytetu Warszawskiego. Na zjeździe plastyków w Nieborowie w lutym 1949 roku wygłosił referat wprowadzający, w którym uznał socrealizm za obowiązującą metodę twórczą. Zob. Wojciech Włodarczyk, Socrealistyczny epizod: Warszawa 1933 - Moskwa 1958, http://culture.pl/pl/artykul/socrealistyczny-epizod-warszawa-1933-moskwa-1958 (25.02.2015). 
o co chodzi temu Gomułkowi [śmiech] i pamiętam, że słabnącym głosem powiedziałam w pewnym momencie: „No tak panie profesorze, nawet jeśli to nie jest właściwy sposób na dzisiejsze czasy, żeby wzajemnie sobie pomagać, ale ta praca ma chociaż ten walor, że dokumentuje, jak było przed wojną, czy do ostatnich czasów, jakie były zwyczaje wsi polskiej”. Pamiętam, że Starzyński wykrzyknął: „Cóż to za pomysł!!!” [śmiech]. No więc już w ogóle zamilkłam jak zbita, wyszłam z gabinetu, nic nie zdziaławszy, nasłuchawszy się takich pogróżek, w każdym razie od początku do końca nie wiedziałam, o co mu chodzi. Poza tym, że wiedziałam, że się nie godzi, aby to wydrukować. Przyjechałam do Łodzi i mówię pani profesor, że absolutnie nie oczarowałam pana Starzyńskiego, nic nie pomogło, w dalszym ciągu twierdzi, że to do niczego się nie nadaje. Pani profesor wyszła ze szpitala i pojechała do sanatorium, do Krynicy. W Krynicy spotkała swoją akademicką koleżankę, wówczas członka partii, panią Ninę Assorodobraj ${ }^{161}$, z którą razem chodziły na wykłady. Profesor Assorodobraj była asystentką profesora Czarnowskiego ${ }^{162}$ i razem uwielbiały profesora Czarnowskiego. Pani profesor zwierzyła się, jaki to ma wielki kłopot, bo nie chcą nam wydrukować tej pracy i pani Nina powiedziała: „Wiesz Kaziuniu, może uda się coś zrobić, siądziemy razem, napiszemy wstęp od redakcji. A ja spróbuję coś zadziałać". Zadziałała i praca poszła do druku. Pani Assorodobraj zawsze była lewicowych poglądów, zawsze miała jakieś kontakty tego typu, była członkiem partii, miała jakichś znajomych i wiedziała, do kogo pójść, może wytłumaczyła, że to niczemu nie zagraża. I praca poszła do druku.

Stefan Banasiak przedstawia losy swojej pracy na temat Ziem Zachodnich:

Prowadziłem badania nad Ziemiami Zachodnimi, które stały się modne, nad repatriantami na Ziemie Zachodnie, później wysiedlaniem ludności niemieckiej $\mathrm{z}$ terenu Polski do Niemiec. Także te badania dały mi dużą satysfakcję, chociaż muszę powiedzieć, że bez przerwy miałem problemy z cenzurą i choć zmieniały się ustroje, zmieniały się ekipy, ale do dnia dzisiejszego nie jest nic odblokowane. W dalszym ciągu istnieje obawa, że mogę zaszkodzić przez poruszanie tematyki niemieckiej w sprawie Polski. Ale jak to zakazany owoc, dzięki temu, że to wzbudzało bardzo duże zainteresowanie, a cenzura zabraniała publikować, to miało wielkie zainteresowanie. Oczywiście że byłem tam w pobliżu $\mathrm{KC}$, tam jest taka maleńka uliczka, Mysia się nazywa, tam był Urząd Kontroli. Rozmawiałem z prezesem tego urzędu, który przyjął mnie bardzo elegancko, wygłosił jakieś

${ }^{161}$ Nina Assorodobraj (1908-1999) - socjolog, historyk myśli społecznej. W latach 1935-1977 profesor Uniwersytetu Warszawskiego; w latach 1945-1948 pracowała na Uniwersytecie Łódzkim. Razem ze Stanisławem Ossowskim i Józefem Chałasińskim brała udział w tworzeniu łódzkiej socjologii.

${ }^{162}$ Stefan Z. Czarnowski (1879-1937) - polski socjolog kultury, folklorysta, religioznawca i historyk kultury, profesor Uniwersytetu Warszawskiego. Interesowała go historia kultury celtyckiej i irlandzkiej. 
takie mowy pochwalne pod moim adresem, trudno mi powiedzieć, czy naiwnemu młodemu człowiekowi schlebiał i próbował mnie w ten sposób udobruchać, ale rozmowa była bardzo treściwa. Miałem ośmiu recenzentów, jedni byli za, inni byli przeciwko, większość była za. Na dziewiątego recenzenta wybrano Zenona Kliszkę ${ }^{163}$, który napisał, że opublikowanie tego byłoby szkodliwe dla Polski i to przesądziło. To było nie w porządku. Mówię: „Dajcie mi zaświadczenie na uczelnię, że nie ma zgody na publikację". I wtedy rozpoczęła się mowa tego prezesa Urzędu Kontroli, który powiada: „Z punktu widzenia Konstytucji to takiego urzędu nie ma, w którym pan tutaj jest. Nasza działalność jest nielegalna. My nie możemy panu dać, nam nie wolno dać takiego zaświadczenia. Ale - powia$\mathrm{da}$ - ponieważ wszystko jest uspołecznione w naszym kraju, więc my radzimy wydawnictwom, czy wydawnictwo może drukować, czy nie, więc panu nie damy poparcia, ale też nie zabronimy”. No to mówię, tak: „W porządku. To w takim razie utajnijcie. Różne wojskowe rzeczy czy coś się utajnia, niech będzie to też utajnione. - Utajnione też nie może być". Koniec końców dali mi zezwolenie na opublikowanie w pięćdziesięciu egzemplarzach tej pracy o wysiedleniu Niemców. Ja sobie przeliczyłem, ile mi potrzeba egzemplarzy. Wyliczyłem, że jest o dziewięć egzemplarzy za mało. Dali mi zezwolenie na pięćdziesiąt dziewięć egzemplarzy [śmiech]. Miałem umowę wydawniczą, honorarium wypłacono, ale publikacja do dnia dzisiejszego leży. Później przyszedł Gierek, Jaruzelski, Wałęsa, rządy posolidarnościowe, a ja na to wszystko machnąłem ręką. Bo dzisiaj już przy tym stanie zdrowia to nie bardzo mi się już chce, nie mówiąc o tym, że jakby przyszło co do czego, to znów byłaby jakaś kłótnia, bo tam było wykłócanie się o takie sprawy, że np. ja pisałem o repatriantach polskich ze Związku Radzieckiego, to w czasie repatriacji zmarło w podróży 1200 osób, tam z jakąś końcówką. Jak wysiedlano Niemców, to zmarło 1100 osób. Ja zestawiłem te dwie liczby i na tle tej migracji ze wschodu i Niemców na zachód nic tu nie ma takiego szokującego, ponieważ ten ruch obejmował miliony ludzi, ale cenzura jest cenzurą. Polacy mogli umrzeć i to mi pozwolono drukować, że repatrianci umierali też, ale że Niemcy umarli, kazali mi wykreślić. I to zostało wykreślone.

Jerzy Kmieciński opowiada zaś o opracowaniu archeologicznym:

Kiedy publikowałem swoją pracę magisterską Sprzęt rybacki i organizacja rybołówstwa w Gdańsku w XII i XIII wieku... ${ }^{164}$ korzystałem również z analiz

${ }^{163}$ Zenon Kliszko (1908-1989) - działacz polityczny okresu PRL, najbliższy współpracownik Władysława Gomułki, komunista, członek Biura Politycznego KC PZPR (1959-1970), poseł do Krajowej Rady Narodowej, na Sejm Ustawodawczy oraz na Sejm PRL II, III, IV i V kadencji, wicemarszałek Sejmu PRL. Uważa się, że pod jego wpływem Władysław Gomułka podjął decyzję o zdjęciu Dziadów ze sceny Teatru Narodowego. Był współodpowiedzialny za akcję pacyfikacyjną w Gdańsku i Gdyni w grudniu 1970. W tym samym miesiącu zwolniony z obowiązków członka Biura Politycznego i Sekretariatu KC, a nieco później usunięty ze składu KC PZPR, następnie z władz PZPR i władz państwowych.

164 Jerzy Kmieciński, Sprzęt rybacki i organizacja rybołówstwa w Gdańsku w XII i XIII w. w świetle prac wykopaliskowych w latach 1948-1951, „Studia Wczesnośredniowieczne” 1955, t. 3. 
ichtiologicznych wykonywanych na Wydziale Biologii i Nauk o Ziemi. W świetle tych analiz okazało się, że najmniej zaznaczającą się rybą w jadłospisie ówczesnych gdańszczan był dorsz. Badania te i ich publikacja przypadały na latach 1950-1954, a więc było to apogeum zamordyzmu stalinowskiego. Kiedy to opracowanie trafiło do szalejącej wtedy cenzury poprosił mnie pan cenzor i oznajmił, że pewne fragmenty opracowania należałoby zmienić: „Widzi pan - rzekł cenzor - tutaj pan pisze, że ten dorsz to taka poślednia ryba, trochę gorsza i dlatego wówczas jej nie jadano. „No bo tak było” - odrzekłem. Pan cenzor jednak był uparty. „No dobrze - utrzymywał - ale pan przecież wie, jaką ważną rolę obecnie odgrywa dorsz w naszym jadłospisie. Zajmuje pierwsze miejsce. Tego tekstu nie można będzie tak puścić. Wyszłoby na to, że karmimy byle czym klasę robotniczą”. Rozłożyłem ręce. „No wie pan, ja niestety nie mogę tej analizy zmienić”. Zacząłem jednak ratować sytuację i thumaczę: „Wie pan, to nie dlatego, że ta ryba była tak mało wartościowa konsumpcyjnie. Ja się tam rzeczywiście źle wyraziłem, ale chodziło o to, że dorsz żyje na znacznych głębokościach co uniemożliwiało ich połowy wówczas używanymi sieciami”. „Aaaa, to zmienia postać rzeczy” - uradował się pan cenzor. Tak więc jak pani widzi należało wtenczas i politycznie żeglować po Bałtyku [śmiech].

Podsumowując przedstawione wspomnienia, powtórzmy: publikacja ta nie jest opracowaniem historycznym. Poruszane zwłaszcza w rozdziale IV i V kwestie, zazwyczaj będące polem rozważań dla historyków, tutaj zostały zarysowane w postaci osobiście przeżywanych i zapamiętanych obrazów czy sytuacji, przywoływanych w opowieści, gdy nasi rozmówcy przedstawiali koleje swojej naukowej biografii. Jak zostało to zaznaczone na początku tego rozdziału, znając z opracowań historycznych dramaturgię tamtego czasu, jednocześnie nie dzielimy z opowiadającym pamięci biograficznej tego okresu. Jest ona w naszym odczuciu podstawowym kluczem do interpretacji przytoczonych opowieści. Wprowadzają one doskonale w klimat minionych dekad, ukazują relacje i napięcia między indywidualnym doświadczeniem biograficznym a kolektywnie konstruowaną ramą ich interpretacji. Pokazują przy tym trudności i dylematy, ale też skuteczne strategie rozgrywania kart systemu. Mamy zatem nadzieję, że ta osobista perspektywa wspomnień, które przybierają często formę odtwarzanych scen, odbytych w przeszłości rozmów, rozegranych interakcji, będąca elementem pamięci komunikacyjnej, być może przekazywana też przez narratorów w ich rodzinach, stanowi istotne uzupełnienie analiz bazujących na źródłach i dokumentach historycznych. 


\title{
Rozdzial VI. Miejsca i materialność akademii ${ }^{1}$
}

\author{
Socjologia byta na czwartym piętrze na Uniwersyteckiej 3, a zakład \\ Kotarbińskich byt na trzecim. Także ci asystenci Kotarbińskich bardzo \\ byli zaprzyjaźnieni ze studentami Chałasińskich i Szczepańskiego. (...) No \\ $i$ wtaściwie caty czas się siedziało u siebie. \\ Z wywiadu z profesor Krystyną Lutyńską
}

Ja nie lubie nowego budynku². Jest bezosobowy. Jest dezintegrujacy ludzi. Pomijając już to, że można chodzić w kótko po tych korytarzach, co jest irytujace. Tam ludzie się $w$ ogóle nie widzq. Moim zdaniem cały szereg przestrzeni jest wlaściwie zgubiony $i$ bez sensu. Nie wiem, może z punktu widzenia bryły $i$ wizji architekta to jakoś tam wyglada. Ale te wiszace schody, po których studenci nawet niechętnie chodza. Nie lubię tego budynku.

$\mathrm{Z}$ wywiadu z profesor Birutą Lewaszkiewicz-Petrykowską

Życie akademickie to nie tylko intelektualne rozważania - nawet najbardziej abstrakcyjne idee rodzą się wszak w określonych okolicznościach, w konkretnych przestrzeniach i w sposób podlegający opisowi. Ostatnia część książki poświęcona jest materialności pracy naukowej i przestrzennemu wymiarowi działania Uniwersytetu. Dotyczy więc zarówno mieszkań, sal wykładowych, bibliotek i laboratoriów, jak również samego procesu tworzenia nauki w jej materialnym i codziennym wymiarze. W wypowiedziach naszych rozmówców znalazło się bowiem wiele odniesień do miejsc, w których pracowali i żyli, które wpływały na życie naukowe, a także do samego warsztatu pracy. Tematem tego rozdziału jest zatem to, jak powstaje nauka w konkretnym miejscu i czasie. Nie mogło tu zabraknąć także lokalnej specyfiki wynikającej z miejsca założenia uniwersytetu - Łodzi - jako robotniczego miasta, które od 1945 roku stawało się także miastem akademickim.

\footnotetext{
${ }^{1}$ Kompendium wiedzy na temat miejsc związanych z Uniwersytetem Łódzkim stanowi niedawno opublikowana książka: Kołodziej Karolina, Maciej Kronenberg, 70 lat Uniwersytetu Łódzkiego w przestrzeni miejskiej Łodzi (1845-2015), Wydawnictwo Uniwersytetu Łódzkiego, Łódź 2015.

${ }^{2}$ Chodzi tutaj o tzw. Paragraf, czyli nowy budynek Wydziału Prawa otwarty w 2008 roku przy ulicy Kopcińskiego 8/12.
} 


\section{Topografia Uniwersytetu}

Kiedy na początku 1945 roku zakładano Uniwersytet Łódzki, sama Łódź była miastem mało zniszczonym i właśnie stosunkowo dobra infrastruktura przyciągała tu wielu przyjezdnych (por. rozdział I). Szybko jednak okazało się, że nie jest to odpowiednie i wystarczające zaplecze dla rodzącego się uniwersytetu. Istniała wprawdzie baza mieszkalna, ale dostęp do niej i wyposażenie stanowiły problem - nawet lokalna prasa donosiła o potrzebie pomocy przybyłym profesorom w tym zakresie. W tamtym czasie w całej Polsce powszechne było zajmowanie pustych mieszkań. Wspominał o tym między innymi cytowany wcześniej Eugeniusz Czerniawski³ ${ }^{3}$.

Działała już większość fabryk, podobnie placówki niższych stopni edukacji, budynki przedwojennej i wojennej administracji także były w ciągłym użyciu, nie istniały więc właściwie żadne wolne zasoby dostosowane dla działalności edukacyjnej. Najpoważniejsze braki dotyczyły przestrzeni odpowiadających funkcjom publicznym i biurowym. Pojedyncze przypadki, jak przedwojenna siedziba oddziału Wolnej Wszechnicy Polskiej na rogu ulicy Rewolucji 1905 oraz POW (w okresie PRL noszącej nazwę Armii Ludowej) stanowiły kroplę w morzu potrzeb. A przecież w ciągu kilku następujących miesięcy otworzono w Łodzi dziesięć wyższych uczelni. Stąd wiele wykładów odbywało się w salach kinowych i teatralnych, w profesorskich mieszkaniach, a nawet na świeżym powietrzu. Braki były na tyle znaczące, iż w niektórych przypadkach proszono studentów o przybycie z własnymi krzesłami ${ }^{4}$ ! Jan Muszyński, jeden z organizatorów i pierwszy dziekan Wydziału Farmaceutycznego Uniwersytetu Łódzkiego, komentował na bieżąco te braki:

W wielkiej Łodzi tak jak grzyby

Wyrastają wciąż wszechnice

Łódź przekształca się w stolicę

Chociaż trochę tak ,na niby”

$\mathrm{W}$ akademia zamieniono

Wszystkie kina, szereg dworów

Profesorskie pełni grono

Role „kinooratorów”.

${ }^{3}$ Zob. rozdział I.

${ }^{4}$ Temat dla Szpilek: studenci maja chodzić na wykłady z krzesłami, „Kurier Popularny”, 19 listopada 1945.

${ }^{5}$ Jan Dylik, Zygmunt Dylik, Nauka: powstanie i organizacja łódzkiego ośrodka naukowego, [w:] Edward Rosset (red.), Łódź w latach 1945-1960, Wydawnictwo Łódzkie, Łódź 1962, s. 280. 


\section{Tak wspominała ten czas Krystyna Śreniowska:}

Uniwersytet nie miał odpowiednich audytoriów. Na przykład prawnicy urzędowali w sądzie przy placu Dąbrowskiego, bo sąd im oddał salę główną. Stąd właśnie wykładał na tym placu Dąbrowskiego pan Vieweger ${ }^{6}$, który krótko był organizatorem Uniwersytetu. To był wielki kłopot z salami wykładowymi. Więc sąd nam oddał sale wykładowe, ale zanim to zrobił, wykłady odbywały się w kinach. Mój mąż $\dot{z}^{7}$ tu w kinie wykładał, co było dla studentów bardzo niewygodne, bo oni siedzieli na krzesłach, ale nie mieli stolików, nie mieli na czym sobie notować. Ale mieściliśmy się, gdzie było możliwe. Jak ktoś zaoferował, to Uniwersytet z tego korzystał.

Trudne początki lokalowe wspomina także Bronisława Kopczyńska-Jaworska:

Uniwersytet powoli ruszał. Wykłady się odbywały trochę na Żeromskiego, odbywały się w kinie na rogu Tuwima i Piotrkowskiej, to było kino „Luna”. Wykłady też w Młodej Gwardii, czyli na ulicy Zielonej, tam gdzie teraz jest Rossmann. Takie wykłady się odbywały przez głośniki i całe kino było pełne młodzieży. Pamiętam, że późniejszy mój mąż studiował ekonomię i chodziliśmy np. na wykłady z geografii gospodarczej razem, na socjologię, wszyscy przychodzili na ten jeden wielki wykład. Na wiosnę jeszcze w 1945 roku dostał Uniwersytet ten dom na rogu Lindleya, gdzie rektorat jest, w tej sali na górze imienia Kotarbińskiego odbywały się wykłady z socjologii. Pamiętam, że były takie ławki, z oheblowanego drzewa pewnie, ale z zadziorami, takie ordynarne, tak z trzech stron poustawiane. I były wykłady Chałasińskiego ${ }^{8}$, na które przychodziło mnóstwo ludzi, ponieważ Chałasiński był uwielbiany przez to środowisko nauczycieli ludowych, pochodzenia wiejskiego w większości, przez to młode pokolenie chłopów, które opisywał. Oni adorowali go nieprawdopodobnie i przychodziło mnóstwo ludzi, bo on był świetnym wykładowcą. Siedziało to wszystko na tych ławkach na podłodze, duszno było jak nieszczęście. Już po pół godziny człowiek myślał, że się udusi, ale

\footnotetext{
${ }^{6}$ Teodor Vieweger (1888-1945) - biolog specjalizujący się w badaniu pierwotniaków i orzęsek. Po ukończeniu gimnazjum w Warszawie udał się na studia medyczne na Uniwersytecie w Liège i zoologiczne w Brukseli, gdzie kilka lat później obronił doktorat w zakresie nauk przyrodniczych. Przed wojną był profesorem Wolnej Wszechnicy Polskiej w Warszawie. Dzięki jego inicjatywie Wolna Wszechnica Polska stała się uczelnią akademicką, a jej oddział został uruchomiony w Łodzi (1928). Brał udział w organizowaniu Uniwersytetu Łódzkiego po wojnie. Zginął tragicznie w wypadku samochodowym.

${ }^{7}$ Stanisław Śreniowski (1912-1957) - historyk państwa i prawa, od 1945 roku profesor na Uniwersytecie Łódzkim.

${ }^{8}$ Józef Chałasiński (1904-1979) - profesor socjologii, jeden z założycieli Uniwersytetu Łódzkiego i rektor tej uczelni w latach 1949-1952, członek PAN.
} 
tam się odbywały. Pamiętam, że Chałasiński, Ossowski ${ }^{9}$, Kotarbińska ${ }^{10}$ tam mieli wykłady.

A sale dydaktyczne były przecież tylko jednym z elementów niezbędnej infrastruktury - nie było gdzie przechowywać książek, składować powstającej dokumentacji, nie było laboratoriów ani magazynów. Dodatkowo Uniwersytet powstawał w niezbyt sprzyjających okolicznościach - władze miasta borykały się z coraz większą ilością kłopotów i wielu uważało powstanie uczelni za nadmierny zbytek - robotniczemu miastu wystarczyłaby politechnika. Ten czas niedoboru być może spowodował, iż w późniejszych latach tak duże znaczenie przypisywano kwestii uniwersyteckiego kampusu (jak pisano wówczas w prasie, „miasteczka” lub „dzielnicy” uniwersyteckiej).

Na początku lat pięćdziesiątych w okolicach ówczesnej ulicy Bystrzyckiej ${ }^{11}$ przy ogromnym zaangażowaniu samych studentów rozpoczęto budowę domów akademickich oraz gmachu biblioteki uniwersyteckiej, o czym opowiada Romuald Olaczek:

W roku akademickim 1952/1953 kończyły się budowy pierwszych domów akademickich w osiedlu studenckim przy ulicy, która wtedy nazywała się Bystrzycka, potem Lumumby. Przy porządkowaniu terenu, a także nawet przy budowie tych akademików pracowali też studenci. ZMP organizował takie brygady, na zmianę kolejne roczniki, grupy studenckie szły pomagać. Także na drugim roku studenckim mieszkałem już w eleganckim akademiku na osiedlu i byliśmy z tego bardzo, bardzo dumni.

Był to początek wpisywania uniwersytetu w topografię miasta, a cel budowy nowoczesnego kampusu organizował myślenie o uczelni przez kolejne dekady - nawet wtedy, gdy w latach dziewięćdziesiątych dla podupadającej Łodzi lepszym rozwiązaniem wydawało się zatrzymanie uczelni i studentów w centrum miasta.

Choć ważnych dla rozwoju uczelni przestrzeni było znacznie więcej, nasi rozmówcy przywołują jedynie kilkanaście z nich. Są to przede wszystkim siedziby instytutów i katedr, biblioteki, ale także mieszkania czy stołówki - wszystkie te miejsca, w których toczyło się życie akademickie.

${ }^{9}$ Stanisław Ossowski (1897-1963) - socjolog, profesor Uniwersytetu Łódzkiego w latach 1945-1947 oraz Uniwersytetu Warszawskiego.

${ }^{10}$ Janina Kamińska-Kotarbińska (1901-1997) - filozof i logik, profesor Uniwersytetu Łódzkiego w latach 1945-1951, później profesor Uniwersytetu Warszawskiego.

${ }^{11}$ Od 1951 roku ulica ta nosi nazwę Patrice'a Lumumby (pierwszego premiera Demokratycznej Republiki Konga) - od tej nazwy wzięła się nazwa wybudowanego tutaj osiedla akademików - Lumumbowo. 


\section{Tak ówczesną Łódź pamięta Jerzy Kmieciński:}

Uniwersytet Łódzki w swych pierwocinach - jak pani zapewne wiadomo - nie miał jakiejś jednej, większej siedziby. Najstarszą siedzibą były budynki przy Narutowicza 65 i 68, czyli po jednej stronie rektorat, po drugiej zaś, naprzeciw, Wydział Chemii. Przy rektoracie był Wydział Humanistyczny i kierunek historia oraz filologie. Reszta rozproszona była po mieście w czterdziestu paru punktach. Zakład Archeologii, później Katedra, mieścił się na placu Wolności 14 przy Muzeum Archeologicznym i Etnograficznym. Władze miejskie użyczyły rozrastającemu się Uniwersytetowi budynków o bardzo różnej, czasem podejrzanej przeszłości. Do takich należała kamienica przy ulicy Próchnika 5, przeznaczona w 1945 r. na tymczasowe miejsce zamieszkania dla przyjezdnej - z Wilna, Lwowa, Warszawy - kadry profesorskiej UŁ. Wspomniana kamienica przed wojną pełniła rolę, eufemistycznie mówiąc, ,zakładu masażu erotycznego". W czasie okupacji zmieniła tylko użytkowników, którymi byli oficerowie formacji wojskowych okupanta. Ponieważ zaraz po wojnie co poniektórzy łodzianie, odwiedzający ten przybytek Afrodyty w dobrych czasach przedwojennych, pałali znów ochotą skorzystania z usług tej instytucji, dochodziło niejednokrotnie do bardzo kłopotliwych sytuacji.

Bez wątpienia od samego początku na mapie akademickiej Łodzi szczególne miejsce zajmowała kamienica przy ulicy Uniwersyteckiej 3. Wzmianki o tym niepozornym budynku, który do dziś jest budynkiem uniwersyteckim, znajdziemy w wielu zebranych przez nas opowieściach. Przenikały się tu przestrzeń prywatna i publiczna, tworząc tym samym szczególną, niepowtarzalną atmosferę - mieścił się tu po wojnie wspomniany Wydział Humanistyczny, wiele katedr i instytutów, organizowano prowizoryczne sale wykładowe i seminaryjne, a dodatkowo mieszkali tam także uniwersyteccy profesorowie. To właśnie na Uniwersyteckiej 3 zaczęto tworzyć początki biblioteki socjologicznej, która niebawem miała stać się drugim największym tego typu księgozbiorem w Polsce, o czym za chwilę jeszcze będzie mowa ${ }^{12}$. Krystyna Śreniowska opowiada:

Gdzie Uniwersytet obierał sobie siedziby? To różnie było. Tutaj, na rogu Narutowicza i Jaracza w tej kamienicy się socjologowie zagnieździli. Tam Chałasiński ${ }^{13}$ królował, na trzecim piętrze organizował Instytut Socjologii. Chałasiński był stale w ruchu, bo on właśnie zabiegał o księgozbiór. Jeździł stale do Warszawy i zwoził ogromne ilości książek. Ja się zatrudniłam jako bibliotekarz u socjologów. A Chałasiński mnie ze Lwowa znał. Także pracowałam

${ }^{12}$ Biblioteka im. Józefa Chałasińskiego istniała do 2010 roku, kiedy połączono ją z Biblioteką Ekonomiczną, tworząc wspólny zbiór dla całego Wydziału Ekonomiczno-Socjologicznego.

${ }^{13}$ Zob. przypis $8 \mathrm{w}$ tym rozdziale. 
jakby na dwóch etatach, bo tam te książki katalogowałam. Początki biblioteki socjologicznej - to wszystko przechodziło przez moje ręce.

Przyjrzyjmy się jak Krystyna Lutyńska drobiazgowo rekonstruuje, w jaki sposób rozplanowana i zagospodarowana była przestrzeń na Uniwersyteckiej 3:

Kotarbińscy ${ }^{14}$ mieli swój zakład piętro niżej. Socjologia była na czwartym piętrze na Uniwersyteckiej 3, a zakład Kotarbińskich był na trzecim. No i właściwie cały czas się siedziało u siebie. Ija Pawłowska, Przełęcki ${ }^{15}$, to byli jego najstarsi uczniowie, bardzo mądrzy i bardzo sympatyczni ludzie. I oni wszyscy przesiadywali u socjologów. Wszyscy spotykali się na zebraniach PTS-u czy na zebraniach Polskiego Towarzystwa Filozoficznego. Najpierw Polskie Towarzystwo Socjologiczne powstało przecież jako sekcja Polskiego Towarzystwa Filozoficznego, potem się wyodrębniło. Była też na Uniwersyteckiej 3 pedagogika społeczna i pani profesor Radlińska ${ }^{16}$. Chyba na pierwszym piętrze

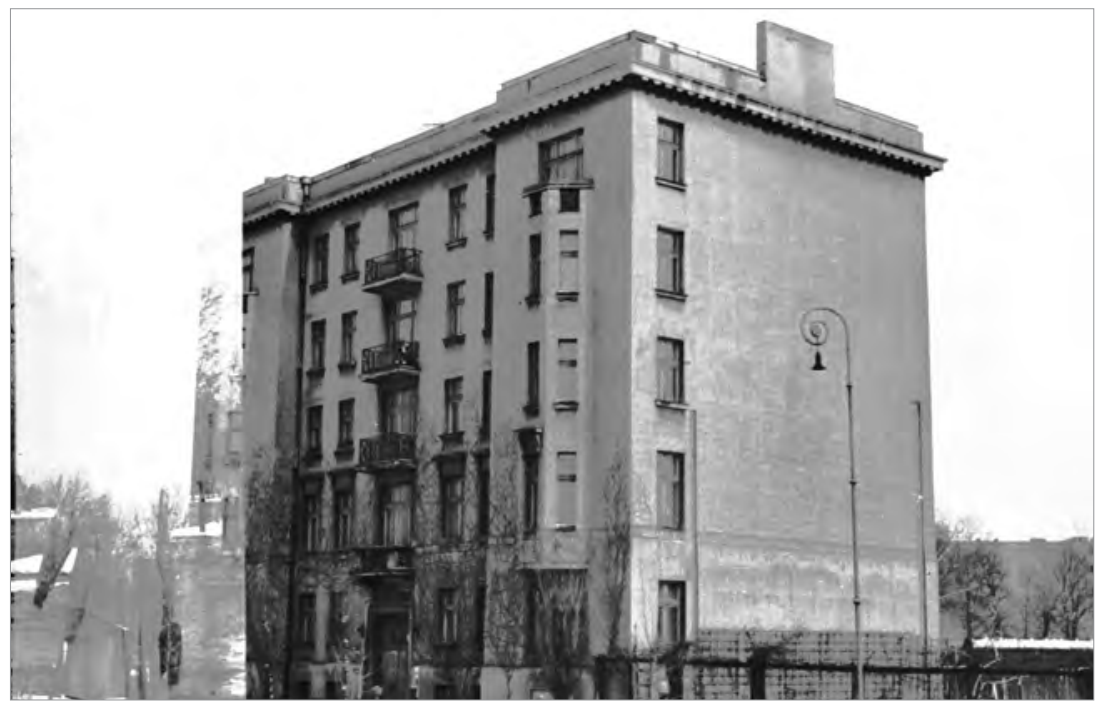

Fot. 65. Budynek przy Uniwersyteckiej 3

${ }^{14}$ Tadeusz Kotarbiński (1886-1981) - profesor filozofii, logik, współzałożyciel Uniwersytetu Łódzkiego i pierwszy rektor uczelni. Janina Kotarbińska - Zob. przypis 10 w tym rozdziale.

${ }^{15}$ Ija Lazari-Pawłowska (1921-1994) - etyk i filozof, twórczyni Katedry Etyki na Uniwersytecie Łódzkim; Tadeusz Pawłowski (1924-1996) - logik i filozof. Absolwent i profesor Uniwersytetu Łódzkiego; Marian Przełęcki (1923-2013) - logik i filozof, absolwent Uniwersytetu Łódzkiego, profesor Uniwersytetu Warszawskiego.

${ }^{16}$ Helena Radlińska (1879-1954) - profesor pedagogiki, stworzyła pedagogikę społeczną w Polsce, w 1945 roku po przyjeździe do Łodzi uruchomiła na Uniwersytecie Łódzkim Zakład Pedagogiki Społecznej. Jej współpracownikami byli m.in. Aleksander Kamiński i Irena Lepalczyk. 
była pedagogika, był profesor Truchim ${ }^{17}$. I oczywiście Aleksander Kamiński ${ }^{18}$ przyszedł. Kamiński ciągle siedział u socjologów. To był przesympatyczny człowiek, z nim to można było dyskutować, opowiadać do upadłego.

Zbigniew Bokszański także opisuje to miejsce:

Ten Instytut [Socjologii] mieścił się na Uniwersyteckiej 3. Myśmy zajmowali tam jako Instytut piętro trzecie i czwarte. Na drugim piętrze mieszkała profesor Kłoskowska ${ }^{19}$, miała prywatne mieszkanie. Na parterze mieszkał profesor Lutyński ${ }^{20}$. Na pierwszym piętrze mieszkał profesor Hrabec ${ }^{21}$, językoznawca, filolog. W ogóle cała ta kamienica rogowa była oddana we władanie Uniwersytetu.

Swoje miejsce znalazła tam ponadto historia sztuki, z którą wiąże się wspomnienie czasów studenckich Wandy Nowakowskiej:

Pamiętam, że najpierw mieliśmy zajęcia w tym pałacyku zabytkowym przy ulicy Skłodowskiej-Curie 11, później mieliśmy zajęcia na Uniwersyteckiej 3, gdzie była Katedra Historii Sztuki, a później na Lindleya 3. I tam [na Uniwersytecka], pamiętam, chodziłam na egzaminy do profesora Truchima ${ }^{22}$ właśnie, i tam była obrona mojej pracy magisterskiej z estetyki.

Nic dziwnego, że Uniwersytecka 3 stała się żywym miejscem spotkań, co więcej nie tylko humanistów, ale także przedstawicieli nauk ścisłych i przyrodniczych. Romuald Skowroński - chemik, wspominając swoją mistrzynię - profesor Annę Chrząszczewską ${ }^{23}$, opowiada: „Chrząszczewscy organizowali dla swoich najbliższych współpracowników przyjęcia w ich domu, mieszkaniu na Uniwersyteckiej 3, na drugim piętrze, po lewej

${ }^{17}$ Stefan Truchim (1896-1967) - historyk kultury i oświaty, od 1945 roku profesor Uniwersytetu Łódzkiego.

${ }^{18}$ Aleksander Kamiński (1903-1978) - pedagog, harcmistrz i wychowawca młodzieży, zatrudniony na Uniwersytecie Łódzkim do 1950 roku, odsunięty od nauczania z przyczyn ideologicznych, od 1958 roku ponownie zatrudniony.

${ }^{19}$ Antonina Kłoskowska (1919-2001) - socjolog, absolwentka Uniwersytetu Łódzkiego, profesor na Uniwersytecie Łódzkim i Uniwersytecie Warszawskim, w latach 1989-1994 przewodnicząca Polskiego Towarzystwa Socjologicznego.

${ }^{20}$ Jan Lutyński (1921-1988) - socjolog i metodolog, profesor Uniwersytetu Łódzkiego, Dyrektor Instytutu Socjologii UŁ, kierownik Zakładu Metod i Technik Badań Społecznych. Ekspert i doradca struktur związkowych „Solidarności”. W 1981 roku podczas strajku studenckiego na UŁ pełnił funkcję doradcy komitetu strajkowego.

${ }^{21}$ Stefan Hrabec (1912-1972) - językoznawca, profesor i w latach 1962-1965 rektor Uniwersytetu Łódzkiego.

${ }^{22}$ Zob. przypis $17 \mathrm{w}$ tym rozdziale.

${ }^{23}$ Anna Chrząszczewska (1889-1988) - chemik, specjalizująca się w chemii organicznej, od 1945 roku profesor Uniwersytetu Łódzkiego 
stronie".W pamięci naszych rozmówców zachowały się niemal plany wnętrz poszczególnych katedr. Opowiada Olga Czerniawska:

To jest, jak pani widzi, wyjątkowa katedra, pięknie urządzona. Profesor miał te stałe regały z „Ładu”24, a na środku stał stół „Chippendale”, piękny taki mahoniowy stół, który dalej wędruje, w tej chwili jest u pani profesor Marynowicz-Hetki ${ }^{25}$. Profesor [Kamiński] ${ }^{26}$ siadał sobie czasami przy tym stole, coś tam robił. Biurka naturalnie też były. W ogóle cała katedra zajmowała dwa małe pokoje, jeden duży pokój - to uniwersytecki, tam stały te książki, stół, a gdzieś z boku biurko; i taki malutki pokoik, gdzie stało biurko i drewniane stoły. Myśmy siadali przy tych stołach, tam były seminaria, zajęcia się odbywały. Wszystko w budynku przy Uniwersyteckiej 3.

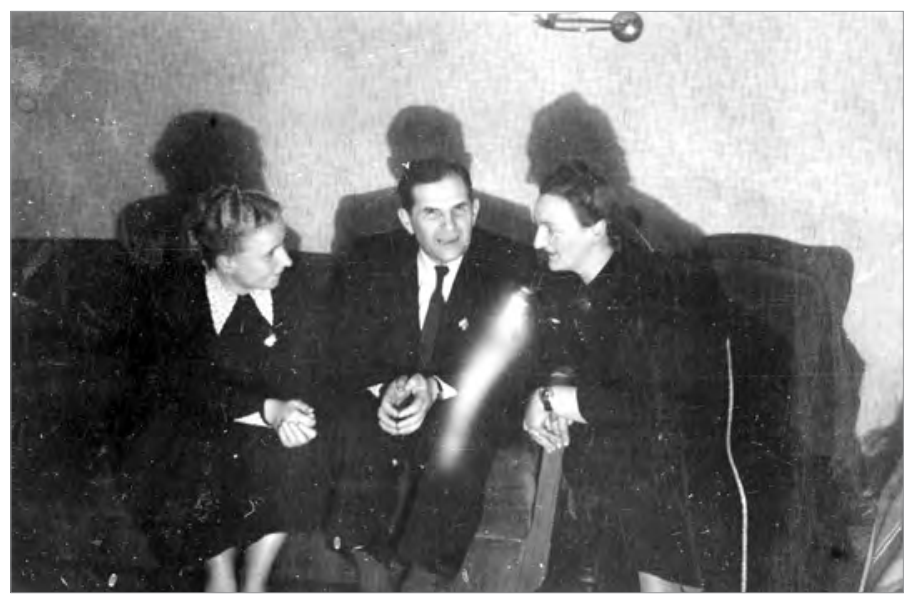

Fot. 66. Uniwersytecka 3: od lewej siedza

Irena Lepalczyk, Aleksander Kamiński oraz Anna Chrzaszczewska

Dodać należy, że kamienica przy Uniwersyteckiej 3 sąsiadowała ze stojącym przy prostopadłej ulicy Narutowicza gmachem, w którym znajdował się między innymi Wydział Matematyczno-Fizyczno-Chemiczny. Także nieopodal, przy ulicy Narutowicza 65 i 68 oraz przy ulicy Lindleya ulokowane były inne uczelniane budynki. Przy ulicy Narutowicza 68 mieścił się

\footnotetext{
${ }^{24}$ Spółdzielnia Artystów „Ład”, założona w Warszawie w 1926 roku, produkowała meble projektowane przez artystów-plastyków na indywidualne zamówienia. Reaktywowana w 1945 roku jako Spółdzielnia Pracy Architektury Wnętrz.

${ }^{25}$ Ewa Marynowicz-Hetka (ur. 1946) - profesor w Katedrze Pedagogiki Społecznej Uniwersytetu Łódzkiego.

${ }^{26}$ Zob. przypis $18 \mathrm{w}$ tym rozdziale.
} 
wówczas Wydział Biologii i Nauk o Ziemi. Jego opis znajdziemy w relacji Krzysztofa Jażdżewskiego:

Wtedy nasza instytucja, w której teraz tu siedzimy [Wydział Biologii i Ochrony Środowiska], była w budynku uniwersyteckim na Narutowicza 68. Naprzeciwko rektoratu jest taki stareńki budynek, tam była przed wojną Szkoła Zgromadzenia Kupców i tam ten zakład, bo wtedy to się nazywało zakład, a z czasem przechodziła na jakby wyższy stopień $\mathrm{i}$ teraz to jest katedra - to tak się nazywa bardzo kościelnie. Teraz to już zanika, ale u nas w Uniwersytecie jeszcze te katedry są, a katedra dopiero dzieli się na zakłady. A początkowo jak pracowałem, to się jeszcze „zakład” nazywało, Zakład Zoologii Ogólnej. Tam on się mieścił i tam myśmy byli do 1968 roku, kiedy ten nowy gmach wybudowano i od 1968 roku to już szmat czasu, jak tutaj jesteśmy.

Edward Tranda swą opowieścią niemalże oprowadza nas po wnętrzach budynku przy ulicy Narutowicza 68:

Na Narutowicza 68 było dawne przedwojenne Gimnazjum Zgromadzenia Kupców, to było takie duże gmaszysko bardzo szanowanego przed wojną gimnazjum i liceum. Tam były w suterenach zakłady Wydziału Lekarskiego, Wydział Biochemiczny i tak dalej. Tam królował profesor Filipowicz ${ }^{27}$. Na parterze była z jednej strony aula, dzisiaj zresztą też jest. Może tam jest taka sala wykładowa po lewej, a w prawo był korytarz, z którego były wejścia do tych pomieszczeń, salek ewentualnie. Tam mieściły się zakłady mikrobiologii i fizjologii roślin profesora Moycho ${ }^{28}$. Tam też w jednym pokoju chyba jeszcze, a może w dwóch pokojach mieścił się zakład antropologii profesora Ireneusza Michalskiego ${ }^{29}$, myśmy go wtedy nazywali Pireneusz. Był gabinet profesora Skupieńskiego ${ }^{30}$, botanika, który prowadził wykłady z botaniki ogólnej, i gabinet profesora Moychy od fizjologii roślin. Na piętrze były chemia nieorganiczna, na piętrze wyżej była chemia organiczna profesor Chrząszczewskiej ${ }^{31}$ i jej męża, a na ostatnim piętrze były dość spore sale wykładowe. To był budynek

\footnotetext{
${ }^{27}$ Bronisław Filipowicz (1904-1988) - biochemik, profesor Uniwersytetu Łódzkiego, a od 1952 roku Akademii Medycznej.

${ }^{28}$ Wacław Moycho (1884-1965) - botanik, specjalista z zakresu fizjologii roślin i mikrobiologii, od 1945 roku profesor Uniwersytetu Łódzkiego.

${ }^{29}$ Ireneusz Michalski (1908-1965) - antropolog, profesor Uniwersytetu Łódzkiego. W 1945 roku zorganizował Zakład Antropologii na Wydziale Matematyczno-Przyrodniczym tegoż uniwersytetu. Twórca metody morfologiczno-porównawczej w systematyce człowieka (tzw. szkoła łódzka). Uczestnik wielu wypraw naukowych, w tym m.in. do Chin, Korei, Egiptu i Mongolii.

${ }^{30}$ Franciszek Ksawery Skupieński (1888-1962) - botanik, mikrobiolog, badacz grzybów i śluzowców. Przed wojną profesor Uniwersytetu Wileńskiego, potem Wyższej Szkoły Gospodarstwa Wiejskiego w Łodzi oraz od 1945 roku Uniwersytetu Łódzkiego.

${ }^{31}$ Zob. przypis $23 \mathrm{w}$ tym rozdziale.
} 
przystosowany do celów dydaktycznych i nie trzeba było żadnych przeróbek i żadnych specjalnych adaptacji tam robić.

Wtóruje mu opisując wnętrza budynku Romuald Skowroński:

Jeżeli chodzi o nauki ścisłe, to takim centrum był gmach na Narutowicza 68. Tam wtedy znajdowała się biologia, chemia i fizyka. Ten gmach na Narutowicza to była własność Zrzeszenia Kupców Polskich. Bardzo ładny gmach, pani nie wiem, czy go zna, tam jest sala posiedzeń Senatu. Tam są piękne schody, a na każdym piętrze duże sale seminaryjne wysokości cztery i pół metra. Dla kierunków eksperymentalnych solidny gmach to bardzo ważna sprawa. Historycznie ten budynek jest jeszcze o tyle ważny, że tam się też odbył w auli pierwszy bal uniwersytecki i w pierwszej parze był profesor Kotarbiński ${ }^{32}$.

Z czasem Uniwersytet zaczął dysponować coraz większą liczbą lokali. Wiele katedr zatem przeprowadzało się i zmieniało miejsce, co nieuchronnie oznaczało rewolucję w codziennym toku prac naukowych i dydaktycznych. Eugeniusz Czerniawski wspomina przeprowadzkę biologii z Narutowicza 68, podkreślając, że każde nowe pomieszczenie musiało zostać odpowiednio zagospodarowane i wyposażone:

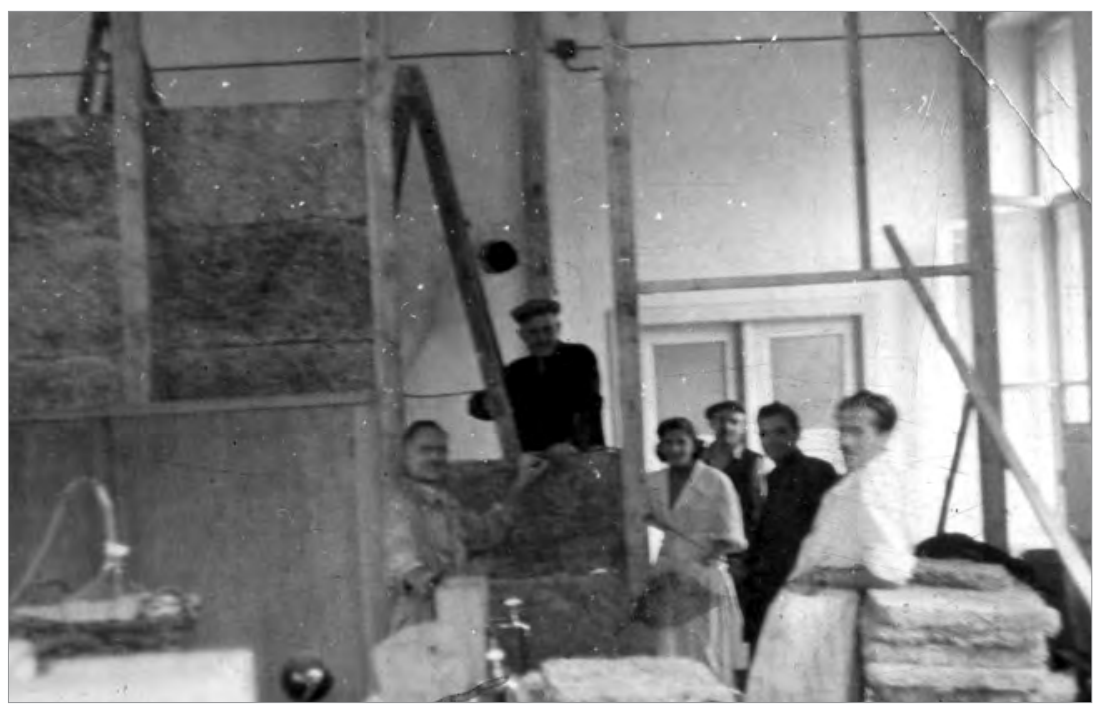

Fot. 67. Przeprowadzka do budynku przy ulicy Pomorskiej 18. Do 1968 roku mieścity się tam m.in. Katedra Mikrobiologii, Katedra Systematyki i Geografii Roślin, Katedra Antropologii i Zakład Metodyki Biologii

${ }^{32}$ Zob. przypis $14 \mathrm{w}$ tym rozdziale. 
W 1951 roku profesor Zabłocki ${ }^{33}$ przychodzi i mówi: „Dostaliśmy lokum na Pomorskiej 18, a drugie na Skłodowskiej-Curie, taki pałacyk ładny jest”. Myśmy woleli ten pałacyk, ale profesor [Zabłocki] zadecydował, że przechodzimy na Pomorską, później to była już Nowotki. Wprowadziliśmy się, a tam znowuż nic nie było. W budynku, w którym obecnie jest Gmina Żydowska, myśmy dostali dużą salę jako salę wykładową i ćwiczeniową. Nic nie było. Dostaliśmy autoklaw. Otrzymaliśmy partię pierwszych mikroskopów z NRD, Zeissa. Powoli, powoli zaczęło się wszystko tutaj poprawiać. Z Narutowicza 68, bo tam cała biologia się mieściła i stamtąd również na Pomorską profesor Mowszowicz ${ }^{34}$ przeprowadził się, jak też kilka innych zakładów, a część jeszcze została na miejscu. Tu był ten taki początek i trzeba była to organizować, dźwigać, jeździć, nosić, przepakowywać. Powoli rozbudowywaliśmy to wszystko.

Dodaje dalej, że przy przeprowadzce czekały biologów kolejne niespodzianki:

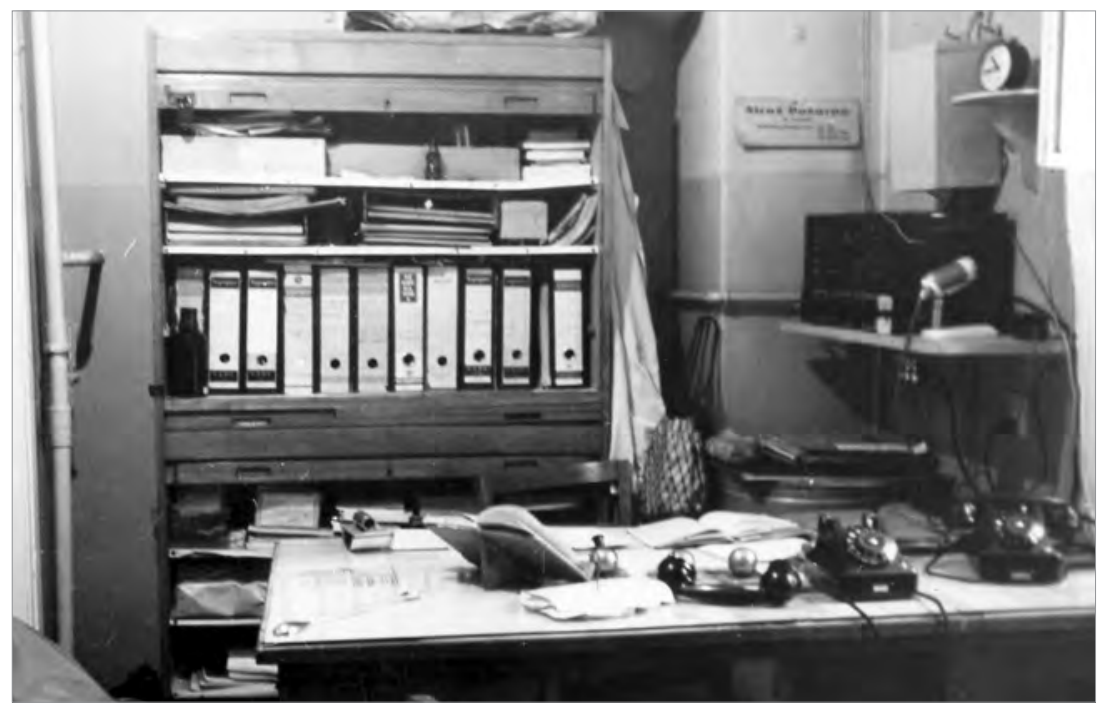

Fot. 68. Gabinet profesora Bernarda Zabłockiego ,nad butlami z eterem”, Pomorska 18

${ }^{33}$ Bernard Zabłocki (1907-2002) - mikrobiolog i immunolog, absolwent Uniwersytetu im. Stefana Batorego, od 1945 roku profesor Uniwersytetu Łódzkiego, kierownik Katedry Mikrobiologii UŁ.

${ }^{34}$ Jakub Mowszowicz (1901-1983) - urodzony w Wilnie biolog i botanik, profesor Uniwersytetu Łódzkiego. Doktorat uzyskał na tamtejszym Uniwersytecie Stefana Batorego. Badał florę regionu łódzkiego. Był jednym z założycieli łódzkiego Ogrodu Botanicznego. Przez wiele lat sprawował funkcję dziekana Wydziału Biologii i Nauki o Ziemi na Uniwersytecie Łódzkim. 
Laboratorium mieściło się $\mathrm{w}$ takiej oficynie na Pomorskiej 18, po prawej stronie wewnątrz głównego budynku. Jak oni się wyprowadzili [Wyższa Szkoła Gospodarstwa Wiejskiego przeniesiona do Olsztyna], to były potrzebne piwnice. Oni z piwnic zaczęli wynosić swoje rzeczy. I okazało się, że w piwnicy był eter w takich piętnastolitrowych czy więcej szklanych butlach. Do ekstrakcji był potrzebny. To była bomba nie z tej ziemi, bo to mogło wybuchnąć nawet przy zmianie temperatury. Cały budynek mógł wylecieć w powietrze! A nad tym był gabinet profesora [Zabłockiego]. Profesor nie wiedział i myśmy nie wiedzieli.

Przeprowadzka Instytutu Historii do nowego budynku nie tylko nie była łatwa, ale też nie poprawiła znacząco warunków pracy, o czym opowiada Stefan Banasiak:

Ulica Kamińskiego wcześniej się nazywała Buczka, a przedtem jeszcze inaczej, ale mówmy Buczka. Tu gdzie jest Instytut [Historii], był budynek pofabryczny. Urząd Bezpieczeństwa zrezygnował z tego budynku, oddał go miastu, ponieważ to należało do miasta, a miasto przekazało Uniwersytetowi, z tym parkanem, który istnieje chyba do tej pory. Do tego budynku został przeprowadzony Instytut Historii. Ja przy tej przeprowadzce brałem udział. Przewoziłem książki, wiem, że wystawiliśmy taki drąg, zrobiliśmy takie kółko, linkę do wciągania, bo po tych schodach tam z biurkami, z szafami nie można sobie było dać rady, a okna są wielkie, więc oknami przez salę 23 było to rozprowadzane dalej. W tych pokojach od środka zostały ulokowane katedry filozofii, a tam, w tych klitkach, w oficynie - katedry historii. Oprócz tego w tym budynku mieściła się Katedra Ekonomii, tej Ekonomii Politycznej, która obsługiwała cały Uniwersytet, i Katedra Filozofii. Więc to nie był budynek zajmowany tylko przez historię. Ponadto sale wykładowe na pierwszym i drugim piętrze podlegały działowi nauczania rektoratu. To nie były sale Instytutu, ale ponieważ my tu byliśmy, więc w pierwszej kolejności biegliśmy do wydziału nauczania i żeśmy swoje sprawy zaklepywali. Ale były targi, bo trzeba było biologów, filologów, którzy byli jeszcze w gorszej sytuacji, przygarnąć, to znaczy umożliwić im odbywanie zajęć. Była ciasnota. Uniwersytet był w trudnej sytuacji cały czas.

Problemy lokalowe sprawiały, że życie uniwersyteckie w tamtym czasie często związane było dla większości kierunków z ciągłym przemieszczaniem się. O niełatwych losach Wydziału Filozoficznego opowiada Ewelina Nurczyńska-Fidelska:

Kończyłam studia polonistyczne w gmachu naszego rektoratu. Wejście na polonistykę było od strony Lindleya i na parterze, pierwszym piętrze, tam gdzie dzisiaj są różne biura rektorskie, była polonistyka. Myśmy oczywiście jeszcze 
mieli wykłady w jakichś większych aulach, bo tam większych auli nie było. Mieliśmy wykłady na przykład razem z historykami, niektóre tak jak filozofia. W każdym razie tam polonistyka się straszliwie męczyła. I była gdzieś połowa lat sześćdziesiątych, kiedy uczelnia zaczęła znajdować miejsce dla Wydziału Filologicznego - to nie była tylko polonistyka, ale i już była tworzona powoli anglistyka, romanistyka, klasyczna filologia, była rusycystyka, była germanistyka. My jeszcze nie byliśmy kulturoznawstwem, byliśmy częścią polonistyki, ale właśnie katedrę pani profesor [Skwarczyńskiej] ${ }^{35}$ Teorii Literatury, Teatru i Filmu, bo tak to się wówczas nazywało, przeniesiono do tych salek, w jedno skrzydło biblioteki. Myśmy to nazywali ,akwarium”. Tam była sala wykładowa, chyba tam, gdzie później była biblioteka. Stamtąd przenieśliśmy się na Sienkiewicza. Musiało jeszcze być gdzieś jakieś małe pomieszczenie na bibliotekę. Na pewno pierwsze piętro, gdzie mieliśmy te przedzielone dyktą na trzy: Zakład Teorii Literatury i „Teatr”, pośrodku był sekretariat, a z lewej strony było filmoznawstwo. Mieliśmy salę numer 109 chyba, jedną salę dydaktyczną i jedną większą na parterze, która później została przekształcona na bibliotekę, ale myśmy się tam bardzo męczyli.

W latach sześćdziesiątych, po przyłączeniu do Uniwersytetu Łódzkiego Wyższej Szkoły Ekonomicznej, utworzono oddzielny Wydział Ekonomiczno-Socjologiczny - socjologowie opuścili Uniwersytecką 3 i przenieśli się do najstarszego historycznie akademickiego budynku Łodzi na rogu ulicy P.O.W. oraz ulicy Rewolucji 1905 roku. Krystyna Lutyńska wspominając to wydarzenie, opowiada nie tylko o zmianie lokalizacji, ale także o utracie trudnej do uchwycenia atmosfery tamtego miejsca:

My mieszkaliśmy na Uniwersyteckiej 3 od 1952 roku. Na Uniwersyteckiej mieszkała też Kłoskowska ${ }^{36}$, i Kądzielscy ${ }^{37}$ oraz profesorowie z innych wydziałów uniwersytetu, co sprzyjało kontaktom osobistym i przyjaźniom. $\mathrm{Na}$ czwartym piętrze był Instytut [Socjologii]. Potem dopiero, jak w latach sześćdziesiątych socjologia została przyłączona do ekonomii za karę, Instytut przeniesiono na ulicę Rewolucji. Wydaje się, że w Instytucie na Uniwersyteckiej było bardzo tak przytulnie powiedziałabym. A tutaj [na Rewolucji] wszystko zmieniło charakter. Wtedy Instytut był bardzo zintegrowany w tych ciężkich

${ }^{35}$ Stefania Skwarczyńska (1902-1988) - teatrolog, teoretyk i historyk literatury, przed wojną związana z Uniwersytetem im. Jana Kazimierza we Lwowie oraz Łódzkim Oddziałem Wolnej Wszechnicy Polskiej, po 1945 roku profesor Uniwersytetu Łódzkiego i doktor honoris causa tej uczelni.

${ }^{36}$ Zob. przypis $19 \mathrm{w}$ tym rozdziale.

${ }^{37}$ Józef Kądzielski (1929-1990) - socjolog, uczeń Józefa Chałasińskiego, zajmujący się kulturą masową, opinią społeczną i propagandą. Członek-założyciel Polskiego Towarzystwa Socjologicznego. 
latach stalinowskich i potem gomułkowskich. Tutaj, wydaje mi się, zaczęła się już taka separacja poszczególnych katedr. Ale to już są dzieje współczesne.

Grażyna Kononowicz wspomina z kolei początki swoich studiów przypadające właśnie na wczesne lata sześćdziesiąte:

Myśmy zdawali jeszcze [egzaminy wstępne] na Wydziale Filozoficzno-Historycznym, bo tam wtedy była socjologia. Udało się, byłam jedną z dziesięciorga studentów pierwszego roku. Ten pierwszy rok spędziliśmy na Wydziale Filozoficzno-Historycznym, później Uniwersytet zgodził się przyłączyć szkołę ekonomiczną, nie wiem, jakie tam były mechanizmy, w każdym razie nastąpiło połączenie Wyższej Szkoły Ekonomicznej z Uniwersytetem. Socjologia weszła do tego Wydziału Ekonomicznego i powstał Wydział Ekonomiczno-Socjologiczny. Przeniesiono nas do najstarszej części budynku, bo wtedy tylko to było, i tu się toczyły losy studenckie.

Na kształt powstających przestrzeni uniwersyteckich miały wpływ czasem pojedyncze osoby, które niejednokrotnie przedkładały budowę instytucji nad własne kariery naukowe. Taką osobą był Jan Ziomek, który stał się głównym organizatorem i założycielem Muzeum Geologicznego Uniwersytetu Łódzkiego, a we wcześniejszym okresie wiele pracy poświęcił stworzeniu materialnego zaplecza dla badań geologicznych, przede wszystkim „laboratorium z prawdziwego zdarzenia”:

[T]rzeba było wiercić otwory, badać skały i wykonywać mapy. Tutaj właśnie w pracowni kartografii geologicznej miałem najpierw na Kościuszki 21, na parterze, jeden pokój. Później przeniosłem się na ulicę Źródłową, na której dostałem do dyspozycji całe drugie piętro i parterowe piwnice, które zapełniałem rdzeniami geologicznymi. Natomiast w pracowni, na drugim piętrze urządziłem Muzeum Geologiczne, które mieściło się w trzech salach i na korytarzu, i do którego przychodziła już młodzież szkolna. Oczywiście za darmo. Nie braliśmy żadnych pieniędzy.

Muzeum stało się najważniejszym przedsięwzięciem w życiu akademickim geografa, który odpowiadał nie tylko za jego zbiory, ale także za organizację:

Lubiłem takie przestrzenie wolne, czyste, ładne, a w tym Muzeum Sztuki na Więckowskiego były parkiety takie lśniące, po których się chodziło w ciapciach, coś pięknego w tym wszystkim było. To skłoniło mnie do poszukiwania czegoś oryginalnego, ciekawego, ważnego. I w zasadzie, wie pani, ten ogród skalny czy muzeum to stworzyłem ja. Tego nikt nie projektował, ja projektowałem. Nawet niektórzy mówili, że „dlaczego Ziomek nie wziął projektanta, żeby to zaprojektował odpowiednio?" i tak dalej. A ja powiedziałem: 
„Projektantem jestem ja, bo ja wiem, co tu wstawić, jak wstawić, jak wyeksponować”. Tak samo ogród skalny. Też mówili, że trzeba projektanta tutaj. Projektant by wziął kupę pieniędzy i nie wiem, czy by lepiej zrobił. Może lepiej, ale ja starałem się, żeby obniżyć koszt tej inwestycji. Bo jednak, wie pani, Uniwersytet jest biedny. Także jest wielką moją radością, że rektorzy Uniwersytetu tak to wspomogli. Tu chcę w pierwszym rzędzie wymienić profesora Liszewskiego ${ }^{38}$, który pomagał, który przekazał na muzeum ten budynek przy ulicy Kopcińskiego 31. Później, rektor Puś39, który wspomagał nas, administracja cała! Uniwersytet $\mathrm{z}$ całego serca pomagał w tworzeniu tego muzeum. Wszędzie spotykałem się z wielką sympatią.

W późniejszym okresie istnienie muzeum zostało zagrożone i Jan Ziomek już na emeryturze ponownie zaangażował się w jego reorganizację:

Poprosiłem pana dziekana Wydziału, dziekanem Wydziału był dzisiejszy prorektor do spraw nauki, profesor Różalski ${ }^{40}$, który był moim szefem jako kierownik, a jednocześnie był życzliwy dla moich postulatów, żebym zorganizował Muzeum Geologiczne z prawdziwego zdarzenia. I wtedy na Radzie Wydziału złożyłem pismo z prośbą o utworzenie Muzeum Geologicznego przy Wydziale Biologii i Nauk o Ziemi. To był rok 2000 i Rada Wydziału jednomyślnie zaakceptowała właśnie powołanie tego Muzeum Geologicznego w takich warunkach, w jakich jest na Kopcińskiego 31. W ten sposób narodziło się Muzeum Geologiczne, a obok niego zorganizowałem ogród skalny, który także jest wizytówką Uniwersytetu Łódzkiego.

Podobne zaangażowanie w dosłownie rozumianą budowę instytucji, a dokładniej w rozbudowę nowej siedziby biologów na Pomorskiej 18 wykazał Eugeniusz Czerniawski:

Aparatury przybywało, aż stała na korytarzu. To były jeszcze lata pięćdziesiąte, mówię profesorowi Zabłockiemu i innym, że musimy dobudować część budynku, przynajmniej dwadzieścia metrów powierzchni. Profesor cały czas myślał o gmachu biologii, powiedział, że na ten temat w ogóle nie pozwala się odzywać. I cisza. Ale wkrótce profesor dostał roczne stypendium do Stanów Zjednoczonych, to ja zacząłem działać. Zresztą od samego początku, tak jak powiedziałem, chodziło mi o to, żeby jak najszybciej odbudować, żeby Wydział usamodzielnił się i dał możliwości rozwoju, pracy i studentom, i pracownikom. Ja to realizowałem cały czas z wielkim uporem. Jak profesor wyjechał, to napisałem pismo na Uniwersytet, do takiego niby pionu technicznego, który

${ }^{38}$ Stanisław Liszewski - patrz biogramy rozmówców.

${ }^{39}$ Wiesław Puś (ur. 1940) - historyk, profesor Uniwersytetu Łódzkiego, rektor uczelni w latach 2002-2008.

${ }^{40}$ Antoni Różalski (ur. 1952) - mikrobiolog, immunobiolog bakterii, professor na Wydziale Biologii i Ochrony Środowiska. Obecnie prorektords. nauki UŁ. 
był jeszcze w zarodku, o dobudowanie dwudziestu metrów. Po kilku miesiącach w administracji naszej mówią, że kopię pisma wysłano na posiedzenie do Ministerstwa. Jak chcę, to mogę pojechać i swoją sprawę ruszyć. Pojechałem. Tam miałem płomienną mowę. Podobało się i dali sto tysięcy złotych na dokumentację, żebym do wakacji to zrobił. Ja się zgodziłem, nie wiedząc, na co. Jak zaczęło się wszystko, to trzeba było tym samochodem do straży pożarnej, do sanepidu, różne instytucje. W końcu miałem już dokumentację gotową. Trzy dni chyba przed wyjazdem do Warszawy, na Piotrkowską do Urzędu Miasta idę, do głównego architekta Łodzi, to był pan inżynier Gromski, i przedstawiam mu sprawę, a on mówi: „To zrobimy za jakieś trzy miesiące, niech pan zobaczy, co się dzieje". A za jego biurkiem, przy ścianie, leżał stos teczek! Ale tam wśród kierownika i ekspertów w Radzie Narodowej był, jak się okazało, mój kolega z klasy, maturę razem robiliśmy. Oni zaraz zwołali posiedzenie, zatwierdzili i ja prosto z biura część papierów wziąłem, ta cała dokumentacja była jeszcze sklejana, wilgotna, i zgłosiłem się do Warszawy. Tam była konsternacja, że to już gotowe. Dostałem pół miliona - na tamte czasy!

Był to dopiero początek przygód Eugeniusza Czerniawskiego. Wiele nadchodzących tygodni i miesięcy poświęcił on swojemu projektowi:

Potem trzeba było szukać wykonawcy. Znaleźliśmy, zaczęli budować, rozbudowywać salę ćwiczeń. Szedłem, patrzę, co się dzieje: jedni robotnicy na taczce wywozili cement, ukradli. „Co wy tu robicie?”. Zatrzymałem, w końcu i pożar był, to było makabryczne. Zerwałem umowę, to znaczy Uniwersytet na mój wniosek zerwał, znowu spółdzielni poszukali i zostało zrobione. Profesor Zabłocki wraca, a tu budynek się wykańcza. O, to był zadowolony! Ja przy tym zdobyłem bardzo wielkie doświadczenie. Jak budynek został już oddany do użytku, centralne ogrzewanie zostało przeprowadzone, miejscowe, bo kotłownia była, to to już zaczęło normalnie funkcjonować. Aparatura była rozstawiona, był pokój-chłodnia, pokój-cieplarka. Na tamte czasy to był sukces wielki. Ćwiczenia już normalnie się odbywały i zbliżał się okres budowy gmachu biologii. Ja już do tego byłem po tym doświadczeniu przygotowany, wiedziałem, co i jak.

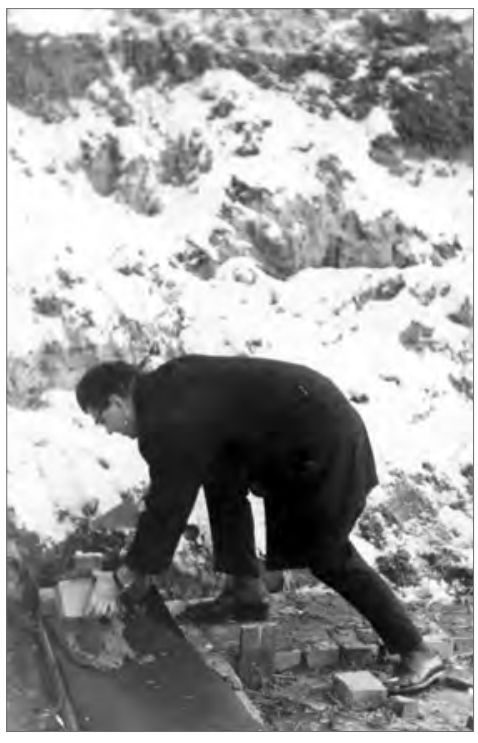

Fot. 69. Pierwsze warstwy muru audytorium gmachu biologii kładzie Eugeniusz Czerniawski (10 grudnia 1966) 
Początkowe zmagania z przybudówką miały być kluczowe dla dalszych losów narratora. Okazał się nieocenionym projektantem i organizatorem i dlatego, choć chciał już zajmować się swoimi badaniami, nalegano, by dopilnował budowy nowego gmachu. Wiadomo już było, jak skomplikowane jest to przedsięwzięcie. Tymczasem przedłużające się budowy (oraz towarzyszące im fuszerki) siedziby Biblioteki Uniwersyteckiej czy Centrum Konferencyjnego nie napawały optymizmem. Eugeniusz Czerniawski zdecydował się zaangażować w ten nowy projekt kosztem własnej kariery naukowej. Rozpoczęly się pertraktacje z Ministerstwem oraz prace nad planami budowy $z$ architektami. Nie były to rozmowy łatwe ani przewidywalne, o czym może świadczyć efekt końcowy: jak relacjonował nasz rozmówca, niespodziewanie projekt kazano skrócić, w efekcie czego budynek jest asymetryczny, bo po jednej stronie obcięto 4 sekcje okien. W czasie budowy trudności także nie brakowało, zwłaszcza ze względu na specyficzne wymogi wynikające z jego naukowych funkcji. Problemy i ich rozwiązywanie zależało od zaangażowania pojedynczych osób (lub niewiedzy i obojętności pozostałych):

Najgorsza rzecz była z wodociągami i z elektrycznością. Pokazywali mi stos różnych przepisów, różnych ksiąg. Mnie to nie obchodzi, bo to wszystko do budowy fabryk. Jak budują fabrykę, potrzeba piętnaście kilowatów, to tam dociągają, stawiają tokarnię, maszynę jakąś, cokolwiek i to pracuje. A u nas aparatura jest energochłonna, suszarka dwa kilowaty, autoklaw dziewięć. Te rzeczy to można przewidzieć, od razu zrobić. Ale aparatura jest przenośna, bo musi być współczynnik jednoczesności 0,2 przyjęte, bo jest mała trawestacja, stąd przychodzi do podstacji niskiego napięcia, już tu w budynku i stamtąd ta energia elektryczna ma być rozprowadzona. To mówię: jest wyjście - w pomieszczeniach, tam gdzie potrzeba, narysowałem, jakie mają być tablice. One się nazywały TS, gdzie były trzy gniazda jednofazowe, jedno trójfazowe, a tablice zasilało się czterema kilowatami. Czasami dwie tablice w pokoju były. Tam współczynnik jednoczesności był wysoki, jeden na jeden. Można było śmiało cały czas cztery kilowaty pobierać, ale stamtąd szła zbiorcza tablica, tam było już 0,8 , później na korytarzu była następna, jeszcze spadało i 0,2 było w podstacji. W ten sposób nasze oczekiwania zostały spełnione. Z Politechniki przyjeżdżali oglądać moje TS-y, bo oni byli w podobnej sytuacji. A instalacja była niestety aluminiowa. Miedź była na szpitale, jednostki wojskowe, milicyjne i takie strategiczne miejsca. $\mathrm{Z}$ całą resztą wówczas był kłopot. Jak to wszystko zrobili, zostawili mi dokumentację wykonawczą - dopiero piątą wersję przyjąłem, wcześniejsze odrzucałem. I przez wiele lat ta instalacja wytrzymała. Wszyscy się dziwili: tyle energii się pobiera, a nic się nie dzieje. Ten gmach był bardzo funkcjonalnie zrobiony, zaplanowany, wykonany. 
Sprawa transportu, przechodzenia $\mathrm{z}$ jednego pomieszczenia do drugiego, bo po remoncie na przykład mikroskop elektronowy cytolodzy chcieli wynieść i nie mogli, bo drzwi się okazały za wąskie, a u mnie to wszystko funkcjonowało. Także tutaj te rzeczy były dopilnowane. Wykonawstwo było bardzo liche, okna podszyte wiatrem, $\mathrm{z}$ tego powodu zimno było. I był duży kłopot z kanalizacją. Były zaznaczone piony, gdzie miała być kanalizacja kamionkowa. Chodziło o kwasy do mycia szkła laboratoryjnego. To w jednym pionie miało być, ale kamionki nie można było dostać i wykonawca zadecydował, że mają być winidurowe rury tam wstawione. Ja na to się nie godziłem zupełnie. I później trzeba było rozpruwać ściany, chociażby dlatego, że zalaliśmy antropologię, oni mieli na parterze bibliotekę, a myśmy ich z drugiego piętra zalali. Szukamy, jak to się stało. Tam szaleli, sprawę do prokuratury chcieli oddać.

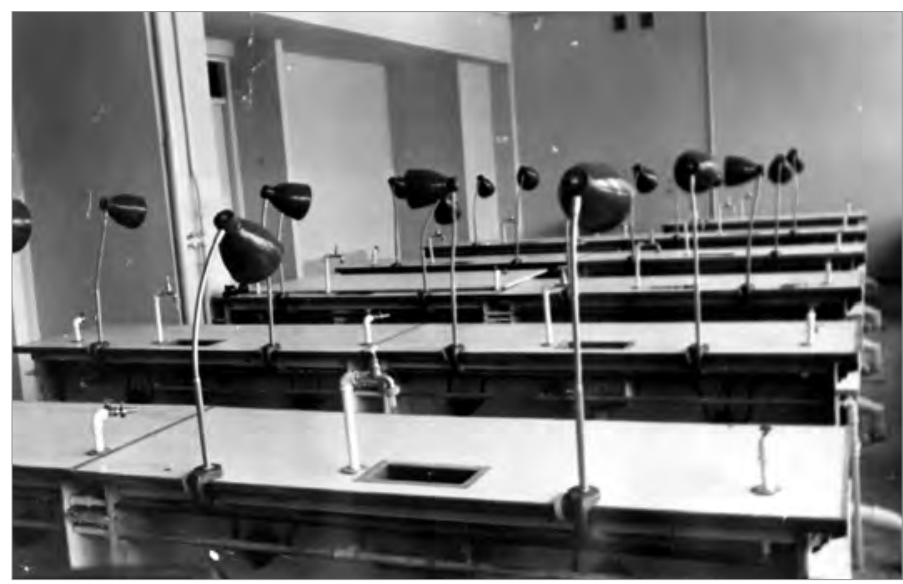

Fot. 70a. Sala ćwiczeń w budynku biologii (lata siedemdziesiąte)

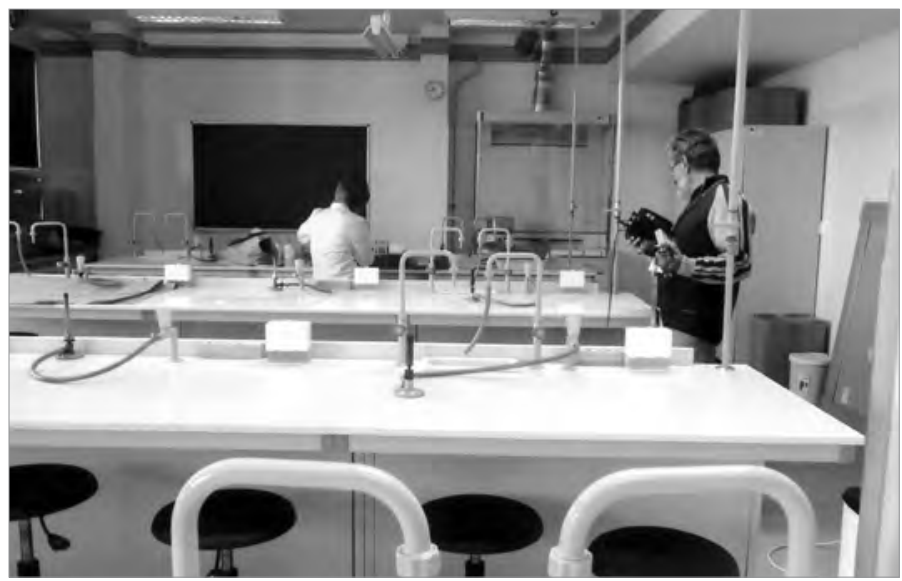

Fot. 70b. Sala ćwiczeń w budynku biologi (2015) 
Mówię: „Rozkujcie ściany koło nas, bo wyżej są całe”. I okazało się, że te rury winidurowe od ciepłej wody od tego ciepła i ogrzewania, bo to zamknięte było wszystko, się skręciły, winidur wywinięty w takie kawały. Ale budynek został oddany w terminie. Nie w pełni wykończony, bo nie było pieniędzy.

Problemy pojawiały się z różnych stron:

Jeszcze właściwie miała być sala wykładowa, później architekt wymyślił, że tam będzie taka kawiarnia, na to wszystko profesor Zabłocki ${ }^{41}$ podpisał zgodę. Ja musiałem dwa tygodnie leżeć w szpitalu, bo z nerkami miałem kłopot, przychodzę, profesor i zarząd inwestycji zadowoleni pokazują mi, że to tak ładnie. Mówię: „A coście zrobili, a gdzie sala wykładowa, jakieś audytorium?!”. „Nie ma”. To profesor powiedział: „Ale mnie wprowadzili w błąd”. I napisał: „Zostałem wprowadzony w błąd i proszę wycofać". Wtenczas Uniwersytet musiał płacić za podium do tej sali ćwiczeń i za wyposażenie tej sali. A zarząd inwestycji chętnie się zgodził, bo nie było pieniędzy. I tak po kolei zostało dobrze zrobione. Teraz ta sala pięknie wygląda.

Efekty tych starań nie zawsze były idealne, jednak należy docenić poświęcenie i oddanie sprawie, kiedy np. nie było...

...ciepło. Żaluzje były, ale wykonawstwo i same żaluzje były do niczego. Jak był mróz, to w zakładzie było piętnaście stopni. W całym budynku też tyle. Kolega mówi: „Ja do pracy nie będę przychodził”. Mówię: „No dobrze. To jak ja spuszczę rękawy, bo zawsze miałem podwinięte, to wtenczas możesz nie iść". Później marzłem, ale tak chodziłem.

Podobnie wiele czasu budowie (w fizycznym sensie) poświecił profesor ekonomii Władysław Welfe, który opowiada o rozbudowie byłego budynku Wolnej Wszechnicy Polskiej, który miał się stać siedzibą nowo powstającego w latach sześćdziesiątych Wydziału Ekonomiczno-Socjologicznego:

Przyznaję, uważano, że jestem dobrym administratorem. Jako zastępca profesora, magister, byłem dziekanem, najpierw Wydziału Handlu [na WSE], a potem Wydziału Handlowo-Towaroznawczego. WSE została połknięta, bo miała miejsce fuzja $\mathrm{z}$ Uniwersytetem i powstał

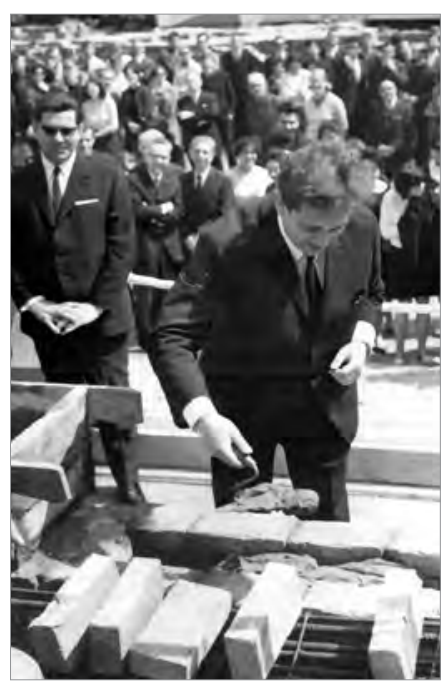

Fot. 71. Wtadystaw Welfe wmurowuje cegłe pod gmach Pawilonu Technik Obliczeniowych Wydziatu Ekonomiczno-Socjologicznego

${ }^{41}$ Zob. przypis $33 \mathrm{w}$ tym rozdziale. 
najpierw Wydział Ekonomiczny, a po roku Wydział Ekonomiczno-Socjologiczny, wtedy kiedy zdecydowano o mariażu ekonomistów z socjologami. W moim przekonaniu to było jedno z genialnych posunięć organizacyjnych, ponieważ taki twór jest unikalny w Polsce i, jak myślę, korzystny dla obu stron. Za wydział zacząłem odpowiadać w roku 1964, kiedy profesor Mujżel ${ }^{42}$ przeniósł się do Warszawy, a ja zostałem dziekanem. To był bardzo interesujący okres, dlatego że w tym czasie rozpoczęła się budowa, zaczęta jeszcze przez profesora Mujżela, tej części gmachu, która jest od strony Rewolucji. Także trzeba było mieć mnóstwo znajomości w strefach gospodarczych, żeby ułatwić proces budowy. Na szczęście wszystko zakończyło się pomyślnie. Potem jeszcze za mojej kadencji rozpoczęto budowę tego pawilonu ${ }^{43}$, który widać z mojego okna. Muszę powiedzieć, że z dumą patrzę na te budynki, bo koniec końców włożyłem sporo czasu w to, żeby to powstało.

Mimo upływu kolejnych lat i znaczącej poprawy warunków, trudności lokalowe odczuwalne były też w następnych dekadach. Tak o perypetiach pracowników reaktywowanego w latach dziewięćdziesiątych kierunku historia sztuki opowiada Wanda Nowakowska:

Kiedy rektor Michał Seweryński ${ }^{44}$ reaktywował kierunek historii sztuki w 1992 roku nie mieliśmy lokalu, a tylko dwunastometrowy pokoik w Bibliotece Uniwersyteckiej zapełniony regałami z naszym obfitym księgozbiorem, więc trzeba było szukać zastępczych sal. Tułaliśmy się zatem, wypożyczając sale wykładowe od zaprzyjaźnionych kierowników Instytutów: profesor Teresy Cieślikowskiej ${ }^{45} \mathrm{z}$ Instytutu Teorii Literatury, Teatru i Filmu, profesora Ryszarda Panasiuka ${ }^{46} \mathrm{z}$ Instytutu Filozofii i profesora Leszka Kajzera ${ }^{47}$ z Instytutu Archeologii, korzystaliśmy też z sal Działu Ikonografii Biblioteki UŁ. Ten trudny, pierwszy dwuletni okres zakończył się gdy rektor Seweryński przydzielił nam całe piętro w zabytkowej kamienicy przy Kościuszki 17. Gmach ten dzieliliśmy z Zakładem Filologii Słowiańskiej, który zajmował parter i Katedrą Bibliotekoznawstwa mieszczącą się na II i III piętrze. My królowaliśmy na I piętrze, zabytkowym, z pięknym kominkiem i boazeriami, z kuchnią $\mathrm{z}$ wielki piecem i łazienką z równie wielką i zabytkową wanną opartą na

\footnotetext{
42 Jan Mujżel (1923-2006) - ekonomista, profesor Uniwersytetu Łódzkiego, zajmował się teorią ekonomii, w tym przede wszystkim teorią funkcjonowania gospodarki i przedsiębiorstw. Uczestnik obrad Okrągłego Stołu.

${ }^{43}$ Mowa tu o Pawilonie Technik Obliczeniowych, który znajduje się w kompleksie budynków Uniwersytetu Łódzkiego przy ulicy Rewolucji 1905 r. Obecnie oznaczony jest literą „T”.

${ }^{44}$ Michał Seweryński - patrz biogramy rozmówców.

${ }^{45}$ Teresa Cieślikowska - patrz biogramy rozmówców.

${ }^{46}$ Ryszard Panasiuk - patrz biogramy rozmówców.

${ }^{47}$ Leszek Kajzer (ur. 1944) - archeolog, profesor na UŁ, specjalista w dziedzinie budownictwa i architektury obronnej.
} 
nogach w kształcie lwich łap! Mieścił się tam wcześniej szpital uniwersytecki i trzeba było wszystko na nowo zaaranżować, przystosować do nowych potrzeb. Prowadzono tam zarazem prace konserwatorskie wykonywanie przez naszych studentów z historii sztuki w ramach naszych zajęć z konserwatorstwa prowadzonych przez profesor Ewę Marxen-Wolską ${ }^{48}$. No i wszyscy pracownicy starali się włożyć w to jakąś swoją „,cegiełkę”, chociaż najwięcej energii, zwłaszcza w wyposażenie wnętrz poświęcał nasz pracownik ówczesny techniczno-administracyjny mgr Krzysztof Rutkowski - później magister i doktor, historyk sztuki. Pamiętam, że jeździłam z nim w szoferce jakiejś wielkiej uniwersyteckiej ciężarówki wybierać materiał do obić ściennych w jakiś magazynach położonych daleko poza Łodzią (śmiech). W 1996 roku, w tych naszych „wypieszczonych” wnętrzach odbyła się pierwsza w nowej siedzibie inauguracja tego naszego reaktywowanego kierunku, już w pełnej gali z zaproszonymi rektorami, dziekanami, gośćmi z zewnątrz - z listem odczytanym w imieniu biskupa przez prałata Fijałkowskiego. Wszystko to udokumentowały zdjęcia robione przez mgr Janusza Frenkla, naszego wykładowcę sztuki fotograficznej - gdyż taki przedmiot wprowadziliśmy. On jest teraz dyrektorem administracyjnym w Instytucie Historii.

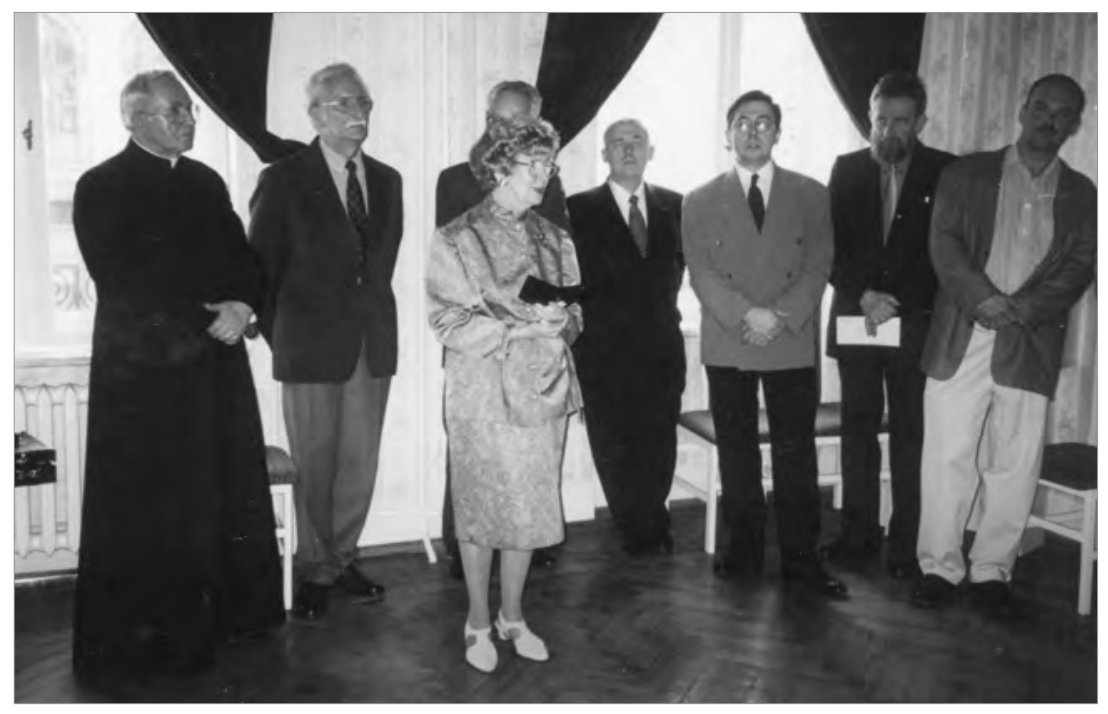

Fot. 72 Uroczysta inauguracja dziatalności i poświęcenie Katedry Historii Sztuki w nowej siedzibie, czerwiec 1996. Od lewej stoja: Ks. Prałat Józef Fijałkowski, prof. Jerzy Wolski, prof. Wanda Nowakowska, prof. Krzysztof Jażdżewski (zastonięty), rektor Stanistaw Liszewski, prorektor Marek Zirk-Sadowski, prodziekan Adam Nowaczyk, dr Jan Salm

${ }^{48}$ Ewa Marxen-Wolska (1924- 2013) - historyk sztuki, współtwórca i wykładowca Katedry Historii Sztuki na Uniwersytecie Łódzkim, światowej klasy konserwator zabytków. 
Już tylko z tych kilku zebranych opowieści widać ogromną skalę pracy i zaangażowania, które zostały włożone w rozwój Uniwersytetu Łódzkiego. Warto zdać sobie sprawę, że to one były głównymi spoiwami uniwersytetu jako instytucji.

\section{Warsztat pracy}

W zależności od dyscypliny profesorowie i ich studenci, co oczywiste, potrzebują innego zaplecza, inny jest warsztat pracy matematyka szukającego sprzeczności w danym twierdzeniu, archeologa porządkującego materiał z badań, filozofa opracowującego syntezę rozumienia któregoś z pojęć czy wreszcie chemika prowadzącego zespołowe badania laboratoryjne. Dla wszystkich tych naukowców początki Uniwersytetu nie były łatwe, bowiem brakowało nie tylko pomieszczeń, ale i sprzętu. Wspomina Eugeniusz Czerniawski:

Mam tutaj wyciąg, spis inwentarza Zakładu Bakteriologii UŁ, dnia 22 kwietnia 1950 roku. Ja jeszcze wówczas nie pracowałem. Pozycji jest trzydzieści trzy. Ale co to był za inwentarz... Dla przykładu: stół biały, szafa dwudrzwiowa, szafa biblioteczna, biurko, etażerka, stolik, kosz na śmieci - to było w inwentarzu. I później była suszarka do tego, dwie lampy były, była jakaś niby to cieplarka, była lodówka sprzed wojny jeszcze, zostawione, bo może się da zreperować, ale nigdy nie zreperowali. I nic więcej. Także od samego początku musiałem tutaj razem z kolegami wszystko zbierać, kupować i już.

Aby móc prowadzić ćwiczenia dla studentów, biologowie podejmowali się niełatwych zadań. W pierwszym okresie powstawania uczelni, o czym także opowiada Eugeniusz Czerniawski, braki odczuwały najbardziej właśnie nauki przyrodnicze:

Nic nie było. Dostaliśmy autoklaw [zamknięty hermetycznie i podgrzewany pojemnik służący przeprowadzaniu reakcji chemicznych]. Pierwszy autoklaw był z demobilu, na ognisku można było rozpalić i sterylizować. Ale bez tego nie było żadnej możliwości pracy. Nie było naprawdę żadnych odczynników. Jak myśmy mieli ćwiczenia z salmonelli i trzeba było podłoże zrobić, SF się nazywało, to myśmy to dorabiali sami i wyniki wychodziły. Potrzebne było mięso końskie do sporządzenia bulionu. A bulion to podstawowa pożywka dla bakterii. Była taka maszynka ręczna do mięsa, to się kręciło te dziesięć kilogramów czy więcej, robiono odpowiednio ten bulion, a później był już sterylizowany w autoklawie. Czasami tego mięsa nie można było dostać. Czasami udało się dostać przydział już gotowy, bulion tam dali, w płynie, w kolbach. $\mathrm{Na}$ sali ćwiczeń była praca, jednocześnie prace magisterskie studenci robili - jeden był lekarzem weterynarii, sprzed wojny, ale chciał mikrobiologiem 
zostać, dwóch było z Zakładu Mięsnego po WSGW. I tak powoli, powoli jakoś do tego weszliśmy.

Aparatura naukowa stanowiła towar deficytowy, nic dziwnego więc, że ów sprzęt zdobywany był nawet podstępem. Na początku lat pięćdziesiątych toczyły się nierzadko zaciekłe walki i boje, jak w przypadku wagi, w której posiadanie chcieli wejść zarówno fizycy, jak i biologowie, reprezentowani przez Eugeniusza Czerniawskiego:

Profesor Bernard Zabłocki był wtenczas prodziekanem na Wydziale Matematyczno-Przyrodniczym i powiedział: „Ach, przywieźli nam jakąś tam czeską wagę", ale fizycy zobaczyli, powiedzieli: „E, taka waga to panu będzie niepotrzebna" i profesor im oddał. Jak profesor to powiedział, to myśmy wzięli kij od szczotki, poszliśmy do dziekanatu, to pudło przywiązaliśmy na kiju i jak Chińczycy przenieśliśmy do tego budynku. Pokój profesora był nieduży. Myśmy tę wagę ustawili, a profesor mówi: „Przecież ja tę wagę oddałem”. „Panie profesorze, ale oni pana profesora tutaj w błąd wprowadzili, takiej wagi my teraz nigdzie nie dostaniemy”. „Ach to, to dobrze zrobiliście”. I waga nam służyła przez wiele lat. Na początku, bo później przyszły już nowoczesne.

Nie wszystkie dyscypliny wymagają jednak tak wyrafinowanej aparatury. Ryszard Jajte opowiada z kolei o warsztacie pracy matematyka i specyfice postępowania badawczego w tej nauce, gdzie wymagania co do oprzyrządowana mają inny charakter:

Nie ma prostszej rzeczy pod słońcem: matematyk bierze kartkę, ołówek, ślini ołówek często, jeśli jest do tego przyzwyczajony i coś próbuje gryzmolić. I albo to wyrzuca, albo uważa, że to jest coś warte.

Czasem wystarczał więc ołówek i kartka papieru, czasem zaś nawet najprostsze czynności, takie jak robienie notatek na zajęciach, mogły wymagać ,profesjonalnego" sprzętu, jak to miało miejsce w przypadku filmoznawstwa. Mówi o tym Ewelina Nurczyńska-Fidelska:

Kiedyś myśmy namiętnie wszyscy z zagranicy przywozili te długopisy z takimi latareczkami, bo w czasie projekcji filmowej można było robić notatki. To już było chyba w latach siedemdziesiątych, myśmy namiętnie po ciemku na kolanach robili tzw. fiszki. Ja już jako wykładowca, a także nasi studenci. W ogóle w latach sześćdziesiątych pisało się na kolanach, spisywało scena po scenie jakieś rzeczy, żeby zapamiętać strukturę fabuły, czyli później kompozycję. Myśmy to nazywali fiszkami. Robiło się te fiszki namiętnie, bo bez tego ani rusz. Fiszka to była kartka jak w katalogach: autor, reżyser, wykonawca, długość, kolor, to, tamto, owo. A co bogatsi, chyba w latach siedemdziesiątych 
dopiero, budzili zazdrość wśród innych, bo mieli te świecące w ciemności długopisy.

Z kolei prawnik, Michał Seweryński opisuje swoją codzienną pracę i szczególny sposób uprawiania nauki, jaką jest prawo:

Codzienna praca to przede wszystkim udział w seminarium doktorskim, potem jak się człowiek trochę usamodzielnił, to były ćwiczenia ze studentami, wykłady, seminaria, czyli normalne zajęcia dydaktyczne. Praca naukowa na szczęście mogła być organizowana w domu. Wystarczy książka i ołówek. W mojej dziedzinie to wystarczy. U pani to nie wiem, może pani jeszcze wyjść w teren i robić badania praktyczne, eksperymentalne. U nas rzadko się to robiło, bo prawo to jest dziedzina dogmatyczna i spekulacyjna, pełna rozważań filozoficznych. Czasu było dużo i była samodyscyplina. Nie było czegoś takiego jak zwolnienie lekarskie z powodu choroby. Zajęcia musiały być prowadzone. Kto inny je brał. Poza tym zajęć obowiązkowych nie było bardzo wiele. Zostawało dużo czasu na pracę naukową, nawet na podróże. Jak było trzeba, to się dostawało urlop naukowy, żeby gdzieś pojechać z wykładami.

Przedstawiciele różnych dyscyplin musieli stawić czoła odmiennym niedogodnościom i problemom, związanym z brakiem odpowiedniego sprzętu, przestarzałą aparaturą, ograniczoną przestrzenią, oporem materii itp., co niezmiennie ograniczało komfort ich prac. Przygotowywanie samemu pożywek do hodowli bakterii czy konstruowanie odpowiednich narzędzi, aby móc prowadzić zajęcia ze studentami to tylko niektóre $\mathrm{z}$ wielu przykładów zaradności i pomysłowości pracowników Uniwersytetu Łódzkiego. Niedobory w zaopatrzeniu, brak procedur czy strategii radzenia sobie z nowymi problemami spowodowane były po części trudną sytuacją powojenną, specyfiką systemu ekonomiczno-politycznego, a po części peryferyjnością polskiej nauki, w pewnej mierze wynikającą z jej niedofinansowania przed wojną, ale też z powojennej izolacji. Wszystkie te czynniki, ściśle ze sobą powiązane, wymuszały na pracownikach nauki ciągłe innowacje, kreatywność wzmacnianą peryferyjnością, którą roboczo można nazwać pomysłowościa niedoboru. Ważnym czynnikiem w powstawaniu tego typu praktyk było także przekonanie o konieczności radzenia sobie samemu, zaradności nabytej i wyniesionej jeszcze $\mathrm{z}$ trudnego czasu wojny oraz ciągnącymi się od zaborów tendencji do obchodzenia oficjalnych kanałów i załatwiania spraw ,po swojemu”. Jan Ziomek wspomina:

Zbudowałem sobie takie własne laboratorium, na przykład szlifiernię, na której wykonywałem szlify do światła odbitego, światła przechodzącego do mikroskopii w świetle spolaryzowanym. Zbudowałem sobie także taką aparaturę, 
głównie ze szkła, która posłużyła mi do szukania mineralizacji - niewielkich ilości tych mineralizacji, ale ważnych ze względu na ich genezę. Ćwiczenia odbywały się w laboratorium, chemicznie pokazywaliśmy mikroreakcje w rurce zamkniętej, w rurce otwartej, barwienie różnych minerałów. Później tworzyliśmy różne kolumny zbudowane właśnie ze szkła. Na Uniwersytecie byli tacy dobrzy szklarze, którzy wykonywali urządzenia laboratoryjne. Robiliśmy takie kolumny, w których rozdzielaliśmy minerały ilaste na poszczególne drobne frakcje. Budowaliśmy wieżę ciśnień, ale był problem z ciśnieniem wody - nieraz to ciśnienie spadało ze względu na wodociągi, które raz tłoczyły szybciej wodę, raz wolniej, ale nieraz się za kołnierz wylewała woda. Dzięki tej wieży ciśnień oddzielaliśmy różne frakcje i identyfikowaliśmy właśnie minerały ilaste, a nieraz znajdowaliśmy również minerały kruszcowe. Chcę jeszcze na jedną rzecz zwrócić uwagę, że przy szlifowaniu grubość szlifu miała dwie setne milimetra - to była ręczna robota. Więc dziennie takich szlifów, już przy dobrej wprawie, mogłem wykonać około ośmiu sztuk. One były niezbędne do kontynuowania badań mineralogiczno-petrograficznych, bo później pracę pisałem właśnie z zakresu petrografii. Robiłem też szlify dla fizyków, dla chemików, a nawet dla stomatologów - chodziło tutaj o szlify zębów dzieci, którym mleczne zęby wypadały. Przynosili mi w słoikach takie zęby i trzeba było je zeszlifować, zrobić preparaty, by ci stomatolodzy mogli bardzo szczegółowo prowadzić badania mikroskopowe na tych preparatach. Myśmy wszystko robili sami.

Uprawianie nauki wymagało pomysłowości, samodzielności, radzenia sobie w róznych sytuacjach - tego typu cechy stoją w opozycji do stereotypu „naukowca-pięknoducha”, oderwanego od materialnych spraw i niezaradnego życiowo. Nasi rozmówcy, choć pracują w świecie idei i abstrakcyjnego języka, musieli niejednokrotnie wykazywać także innymi przymiotami, jak właśnie pomysłowością niedoboru, nawigując w nieprzyjaznych warunkach.

Czasem materialność pracy miała wręcz dotkliwie fizyczny wymiar. Cytowany powyżej Jan Ziomek opowiada o pełnym poświęcenia gromadzeniu materiałów dydaktycznych dla studentów geografii:

Profesor powiedział, żebym pojechał po skamieniałości do Łukowa Lubelskiego. Tam były cegielnie i w tych cegielniach były pięknie wykształcone głowonogi, głównie amonity, pięknie inkrustowane pirytem. Piryt wietrzejąc dawał całą gamę różnych barw. I tam, w tych cegielniach Łukowa Lubelskiego pracowałem kilka dni, by zebrać dużą liczbę okazów. Od cegielni do stacji kolejowej było około dwóch i pół kilometra i w plecakach, w skrzynkach nosiłem to na stację kolejową. Byłem sam i po zebraniu tych okazów zapakowałem je do pociągu i przyjechałem z nimi do Warszawy Śródmieście. Dworzec był taki 
jeszcze drewniany, podłogi były drewniane. Stamtąd wyładowałem te paczki i przenosiłem je na perony, do pociągu, który szedł do Łodzi. Pomagali mi w tym nawet pasażerowie, ludzie, którzy jechali, bo widzieli, że tyle mam różnych rzeczy i nie będę w stanie sam tego przenieść! To wielka sprawa: ludzie serdeczni, przyjemni, pomagali. Tak przyjechałem na dworzec Łódź Fabryczna, tam właśnie zameldowałem się do pana w czarnym mundurze i czerwonej czapeczce - to był zawiadowca stacji - prosząc go, żeby te paczki wszystkie i to co miałem przechował mi w swoich pokojach. Początkowo to nie za bardzo chciał to zrobić, ale później powiedział, żebym poprzynosił te wszystkie skrzyneczki, paczki, a na drugi dzień poprosiłem studentów, którzy te paczki pieszo z Dworca Fabrycznego nosili na ulicę Kościuszki 21. Zakład Geologii nr 2 był na czwartym piętrze. To była moja pierwsza taka wędrówka po świecie skamieniałości i to był zaczątek Muzeum Geologicznego. To było kilkanaście szaf, w których gromadziliśmy eksponaty.

Kolekcja muzeum rozrastała się dalej, sprawiając coraz większą satysfakcję nie tylko doktorowi Ziomkowi:

Z profesorem Wojciechowskim ${ }^{49}$ zbieraliśmy minerały Dolnego Śląska, wyjeżdżaliśmy zawsze na dwa tygodnie co roku do kamieniołomów na Dolny Śląsk, tam żeśmy gromadzili minerały. I w wyniku tego gromadzenia minerałów zapełniliśmy praktycznie wszystkie piwnice na Kościuszki 21 ogromną ilością zbiorów, które później częściowo uległy zniszczeniu, bo po prostu niefrasobliwi ludzie je wyrzucali, ale to już niech ich grzech będzie, że oni się tak zachowali w stosunku do dokumentów, które byłyby teraz trudne do odzyskania. Z profesorem Wojciechowskim na Kościuszki 21 zrobiliśmy takie muzeum geologiczne w piwnicy, obok kotłowni. To był jeden taki pokój, w którym żeśmy uczty mineralogiczne robili z profesorem: ucztowaliśmy, rozmawialiśmy. Do naszego muzeum przychodziła garstka ludzi, głównie zainteresowanych, to byli chemicy.

Zupełnie inaczej wyglądał materialny aspekt pracy na filmoznawstwie. W swojej opowieści inny przykład pomysłowości niedoboru przedstawia Ewelina Nurczyńska-Fidelska.

Kiedyś nie było video i nie było DVD, była sala i mieliśmy w niej aparat „16 mm”, na którym jeśli były filmy, to się je puszczało z tejże „szesnastki” i to potwornie warczało i huczało. Hałas był straszny w tej salce naszej jedynej dydaktycznej, przylegającej do pokoi zakładowych. Pan Eugeniusz ${ }^{50}$ wpadł na genialny pomysł: zdobył gdzieś szafę lekarską, taką do leków, medyczną,

${ }^{49}$ Jan Wojciechowski - geograf i geolog, profesor UŁ, pracował w Katedrze Mineralogii i Krystalografii, następnie w Katedrze Geologii prowadził pracownię mineralogiczno-petrologiczną.

${ }^{50}$ Eugeniusz Łabiniec (1920-2011) - wieloletni pracownik Instytutu Teorii Literatury, Teatru i Filmu Uniwersytetu Łódzkiego. Kinooperator Łódzkiego Ośrodka Polskiego Radia i Telewizji, 
białą, oszkloną, zamykaną i wstawił tam przy pomocy jakiś różnych przeróbek tenże aparat, więc jak się go włączyło, można było zamknąć szafę i tak nie warczało. Szafa z tym aparatem to przyjechała i funkcjonowała jeszcze na ulicy Sienkiewicza. Dopiero jak myśmy się przeprowadzali do Pałacu Biedermanna, to zapadła dramatyczna decyzja, że już koniec z tą szafą. Ale ta „szesnastka" funkcjonowała bardzo długo, od 1956 do 2004 roku.

Warsztat pracy filmoznawców, jak pokazuje Ewelina Nurczyńska-Fidelska, okazywał się jeszcze bardziej skomplikowany, kiedy przychodziło do analizy poszczególnych scen:

W podziemiach biblioteki mieliśmy jeszcze jedną salę, gdzie został postawiony stół montażowy i przy tym stole odbywały się analizy filmów, bo tam można było film zatrzymać i cofnaćc. Wchodziło tam kilka osób, kilku studentów czy kilkunastu, jeden nad drugim i w ten mały monitorek się patrzyło i analizowało, nie cały film, ale jakieś fragmenty, sekwencje. Takie to było filmoznawstwo: dysponowaliśmy zdezelowanym stołem montażowym, przy którym nie wszyscy umieli pracować, tą właśnie „szesnastką”, szafą lekarską, a do kina się chodziło na zewnątrz, więc myśmy korzystali najwięcej, zamawialiśmy kursy filmowe, projekcje filmowe odbywały się w Łódzkim Domu Kultury albo w kinie „Tatry”. To była taka niepisana umowa zawsze przez wszystkie kadencje z rektorami Szkoły Filmowej, że nasi studenci, ci bardziej chętni, mogli pójść do szkoły i coś tam sobie pooglądać.

Dzięki pomysłowości niedoboru (jak w przypadku konstruowania wyciszającej szafy na projektor) praktyki pracowników dostosowywały się do zmiennych warunków. Kiedy pojawiły się kasety video, które wydawały się nowoczesnym i trwałym nośnikiem, zbudowano kolekcję filmów, która już po kilkunastu latach stała się przeżytkiem:

Rewolucja dydaktyczna nastała w momencie gdy dostaliśmy pierwsze video i zaczęliśmy kolekcjonować taśmy video, które teraz nam niszczeją - nie wiadomo, co z tym robić! Potem udało nam się jeszcze na Sienkiewicza trzy czy cztery telewizory kupić, podłączało się video i projekcje szły na tych telewizorach. Już później, jak przenieśliśmy się do Biedermanna, to była epoka płytek i projektorów, to znaczy obrazu rzucanego przez projektor. Dzisiaj ci studenci w ogóle sobie nie mogą wyobrazić, jak się to filmoznawstwo studiowało kiedyś. Na pewno te wszystkie techniczne możliwości sprawiły, że tak dużo refleksji medioznawczej powstało, to umożliwiło zupełnie inne techniki oglądu, analiz filmowych itd.

członek NSZZ „Solidarność” UŁ oraz Związku Pracowników Sztuki i Kultury, odznaczony Srebrnym Krzyżem Zasługi. 
Przez lata zasoby te były może skromne, ale funkcjonowały. Cała instytucja uniwersytetu opierała się na wysiłku poszczególnych osób, ich poświęceniu i zaradności. Jeśli przy budowie jednego budynku i konstrukcji podstawowego narzędzia dydaktycznego potrzebne było tyle dodatkowej pracy i uwagi, trudno sobie wyobrazić, jak wiele trzeba ich było dla funkcjonowania całej instytucji - a przecież równie często tej pracy i uwagi brakowało.

\section{Książki i biblioteka}

Przez pierwsze powojenne lata studenci i pracownicy Uniwersytetu Łódzkiego musieli korzystać głównie z Biblioteki Miejskiej i własnych domowych księgozbiorów oraz powoli zakładanych bibliotek instytutowych. A przecież tam gdzie jest uniwersytet, musi być też biblioteka - o czym mówi m.in. Krystyna Śreniowska, od której wspomnień zaczniemy:

Żeby uczelnia mogła funkcjonować, musi mieć bibliotekę, a tu nie było. To znaczy była biblioteka, ale o takim profilu popularnym. To nie była biblioteka naukowa. Więc bardzo energicznie do zakupu książek zabrał się właśnie Chałasiński ${ }^{51}$, który jeździł często do Warszawy, a tam na takich wózkach, na ulicy sprzedawano książki, które zabrano z rozbitych mieszkań w Warszawie. I tam się kupowało książki naukowe i powstawała Biblioteka Uniwersytetu Łódzkiego.

Jeden z najwcześniej funkcjonujących i największych księgozbiorów został zgromadzony - jak zaraz zobaczymy dzięki ogromnemu wysiłkowi profesorów i pracowników Uniwersytetu Łódzkiego - w bibliotece socjologicznej. Zbigniew Bokszański z entuzjazmem opowiada o jej początkach i dalszych losach:

Biblioteka Uniwersytecka, która mieściła się na dzisiejszym Wydziale Prawa w budynku na Składowej, była niesłychanie blisko i to było rzeczywiście dla mnie fascynujące, ile rzeczy było dostępnych, mimo iż zasoby były skromniutkie, nie ma co czarować. Natomiast zasoby biblioteki instytutowej... Książki były we wszystkich pokojach, także pokojach wykładowych. Nikt tych książek nie pilnował szczególnie, co też charakteryzuje pewną atmosferę i zaufanie. Książki po prostu się brało z półki, szło się do pani, która w sekretariacie pracowała i zostawiało się rewers, albo zostawiało się rewers na półce nawet, między sąsiednimi książkami. Przy czym książki były zupełnie fascynujące, dlatego że jakimś cudem udało się ocalić częściowo - przez szczęśliwy zbieg okoliczności, w związku z tym, że Łódź była niezbombardowana, niezniszczona - księgozbiór Wolnej Wszechnicy Polskiej, taki

\footnotetext{
${ }^{51}$ Zob. przypis $8 \mathrm{w}$ tym rozdziale.
} 
ekonomiczno-politologiczno-socjologiczny. I w dodatku w latach czterdziestych profesorowie Chałasiński ${ }^{52}$ i Szczepański ${ }^{53}$ z pomocą młodszych pracowników, których nazwisk już nie pamiętam, odbywali podróże do Warszawy, do Wrocławia zwłaszcza i książki z rozbitych bibliotek, ze zrujnowanych domów, instytucji naukowych przywozili. Ponieważ Uniwersytet dysponował już możliwością transportu, a poza tym można było jakieś ciężarówki wynająć, wobec tego obaj profesorowie jeździli. Pamiętam, jak profesor Szczepański opowiadał, że na własnych barkach i na własnym karku przenosił jakieś nieprawdopodobne kwintale tych książek. Strasznie dużo tego było. Książki były fantastyczne i oczywiście tylko drobniutką część z nich mogłem przejrzeć czy przeczytać, ale świadomość, że siedzi się pod książkami jakiegoś Sorokina $^{54}$, przy czym w grę wchodziły lata trzydzieste, późne lata dwudzieste, była niesamowita. Myśmy na seminariach wykorzystywali książki z późnych lat dwudziestych, co może się wydawać trochę dziwne, ale ja sam z takiego podręcznika socjologii Armanda Cuvilliera ${ }^{55}$ się uczyłem, który to podręcznik był wydany chyba w 1927/28 roku. Niekiedy te książki nosiły ślady wojny. Pamiętam taką książkę socjologa amerykańskiego, chyba Johna Dollarda ${ }^{56}$ Criteria for the Life History. To była książka poświęcona autobiografistyce i profesorowie ją ściągnęli ze zrozumiałych względów. Wyciągnęli ją ze stosu takich rozstrzelanych książek. Miała w środku odłamek bomby i zupełnie poszarpany grzbiet. Wyglądała jak takie poszarpane ciało człowieka. Proszę wyobrazić sobie, że już w trakcie moich studiów, to były lata sześćdziesiąte, rok 1962 albo 1963, autor tej książki przyjechał do nas, wizytował. I przypadkowo dostrzegł tę rozstrzelaną książkę. Zrobił zdjęcia. Ukazał się reportaż i w Ameryce, i w Polsce. Było takie pismo „Polska” i tam tekst pod tytułem Rozstrzelane ksiązki, w którym była cała historia tej biblioteki. Jest dokładne zdjęcie tych książek. Była cała seria takich rozstrzelanych książek. Tam były różne Parsonsy ${ }^{57}$, Sorokiny ${ }^{58}$ i tak dalej, które były niedostępne wtedy chyba gdzie indziej w Polsce nawet.

${ }^{52}$ Zob. przypis $8 \mathrm{w}$ tym rozdziale.

${ }^{53}$ Jan Szczepański (1913-2004) - wybitny polski socjolog, urodzony w Ustroniu, przez wiele lat związany z Uniwersytetem Łódzkim (1945-1970), którego był profesorem a później także rektorem, członek PAN.

${ }^{54}$ Pitrim Sorokin (1889-1968) - rosyjski socjolog i opozycjonista.

${ }^{55}$ Armand Cuvillier (1887-1973) - francuski filozof i dziennikarz.

${ }^{56}$ John Dollard (1900-1980) - amerykański psycholog i socjolog zajmujący się podziałami rasowymi w USA.

${ }^{57}$ Talcott Parsons (1902-1979) - amerykański socjolog, twórca funkcjonalno-strukturalistycznej teorii systemów społecznych.

${ }^{58}$ Pitirim Sorokin (1889-1968) - rosyjski socjolog zajmujący się dynamiką społeczną, stratyfikacją i ruchliwością społeczną, problematyką miasta i wsi. Na początku lat dwudziestych XX wieku wyemigrował do Stanów Zjednoczonych, gdzie przez większość czasu pracował na Harvardzie. 
Biblioteka Instytutu Socjologii stanowiła wyjątek od reguły powojennych braków i nieprzygotowania Łodzi do pełnienia funkcji miasta akademickiego - pozostałe dyscypliny musiały gromadzić swoje zbiory od podstaw. W pierwszych miesiącach odbudowy takim źródłem nie tylko dla socjologów były Ziemie Odzyskane i porzucone zbiory z tamtejszych bibliotek. Stefan Banasiak opowiada, w jaki sposób historycy gromadzili księgozbiór, ale nie tylko:

Profesor Chałasiński ${ }^{59}$, ale od nas $\mathrm{z}$ historii też, organizował wyjazdy asystentów, do których wciągano też niektórych studentów, na Ziemie Odzyskane, żeby szabrować biblioteki. I my w Instytucie mamy trochę książek niemieckich z szabru poniemieckiego, z terenów odzyskanych. Przeglądając jakieś dokumenty natknąłem się na zakup maszyny do pisania na Wodnym Rynku, czyli na placu Zwycięstwa, z podpisem jednego z profesorów historii. Tak się to wtedy odbywało.

W późniejszym okresie podejmowano już nieco bardziej standardowe kroki mające na celu budowę księgozbioru naukowego. Przez lata pracy naukowej na wielu wydziałach powstawały specjalistyczne zbiory. Krzysztof Jażdżewski opowiada o tworzonej przez lata bibliotece biologicznej, w której skład wchodziły nie tylko książki:

Literatura, którą zebrałem przez pół wieku, to jest biblioteka dotycząca tej właśnie dziedziny, mimo tego, że wszystko można niby znaleźć w komputerach. A biblioteka ta jest, przypuszczam, jedną z największych na świecie - jakieś siódme, ósme miejsce w skali światowej. Materiały tych zwierząt zakonserwowanych w alkoholu bądź w formalinie są ogromne, jeszcze nieprzebrane, więc naprawdę by było szkoda. Jakby nie było następcy w tej wąskiej specjalności, to chyba nikt tego nie wyrzuci. Ktoś może przyjechać z zagranicy, zajrzeć.

Tak początki biblioteki na etnografii, ale też zakup niezbędnych mebli wspomina Bronisława Kopczyńska-Jaworska:

Instytut Socjologiczny miał jedną ogromną szansę, mianowicie Chałasiński ${ }^{60}$ ocalił przed wojną jedyną bibliotekę Instytutu Socjologicznego z Uniwersytetu Poznańskiego ${ }^{61}$. Potem przeniósł się do Warszawy. Przywiózł ją szczęśliwie nie do Warszawy, ale do Zielonki pod Warszawą i ta biblioteka ocalała. Także oni mieli wspaniały warsztat po wojnie. W Łodzi w ogóle nie było wyższych uczelni, nie było bibliotek przyzwoitych, myśmy takie podstawowe prace dotyczące etnografii Polski kupili dopiero jak już byłam asystentką. To pani

${ }^{59}$ Zob. przypis $8 \mathrm{w}$ tym rozdziale.

${ }^{60}$ Zob. przypis $8 \mathrm{w}$ tym rozdziale.

${ }^{61} \mathrm{Na}$ uniwersytecie w Poznaniu powstał pierwszy Instytut Socjologiczny w Polsce, założony w 1921 roku przez Floriana Znanieckiego. 
profesor Zawistowicz ${ }^{62}$ pojechała do Warszawy i przyjechała, mając w torebce dziesięć tysięcy złotych, które dostała w Warszawie na zakup potrzebnych pomocy dla naszego Zakładu. Za te pieniądze pani Jadwiga Świątkowska ${ }^{63}$ jeździła po antykwariatach i skupywała książki. Kupione zostały dwa stoły, najpotrzebniejsze krzesełka, chyba maszyna do pisania. Ja jeszcze pamiętam, że ręcznie pisałam, nie na maszynie, druczkiem bibliotecznym rozliczenie na to 10 tysięcy, które pani profesor podpisała. Nie wiem, czy myśmy załączały jakieś rachunki. Nie do wiary. Dzięki tym pieniądzom był taki podstawowy trzon, jak na przykład tzw. Dzieła wszystkie Oskara Kolberga ${ }^{64}$, klasyka jeszcze z XIX wieku, czasopisma „Wisła” i „Lud”, zbiór wiadomości do antropologii krajowej, prace i materiały etnograficzne, takie komplety do czasopism etnograficznych oraz takie monografie etnograficzne francuskie, wydane przez „Plon” w Warszawie zaraz po wojnie.

Ręczne wypełnianie bibliotecznych fiszek, o czym mówi Jaworska, stało się niemal pokoleniowym doświadczeniem łódzkich doktorantów. Do lat sześćdziesiątych pełnili oni dyżury w bibliotece, mogąc nie tylko poznać jej funkcjonowanie od wewnątrz, zapoznać się z jej zbiorami, ale też nawiązać kontakty i wymieniać poglądy $z$ innymi studentami czy pracownikami naukowymi. Jolanta Kulpińska opowiada:

Jak myśmy pracowali jako asystenci w tej bibliotece, to oczywiście dyżury były uciążliwe, ale jednocześnie to miało dla nas takie znaczenie integracyjne $\mathrm{i}$ intelektualne. Każda $\mathrm{z}$ tych książek przeszła przez nasze ręce i miała dla nas także jakieś znaczenie osobiste.

Biblioteka była miejscem pracy przed otrzymaniem posady asystenta na Uniwersytecie dla wielu ówczesnych młodych akademików. Pracowała w niej przez pierwsze lata także Bronisława Kopczyńska-Jaworska:

Na Kościuszki był magazyn książek, nie było biblioteki jeszcze. Pierwsze książki na takich prymitywnych drewnianych półkach były poustawiane i porządkowało się je, a do mojej wspaniałej działalności należało między innymi, jak całą jesień rozpakowywałam skrzynie z książkami, które przyjechały z Wilna. I to nie były skrzynie z książkami z biblioteki uniwersytetu, tylko z jakichś

${ }^{62}$ Kazimiera Zawistowicz-Adamska (1897-1984) - profesor etnologii, w 1945 roku założyła na Uniwersytecie Łódzkim Zakład Etnografii.

${ }^{63}$ Jadwiga Chełmińska-Świątkowska (1900-1952) - etnograf, przebywała w Łodzi do 1949 roku, pracując jako asystent w Zakładzie Etnografii Uniwersytetu Łódzkiego, następnie pracowała w Muzeum Kultur Ludowych w Młocianach.

${ }^{64}$ Oskar Kolberg (1814-1890) - polski etnograf, prekursor dyscypliny, autor monumentalnego dzieła Lud: jego zwyczaje, sposób życia, mowa, podania, przysłowia, obrzędy, gusła, zabawy, pieśni, muzyka i tańce (1857-1890). 
polskich bibliotek publicznych. Powieści rozmaite, czasopisma, z dużym zainteresowaniem oglądałam sobie „Światowida”, taki tabloid przedwojenny.

Podobnie potoczyły się losy Krystyny Lutyńskiej. W jej relacji znajdziemy też wspomnienie o ówczesnej kierowniczce biblioteki - Krystynie Chałasińskiej ${ }^{65}$, która - co widzieliśmy już w wypadku innych pracowników Uniwersytetu Łódzkiego - sama dbała także o wyposażenie pomieszczeń. Krystyna Lutyńska szczegółowo opowiada o funkcjonowaniu biblioteki:

Zaczęłam pracować w Instytucie. Wtedy się ręcznie przepisywało kartki katalogowe. Ja bardzo ładnie pisałam, umiałam pisać bardzo wyraźnie, więc to się robiło. Były dyżury, biblioteka była czynna wtedy od ósmej rano do ósmej wieczorem. Nie można było się spóźnić. Wszyscy asystenci mieli dyżury. Instytut Socjologii znajdował się wtedy na czwartym piętrze przy ulicy Uniwersyteckiej 3. Przed wojną to był budynek mieszkalny dla nauczycieli dawnej Szkoły Kupców. Tam były takie ogromne pokoje, mające po sześćdziesiąt metrów, więc można było tam zrobić sale seminaryjne i czytelnie. Czytelnia była bardzo ładna, pani Krystyna Chałasińska niesłychanie o to dbała. A książki po prostu stały na półkach, nie było osobnych magazynów, tylko w tych pokojach, gdzie siedzieli asystenci, na wszystkich ścianach wysoko stały książki. Można było też wypożyczyć na noc czy nawet na parę dni. W soboty na pewno też były dyżury. I rzeczywiście ta biblioteka wtedy pracowała fantastycznie. W całym tym wielkim pokoju, który był czytelnią, naprzód były takie zwykłe stoły, a potem pani Krystyna Chałasińska wytrzasnęła pieniądze i zrobiono takie stoliki, tylko potem przemalowano je na zielono. Ale ja pamiętam, że jak one były nowe, to było takie ładne białe drzewo przykryte szkłem. To była bardzo fajna, ładna sala i zawsze tam było pełno czytających.

W tym wypadku biblioteka nie pełniła jedynie funkcji księgozbioru, ale była kluczową przestrzenią wspólnoty akademickiej. To w niej odbywały się wypełnione dyskusjami zebrania Instytutu Socjologii, obrony doktoratów

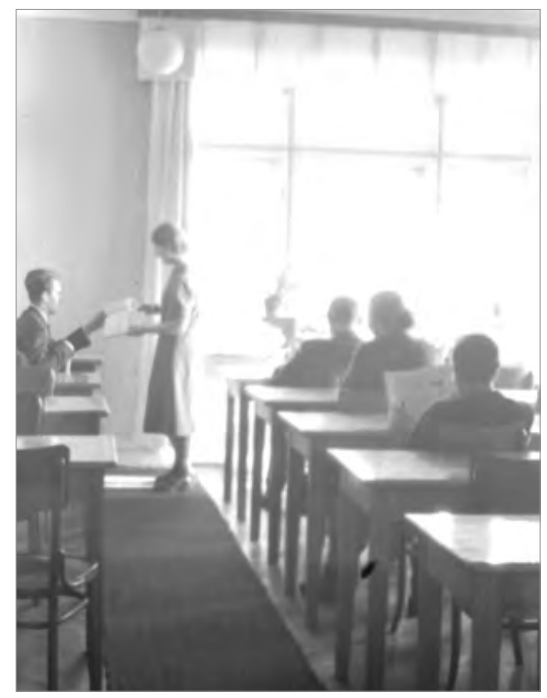

Fot. 73. Biblioteka Socjologiczna w budynku przy Uniwersyteckiej 3

${ }^{65}$ Krystyna Chałasińska (Duda-Dziewierz) (zm. 1983) - socjolog, autorka przedwojennej znanej pracy o polskiej wsi i emigracji, pierwsza dyrektor Biblioteki Socjologicznej, wieloletnia redaktor „Przeglądu Socjologicznego". 
i habilitacji, toczyły się intelektualne spory, a doktoranci, poprzez system wspomnianych dyżurów, stawali się członkami społeczności akademickiej. Aby podkreślić wyjątkowy charakter i historię biblioteki, nadano jej patrona i przez lata funkcjonowała ona jako Biblioteka Socjologiczna im. Józefa Chałasińskiego. Wielokrotnie jednak, mimo tak różnorodnych i ważnych funkcji, jej istnienie było zagrożone, o czym mówi Janina Tobera:

Przeniesienie socjologii na Wydział Ekonomiczny w 1961 roku spowodowało, że z Uniwersyteckiej 3, z Wydziału Historyczno-Filozoficznego, trzeba było się przenieść do tego gmachu, gdzie była dawniej Wyższa Szkoła Ekonomiczna, przy dawnej ulicy Armii Ludowej, a teraz P.O.W. biblioteka, która była w tamtym gmachu, musiała być przeniesiona tutaj i od razu były zakusy biblioteki wydziałowej, to znaczy dawnej biblioteki ekonomicznej, żeby włączyć księgozbiór socjologiczny, żeby była wspólna wydziałowa biblioteka. A nam chodziło o to, żeby to jednak był księgozbiór własny z własnym kierownictwem, i czytelnia oddzielna i tak dalej. No i to się stało, prawda. Ale już w 1968 roku były takie zawirowania, nie wiadomo było, czy zostanie ta nasza biblioteka, czy się połączy, bo ekonomiści krzywym okiem patrzyli na to, że jest taka separacja kierunku, własna biblioteka. Myśmy występowali jako Instytut [Socjologii] i biblioteka była przy Instytucie, ale zwyczaje z Uniwersyteckiej 3 zostały przeniesione na tą P.O.W. - nadal wszyscy asystenci, a zwłaszcza stażyści i doktoranci mieli dyżury w bibliotece. Był taki grafik specjalny i pani profesor Kłoskowska ${ }^{66}$ pilnowała, żeby to były jednocześnie kontakty ze studentami, rozmowy o lekturach, podsuwanie różnych tekstów. Zresztą były zawsze czasopisma do czytania, to było coś fajnego. Pamiętam, że tych wszystkich czasopism, które warto było znać, żeby być na bieżąco, człowiek ani nie musiał, ani nie mógł przecież kupować, a dzięki bibliotece można było kontaktować się ze światem.

W wielu zgromadzonych przez nas relacjach (nie tylko osób związanych z socjologią jako dyscypliną) znajdziemy opis biblioteki socjologicznej i jej zasobów. Po części może to być spowodowane głośną sprawą jej zamknięcia w 2010 roku i utworzenia wspólnego księgozbioru dla całego Wydziału Ekonomiczno-Socjologicznego. Wiązało się to nie tylko z okrojeniem zbiorów, ale także ze zmianą siedziby biblioteki i przeniesieniem jej z samego serca Instytutu Socjologii na trzecie piętro innego budynku. Ten smutny koniec przywoływał w pamięci naszych rozmówców - niczym klamra - początki biblioteki. Opowiada o tym Jolanta Kulpińska:

Tak samo zresztą przyjęłam zasadę, żeby się nie wtrącać w sprawy Instytutu, nawet wtedy kiedy mnie szlag trafiał i niektórych rzeczy nie mogłam przeżyć.

${ }^{66}$ Zob. przypis $19 \mathrm{w}$ tym rozdziale. 
Między innymi utraty biblioteki. Być może nie dało się inaczej, ale myśmy cały czas walczyli o utrzymanie biblioteki, którą nam chciano odebrać na rzecz PAN-u, na rzecz Wydziału. Nawet w trudniejszych zdawałoby się czasach, nie z powodów czysto organizacyjnych, tylko z powodów politycznych, udawało nam się ją utrzymać, a tu coś takiego! Była taka sytuacja, która potem miała śmieszny dalszy ciąg. Mianowicie, był taki moment, że ponieważ biblioteka była częściowo PAN-owska, z czasów, kiedy jeszcze Chałasiński ${ }^{67}$ miał pracownię $\mathrm{w}$ Łodzi ${ }^{68}$, zaczęły się jakieś takie podchody z Warszawy, żeby tę bibliotekę przejąć. Nie wchodzę w szczegóły ani w personalia. My strasznie nie chcieliśmy, także walczyliśmy o to z różnej strony, szukając różnych poparć. Ze strachu, że ta biblioteka może być wywieziona, wszyscy wypożyczyli całą masę książek, fikcyjnie. I potem przyszła nowa pani, po studiach bibliotekarskich, z biblioteki głównej przysłana i zaczęła nas ścigać o te książki. A my mówimy, że ich sami już nie pamiętamy, jakie były źródła tych rewersów, bo tych książek w domu nie mamy. Dopiero potem żeśmy sobie przypomnieli sytuację i okazało się, że książki są, a jeżeli ich nie ma, to nie z powodu tych list, że tak powiem, rewersowych. No i teraz jest tablica „Biblioteka im. Chałasińskiego", którą załatwił u budowlańców prof. Andrzej Majer ${ }^{69}$. To był jedyny sposób, na który nas było stać, żeby zrobić tablicę na marmurze nagrobkowym. Wisi tam na drzwiach. Bardzo ubolewam nad tym, że biblioteka wtopiła się. Podobno zresztą sporo starych książek zostało wręcz wyrzuconych - a tam były książki zdobywane w ramach kwerend socjologów, również z bibliotek poniemieckich. Jeździło się tam, bo tam przecież też wyrzucano te książki, więc taką wyprawę z workami to Janek Strzelecki, Janek Lutyński ${ }^{70}$ i Wacek Piotrowski ${ }^{71}$ zrobili i na własnych plecach parę worów książek przywieźli. Chyba też Szczepański w tym kiedyś uczestniczył. Oni wybierali oczywiście klasykę niemiecką nauk społecznych. Książki też, które były postrzelone w czasie powstania. Nie wiem, jak wygląda ta nowa biblioteka. Podobno też czytelnia jest stosunkowo mała. Nam o to też chodziło wtedy, dlatego tak broniliśmy tej własnej czytelni. Tego też mi szkoda rzeczywiście. Ale jak idę korytarzem i widzę w gablotkach tyle publikacji, których nawet już nie znam, już nawet nikt nie pamięta, żeby mi je dać, to widać, że się dzieją różne dobre rzeczy w Instytucie. To jest też normalne, musi tak być, na nowo.

${ }^{67}$ Zob. przypis $8 \mathrm{w}$ tym rozdziale.

${ }^{68}$ Chodzi tu o Zakład Historii Czasopiśmiennictwa PAN - była to jedna z ,przechowalni” socjologów w okresie stalinizmu i likwidacji socjologii.

${ }^{69}$ Andrzej Majer (ur.1948) - socjolog, pracuje w Katedrze Socjologii Miasta i Wsi UŁ.

${ }^{70}$ Jan Strzelecki (1918-1988) - socjolog związany z IFiS PAN w Warszawie, internowany $\mathrm{w}$ czasie stanu wojennego. Zob. przypis $20 \mathrm{w}$ tym rozdziale.

${ }^{71}$ Wacław Piotrowski (1924-1998) - socjolog, absolwent łódzkiej socjologii i późniejszy profesor socjologii na Uniwersytecie Łódzkim. 
Także Krystyna Lutyńska z ubolewaniem wspomina moment likwidacji biblioteki socjologicznej:

Biblioteka socjologiczna powstała z niczego. Trzeba o tym koniecznie powiedzieć. Powstała dzięki Chałasińskiemu i Szczepańskiemu ${ }^{72}$ i jego wszystkim uczniom. Wtedy, bezpośrednio po wojnie, ludzie jeździli na szaber, zapomniałam tego słowa, to się jakoś inaczej nazywało, na Ziemie Odzyskane. Chałasiński kombinował ciężarówki, takie zwykłe ciężarówki i brał męską młodzież, jechało się, wybierali książki i powstał przepiękny księgozbiór, bardzo cenny. Wśród książek były tomy, które miały postrzelane grzbiety. Nie wiem, co teraz zrobili z tymi książkami, jak zlikwidowali naszą czytelnię. Biblioteka Instytutu Socjologii ma bardzo stare i bardzo piękne tradycje. Kiedy w 2010 roku dowiedziałam się, że księgozbiór zostaje połączony z biblioteką Wydziału Ekonomii, a czytelnia w ogóle zlikwidowana, to muszę powiedzieć, że to było dla mnie duże przeżycie. Zresztą nie tylko dla mnie, bo spotykam często ludzi na ulicy i mówią o tym.

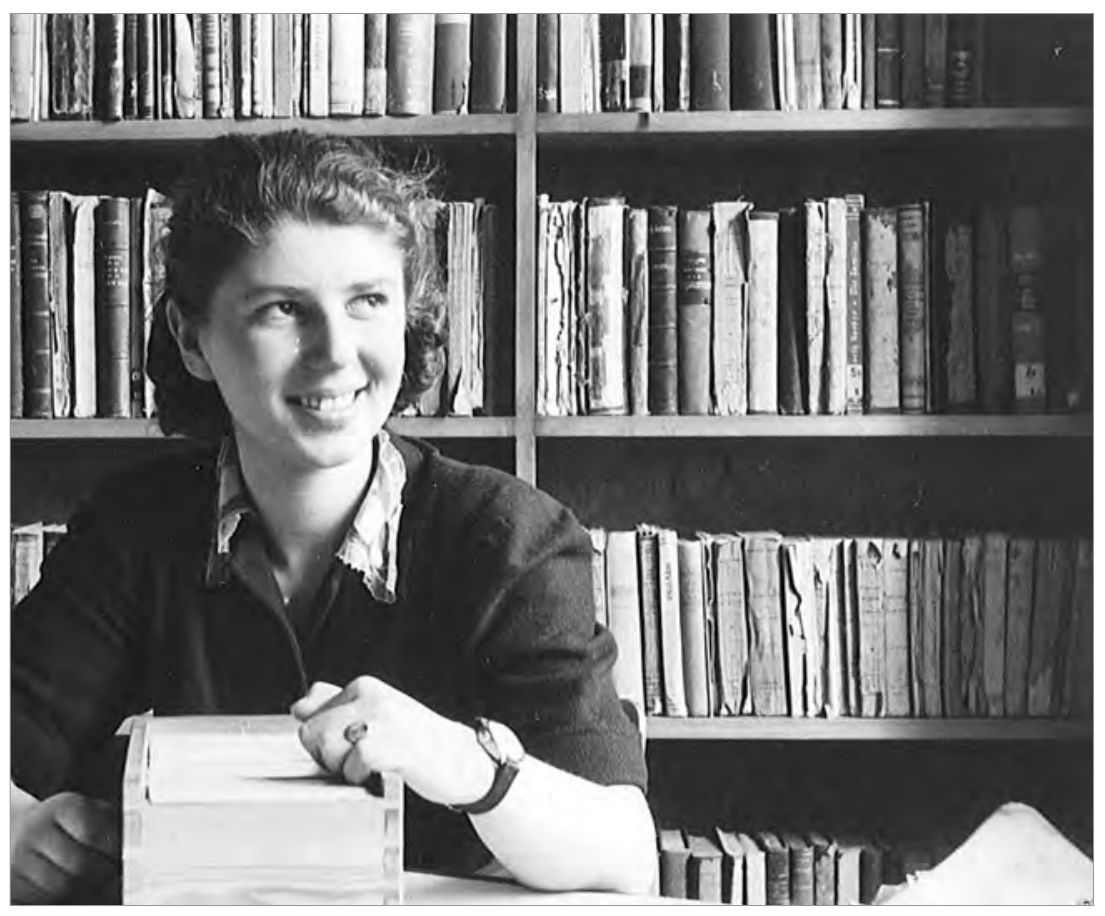

Fot. 74. Krystyna Leśniewska (wkrótce) Lutyńska przy pracy w bibliotece socjologicznej Instytutu Socjologii (1950 lub 1951 rok)

${ }^{72}$ Zob. przypisy 8 i $53 \mathrm{w}$ tym rozdziale. 
Pokolenie naszych rozmówców, pamiętające powojenne braki, późniejsze niedobory czy trudności w dostępie do niektórych książek, mogło $\mathrm{w}$ pełni docenić znaczenie dobrej biblioteki z bogatym księgozbiorem. Współczesne zmiany czytelnictwa studentów, wynikające po części ze zmiany sposobu studiowania, cyfryzacji, przekazywania kopii tekstów przez wykładowców, mogą zatem budzić obawy tego pokolenia. Jego głos wyraża Jolanta Kulpińska:

Ale przecież było tak, że Grażyna Kononowicz ${ }^{73}$ pożyczała od nas książki, żeby zrobić ksero, bo już biblioteczne były tak zniszczone, że nawet ksero było niemożliwe. Bo był jeden egzemplarz z trudem kupowany, ja nawet chyba nie miałam nigdy, bo nie załapałam się na niektóre książki prywatnie. Teraz bardzo dużo wychodzi, a studenci teraz nie czytają książek, tylko szukają skrótów.

\section{Poza uczelnią}

Początkowe trudności lokalowe oznaczały przenikanie Uniwersytetu do miasta. Łódź robotnicza stawała się miastem akademickim i efekty tego procesu widać było na ulicach. Studenci, wówczas łatwo rozpoznawalni dzięki wyróżniającym się strojom - przede wszystkim charakterystycznym czapkom, wypełniali łódzkie ulice. Budynki uniwersyteckie znajdowały się w centrum miasta, a ich przestrzenne rozbicie wymuszało przemieszczanie się codziennie kilku tysięcy studiujących.

Sale kinowe, które w początkowych latach uczelni stanowiły miejsce wykładów, po latach nadal pełniły funkcję dydaktyczną, ale już dla studentów filmoznawstwa. Ewelina Nurczyńska-Fidelska wymienienia nazwy kin studyjnych:

Najbardziej ukochanym kinem było kino „Stylowy”. Zresztą warto zwrócić uwagę na nazwę „Stylowy”, od przed wojny tak się kino nazywało. Ono było na Kilińskiego. Teraz tam znajduje się jakaś dyskoteka, blisko już Głównej, czyli obecnej Piłsudskiego, w głębi. To kino było przed wojną i nazywało się „Kino Teatr Stylowy” i ta nazwa „Stylowy”, nie „Stylowe” zostało już do końca istnienia tego kina i to było nasze ukochane kino. A dlaczego? Bo szefował mu Janusz Bujacz ${ }^{74}$ i ono było kinem studyjnym, miejscem projekcji, nawet miejscem pokazów prasowych wszelkich możliwych festiwali. Dość może obskurnym, ale w pamięci tamtych generacji bardzo ważnym kinem była też „Gdynia”, która też była kinem studyjnym. Dziś już nie istnieje, było na Piotrkowskiej, tam gdzie taki wieżowiec bankowy stoi. Było także kino „Tatry”,

${ }^{73}$ Grażyna Kononowicz - patrz biogramy rozmówców.

74 Janusz Bujacz - filmoznawca, założyciel kin studyjnych i działacz Dyskusyjnych Klubów Filmowych, wychowanek prof. B.W. Lewickiego, propagator i animator kultury. 
małe i bardzo biedne, ale jakoś wtedy biedne kina były. Był jeszcze „Bałtyk”, „Polonia”, „Wisła” i tak dalej.

Przestrzenie mieszkalne odgrywały niebagatelną rolę, nawet jeśli piętro wyżej nie znajdowała się instytutowa biblioteka jak na Uniwersyteckiej 3. W ciągu 1945 roku wielu profesorów przyjeżdżających do Łodzi zatrzymywało się w hotelu „Monopol”, który stał się jednocześnie pierwszym miejscem spotkań łódzkich akademików, o czym mówi Krystyna Śreniowska:

W hotelu „Monopol” zawierały się znajomości różne. Na przykład tam mieszkał bardzo wybitny slawista pan Henryk Ułaszyn ${ }^{75}$. Tam była stołówka, więc przy obiedzie żeśmy się spotykali i zaznajamiali ze sobą.

Innym ważnym miejscem przywoływanym w wywiadach jest kamienica przy Kościuszki 52, gdzie podobnie jak przy Uniwersyteckiej 3 mieściło się wiele profesorskich mieszkań. Krzysztof Jażdżewski - syn wybitnego archeologa profesora Konrada Jażdżewskiego ${ }^{76}$ - zamieszkał tam ze swoimi rodzicami. Raz jeszcze przypomnijmy, jak to miejsce zapisało się w jego pamięci:

Takim naszym ukochanym mieszkaniem przez wiele lat było mieszkanie na ulicy Kościuszki 52. To taka kamienica zbudowana tuż przed wojną, elegancka dosyć, czteropiętrowa, gdzie mieszkali profesorowie Uniwersytetu Łódzkiego. Niektórych sąsiadów jeszcze pamiętam: na czwartym piętrze mieszkał profesor Ireneusz Michalski ${ }^{77}$, przyjaciel ojca. To był antropolog, chodziłem na jego wykłady. Na trzecim piętrze, nad nami, mieszkał profesor Skupieński ${ }^{78}$. To był botanik, którego żona, rodowita Francuzka, była wielką przyjaciółką rodziny i od niej nauczyłem się pierwszych słów i różnych powiedzonek po francusku, bo babcie rozmawiały z panią Skupieńską po francusku i polecenia do dzieci były wydawane w tym języku. Na drugim piętrze nad nami, bo myśmy mieszkali na pierwszym, mieszkała rodzina profesora Dmochowskiego ${ }^{79}$, biochemika. Póź-

${ }^{75}$ Henryk Ułaszyn (1874-1956) - językoznawca, slawista, profesor Uniwersytetu we Lwowie i Uniwersytetu Łódzkiego.

${ }^{76}$ Konrad Jażdżewski (1908-1985) - archeolog. Studia ukończył w Poznaniu pod kierunkiem prof. Józefa Kostrzewskiego; badacz prehistorii, od 1945 roku profesor Uniwersytetu Łódzkiego.

${ }^{77}$ Ireneusz Michalski (1908-1965) - antropolog, profesor Uniwersytetu Łódzkiego. W 1945 roku zorganizował Zakład Antropologii na Wydziale Matematyczno-Przyrodniczym tegoż uniwersytetu. Twórca metody morfologiczno-porównawczej w systematyce człowieka (tzw. szkoła łódzka). Uczestnik wielu wypraw naukowych, w tym m.in. do Chin, Korei, Egiptu i Mongolii.

${ }^{78}$ Franciszek Ksawery Skupieński (1888-1962) - botanik, mikrobiolog, badacz grzybów i śluzowców. Przed wojną profesor Uniwersytetu Wileńskiego, potem Wyższej Szkoły Gospodarstwa Wiejskiego w Łodzi oraz od 1945 roku Uniwersytetu Łódzkiego.

${ }^{79}$ Antoni Dmochowski (1896-1983) - profesor biochemii, współtwórca Uniwersytetu Łódzkiego i tzw. łódzkiej szkoły biochemicznej, założyciel Katedry Biochemii na Uniwersytecie Łódzkim, która byłą pierwszą taką placówką w Polsce. 
niej też słuchałem jego wykładów. Na parterze mieszkał profesor Wiśniewski ${ }^{80}$, fizyk. Mieszkał tu też profesor Zabłocki ${ }^{81}$, który jest ważną osobą w tym gmachu, bo on jako prorektor Uniwersytetu przyczynił się do jego wybudowania $^{82}$. To był mikrobiolog z kolei. Już w tej chwili nie wszystkich sąsiadów pamiętam z nazwiska, to się zresztą potem zmieniało, ale w każdym razie ten dom na Kościuszki 52 to takie wspaniałe dzieciństwo i młodość.

Przyszli profesorowie zmuszeni byli bezustannie borykać się z przeprowadzkami, często również informacja o możliwości otrzymania przydziału na mieszkanie determinowała ich decyzje o pozostaniu lub wyjeździe z Łodzi. Problem mieszkań dla naukowców stał się na tyle istotny, iż, jak wspomina Romuald Olaczek:

Uniwersytet wspólnie z Politechniką w 1964 roku wybudował dom na Narutowicza 79. Sprowadzili się tam pracownicy i Uniwersytetu, i Politechniki, przeważnie po doktoratach, adiunkci lub młodzi docenci. Wszyscy wtedy byli młodzi, mieli dzieci, podwórze było wesołe, dzieciarnia grała w piłkę, hałasowała, biegała, życie towarzyskie jakieś było. Ci panowie, którzy już mieli samochody, a coraz więcej takich było, to spędzali dużo czasu przy swoich maszynach na podwórku. Obecnie podwórko jest ciche, dzieci i wnuki już się wyniosły.

Poza przestrzeniami mieszkalnymi, warunki bytowe określane były także przez inne miejsca. W opowieściach Edwarda Trandy i Romualda Skowrońskiego znajdziemy żywe i ciepłe wspomnienie studenckiej stołówki „Gęsie Pióro”, która mieściła się przy ulicy Piotrkowskiej 48. Choć nieraz rozmówcy błędnie podają numer, pod jakim znajdowała się owa jadłodajnia, nie ma to większego znaczenia dla samej treści wspomnień. Edward Tranda tak opowiada o tym miejscu:

[Jadłodajnia] „Gęsie Pióro” mieściła się na ulicy Piotrkowskiej 4283, blisko Narutowicza i były dwa punkty na ulicy Piotrkowskiej, w których brać studencka uniwersytetu w czasie pochodów pierwszomajowych okazywała najgłośniejszy entuzjazm. Pierwszy to oczywiście była trybuna, która zwykle stała gdzieś w pobliżu pasażu Schillera. Tam entuzjazm był trochę taki na pokaz. A drugi prawdziwy entuzjazm był kiedy mijaliśmy stołówkę. Korpulentna kierowniczka stołówki i kucharki wychodziły wtedy przed [śmiech] drzwi stołówki

${ }^{80}$ Feliks Joachim Wiśniewski (1890-1963) - fizyk, profesor Wolnej Wszechnicy Polskiej, a po II wojnie światowej profesor Uniwersytetu Łódzkiego i Politechniki Łódzkiej.

${ }^{81}$ Zob. przypis $33 \mathrm{w}$ tym rozdziale.

${ }^{82}$ Mowa tu o budynku mieszczącym się przy ulicy Banacha 14/16.

${ }^{83}$ Stołówka „Gęsie Pióro” mieściła się przy ulicy Piotrkowskiej 48. Pomyłek rozmówców nie korygujemy. 
i brać studencka wiwatowała na ich cześć. Jakkolwiek stołówka żywiła tak, jak wtedy to było możliwe. Na przykład wtedy każdego tygodnia były ryby, najczęściej dorsze. Uważano wtedy, że dorsz to jest taka podła ryba, ponieważ dorszy było pod dostatkiem. Mieliśmy własną flotę rybacką, łowiono tych ryb dużo i dorsze były w ciągłej sprzedaży, a w stołówkach były bardzo częstym daniem. To dzisiaj dopiero dorsz stał się taką rzadką rybą.

W swym pełnym smakowitych wspomnień opisie wtóruje mu Romuald Skowroński:

Przede wszystkim były stołówki. Taką najsłynniejszą stołówką akademicką było wtedy „Gęsie Pióro”, ulica Piotrkowska 48. Tam była kierowniczką pani Szulc, teraz już starsza pani. Te obiady tam były, jak na ówczesne czasy, naprawdę rewelacyjne. Ona cuda robiła. Najbardziej lubiliśmy piątki, bo był zawsze śledź w śmietanie z kartofelkami.

Studenckie jadłodajnie, stołówki i kluby pełniły ważną rolę nie tyle jako miejsca stołowania się, ale także jako miejsca spotkań i obiegu myśli. Jak widać z powyższego opisu spektrum miejsc, życie akademickie bynajmniej nie było uzależnione wyłącznie od przestrzeni uniwersyteckich.

\section{Uniwersytet $\mathrm{w}$ robotniczym mieście}

„Jestem Lodzermensch” - zadeklarował z dumą jeden z naszych rozmówców. Łódź jako miasto dopiero odnajdujące się w swoich nowych akademickich funkcjach, dodatkowo o nieco obcym wobec pozostałych polskich miast charakterze, budziło często bardzo odmienne reakcje. Przybyli thumnie w okresie powojennym profesorowie, gdy tylko pojawiała się tylko taka możliwość, chętnie wracali do Warszawy czy Krakowa. Ten exodus stał się pod koniec lat czterdziestych poważnym problemem dla młodej uczelni, dodatkowo zdegradowanej reformą nauki do roli prowincjonalnego uniwersytetu, zagrażając w ogóle jej dalszemu trwaniu. Stosunki między władzami miejskimi, rola uniwersytetu w rozwoju miasta stanowią tło dla osobistych refleksji naszych rozmówców na temat tego, często problematycznego, miejsca zamieszkania i rozwoju kariery naukowo-badawczej. Często już same motywy przeprowadzki i podjęcia pracy na Uniwersytecie Łódzkim były złożone. O swojej decyzji przyjazdu do Łodzi opowiada Jerzy Dietl:

Zgodziłem się [na przeniesienie do Lodzi z Poznania] dlatego, że to było jedyne miasto w Polsce, którego nie znałem. Raz byłem w Łodzi jako konwojent ubiorów robotniczych, odbierałem je w jakiejś fabryce zaraz po wojnie, bo tym się trudniłem jako student. Łódź taka była raczej dosyć biedna, ale 
pomyślałem, że może tu będzie spokojnie, to takie robotnicze miasto, to nie będzie tak źle. Zgodziłem się przyjść do Łodzi, zresztą miałem już wtedy wniosek o unadzwyczajnienie i w Ministerstwie mi niedwuznacznie powiedziano, że Ministerstwo mnie nie poprze, jeśli ja się nie zgodzę przejść do Łodzi, bo tam nie było kierownika tej katedry.

Zaniedbywany przez dekady przemysłowy moloch budził często negatywne reakcje przyjezdnych. Profesorowie, zwłaszcza ci, którzy poświęcili Łodzi swoje zainteresowania badawcze, stawali się jednocześnie krytycznymi obserwatorami i recenzentami rozwoju miasta. Stanisław Liszewski, znawca Łodzi, podkreśla wyjątkowość relacji Uniwersytetu Łódzkiego i miasta:

Historycznie Łódź była pewnym wrzodem na sieci osadniczej Polski. To znaczy ona nie miała prawa tu urosnąć do miasta takiej wielkości, bo jednak leżała w zasięgu wpływów Poznania, Warszawy, Krakowa, Torunia po części, Sandomierza ongiś, czyli tych miast, które miały przeszłość historycznie bogatą i Łódź nie miała szans. Ale wyrosła - to jest ten ewenement. I mnie się wydaje, że jak ona wyrosła, to już potem nikt tego nie zaakceptował. Ona została w pewnym momencie w próżni i dzisiaj mamy taką sytuację, że ta podstawowa funkcja, która doprowadziła do tego gigantycznego wzrostu, upadła i miasto chyli się ku upadkowi, naprawdę chyli się ku upadkowi.

Przez lata narastał mit na temat niechęci władz miasta, a nawet samych mieszkańców wobec wyższych uczelni. Tak przedstawia ten problem Michał Seweryński:

Łódź dobrze przyjęła swoje uczelnie wyższe, uniwersytet. To było faktyczna stolica Polski przez pierwsze miesiące po wojnie. Tu się koncentrowało życie publiczne. Wiadomo było, że uniwersytet musi tu być. Także w późniejszych latach, kiedy ja ogrywałem bardziej aktywną rolę w UŁ i w łódzkim środowisku akademickim, nasze otoczenie zewnętrzne, miasto było przyjazne uniwersytetowi. Myślę, że raczej nie. Chociaż, mówiąc lekko złośliwie, najbardziej czuliśmy zainteresowanie wtedy, kiedy była sesja egzaminacyjna i egzaminy wstępne na uczelnie. Nie można więc powiedzieć, że Łódź to jest ziemia zła dla swoich uczelni, że ich nie chce, że nie docenia, że ich nie lubi. Przeciwnie, i zwłaszcza teraz widać wzajemne zainteresowanie, kiedy przekłada się dorobek uczelni na status Łodzi, na możliwości rozwojowe miasta, bo rośnie liczba mieszkańców wykształconych, rośnie nasz potencjał intelektualny, potencjał zawodowy, rośnie kapitał społeczny. Samych studentów jest w Łodzi około100 tysięcy. Jak dodać jeszcze do tego profesorów, asystentów i jeszcze ich rodziny, pracowników administracyjnych uczelni, to jest razem bardzo poważny odsetek mieszkańców miasta. Właściwie to jest największe 
środowisko, które oddziałuje na miasto, nadaje mu akademicki charakter. W czasach głębokiej komuny, może to był koniec lat siedemdziesiątych... czytałem reportaż w jakiejś francuskiej gazecie, w którym była mowa o Łodzi. To był bardzo pesymistyczny obraz naszego miasta, borykającego się ze swoją biedą i wszystkimi wyzwaniami miasta postindustrialnego. I ten autor napisał tak: „Jedyny jasny punkt na horyzoncie tego miasta to Uniwersytet. To miejsce, które jest otwarte na świat, w którym jakieś życie umysłowe fermentuje, które dźwiga miasto trochę wzwyż”. Myślę, że uczelnie zawsze taką rolę odgrywają. Uważam, że łódzkie uczelnie to jest wszystko to, co najlepsze, co się przytrafiło temu miastu po 1945 roku. Gdyby podsumować ten czas w historii miasta po wojnie, to można powiedzieć, że ono się wybiło na miasto akademickie, ze wszystkimi tego dobrymi konsekwencjami. Gdyby tego środowiska tu nie było, to byśmy byli prowincją nie tylko w Europie, ale także w skali kraju. Nie chcę przez to deprecjonować przemysłu czy innych sfer życia, które się tutaj rozwijały, tego, że to jest także wielkie centrum administracyjne, ale - powtórzę, że Łódź akademicka to jest wszystko, co najlepsze mogło się przytrafić Łodzi.

Oddajmy ponownie głos Stanisławowi Liszewskiemu, który tak opowiada o Łodzi:

Myślę tak: nie ma pomysłu od dwudziestu lat na Łódź. Ja uczestniczyłem w różnych dyskusjach o Łodzi. Nie ma pomysłu, czym ma być dalej Łódź. Skończył się okres Łodzi przemysłowej, zostało po tej Łodzi to, co zostało, czyli budowle do rozebrania raczej niżeli do renowacji, ale przede wszystkim zniknęła główna funkcja, która dawała mieszkańcom Łodzi życie. To jednak było około 150 tysięcy ludzi pracujących w przemyśle. Czy my chcemy być miastem np. akademickim, wobec tego trzeba w tę akademickość zainwestować. Tu jeszcze może dokończę pierwszą myśl, że ta część życia miasta jako przemysłowego była jednak szalenie mocno wspierana przez wszystkie władze od XIX wieku począwszy. To nie było tak, że fabrykant budował fabrykę i na tym zarabiał. On dostawał kredyty, często ich nie spłacał, wyjeżdżał, różne były kombinacje, ale te kredyty tu zostały, w postaci fabryk. I wobec tego ten przemysł, zwłaszcza w XIX wieku, był ciągle doinwestowywany. Po wojnie może nie, ale potem też, w rożny sposób. Natomiast o Łodzi akademickiej wszyscy mówią, zachłystują się, bardzo dobrze, żeby była, ale nikt nie mówi, czy można coś w tym kierunku zrobić, żeby Łódź się przygotowała na przyjęcie tej akademickości. Niechaj miasto wybuduje akademik miejski. Niechaj miasto wybuduje mieszkanie powiedzmy dla młodych pracowników, którzy mogliby tu być. Czyli niech zrobi to, co może zrobić, żeby wesprzeć rozwój tej nowej, ważnej funkcji. 
Pokolenie naszych rozmówców, o czym już dobrze wiemy, w większości studiowało pod koniec lat czterdziestych, czyli w czasie, kiedy ich mistrzowie podejmowali decyzje, czy wyjechać, czy pozostać w ,stolicy polskiego proletariatu”. Niektórzy trafili tutaj przez współmałżonków, przez decyzje rodziców, dalekich krewnych, a nawet plotkę czy przypadek. W późniejszych latach, kiedy niektóre dyscypliny czy środowiska zyskały już odpowiednią rangę, Łódź mogła przyciągać także jako miasto akademickie - łódzka matematyka, prawo czy socjologia były szeroko uznawane i szanowane. Tak o łódzkiej socjologii opowiada jej dzisiejszy profesor Zbigniew Bokszański:

$\mathrm{Na}$ Łódź patrzono przez pryzmat Chałasińskiego ${ }^{84}$, Szczepańskiego ${ }^{85}$. Chałasiński to było nazwisko [wypromowane przez] Znanieckiego ${ }^{86}$. W związku z tym, że profesor Chałasiński chyba dwu- czy trzykrotnie na dłuższych pobytach w Stanach Zjednoczonych przebywał, ludzie z Ameryki, profesorowie o ugruntowanej pozycji tutaj przyjeżdżali.

Z czasem, jak pokazuje dalej profesor Bokszański, kiedy coraz więcej osób przeprowadziło się do stolicy...

Łódź była traktowana jako właściwie cząstka Warszawy. Myślę, że gdyby nie Kłoskowska ${ }^{87}$, Szczepański ${ }^{88}$, Chałasiński ${ }^{89}$, to bylibyśmy bardzo prowincjonalnym ośrodkiem i to by się odbiło na naszych karierach. Ale dzięki tym ludziom i ich takiemu bardzo życzliwemu traktowaniu młodszych pracowników, a z drugiej strony wielkiej energii i wiedzy, to coś się w tej Łodzi działo.

Zdaniem Stanisława Liszewskiego, specjalisty od lat zajmującego się Łodzią, ta zmiana pokoleniowa i ukształtowanie się łódzkiego środowiska akademickiego stały się kluczowe dla zrozumienia obecnej sytuacji tak miasta, jak i Uniwersytetu:

Poza tym proszę pamiętać, że Łódź nie miała własnego środowiska akademickiego, większość ludzi przybyła tutaj z innych miejsc. W momencie, kiedy Warszawa się odbudowywała i powstała jeszcze Akademia [Polska Akademia Nauk], to duża część profesorów wyjechała do Warszawy. I tutaj zostali jeszcze nie do końca wykształceni uczniowie tych mistrzów, którzy zaczęli organizować naukę w Łodzi. I też powtarzam, że pierwszym absolwentem łódzkiego Uniwersytetu, który został rektorem, był mój poprzednik, profesor Leszek

\footnotetext{
${ }^{84}$ Zob. przypisy 8 w tym rozdziale.

${ }^{85}$ Zob. przypis $53 \mathrm{w}$ tym rozdziale.

${ }^{86}$ Florian Znaniecki (1882-1958) - filozof i socjolog, ojciec założyciel socjologii w Polsce.

${ }^{87}$ Zob. przypis $19 \mathrm{w}$ tym rozdziale.

${ }^{88}$ Zob. przypis $53 \mathrm{w}$ tym rozdziale.

${ }^{89}$ Zob. przypis $8 \mathrm{w}$ tym rozdziale.
} 
Wojtczak ${ }^{90}$. Wszyscy poprzedni nie wywodzili się z Łodzi. Więc to jest ta bariera pięćdziesięciu lat, zanim środowisko łódzkie, własne środowisko zaczęło coś tworzyć. Oczywiście druga przeszkoda była taka, że Łódź, ale myślę, że nie tylko Łódź, była uznana za miasto robotnicze i to tak było zakodowane formalnie, w mentalności władz. I wobec tego środowisko akademickie było potrzebne tylko jak kwiatek do kożucha Łodzi przemysłowej.

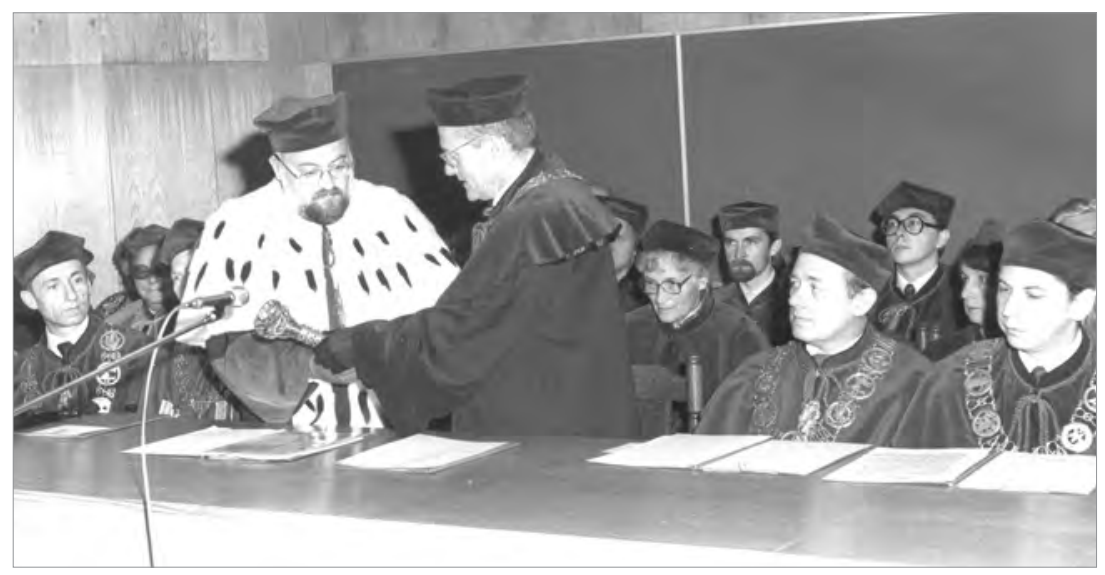

Fot. 75. Październik 1984, Rektor Jerzy Wróblewski przekazuje władze rektorowi Leszkowi Wojtczakowi. Na zdjęciu również prorektorzy:

Marcin Bielski, Stanisław Liszewski oraz Cezary Kosikowski

Podsumowując tak zarysowaną dynamikę rozwoju środowiska akademickiego Łodzi, można skonstatować, że wiele osób z pokolenia profesorów przybyłych do Łodzi po wojnie było dla naszych narratorów mistrzami. Byli to często uczeni wybitni, ale niezwiązani z miastem, pozostający w środowiskach rozproszonych przez wojenną zawieruchę, często traktujący pobyt w Łodzi jako chwilowy - często zupełnie przypadkowy - przystanek na dłuższej drodze ${ }^{91}$. Dopiero kolejne pokolenie miało szanse identyfikować się z miastem i lokalnym środowiskiem badawczym, co mogło mieć przełożenie na wybór przedmiotu badań, decyzje dotyczące własnej kariery, wreszcie zaangażowanie w działalność pozanaukową na rzecz Łodzi czy samego uniwersytetu jako instytucji.

${ }^{90}$ Leszek Wojtczak - patrz biogramy rozmówców.

${ }^{91}$ Irena Bołtuć-Staszewska i in., Tranzytem przez Łódź, Wydawnictwo Łódzkie, Łódź 1964; Bohdan Baranowski, Krzysztof Baranowski, Trudne lata Uniwersytetu Lódzkiego: 1949-1956, Wydawnictwo Uniwersytetu Łódzkiego, Łódź 1990. 


\section{Przestrzenie Uniwersytetu}

Materialne przestrzenie ogrywały ważną rolę w tworzeniu niematerialnej myśli. Często stawały się punktami węzłowymi dla danego obiegu naukowego - miejscami przypadkowych spotkań i interakcji, które pozwalały tworzyć się i rozwijać universitas. Ich rola mogła być równie konstruktywna, jak destrukcyjna i alienująca. Procesy te przebiegały zarówno na poziomie poszczególnych pomieszczeń, budynków, jak i całego miasta. Źle zaprojektowana przestrzeń mogła prowadzić do izolacji uczonych od studentów i od siebie nawzajem. Zbyt daleko umieszczona biblioteka mogła zniechęcać do korzystania z jej bogatych zbiorów. Zbyt duże odległości czy brak przestrzeni wspólnych - do spotkań i wymiany myśli, która nie ogranicza się przecież do polemik w naukowych czasopismach, ale równie dobrze może odbywać się przy parzeniu kawy czy odnoszeniu książek. Być może stworzenie przestrzeni przyjaznej wymianie myśli jest jednym z ważniejszych wyzwań, jakie stoją przed Uniwersytetem Łódzkim, jak wspomina Stanisław Liszewski:

My oczywiście nie mieliśmy warunków ku temu, bo tu nie jest tak jak w Krakowie, gdzie jest jedna przestrzeń, stary budynek rektoratu, gdzie wszyscy przychodzą i się spotykają. U nas tego nie było. Był jakiś klub czy klubik, gdzie się herbatę piło, na Narutowicza. I był taki moment, kiedy tam się spotykało wiele osób. A teraz to się już zupełnie zdezorganizowało i jest inaczej. Dlatego ja myślę, że wytwarzanie takiej atmosfery akademickiej jeszcze jest przed nami. Bo my, poprzez decyzje finansowe na uczelni, poprzez decentralizację, odchodzimy tego. Te kontakty są coraz gorsze, coraz mniejsze, ludzie się zamykają w pokojach, nie ma takich okoliczności, które by integrowały.

Wraz z modernizacją uniwersyteckiej infrastruktury zmianie uległy także międzyludzkie więzi - jak często wspominają nasi rozmówcy, wraz z upływem lat coraz mniej miejsca pozostawało na dyskusje i niekończące się zebrania. Choć może to być ocena jednostronna, a procesy, jakim podlegała akademia, są złożone, to często ważną rolę odgrywała w nich właśnie przestrzeń. Krytycznie nowe uniwersyteckie budynki, pozbawione wcześniejszej atmosfery opisuje Biruta Petrykowska:

Ja nie lubię nowego budynku. Jest bezosobowy. Jest dezintegrujący ludzi. Pomijając już to, że można chodzić w kółko po tych korytarzach, co jest irytujące. Tam ludzie się w ogóle nie widzą. Moim zdaniem cały szereg przestrzeni jest właściwie zgubiony i bez sensu. Nie wiem, może z punktu widzenia bryły i wizji architekta to jakoś tam wygląda. Ale te wiszące schody, po których studenci nawet niechętnie chodzą. Nie lubię tego budynku. 
Nawet jeśli nie jest to kwestia samej przestrzeni, ale także wymagań stawianych uniwersytetowi i jego kadrze, zmiany tempa życia, nostalgii za przeszłością czy przeobrażeń etosu pracy akademickiej, dzisiejszy uniwersytet w niewielkim stopniu przypomina instytucję z połowy XX wieku. Instytucję pełną braków, wymagającą pomysłowości niedoboru, niewielką z dzisiejszej perspektywy, ale wobec której wszyscy nasi rozmówcy odczuwają ogromny sentyment. Zarówno do tego, co w niej cenili, jak i do tego, co krytykowali, nie ma już powrotu. 



\section{Zamiast zakończenia \\ Universitas - czym byl, czym jest Uniwersytet?}

Uważam, że łódzkie uczelnie tojest wszystko to, conajlepsze, co sięprzytrafito
temu miastu po 1945 roku. Gdyby podsumować ten czas w historii miasta
po wojnie, to można powiedzié́, że ono się wybiło na miasto akademickie,
ze wszystkimi tego dobrymi konsekwencjami. Gdyby tego środowiska tu nie
byto, to byśmy byli prowincją nie tylko w Europie, ale także w skali kraju.

$\mathrm{Z}$ wywiadu z profesorem Michałem Seweryńskim

Zaprezentowane w poprzednich rozdziałach wypowiedzi wyraźnie pokazują, że Uniwersytet stał się dominującą ramą doświadczenia biograficznego i ważnym wymiarem definiowania siebie, choć nasi rozmówcy w różny sposób wykorzystywali oferowane przez akademię struktury możliwości, nadawali im różne znaczenia oraz przypisywali im różną wartość. Owe struktury możliwości kształtowane były zarówno przez trudy budowy nowej uczelni, niedostatki materialne związane $\mathrm{z}$ bazą lokalową, wyposażeniem pracowni i bibliotek - krótko mówiąc z pracą od podstaw; jak i przez skomplikowane warunki społeczno-polityczne, zmieniające się na przestrzeni dekad oraz przede wszystkim przez to, co w naszym odczuciu stanowi istotę życia akademickiego, czyli przez proces budowy środowiska w odniesieniu do idei universitas. I tę właśnie ideę chcemy przedstawić w zakończeniu, po raz kolejny oddając głos naszym rozmówcom. Kiedy analizowałyśmy opowieści emerytowanych dziś pracowników naukowych, wykładowców, a kiedyś studentów Uniwersytetu Łódzkiego, naszą uwagę przykuły te momenty, w których odnosili się oni do artykułowanej wprost idei uniwersytetu jako wspólnoty wartości i do jej obrazów, które tak bardzo kontrastują ze współczesną społeczną konstrukcją świata akademii. Naukę uprawiają [dziś] zawodowo dziesiątki tysięcy „,pracowników nauki”. Pracują ciężko i w pośpiechu, publikują dużo, od tego bowiem zależy ich pozycja w ,rankingu”. To z kolei rzutuje na sprawy uzyskania kolejnego grantu na badania, a w rezultacie nieraz na możliwość pozostania na uczelni w ogóle - bycia jej „użyteczną” częścią. Ciągle w rozjazdach, na 
różnych konferencjach, nie mają czasu na chodzenie na ryby ${ }^{1}$. Tymczasem w zebranych opowieściach, choć dotyczyły czasów trudnych, nierzadko krępujących swobodny rozwój naukowy, zarysowany został obraz uczelni jako universitas - społecznie skonstruowanej rzeczywistości dającej możliwość nieustannego poszerzania horyzontów poznawczych dzięki dostępowi do różnych (często zasadniczo odmiennych) koncepcji naukowych, podejść teoretycznych, punktów widzenia. Universitas miała stanowić arenę debaty i sporu, umożliwiać prezentację osiągnięć naukowych, artykulację własnej opinii, a jednocześnie uczyć twórczej krytyki i refleksji nad własnymi dokonaniami i dokonaniami innych osób. Idea uczelni jako universitas, kształtowana w procesie ciągłej dyskusji, pozwalała na usensownienie i uporządkowanie codziennego świata życia przez określone struktury istotności oraz wpływała na schematy orientacji i podejmowane wybory życiowe, dostarczała też określonych sposobów postępowania dla realizacji wspólnych przedsięwzięć oraz kryteriów oceny ich autentyczności i jakości.

Chcemy więc na zakończenie odwołać się do tych najbardziej ogólnych, ale też w naszym odczuciu fundamentalnych dla funkcjonowania akademii kwestii, a zatem skoncentrować się na obrazie tego, czym była dla narratorów uczelnia jako universitas oraz na wyobrażeniu tego czym jest/powinna być.

Odniesienia naszych rozmówców do idei universitas pojawiały się w różnych kontekstach, zwłaszcza w związku z własnymi studiami, stylem studiowania, kontaktami z pracownikami uniwersytetu, przyswajaniem sobie atmosfery akademii - przede wszystkim w wymiarze życia intelektualnego, mniej instytucjonalnego. W opisach tych, budowanych z teraźniejszej perspektywy, często przebija nuta nostalgii, związana jednak mniej z sentymentalnym wspomnieniem młodości, bardziej zaś z perspektywą porównawczą odnoszącą się do czasów współczesnych. Dla nas uderzający był przede wszystkim właśnie kontrast obrazów, które rysowali rozmówcy, z naszym własnym doświadczeniem współczesnego uniwersytetu. To czasem skłaniało do stawiania, naiwnych niekiedy, pytań: ,jak to (było) możliwe?".

Logika prezentacji fragmentów wypowiedzi, które mają pełnić funkcję podsumowania, jest następująca: zaczynamy od konkretnego przykładu,

${ }^{1}$ Ryszard Herczyński, Spętana nauka: opozycja intelektualna w Polsce 1945-1970, Wydawnictwo Naukowe Semper, Warszawa 2008, s. 12 W tym fragmencie autor nawiązuje do słów sir Freda Hoyle'a, który uważał, iż chodzenie na ryby sprzyja spokojnemu myśleniu o własnej pracy. Fragment ten został zacytowany w rozdziale II. 
w naszym odczuciu bardzo dobrze charakteryzującego zmiany idei universitas jako swoistej wspólnoty uczonych zarówno z perspektywy studenta, jak i wykładowcy. Następnie poszerzamy kontekst przez odwołanie do cytatów pokazujących, co zdaniem rozmówców tworzyło i winno kształtować istotę uniwersytetu. Rzecz jasna przykłady te odnoszą się do konkretnych przypadków: dyscyplin, okoliczności - można je jednak potraktować jako charakterystyczne dla ówczesnej akademii, której istotą była idea universitas.

Prezentację cytatów zaczniemy od przykładu „zadziwienia” odmiennością ówczesnego i współczesnego wyobrażenia tego, na czym polega proces zdobywania wykształcenia uniwersyteckiego. W zasadzie cytat ów mógłby znaleźć się w części poświęconej studiowaniu, ale doskonale ilustruje on nie tyle sposób prowadzenia zajęć, kompetencje wykładowców czy wzajemne relacje między nauczycielami akademickimi a studentami, ile ówczesną ideę studiowania zawierającą się w określonej koncepcji wyższej uczelni.

Sławomir Cieślikowski, student psychologii na przełomie lat czterdziestych i pięćdziesiątych, opowiadając o wykładach, od problemu ich organizacji przechodzi do wyjaśnienia kluczowej kwestii tego czym winna być akademia. Kontrast ówczesnego i współczesnego obrazu studiowania wzmacniają występujące na początku cytowanego fragmentu ,naiwne” pytania i ,prowokacyjne” odpowiedzi:

Kaja Kaźmierska: Mam takie pytanie nie o fakty, tylko bardziej o okoliczności. Mówił pan, że był na wykładzie jedynym słuchaczem. Jak to było możliwe, żeby był prowadzony wykład dla jednego studenta?

Sławomir Cieślikowski: A dlaczego nie?

KK: W dzisiejszych czasach to absolutnie niemożliwe!

SC: A dlaczego?

KK: A dlatego, że my mamy system elektroniczny, student się musi zarejestrować i wykład rusza, jeżeli jest minimum trzydzieści osób.

SC: A dlaczego minimum trzydzieści?

KK: Bo tak ktoś zadecydował.

SC: Otóż właśnie - system nauczania na uniwersytecie. Pomijam trymestr, semestr, darujmy to sobie. Chociaż to jest istotne, bo jednostka wykładu dziesięciogodzinna lub dwudziestogodzinna, jeżeli po półtorej godziny, to rzeczywiście jest wystarczająca do ujęcia jakiegoś zagadnienia i zrobienia po dziesięciu 
czy dwudziestu godzinach z tego książki. Pomyślmy, godzina lekcyjna to ile to jest stron? Nigdy nie mniej niż jakieś sześć do dwunastu. Otóż w ciągu godziny lekcyjnej sześć do dwunastu stron maszynopisu. Zależy, jak kto mówi i co dodaje, ale na pewno nigdy mniej niż sześć. Teraz weźmy sobie dwadzieścia takich godzin razy sześć, to jest książka studwudziestostronnicowa. Stąd wielu profesorów, nie tylko profesorów, przygotowywało wykłady jako materiał do książki od razu. To jest punkt pierwszy ${ }^{2}$. Druga rzecz, od strony studenta patrząc. Wydział Humanistyczny obejmował bibliotekoznawstwo, psychologię, filologię angielską, polską. Wszystko to mieściło się w Wydziale Humanistycznym. Czyli ujęcie było ogólne. Było podane pewne minimum zarówno tematów, jak i typu wykładów. Na przykład: musi być w każdym trymestrze przynajmniej dziesięć godzin w tygodniu zajęć, w tym jedno zajęcie musi mieć charakter ćwiczeń, proseminariów lub seminariów. Tylko dziesięć godzin. A reszta czytanie, inny cel. Mówię o celu. Tylko siedemdziesiąt parę pozycji z literatury. Czy to jest tylko czy to jest aż? Dla mnie wtedy to było tylko. Ale dzisiaj, tak jak słyszę i wiem, to jest aż siedemdziesiąt. Jak można żądać siedemdziesięciu lektur. A jeżeli jest inny cel egzaminu, to i inne przygotowanie, i inny zestaw podstawowych materiałów. Co jest w takim razie w zakresie wykładu? Albo zagadnienie szczegółowe jedno, albo takie ogólne ujęcie całego przedmiotu, którego nie ma, bo jest własnością wykładającego i nie ma w innych lekturach. Wtedy trzeba chodzić pilnie, notować dokładnie, uczyć się, bo nie to, że z wykładów będzie profesor pytał, tylko trzeba się nauczyć sposobu myślenia o przedmiocie, z którego zdaję egzamin. Muszę się nauczyć sposobu myślenia. To jest zupełnie co innego niż w tej chwili się prowadzi. Tak więc tylko dziesięć godzin zajęć, reszta dowolna. A jakie wykłady w takim razie, jaki zakres? Poza tymi przedmiotami dwoma, trzema, czterema, wobec tego ktoś zdał cztery egzaminy, tylko cztery i ma przedmiot zaliczony. Jak weźmiesz moje egzaminy [pokazuje indeks], to zobaczysz, że ja naprawdę mam tylko dwa egzaminy z psychologii i oba z eksperymentalnej. A to się okazało potem, że psychologia eksperymentalna to jest właściwie połowa całej psychologii. Ja o każdej z dziedzin musiałem coś wiedzieć. Ja przecież zdając eksperymentalną, musiałem powiedzieć o psychologii rozwojowej, musiałem powiedzieć o wychowawczej, pedagogicznej, a to jest ściśle powiązane z rozwojową. Czyli mój egzamin wymagał minimum roku, a w zasadzie półtora do dwóch lat pilnego czytania i uczenia się, żeby móc zdać jeden egzamin. Egzamin nigdy nie trwał krótko. Krótko było tylko w jednym przypadku - jak po pierwszym, drugim pytaniu ktoś oblewał. Z punktu widzenia studenta i przedmiotów zakres jest dowolny. Mam małe obowiązki, tylko kilka przedmiotów. Tylko do nich

${ }^{2}$ Np. Jan Szczepański w swoim dzienniku pod datą 1.01.1946 pisał: „Mój program na rok 1946 jest duży. Przede wszystkim habilitacja. Praca habilitacyjna o środowisku. Będzie to duża praca złożona z trzech części. Pierwsza część stanowi treść wykładów, które rozpoczynam 4 stycznia, w piątek”. Jan Szczepański, Dzienniki z lat 1945-1968, Ustroń 2013, s. 25. 
się muszę uczyć. A douczać się po to, żeby mieć lepszy ogląd jakiejś całości, to jest moja prywatna sprawa. Wpisuję do indeksu. Jeżeli chcę, to mogę wziąć jeden z tych przedmiotów jako uzupełniający. Ja wziąłem indianistykę. Czemu nie. Zrobiłem jeszcze dwa egzaminy i mam dwa fakultety od razu, w jednym indeksie naraz. Jeden jako uzupełniający, drugi jako główny. Musiałem wziąć psychologię jako główny, a dowolny mogłem wybrać. Na przykład u profesora Batawii ${ }^{3}$ psychopatologię młodzieży przestępczej. Mogłem? Mogłem chodzić na jego wykłady i seminaria, bo to było coś, co otwierało mi oczy na psychologię. Nie było żadnego obowiązku. Mogłem to wybrać. Chciałem wybrać podstawy psychologii osobowości w Indiach. Czemu nie, wolno mi. Może to nie mieć pozornie związku, bo to się nazywało filozofia Upaniszadów. I to nie cała, tylko jeden wycinek. Mogłem, wolno. Czyli z punktu widzenia studenta mogłem dla uzupełnienia podstawowego przedmiotu dobierać sobie dowolne elementy, jakie chciałem w ramach wydziału. Jeżeli chciałem wziąć filozofię prawa, a chciałem - był taki matematyk Tadzik Gesternkorn ${ }^{4}$, z nim zdecydowaliśmy się i poszliśmy do dziekanatu jednego i drugiego, i uzyskaliśmy zgodę dwóch dziekanów, żebyśmy chodzili na filozofię prawa. Nie było nam to do niczego potrzebne poza ciekawością, jak to z punktu widzenia prawa wygląda. Tylko tyle. Dostaliśmy zgodę, bo uznano, że to będzie rozszerzało nasze podejście, do filozofii u Tadzika i do psychologii u mnie. Czyli zakres doboru był indywidualny. Czemu w ten sposób robiono? Mianowicie po to, by każdy ucząc się indywidualnie, miał swój własny, własnymi zdolnościami i zainteresowaniami uwarunkowany sposób patrzenia na dziedzinę, w której żyje ${ }^{5}$. Bo tylko i wyłącznie dzięki temu można mówić o rozwoju nauk wszerz, poszerzać każdą dyscyplinę. Wąsko to wgłębiamy się w jeden temat, ale wąskość nam i głębokość nie wystarcza. Trzeba także umieć spojrzeć wielostronnie. Dlatego nie tylko pozwalano, ale zalecano, żeby student sam dobierał sobie kierunki i dodatkowe wykłady według własnego uznania. Bo on poszerza swoją wiedzę o własnym temacie. W latach marksizmu nie pozwolono na to, bo miało być wszystko tylko marksistowskie. Ponieważ początkowo była tylko filozofia czy ekonomia marksistowska, to wyeliminowano wszystkie inne rzeczy. A zamiast wyboru z marksizmu tego, co się chciało, był obowiązkowy zestaw wykładów.

${ }^{3}$ Stanisław Batawia (1898-1980) - kryminolog, lekarz, do 1949 roku prowadził na Uniwersytecie Łódzkim wykłady z kryminologii i psychiatrii sądowej.

${ }^{4}$ Tadeusz Gesternkorn - matematyk, dr hab. Profesor UŁ w Katedrze Teorii Prawdopodobieństwa i Statystyki.

${ }^{5}$ Podobnie swoje doświadczenia studenckie opisał Ryszard Herczyński (Spętana nauka..., s. 23): „Profesor Jan Oko, filolog klasyczny wykładał dla jednego studenta, który samotnie siedział w ławce naprzeciw niego. Słuchaczem tym był Leszek Kołakowski. (...) staraliśmy się poznać wszystko: Leszek Kołakowski bezskutecznie zgłębić analizę matematyczną, ja równie bezskutecznie filozofię i socjologię. O naszych próbach świadczyć mogą, jeśli zachowane, indeksy. Po wykładach profesora filozofii, Henryka Mehlberga, odbywaliśmy z nim długie, dyskusyjne spacery przez Łódź". 
To myślenie pozostało do dzisiaj. Dawno marksizmu już nie ma, dawno marksistów jako decydentów o kierunku studiów nie ma, ale podejście pozostało. Ważne jest to, żeby wiedzieć, jaka dyscyplina i w tej dyscyplinie się mieścić. Podstawowe elementy, a więc zakres i metodologia musi być znana, czyli kilka egzaminów - dwa, trzy, cztery. A reszta to jest dokształcanie, dopowiadanie, dodawanie innych rzeczy dookoła według tego, jak chce rozumieć to ewentualnie przyszły naukowiec albo przyszły praktyk, który będzie miał prawo podejmowania decyzji o tekście własnym albo o tekstach innych, albo o losach człowieka, jeżeli to jest psycholog czy socjolog, czy pedagog, czy ktokolwiek inny. A więc typ studiów, rodzaj studiów, cel studiów, sposoby kształcenia były całkowicie obce dzisiejszemu światu, który jest zdeterminowany myśleniem marksistowskim - mówię o Polsce - w sposób nieprzyzwoity.

Zgodnie $\mathrm{z}$ regułą przyjętą $\mathrm{w}$ tej pracy, interpretację cytowanej argumentacji pozostawiamy Czytelnikowi. Chcemy jedynie zwrócić uwagę na drobny szczegół. Nie tylko w przypadku tego spotkania rozmówca pokazywał swój indeks. Wiele razy miałyśmy okazję przerzucać pożółkłe już kartki indeksów, oglądając podpisy profesorów, którzy przeszli do historii swoich dyscyplin. Nasi rozmówcy traktowali je zarówno jako „materiał źródłowy” przypominający daty, nazwiska czy zaliczone przedmioty, ale również jako symboliczny „dowód” relacji z przeszłością akademicką, w której mieli możliwość spotkania z mistrzami. Zniknięcie indeksów ze współczesnych uniwersytetów, wsparte racjonalną argumentacją modernizacji, ekonomii czasu i zasobów, traktować można jako symbol dzisiejszych zmian. Dobrą ilustracją ich tempa i kierunku może być przykład dyskusji z 2006 roku na forum internetowym na temat użyteczności indeksów:

Wpis:

Po co student musi po zaliczeniu egzaminu biegać za wielmożnym profesorkiem tylko po to, aby ten łaskawie dał mu autograf do indeksu? Czemu zamiast wpisów w indeksach wszystkie dane nie leżą w bazie danych uczelni? Zaoszczędziłoby to masę pracy, czasu, nerwów, a w rezultacie pieniędzy.

Komentarz do wpisu:

Taka jest tradycja:) A tak na serio - skomputeryzowanie całej uczelni, tak aby każdy profesor $\mathrm{w}$ odpowiednim momencie miał dostęp do komputera podpiętego do uczelnianej sieci i mógł wprowadzić wyniki egzaminów i zaliczeń, to nie jest błahostka. Zaliczenia przecież mogą odbywać się na auli, w laboratorium, na sali... Każda z tych sal musiałaby być wyposażona w komputer. Po drugie - tak czy inaczej - po egzaminie czy zaliczeniu - ktoś musiałby wprowadzić dane - zamiast do indeksu to do bazy danych. Po trzecie - ktoś i tak 
musiałby wydrukować wprowadzone dane w celach archiwizacji. Po czwarte - w takim przedsięwzięciu najwięcej ma do powiedzenia kadra uczelni. A profesorom - nieraz osobom starszym - niekoniecznie zależy na zmianie stanu rzeczy. Oni są przyzwyczajeni do wpisywania ocen do indeksów i przejście na system komputerowy wcale nie oznaczałoby dla nich ułatwienia zadania. Po piąte - ludzie którzy muszą godzinami wyczekiwać pod drzwiami profesora i uganiać się za nim, nie mają na uczelniach zbyt wiele do powiedzenia. Po szóste - nie mając indeksu nie można zagiąć ostatniej strony I na koniec - z perspektywy czasu, ganianie z indeksem nie wygląda wcale tak strasznie. A czasem fajnie jest przejrzeć tą książeczkę 6 .

Pomijamy tu styl dyskusji i argumentację pytającego, koncentrując się jedynie na odpowiedzi. Z dzisiejszej perspektywy można zauważyć, iż jej autor nie przewidział, że procesy modernizacji uczelni wkrótce doprowadzą do zniknięcia indeksów, a bariery technologiczne i nawykowe zostaną pokonane. Jednak ze sposobu argumentacji można wnioskować, że autor wpisu zapewne już skończył studia i docenia symboliczne znaczenie dokumentu odnoszącego się do tej fazy biografii, którą, jak można sądzić z tonu wypowiedzi, wspomina dziś z nostalgią. Co ciekawe, obecnie indeks, chociaż nie ma desygnatu, nadal funkcjonuje w języku jako symbol roli społecznej studenta np. w takich sformułowaniach jak „,zdobyć indeks”, „wygrać indeks” czy ,indeks elektroniczny”. Zmianie musiały natomiast ulec rytuały związane z immatrykulacją. Otrzymanie indeksu na uniwersyteckiej inauguracji roku akademickiego przez najlepszych kandydatów oraz przez wszystkich studentów na inauguracji kierunkowej, było symbolicznym aktem włączenia w społeczność akademicką. Obecnie inauguracje kierunkowe przypominają bardziej zebrania informacyjne niż ceremonię potwierdzającą zmianę statusową. Niewątpliwie zatem funkcja indeksu wybiegała daleko poza instytucjonalny czy prawny aspekt tego dokumentu. Decyzja o jego zlikwidowaniu bazowała właśnie na tych aspektach z pominięciem znaczenia symbolicznego, które, jak się zdaje, nie jest już dziś uznane za konieczny element współczesnego uniwersytetu. Z satysfakcją stwierdzamy, że my jeszcze indeksy mamy.

Dygresja na temat znaczenia indeksów została tu rozwinięta celowo aby zwrócić uwagę, iż ich likwidacja to element szerszego zjawiska. Indeks zdaje się nie pasować do współczesnego umasowienia studiów, zaś sam fakt ich podjęcia coraz rzadziej uznawany jest za wyjątkowe czy szczególnie

${ }^{6}$ Forum internetowe pytamy.pl, http://pytamy.pl/title,dlaczego-na-studiach-s-indeksy, pytanie.html?_ticrsn=3\&smclgnzlticaid=51427a (pisownia oryginalna), (12.10.2015). 


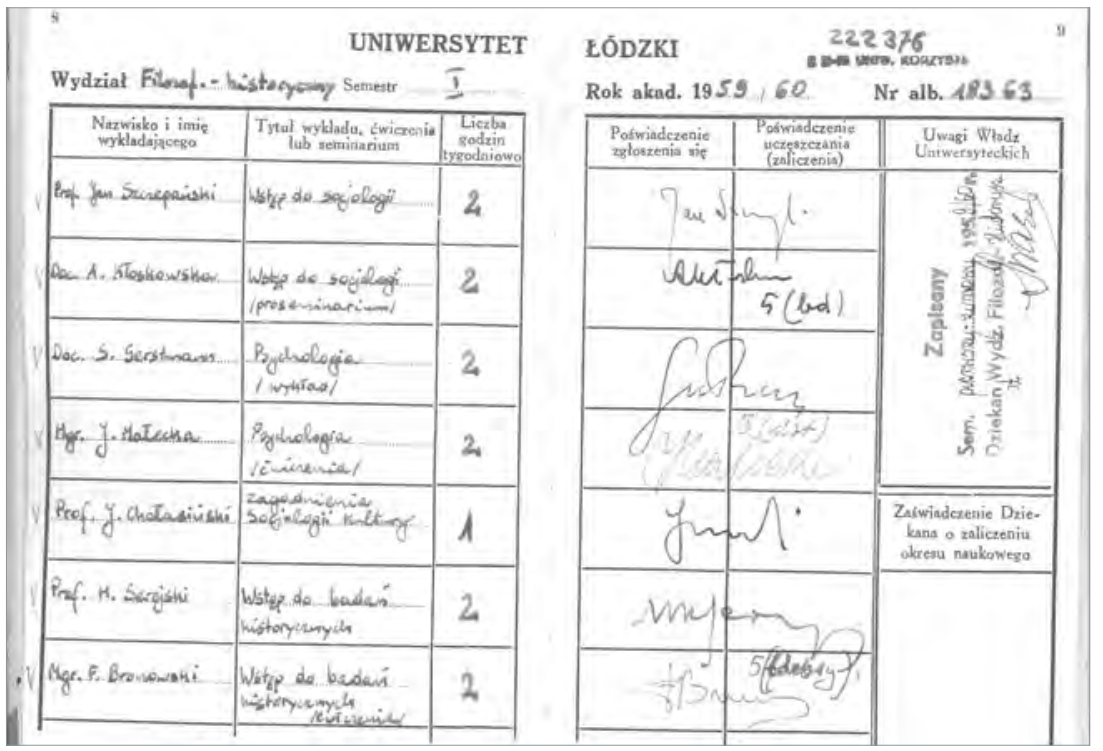

Fot. 76. Strony z indeksu Zbigniewa Bokszańskiego

znaczące, opisywane z entuzjazmem, doświadczenie biograficzne, które w następujący sposób relacjonował Romuald Olaczek:

Pierwsze lata zaczynały od 1 września na uniwersytecie, tak jak w szkołach. Więc 31-wszego sierpnia z kuferkiem, z którym dziadek mój jeszcze z wojny japońskiej wrócił, a w tym kuferku [miałem] parę książek, jedną koszulę, trochę bielizny. Jechałem do Łodzi z Łowicza tzw. towosem, czyli to był wagon towarowy przerobiony na osobowy. Koła.. jak to zwykle, stukały na spojeniach szyn, a mnie się zdawało, że ten wagon śpiewa: „na studia!, na studia!, na studia!" [śmiech].

Niestety coraz rzadziej można spotkać tego typu emocje. Studia często postrzegane są dziś jako niezbędny element kariery zawodowej i traktowane nie jako pasja lecz rodzaj zdobytej „sprawności” i uzyskanych „kompetencji” mających zwiększać atrakcyjność tzw. C.V. Dodajmy - sprawności i kompetencji kształtowanych, w oczekiwaniu nie tylko studentów ale też i zarządzających światem nauki, w trybie pragmatycznych umiejętności. Krótko mówiąc, częściej mamy do czynienia z wyższą szkołą zawodową niż kształceniem uniwersyteckim.

Od szczegółowego przykładu pokazującego zarówno wyobrażenia wykładowców, jak i studentów odnośnie do tego, czym uniwersytet jest, przechodzimy do stwierdzeń bardziej ogólnych ukazujących, czym w rozumieniu opowiadających był/powinien być uniwersytet jako specyficzna forma 
wspólnoty, której celem jest nieustanne poznawanie świata i człowieka. Wypowiedzi zamieszczone w poszczególnych rozdziałach potwierdzają, że opowiadający zwracali uwagę również na instytucjonalny aspekt uniwersytetu, chociażby przez pokazanie jego struktury, podporządkowanie kariery zawodowej wzorcom instytucjonalnym, jednak w wielu wypowiedziach przede wszystkim ukazywano uniwersytet w odniesieniu do idei universitas. Na początku przedstawiamy wypowiedź, której autorka określa, co stanowi jej zdaniem podstawę wspólnoty uniwersyteckiej.

Olga Czerniawska - profesor pedagogiki, która urodziła się w Łodzi, studiowała i pracowała na Uniwersytecie Łódzkim, w ten sposób odpowiada na postawione jej na koniec wywiadu pytanie o rolę i rangę Uniwersytetu Łódzkiego:

Katarzyna Waniek: Zastanawiałam się nad tym, jak w ogóle pani jako osoba, która mieszkała w Łodzi od tylu lat, a Łódź nie jest miastem bardzo osadzonym w historii Polski, jak pani postrzega pozycję Uniwersytetu Łódzkiego wśród polskich uczelni?

Olga Czerniawska: Proszę pani, ja myślę, że uniwersytet to jest instytucja, ale ważni są profesorowie, więc ponieważ szereg profesorów to były wybitne osoby, przede wszystkim pierwszy rektor, profesor Tadeusz Kotarbiński ${ }^{7}$ to była osobowość. No i poszczególni profesorowie: Aleksander Kamiński ${ }^{8}$, osobowość niedoceniona i to w ogóle na skalę Polski, następnie Pawłowscy ${ }^{9}$, rodzina Pawłowskich, nieżyjących, to byli wszystko wybitni uczeni. Także ważni są uczeni. Profesor Szczepański ${ }^{10}$, teraz cała szkoła prehistorii, Jażdżewscy ${ }^{11}$, pani profesor Gąsiorowska ${ }^{12}$, która była historykiem, był profesor

${ }^{7}$ Tadeusz Kotarbiński (1886-1981) - profesor filozofii, logik, współzałożyciel Uniwersytetu Łódzkiego i pierwszy rektor uczelni.

${ }^{8}$ Aleksander Kamiński (1903-1978) - pedagog, harcmistrz i wychowawca młodzieży, zatrudniony na Uniwersytecie Łódzkim do 1950 roku, odsunięty od nauczania z przyczyn ideologicznych, od 1958 roku ponownie zatrudniony.

${ }^{9}$ Ija Lazari-Pawłowska (1921-1994) - etyk i filozof, twórczyni Katedry Etyki na Uniwersytecie Łódzkim; Tadeusz Pawłowski (1924-1996) - logik i filozof. Absolwent i profesor Uniwersytetu Łódzkiego.

${ }^{10}$ Jan Szczepański (1913-2004) - wybitny polski socjolog, urodzony w Ustroniu, przez wiele lat związany z Uniwersytetem Łódzkim (1945-1970), którego był profesorem a później także rektorem, członek PAN.

${ }^{11}$ Konrad Jażdżewski (1908-1985) - archeolog. Studia ukończył w Poznaniu pod kierunkiem prof. Józefa Kostrzewskiego; badacz prehistorii, od 1945 roku profesor Uniwersytetu Łódzkiego. Jego syn - Krzysztof Jażdżewski jest jednym z bohaterów tej książki. Patrz biogramy rozmówców.

${ }^{12}$ Natalia Gąsiorowska-Grabowska (1881-1964) - historyk, badacz dziejów ruchu robotniczego, profesor Uniwersytetu Łódzkiego i Uniwersytetu Warszawskiego, profesor i rektor Wyższej Szkoły Pedagogicznej w Łodzi. 
Dryjski ${ }^{13}$, psycholog, który był uczniem Pawłowa. Potem była taka osobowość niesłychana na psychologii, profesor Natalia Han-Ilgiewicz ${ }^{14}$, przepiękna postać, nadzwyczajna. Także uniwersytet to przecież nie jest gmach, tylko to są ludzie, profesor Radlińska ${ }^{15}$, jej szkoła, powstałe dzięki temu archiwum, które jest w Bibliotece Uniwersyteckiej, pierwsza dyrektor Biblioteki Uniwersyteckiej Helena Więckowska ${ }^{16}$, to są wszystko kluczowe postacie. Profesor Wróblewski ${ }^{17}$ świętej pamięci - wybitny prawnik, też rektor. Profesor Szpunar ${ }^{18}$ na prawie, profesor Rosset ${ }^{19}$, twórca demografii polskiej... To są osoby, które tu były i wyniosły ten Uniwersytet. Też na tych innych wydziałach, np. mojego męża profesor Bernard Zabłocki ${ }^{20}$ to też była firma, profesor Dmochowski ${ }^{21}$ firma, chemik. Profesor Nadolski ${ }^{22}$, świętej pamięci rektor i archeolog, znawca militariów. Także to ludzie i ich dorobek, to, co po sobie zostawili, całe szkoły, to tworzy uniwersytet.

Zatem uniwersytet to przede wszystkim uczeni i ich dorobek (o czym wielokrotnie mogliśmy się przekonać na łamach tej książki właśnie w odniesieniu do wymienionych przez Olgę Czerniawską postaci), to osobowości, wspaniali ludzie reprezentujący różne dziedziny wiedzy. ,[J]akość profesorów, tzn. poziom ich wiedzy, zdolności twórcze, opanowanie naukowego rzemiosła, umiejętności pedagogiczne, ich postawy, pracowitość i intelektualna rzetelność są decydującymi czynnikami jakości szkolnictwa wyższego" "23. Taki sposób postrzegania istoty uniwersytetu odnieść

\footnotetext{
${ }^{13}$ Albert Dryjski (1889-1956) - psycholog, profesor Uniwersytetu Łódzkiego.

${ }^{14}$ Natalia Han-Ilgiewicz (1895-1978) - psycholog i pedagog leczniczy, związana z Katolickim Uniwersytetem Lubelskim.

15 Helena Radlińska (1879-1954) - profesor pedagogiki, stworzyła pedagogikę społeczną w Polsce, w 1945 roku po przyjeździe do Łodzi uruchomiła na Uniwersytecie Łódzkim Zakład Pedagogiki Społecznej. Jej współpracownikami byli m.in. Aleksander Kamiński i Irena Lepalczyk.

${ }^{16}$ Helena Więckowska (1899-1984) - historyk, bibliotekarz, profesor Uniwersytetu Łódzkiego, w latach 1948-1969 dyrektor Biblioteki Uniwersytetu Łódzkiego.

${ }^{17}$ Jerzy Wróblewski (1926-1990) - teoretyk prawa, profesor Uniwersytetu Łódzkiego i jego rektor w latach 1981-1984.

${ }^{18}$ Adam Szpunar (1913-2002) - profesor prawa, specjalista w zakresie prawa cywilnego, w latach 1956-1962 rektor Uniwersytetu Łódzkiego.

${ }^{19}$ Edward Rosset (1897-1989) - demograf, profesor Uniwersytetu Łódzkiego.

${ }^{20}$ Bernard Zabłocki (1907-2002) - mikrobiolog i immunolog, absolwent Uniwersytetu im. Stefana Batorego, od 1945 roku profesor Uniwersytetu Łódzkiego, kierownik Katedry Mikrobiologii UŁ.

${ }^{21}$ Antoni Dmochowski (1896-1983) - profesor biochemii, współtwórca Uniwersytetu Łódzkiego i tzw. łódzkiej szkoły biochemicznej, założyciel Katedry Biochemii na Uniwersytecie Łódzkim, która byłą pierwszą taką placówką w Polsce.

${ }^{22}$ Andrzej Nadolski (1921-1993) - historyk, archeolog, uczeń prof. Konrada Jażdżewskiego, profesor Uniwersytetu Łódzkiego.

${ }^{23}$ Jan Szczepański, Socjologiczne zagadnienie wyższego wykształcenia, PWN, Warszawa 1963.
} 
można do przywołanego już wcześniej rozróżnienia między Gemeinschaft i Gesellschaft w znaczeniu, jakie nadał tym pojęciom Ferdinand Tönnies ${ }^{24}$. Dwa typy zbiorowości - wspólnota i społeczeństwo - są rezultatem dwóch typów więzi społecznej. W przypadku Gemeinschaft więź ta prowadzi do „działania z wewnętrznej potrzeby”, wynikającego z powiązania wszystkich aspektów aktywności i całościowego ujmowania ludzkiego doświadczenia - połączenia sfery prywatnej i zawodowej, uczuciowej i racjonalnej, formalnej i nieformalnej. W odniesieniu do Gesellschaft jednostka działa ze względu na zewnętrzne cele i oczekiwania związane z konkretną rolą społeczną. Koncepcja Tönniesa ma też sens ideologiczny - pokazuje zmianę/zanik w świecie współczesnym określonych wartości społecznych, które w pełni rozwijały się w Gemeinschaft. Otóż uniwersytet, chociaż wpisany w porządek instytucjonalny, zdaniem naszych rozmówców powinien przede wszystkim zachować cechy wspólnoty. Bowiem uczony ,to człowiek, u którego nie ma rozdziału między tym, co robi, nad czym pracuje, a jego życiem osobistym. To nie ktoś, kto prowadzenie badań uważa za swój zawód, sposób zarabiania na życie, jak sugeruje to dziś coraz częściej używany termin «pracownik naukowy»"25. Przedstawiony poniżej komentarz Jolanty Kulpińskiej pokazuje naukowców w takiej właśnie ,„pełnej” roli, opisuje proces tworzenia i wymiany poglądów, który winien dokonywać się dzięki nieustannej dyskusji, wzajemnej inspiracji:

Trzeba powiedzieć, że dla tego naszego pokolenia - choć Janek ${ }^{26}$ [Jan Lutyński] i Tola [Antonina Kłoskowska] ${ }^{27}$ trochę starsi ode mnie, ale byliśmy zawsze w bardzo bliskich kontaktach - to dla nas troska o rozwój socjologii była rzeczywiście jakąś życiową misją, to było dla nas niesłychanie ważne i to kształtowało nas, nasz stosunek do pracy i do nauczania, do badań i dyskusji

${ }^{24}$ Ferdinand Tönnies, Wspólnota i stowarzyszenie, PWN, Warszawa 1988. Od czasów Tönniesa pojawiło się wiele nowych koncepcji ukierunkowanych na bardziej dziś adekwatną analizę, dostosowaną do dynamiki przemian społeczeństwa (po)nowoczesnego. Tym niemniej relacja między Gemeinschaft a Gesellschaft, w naszym odczuciu, bardzo trafnie pozwala uchwycić sens zmian w życiu uniwersyteckim a tym samym zinterpretować intencje naszych rozmówców.

${ }^{25}$ Ryszard Herczyński, Spętana nauka..., s. 12.

${ }^{26}$ Jan Lutyński (1921-1988) - socjolog i metodolog, profesor Uniwersytetu Łódzkiego, Dyrektor Instytutu Socjologii UŁ, kierownik Zakładu Metod i Technik Badań Społecznych. Ekspert i doradca struktur związkowych „Solidarności”. W 1981 r. podczas strajku studenckiego na UŁ pełnił funkcję doradcy komitetu strajkowego.

${ }^{27}$ Antonina Kłoskowska (1919-2001) - socjolog, absolwentka Uniwersytetu Łódzkiego, profesor na Uniwersytecie Łódzkim i Uniwersytecie Warszawskim, w latach 1989-1994 przewodnicząca Polskiego Towarzystwa Socjologicznego. 
wokół tego, co się robi. Dobrze temu sprzyjała też ta Uniwersytecka $3^{28}$, dlatego że tam na czwartym piętrze był taki duży pokój, w którym siedziała Tola, Janek, Zygmunt Gostkowski ${ }^{29}$ - to był taki salon dyskusyjny, tam się przychodziło rzeczywiście o wszystkim dyskutować, musieli nas wyrzucać, jeżeli chcieli pracować. To takie miejsce dyskusji jeszcze trochę trwało po przeprowadzce na Wydział Ekonomiczny, ale jednak układ pokojów był już trochę inny, już to nie działało tak samo, ale jeszcze trochę było. A im lepsze warunki, tym większe jakby rozbicie. Już nie ma tej wspólnej agory, nawet zebrań naukowych instytutu już nie ma, bo się okazuje, że uzyskanie frekwencji jest prawie niemożliwe, bo ludzie mają inne zajęcia. Tych zajęć jest teraz zbyt wiele gdzie indziej. A to jest strata moim zdaniem nie tylko dla instytutu, ale także dla jakiegoś interesującego rozwoju naukowego, bo nie jest się w stanie znać na wszystkim, ale warto wiedzieć, co robią inni, w innych dziedzinach, a tego nie ma teraz wydaje się, ja nad tym dosyć ubolewam.

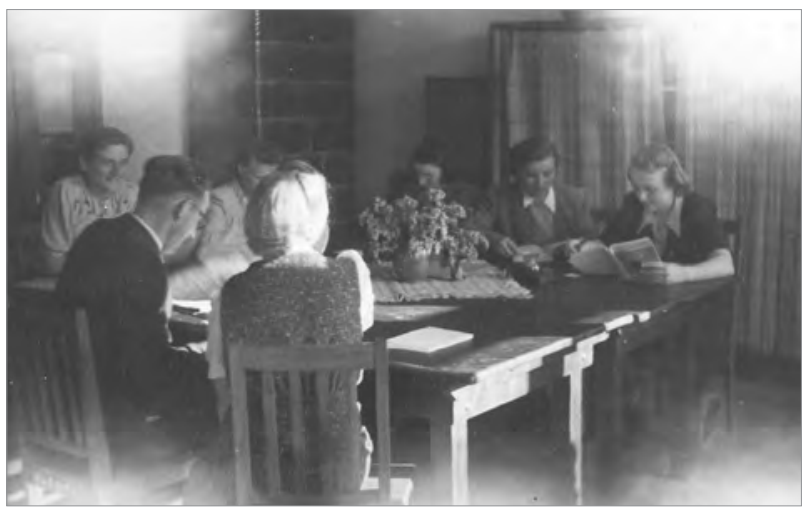

Fot. 77. Uniwersytecka 3 jako przestrzeń spotkan, pracy $i$ dyskusji intelektualnych

Wybrałyśmy ten właśnie cytat, ponieważ w sposób syntetyczny przedstawia wszystkie cechy ówczesnej idei universitas i przyczyny jej zmiany. Współbrzmiący z początkiem powyższej wypowiedzi komentarz przedstawia Herczyński:

Środowisko naukowe okazywało się odporne na próby podporządkowania. Ta odporność wynikała z jego wewnętrznej integracji, a w pierwszych

${ }^{28}$ Przypomnijmy, że mieszcząca się przy ulicy Uniwersyteckiej 3 kamienica w latach tuż powojennych była siedzibą Wydziału Humanistycznego oraz miejscem zamieszkania wielu profesorów Uniwersytetu Łódzkiego. W kolejnych latach swoją siedzibę miały tam różne jednostki uniwersyteckie, obecnie - Instytut Archeologii.

${ }^{29}$ Zygmunt Gostkowski (1926-2014) - profesor socjologii na Uniwersytecie Łódzkim, metodolog pracownik PAN. 
powojennych latach z przywiązania do przedwojennych autorytetów, doświadczeń okresu lat wojny, które nie pozwalały na przekroczenie ethosu środowiska naukowego. (...) Sądzę, że zachowanie ethosu w tym pierwszym okresie w poważnym stopniu określiło dalsze losy środowiska naukowego: ethos okazał się dziedziczny ${ }^{30}$.

Oczywiście nie zawsze to się udawało. Pozytywny przykład łódzkiego środowiska socjologicznego, które przetrwało i rozwijało się, pokazuje, że było to między innymi efektem wskazanych przez Jolantę Kulpińską okoliczności, wśród których na plan pierwszy wysuwa się intelektualny wysiłek nieustannego tworzenia (wbrew niesprzyjającym okolicznościom) społeczności naukowej. Autorka cytatu używa w tym kontekście określenia agora. Wątek ten pojawił się w wielu innych wypowiedziach - nasi rozmówcy podkreślali potrzebę a nawet konieczność swobodnej dyskusji oraz przestrzennie czy symbolicznie określonego miejsca wymiany myśli i poglądów. Paradoksalnie, często to modernizacja, tak skądinąd potrzebna i oczekiwana, doprowadzała, co pokazane zostało w rozdziale VI, do odspołecznienia przestrzeni uczelni. Innym elementem wspomnianym przez Jolantę Kulpińską, modelującym współcześnie kontakty naukowe, jest czas, a w zasadzie jego brak. Przytaczane nie tylko przez naszych rozmówców anegdoty o niekończących się dyskusjach toczących się w pokojach pracowników czy, częściej, zlikwidowanych dzisiaj kawiarenkach, tzw. klubach pracowniczych bądź też podczas drogi z i na uczelnię, przybierają dziś postać mitycznych opowieści. Określenie mityczny jest tu nieprzypadkowe, można bowiem metaforycznie stwierdzić, że dyskusja, wymiana poglądów winny być, i jak wynika choćby z powyższego cytatu, była „aktem” fundacyjnym życia uniwersyteckiego. Podkreśla to również reprezentujący kolejną generację łódzkich profesorów Michał Seweryński, opowiadając o czasie studiów oraz pierwszych latach pracy na uczelni:

Były przyjaźnie oczywiście. Życie bez przyjaźni jest niemożliwe. Były takie osoby, z którymi się przyjaźniłem, uczyłem się bardzo długo, zwłaszcza $\mathrm{z}$ jedną osobą, z jednym kolegą, z którym też przypadkiem spotkaliśmy się na przystanku tramwajowym. A potem zaprzyjaźniliśmy się, uczyliśmy się do różnych egzaminów i tam właśnie toczyliśmy różne dyskusje. To był Andrzej Zębik. Jego żona studiowała socjologię. Nazywa się Koralewicz-Zębik ${ }^{31}$. To tam się odbywały takie dyskusje szczere, odważne, gorące. Bo trudno, żeby

${ }^{30}$ Ryszard Herczyński, Spętana nauka ..., s. 10.

${ }^{31}$ Andrzej Zębik - prawnik; Jadwiga Koralewicz Zębik (ur. 1942) - socjolog, psycholog społeczny, przez wiele lat związana z Uniwersytetem Łódzkim, współtwórczyni i pierwszy rektor Collegium Civitas w Warszawie. 
o pewnych sprawach, które były w czasie wykładów omawiane, par excellence politycznych, nie dyskutować, potem jeszcze na korytarzu jakoś wstępnie, a później tam, gdzie się spotykaliśmy. Te osoby, które miały trochę, powiedzmy otwarcie, szersze spojrzenie na pewne sprawy, dalej sięgające zainteresowania, zaciekawienia, oczywiście prowadziły dyskusje pogłębione, często emocjonalne, ale takie właśnie tworzyło się przez to studenckie środowisko intelektualne, w którym się wykuwały nasze poglądy, opinie, przekonania. Tym bardziej że przecież nie wszyscy mieliśmy jednakowe spojrzenie na życie, na świat. Były te różnice wyznaniowe, środowiskowe zróżnicowania. Kilka takich osób było, z którymi właśnie ten typ wymiany myśli się odbywał. I to jakoś też na pewno było dla nas kształcące. Bo nie było przecież nigdy tak, żeby się z opiniami innych osób w ogóle nie liczyć. Nie w ten sposób, żeby je przejmować, zwłaszcza bezkrytycznie, ale że się je słyszało, trzeba było się z nimi rozprawić wtedy, kiedy była mowa o ważnych sprawach. Więc takie życie oczywiście było też. Potem niektórzy z moich kolegów stali się asystentami, to już byliśmy częściej w kontakcie, mieliśmy powód do tego, żeby prowadzić dyskusje naukowe w tych sprawach, które nas razem interesowały. Oczywiście nie wszystkie te spotkania, rozmowy, dyskusje miały charakter naukowy, światopoglądowy, ideowy, polityczny, ale tych politycznych było dużo. Byli wśród nas działacze politycznie przekonani do tamtejszej rzeczywistości; potem się okazało, że raczej marnie przekonani, że to byli marni koniunkturaliści. No ale wtedy uchodzili za innych. Więc było takie bardzo zdecydowane starcie poglądów, opinii. W takim wieku to się wyraża opinie stanowczo i nawet niezbyt eleganckim językiem. Więc temperatura tych różnych rozmów, dyskusji była dosyć wysoka. To jakoś też pozostaje w pamięci. Do dzisiaj jeszcze z niektórymi się spotykam. Wspominamy tamten czas, tamte rozmowy. Dzisiaj się okazuje, kto miał bardziej dalekowzroczne spojrzenie na pewne sprawy, mylił się albo nie. Wielu z nas już ma przecież właściwie kariery za sobą. Ale tamto środowisko miało też oczywiście jakiś wpływ. Także na moje myśli i wyobrażenia. A gdy już pracowałem na uczelni krąg ludzi, w którym się obracałem, z natury rzeczy był ograniczony do tego uniwersyteckiego kręgu. Na moim wydziale ci inni asystenci, doktoranci - myśmy się czasem spotykali. Sprzyjała temu inicjatywa jednego z profesorów, profesora Jerzego Wróblewskiego ${ }^{32}$, żeby zrobić seminarium, jak ono się nazywało? Seminarium wydziałowe, takie seminarium doktoranckie dla wszystkich asystentów, doktorantów, takie seminarium z prawoznawstwa generalnie, powiedzmy z filozofii prawa. Raz w miesiącu się chyba odbywały takie spotkania i inni profesorowie mieli wykłady o swoich dziedzinach. To było coś niezmiernie pożytecznego: spojrzenie na prawo jako na pewną całość - element systemu. My to na studiach dzielimy

32 Jerzy Wróblewski (1926-1990) - teoretyk prawa, profesor Uniwersytetu Łódzkiego i jego rektor w latach 1981-1984. 


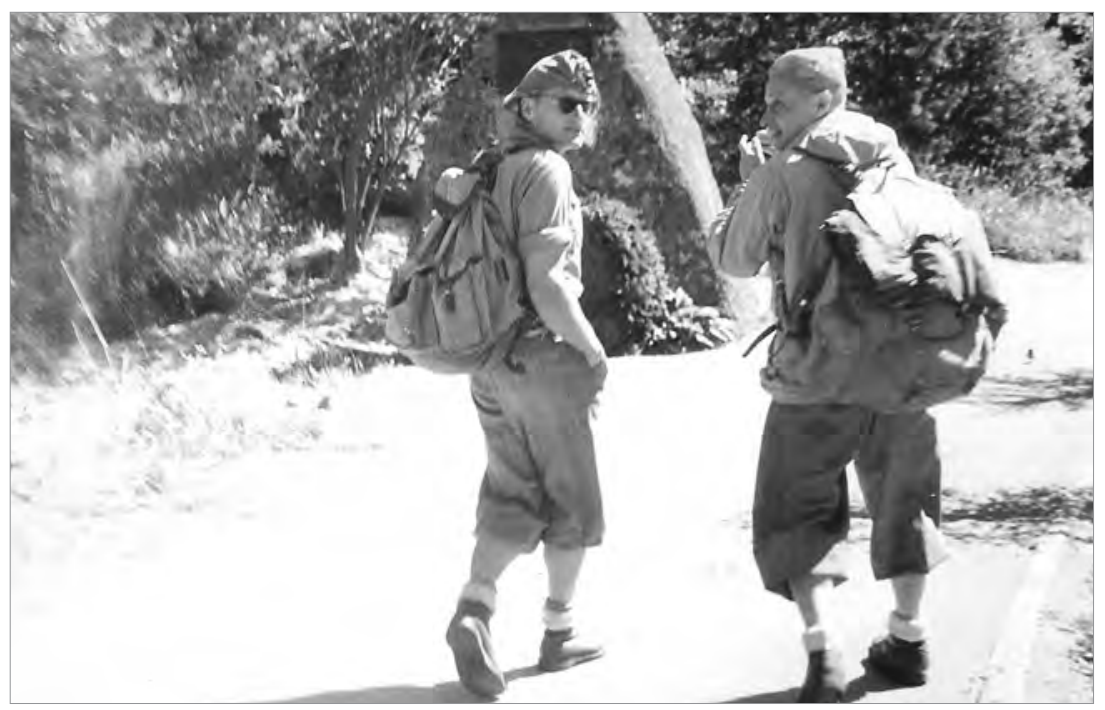

Fot. 78. Wacław Szubert i Jerzy Wróblewski w górach

na kawałki. Trzeba po kawałeczku studentom wyjaśniać i jest trudno dokonać takiej syntezy. Ja do tego zachęcam, mam z nimi zajęcia na czwartym, piątym roku. A tamte były jeszcze lepsze z tego punktu widzenia, że myśmy byli lepiej przygotowani do odbioru takiego wykładu scalającego, uogólniającego, interdyscyplinarnego, bo były takie okazje do ogólniejszych dyskusji w większych czy mniejszych kręgach.

Z kolei Stanisław Liszewski i Wanda Nowakowska przedstawiają problem agory w szerszym spektrum budowania poczucia więzi w rozumieniu Gemeinschaft - wspólnoty osób, które nie tylko wymieniają poglądy, budują środowisko oparte o relacje interdyscyplinarne, ale również przez różnego typu wspólne aktywności budują określone środowisko społeczne.

\section{Stanisław Liszewski:}

Ja myślę, że Uniwersytet Łódzki wciąż ma za mało życia akademickiego, a ja rozumiem to życie jako pewną wspólnotę zarówno pracowników jak i studentów. (...) Ja pamiętam, bo to nawet rektor Nykiel ${ }^{33}$ mi przypomniał, że chyba w pierwszym roku po podjęciu władzy zorganizowaliśmy pierwszego sylwestra uniwersyteckiego, w salach operetki, czyli w Teatrze Muzycznym. I on potem był chyba jeszcze ze dwa razy organizowany, a potem jakoś się to skończyło, nie wiem, nie było chętnych. Teraz rektor Nykiel podjął, pewnie drugi czy trzeci raz organizuje, i bardzo dobrze, bardzo dobrze, bo to też jest taki element ważny. Natomiast ta integracja, z tego co ja obserwowałem, była poprzez

${ }^{33}$ Włodzimierz Nykiel (ur. 1951) - prawnik, specjalista w dziedzinie prawa finansowego, wieloletni wykładowca Uniwersytetu Łódzkiego. Od 2008 roku pełni funkcję rektora tejże uczelni. 
działalność na przykład w różnych klubach pracowniczych, to znaczy, był klub szachistów, matematycy rozwinęli i tam się różne osoby spotykały. Był klub żeglarzy, był klub narciarzy, klub jeżdżących na rowerze, to do dzisiaj chyba jest. I to było z jakimiś dopłatami z funduszu socjalnego. Czyli młode pokolenie się integrowało, młode pokolenie było razem i to tworzyło pewną całość. Jeszcze warto przypomnieć to czego do dzisiaj nie ma, i ja ubolewam nad tym: otóż, jak ja zostałem zatrudniony jako asystent, to nie wolno mi było podjąć zajęć dydaktycznych do czasu zakończenia kursu pedagogizującego. To był kurs organizowany dla asystentów, dla młodych asystentów, w którym były elementy pedagogiki, szkolnictwa wyższego, socjologii szkolnictwa wyższego, i tak dalej, i tak dalej, ale także pewna dyskusja wokół różnych spraw. Przez wiele lat szefową tego kursu, jeśli dobrze pamiętam, była pani profesor Kulpińska ${ }^{34}$. Jakie to miało znaczenie, oczywiście po pierwsze, człowiek, który nie miał na studiach nic wspólnego z dydaktyką mógł się zorientować, o co chodzi. Po drugie, było to spotkanie asystentów z danego rocznika. Rocznie to było około trzydziestu, trzydziestu pięciu takich asystentów i ja pamiętam z tego kursu większość osób, bo to byli potem moi przyjaciele z różnych wydziałów. Więc to jest ta integracja środowiska. Pomijam już korzyści merytoryczne. A powiedziałem, że jestem przerażony, bo dzisiaj wygląda to trochę tak, że przychodzi młody człowiek na studia doktoranckie i przydzielają mu od razu, od pierwszego października zajęcia. Mówią: „Idź na zajęcia!” Ja nie wiem, być może, że ten młody człowiek

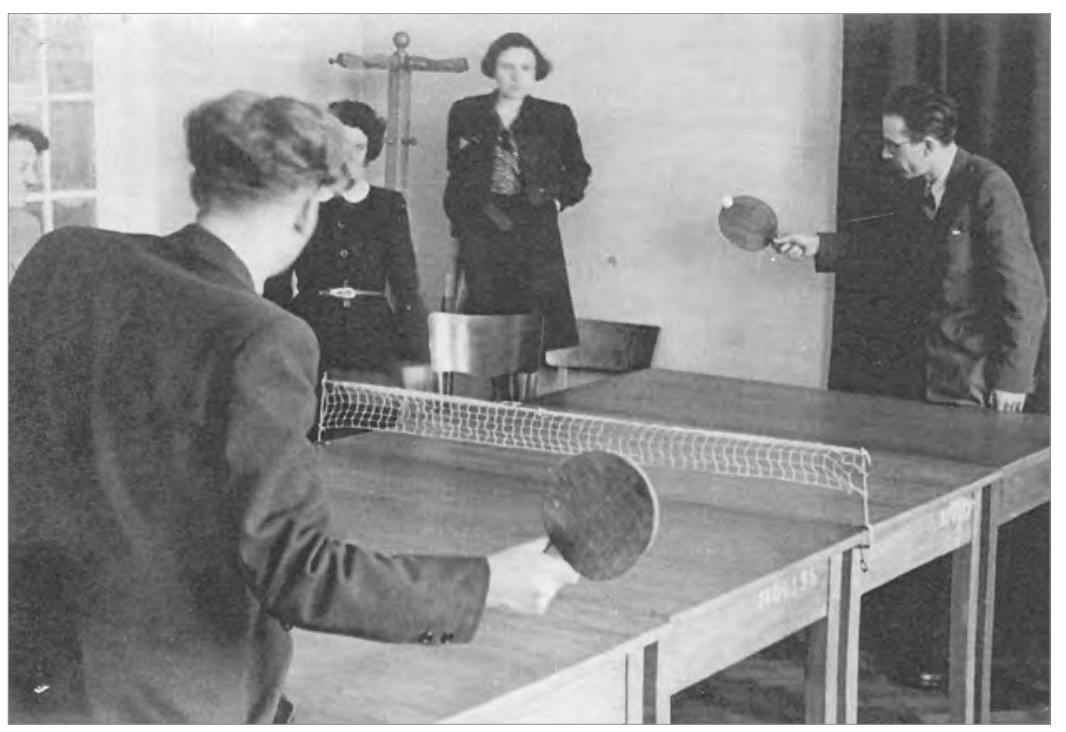

Fot. 79. Rekreacja na Uniwersyteckiej 3. Zygmunt Gostkowski (tyłem), od lewej: Jolanta Kulpińska, Krystyna Lutyńska, Antonina Kłoskowska i Jan Lutyński

${ }^{34}$ Jolanta Kulpińska - patrz biogramy rozmówców. 
jest genialny merytorycznie, ale dydaktycznie to na pewno nawet nie co drugi. Więc uważam, że popełniamy nie tylko błąd, ale i wyrządzamy krzywdę temu młodemu człowiekowi, jak i studentom, którzy mają się uczyć pod jego kierunkiem. To jest jakieś niedopatrzenie i myślę, że tak nie powinno być.

\section{Wanda Nowakowska:}

Kiedy w ramach reaktywowania kierunku historia sztuki otrzymaliśmy siedzibę w zabytkowej kamienicy przy ul Kościuszki 17 pomyślałam sobie, że trzeba będzie w naszej Katedrze urządzać bale! I zaczęliśmy to robić. Odbywały się one regularnie w każdym roku akademickim i były to dwa bale: jeden zimą w karnawale, w naszych salach wykładowych, a drugi wiosną, zwykle w maju, na podwórcu udekorowanym przez naszych studentów według określonych haseł; np. kolor „,anielski”, „błękitny”, „barwy fin de siècle'u”. Chciałam, żeby jednoczyły one studentów i nas czyli kadrę akademicką, tworzyły inną niż ściśle oficjalną więź i myślę, że mi się to udało. Było wino, studentki przygotowywały pomysłowe i pyszne sałatki, a bawiono się przy muzyce ,adapterowej” a czasem ktoś grał na fortepianie, który był w Katedrze. Tańczono i śpiewano do białego rana. Nigdy też nie było żadnej awantury, zresztą była taka zasada, że

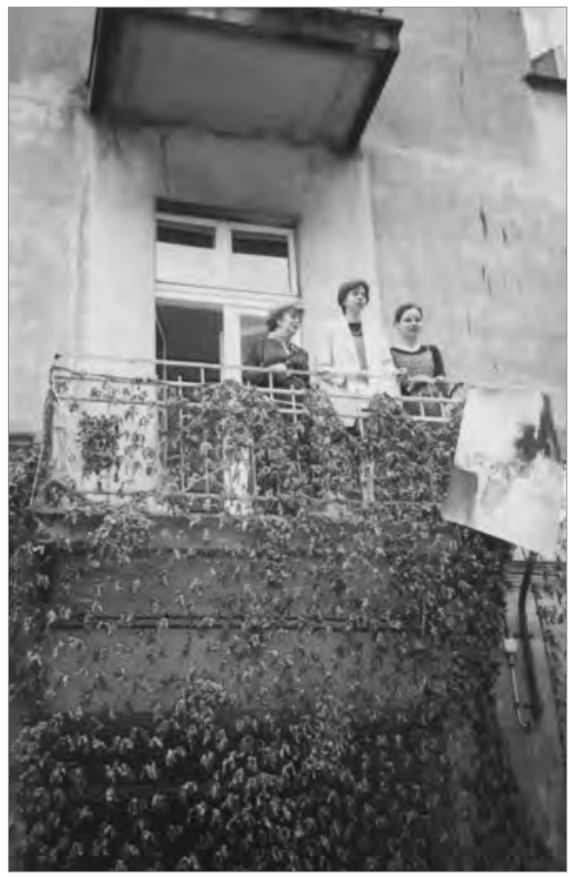

Fot. 80. „Zdjęcie na balkonie” Wandy Nowakowskiej. Bal wiosenny w gmachu przy ulicy Kościuszki 17 każdy student mógł przyprowadzić tylko jedną osobę do pary, z którą odpowiadał. Stosy zdjęć uwiecznily te imprezy. Wiosną na podwórcu było jeszcze smażenie kiełbasek, toczenie piwa z beczki i moje przemówienia na balkonie. To były świetne imprezy, naprawdę integrujące tą naszą społeczność, ale po moim odejściu z Katedry żaden z moich dwóch następców już ich nie organizował. No cóż, ja zawsze lubiłam bale, kochałam tańczyć i dlatego też chciałam radość bawienia się razem przekazać „moim dzieciom”, bo tak w cichości ducha nazywam moich studentów nie mając własnych dzieci. Bale nie przetrwały ale przetrwała tradycja opłatkowa. Zawsze w grudniu, przed zbliżającym się Bożym Narodzeniem organizowane były w Katedrze, i są do dziś, spotkania opłatkowe. Przy choince, z zapalonymi lampkami dzielimy się opłatkiem - pracownicy i nasi studenci. Składamy sobie życzenia i śpiewamy kolędy. Jestem zawsze zapraszana przez 
moich następców i niezmiernie sobie cenię ten gest, tym bardziej, że po części „oficjalnej” ze studentami, spotykamy się z pracownikami na wieczerzy ,,przed wigilijnej" i rozmawiamy o sprawach katedry i własnych.

Dalej Wanda Nowakowska wraca także do swojej działalności na rzecz całej społeczności akademickiej.

W latach 1968-1971 pełniłam funkcję przewodniczącej Komisji Kulturalno-Oświatowej w Radzie Zakładowej Uniwersytetu, której przewodniczył późniejszy rektor profesor Romuald Skowroński ${ }^{35}$. Wiceprzewodniczącymi byli profesor Waldemar Michowicz ${ }^{36}$ i docent Zdzisław Batorowicz ${ }^{37}$, których ośmielam się zaliczyć do grona bliskich, dziś już nieżyjących przyjaciół. Niedawno znalazłam w swoim archiwum obszerne sprawozdanie z tej swojej działalności - liczące osiemnaście stron! - i stwierdziłam w zdumieniu jak wielu członków, dziś znakomitych profesorów, działało w niej i jak dużą rolę odgrywały organizowane pod jej auspicjami akcje, jak choćby spotkanie Klubowe z Tadeuszem Różewiczem czy Gustawem Holoubkiem ${ }^{38}$. Rok pracowałam nad tym żeby go tu ściągnąć... Były też rewie mody z „Telimeny” w święto kobiet ${ }^{39}$ w naszej auli, które otwierał prorektor, było działanie klubów brydżowego i szachowego, wystawy fotografii profesora Hereźniaka ${ }^{40}$, cykle filmów archiwalnych a także choinki dla dzieci i bale sylwestrowe w Bibliotece Uniwersyteckiej. To wszystko cieszyło się dużym powodzeniem - pamiętam te thumy na spotkaniach klubowych no i to przede wszystkim integrowało społeczność akademicką. Teraz jak patrzę na to sprawozdanie to rodzi się refleksja na temat wartości pracy społecznej w życiu i aktywności pracownika naukowego. I tak sobie myślę, że i dzisiaj gotowa jestem się pod tym podpisać, chociaż wiem jak bardzo nie przystaje to do naszych czasów.

Jeśli dokładnie przyjrzeć się przytoczonej argumentacji, okazuje się, że nie chodzi tylko o budowanie relacji na gruncie towarzyskim, lecz o całościowe stworzenie środowiska akademickiego jako wspólnoty uczonych i studentów

\footnotetext{
${ }^{35}$ Romuald Skowroński - patrz biogramy rozmówców.

${ }^{36}$ Waldemar Michowicz (1929-2005) - historyk, specjalizował się w historii dyplomacji, profesor Uniwersytetu Łódzkiego.

${ }^{37}$ Zdzisław Batorowicz (1912-1993) - geograf, specjalizował się w geografii ekonomicznej, autor podręczników szkolnych, docent UŁ.

38 Tadeusz Różewicz (1921-2014) - poeta, dramaturg, pisarz; Gustaw Holoubek (1923-2008) wybitny aktor teatralny i filmowy.

${ }^{39}$ Dom Mody Telimena jest jednym z najstarszych domów mody w Polsce, założony w Łodzi w 1958 roku istnieje do dziś. W czasach PRL-u kreacje z Telimeny uznawane były za wyjątkowo eleganckie, gustowne i ekskluzywne. Pokaz w „święto kobiet” czyli 8 marca wpisywał się doskonalę w stylistykę tamtych lat.

${ }^{40}$ Janusz Hereźniak (ur 1935) - biolog, geobotanik, ekolog, dendrolog, profesor kierownik Katedry Geobotaniki i Ekologii Roślin UŁ.
} 
zawsze gotowych do podjęcia dyskusji, ale też tworzących więzi społeczne dające podstawę połączenia sfery profesjonalnej z prywatną, formalnej z nieformalną, Gemeinschaft z Gesellschaft. To zaś buduje poczucie wzajemnej odpowiedzialności międzypokoleniowej oraz międzystatusowej - uniwersytet to nie tylko uczeni, ale też kształceni przez nich studenci, zaś środowisko naukowe nie jest tylko luźnym zbiorem ,pracowników naukowych, ale [to] połączona różnymi więzami społeczność. Więzami poziomymi, ze współczesnymi sobie uczonymi, więzami pionowymi - ze swoimi bezpośrednimi i oddalonymi w czasie poprzednikami" ${ }^{\prime 1}$. Siła i formacyjny charakter tej relacji został przedstawiony w rozdziale I i II. W bardzo ciekawy sposób charakteryzuje ją Stanisław Liszewski pokazując, że idea universitas musi rozwijać się w oparciu o kultywowanie „więzów pionowych” kształtujących tożsamość środowiska oraz odnościć się do zasady harmonijnego łączenia tradycji ze współczesnością. Profesor Liszewski wyraża tę myśl, opisując jedną z form działalności Łódzkiego Towarzystwa Naukowego ${ }^{42}$. Jest to stowarzyszenie łączące przedstawicieli wszystkich łódzkich uczelni.

Jedną z takich rzeczy eksperymentalnych, którą zrobiliśmy i którą dyskutowaliśmy przez dwa lata, gdyż były spory w naszym kręgu, jest konwersatorium, które się nazywa „Szkoły naukowe - zespoły naukowe”. Idea była taka, i tego dotyczył spór, że część naszych kolegów uważa, że najważniejszym elementem w twórczości jest sam człowiek, czyli jedna osoba, że naukowiec tworzy jednoosobowo, on jest najważniejszy, najistotniejszy. Ale jest druga grupa ludzi, która uważa, że dla budowania pewnych rzeczy jest potrzebna szkoła, czyli jest potrzebny mistrz, uczniowie, problem, metody i tak dalej. I zanim doszliśmy do porozumienia, że w nazwie będą i szkoły, i zespoły naukowe, minęły dwa lata. Ale od dwóch lat mamy trzy, cztery spotkania rocznie, gdzie zapraszamy taką szkołę czy taki zespół koleżanek i kolegów z różnych dziedzin. Byli już językoznawcy, mikrobiolodzy, immunolodzy, byli też naukowcy z Politechniki. Teraz się zasadzamy na Szkołę Filmową Hasa ${ }^{43}$, na zespół filmowy. Zaproszeni przedstawiciele szkół przygotowują opracowania na temat działalności takiej szkoły czy mistrza, najpierw referatowe, a potem my [ $\mathrm{\ell TN}]$ to wydajemy. Z reguły ten mistrz już nie żyje, więc jest łatwiej o nim mówić. I to jest pasjonujące, bo byłem na takim zebraniu, gdzie szkoła, która liczyła sześćdziesiąt pewnie osób, w większości profesorów, którzy się pokłócili o to, który był bliższy tego mistrza, cały czas jeszcze o niego rywalizując. Takie spotkania przynoszą

${ }^{41}$ Ryszard Herczyński, Spętana nauka ..., s. 10.

${ }^{42}$ Łódzkie Towarzystwo Naukowe (ŁTN) powstało w 1936 roku jako Towarzystwo Przyjaciół Nauki w Łodzi; aktualną nazwę nosi od 1946 roku. Zob. www.ltn.lodz.pl (15.06.2015).

${ }^{43}$ Krakowska Szkoła Filmowa im. Jerzego Hasa - niepubliczna uczelnia wyższa istniejąca od 2007 roku. 
naprawdę kapitalne efekty, bo ujawniają powstawanie Łodzi akademickiej. To jest własnie pokazanie tej Łodzi akademickiej.

Jako podsumowanie zarysowanego przez naszych rozmówców obrazu może posłużyć wypowiedź Zbigniewa Bokszańskiego, który umieszcza swoją refleksję w kontekście własnych doświadczeń uczonego współtworzącego łódzki Instytut Socjologii. Podkreślanie walorów własnego środowiska przekładające się na atmosferę pracy i możliwości rozwoju, sugeruje, że przedstawiony poniżej pozytywny obraz nie musi być regułą. Potraktujmy ów opis jako dobry przykład budowania wspólnoty akademickiej i wzajemnych relacji, który zapewne stanowi wypadkową rozpoczętego tuż po założeniu Uniwersytetu procesu kształtowania i walki o utrzymanie środowiska socjologicznego w naszej uczelni:

Mówiąc wprost, mogę uważać się za szczęśliwego człowieka, ponieważ przyszło mi pracować i spędzić bardzo znaczną część życia w gronie ludzi niesłychanie życzliwych, przyzwoitych, porządnych ludzi, a do tego normalnych psychicznie. Patrząc z perspektywy tych przecież bardzo wielu lat, mogę mówić tylko o życzliwości bądź życzliwej neutralności, bądź poparciu. Natomiast nigdy się tak nie zdarzyło, nic mi do głowy w tej chwili nie przychodzi, żebym kiedykolwiek się czul, nie wiem, dyskryminowany, skrzywdzony, odepchnięty. Absolutnie nic. To było coś, co niesłychanie sporo energii pozwoliło zaoszczędzić, bo nic tak człowieka nie niszczy, nie marnuje czasu i energii, uwagi, jak jakieś drobne sprawy i scysje natury towarzysko-prestiżowej, jakieś różnice, które są zupełnie niepotrzebne. To był zespół zupełnie wyjątkowych z tego punktu widzenia ludzi. Bardzo przyzwoicie i wysoko notowanych pod względem naukowym i pod względem po prostu ludzkim. Myślę, że to był wpływ i profesora Chałasińskiego, i profesora Szczepańskiego ${ }^{44}$, którzy stworzyli ten zespół i on się jakoś reprodukował. To był jakiś kod genetyczny [śmiech], który chyba się w kolejnych pokoleniach jakoś odtwarzał. Nie powiem, iż by nie było, nie wiem, pięciu czy dziesięciu drobnych scysji korytarzowych. Ktoś komuś nie oddał książki albo zagubił, albo nie zrobił na czas jakichś wywiadów. Ale to były drobiazgi zupełne, bez znaczenia. Natomiast ja widzę niesłychanie jasny obraz tego wszystkiego, z tymi postaciami moich kolegów starszych zwłaszcza i młodszych zresztą też. Po prostu ludzie sobie pomagali i to niekiedy bardzo pomagali, a o przeszkadzaniu zupełnie nie było mowy. Absolutnie. Żadne prestiżowe ani ambicjonalne względy. Ja przynajmniej o niczym takim pani powiedzieć nie mogę. I to uważam za ogromny swój, choć niesprowokowany przeze mnie sukces. To po prostu zrządzenie losu [śmiech]. Szczęśliwe bardzo.

${ }^{44}$ Józef Chałasiński (1904-1979) - profesor socjologii, jeden z założycieli Uniwersytetu Łódzkiego i rektor tej uczelni w latach 1949-1952. Jan Szczepański - Zob. przypis 10 w tym rozdziale. 
W kontekście tego cytatu powróćmy raz jeszcze do pytania: ,jak to (było) możliwe?” i ,jak jest dzisiaj?”. Niewątpliwie uniwersytet, tak jak i inne instytucje podlega szerszym procesom, obejmującym nie tylko świat akademii. Aby je opisać, świadomie nie odnosimy się tu do współczesnych koncepcji stawiających diagnozę dla społeczeństwa (po)nowoczesnego. Odwołanie się w naszych rozważaniach do, ktoś powiedziałby, nieco już dziś anachronicznej koncepcji Gemeinschaft i Gesellschaft dobrze w naszym odczuciu ilustruje kierunek zmian całej struktury społecznej. Z tej perspektywy universitas zaczyna się jawić jako równie przestarzały sposób podejścia do współczesnych realiów wyższej uczelni. Można też stwierdzić, że, nieco paradoksalnie, marzenia Józefa Chałasińskiego, jednego z założycieli naszej uczelni, o uniwersytecie egalitarnym, otwartym dla wszystkich, niwelującym różnice klasowe, ziściły się dopiero w uczelni kierowanej coraz mocniej neoliberalnymi regułami kalkulacji ekonomicznej. Masowość edukacji jest opłacalna dla uczelni. Wiedza przestaje być postrzegana jako przywilej i forma wtajemniczenia. Opisany przez Karla Mannheima proces dedystancjacji - zniwelowania dystansu wobec elit w wyniku umasowienia wielu procesów społecznych, w tym i edukacji - pokazuje nieuniknione koszty demokratyzacji. Rozmywają się granice, dewaluują wymagania stawiane studentom, zmieniają kryteria jakości pracy naukowej. Pozytywnym aspektem tego procesu jest wyższy wskaźnik osób z wyższym wykształceniem. Pozostają jednak pytania: Jak wykształcenie uniwersyteckie jest dziś postrzegane? Czy stanowi jeszcze formę nobilitacji społecznej? A przede wszystkim, jak jest definiowane? Z tej perspektywy universitas osuwa się w sferę mitu i legendy o dawnym sposobie uprawiania nauki. Czy można jeszcze powstrzymać ów proces zmiany, który pod modnym dziś hasłem modernizacji prowadzi do swoistej rewolucji kulturowej? Dlaczego nasi rozmówcy, zachowując tak dobrą pamięć o swoich mistrzach, tak mało mogli/chcieli powiedzieć o swoich uczniach, którzy dzisiaj zapewne kształtują życie naukowe i instytucjonalne uniwersytetu? Czy mamy dzisiaj potrzebę posiadania mistrza, czy mistrz ma czas na rozmowę z uczniem? Czy poszukujemy agory dla wymiany myśli? To pytania, które kierujemy do nas samych i do Czytelnika.

Zdajemy sobie sprawę, że przedstawione tu dylematy dość krytycznie odnoszą się do współczesności, którą również i my tworzymy. Nie oznacza to, iż deprecjonujemy procesy demokratyzacji i modernizacji uczelni. Doceniamy, że dane jest nam żyć i pracować w czasach, gdy przedstawione w opowieściach obrazy upolitycznienia rzeczywistości, wymuszanych kontrybucji wobec panującej, jedynie słusznej ideologii, siermiężne 
warunki pracy, należą do przeszłości. Nieograniczony dostęp do publikacji, możliwość wyjazdów na konferencje, stypendia, kwerendy, praca w nowoczesnych, dobrze wyposażonych budynkach to niewątpliwie pozytywne doświadczenia współczesności. Niepokój budzi jednak cena, jaką trzeba (?) za to płacić, a jest nią zanikanie idei universitas. Nasze spotkania i wysłuchane opowieści były dla nas bardzo pouczające. I nie jest tak, że współczesny obraz uniwersytetu został skonstruowany pod wpływem krytycznego spojrzenia naszych rozmówców na teraźniejszość. Właściwe nie tak często, zwłaszcza ci, którzy nie biorą już czynnego udziału w życiu akademickim, dokonywali deprecjonujących współczesność porównań. Ów krytyczny obraz został skonstruowany przez nas na zasadzie kontrastu między przedstawionymi nam wspomnieniami a współczesnością, której jesteśmy teraz częścią. Jest to więc krytyka skierowana również wobec nas samych. Skoro, jak powiedziała jedna z naszych rozmówczyń: „Uniwersytet to jest instytucja, ale ważni są ludzie i ich dorobek, to co po sobie zostawili, całe szkoły, to tworzy uniwersytet", to odpowiedź na pytanie, jaki będzie uniwersytet za kolejnych dziesięć, dwadzieścia, trzydzieści lat, zależy od połączenia jego tradycji i stanowionej przez nestorów naszej uczelni historii ze współczesnością - krótko mówiąc, zależy od nas.

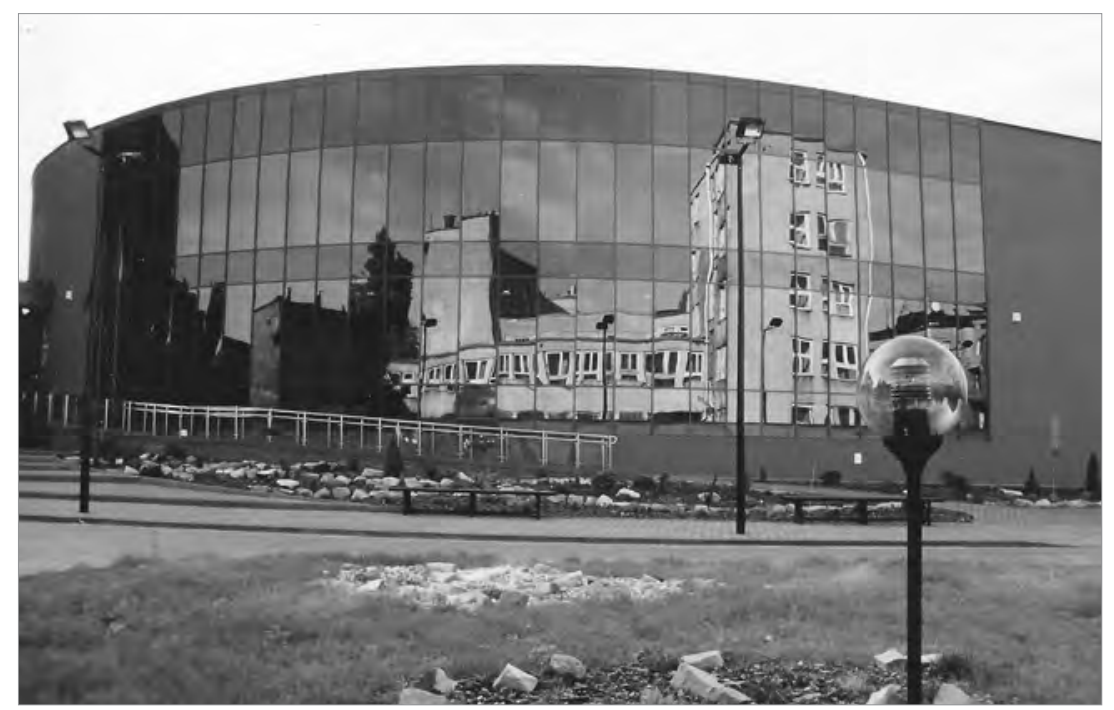

Fot. 81. Przeszłość przegląda się w przyszłości. Wydziat Ekonomiczno-Socjologiczny 


\section{Bibliografia}

Antonowicz Dominik: Od korporacji do instytucji, „Zagadnienia Naukoznawstwa” 2002, nr 4, s. 517-537.

Archiwum Ośrodka KARTA, Ustalenia negocjacyjne, postulaty - wersja robocza [nazwa red.], 1981, www.dlibra.karta.org.pl/dlibra/publication?id=14214\&ta $b=3$ (18.02.2104).

Assmann Jan, Pamięć kulturowa: pismo, zapamiętywanie i polityczna tożsamość w cywilizacjach starożytnych, Wydawnictwo Uniwersytetu Warszawskiego, Warszawa 2008.

Baczko Bronisław, Rousseau: samotność i wspólnota, PWN, Warszawa 1964.

Baranowski Bohdan (red.), Uniwersytet Łódzki: historia, teraźniejszość, perspektywy, Wydawnictwo Uniwersytetu Łódzkiego, Łódź 1978.

Baranowski Bohdan, Uniwersytet Łódzki 1945-1980, Wydawnictwo Uniwersytetu Łódzkiego, Łódź 1980.

Baranowski Bohdan, Pierwsze lata Uniwersytetu Łódzkiego: 1945-1949, Wydawnictwo Uniwersytetu Łódzkiego, Łódź 1985.

Baranowski Bohdan, Baranowski Krzysztof, Trudne lata Uniwersytetu Łódzkiego: 19491956, Wydawnictwo Uniwersytetu Łódzkiego, Łódź 1990.

Biały Kamila, Przemiany współczesnego uniwersytetu. Od idei von Humboldta do modelu uczelni przedsiębiorczej. Wydawnictwo Uniwersytetu Łódzkiego, Łódź 2011.

Bołtuć-Staszewska Irena i in., Tranzytem przez Łódź, Wydawnictwo Łódzkie, Łódź 1964.

Bourdieu Pierre, Dystynkcja: społeczna krytyka władzy sądzenia, thum. Piotr Biłos, Wydawnictwo Naukowe SCHOLAR, Warszawa 2005.

Buber Martin, Ja i Ty: wybór pism filozoficznych, tłum. i wstęp Jan Doktór, PAX, Warszawa 1992.

Chałasiński Józef, Młode pokolenie chłopów, t. 1-4, Ludowa Spółdzielnia Wydawnicza, Warszawa 1938.

Chałasiński Józef, Przeszłość i przyszłość inteligencji polskiej, Instytut Literacki, Rzym 1947.

Chałasiński Józef, Społeczna genealogia inteligencji polskiej, Czytelnik, Kraków 1947.

Chróścielewski Tadeusz, W miejsce zleconego wstęu, [w:] Irena Bołtuć-Staszewska i in., Tranzytem przez Łódź, Wydawnictwo Łódzkie, Łódź 1964.

Connelly John, The Foundations of Diversity: Communist Higher Education Policies in Eastern, 1945-1955 Europe, [w:] Kristie Macrakis, Dieter Hoffmann (red.), Science under Socialism: East Germany in Comparative Perspective, Harvard University Press, Cambridge, MA 1999.

Connelly John, Polish Universities and State Socialism 1944-1968 [w:] Connelly J., Grüttner M. (red.), Universities under Dictatorship, Pennsylvania State University Press, University Park 2005. 
Connelly John, Zniewolony uniwersytet: sowietyzacja szkolnictwa wyższego w Niemczech wschodnich, Czechach i Polsce 1945-1956, thum. Witold Rodkiewicz, Instytut Historii Nauki, Warszawa 2014.

Czyżewski Andrzej, „Niemniej to jest farsa, która może być groźna”: reakcja aparatu partyjno-państwowego, władz uczelnianych oraz NSZZ ,, Solidarnośc” na strajk łódzkich studentów, [w:] Krzysztof Lesiakowski (red.), Lódzki strajk studencki. Styczeńluty 1981: spojrzenie po latach, Wydawnictwo Uniwersytetu Łódzkiego, Łódź-Warszawa 2014.

Czyżewski Marek, Repatrianci i wypędzeni: wzajemne uprzedzenia w relacjach autobiograficznych, [w:] Marek Czyżewski, Andrzej Piotrowski, Alicja Rokuszewska-Pawełek (red.), Biografia a tożsamość narodowa, wyd. 2, Katedra Socjologii Kultury, Łódź 1997.

Dylik Jan, Dylik Zygmunt, Nauka: powstanie i organizacja tódzkiego ośrodka naukowego, [w:] Edward Rosset (red.), Łódź w latach 1945-1960, Wydawnictwo Łódzkie, Łódź 1962.

Friszke Andrzej, Spór o PRL w Trzeciej Rzeczpospolitej, „Tygodnik Powszechny” 2002, nr 16, 21 kwietnia 2002.

Herczyński Ryszard, Spętana nauka: opozycja intelektualna w Polsce 1945-1970, Wydawnictwo Naukowe Semper, Warszawa 2008.

Hirszowicz Maria, Pułapki zaangażowania: intelektualiści w stużbie komunizmu, Scholar, Warszawa 2001.

Hübner Piotr, I Kongres Nauki Polskiej jako forma realizacji założeń polityki naukowej państwa ludowego, Zakład Narodowy im. Ossolińskich, Wrocław 1983.

Hübner Piotr, Kotarbiński versus Chałasiński, „Forum Akademickie” 2011, nr 4, forumakademickie.pl/fa/2011/04/kotarbinski-versus-chalasinski/ (23.09.2014).

Jakubowski Zbigniew, Ludzie matematyki łódzkiej, Łódzkie Towarzystwo Naukowe, Łódź 2012.

Kita Jarosław, Profesorowie Uniwersytetu Łódzkiego w latach 1945-1994: pro memoria, Wydawnictwo Uniwersytetu Łódzkiego, Łódź 1995.

Kita Jarosław, Uniwersytet Łódzki w latach 1945-1995, Wydawnictwo Uniwersytetu Łódzkiego, Łódź 1996.

Kita Jarosław, Pytlas Stefan, W stużbie nauki. Profesorowie Uniwersytetu Łódzkiego w latach 1945-2004: pro memoria, Wydawnictwo Uniwersytetu Łódzkiego, Łódź 2005.

Kołakowski Leszek, Świadomość religijna i więź kościelna, PWN, Warszawa, 1965.

Kołodziej Karolina, Maciej Kronenberg, 70 lat Uniwersytetu Łódzkiego w przestrzeni miejskiej Łodzi (1845-2015), Wydawnictwo Uniwersytetu Łódzkiego, Łódź 2015.

Kmieciński Jerzy, Sprzęt rybacki i organizacja rybołówstwa w Gdańsku w XII i XIII w. w świetle prac wykopaliskowych w latach 1948-1951, ,Studia Wczesnośredniowieczne" 1955 , t. 3.

Krajewska Wanda Małgorzata, 50 lat biologii i nauk o ziemi w Uniwersytecie Eódzkim: 1945-1995, Wydawnictwo Uniwersytetu Łódzkiego, Łódź 1995.

Krasiewicz Bolesław, Odbudowa szkolnictwa wyższego w Polsce Ludowej w latach 19441948, Zakład Narodowy im. Ossolińskich, Wrocław 1976.

Kuciński Julian, Czterdzieści lat Wydziału Ekonomiczno-Socjologicznego Uniwersytetu Łódzkiego 1965-2005, Wydawnictwo Uniwersytetu Łódzkiego, Łódź 2006. 
Kuroń Jacek, Wiara $i$ wina: do i od komunizmu, Niezależna Oficyna Wydawnicza, Warszawa 1989.

Lemann-Zajiček Jolanta (red.), Polska kultura filmowa do 1939 roku, Państwowa Wyższa Szkoła Filmowa, Telewizyjna i Teatralna, Łódź 2003.

Lesiakowski Krzysztof, Łódź akademicka - powstanie, tendencje rozwojowe, znaczenie (1945-1980), [w:] Krzysztof Lesiakowski (red.), Lódzki strajk studencki. Styczeń-luty 1981: spojrzenie po latach, Wydawnictwo Uniwersytetu Łódzkiego, Łódź-Warszawa 2014.

Lesiakowski Krzysztof, Zrewoltowana Łódź akademicka 1945-1980, [w:] Krzysztof Lesiakowski (red.), Łódzki strajk studencki. Styczeń-luty 1981: spojrzenie po latach, Wydawnictwo Uniwersytetu Łódzkiego, Łódź-Warszawa 2014.

Lévi- Strauss Claude, Myśl nieoswojona, tłum. Andrzej Zajączkowski, Wydawnictwo KR, Warszawa 2001.

Lewicki Bolesław, O filmie: wybór pism, red. Ewelina Nurczyńska-Fidelska, Bronisława Stolarska, Wydawnictwo Uniwersytetu Łódzkiego, Łódź 1995.

Lewicki Bolesław, Wprowadzenie do wiedzy o filmie, Zakład Narodowy im. Ossolińskich, Wrocław 1964.

Lubaś Marcin, Lévi-Strauss, etnocentryzm i zróżnicowanie kulturowe, [w:] Ewa Nowicka, Małgorzata Głowacka-Grajper (red.), Antropolog i jego magia: współczesne inspiracje twórczościa Claude’a Lévi-Straussa, Nomos, Kraków 2013.

Lutyńska Krystyna, Pozycja społeczna urzędników w Polsce Ludowej: tódzcy urzędnicy w świetle badań socjologicznych, Zakład Narodowy im. Ossolińskich., Wrocław 1965.

Lutyński Jan, Ewolucjonizm w etnologii anglosaskiej a etnografia radziecka, Zakład Narodowy im. Ossolińskich, Wrocław 1956.

Lutyński Jan, Nauka i polskie problemy: komentarz socjologa, słowo wstępne Krystyna Lutyńska, Państwowy Instytut Wydawniczy, Warszawa 1990.

Lutyński Jan (red.), Strajk studentów łódzkich '81 w świetle analiz socjologicznych: praca zbiorowa, Wydawnictwo UŁ, Łódź 2010.

Macrakis Kristie, Hoffmann Dieter (red.), Science under Socialism: East Germany in Comparative Perspective, Harvard University Press, Cambridge, MA 1999.

Mannheim Karl, Essays on Sociology of Knowledge, Oxford University Press, New York 1952.

Miszalska Anita, Kowalewicz Kazimierz, Niepokojąca współczesność: zbiór, Instytut Socjologii Uniwersytetu Łódzkiego, Łódź 2001.

Mucha Janusz, Keen Mike F. (red.), Autobiografie czasu transformacji: socjologowie Europy Środkowej $i$ Wschodniej, tłum. Janusz Mucha i in., IFiS PAN, Warszawa 2006.

Nowak-Dziemianowicz Mirosława, Edukacja $i$ wychowanie w dyskursie nauki i codzienności, Impuls, Kraków 2012

Nowinowski Sławomir M. (red.), Marzec ‘68 w Łodzi, IPN, Łódź 2010.

Pieter Józef, Biografia ogólna. Wstęp do nauki o życiu ludzkim. Wiedza-Zawód-Kultura, Kraków 1946.

Piskała Kamil, Zysiak Agata, Świątynia nauki, fundament demokracji czy fabryka specjalistów?, „Praktyka Teoretyczna” 2013, nr 3, www.praktykateoretyczna.pl/PT_ nr9_2013_Po_kapitalizmie/11.Piskala,Zysiak.pdf(15.04.2015) 
Pleskot Patryk, Rutkowski Tadeusz P. (red.), Spętana akademia: Polska Akademia Nauk w dokumentach władz PRL, IPN, Warszawa 2009.

Puś Wiesław, Zarys historii Uniwersytetu Łódzkiego 1945-2015, Wydawnictwo Uniwersytetu Łódzkiego, Łódź 2015.

Redlich Shimon, Na rozdrożu. Żydzi w powojennej Łodzi 1945-1950, Wydawnictwo IPN, Łódź 2012.

Schaff Leon, Proces karny w Polsce Ludowej, PWN, Warszawa 1952.

Schütze Fritz, Analiza biograficzna ugruntowana empirycznie w autobiograficznym wywiadzie narracyjnym: jak analizować wywiady narracyjne, [w:] Kaja Kaźmierska (red.), Metoda biograficzna w socjologii: antologia tekstów, Nomos, Kraków 2012.

Schütze Fritz, Pressure and Guilt: War Experiences of a Young German Soldier and Their Biographical Implications (Part 1), „International Sociology” 1992, nr 7.

Schütze Fritz, Trajektorie cierpienia jako przedmiot badań socjologii interpretatywnej, „Studia Socjologiczne” 1997, nr 1.

Sosnowska Joanna, Miejska Szkoła Pracy jako przykład nowatorstwa pedagogicznego w szkolnictwie powszechnym międzywojennej Łodzi, [w:] Jolanta Bonar, Anna Buła (red.), Poznać - zrozumieć - doświadczyć: konstruowanie wiedzy nauczyciela wczesnej edukacji, Oficyna Wydawnicza „Impuls”, Kraków 2013.

Stobiecki Rafał, Historiografia PRL: ani dobra, ani madra, ani piękna... ale skomplikowana. Studia i szkice, Wydawnictwo Trio, Warszawa 2007.

Szczepański Jan, Dzienniki z lat 1945-1968, Ustroń 2013

Szczepański Jan, Problemy i perspektywy szkolnictwa wyższego w Polsce, Wiedza Powszechna, Warszawa 1968.

Szczepański Jan, Socjologiczne zagadnienie wyższego wykształcenia, PWN, Warszawa 1963.

Szenajch Piotr, Ponadindywidualne uwarunkowania ,,talentu” oraz kulturowe źródła i społeczne koszty ich pomijania (niepublikowana praca doktorska, 2015).

Szubert Wacław, Problemy pracy w koncepcjach programowych Delegatury Rzadu na Kraj (1941-1945), red. Michał Seweryński, Wydawnictwo Uniwersytetu Łódzkiego, Łódź 2012.

Świda-Ziemba Hanna, Człowiek wewnętrznie zniewolony. Mechanizmy i konsekwencje minionej formacji: analiza psychosocjologiczna, Instytut Stosowanych Nauk Społecznych, Warszawa 1997.

Świda-Ziemba Hanna, Urwany lot. Pokolenie młodzieży powojennej w świetle listów i pamiętników z lat 1945-1948, Wydawnictwo Literackie, Kraków 2003.

Temat dla Szpilek: studenci maja chodzić na wykłady z krzesłami, „Kurier Popularny”, 19 listopada 1945.

Thomas William I., Thomas Dorothy Swaine, The Child in America: Behavior Problems and Programs, Knopf, New York 1928.

Tönnies Ferdinand, Wspólnota i stowarzyszenie, tłum. Małgorzata Łukasiewicz, PWN, Warszawa 1988.

Turner Victor, Proces rytualny: struktura i antystruktura, tłum. Ewa Dżurak, PIW, Warszawa 2010.

Tymowski Janusz, Organizacja szkolnictwa wyższego w Polsce, PWN, Warszawa 1980. 
Walicki Andrzej, W kręgu konserwatywnej utopii: struktura i przemiany rosyjskiego stowianofilstwa, PWN, Warszawa 1964.

Welfe Władysław, Macroeconometric Models, Springer, Berlin-Heidelberg 2013.

Welfe Władysław (red.), Metody ekonometryczne. Ekonometryczne modele rynku: analiza - prognozy - symulacja, t. 1, PWE, Warszawa 1977.

Welfe Władysław (red.), Modele konsumpcji. Ekonometryczne modele rynku: analiza prognozy - symulacja, t. 2, PWE, Warszawa 1978.

Welfe Władysław (red.), Modele popytu konsumpcyjnego i równowagi rynkowej: analiza - prognozy - symulacja, t. 3, PWE, Warszawa 1982.

Wojsław Jacek, Kampania propagandowa towarzyszaca wyborom do sejmu z 26 października 1952 r., „Polska 1944/1945-1989: studia i materiały”, t. 9, Instytut Historii Polskiej Akademii Nauk, Warszawa 2010.

Znaniecki Florian, Socjologia wychowania, t. 1, PWN, Warszawa 2001.

Zysiak Agata, Uniwersytet w modernizujacym się mieście przemysłowym: przypadek Łodzi (1945-1980), Nomos, Kraków, 2016. 



\section{Mapa}

Książka ta adresowana jest do różnych Czytelników. Zapewne pierwszymi jej odbiorcami będą łodzianie a zwłaszcza członkowie społeczności akademickiej Uniwersytetu Łódzkiego. Mamy jednak nadzieję, że zainteresują się nią również osoby nie związane z Łodzią, zajmujące się historią nauki, badaniami biograficznymi, historią mówioną. W obu przypadkach pomocne w kontekstualizacji opowiadanych zdarzeń i wspominanych miejsc może być przedstawienie planu sytuacyjnego ilustrującego obecność Uniwersytetu w topografii miasta.

Zamieszczone na następnej stronie rysunki pokazują lokalizację miejsc związanych z Uniwersytetem na mapie Łodzi. Pierwsza mapa (rys. 1) przedstawia miejsca pojawiające się we wspomnieniach naszych rozmówców, obejmujące lata od 1945 roku aż do czasów współczesnych. Są to przede wszystkim siedziby katedr oraz sale, gdzie odbywały się zajęcia. Na przestrzeni dekad zmieniały się zarówno nazwy jak i układ ulic, jednak wzmiankowane lokalizacje pokazane zostały na współczesnym układzie ulic. Druga mapa (rys. 2) prezentuje obecne lokalizacje budynków uniwersyteckich, a więc topografie Uniwersytetu Łódzkiego w 2015 roku. Wiele z nich jest przywoływanych przez naszych rozmówców.

Porównanie tych dwóch map ukazuje jak na przestrzeni lat, a zwłaszcza na przełomie XX i XXI wieku, zmienił się topograficzny obraz Łodzi uniwersyteckiej. Widać wyraźnie koncentrację budynków w północno-wschodniej części Łodzi, gdzie od lat pięćdziesiątych XX wieku tworzono tzw. miasteczko uniwersyteckie - Lumumbowo. Inwestycje z ostatnich lat lokowane były w okolicach ulicy Pomorskiej lub przy historycznych lokalizacjach, jak w przypadku Wydziału Ekonomiczno-Socjologicznego przy ulicy Rewolucji 1905 roku.

Uniwersytet realizował raczej koncepcję zwartego akademickiego kampusu niż uczelni współtworzącej centrum miasta. Taka separacja obserwowana jest $\mathrm{w}$ wielu miastach na świecie. Jednak w przypadku kurczącego się miasta poprzemysłowego jakim jest Łódź, oznacza to także wycofanie się $\mathrm{z}$ aktywnej roli uczelni $\mathrm{w}$ tworzeniu przestrzeni centrum poprzez 


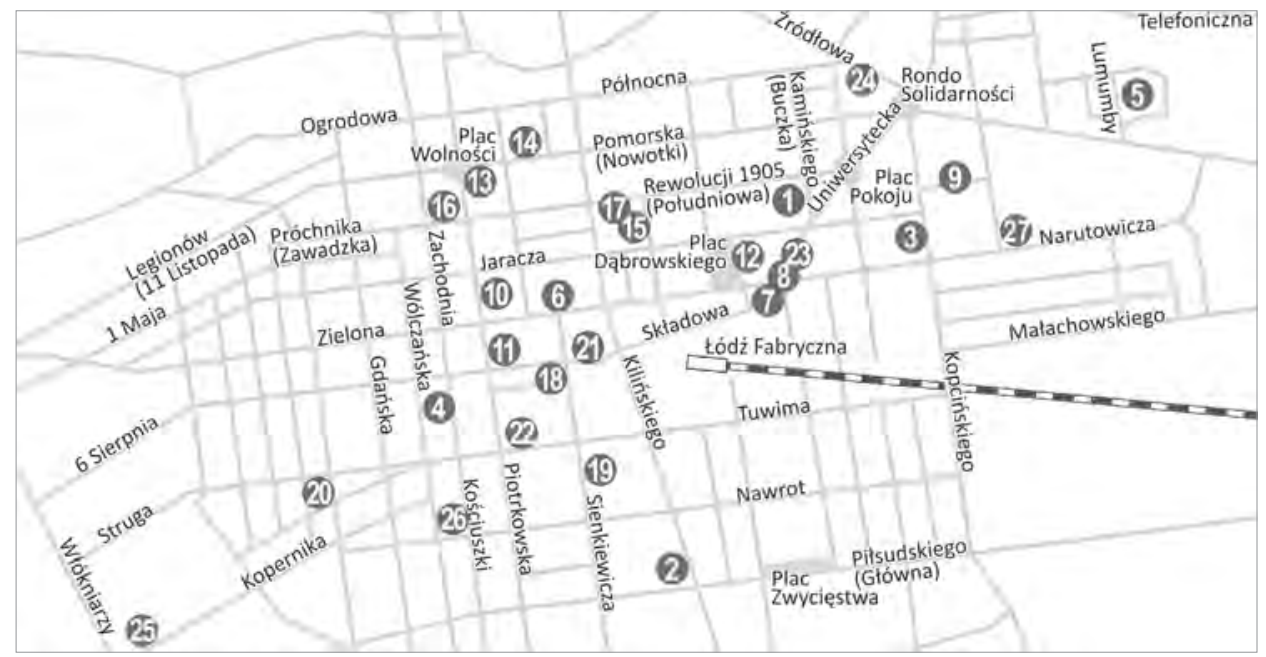

Rys. 1. Lokalizacje miejsc zwiazanych z Uniwersytetem Lodzkim od roku 1945 na planie Łodzi (układ ulic - wspótczesny)

Legenda:

1. Kamińskiego (Buczka) 27a - siedziba Instytutu Historii

2. Kilińskiego 117 - Kinoteatr „Stylowy” przy ulicy Głównej (obecnie Piłsudskiego), sala kinowa, z której korzystali studenci filmoznawstwa

3. Kopcińskiego 31 - nowa siedziba Muzeum Geologicznego przy Wydziale Biologii i Nauk o Ziemi

4. Kościuszki 21 - siedziba katedr matematycznych oraz Wydziału Biologii i Nauk o Ziemi w latach czterdziestych

5. Lumumby (Bystrzycka) - miasteczko akademickie

6. Narutowicza 20 - Kino „Bałtyk”, sala kinowa, z której korzystali studenci filmoznawstwa

7. Narutowicza 65 - Rektorat (do jesieni 2015 roku), wcześniej także, Wydział Biologii, Instytut Historii oraz części katedr Wydziału Filologicznego

8. Narutowicza 68 - dawne Gimnazjum Zgromadzenia Kupców, siedziba Wydziału Biologii i Nauk o Ziemi oraz Wydziału Matematyczno-Fizyczno-Chemicznego, od jesieni 2015 roku siedziba Rektoratu

9. Banacha 14/16 - siedziba Wydziału Biologii i Nauk o Ziemi (obecnie i Ochrony Środowiska) od 1968 roku

10. Piotrkowska 46 - stołówka studencka „Gęsie Pióro”

11. Piotrkowska 68 - Kino „Polonia”, sala kinowa, z której korzystali studenci filmoznawstwa

12. Plac Dąbrowskiego 5 - budynek sądu, gdzie użyczano sale UŁ w pierwszych miesiącach istnienia uczelni

13. Plac Wolności 14 - Muzeum Archeologiczne i Muzeum Etnograficzne, siedziba Katedry Archeologii

14. Pomorska 18 - siedziba części katedr Wydziału Biologii i Nauk o Ziemi w latach pięćdziesiątych do 1968 roku, zaraz po wojnie siedziba Wyższej Szkoły Gospodarstwa Wiejskiego

15. POW (Armii Ludowej) 3/5 - planowana siedziba Wolnej Wszechnicy Polskiej, po 1945 siedziba Wyższej Szkoły Ekonomicznej, następnie siedziba Wydziału Ekonomiczno-Socjologicznego

16. Próchnika (Zawadzka) 7 - Hotel Monopol, miejsce zamieszkania wielu profesorów w pierwszych powojennych miesiącach, potem także akademik dla studentów

17. Rewolucji 1905 r. 41 - nowa siedziba Wydziału Ekonomiczno-Socjologicznego

18. Sienkiewicza 21 - siedziba Wydziały Filologicznego

19. Sienkiewicza 40 - Kino „Tatry” sala kinowa, z której korzystali studenci filmoznawstwa

20. Skłodowskiej Curie 11 -zabytkowy pałacyk, po wojnie miejsca wykładów wielu kierunków studiów prowadzonych przez UŁ, siedziba Instytutu Geografii, obecnie siedziba $€ T N$

21. Traugutta 18 - ŁDK, sala kinowa, z której korzystali studenci filmoznawstwa

22. Tuwima 1 - Kino „Luna” (później „Wisła”), róg Tuwima/Piotrkowska - pełniło funkcje sali wykładowej w pierwszych latach UŁ

23. Uniwersytecka 3 - pierwsza siedziba Wydziału Humanistycznego, Biblioteki Socjologicznej oraz miejsce zamieszkania wielu profesorów

24. Źródłowa 47 - pierwsza siedziba Muzeum Geologicznego

25. Kopernika 53/55 - pierwsza siedziba Wydziału Prawa, później siedziba Studium Wojskowego, w którym studenci ostatnich lat przechodzili obowiązkowe szkolenia a następnie Wydziału Nauk o Wychowaniu

26. Kościuszki 65 - siedziba Wydziału Filologicznego

27. Matejki 34/36 - Biblioteka Uniwersytecka 


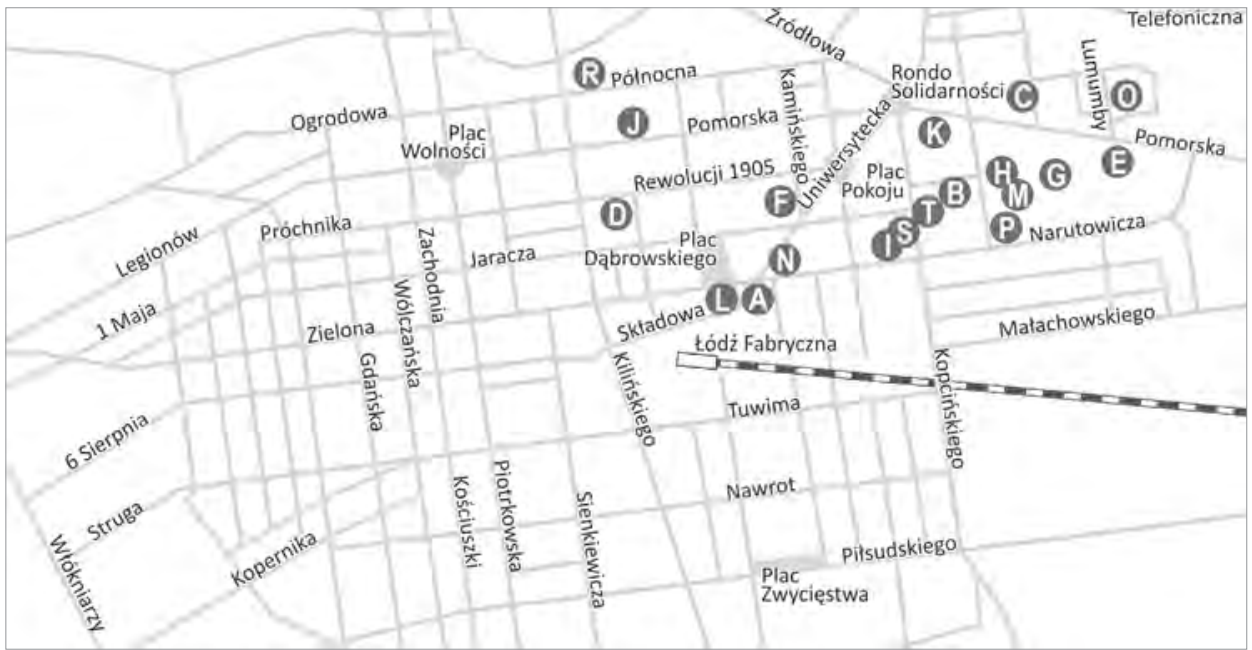

Rys. 2. Współczesne lokalizacje wydziałów Uniwersytetu Łódzkiego

Legenda:

A - Rektorat (do października 2015), Narutowicza 65

B - Wydział Biologii i Ochrony Środowiska, ulica Pilarskiego 14/16

C - Wydział Chemii, ulica Tamka 12

D - Wydział Ekonomiczno-Socjologiczny, ulica POW 3/5

E - Wydział Filologiczny, ulica Pomorska 171/173

F - Wydział Filozoficzno-Historyczny, ulica Kamińskiego 27a

G - Wydział Fizyki i Informatyki Stosowanej, ulica Pomorska 149/153

H - Wydział Matematyki i Informatyki, ulica Banacha 22

I - Wydział Nauk Geograficznych, ulica Narutowicza 88

J - Wydział Nauk o Wychowaniu, ulica Pomorska 46/48

K - Wydział Prawa i Administracji, ulica Kopcińskiego 8/12

L - Wydział Studiów Międzynarodowych i Politologicznych, ulica Składowa 43

M - Wydział Zarządzania, ulica Matejki 22/26

N - Nowa siedziba Rektoratu (od listopada 2015), Narutowicza 68

$\mathrm{O}$ - Osiedle akademickie, Lumumbowo

P - Biblioteka Uniwersytecka, ulica Matejki 32/38

$\mathrm{R}$ - Pałac Biedermana, ulica Franciszkańska1/5

S - Muzeum Geologiczne, ulica Kopcińskiego 31

T - Centrum Szkoleniowo-Konferencyjne, ulica Kopcińskiego 16/18

inwestycje, ale także, co nie jest bez znaczenia, ożywienia centrum poprzez samą obecność studentów i pracowników UŁ.

Choć pierwsza mapa przedstawia nie tylko siedziby Uniwersytetu Łódzkiego, ale wiele przestrzeni jedynie użytkowanych przez studentów i pracowników UŁ, czy też lokalizacji tymczasowych, których obecność wynikała z powojennych braków w infrastrukturze, to widać wyraźnie odwrót Uniwersytetu $\mathrm{z}$ centrum Łodzi i koncentrację na tworzeniu oddzielnego kampusu uniwersyteckiego. 



\section{Wykaz skrótów}

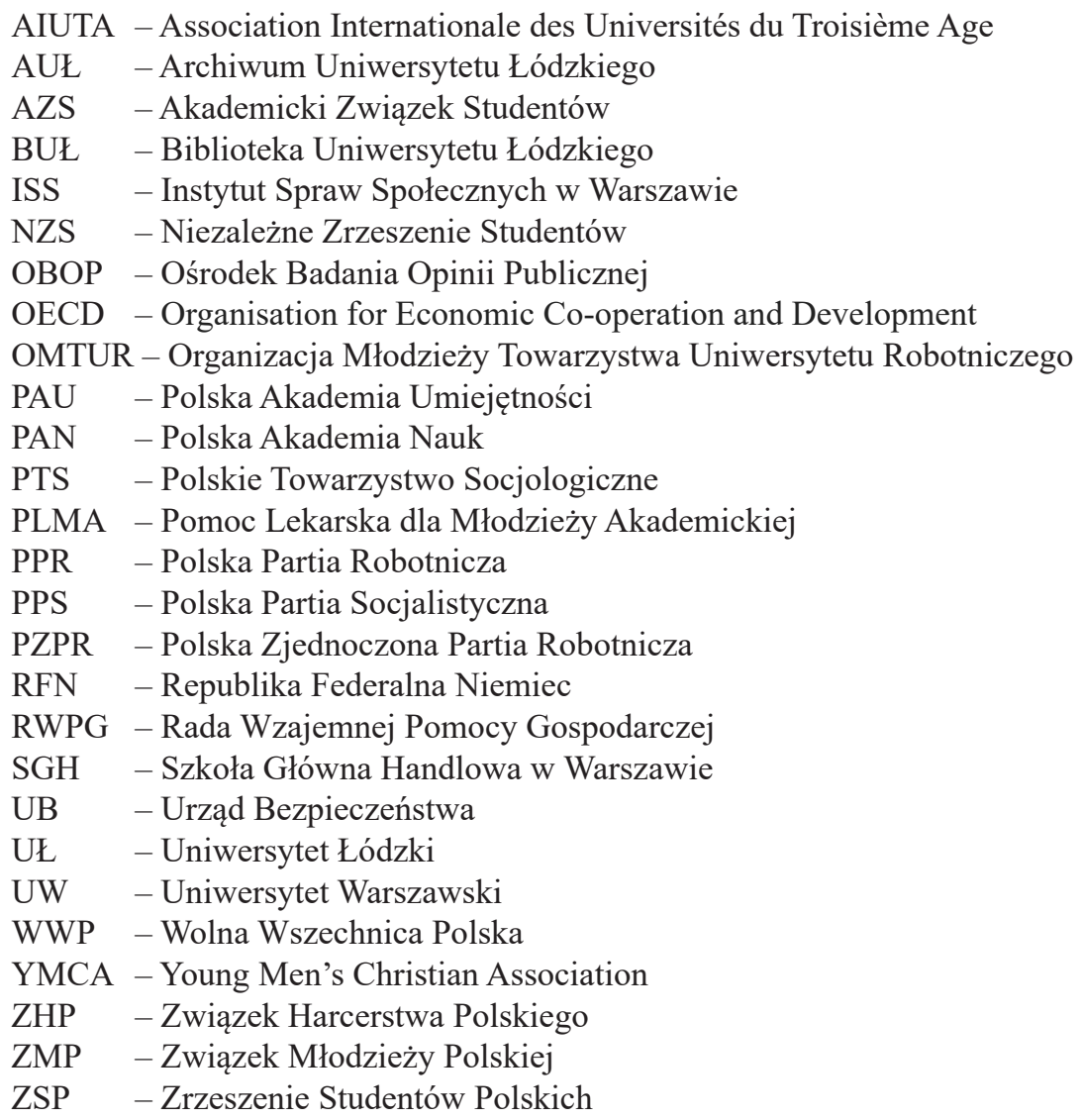





\section{Wykaz fotografii}

Fot. 1. Stefan Banasiak. Ze zbiorów Archiwum UŁ ..................................................... 29

Fot. 2. Zbigniew Bokszański. Ze zbiorów Archiwum UŁ ......................................... 29

Fot. 3. Teresa Cieślikowska. Z prywatnych zbiorów Teresy Cieślikowskiej ............... 29

Fot. 4. Sławomir Cieślikowski. Z prywatnych zbiorów Sławomira Cieślikowskiego .. 30

Fot. 5. Olga Czerniawska. Z prywatnych zbiorów Olgi Czerniawskiej ....................... 30

Fot. 6. Eugeniusz Czerniawski. Z prywatnych zbiorów Eugeniusza Czerniawskiego.. 30

Fot. 7. Jerzy Dietl. Ze zbiorów Archiwum UŁ .................................................. 30

Fot. 8. Ryszard Jajte. Ze zbiorów Archiwum UŁ ...................................................... 31

Fot. 9. Zbigniew Jakubowski. Ze zbiorów Archiwum UŁ ....................................... 31

Fot. 10. Krzysztof Jażdżewski. Ze zbiorów Archiwum UŁ ..................................... 31

Fot. 11. Jerzy Kmieciński. Ze zbiorów Archiwum UŁ ........................................... 31

Fot. 12. Grażyna Kononowicz. Ze zbiorów Archiwum UŁ ...................................... 32

Fot. 13. Bronisława Kopczyńska-Jaworska. Ze zbiorów Archiwum UŁ ................... 32

Fot. 14. Jolanta Kulpińska. Ze zbiorów Archiwum UŁ ............................................. 32

Fot. 15. Biruta Lewaszkiewicz-Petrykowska. Ze zbiorów Archiwum UŁ .................. 32

Fot. 16. Stanisław Liszewski. Ze zbiorów Archiwum UŁ .......................................... 33

Fot. 17. Krystyna Lutyńska. Z prywatnych zbiorów Krystyny Lutyńskiej ................. 33

Fot. 18. Wanda Nowakowska. Ze zbiorów Archiwum UŁ .................................... 33

Fot. 19. Ewelina Nurczyńska-Fidelska. Ze zbiorów Archiwum UŁ ........................... 33

Fot. 20. Romuald Olaczek. Ze zbiorów Archiwum UŁ .......................................... 34

Fot. 21. Ryszard Panasiuk. Ze zbiorów Archiwum Ut ............................................ 34

Fot. 22. Andrzej Piechocki. Ze zbiorów Archiwum UŁ ........................................... 34

Fot. 23. Michał Seweryński. Ze zbiorów Archiwum UŁ ........................................... 34

Fot. 24. Romuald Skowroński. Ze zbiorów Archiwum UŁ ...................................... 35

Fot. 25. Krystyna Śreniowska. Ze zbiorów Archiwum UŁ ........................................ 35

Fot. 26. Edward Tranda. Ze zbiorów Archiwum UŁ ................................................. 35

Fot. 27. Janina Tobera. Ze zbiorów Archiwum UŁ .................................................... 35

Fot. 28. Władysław Welfe. Ze zbiorów Archiwum UŁ ......................................... 36

Fot. 29. Leszek Wojtczak. Ze zbiorów Archiwum UŁ ............................................ 36

Fot. 30. Jan Ziomek. Ze zbiorów Archiwum UŁ .................................................... 36

Fot. 31. Leszek Wojtczak i jego - nadal trwająca - ,przygoda intelektualna”. Ze zbiorów Archiwum UŁ ................................................................................. 65

Fot. 32. Lata czterdzieste. Seminarium dr Aleksandra Kamińskiego, Uniwersytecka 3, Ze zbiorów Archiwum UŁ ........................................................................ 76

Fot. 33. Helena Radlińska i Tadeusz Kotarbiński. Ze zbiorów Archiwum UŁ ........... 85

Fot. 34. Lata pięćdziesiąte, sala wykładowa przy Pomorskiej 18. Z prywatnych zbiorów Eugeniusza Czerniawskiego 
Fot. 35. Józef Chałasiński. Ze zbiorów Elżbiety Psyk-Piotrowskiej przekazanych Instytutowi Socjologii

Fot. 36. Jakub Mowszowicz. Ze zbiorów Archiwum UŁ

Fot. 37 Janina Kotarbińska. Ze zbiorów Archiwum UŁ

Fot. 38. Lata sześćdziesiąte. Jan Szczepański z grupą studentów. Na pierwszym planie z lewej strony Grażyna Kononowicz. Z prywatnych zbiorów Grażyny Kononowicz

Fot. 39. Jan Dylik. Ze zbiorów Archiwum UŁ

Fot. 40. Adam Szpunar. Ze zbiorów Archiwum UŁ

Fot. 41. Katedra Pedagogiki Społecznej przy ulicy Uniwersyteckiej 3. Przy stole „Chippendale” siedzą od lewej: Jan Badura, Irena Lepalczyk, Aleksander Kamiński, Olga Czerniawska, Ewa Marynowicz-Hetka. Ze zbiorów Archiwum UŁ

Fot. 42. Od lewej: Henryk Lewandowski, Wacław Szubert i Michał Seweryński.

Z prywatnych zbiorów Michała Seweryńskiego

Fot. 43. Mieczysław Wallis z Wandą Nowakowską w parku imienia Jana Matejki w Łodzi. Pierwsza połowa lat sześćdziesiątych. Z prywatnych zbiorów Wandy Nowakowskiej

Fot. 44. Bolesław Lewicki. Ze zbiorów Archiwum UŁ ........................................ 131

Fot. 45. Stefania Skwarczyńska. Z prywatnych zbiorów Teresy Cieślikowskiej ....... 136

Fot. 46. Antonina Kłoskowska przy pracy w budynku na Uniwersyteckiej 3. Ze zbiorów Archiwum UŁ

Fot. 47. Kazimiera Zawistowicz-Adamska. Ze zbiorów Archiwum UŁ .................. 140

Fot. 48. Tadeusz Kotarbiński. Ze zbiorów Archiwum UŁ ....................................... 142

Fot. 49. Ludwik Straszewicz. Ze zbiorów Archiwum UŁ ....................................... 144

Fot. 50. Konrad Jażdżewski. Ze zbiorów Archiwum UŁ ...................................... 145

Fot. 51. Jan Wojciechowski. Ze zbiorów Archiwum UŁ ........................................ 147

Fot. 52. Witold Janowski. Ze zbiorów Archiwum UŁ ............................................. 148

Fot. 53. Anna Chrząszczewska. Ze zbiorów Archiwum UŁ .................................... 148

Fot. 54. Matematycy i fizycy na wspólnym wyjeździe do Wilna. Od lewej stoją: Ryszard Jajte, Leszek Wojtczak, z żonami oraz Julian Ławrynowicz. Z prywatnych zbiorów Ryszarda Jajte

Fot. 55. Od lewej siedzą: Krystyna Chałasińska, Jan Szczepański, Renata SzwarcTuli, Jolanta Kulpińska, Janina Kremky-Salony. Od lewej stoją: Zygmunt Gostkowski, Jan Lutyński, Wacław Piotrowski i Antonina Kłoskowska. Fotografię wykonano w budynku przy ulicy Uniwersyteckiej 3. Z prywatnych zbiorów Jolanty Kulpińskiej

Fot. 56. Eugeniusz Czerniawski przy pracy. Z prywatnych zbiorów Eugeniusza Czerniawskiego.

Fot. 57. Jan Ziomek ze studentami na ćwiczeniach terenowych. Ze zbiorów Archiwum UŁ

Fot. 58. Strajk studentów na Wydziale Biologii i Nauk o Ziemi. Z prywatnych zbiorów Eugeniusza Czerniawskiego 258

Fot. 59. „Głód demokracji i pragnienie wolności” - strajk studentów na Wydziale Ekonomiczno-Socjologicznym. Ze zbiorów Archiwum UŁ 
Fot. 60. Strajk studentów na Wydziale Ekonomiczno-Socjologicznym. Ze zbiorów

Archiwum UŁ 269

Fot. 61. Leszek Kołakowski jako kontestujący student. Ze zbiorów Archiwum UŁ .... 290

Fot. 62. Krystyna i Jan Lutyńscy. Ze zbiorów Archiwum UŁ .................................. 296

Fot. 63. Uniwersytecka 3. Jan Lutyński przy pracy. Ze zbiorów Archiwum UŁ .......... 315

Fot. 64. Retoryka PRL-u. Fot. wykonane podczas obchodów trzydziestej rocznicy

powstania UŁ. Ze zbiorów Archiwum UŁ ...................................................... 326

Fot. 65. Budynek przy Uniwersyteckiej 3. Ze zbiorów Archiwum UŁ ..................... 356

Fot. 66. Uniwersytecka 3: od lewej siedzą Irena Lepalczyk, Aleksander Kamiński oraz Anna Chrząszczewska. Ze zbiorów Archiwum UŁ.

Fot. 67. Przeprowadzka do budynku przy ulicy Pomorskiej 18. Do 1968 roku mieściły się tam m.in. Katedra Mikrobiologii, Katedra Systematyki i Geografii Roślin, Katedra Antropologii i Zakład Metodyki Biologii. Z prywatnych zbiorów Eugeniusza Czerniawskiego.

Fot. 68. Gabinet Bernarda Zabłockiego ,nad butlami z eterem”, Pomorska 18. Z prywatnych zbiorów Eugeniusza Czerniawskiego.

Fot. 69. Pierwsze warstwy muru audytorium gmachu biologii kładzie Eugeniusz Czerniawski (10 grudnia 1966). Z prywatnych zbiorów Eugeniusza Czerniawskiego ... 366

Fot. 70 a i b. Sala ćwiczeń w budynku biologii (lata siedemdziesiąte). Sala ćwiczeń w budynku biologii (2015). Z prywatnych zbiorów Eugeniusza Czerniawskiego ... 368

Fot. 71. Władysław Welfe wmurowuje cegłę pod gmach Pawilonu Technik Obliczeniowych Wydziału Ekonomiczno-Socjologicznego. Ze zbiorów Archiwum UŁ .... 369

Fot. 72. Uroczysta inauguracja działalności i poświęcenie Katedry Historii Sztuki w nowej siedzibie, czerwiec 1996. Od lewej stoją: Ks. Prałat Józef Fijałkowski, prof. Jerzy Wolski, prof. Wanda Nowakowska, prof. Krzysztof Jażdżewski (zasłonięty), rektor Stanisław Liszewski, prorektor Marek Zirk-Sadowski, prodziekan Adam Nowaczyk, dr Jan Salm. Z prywatnych zbiorów Wandy Nowakowskiej

Fot. 73. Biblioteka Socjologiczna w budynku przy Uniwersyteckiej 3. Ze zbiorów Archiwum UŁ

Fot. 74. Krystyna Leśniewska (wkrótce) Lutyńska przy pracy w bibliotece socjologicznej Instytutu Socjologii (1950 lub 1951 rok). Z prywatnych zbiorów Krystyny Lutyńskiej.....

Fot. 75. Październik 1984, Rektor Jerzy Wróblewski przekazuje władzę rektorowi Leszkowi Wojtczakowi. Na zdjęciu również prorektorzy: Marcin Bielski, Stanisław Liszewski oraz Cezary Kosikowski. Ze zbiorów Archiwum UŁ

Fot. 76. Strony z indeksu Zbigniewa Bokszańskiego. Ze zbiorów Archiwum UŁ ........ 404

Fot. 77. Uniwersytecka 3 jako przestrzeń spotkań, pracy i dyskusji intelektualnych.

Ze zbiorów Archiwum UŁ 408

Fot. 78. Wacław Szubert i Jerzy Wróblewski w górach. Z prywatnych zbiorów Michała Seweryńskiego

Fot. 79. Rekreacja na Uniwersyteckiej 3. Zygmunt Gostkowski (tyłem), od lewej: Jolanta Kulpińska, Krystyna Lutyńska, Antonina Kłoskowska i Jan Lutyński. Ze zbiorów Archiwum UŁ 
Fot. 80. „Fot. na balkonie” Wandy Nowakowskiej. Bal wiosenny w gmachu przy ulicy Kościuszki 17. Z prywatnych zbiorów Wandy Nowakowskiej 413

Fot. 81. Przeszłość przegląda się w przyszłości. Wydział Ekonomiczno-Socjologiczny.

Z prywatnych zbiorów Grażyny Kononowicz 418

Rys. 1. Lokalizacje miejsc związanych z Uniwersytetem Łodzkim od roku 1945 na planie Łodzi (układ ulic - współczesny) 426

Rys. 2. Współczesne lokalizacje wydziałów Uniwersytetu Łódzkiego 427 


\section{Indeks nazwisk}

Ajdukiewicz Tadeusz 81, 312, 330

Amsterdamski Stefan 118, 119, 170, 192, 213, 239-240, 244, 247

Archer Margaret 210

Arctowski Henryk 212-213

Assorodobraj Nina 70, 348

Balcerowicz Leszek 275-276

Banasiak Stefan 29, 80, 228-231, 238, 250-251, 260, 266, 306, 348, 362, 380, 431

Baranowski Bohdan 20, 167, 266-267, 393, 419

Barszczewska-Krupa Alina 266

Batorowicz Zdzisław 414

Bauman Zygmunt 250

Bejze Bohdan 273

Bendix Reinhard 210

Bielski Marcin 339, 393, 433

Biliński Wacław 249, 250

Błaszczyk Leon 129, 171, 239

Bokszański Zbigniew 27, 29, 69, 94, 104, 136, 180, 209, 279, 334-335, 338, 357, 378, 392, 404, 416, 431, 433

Boltanski Luc 334

Borkowski Janusz 261

Borucki Andrzej 245, 325

Bourdieu Pierre 39, 46, 138, 334-335, 421

Boznańska 48

Brodzka-Wald Alina 55

Bujacz Janusz 386

Bystroń Jan Stanisław 140

Chałasińska Krystyna 176, 382, 432

Chałasiński Józef 32, 70, 73-74, 76-77, 79-81, 84, 89, 91-95, 100, 104, 137, 170, 174 $175,191,227,232-235,243,310,312,316,334,337,343,345,348,351,353-355$, $363,378-380,383-385,392,416-417,419,420,432$

Charzyński Zygmunt 88, 95, 155, 168, 206

Chełmińska-Świątkowska Jadwiga 46, 381

Chrząszczewska Anna 148-149, 357-359, 432-433

Chrząszczewski Józef 148 
Cichoń Krzysztof 173

Cieślikowska Teresa 29, 130, 134-135, 221, 287, 370, 431-432

Cieślikowski Sławomir 30, 97-98, 290, 308-309, 399, 432

Czapczyńska Janina 42, 47-48, 50, 53-54, 301

Czapczyński Tadeusz 42, 44, 54

Czerniawska Olga 30, 50, 75, 113, 120, 179, 198-199, 241, 285, 291, 294, 301, 311-312, 358, 405-406, 431-432

Czerniawski Eugeniusz 30, 68, 183-184, 208, 247, 271, 272, 300, 304, 352, 360, 365$367,372-373,431-433$

Deleuze Gilles 39

Demetrio Duccio 201

Filippo de Sanctis 202

Dietl Jerzy 30, 57, 173, 177, 181, 196, 222, 275-276, 329, 339, 389, 431

Dmochowski Antoni 61, 387, 406

Dobrowolski Kazimierz 141

Dobrushin Roland Lvovich 207

Dollard John 379

Dryjski Albert 98, 406

Durand Claude 193

Dylik Anna 44-45, 103, 145

Dylik Jan 44, 103, 144, 352, 420, 432

Edelman Marek 261

Fijałkowski Józef 371, 433

Filipowicz Bronisław 359

Freuchen Peter 77

Friedmann 192

Fuka Jarosław 206

Gajl Natalia 189

Gardawski Aleksander 163

Garfinkel Harold 209

Gąsiorowska-Grabowska Natalia 70, 74, 80, 176, 291, 405

Geblewicz Eugeniusz 309-310

Gelfand Izrail Moisiejew 207, 329

Gelpi Ettore 201

Giedroyć Jerzy 243-245

Głogowski Karol 258, 261

Gniazdowski Andrzej 338

Gniazdowski Paweł 255

Goldstein Stanisław 221 
Gostkowski Zygmunt 91, 176, 236, 334, 408, 412, 432- 433

Górecki Jan 275

Górska Teresa 290

Górski Janusz 252, 257, 261-264

Gregor Bohdan 198

Gromczyński Wiesław 170, 241

Grotowski Marian 168-169, 284

Grotowski Olek 267

Gryglewski Piotr 173

Guzek Ryszard 155

Gwiazdomorski Jan 112

Halicz Benedykt 248

Haman Janusz 275

Helman Alicja 132

Hereźniak Janusz 414

Hirszowicz Maria 91, 250, 281, 420

Holoubek Gustaw 414

Hrabec Stefan 357

Husarski Wacław 171

Ingarden Roman 134

Jackiewicz Aleksander 135

Jajte Ryszard 31, 154-155, 169, 178, 206-208, 221, 329, 373, 431-432

Jakubowski Zbigniew 31, 58, 88, 95, 148, 154-156, 167, 206, 218-219, 225, 292, 431

Janowska Zdzisława 243

Janowski Witold 88, 95, 148, 155, 167

Jaruzelski Wojciech 252, 271-272, 342, 349

Jaśkiewicz Włodzimierz 246

Jażdżewski Konrad 31, 49, 61-62, 87, 100, 145-146, 163, 387, 406, 432

Jażdżewski Krzysztof 31, 61, 63, 87, 182, 212, 254, 342, 359, 371, 380, 405, 431, 433

Jedlińska Eleonora 173

Józefiak Cezary 275-276, 339, 342

Kajzer Leszek 173, 370

Kalecki Michał 331

Kamińska-Kotarbińska Janina 76, 85, 98-99, 101, 175, 308,101, 351, 354, 356, 432

Kamiński Aleksander 35, 41, 51, 76, 79, 113-117, 119, 121, 123, 135, 175-176, 241-242, 311, 356-358, 405-406, 431-433

Kargulowa Alicja 179

Kaszyński Stanisław 130, 132, 136

Katz Henryk 84, 191, 239, 290-292

Kawyn Stefan 135

Kerszman Gustaw 247 
Klein Lawrence Robert 193, 195-196

Kliszko Zenon 349

Kłoskowska Antonina 29, 32, 25 77, 84, 91-92, 94, 101, 136-9, 170, 176, 180, 233, 235-6, $245,333-34,357,363,383,392,407,412$

Kmiecińska-Kaczmarek Teresa 173

Kmieciński Jerzy 31, 49, 60, 72, 145, 162-163, 349, 355, 420, 431

Kolberg Oskar 381

Kołakowski Leszek 77, 143, 170, 288, 290-291, 401, 420, 432

Konecki Krzysztof 222

Kononowicz Grażyna 32, 89, 101- 102, 104, 246, 342, 364, 386, 431-433,

Kopczyńska-Jaworska Bronisława 32, 41- 44, 53, 68, 70- 71, 73, 75-77, 81, 89, 92-93, $100,140,163,176,202,312,316,318-320,332,346,353,380-381,431$

Koprowski Jan 250

Koralewicz-Zębik Jadwiga 409

Kortan Jerzy 244, 326-327

Korzec Paweł 239

Kotarbiński Tadeusz 13, 73, 75-81, 85, 98- 99, 128- 129, 141-142, 161, 170, 175, 192, $234,284,288,290,312,356,360,405,420,431,432$

Kotełko Krystyna 319

Kozielski Robert 198

Krasiński Zygmunt 60

Kraszewski Józef Ignacy 60, 180

Kremky-Salony Janina 176, 432

Kroński Tadeusz 141-142, 143,288, 314

Kropiwnicki Jerzy 253-254, 341, 342

Król Józef 75, 114

Kruk-Michałowska Barbara 55

Krysicki Włodzimierz 88, 168

Krzemiński Tadeusz 232, 261

Kubiak Anna 253

Kucharska Jadwiga 320

Kuczyński Janusz 289

Kuczyński Stefan 89, 90

Kula Witold 70

Kulpińska Jolanta 32, 54, 55, 93, 176-177, 181, 188, 190-193, 222, 235, 242, 250, 252, $316,325,339,381,383,386,407,409,412,431,432,433$

Lande Jerzy 314

Lange Oskar 331

Lani-Bayle Martine 202

Latreille Geneviève 199

Lazari-Pawłowska Ija 85, 169, 175, 261, 356, 405

Leśniewski Adam 239

Lévi-Strauss Claude 24, 421 
Lewandowski Henryk 124, 434

Lewaszkiewicz-Petrykowska Biruta 32, 96, 110, 159, 161, 188-189, 217, 258, 260-261, $273,279,313-314,317-318,322,345,351,394,431$

Lewicki Tadeusz 91, 130-135, 185-186, 249, 271, 386, 421, 432

Lipiński Eryk 48

Lipset Seymour Martin 210, 336

Liszewski Stanisław 33, 64, 103, 144, 157, 241, 253-254, 365, 371, 390, 391-394, 411, $415,431,433$

Litwin Jakub 77, 192

Livečka Emil 199

Lorenzetto Anna 200, 202

Lutyńska Krystyna 32-33, 37, 74, 83-84, 92-93, 174, 227-228, 232, 266, 289, 290, 294 $295,297,302,304,310,315-316,324-325,333,337-338,340-341,344-345,351$, $356,363,382,385,412,421,431,433$

Lutyński Jan 32, 78-79, 91, 170, 174-177, 232-233, 235-236, 245-246, 253, 255, 257-261, 264-267, 297, 315-316, 333-334, 339-342, 345, 357, 384, 407, 412, 421, $431-433$

Ladnowska Janina 173

Ławrynowicz Julian 169, 432

Ławrynowicz Maria 220

Łubnicki Narcyz 161

Łuczak Andrzej 221

Majer Andrzej 384

Majewska Aleksandra 84, 114, 272

Makowski Tadeusz 48

Markowski Janusz 220

Marxen-Wolska Ewa 173, 371

Marynowicz-Hetka Ewa 113, 122, 358, 432

Maurice Marc 193

Mazur Stanisław 168

Michalski Ireneusz 61, 87, 359, 387

Michalski Jan 204

Michowicz Waldemar 172, 414

Mickiewicz Adam 65,228

Mikołajczyk Leon 95

Miller Andrzej 77

Miller Tadeusz 84

Miłosz Czesław 141-142, 288

Minich Marian 50

Missalowa Gryzelda 313

Molska Alina 55

Mortimer-Szymczak Halina 263, 316

Mowszowicz Jakub 96-97, 158, 248, 361, 432 
Moycho Wacław 369

Mujżel Jan 237, 289, 331, 370

Muszyński Jan 352

Namitkiewicz Jan 160, 313

Niekrasz Anna 159

Niemczynow Wasilij 193-194

Niemyska-Hessen Maria 326

Niesiołowski Stefan 220, 254, 342

Nikołajczuk Aleksander 58, 59

Nowak Leszek 339

Nowak Stefan 339, 341

Nowakowska Wanda 33, 49, 53, 98, 128, 162, 171, 203, 218, 222, 304,318, 320-321, 357, $370-371,411,413-414,431-433$

Nurczyńska-Fidelska Natalia 33, 130, 134, 185, 248, 270, 362, 373, 376-377, 386, 421, 431

Nykiel Włodzimierz 411

Obrębski Józef 175, 233

Oko Jan 284, 401

Olaczek Romuald 34, 59, 96, 151, 158, 220, 224, 250-251, 287, 296, 354, 388, 404, 431

Olszewski Jan 276

Olszewski Tadeusz 241

Orłowski Aleksander 241, 288

Orszulik Alojzy 275

Ossowska Maria 76, 175, 233, 284

Ossowski Stanisław 70, 76, 89, 175, 233, 284, 310, 312, 348, 354

Otto Edward 168

Panasiuk Ryszard 34, 141, 161, 169, 205-206, 220, 240, 287, 370, 431

Parsons Talcott 137, 180-181, 379

Pasierbiński Tadeusz 114

Paszkiewicz Adam 221

Pawłowski Leszek 85-88, 165

Pawłowski Tadeusz 85, 99, 169-170, 292, 317, 356, 405

Piątowski Józef Stanisław 238, 239, 340

Piechocki Andrzej 34, 64,165, 278, 431

Piotrowski Wacław 78, 176, 235, 270, 384, 420, 432

Płuciennik Jarosław 221

Pogorzelski Witold 168

Poniatowski Stanisław 100

Popławska Irena 129, 171-173

Przełęcki Marian 85, 170, 175, 356

Puś Wiesław 20, 167, 172, 365, 422 
Radlińska Helena 41, 45-46, 80, 84-85, 101, 114, 116, 121, 140, 175, 177, 272, 311, 347, $356,406,422,431$

Rakusa-Suczewski Stanisław 212

Rapacki Adam 321

Reboul Helène 198

Reynaud Jean-Daniel 192

Richmond Mary 116

Rosset Edward 156, 157, 352, 406, 420

Rostworowski Tomasz 70, 300

Różalski Antoni 272, 365

Różewicz Tadeusz 414

Różycki Feliks 67, 147, 157

Rutkowski Krzysztof 281, 371

Rybicki Zygmunt 243

Rynkowska Anna 126

Sadowski Franciszek 53, 54,

Schaff Adam 235, 240, 314, 319, 422

Schaff Leon 319

Serejski Marian 74, 84, 90, 92, 291

Seweryński Michał 34, 66, 107, 123-126, 160-161,172, 181, 209-210, 242, 253-254, 277, 370, 374, 390, 397, 409, 422, 431-432, 433.

Siciński Jacek 213-214

Siemiatycki Michał 204

Sienkiewicz Jerzy 48

Skowroński Romuald 35, 56, 148, 172, 203-204, 258, 260-262, 264-265, 298, 357, 360, 377, 388-389, 414, 431, 441

Skubiszewski Krzysztof 196

Skupieński Franciszek 61, 87, 359, 387

Skwarczyńska Stefania 90, 92,130-132, 135-136, 363, 432

Słomczyński Kazimierz Maciej 103

Słowik Andrzej 341-342

Smelser Neil 210

Sorokin Pitrim 379

Staliński Janusz 167

Staniszkis Jadwiga 339, 341

Starzyński Juliusz 347-348

Stefański Krzysztof 173

Stelmachowski Andrzej 275-276

Stolarska Bronisława 134-135, 421

Stone John Richard 193-194

Straszewicz Ludwik 104, 144-145, 157, 241, 432

Strzelecki Jan 341, 384

Susi Francesco 201 
Szczepański Jan 33, 55, 72-73, 76, 80, 84-85, 91, 95, 101-104, 109, 114, 137, 150, 170, 174-176, 181, 232, 235-236, 245-246, 310, 316-317, 321, 325-326, 333, 344, 351, 379, 384-385, 392, 400, 405-406, 416, 422, 432

Szejnert Danuta 221

Szenajch Piotr 39-40, 422

Szereda Stanisław 246

Szostkiewicz Stefan 78, 333

Szpunar Adam 96, 110-112, 159-160, 317-319, 406, 432

Szubert Wacław 34, 92, 123-125, 160-161, 181, 210-211, 411, 432-433

Szwarc Helena 199

Szwarc-Tuli Renata 176, 432

Szymanowski Zygmunt 75

Szymczak Tadeusz 316

Śreniowska Krystyna 35, 37, 69, 70-71, 78, 268, 281, 284, 353, 355, 378, 387, 431

Śreniowski Stanisław 353

Świątkowski Tadeusz 155

Świda-Ziemba Hanna 49, 281-283, 285-286, 288, 422

Tadzik Bogdan 401

Taładaj Henryk 155

Tatarkiewicz Władysław 45-46, 141, 287-288

Tatarkówna Michalina 325

Tietz Tadeusz 168-169

Tinbengen Jan 195

Tobera Janina 35, 75, 79, 216, 245, 267, 318, 324, 383, 431

Tobera Piotr 245

Toeplitz Jerzy 132

Tomczak Andrzej 53

Tomczak Kazimierz 53

Tourain Alain 192, 334

Tranda Edward 35, 85, 87-88, 182, 247-248, 359, 388, 431

Truchim Stefan 92, 176, 357

Trzeciakowski Witold 275

Trzynadlowski Jan 135

Turner Victor 269-270, 422

Tylman Janusz 232, 263

Tönnies Ferdinand 40, 407, 422

Twardowski Kazimierz 45, 142, 287

Ułaszyn Henryk 76, 284, 311, 387

Vieweger Teodor 73, 353 
Wallis Mieczysław 33, 50, 81, 91, 99, 128-129, 171, 312, 321, 432

Waliszewski Włodzimierz 155

Welfe Władysław 36, 156, 193-196, 202, 222-224, 237, 263, 327, 331, 346, 369, 422, 423, 431

Wereszyński Jan Stanisław 157

Wesołowski Włodzimierz 91

Wiatr Jerzy 250, 327

Wierzbowski Ryszard 131

Więcek Adam 128, 129

Willemart Anoine 204-205

Winiarski Bohdan 197

Wiśniewski Feliks Joachim 61, 168-169, 284, 285, 388

Witkiewicz Stanisław 33, 161, 162

Włodarski Lech 155

Wojciechowska Maria 86-87

Wojciechowski Jan 147, 376

Wojciechowski Adam 258

Wojtczak Leszek 36, 65, 168-169, 203, 393, 431-433

Wolski Jerzy 371, 433

Wolski Tadeusz 86,

Woskowski Jan 244

Wróbel Robert 173

Wróblewska Elżbieta 131

Wróblewski Jerzy 111, 261, 393, 406, 410-411, 433

Wyżykowski Jan 216

Zabłocki Bernard 30, 62, 208, 361, 362, 365-366, 369, 373, 388, 406, 433

Zahorski Zygmunt 88, 95, 155

Zajączkowski Stanisław 24, 121, 291, 304, 421

Zawadzki Aleksander 168-169

Zawadzki Romuald 167-168

Zawistowicz-Adamska Kazimiera 32, 46, 76, 84-85, 100, 140-141, 176-177, 312, 316, 319-320, 346-347, 381, 434

Zębik Andrzej 409

Ziomek Jan 36, 66, 67, 147, 157, 188, 190, 212, 214, 218-220, 231, 247, 364-365, $374-376,433,435$

Znaniecki Florian 39, 107-110, 137, 180-181, 197, 232, 338, 380, 392, 423 



\section{Indeks miejsc w Lodzi}

Bałuty 58

Banacha 14/16 62, 388, 426

Banacha 22427

Dworzec Łódź Fabryczna 335, 376

Dworzec Łódź Widzew 58

Franciszkańska 1/5 58, 427

Kamińskiego (Buczka) 27 362, 426-427

Kilińskiego 117 386, 426

Kopcińskiego 8/12 351, 427

Kopcińskiego 16/18 427

Kopcińskiego 31 365, 426-427

Kopcińskiego 52

Kopcińskiego 54 51, 67

Kopernika 53/55

Kościuszki 17 370, 413, 433

Kościuszki 21 46, 67, 144, 241, 364, 376, 426

Kościuszki 52 61-62, 87, 387-388

Kościuszki 65 261, 263, 271, 426

Lindleya 116, 136, 273-274, 296, 353, 357-358, 362

Lipowa 44, 67

Lumumby (Bystrzycka) 354, 426

Matejki 22/26 174, 427

Matejki 32/38 129, 427

Moniuszki 110, 158

Narutowicza 20426

Narutowicza 6042

Narutowicza 65 296, 355, 358, 394, 426-427

Narutowicza 68 87, 360, 358-361, 426-427

Narutowicza 79388

Narutowicza 12087

Pasaż Schillera 388

Pilarskiego 14/16 427 
Piotrkowska 329, 366, 426

Piotrkowska 46 389, 426

Piotrkowska 68426

Plac Dąbrowskiego 231, 274, 353, 426

Plac Niepodległości 96

Plac Wolności 167

Plac Wolności 14 49, 312, 355, 426

Pomorska 18 90, 360-362, 365, 426, 431, 433

Pomorska 46/48 427

Pomorska 149/153 427

Pomorska 171/173 427

POW (Armii Ludowej) 3/5 352, 363, 383, 426-427

Próchnika 5355

Próchnika (Zawadzka) 7 61, 426

Retkinia 251

Rewolucji 1905 r. 41/43 352, 363, 370, 425-426

Sienkiewicza 21 366, 377, 426

Sienkiewicza 40426

Skłodowskiej-Curie 11 103, 157, 357, 361, 426

Sporna 58

Składowa 273,378

Składowa 43427

Staszica 58

Sterlinga 50

Tamka 12427

Teofilów 251

Tokarzewskiego 58

Traugutta 18426

Tuwima 1353,426

Uniwersytecka 376,84 113, 137, 148, 174-176, 234, 261, 274-275, 312, 315, 341, 351, $355-358,363,382-383,387,408,412,426,431-433$

Widzew 251

Więckowskiego 36 48, 67, 364

Wierzbowa 43, 129

Wólczańska $55 \quad 55$

Wólczańska $41 \quad 47$

Zgierska 68

Zielona 87,353

Źródłowa 47426 


\section{Indeks instytucji, organizacji, firm}

Akademia Górniczo-Hutnicza w Dudley w Kolorado 216

Akademia Górniczo-Hutnicza w Krakowie 159

Akademia Humanistyczno-Ekonomiczna w Łodzi 203

Akademia Medyczna w Łodzi 75, 185, 257, 261, 299, 359

Akademia Muzyczna w Łodzi 162

Akademia Sztuk Pięknych w Łodzi 162

Akademia Sztuk Pięknych we Lwowie 203

Association Internationale des Universités du Troisième Âge (AIUTA) 199, 198

Biblioteka Socjologiczna im. Józefa Chałasińskiego 246, 355, 380, 382, 383, 384, 385, 387

Biblioteka Uniwersytetu Łódzkiego 110, 378

Bułgarska Akademia Nauk 332

Caritas 77, 78, 290

Caritas Academica 300

Centre National de Recherche Scientifique (CNRS) 204, 205

Cepelia 320

Delle Terme di Caracalla w Rzymie 197

École des Hautes Études en Sciences Sociales 192

Fondation France-Pologne 198

Francuskie Towarzystwo Chemiczne 204

Gimnazjum im. Emilii Plater w Warszawie 48

Gimnazjum im. Józefa Piłsudskiego 51, 325

Gimnazjum Janiny Czapczyńskiej 42, 47, 48, 50, 53-54

Gimnazjum Narcyzy Żmichowskiej w Warszawie 46-47

Gimnazjum Społeczne im. Elizy Orzeszkowej w Łodzi 46

Gimnazjum (Szkoła) Zgromadzenia Kupców w Łodzi 46, 359, 382

Hotel „Monopol” 387

Kawiarnia „Lajkonik” w Warszawie 48

Kino „Bałtyk” 387

Kino „Gdynia” 386 
Kino „Hel” 87

Kino „Luna” 353

Kino „Polonia” 387

Kino „Stylowy” (Kino-Teatr „Stylowy”) 386

Kino „Tatry” 377, 386

Kino „Wisła” 387

Kościół pw. Najświętszego Imienia Jezus w Łodzi 300

Kościół San Giovanni w Rzymie 201

Kościół św. Anny w Krakowie 145, 159,

Krakowska Szkoła Filmowa im. Jerzego Hasa 415

Liceum Humanistyczne im. M. Konopnickiej 55

Liceum Ogólnokształcące nr I im. Bolesława Chrobrego w Piotrkowie Trybunalskim 56, 146,231

Liceum Ogólnokształcące nr III im. Tadeusza Kościuszki w Łodzi 43

Liceum Ogólnokształcącego nr IV im. Emilii Sczanieckiej w Łodzi 43, 48

Liceum Ogólnokształcące nr XI im. Michała Kajki w Łodzi 58

Liceum Ogólnokształcące nr XII im. Stanisława Wyspiańskiego w Łodzi 42

Liceum Pedagogiczne w Końskich 67

Liceum Pedagogiczne w Łowiczu 59

Łódzkie Towarzystwo Naukowe (ŁTN) 17, 33, 42, 103, 129, 165, 222, 415

Międzynarodowe Towarzystwo Heglowskie 206

Muzeum Archeologiczne w Łodzi 49

Muzeum Archeologiczne w Warszawie 163, 355

Muzeum Geologiczne UŁ 36, 67, 231, 364-365, 376

Muzeum Historii i Sztuki im. Bartoszewiczów 47

Muzeum Narodowe w Warszawie 48

Muzeum Przyrodnicze UŁ 35, 248

Muzeum Sztuki w Łodzi 48, 49-50, 67, 161, 173

Niezależne Zrzeszenie Studentów (NZS) 252, 255-257, 264, 273, 298

Niezależny Samorządny Związek Zawodowy „Solidarność” 30, 78, 118, 127, 170, 210, $211,227,234,239,242,245,246,252-253,257,261,266,267,270,271,272,273$, $275,277,333,338,339,341,357,377,407$

Okopy św. Trójcy pod Chocimiem 60

Ośrodek Badania Opinii Publicznej (OBOP) 78, 333

Organizacja Młodzieży Towarzystwa Uniwersytetu Robotniczego (OMTUR) 227-228, $292,301-302$

Palais de Justice w Paryżu 211

Państwowa Wyższa Szkoła Muzyczna w Łodzi 257

Państwowa Wyższa Szkoła Teatralna i Filmowa w Lodzi 162 
Politechnika Łódzka 31, 88, 129, 146, 155, 157, 168, 171, 239, 257, 284, 367, 388, 415

Polska Akademia Nauk (PAN) 31, 33, 34, 36, 40, 55, 62, 70, 76, 77, 81, 91, 103, 114, 118, $131,132,135,136,137,140,141,143,156,170,175,176,204,205,214,232,233$, $236,239,247,249,285,310,317,320,334,341,347,353,384,392,405,408$

Polskie Towarzystwo Ludoznawcze 346

Polskie Towarzystwo Socjologiczne (PTS) 33, 76, 136, 170, 175, 233, 333, 334, 337-338, $341,356,357,363,407$

Publiczne Gimnazjum nr 28 w Łodzi 67

Rada Wzajemnej Pomocy Gospodarczej (RWPG) 208, 323

Socjalistyczny Związek Studentów Polskich (SZSP) 255, 256

Sodalicja Mariańska 301-302

Stołówka „Gęsie Pióro” 388, 389

Szkoła Główna Handlowa (SGH) 144, 237, 331

Szkoła im. Królewny Anny Wazówny w Warszawie 45

Teatr im. Stefana Jaracza w Lodzi 297

United Nations Relief and Rehabilitation Administration (UNRRA) 298, 301

Uniwersytet Arystotelesa w Grecji 214

Uniwersytet Aleksandryjski 215

Uniwersytet Gorkiego w Charkowie 215

Uniwersytet Harvarda 197

Uniwersytet im. Łomonosowa w Moskwie 191, 207

Uniwersytet im. Marii Curie-Skłodowskiej w Lublinie 161

Uniwersytet im. Mikołaja Kopernika w Toruniu 134

Uniwersytet Jagielloński 30, 32, 45, 47, 110-112, 115, 132, 134, 140-141, 145, 159, 172, $175,314,318,322,331$

Uniwersytet Lwowski im. Jana Kazimierza 35, 90, 91, 130, 134, 135, 185, 249, 268, 304, 363

Uniwersytet North Western, w Chicago, Illinois 197

Uniwersytet Pensylwański w Filadelfii 195

Uniwersytet Urbana-Champaign 197

Uniwersytet Warszawski 20, 29, 34, 49, 55, 70, 76, 77, 78, 85, 86, 91, 100, 114, 118, 136, $141,148,160,169,170,175,176,233,240,243,250,282,284,285,287,288,289$, $291,309,319,322,333,339,341,347,348,354,356,357,405,407$

Uniwersytet Wrocławski 135, 221

Uniwersytet w Bordeaux 211

Uniwersytet w Cambridge 193-194

Uniwersytet w Segedzie 214

Uniwersytet w Strasburgu 189

Uniwersytet $\mathrm{w}$ Tampere 32, 340

Uniwersytet w Tbilisi 196, 203

Uniwersytet Wileński im. Stefana Batorego 62, 96, 141, 146, 158, 248, 284, 361, 406

Uniwersytet II w Lyonie 189, 198, 199, 206 
Urząd Bezpieczeństwa (UB) 75, 77, 159, 215, 249, 300, 308, 341, 342, 345

Warton School w Filadelfii 197

Wayne State University w Detroit 207

Wyższa Szkoła Gospodarstwa Wiejskiego 61, 359, 362, 387

Wyższa Szkoła Pedagogiczna w Warszawie 114

Wyższa Szkoła Sztuk Pięknych w Łodzi 43, 58

Young Men’s Christian Association (YMCA) 110

Zakłady im. Marchlewskiego 231

Związek Młodzieży Polskiej (ZMP) 228, 229, 292, 293, 295-296, 297, 298, 300, 302, $303,316,354$

Zrzeszenie Studentów Polskich (ZSP) 296, 297 


\section{Indeks nazw geograficznych}

Afganistan 214-215

Afryka Północna 214-215

Algieria 215

Antarktyda 212-214

Antarktyka 213-214

Arktyka 214

Azja 196, 298

Bad Brambach 208

Baku 208

Bangkok 196

Belgia 43

Bielsk Podlaski 58

Bierszów 299

Bombaj 209

Borki 133

Brańsk 58

Brno 208-209

Bruksela 73, 197, 353

Bucze na Śląsku 43

Cambridge 193-194

Częstochowa 46, 48

Czortków na Podolu 60

Egipt 61, 214-215, 359, 387

Finlandia 32, 191, 198, 337, 340

Generalna Gubernia 44, 48

Getynga 285

Giessen 197, 206

Głowno 52

Grotniki 51

Gruzja 203
Haga 196-197

Hanoi 253

Heidelberg 285

Helsinki 340

Holandia 195, 197, 279

Indie 90, 208

Inowłódz 52

Jabłonna 138, 334

Jaszczurówka 301

Jugosławia 116, 324

Kanada 31, 190, 214-216

Katyń 58, 294

Kazimierz 319

Kiecz 144

Kłodzko 231

Knoxhill (Tennessee) 207

Koło 47

Konstantynów 163

Konopnica nad Wartą 43

Kraków 37, 47-48, 56, 65, 69-70, 75, 80, 95, 110-111, 140, 145-146, 159-160, $175,203,234,255,290,301,314,321$, 389-390, 394

Kutno 68, 338

Leningrad 208

Lidzbark Welski 63

Lwów 50, 56, 69, 84, 91, 134-135, 159, $168,185,191,203,234-235,239,249$, $268,290-291,355$

Lyon 189, 198-199, 206 
Lask 47

Łosinka 58

Łowicz 59, 158, 168, 404

Łuków Lubelski 375

Manila 196

Maroko 215

Meksyk 196, 201, 331

Międzyrzecze-Obrzyce 309

Modlica 96

Montreal 215-216

Moskwa 55, 170, 191-194, 196, 202-203, 207-209, 227, 253, 310, 316

Nasielsk 165

Niemcy 45, 72, 215, 231, 275, 337, 348

Nowogródek 300

Nowy Jork 24

NRD 208, 226, 306, 332-333, 346, 361

Ostrowiec Świętokrzyski 57

Pabianice 85-86, 184

Paryż 35, 84, 48, 191-192, 196, 198-199, 202, 204-205, 210-211, 239, 243, 247, 264, 290, 309, 333

Piotrków Trybunalski 56, 146

Poronin 299

Poznań 30, 41, 44, 49, 57, 80, 140, 145, $173,175,177,222,231,276,309,319$, $330,338,387,389-390,405$

Praga 206

RFN 31, 332

Rzgów 64, 96, 182

Rypin 164

Seroczyn 47

Sofia 332

Sorkwity 299

Siemigostycze 58

Sierpce 164

Stany Zjednoczone/Ameryka/USA 31, 45, 114-115, 142, 145, 188, 195, 202, 204, 207-208, 214-215, 236, 298, 331, 334, 379,392
Strasburg 189

Sulęcin 299

Szwajcaria 31, 77, 115, 208, 243, 336

Szwecja 337

Tbilisi 203, 196,

Tunis 215

Turek 47

Turku 196

Tuszyn 96, 182

Uppsala 209

Urugwaj 213

Warszawa 41, 44, 46-48, 54, 56, 59, 66, 69, 71, 73 80-81, 86, 91, 95, 117-118, 131-133, 137, 140, 148, 163-164, 176, $200,228,230,234,236,241,243,247-$ $248,255,257,297,314,322,331,333$, $337,344,347,353,358,378,380-381$, 392

Wielka Brytania/Anglia 84, 91, 191, 194 196, 250, 331, 341

Włochy 60, 197, 199-200, 202-203

Włocławek 343-344

Wiedeń 204, 285

Wilno 56, 68, 96, 141, 147, 158-159, 169, 234, 247-248, 272, 284, 299-300, 304, $355,361,381$

Woldenberg 130, 148, 167

Wyspy Kanaryjskie 213

Wyspa Króla Jerzego 212-213

Zabrzeźnia k. Głowna 52-53

Zakopane 148

Zielona Góra 299

Związek Radziecki/Rosja 175, 187, 192, 194, 205, 208, 210, 227-228, 231, 238, $271,288,316,332-333,347,349$ 